
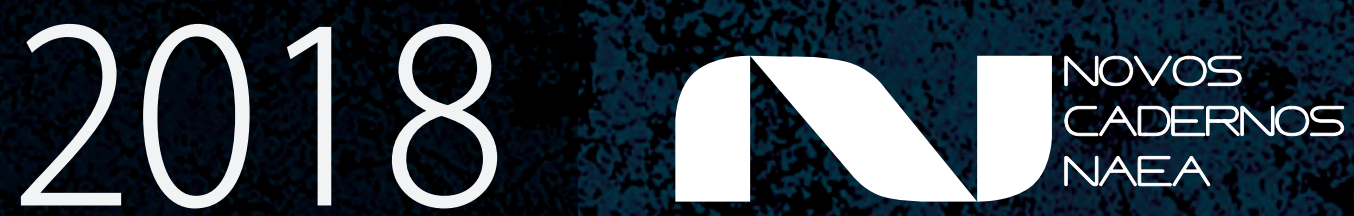

volume 21 | número 1 | jan-abril 


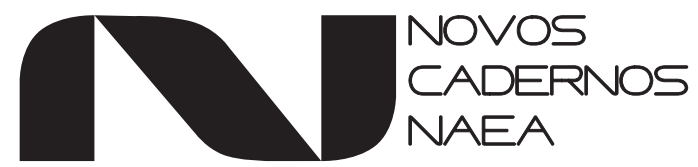

v. 21, n. 1 • janeiro-abril, 2018 


\section{UNIVERSIDADE FEDERAL DO PARÁ}

Reitor: Emmanuel Zagury Tourinho

Pró-Reitora de Pesquisa e Pós-Graduação: Rômulo Simões Angélica

\section{NÚCLEO DE ALTOS ESTUDOS AMAZÔNICOS}

Diretor Geral - Durbens Martins Nascimento $\bullet$ Diretor Adjunto: Silvio Figueiredo

\section{NOVOS CADERNOS NAEA}

Publicação do Núcleo de Altos Estudos Amazônicos/UFPA

Periodicidade quadrimestral, volume 21, número 1, janeiro-abril de 2018

Print ISSN: 1516-6481 - Eletrônica ISSN: 2179-7536 - DOI:10.5801/S21797536

\section{EDITOR CIENTÍFICO}

Edna Maria Ramos de Castro - NAEA/UFPA

\section{COMISSÃO EDITORIAL • NAEA}

Edna Ramos de Castro $\bullet$ Sociologia $\mid$ Francisco de Assis Costa $\bullet$ Economia

Luís Aragon Vaca $\bullet$ Geografia | Oriana Trindade $\bullet$ Economia

Raimundo Heraldo Maués • Antropologia | Silvio Figueiredo • Sociologia

\section{CONSELHO EDITORIAL}

Alfredo Wagner de Almeida $\bullet$ Universidade do Estado do Amazonas, Manaus, Brasil

Andréa Zhouri • Universidade Federal de Minas Gerais, Belo Horizonte, Brasil

Ana Maria Araújo • Universidad de la República, Uruguay

Célio Bermann • Universidade de São Paulo, São Paulo, Brasil

César Barreira • Universidade Federal do Ceará, Fortaleza, Brasil

Christian Azais • Université d'Amiens, Amiens, França

Clóvis Cavalcanti • Fundação Joaquim Nabuco, Recife, Brasil

German Palacio • Universidad Nacional de Colômbia, Letícia, Colômbia

Eduardo José Viola • Universidade de Brasília, Brasília, Brasil

Elmar Altvater • Instituto Hudson, Berlin, Alemanha

Emilio Moran • Indiana University, Indiana, Estados Unidos

Geraldo Magela Costa $\bullet$ Universidade Federal de Minas Gerais, Belo Horizonte, Brasil

Henri Acselrad • Universidade Federal do Rio de Janeiro, Rio de Janeiro, Brasil

Heloisa Costa • Universidade Federal de Minas Gerais, Belo Horizonte, Brasil

Ignacy Sachs • École dês Hautes Etudes em Sciences Sociales, Paris, França

Jose Ricardo Ramalho $\bullet$ Universidade Federal do Rio de Janeiro, Rio de Janeiro, Brasil

José Vicente T. dos Santos • Universidade Federal do Rio Grande do Sul, Porto Alegre, Brasil

Marcel Bursztyn • Universidade de Brasília, Brasília, Brasil

Marcelo Sampaio Carneiro • Universidade Federal do Maranhão, São Luís, Brasil

Maria Manoel Batista $\bullet$ Universidade de Aveiro, Aveiro, Portugal

Marilene da Silva Freitas $\bullet$ Universidade Federal do Amazonas, Manaus, Brasil

Martin Coy • Universität Innsbruck, Innsbruck, Áustria

Paola Bolados • Universidade de Valparaíso, Chile

Pedro Jacobi • Universidade de São Paulo, São Paulo, Brasil

Pierre Salama • Université Paris XIII, Paris, França

Pierre Teisserenc • Université Paris XIII, Paris, França

\section{EQUIPE TÉCNICA}

Assistentes editoriais: Jondison Cardoso Rodrigues, Rafaela Santos Carneiro, Cleyson Nunes Chagas

Revisão: Albano Rita Gomes, Iraneide Silva

Editoração eletrônica: Ione Sena

Capa: Andrea Pinheiro 
Universidade Federal do Pará

Núcleo de Altos Estudos Amazônicos

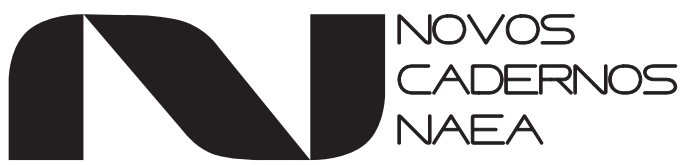

Novos Cadernos NAEA • v. 21, n. $1 \bullet$ p. 1-312 • janeiro-abril, 2018

Print ISSN: 1516-6481 - Eletrônica ISSN: 2179-7536 - DOI:10.5801/S21797536 
A Revista Novos Cadernos NAEA é um periódico quadrimestral, de caráter interdisciplinar, dedicado à publicação de trabalhos científicos e acadêmicos sobre temas relevantes às áreas do desenvolvimento, sociedade, economia e meio ambiente, com o objetivo de fomentar o diálogo entre as diversas áreas do conhecimento e suas competências, de pesquisadores e instituições de ensino e pesquisa do Brasil e do exterior.

A revista publica textos originais e inéditos em português, espanhol, inglês e francês. Adota a avaliação anônima por pares (peer review) para trabalhos submetidos às seções: artigos originais e de revisão, resenhas, notas de pesquisa, conferências e, eventualmente, dossiês temáticos, volumes especiais e/ou suplementos

\section{INDEXADORES}

Latindex - Crossref - Portal de Periódicos da CAPES - Google Scholar - Research Bib - e-Revistas/Plataforma Open access de Revistas Científicas Electrónicas Espanholas y Latinoamericanas - Directory of Open Acess Journals (DOAJ) - DRJI - Directory of Research Journal Indexing

\section{IDENTIFICADORES}

Univrsal Impact Factor - Journal For Free - Portal para Periódicos de Livre Acesso na Internet - LivRe Diretório Luso-Brasileiro IBICT - Sumarios.org - Repositório Científico de Acesso Aberto de Portugual Microsoft Academic Search - Library of Congress/HLAS Online - Elektronische Zeitschriftenbibliothek (EZB) - Georgetown University Library - SEER IBICT - Cibera: Iberoamérica/España/Portugal - Library Catalog - University of Texas at Austin - WordCat - Diadorim - Diretório de Políticas de Acesso Aberto das Revistas Científicas Brasileiras

\section{CONTATOS}

Núcleo de Altos de Estudos Amazônicos/Universidade Federal do Pará

Rua Augusto Corrêa, no 1, Campus Universitário do Guamá

CEP: 66.075-900, Belém, Pará, Brasil

Tel: (+55-91) 32018515

e-mail: revistanovoscadernosnaea@gmail.com

\section{SUBMISSÃO DE ARTIGOS}

http://www.periodicos.ufpa.br/index.php/ncn

Homepage do NAEA: www2.ufpa.br/naea

Dados Internacionais de Catalogação na Publicação - CIP

(Câmara Brasileira do Livro, SP, Brasil)

Novos Cadernos NAEA, v. 21, n. 1 - janeiro-abril, 2018 - Belém. Núcleo de Altos Estudos Amazônicos/UFPA, 2016.

Quadrimensal

ISSN Print 1516-6481

ISSN Eletrônico 2179-7536

DOI: $10.5801 / \mathrm{S} 21797536$

O vol. 1, no 1 desta Revista foi publicado em junho de 1998. 1. Desenvolvimento - Periódicos. 2. Meio Ambiente - Periódicos. 3. Amazônia - Periódicos.

CDD 338.9811

(C) Copyright/Direitos de cópia para este número: NAEA/UFPA

Título e textos amparados pela Lei 5.988, de 14 de dezembro de 1973.
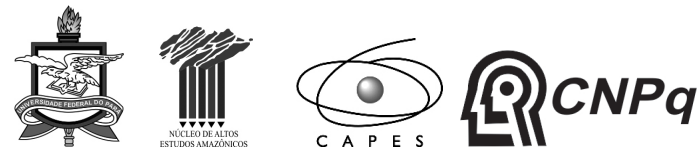

C A P E S

Ministério da Educação

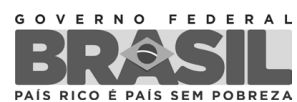




\section{S U M Á R I O}

\section{Editorial}

\section{Artigos}

09 Crescimento econômico, padrões de especialização e industrialização: um estudo comparativo das exportações do BRIC (1980-2013)

Economic growth, patterns of specialization and industrialization: a comparative study of BRIC exports (1980-2013)

André Luís Cabral de Lourenço e Franciane Alves Cardoso

35 Encadeamento ecossocioeconômico e gestão urbana: um estudo das feiras livres na cidade de Curitiba (PR)

Socio-economic and urban management: a study of the free trade fairs in the city of Curitiba (PR)

Isabel Jurema Grimm, Carlos Cioce Sampaio e Mario Procopick

57 Um "skyline" em mutação: o velho centro e as transformações urbanas em Belém A "skyline" in changing: the old center and the urban transformations in Belém Saint-Clair Cordeiro da Trindade Júnior

79 Comunidades quilombolas e o Programa Nacional de Habitação Rural The quilombola communities and the National Rural Housing Program André Augusto Brandão, Salete Da Dalt e Sidimara Cristina de Souza

99 Saberes e práticas tradicionais em movimento: a comunidade do Maracanã na rota de um projeto global

Traditional knowledge and practices in movement: yhe community of Maracanã on the route of a global project

Joaquim Sbiraishi Neto, Rosirene Martins Lima e Luzinele Everton de Alcobaşa

117 Território e trabalho: análise geoeconômica com base em trajetórias camponesas

Territory and work: a geoeconomical analysys based on peasant trajectories

Karen de Nazareth Santos Nogueira, Francisco de Assis Costa e Marcos Adami

139 Estratégias e formas de reprodução social na agricultura familiar da fronteira oeste do Rio Grande do Sul

Strategies and reproduction of social forms family in fronteira oeste do Rio Grande do Sul

Alessandra Troian e Raquel Breitenbach

159 Usinas hidrelétricas sob os véus da "sustentabilidade": o pescador artesanal da Ponta do Abunã e a Usina Hidrelétrica de Jirau, em Rondônia

Hydroelectric plants in the Amazon under the veils "sustainability": the fishermen of Ponta do Abunã of the Jirau Dam in Rondonia

Fabiano Moreira da Silva e Elder Andrade de Paula 
179 Grandes projetos de mineração e direitos territoriais das comunidades locais em Moçambique

Large mining projects and territorial rights of local communities in Mozambique Albino José Eusébio e Sônia Barbosa Magalhães

199 Desenvolvimento sustentável do Marajó, Pará: uma visão a partir do Barômetro da Sustentabilidade

Sustainable development of Marajó, Pará: an overview based on the Barometer of Sustainability

Patrick Dinir. Alves Quintela, Peter Mann de Toledo e Ima Célia Guimarães Vieira

215 Para além do sucesso técnico: rede sociotécnica em pequenas comunidades rurais amazônicas, Amazonas-Brasil

Besides technical success: socio-technical network in small rural communities of the Brazilian Amazon

Ana Claudeise Nascimento, Edila Arnaud Ferreira Moura e Maria José da Silva Aquino Teisserenc

243 Etnoconservação e história ambiental para um novo modelo conservacionista do século XXI

Etnoconservation and environmental history for a new conservation model of the XXI century

José Aécio Alves Barbosa e José Otávio Aguiar

257 Redes sociopolíticas e territorialidade na Reserva de Desenvolvimento Sustentável IgapóAçu (AM, Brasil)

Sociopolitical networks and territoriality in the Development Reserve Sustainable Igapó-Açu (Amazonas, Brazil)

Marilia Gabriela Gondim Rezende, Therezinha de Jesus Pinto Fraxe e Mônica Suani Barbosa da Costa

275 Prioridades locais e sua relação com o desenvolvimento regional no Codemi de Ijuí

Local priorities and its relationship with regional development in the Codemi from Ijuí

Vinicios Gonchoroski de Oliveira e Rogério Leandro Lima da Silveira

\section{Resenhas}

297 SANTOS, José Vicente Tavares dos. Violências e conflitualidades. Porto Alegre: Tomo Editorial, 2009.

Maria Goreti Góes da Rocha

303 PRADO JÚNIOR, Caio. História e Desenvolvimento: a contribuição da historiografia para a teoria e prática do desenvolvimento brasileiro. 2. ed. São Paulo: Ed. Brasiliense, 1978.

Brenda T. Cardoso de Castro 


\section{EDITORIAL}

Novos Cadernos NAEA vem a público, com 14 artigos que trazem resultados de pesquisas realizadas em várias regiões do Brasil e em Moçambique.

No correr de 2017 presenciamos manifestações políticas em todas as regiões brasileiras, de grandes a pequenas cidades. A insatisfação pela situação do país se espalha, aumentando os questionamentos, mas também intensificando o debate. Crise sobre a ética e a política, a economia, o trabalho, o acesso à terra e aos territórios, incluindo os territórios étnicos. Talvez jamais tenhamos nos defrontado com igual quadro de crise institucional, de insegurança jurídica, legislativa e no plano das ações de governo. Para o cidadão, a sensação é de se estar à deriva. Um confronto que se dá na sociedade, com suas divisões internas atravessadas pela desigualdade de classe, pelos privilégios de grupos que amordaçam e privatizam os recursos de todos, via Estado, pelas escolhas políticas contra coletivos, mas sobretudo, crise moral que disfarça a realidade por meio de discursos eloquentes que se espalham nos canais midiáticos. Uma sociedade fracionada, dividida, com mundos que não se tocam, e portanto, partes de um mesmo conjunto, a sociedade brasileira.

Lançamos um novo exemplar da Revista Novos Cadernos NAEA, mas não passamos ao largo das dificuldades que dizem respeito à redução de financiamento da educação nacional, ao fechamento de instituições de ensino e pesquisa, ao desmonte de programas de Ciência, Tecnologia e Inovação, do empobrecimento das Unidades de Pesquisa do MCTI, fundamentais para fomentar a pesquisa, estimular novos processos criativos e elevar o nível de qualidade, de internacionalização na produção de ciência e tecnologia no país.

Este volume traz ao público dois artigos que se voltam ao entendimento das relações econômicas e do papel do mercado, embora com foco em temas bem diversos. Interessados em entender os processos de crescimento econômico e de industrialização, Lourenço e Cardoso analisam as exportações do bloco BRIC e comparam o desempenho do Brasil, da China, da Índia e da Rússia, visando compreender melhor o papel dos padrões de especialização de seu desempenho. Na perspectiva dos arranjos socioprodutivos e da gestão urbana, denominadas feiras livres, Grimm, Sampaio e Procopick observam as práticas de transformação social na cidade de Curitiba a partir da ecossocioeconomia. Mostram como pequenos negócios ganham visibilidade frente à economia de mercado, colocando em relevo a análise sobre as estratégias coletivas de geração de renda e de inclusão social.

$\mathrm{Na}$ intercessão do urbano, o artigo Um "skyline" em mutação expõe resultados de pesquisa sobre as transformações urbanas no velho centro de Belém. Trindade Júnior descreve os processos de requalificação de áreas centrais nas cidades brasileiras e que seriam semelhantes às repercussões socioespaciais verificadas em outros países que vivenciaram processos de gentrificação. Em outra perspectiva que pensa as formas de viver e habitar, mas relacionadas ao modos de vida rural, a análise no trabalho de Brandão, Dalt e Souza - Comunidades quilombolas e o Programa Nacional de Habitação Rural - é direcionada ao acesso desses grupos à política habitacional, particularmente, à moradia, à construção das unidades habitacionais e aos impasses na sua execução. As relações entre espaços urbanos e rurais, e transversalidade étnica, é tratado no artigo Saberes e práticas tradicionais em movimento, que 
analisa interfaces de uma comunidade quilombola localizada na zona rural de São Luis. O artigo de Shiraishi Neto, Lima e Alcobaça cartografa a expansão urbana e sua relação com o Programa Minha Casa Minha Vida, e a reorganização das maneiras de viver.

Desenvolvimento é tema de vários trabalhos aqui publicados. $\mathrm{Na}$ interpretação da democracia participativa/deliberativa, Oliveira e Silveira observan a valorização da participação dos cidadãos, seu empoderamento político e as tomadas de decisão no desenvolvimento das regiões, concentrando observação no processo de votação da Consulta Popular (CP) em Ijuí, Rio Grande do Sul. Desenvolvimento regional e agriculturas familiares estão presentes na artigo sobre território e trabalho de Nogueira, Costa e Adami. Os autores aprofundam as bases da teoria de trajetórias tecnológicas rurais para a Amazônia, demonstrando a especificidade da economia camponesa. Esta análise geoecônomica com base em trajetórias camponesas é resultado de pesquisa no município de Mocajuba, no Pará. Ainda na linha da análise sobre as formas de reprodução social na agricultura familiar, porém em outra fronteira, também do Rio Grande do Sul, Troian e Breitenbach destacam a importância da agricultura familiar nas duas últimas décadas, reconhecendo a relevância do debate sobre sua heterogeneidade.

Dois artigos tratam de megaprojetos de investimento. Um estudo sobre mineração em Moçambique e outro sobre hidrelétricas no Brasil. Na análise sobre o trabalho de pescadores artesanais da Ponta do Abunã, o texto de Silva e Paula mostra as tensões decorrentes da construção da hidrelétrica de Jirau, estado de Rondônia. Igualmente, Eusébio e Magalhães revelam os efeitos da mineração em Moçambique a partir de uma perspectiva crítica, associando questão fundiária, direitos territoriais e discursos de desenvolvimento. Nesta edição, contempla-se os leitores com quatro artigos sobre problemas ambientais. Quintela, Toledo e Vieira apresentam uma análise da sustentabilidade de 16 municípios que compõem a mesorregião do Marajó, utilizando o Barômetro da Sustentabilidade (BS) como ferramenta de análise. Diante do atual cenário ambiental mundial, Barbosa e Aguiar discuten algumas estratégias que vêm sendo postas como recursos úteis aos novos modelos de conservação necessários ante os desafios do século XXI. A ilha do Marajó, lócus da pesquisa, mostra desequilíbrio em relação ao nível de sustentabilidade dos municípios, políticas públicas e modelos de gestão municipal. Nascimento, Moura e Teisserenc, no artigo Para além do sucesso técnico, refletem sobre a relação entre a técnica e os modos de vida das comunidades rurais que vivem na Reserva Mamirauá, no Oeste do estado do Amazonas, mais especificamente a constituição de uma rede sociotécnica para desenvolver práticas de uso da água para o consumo em pequenos povoados na floresta alagada amazônica.

Rezende, Fraxe e Costa no estudo sobre a Reserva de Desenvolvimento Sustentável Igapó-Açu, no Amazonas, procuram compreender as organizações sociais, seus desdobramentos territoriais e os processos de ordenamento territorial.

Esta edição traz ainda duas resenhas. A primeira é sobre o livro de José Vicente Tavares dos Santos intitulado Violências e conflitualidades, publicado em Porto Alegre, em 2009, elaborada por Maria Goreti da Rocha. A segunda, de Brenda Castro, do festejado clássico da literatura brasileira das ciências sociais, Caio Prado Júnior, História e desenvolvimento: a contribuição da historiografia para a teoria e prática do desenvolvimento brasileiro. 


\section{Crescimento econômico, padrões de especialização e industrialização: um estudo comparativo das exportações do BRIC}

\section{Economic growth, patterns of specialization and industrialization: a comparative study of BRIC exports (1980-2013)}

André Luís Cabral de Lourenço - Doutor em Economia pela Universidade Federal do Rio de Janeiro e mestre em Ciência Econômica pela Univerdade Estadual de Campinas (UNICAMP). Professor associado da Universidade Federal do Rio Grande do Norte (UFRN). E-mail: andre.lclourenco@gmail.com

Franciane Alves Cardoso - Mestre em Ciências Econômicas pela Universidade Federal do Rio Grande do Norte (UFRN). E-mail: franufrn_05@yahoo.com.br

\section{Resumo}

Compara-se, neste artigo, o desempenho dos países componentes do BRIC (Brasil, China, Índia e Rússia) no período 1980-2013, visando compreender melhor o papel dos padrões de especialização (em particular das exportações) no desempenho díspar em termos de crescimento do Brasil em relação aos demais membros do grupo. As principais conclusões do trabalho são: 1) As taxas de crescimento relativas dessas economias estiveram estreitamente associadas às respectivas razões entre as elasticidades-renda da demanda por exportações e por importações, de forma consistente com o sugerido pelo modelo de crescimento de Thirlwall; 2) Os países que cresceram mais rapidamente entre os do grupo são os que menos perderam participação tanto do setor industrial em geral quanto especificamente da indústria de transformação no valor agregado, de forma consistente com o tratamento teórico de Kaldor.

\section{Palavras-chave}

BRIC. Crescimento. Especialização. Indústria. Exportações.

\begin{abstract}
The paper compares the performance of the BRIC countries (Brazil, China, India and Russian Federation) in the period 1980-2013, to better understand the role of specialization patterns (particularly exports) in disparate performance in terms of growth of Brazil in relation to other group members. The main conclusions are: 1) The growth rates for these economies were closely associated with the respective ratio between the income elasticities of demand for exports and imports, consistently with Thirlwall's growth model; 2) The countries that grew faster among the group are the ones that lost least share of the industrial sector in general and specifically of the manufacturing industry in aggregate value, in a way consistent with the theoretical treatment of Kaldor.
\end{abstract}

\section{Keywords}

BRIC. Growth. Specialization. Manufacturing. Exports. 


\section{INTRODUÇÃO}

Nos últimos anos o BRIC ${ }^{1}$ - sigla do grupo de países ao qual pertencem Brasil, Rússia, Índia e China - vem ganhando destaque no cenário internacional, tanto no âmbito econômico quanto em termos de influência geopolítica. Embora não se trate de um bloco econômico, este agrupamento, antes apenas citado nos meios acadêmicos, tem motivado a discussão sobre a relevância de acordos bilaterais e multilaterais no âmbito da política internacional.

Como observa Fiori (2007), contudo, o grupo é composto por países altamente heterogêneos sob variados aspectos. Historicamente, sua formação é muito diversa: um antigo Império "excêntrico" oriental, outrora a grande potência mundial, agora "reemergente" e semi-socialista; um ex-Império de passado servil e ex-socialista; e duas ex-colônias de exploração, uma herdeira do antigo "modo de produção asiático", e a outra como antiga plantation escravista. Geopoliticamente, enquanto Rússia e China adentram o século XXI como integrantes da cúpula do sistema interestatal, Brasil e Índia permanecem relegados à condição de potências regionais. Economicamente, a dispersão dos níveis de desenvolvimento pode ser claramente observada a partir das respectivas rendas per capita. Medidas em poder de compra constante, a Rússia é a $58^{a}$ no ranking, com cerca de US $\$ 17,9$ mil; o Brasil $\left(79^{\circ}\right)$ possui US $\$ 12,2$ mil; a China $\left(93^{\mathrm{a}}\right)$, US $\$ 9,8$ mil; e a Índia $\left(133^{\mathrm{a}}\right)$, US $\$ 4,1$ mill $^{2}$. Também são muito heterogêneos seus indicadores sociais ${ }^{3}$.

Entretanto, os países que compõem este grupo, além de considerados em desenvolvimento, apresentam algumas semelhanças quando observadas as dimensões territoriais, as elevadas taxas de crescimento do Produto Interno Bruto (PIB) e o crescente peso que suas economias assumiram na economia mundial durante a década passada (BAUMANN; ARAÚJO; FERREIRA, 2010). Em particular, são os únicos países em desenvolvimento entre as nove maiores economias mundiais.

Nos anos 2000, tais países tiveram ampla contribuição na elevação da produção mundial, ajudando a reduzir os efeitos da crise financeira global iniciada em 2007/8, que atingiu principalmente os países desenvolvidos. Entretanto, no início desta década, o desempenho do PIB destes países apresentou brusca

\footnotetext{
Termo formulado por Jim O`Neill (2001), diretor da Goldman Sachs. Ressalta-se que a África de Sul não foi incluída na análise, com a consequente exclusão do "S" dos BRICS. Justifica-se tal procedimento pelo fato de que, embora subdesenvolvida e no mínimo potência regional, ela é apenas o $25^{\circ}$ país no ranking dos PIBs, enquanto todos os demais países considerados na análise estão entre as 7 maiores economias.

FMI (2014).

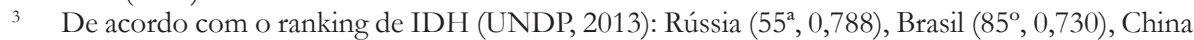
(101 $\left.{ }^{\mathrm{a}}, 0,699\right)$, e Índia $\left(136^{\mathrm{a}}, 0,554\right)$.
} 
desaceleração. Contudo, ainda não se sabe se este movimento é apenas temporário, ou algo duradouro (THE ECONOMIST, 2013).

A trajetória de crescimento vivenciada pela China (com maior destaque) e pela Índia nos últimos 30 anos desperta interesse de muitos estudiosos, visto que na década de 1970, a China cresceu em média 5\% ao ano (a.a), ao passo que no período entre 2001 e 2010 este saltou para cerca de 11\%. Já a Índia, que cresceu aproximadamente $3 \%$ a.a na década de 1970, apresentou crescimento médio de 7,8\% a.a no período entre 2001 e 2010.

No tocante a Rússia, sua trajetória de crescimento foi ainda mais distinta das demais, na medida em que saltou de uma taxa média negativa (de -3,6\% a.a) no período pós-dissolução da União Soviética, na década de 1990, para uma média de 5\% a.a no período 2001-2010.

Estes "saltos" na trajetória de crescimento contrastam significativamente com o movimento oposto ocorrido no Brasil. No período entre 1890 e 1980, o crescimento do PIB brasileiro mostrou-se bastante significativo, sendo considerada por Maddison (2001) como a economia que apresentou a maior taxa de crescimento quando comparada às demais nações. Ao considerar-se apenas a década de 1970, esta taxa foi de 8,5\% anual.

Porém, o declínio da taxa de crescimento no período de 1980 a 2000 para um valor próximo a um terço da média anterior marca uma importante perda de posição relativa perante os demais países. Na década de 1980, o Brasil registrou um crescimento do PIB real médio de apenas 1,7\% anual. Em que pesem as enormes diferenças estruturais que envolvem essas economias, o estudo desse movimento tão contrastante pode trazer maior compreensão acerca da trajetória nacional.

Gráfico 1 - Taxa de crescimento do PIB real (em \%); BRIC, 1990-2012

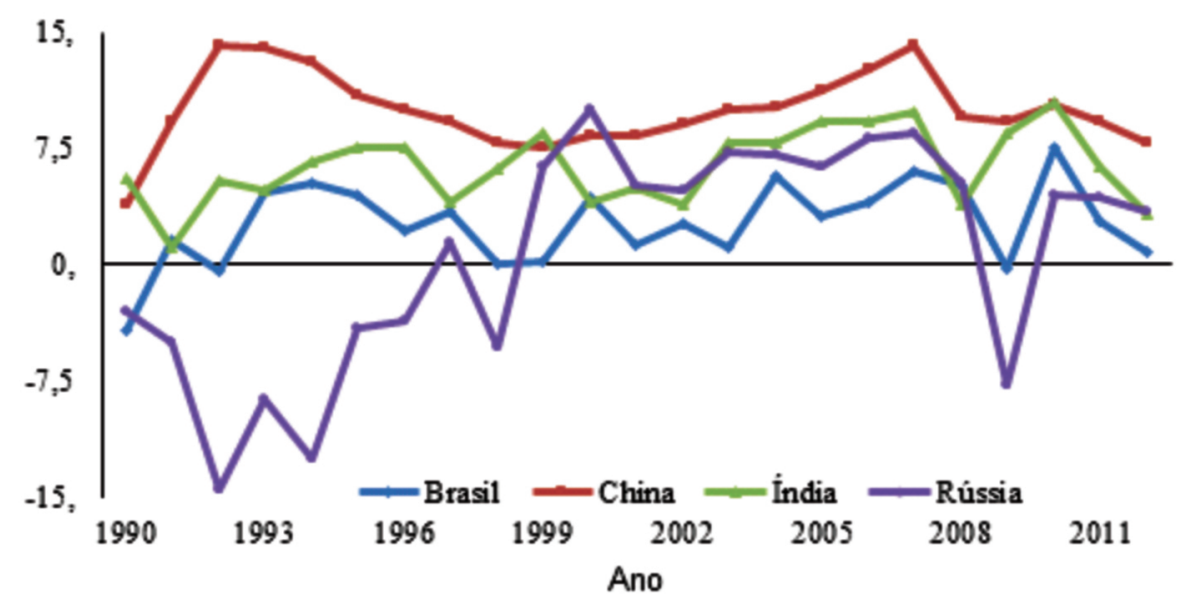

Fonte: World Development Indicators Database (2013). 
Observa-se a partir de 2009, conforme exposto no Gráfico 2, uma desaceleração das taxas de crescimento de todos os BRIC, com exceção do ano de 2010. O curso de crescimento da década passada apontava para os possíveis sinais de retorno do crescimento brasileiro às taxas seculares. Entretanto, a desaceleração mais recente faz-nos lembrar dos problemas enfrentados pelo Brasil para manter um crescimento robusto e sustentável.

A partir do Gráfico 1, parece ainda correto afirmar que as divergências nas taxas de crescimento não constituem exclusividade da relação entre os países desenvolvidos e os em desenvolvimento. Tal divergência ocorre também entre os próprios países em desenvolvimento, como no caso dos BRIC. Neste contexto, o objetivo central deste ensaio é observar o padrão de especialização destas economias, com foco no papel das exportações para o desenvolvimento econômico, entre 1980 e 2012.

Tem-se por hipótese a ideia de que os países que melhor utilizaram as exportações como componente estratégico da política de desenvolvimento (em particular, no sentido de promoverem transformação estrutural em prol de setores produtivos mais sofisticados) obtiveram melhoria na restrição externa e no próprio desempenho em termos de crescimento.

A justificativa deste estudo consiste na importância de compreender as semelhanças e diferenças entre os BRIC, dada a relevância que tais economias vêm adquirindo no âmbito internacional e suas elevadas taxas de crescimento nas últimas duas décadas.

A metodologia utilizada consiste na pesquisa explicativa de delineamento bibliográfico e documental. As fontes dos dados são secundárias, retiradas principalmente da UNCTAD (2013) e do World Development Indicators Online (2013).

O presente trabalho possui quatro seções, incluindo esta introdução. $\mathrm{Na}$ próxima seção discute-se o pensamento de Prebisch (1949) e Singer (1950), onde a industrialização é vista como "elemento propulsor do desenvolvimento econômico", as contribuições heterodoxas à teoria do desenvolvimento, bem como as contribuições atuais em defesa da industrialização para reduzir a vulnerabilidade externa. $\mathrm{Na}$ terceira seção faz-se uma análise da importância do setor industrial para os países que pertencem ao BRIC e a relevância da composição das exportações como forma de auferirem maiores taxas de crescimento. Breves considerações finais compõem a quarta e última seção. 


\section{COMÉRCIO INTERNACIONAL E PADRÕES DE ESPECIALIZA- ÇÃO: PRECURSORES DA IDEIA DA INDUSTRIALIZAÇÃO COMO "ELEMENTO PROPULSOR DO DESENVOLVIMENTO ECONÔMICO"}

A importância do comércio internacional para o crescimento econômico é objeto de discussão desde os primórdios mercantilistas, passando pelos economistas clássicos como Smith (1985) e Ricardo (1965) e prosseguindo até os dias de hoje. O padrão de especialização constitui-se um dos determinantes básicos da inserção externa de uma economia no comércio internacional. A construção de uma inserção adequada, por sua vez, como se arguirá, é um componente fundamental de uma estratégia vitoriosa de desenvolvimento.

Diferentemente do que propõe a corrente convencional, as ideias exploradas nas linhas seguintes questionam a capacidade dos mecanismos equilibradores proporcionados pela livre operação dos mecanismos de mercado conduzir as economias ao equilíbrio dos respectivos Saldos em Transações Correntes (STC) sem afetar permanentemente seu crescimento. Assim, de acordo com o referencial teórico aqui adotado, existe a possibilidade de que tais mecanismos promovam o crescimento do Passivo Externo Líquido (PEL) por trajetórias insustentáveis, ocasionando eventualmente uma crise de endividamento externo de graves consequências.

Para o pensamento neoclássico, porém, os preços relativos refletem adequadamente o grau de escassez dos fatores de produção, bem como opera o princípio da plena substituição destes fatores. Em conjunto com as propriedades de retornos constantes de escala e de rendimentos marginais decrescentes dos fatores, tais hipóteses teóricas suportam a existência de uma tendência à convergência da renda per capita de todos os países do mundo em estado estacionário, como em Solow (1956). Jones (2000) encontra evidências empíricas favoráveis a esta tendência, mas seu estudo é muito controverso, e vários autores ortodoxos parecem mais dispostos a admitir que a convergência incondicional só ocorre de fato no "clube" dos países mais desenvolvidos, mas não entre esses e os subdesenvolvidos ${ }^{4}$. Abre-se assim espaço para abordagens alternativas, tanto no pensamento convencional quanto alhures.

$\mathrm{Na}$ abordagem exposta nesta seção apresentam-se os argumentos heterodoxos a favor da tendência oposta, qual seja, de que a polarização entre as taxas de crescimento de países e regiões é o resultado esperado da livre operação dos mecanismos de mercado.. O desenvolvimento do argumento remete aos primórdios do desenvolvimentismo, em particular às contribuições de

\footnotetext{
$4 \quad$ Vide Carlin e Soskice (2006) para trabalhos empíricos neste sentido.
} 
Prebisch (1949), Singer (1950) e Furtado (1961, 1983), entre outros. A chave da compreensão do subdesenvolvimento repousa em seu padrão de especialização. Países subdesenvolvidos, com uma estrutura produtiva relativamente atrasada, apresentam tendência à especialização na produção e exportação de bens de baixo conteúdo inovativo e tecnológico, e propensão a importar produtos mais intensivos em tecnologia, que apresentam alta elasticidade-renda.

No que concerne ao progresso técnico, argumentava-se que favorecia produtos com elasticidade-renda da demanda mais elevada (na época, as manufaturas). $\mathrm{Na}$ medida em que países subdesenvolvidos importam produtos de maior intensidade tecnológica, perdem a oportunidade de se apropriar dos ganhos do progresso tecnológico. Resulta uma tendência secular de piora dos termos de troca que faz com que os efeitos do progresso técnico sejam transferidos aos países já desenvolvidos.

O desenvolvimento industrial foi então visto como caminho inevitável para o desenvolvimento econômico e social, considerando a indústria como "elemento propulsor do desenvolvimento", na medida em que acelera o progresso técnico incorporado nas máquinas e equipamentos e propicia a retenção dos ganhos dele originários.

\section{CONTRIBUIÇÕESHETERODOXASÀTEORIADOCRESCIMENTO RESTRINGIDO PELO BALANÇO DE PAGAMENTOS}

A teoria heterodoxa do crescimento econômico recebeu expressiva contribuição no trabalho de'Thirlwall(1979), particularmente no sentido de modelar algumas das ideias desenvolvimentistas, bem como em testá-las empiricamente. A restrição externa ao crescimento das economias em desenvolvimento foi o foco de sua análise, assim como a explicação das divergências entre as taxas de crescimento dos países. Segundo o autor, as elasticidades-renda das exportações e das importações têm um papel fundamental na explicação da tendência à polarização verificada nestas economias, bem como das políticas necessárias para a suavização de tais restrições.

Neste contexto, nos países periféricos, a restrição do balanço de pagamentos seria o maior obstáculo encontrado ao crescimento. Contudo, é preciso observar que o balanço de pagamentos atua como elemento de restrição em um contexto no qual o produto é impulsionado pela demanda agregada. Trata-se assim de um modelo demand-led, no qual a restrição operacional imediata não é a disponibilidade 
física de fatores de produção ${ }^{5}$, mas sim de divisas. Ademais, ao assumir a validade da hipótese de paridade de poder de compra no longo prazo, fica descartada a possibilidade de operação da taxa de câmbio real como elemento equilibrador do balanço de pagamentos. É o próprio crescimento econômico portanto que precisa ser ajustado para, via efeito renda, impedir a eclosão de crises de balanço de pagamentos e dos cenários inflacionários a elas tipicamente associados.

Grosso modo, Thirlwall apresenta um modelo teórico no qual a taxa máxima de crescimento de longo prazo $\left(\mathrm{g}_{\mathrm{BP}}\right)$ é dada pela taxa de crescimento do produto mundial ${ }^{6}$ (z), multiplicada pela elasticidade-renda da demanda por exportações $(\varepsilon)$ e dividida pela elasticidade-renda da demanda por importações $(\pi)$ :

$$
\mathrm{g}_{\mathrm{BP}}=\frac{\varepsilon}{\pi} \mathrm{z}
$$

Considerando exógena a taxa de crescimento do produto mundial, as variáveis chave para a execução da política econômica são as elasticidades-renda da demanda por exportações e por importações.

O cerne da contribuição de Thirlwall é a explicação da restrição ao crescimento econômico. Caso uma economia insista em crescer acima do limite possibilitado pela sustentabilidade de suas contas externas, no longo prazo haveria uma escassez de divisas, sendo necessário recorrer a empréstimos externos consecutivos e crescentes. Assim, existiriam países que precisariam conter seu crescimento em decorrência desta restrição, mesmo apresentando capacidade ociosa e mão-de-obra excedente. Há, pois, um limite relativo ao déficit em transações correntes, além do qual os mercados financeiros se inquietam e o país ficaria impossibilitado de atrair mais financiamento externo (THIRLWALL, 2005). Nesta análise, o conteúdo das exportações é relevante e sua elasticidaderenda (determinada pela estrutura produtiva de cada país) pode restringir a obtenção de maiores taxas de crescimento econômico.

Em síntese, Flingespan (2009, p.60) afirma que:

“... Também conhecida como "Lei de Thirlwall”, ela tem como referência um contexto de restrições ao financiamento do Balanço de Pagamentos,

\footnotetext{
Thirlwall assevera, contudo, que tais restrições físicas de oferta podem se tornar operacionais quando e onde houver uma combinação de cenário internacional favorável com estruturas produtivas mais sofisticadas e políticas adequadas de gestão da demanda agregada.

6 Na prática, é conveniente tratar z como uma média das taxas de crescimento dos principais destinos das exportações de cada país, ponderadas pelas respectivas participações desses destinos nas exportações totais do país. Portanto, z tampouco é estritamente independente da política econômica nacional, posto que essas participações podem variar em função do perfil de política externa. O retorno do Itamaraty a uma política externa "terceiro-mundista" a partir de 2002, por exemplo, provavelmente contribuiu para elevar $\mathrm{z}$ durante a primeira década do milênio, quando os países do terceiro mundo via de regra cresceram mais depressa do que os desenvolvidos.
} 
em que as exportações têm que crescer para gerar as divisas necessárias ao pagamento das importações. Estas, por sua vez, não podem se expandir muito em relação à renda, sob pena de gerar déficits crescentes e não financiáveis. Trata-se, portanto, da busca de uma combinação adequada entre crescimento, exportações e importações de modo que as contas externas não representem uma restrição ao crescimento do PIB".

Cumpre frisar que os países que exportam produtos de baixa elasticidaderenda, e importam produtos de alta elasticidade-renda, necessariamente crescerão menos do que a média da economia mundial. Dessa maneira, caso essa estrutura produtiva não seja modificada, haveria uma tendência para que a distância entre as economias desenvolvidas e em desenvolvimento aumente cada vez mais. Nesta análise, o conteúdo das exportações é relevante e sua elasticidade-renda (determinada pela estrutura produtiva de cada país) pode restringir a obtenção de maiores taxas de crescimento econômico.

Os efeitos de longo prazo da continuidade de tal performance fornecem a explicação de Thirlwall para a chamada tendência à polarização. É necessário esclarecer, contudo, que períodos nos quais os países mais atrasados cresçam mais velozmente do que os adiantados (como parece ter sido o caso na primeira década do milênio) não invalidam necessariamente o modelo. Isto porque:

1) O modelo se pretende válido apenas em certo "longo prazo", o qual não é teoricamente especificado; em tese, uma década pode não ser tempo suficiente para que a restrição em questão se manifeste; especialmente quando os fluxos de capitais são abundantes, e os termos de troca particularmente favoráveis;

2) Certos países, talvez particularmente os já desenvolvidos, podem não desejar expandir a demanda agregada na intensidade permitida pela sua restrição de balanço de pagamentos. Neste caso, a despeito da tendência à polarização continuar presente em função dos aspectos estruturais, pode se manifestar empiricamente um processo de convergência;

3) O modelo prevê que a polarização só se manifesta caso os países subdesenvolvidos não vierem a utilizar políticas de mudança estrutural na escala necessária; na prática, os dados empíricos captam o efeito combinado da operação das forças de mercado e dessas políticas governamentais, impedindo que o tratamento meramente descritivo dos dados empíricos tenha peso decisivo para a rejeição do modelo?.

7 Repare que a validade da hipótese de polarização é empiricamente mais exigente do que a da mera validade do modelo de Thirlwall. Para que a hipótese de polarização seja válida, é preciso que a configuração das elasticidades-renda de exportação e importação dos países subdesenvolvidos seja adequada. Já a validade do modelo exige apenas que a taxa de crescimento efetiva do produto não permaneça indefinidamente acima de $\mathrm{g}_{\mathrm{BP}}$. 
Tal qual o modelo de Thirlwall, a abordagem de Kaldor (1970) sobre a teoria do crescimento econômico considera que este também é liderado pela demanda e restringido pelo balanço de pagamentos. Entretanto, o foco de sua análise tem um caráter mais especificamente setorial.

Kaldor estabelece que a taxa de crescimento das exportações determina o crescimento do PIB real, dado o parâmetro ${ }^{8}$ que mede a elasticidade desta relação. Assim, um crescimento mais rápido das exportações proporciona uma maior taxa de crescimento da economia, mediante mecanismo similar ao multiplicador de comércio externo (HARROD, 1939) 9

O passo seguinte do argumento, baseado na Lei de Verdoorn, postula que o aumento na taxa de crescimento da economia eleva a taxa de crescimento da produtividade em geral, da industrial em particular. A produtividade é portanto endógena e depende parcialmente do progresso técnico autônomo e, em boa medida, do induzido. A economia que apresenta maior produtividade se apropria dos ganhos dinâmicos de escala, sendo esta a variável-chave do modelo na explicação das diferentes taxas de crescimento entre os países (tendência à polarização $)^{10}$. Partindo deste princípio, Kaldor observa o setor industrial como o (então) mais dinâmico e o responsável pelo progresso técnico. Para ele parece acertado que neste setor as inovações ocorrem mais rapidamente e os ganhos de produtividade contribuem para o crescimento econômico (FEIJÓ; CARVALHO, 2002) $)^{11}$.

\footnotetext{
Tal parâmetro está relacionado ao comportamento das importações. Quanto maior o setor de produção de bens de capital do país, menor é a elasticidade renda de suas importações, o que por sua vez permite uma taxa de crescimento compatível com o equilíbrio do balanço de pagamentos mais elevada (FREITAS, 2002, 2003).

9 Cabe ainda ressaltar que as exportações podem exercer a liderança do crescimento também como componente de expansão da demanda autônoma, desencadeando, além dos tradicionais efeitos multiplicadores, também efeitos sobre o investimento similares aos do modelo do acelerador proposto por Hicks (1950).

10 Note que, subjacente a estas leis, podemos verificar a presença do "princípio da causação circular e cumulativa" proposto por Myrdal (1957). Dessa maneira, um país que cresce mais rapidamente acaba colhendo os frutos na forma de crescimento acelerado da produtividade industrial, sendo esta repassada e absorvida por outros setores da economia. Caso um país não desfrute inicialmente de tal crescimento, poderá apresentar taxas de crescimento cada vez mais baixas (de forma cumulativa), sendo que, no longo prazo, as divergências de suas taxas de crescimento em relação às demais economias podem aumentar de forma contínua.

11 No que tange às contribuições para a análise das divergências entre as taxas de crescimento das economias, Kaldor apresenta três leis fundamentais ("leis de Kaldor"): 1) a indústria de transformação se apresenta como motor do crescimento de longo prazo das economias, sendo que 2) o próprio crescimento econômico induz ao aumento da produtividade industrial através dos retornos dinâmicos de escala, e 3) o crescimento da produção induz o crescimento da produtividade fora do setor industrial, absorvendo recursos de baixa produtividade de outros setores (THIRLWALL, 1996).
} 
A aceleração do crescimento da produtividade possibilita uma queda na inflação interna, e como a PPC não é considerada válida ${ }^{12}$, a taxa real de câmbio sofre desvalorização. Como a condição de Marshall-Lerner é supostamente obedecida no prazo do modelo, a taxa de crescimento das exportações responde positivamente, dando origem a um novo movimento cumulativo da taxa de crescimento do PIB e da produtividade (causação cumulativa). Em síntese, as exportações desempenham um papel essencial nos dois modelos acima expostos, por ser o único componente da demanda agregada capaz de crescer sem sofrer limites devidos à restrição externa. Pelo contrário, permitem a ampliação da taxa de crescimento compatível com a restrição do balanço de pagamentos, dependendo de seu conteúdo tecnológico ${ }^{13}$.

Pode-se questionar até que ponto - como fazem aliás Dasgupta e Singh (2006) - a indústria continua tão estratégica quanto ao tempo de Kaldor. Mesmo admitindo que alguns serviços sofisticados tenham assumido a liderança, por exemplo, pelo critério da elasticidade-renda, a conclusão desses autores é que ela continua relativamente importante. O ponto, contudo, é que importa para o modelo é o grau de sofisticação da pauta de exportação e da composição do produto, e não propriamente o setor que assume o posto que então era da indústria.

Neste sentido, o conteúdo tecnológico das exportações e das importações nas economias em desenvolvimento torna-se relevante, na medida em que permite tal folga externa, reduzindo ademais a dependência que estas economias possuem de um cenário externo particularmente favorável.

Logo, assim interpretado este referencial teórico parece útil ao entendimento da situação atual do Brasil em relação às demais economias em desenvolvimento, principalmente os demais BRIC.

\section{ESTRUTURA PRODUTIVAE DESEMPENHO DAS EXPORTAÇÕES DOS BRIC (1980-2012)}

No decorrer dos últimos 30 anos, o valor adicionado dos setores produtivos da economia no PIB dos BRIC passou por modificações relevantes. Conforme demonstra o Gráfico 2, ao analisarmos a composição do PIB por setor, a economia brasileira atravessou substanciais modificações em sua estrutura produtiva. Entre

12 Portanto, diferentemente do modelo proposto por Thirlwall, em Kaldor as desvalorizações do câmbio afetam positivamente a taxa de crescimento das exportações e, por consequência, a taxa de crescimento do produto real de longo prazo.

13 Repare contudo um detalhe específico do modelo de Kaldor: o círculo virtuoso cumulativo pode ter por "gatilho" a expansão de uma variável autônoma de demanda doméstica, desde que as condições iniciais do balanço de pagamentos o permitam. Os ganhos dinâmicos de escala daí resultantes poderiam perfeitamente espraiar-se aos setores industriais exportadores, colocando então em marcha um processo de crescimento mais sustentável. 
as décadas de 1980 e 2010, a agricultura reduziu sua participação pela metade (de $11 \%$ para 5,7\%, em média), acompanhada pela indústria (de $43 \%$ para $27 \%$ ). No entanto, a do setor de serviços elevou-se 20 pontos percentuais (p.p.) no mesmo período (passando de 45\% para 66\% do valor adicionado ao PIB).

Gráfico 2 - Valor adicionado por setor (\% do PIB); BRIC; 1980-2012

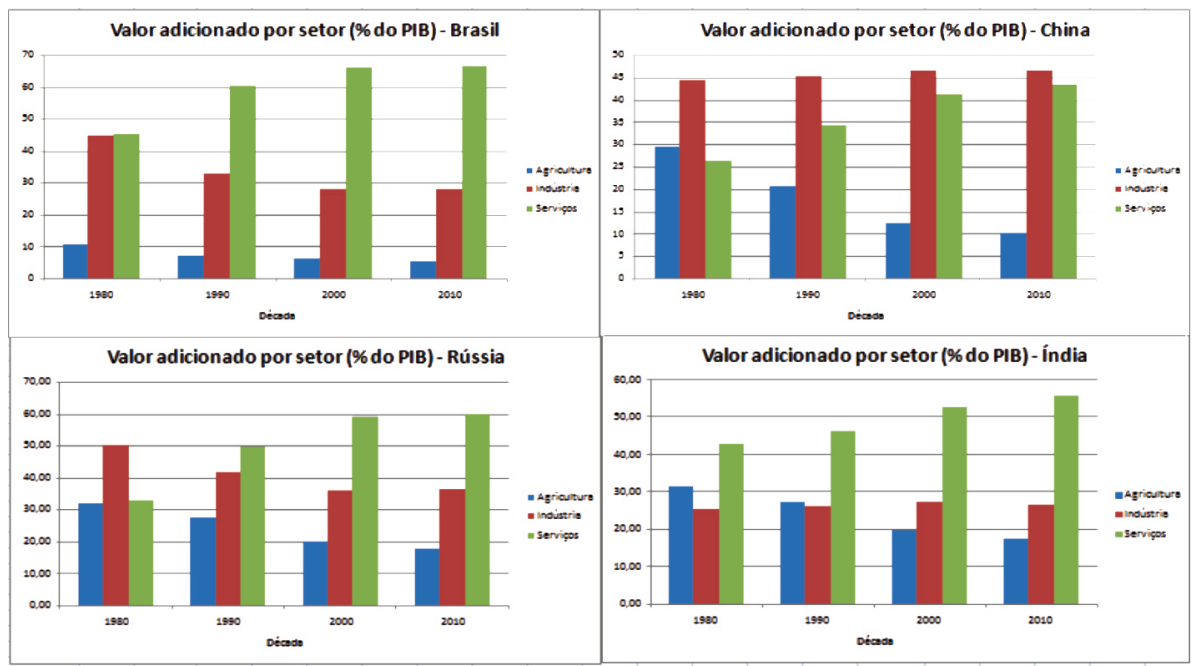

Fonte: World Development Indicators Database (2013).

A China apresenta uma trajetória bastante distinta das demais economias que compõem o grupo. Desde as reformas de Deng Xiaoping em 1978 ${ }^{14}$, a economia chinesa vivenciou um significativo processo de industrialização, com pesados investimentos estatais em setores específicos, especialmente aqueles relacionados com as exportações, como a criação das Zonas Econômicas Especiais (ZEE). Deste modo, na década atual, a participação do setor agrícola foi reduzida para aproximadamente um terço da verificada na década 1980, reduzindo sua participação de 29\% para aproximadamente 10\% no início de 2010, dando lugar à indústria, que saiu de $42 \%$ para $52 \%$ do PIB. O setor de serviços também elevou sua participação, passando de $26 \%$ para $43 \%$, considerando o mesmo período.

$\mathrm{Na}$ Índia, a agricultura e os serviços participavam em aproximadamente $31 \%$ e $42 \%$ do PIB, na década de 1980, respectivamente. No entanto, no decorrer de 30 anos, passaram a apresentar trajetórias significativamente distintas. No caso da agricultura, sua participação foi reduzida para 17\%. Já os serviços saltaram para aproximadamente $55 \%$ no início da década. A indústria, por sua vez, manteve uma participação próxima dos $26 \%$ em todo o período.

14 Não é objetivo deste trabalho examinar as reformas vivenciadas pela China a partir de $1978 \mathrm{e}$ sua performance de crescimento. Acerca desse aspecto, vide Medeiros (1999, 2008, 2010). 
Finalmente, a Rússia quase dobrou a participação do setor de serviços no PIB, saindo de 32\% nos anos de 1980 para aproximadamente 60\% na presente década. Tanto a indústria como a agricultura reduziram suas participações (que eram 50\% e 16\%, nos anos 80, para 36\% e 4,1\%, na década de 2010, respectivamente). Atualmente, a Rússia apresenta pesados investimentos em tecnologias relacionadas a produtos militares e energia (MEDEIROS, 2008).

O Gráfico 2 nos permite obter algumas conclusões: a) apenas no caso da economia chinesa a participação do setor de serviços é menor do que a dos demais setores; b) em todos os países que compõem o BRIC a agricultura apresenta a menor participação atualmente; c) O Brasil e a Rússia têm apresentado uma trajetória de perda na participação relativa da indústria no PIB, no entanto no Brasil tal participação é ainda menor ${ }^{15}$.

Gráfico 3 - Valor adicionado da Indústria de transformação (\% do PIB); BRIC, 1980-2012.

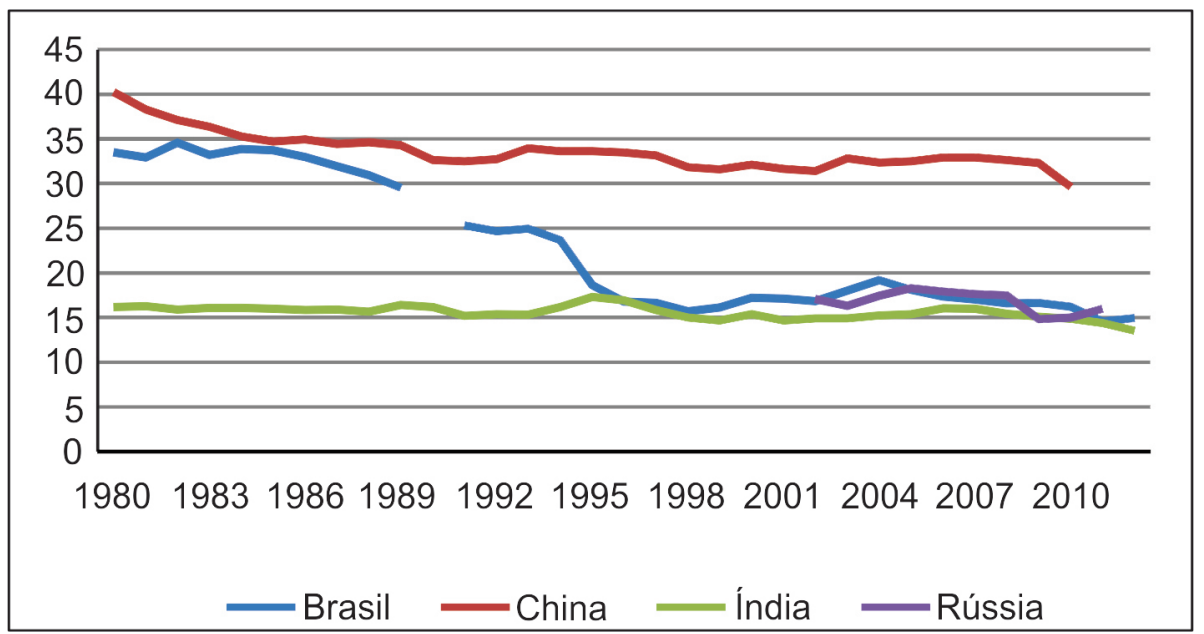

Fonte: World Development Indicators Database (2013).

Face ao exposto, o valor adicionado da indústria no PIB teve um comportamento assimétrico entre os BRIC. Observando especificamente o desempenho da indústria de transformação no Gráfico 3, desde a década de 1980 o Brasil apresenta queda persistente neste segmento. Atualmente esta indústria representa a metade da participação no início dos anos 80. Neste contexto, o Brasil sai de um patamar elevado, próximo ao chinês, igualando-se aos demais BRIC, com participação em torno de $15 \%$.

15 Entretanto, vale lembrar que na Rússia a indústria extrativa é muito importante, e deve ser desmembrada da indústria de transformação para que se tenha uma análise mais adequada do atual estágio da última. 
Não obstante, em se tratando da China, mesmo caindo 10 pontos percentuais, a indústria de transformação continua tendo elevada participação no PIB (aproximadamente 30\%). Já os dados disponíveis a partir de 2003 para a Rússia mostram uma trajetória constante desta variável, fato que também pode ser observado no caso da economia indiana.

A análise acima mostra que atualmente a economia que tem ampliado mais rapidamente a indústria de transformação é a chinesa, e a performance do seu PIB é consistente com o argumento de Kaldor. No mesmo sentido, a queda da participação da indústria de transformação no Brasil parece guardar relação com a queda da taxa de crescimento do produto.

O argumento de Kaldor não é, contudo, a única explicação possível para o fenômeno, posto que a existência de correlação entre ambas as variáveis não implica necessariamente a causalidade por ele postulada. É possível, alternativamente, que a queda na taxa de crescimento do produto - provocada por algum outro fenômeno - tenha, via efeito acelerador, reduzido a participação do investimento no PIB brasileiro. Como apontado pelo próprio Kaldor, o investimento é essencialmente industrial. Por essa via, portanto, seria possível apontar a existência de uma causalidade reversa. Fenômeno simétrico poderia ser invocado para explicar o caso chinês.

A análise de suas respectivas taxas de formação bruta de capital fixo ${ }^{16}$ (FBCF) em percentual do PIB nos ajuda a entender o comportamento da indústria de transformação. Atualmente, a FBCF representa 45\% do PIB chinês, a participação mais elevada entre os BRIC (Gráfico 4).

Gráfico 4 - Formação Bruta de Capital Fixo (\% do PIB); BRIC, 1980-2012

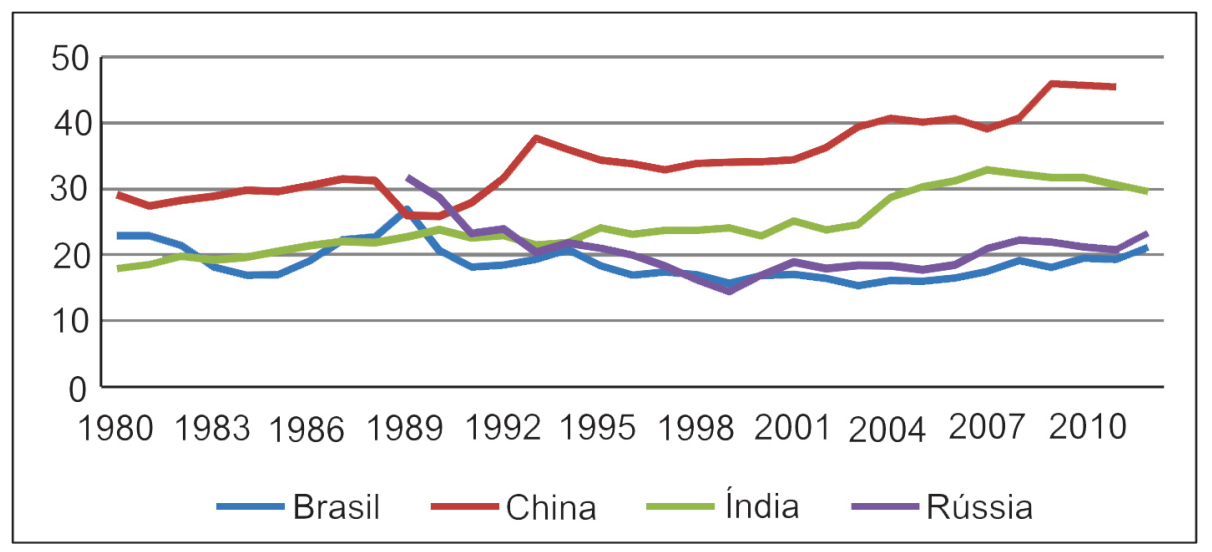

Fonte: World Development Indicators Database (2013).

$\overline{16}$ Considerada como proxy da taxa de investimento. 
No que concerne à Índia, a FBCF ocupa atualmente a segunda maior participação entre os países emergentes selecionados. Este indicador quase dobrou, saindo de 17\% em 1980 para algo em torno de 32\% em 2012.

A partir de 2000 a FBCF do Brasil é a menor do grupo, em torno de 20\% em média. O desempenho desta variável na Rússia apresentou trajetória decrescente ao longo do tempo, com sinais de recuperação a partir de 2001, chegando atualmente aos $22 \%$ do PIB.

Os dados do Brasil e da China são consistentes com ambas as explicações anteriormente aventadas para o co-movimento da participação no PIB da indústria de transformação e do crescimento do produto. Os casos da Índia e da Rússia parecem de mais difícil interpretação, na medida em que a elevação da taxa de investimento em ambas não é acompanhada por um aumento da participação da indústria de transformação.

No que tange à importância adquirida pelo BRIC no cenário internacional, Bamann, Araújo e Ferreira (2010) revelam que a participação das exportações chinesas no comércio mundial merece destaque, na medida em que aumentou aproximadamente cinco vezes na última década (passaram de 1,6\% em 1990 para 7,7\% em 2008).

Não obstante, nos demais países pertencentes ao grupo esta participação pouco se alterou. No caso brasileiro, a participação aumentou em 0,1 p.p. (passando de 0,9\% em 1990 para 1\% em 2008). A Rússia apresentou tendência semelhante à brasileira, elevando sua participação em 0,2 p.p. no mesmo período (de 2,1\% para 2,3\%). Já a Índia aumentou em três vezes sua participação (de 0,5\% em 1990 para 1,4\% em 2008), entretanto continua com uma participação pouco significativa.

Esse indicador de participação das exportações na corrente de comércio mundial nos fornece uma primeira indicação, ainda grosseira, das elasticidadesrenda envolvidas. China e Índia parecem dispor de elasticidades significativamente superiores a um, o oposto se dando com Rússia e Brasil, onde parecem próximas da unidade. Como visto no modelo de Thirlwall, isto tende a dotar as economias chinesa e indiana de uma taxa de crescimento sustentável mais elevada, e a gerar o fenômeno oposto sobre as economias russa e brasileira. E, seguindo Kaldor, esse fenômeno tende a prejudicar o crescimento da produtividade (tanto industrial quanto geral) nestas últimas duas nações vis-à-vis as primeiras, alterando a competitividade relativa das suas exportações e, portanto, reforçando o comportamento heterogêneo do crescimento. 
Tabela 1 - Participação das exportações de bens e serviços (\% do PIB) BRIC, 1970-2012.

\begin{tabular}{c|c|c|c|c|c}
\hline & Década 1970 & Década 1980 & Década 1990 & Década 2000 & Década 2010 \\
\hline Brasil & 7,5 & 10,1 & 8,5 & 13,4 & 11,9 \\
\hline China & 4,7 & 13,0 & 21,6 & 34,3 & 31 \\
\hline Índia & 5,3 & 6,0 & 10,0 & 17,6 & 23,2 \\
\hline Rússia & n.d. & n.d. & 31,4 & 34,3 & 29,6 \\
\hline
\end{tabular}

Fonte: World Development Indicators Database (2013).

n.d.: não disponível.

Os dados da Tabela 1 mostram a participação das exportações de bens e serviços no PIB de cada país, no período 1970-2012. No caso do Brasil, a participação das exportações quase dobrou nos anos 2000, entretanto sua taxa é a mais baixa dentre os países considerados, e representa aproximadamente um terço das participações da Rússia e da China, e a metade da indiana no período recente.

A Rússia e a China são os países que apresentam participações mais elevadas em relação ao grupo, no entanto no caso da Rússia, os dados para as décadas de 1970 e 1980 não se encontram disponíveis para comparações. Observando o caso chinês, verifica-se que a participação das exportações no PIB elevou-se 6,6 vezes. No que se refere à Índia, a participação aumentou em 4,4 vezes, entretanto é a segunda economia com participação mais baixa (à frente apenas do Brasil) dentre os BRIC.

A participação das importações chinesas e indianas no comércio mundial seguiu trajetória semelhante às exportações: a China aumentou sua participação em aproximadamente 5 vezes (passou de 1,3\% em 1990 para 6,0\% em 2008) e a Índia elevou sua participação 3 vezes (de 0,6\% em 1990 para 1,7\% em 2008). O Brasil ampliou sua participação em 1,2 vezes, no entanto representa menos de 1\% do comércio mundial (passando de 0,7\% em 1990 para 0,9\% em 2008). Das economias analisadas a Rússia foi a única cuja participação foi reduzida (de 2,1\% em 1990 para 1,6\% em 2008).

Os dados sobre importações e exportações de bens e serviços como \% do PIB, bem como os dados sobre o PIB mundial disponíveis na base de dados do Banco Mundial podem ser utilizados portanto para estimar a elasticidade-renda média das exportações e das importações para o período 1989-2013, bem como para subperíodos selecionados. Os dados são apresentados na Tabela 2 abaixo: 
Tabela 2 - Estimativas para a elasticidade-renda das exportações $(\boldsymbol{\varepsilon})$, a elasticidaderenda das importações $(\boldsymbol{\pi})$ e a razão entre elas $(\boldsymbol{\varepsilon} / \boldsymbol{\pi})$; BRIC, 1989-2013

\begin{tabular}{c|c|c|c|c}
\hline & Brasil & China & Índia & Rússia \\
\hline$\varepsilon$ & 1,54 & 3,38 & 2,44 & 1,28 \\
\hline$\pi$ & 1,64 & 1,24 & 1,74 & 1,05 \\
\hline$\varepsilon / \pi$ & 0,93 & 2,74 & 1,41 & 1,22 \\
\hline
\end{tabular}

Fonte: World Development Indicators Database (2013), elaboração própria.

Os dados permitem delinear uma hierarquia interessante em termos de potencial de crescimento sustentável: a China pode crescer 2,74 vezes mais depressa que o PIB mundial (ou o dos principais parceiros) a cada ano sem enfrentar restrições de balanço de pagamentos; a Índia, 1,41 vezes; a Rússia, 1,22 vezes; e o Brasil, 0,93 vezes. Isso significa que o comportamento estrutural das exportações e das importações do Brasil é fator fundamental para explicar o desempenho do tipo falling behind que este país vem enfrentando desde a "crise da dívida" dos anos 80: uma razão entre as elasticidades inferior a um simplesmente impossibilitou a aceleração sustentável do crescimento.

Note-se também que essa hierarquia é extremamente sugestiva, pois a ordem de crescimento dos PIBs efetivos só discrepa desta pela inversão de posições entre Brasil e Rússia. Também é interessante observar que, se desconsiderado o caótico início dos 90 neste último país, a hierarquia se mantém estritamente.

O Gráfico 5 permite avaliar a evolução deste indicador, crucial para o desempenho relativo dos países, ao longo de três subperíodos.

Gráfico 5 - Evolução do indicador $\varepsilon / \pi$ em subperíodos selecionados; BRIC, 1989-2013.

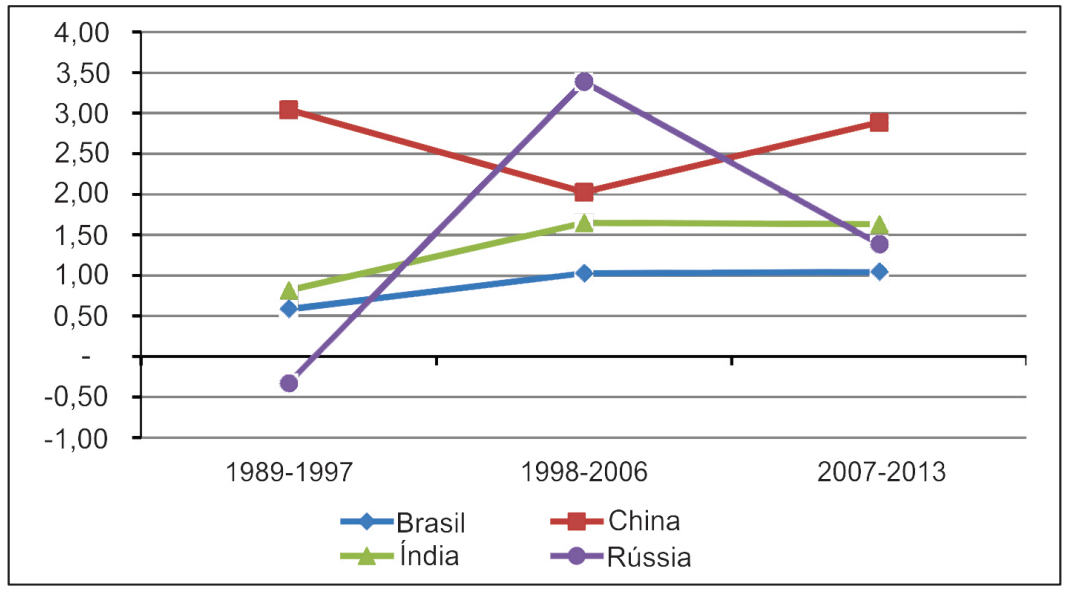

Fonte: World Development Indicators Database (2013).

Novos Cadernos NAEA • v. 21 n. 1 • p. 9-33 • jan-abr 2018 
Em primeiro lugar ressalta-se a volatilidade do indicador russo, posto que o período de crise do desmanche da antiga URSS influencia os dados iniciais (afora a conhecida sensibilidade russa ao movimento dos preços das commodities, claramente expresso pela inflexão causada pela crise recente). Em segundo lugar, chama a atenção o fato de que os demais membros mantêm suas posições relativas ao longo dos três subperíodos. Mostra-se ainda o indicador brasileiro profundamente afetado pelo "desastre" dos anos 90, superando marginalmente o valor crítico um desde então. É interessante também observar que o indicador brasileiro não infletiu desde a eclosão da crise em 2007/2008, o que significa que a desaceleração recente do crescimento não foi causada por uma adicional perda relativa de competitividade.

Passamos agora a tentar entender melhor os componentes estruturais que determinaram este comportamento das exportações. Com base no Gráfico 6, no período entre 1988 e 2009, percebe-se que as exportações de alta tecnologia como percentual das exportações de manufaturas cresceram de forma acelerada na China (passando de 6\% em 1992, para 31\% em 2009). A Índia foi a economia que apresentou participação mais baixa (9\%), assim como a Rússia (9\%), entretanto a primeira seguiu uma trajetória constante, enquanto a segunda vivenciou muitas oscilações durante o período em análise. No caso do Brasil, as exportações de produtos de alta tecnologia representaram 14\% das exportações de manufaturados atualmente, no entanto, chegou a atingir um pico de $19 \%$ do total das exportações em 2000. A Rússia apresentou um pico em 2002 (20\%), seguido contudo por brusca queda a seu ponto de partida nos anos 1990.

Gráfico 6 - Exportações de alta tecnologia (em \% das exportações de manufaturas); BRIC, 1988-2009.

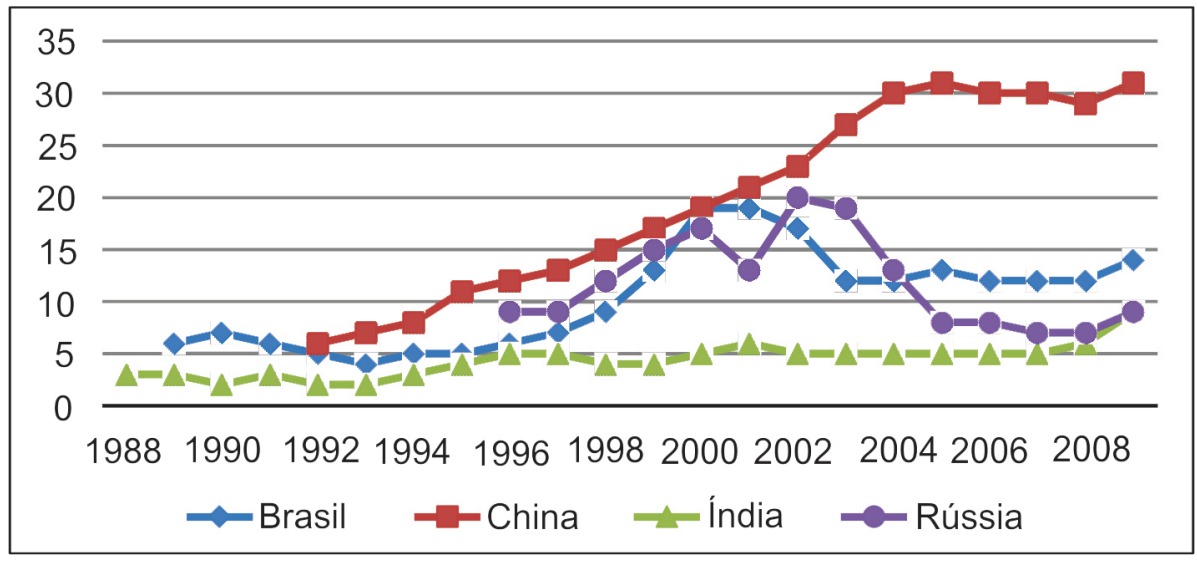

Fonte: World Development Indicators Database (2013). 
Como o foco desta análise é a economia brasileira, pode-se afirmar que fica patente que o padrão de especialização brasileiro não é constituído por produtos de alta tecnologia, onde o minério de ferro, soja e petróleo correspondem a 70\% da pauta exportadora do Brasil (IBGE, 2011). Desta forma, as exportações são intensivas em recursos naturais e commodities, diferentemente da pauta exportadora da China, intensiva em manufaturas e tecnologia da informação.

Gráfico 7 - Exportações e Importações de manufaturas (\% das exportações e importações totais); BRIC, 1980-2012.

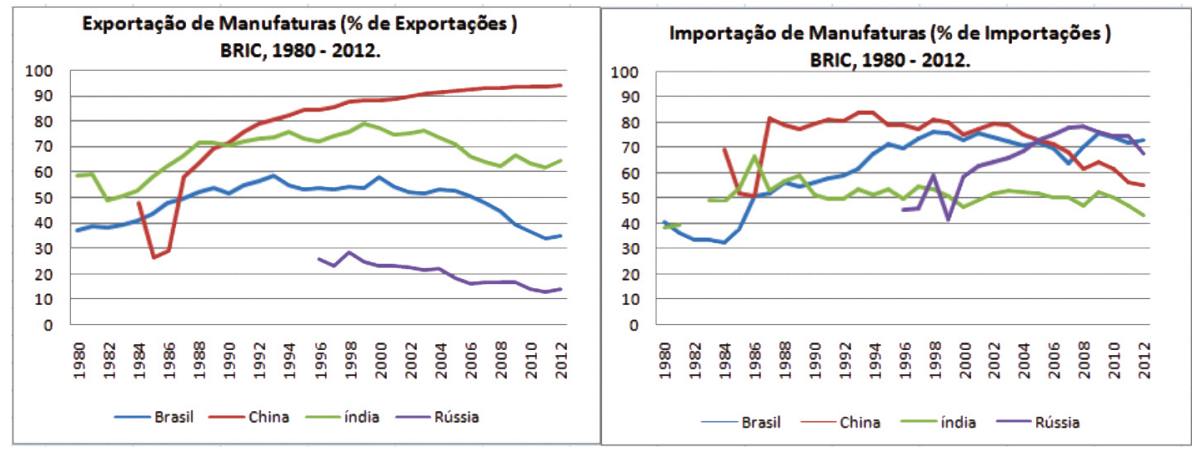

Fonte: World Development Indicators Database (2013).

A China se destaca na medida em que, desde 2000, os termos de troca foram desfavoráveis às suas exportações, o que, entretanto, não a impediu de atingir o status de maior exportadora mundial. Tal performance se deve às elevadas elasticidades renda de suas exportações, conforme ela foi promovendo políticas econômicas voltadas à gradual elevação da sofisticação de sua estrutura produtiva, cujos impactos são visíveis no Gráfico 8. Em contrapartida, o coeficiente de importação chinês é elevado, pois a mesma importa do Japão e de outros países asiáticos produtos fragmentados da cadeia produtiva na área de tecnologia de informação, ficando responsável pela montagem e reprocessamento das exportações (MEDEIROS, 2010).

Atualmente, a China é a maior exportadora do mundo e ocupa a posição de segunda maior importadora mundial, entretanto ela não é a maior produtora. Isto desperta atenção, pois a parcela das exportações chinesas no produto mundial é superior a parcela da produção industrial chinesa no produto mundial (MEDEIROS, 2010).

No tocante à Rússia, o padrão de especialização é voltado para as exportações de commodities (principalmente energéticas), e a elevação nos preços destas na década de 2000 tem contribuído para a significativa expansão econômica vivenciada no período recente. Assim, mesmo após enfrentar uma 
grave depressão na década de 1990, decorrente do esfacelamento da URSS, a partir de 1999, o aumento dos preços do petróleo e uma conjuntura internacional favorável contribuíram para recuperação nas taxas de crescimento do PIB e para o aumento das exportações (CARVALHO, 2009).

A Índia apresentou significativas mudanças na composição de suas exportações desde o início das reformas em 1991. De acordo com Leão e Oliveira (2010), as transformações nesta composição podem ser divididas em duas fases: na primeira, a composição das exportações de todos os tipos de produtos ficou constante (1995 a 2002); entretanto, na segunda fase, os setores básicos e outros manufaturados continuaram liderando as exportações, porém os setores de combustível e máquinas e equipamentos foram os que mais cresceram.

Para se ter uma ideia do estado do Brasil em relação aos demais países que compõem o BRIC, no que tange aos investimentos em Pesquisa e Desenvolvimento $(\mathrm{P} \& \mathrm{D})$, pode-se observar os dados acerca dos respectivos sistemas nacionais de inovação, conforme exposto por Lastres et al (2007, p.16).

A Rússia apresenta forte posição relativa no que concerne ao investimento em educação superior, com poderoso sistema científico, particularmente dedicado às atividades espaciais e relacionadas à defesa, além de apresentar expansão nos gastos em P\&D.

Já a Índia tem se destacado pela alta qualidade do sistema científico (e em expansão), entretanto com P\&D industrial relativamente modesta. Os recursos humanos presentes são de alta qualidade e capacitações produtivas particularmente em tecnologias da informação.

Observando a China, verifica-se um acúmulo de capacitações produtivas e inovativas com esforço em atividades de P\&D crescendo a taxas elevadas, com ênfase nos setores bi-tech.

No Brasil, o sistema científico tem se qualificado. No entanto, as atividades de P\&D são bastante desiguais, com sucessos em áreas específicas (aeroespacial, energia, mineração, metalurgia e agronegócios). A partir da década de 1990 houve uma fragilização e desarticulação de alguns sistemas de inovação.

Ainda segundo Lastres et all (2007, p.17), os principais problemas encontrados no sistema de inovação brasileiro são:

“a'fraca' performance competitiva com significativas fragilidades na produção e na exportação em setores de alto valor agregado e alto conteúdo tecnológico; mudanças patrimoniais significativas em diversos setores, com perda de participação de capital nacional; vulnerabilidade financeira dos grupos de capital nacional, resultado do alto custo do capital e inexistência ou ineficácia de mecanismos de financiamento de longo prazo". 
Fica sugerido pela experiência chinesa o aproveitamento das oportunidades ${ }^{17}$ e a utilização da folga externa para a promoção de modificações relevantes na estrutura produtiva de sua economia. Isto permitiu a intensificação das exportações de bens com maior conteúdo tecnológico ${ }^{18}$.

Deste modo, a economia chinesa, além de aproveitar as oportunidades surgidas pela conjuntura internacional, contou (e ainda conta) com instituições internas, e principalmente, com muitas das políticas (senão todas) fundamentais ao desenvolvimento esboçadas por OCAMPO, JOMO e VOS (2007): política macroeconômica de suporte (sobretudo cambial), proteção seletiva a indústria nascente, subsídios às exportações, direcionamento do crédito, alianças estratégicas com multinacionais e investimento em recursos humanos.

No caso da China, por exemplo, os vários planos quinquenais foram estratégicos e modificaram a estrutura produtiva chinesa, podendo-se citar como principais políticas: a criação das ZEEs; a taxa de câmbio significativamente desvalorizada; pesados investimentos em recursos humanos; acordos bilaterais (principalmente com o Japão) e com multinacionais, entre outros. Assim, os planos quinquenais responderam, e ainda respondem, às necessidades nascentes da indústria nacional em cada período (MEDEROS, 2008).

No caso do Brasil não existe um projeto explícito de desenvolvimento econômico, como verificado na China, nem tampouco uma maior integração entre as cadeias produtivas industriais. Mesmo com os sinais de recuperação do desempenho exportador desde 2002, esta melhora parece ter refletido principalmente o ambiente externo benigno (PRATES, 2005) decorrente do crescimento da China ${ }^{19}$ e dos Estados Unidos, bem como da melhora nos termos de troca para os principais produtos de exportação da pauta brasileira.

Seria precoce, e até mesmo exagerado, afirmar que a Índia alcançará os patamares da China em termos de conteúdo tecnológico das exportações no curto prazo. Entretanto, a FBCF (em \% do PIB) da Índia é a segunda mais alta (em torno de $30 \%$ ) entre os países que compõem os BRIC. Como visto, isto tende a acelerar a velocidade de difusão do progresso técnico incorporado nos bens de capital e o crescimento da produtividade nos diversos setores da sua economia.

\footnotetext{
17 Podendo-se citar o desenvolvimento a convite feito pelos Estados Unidos à China e a Índia.

18 Outro caso de relativo sucesso que pode ser citado é a Coréia do Sul, entretanto não é objeto deste estudo. Uma análise sobre as transformações na estrutura produtiva na Coréia do Sul, bem como as principais políticas que propiciaram tais transformações pode ser encontrada em Coutinho (1999) e Canuto (1994).

19 Decorrente da elevação na demanda chinesa por commodities.
} 


\section{CONSIDERAÇÕES FINAIS}

Mesmo apresentando taxas de crescimento do produto relativamente elevadas na última década, o comportamento das exportações, bem como o seu conteúdo, tem se manifestado de forma distinta em cada um dos BRIC. A comparação entre eles revelou uma série de fenômenos e regularidades empíricas no período analisado que convém resumir:

As taxas de crescimento relativas das economias estiveram estreitamente associadas às respectivas razões entre as elasticidades-renda da demanda por exportações e por importações, como sugere a análise de Thirlwall; a análise porém precisa ser matizada conforme o subperíodo, o que sugere que a extensão dos subperíodos adotados (entre 6 e 8 anos) é insuficiente para que os fatores estruturais da análise teórica se manifestem integralmente;

Os países que cresceram mais rapidamente são os que menos perderam participação tanto do setor industrial em geral quanto especificamente da indústria de transformação no valor agregado, como sugere o tratamento de Kaldor;

Os países que crescem mais depressa apresentaram taxas de investimento mais elevadas (o que pode inclusive ajudar a explicar o fato anterior), também em consonância ao arcabouço empírico tratado no artigo;

Esta "associação de hierarquias" não se mantém completamente quando se observam os indicadores \% das exportações e importações industriais nas exportações e importações totais; e \% das exportações de alta tecnologia nas exportações industriais. Embora de fato a China e a Índia se mantenham como líderes no primeiro indicador, Brasil e Rússia invertem posições, possivelmente devido à enorme concentração das exportações russas em commodities (e todos, exceto a China, perdem participação industrial nas exportações totais). E a despeito da China também permanecer como líder no segundo indicador, o Brasil supera Índia e Rússia (hoje virtualmente empatados). A posição brasileira neste aspecto talvez ajude a explicar porque as elasticidades-renda das exportações e importações se recuperaram ligeiramente dos números desastrosos da década de 1990, sem tampouco gerar situação externa confortável.

Diante desse quadro, a hipótese do trabalho não parece falsificada, embora algumas qualificações precisem ser adotadas.

Os dados revelam que a China tem continuado seu processo de transformação estrutural, mudando o foco das políticas conforme as necessidades dos setores mais sofisticados. Neste sentido, parecem validar (ao menos entre o grupo analisado) o bordão de Myrdal (1957, p. 21), segundo o qual “em geral, são 
os países industrializados os que estão se industrializando mais", e a busca pela inovação neste setor é crescente.

A Rússia tem se recuperado após a terrível crise econômica e mesmo humanitária da década de 1990. Contudo, ela enfrenta hoje sérios problemas estruturais em decorrência de sua dificuldade de empregar civilmente a tecnologia militar que continua a desenvolver, e da elevada sensibilidade da economia às oscilações nos preços das commodities, em particular das energéticas. A escassez de dados comparáveis no período socialista impediu uma análise mais profunda desta economia.

Já a Índia tem crescido de forma relativamente regular ao longo do período analisado e é vista como uma economia bastante promissora para os próximos anos. Sua frágil agricultura, porém, continua sendo seu calcanhar de Aquiles (NAGARAJ, 2008), e sua questão energética continua em aberto, a despeito do recente acordo nuclear com os EUA. Avanços recentes na \% das exportações de alta tecnologia nas exportações industriais parecem apontar um possível canal de aprofundamento do desenvolvimento.

Pode-se concluir que, em termos de estrutura, a economia indiana não se encontra em estágio muito distinto do brasileiro, na medida em que os dados revelam performances semelhantes. Na Índia a participação do valor adicionado da indústria no PIB é $26 \%$, enquanto no Brasil esta participação é de $27 \%$. No que concerne às exportações de produtos de alta tecnologia em percentual das exportações de manufaturas, o Brasil apresenta resultado superior ao indiano, 14\% a 9\%. Entretanto, enquanto as exportações de manufaturas em percentual das exportações totais apresentam trajetória crescente na Índia (média de 70\% entre 2000 e 2012), no Brasil esta trajetória é decrescente (média de 47\% entre 2000 e 2012), principalmente a partir de 2009, quando passou a representar $37 \%$ das exportações totais.

A principal mensagem de política econômica que parece advir da comparação dos dados brasileiros com os dos demais países dos BRIC parecem ser a de que a política econômica deve ir além da perseguição da estabilidade macroeconômica, priorizando a transformação da estrutura produtiva em favor de produtos mais sofisticados e, portanto, com maior elasticidade renda da demanda. É de se esperar que, uma vez implantadas medidas neste campo, a consequente folga externa permita combinar os instrumentos de gestão da demanda agregada de forma a evitar um trade-off forte entre crescimento e estabilidade macro. 


\section{REFERÊNCIAS}

BAUMANN, R.; ARAÚJO, R.; FERREIRA, F. As relações comerciais do Brasil com os demais BRICs. In: O Brasil e os demais BRICs: Comércio e Política. Brasília, DF: CEPAL. Escritório no Brasil/IPEA, 2010.

CANUTO, O. Brasil e Coréia do Sul: os (Des)caminhos da Industrialização Tardia. São Paulo: Editora Nobel, 1994.

CARLIN, W.; SOSKICE, D. Macroeconomics: Imperfections, institutions and policies. Oxford: Oxford University Press, 2006.

CARVALHO, V. S. Evolução das exportações e de seus determinantes nos BRICS (Brasil, Rússia, Índia, China e África do Sul), nas últimas três décadas. 2009. Dissertação (Mestrado em Economia) - Universidade Federal de Uberlândia, Uberlândia-MG, 2009.

COUTINHO, L. Coreia do Sul e Brasil: paralelos, sucessos e desastres. In: FIORI, J. L. (org.). Estados e moedas no desenvolvimento das nações. Petrópolis-RJ: Vozes, 1999.

DASGUPTA, S.; SINGH, A. Manufacturing, services and premature deIndustrialization in developing countries: a kaldorian empirical analysis. 2006. (Não publicado)

FEIJÓ, C. A.; CARvalHO, P. G. M. Uma interpretação sobre a evolução da produtividade industrial no Brasil nos anos noventa e as leis de Kaldor. Nova Economia, Belo Horizonte, jul./dez. 2002.

FIORI, J.L. A nova geopolítica das nações e o lugar da Rússia, China, Índia, Brasil e África do Sul. Oikos, Rio de Janeiro, v. 6, n. 2, 2007.

FLIGENSPAN, F. B. O comércio exterior da indústria brasileira no período 1999-2005. 2009. Tese (Doutorado em Economia) - Universidade Federal do Rio Grande do Sul. Porto Alegre, 2009.

FREITAS, F. Uma análise crítica do modelo kaldoriano de crescimento liderado pelas exportações. In: ENCONTRO NACIONAL DE ECONOMIA - ANPEC, 31. Porto Seguro, 2003. Anais..., Porto Seguro: UFF, 2003.

FREITAS, F. Uma Análise da Evolução das Idéias de Kaldor sobre o Processo de Crescimento Econômico. 2002. Tese de doutorado - Instituto de Economia, Universidade Federal do Rio de Janeiro, Rio de Janeiro, 2002. (Não publicada)

FUNDO MONETÁRIO INTERNACIONAL. World Economic Outlook 2014. Disponível em: <http://www.imf.org/external/Pubs/ft/weo/2014/01/>. Acesso em: 17 jul. 2014. 
FURTADO, C. Teoria e Política do Desenvolvimento Econômico. São Paulo: Abril Cultural, 1983.

Desenvolvimento e subdesenvolvimento. Rio de Janeiro: Fundo de Cultura, 1961.

HARROD, R. F. An essay in dynamic theory. The Economic Journal, n. XLIX, Mar. 1939.

HICKS, J, R. A contribution to the Theory of the Trade Cycle. Oxford University Press, 1950.

IBGE - Instituto Brasileiro de Geografia e estatística. Disponível em: <https:// www.ibge.gov.br/>. Acesso em: 27 jul. 2017.

JONES, C. Introdução à teoria do crescimento econômico. Rio de Janeiro: Campus, 2000.

KALDOR, N. The case for regional policies. Scottish Journal of Political Economy, nov. 1970.

LASTRES, H. M. M. et al. Projeto BRICS: estudo comparativo dos Sistemas de Inovação no Brasil, Rússia, Índia, China e África do Sul, 2007. Disponível em: <www. redesist.ie.ufrj.br>. Acesso em: 15 set. 2012.

LEÃO, R. P. E.; OLIVEIRA, I. T. M. Comércio exterior e política comercial indiana em análise. In: SILVA, L. A.; LEÃO, R. P. F.; HIRATUKA, C (Org.). Comércio Internacional: aspectos teóricos e a experiência indiana e chinesa. Brasília: IPEA, 2010.

MADDISON, A. The World Economy: Historical Statistical. Organization for Economic Co-operation and Development. Development Centre, Source OECD, 2001.

MEDEIROS, C. A. O ciclo recente de crescimento chinês e seus desafios. In: Observatório da economia global, n. 3, jun. 2010.

Desenvolvimento econômico e expansão nacional: rupturas e transições na Rússia e na China. In: FIORI, J. L.; MEDEIROS, C. A.; SERRANO, F. O mito do colapso do poder americano. Rio de Janeiro: Record, 2008.

China: entre os séculos XX e XXI. In: FIORI, J. L. (Org.). Estados e moedas no desenvolvimento das nações. Petrópolis-RJ: Vozes, 1999.

MYRDAL, G. Economic Theory and Underdeveloped Regions. Londres: Duckworth, 1957. Tradução para português: Teoria econômica e regiões subdesenvolvidas. Rio de Janeiro: Saga, 1965.

OCAMPO, J. A.; JOMO, K. S.; VOS, R. Explaining Growth Divergence. In: 
OCAMPO, J. A.; JOMO, K. S.; VOS, R. (Ed.). Growth Divergences. Londres: Zed Books, 2007.

PREBISCH, R. El desarrollo económico de América Latina y sus principales problemas. Santiago do Chile: Comissão Econômica para a América Latina e o Caribe (Cepal), 1949.

RICARDO, D. Princípios de Economia Política e Tributação. Lisboa: Fundação Calouste Gulbenkian, 1965.

SINGER, H. The Distribution of Gains Between Investing and Borrowing Countries. American Economic Review, v. 40, n. 2, May 1950.

SMITH, A. A riqueza das nações: investigação sobre suas naturezas e suas causas. 2. ed. São Paulo: Nova Cultural, 1985.

SOLOW, R. A contribution to the theory of economic growth. The Quarterly Journal of Economics, p. 65-94, 1956.

THE ECONOMIST. Emerging Economies: The Great Deceleration. 2013. Disponível em: < https://www.economist.com/news/leaders/21582256-emergingmarket-slowdown-not-beginning-bust-it-turning-point $>$. Acesso em: 27 jul. 2013.

THIRLWALL, A. P. A natureza do crescimento econômico: um referencial alternativo para compreender o desempenho das nações. Brasília: IPEA, 2005.

The estate of Nicholas Kaldor. New York: Cambridge University Press, 1996.

The balance of payments constraint as an explanation of international growth rates differences. Banca Nazionale del Lavoro Quarterly Review, v. 128, 1979.

UNCTAD - United Nations Conference on Trade and Development. 2013. Disponível em: <http://unctadstat.unctad.org/EN/>. Acesso em: 25 jul. 2013.

UNDP - United Nations Development Programme. Human Development Report 2013. Disponível em:< http://www.undp.org>. Acesso em: 17 jul. 2014. 


\title{
Encadeamento ecossocioeconômico e gestão urbana: um estudo das feiras livres na cidade de Curitiba (PR)
}

\author{
Socio-economic and urban management: a study of the free trade \\ fairs in the city of Curitiba (PR)
}

Isabel Jurema Grimm - Doutora em Meio Ambiente e Desenvolvimento pela UFPR e Mestra em Desenvolvimento Regional pela FURB. Pesquisadora do NECOS da UFPR $\backslash$ PR com ênfase na Ecossocioeconomia Urbana. E-mail: isabelgrimm@gmail.com

Carlos Cioce Sampaio - Doutor em Planejamento e Gestão Organizacional para o Desenvolvimento Sustentável pela UFSC. Pós-doutor em Ecossocioeconomia, Cooperativismo Corporativo e Ciências Ambientais pela Universidade Austral de Chile $(\mathrm{UACH})$. Pesquisador de produtividade do CNPq. Coordenador da Área de Ciências Ambientais da CAPES. E-mail: carlos.cioce@gmail.com

Mario Procopick - Doutor em Administração e Mestre em Gestão Urbana pela PUCPR. Professor do PUCPR. E-mail: procopiuck@gmail.com

\begin{abstract}
Resumo
Neste artigo analisam-se as práticas de transformação social e gestão do espaço urbano na cidade de Curitiba, sob a perspectiva dos arranjos socioprodutivos denominados feiras livres e seus impactos ecossocioeconômicos. Metodologicamente trata-se de pesquisa com abordagem exploratória e qualitativa. Os dados foram coletados em entrevistas junto a gestores municipais, feirantes, prestadores de serviços terceirizados e por meio de registro de campo com visitas à feira do Largo da Ordem, por se constituir em importante espaço de interações culturais e estratégia de promoção da imagem turística da cidade de Curitiba. Os resultados apontam que as feiras livres podem ser consideradas arranjos socioprodutivos a partir da cooperação público-privada para planejamento e gestão do território. As feiras livres apresentam indícios da ecossocioeconomia onde pequenos negócios ganham visibilidade frente à economia de mercado pautada no lucro como máxima, aumentam sua possibilidade de sobrevivência e se estabelecem como estratégia local de geração de renda e inclusão social.
\end{abstract}

\section{Palavras-chave}

Arranjos Socioprodutivos. Ecossocioeconomia. Feiras Livres.

\begin{abstract}
This article analyzes the practices of social transformation and urban space management in the city of Curitiba, under the perspective of socio-productive arrangements called free trade fairs and their eco-socio-economic impacts. Methodologically it is a research with exploratory and qualitative approach. The data were collected in interviews with municipal managers, marketers, outsourced service providers and through field entries with visits to Largo da Ordem fair, as it is an important space for cultural interactions and a strategy to promote the tourist image of the city of Curitiba. The results point out that the free trade fairs can be considered socio-productive arrangements from public-private cooperation for planning and managing the territory. Free trade fairs present signs of eco-socio-economy where small businesses gain visibility facing the profit-driven market economy, increase their chances of survival, and establish themselves as a local strategy for income generation and social inclusion.
\end{abstract}

\section{Keywords}

Socio-productive Arrangements. Eco-socioeconomy. Free Trade Fairs. 


\section{INTRODUÇÃO}

Os dados do Programa das Nações Unidas para Assentamentos Humanos (ONU - Habitat, 2014) apontam que a população urbana mundial foi multiplicada por cinco entre 1950 e 2011. Em 2007, o número de pessoas vivendo em cidades ultrapassou a cifra daquelas que viviam no campo. Exemplificando o potencial desse processo, somente entre 1995 e 2005, a população das cidades nos países subdesenvolvidos ou em desenvolvimento cresceu, em média, em 1.200.000 por semana, ou 165.000 habitantes por dia. Calcula-se que até 2050, 86\% da população de países ricos e $67 \%$ de países pobres estejam vivendo fora do campo (ONU - Habitat, 2014), o que significa que três quartos da população mundial estará ocupando áreas hoje cobertas por vegetação, criando espaços diminutos de sobrevivência e habitação, utilizando recursos naturais, buscado formas de subsistência e demandando a prestação dos serviços públicos.

Esse cenário envolve a comunidade mundial na tentativa de criar estratégias e ações para superar a própria modernidade, pois, na medida em que a população das cidades e o consumo aumentam, a questão socioambiental exige soluções inovadoras capazes de influenciar no planejamento e na tomada de decisões em cenário de pós-modernidade.

Possuidora de características próprias, é na cidade onde se torna essencial determinar a forma de governo e gestão, com instrumentos que apresentem relação direta com o tipo de desenvolvimento adotado localmente, servindo como influenciador direto na criação e na formulação de políticas públicas, que satisfaçam as diversas necessidades da população, como saúde, educação, segurança e a geração de trabalho e renda.

Nesse contexto, como espaços de intensa interação humana, as feiras, desde a antiguidade, têm desempenhado papel fundamental como canais de comercialização agrícolas e artesanais, constituindo-se em importantes arranjos socioprodutivos que absorvem mão de obra com diferentes níveis de qualificação. São atividades que, para alguns, representam opções mais importantes que aquelas oferecidas pelo mercado, possibilitando bons níveis de renda e autonomia para condução das próprias vidas em condições mais atrativas que aquelas impostas para condicionamento por tradicionais postos de trabalho, e, para outras, de acordo com Santos M., Ferreira D. e Santos R. (2014), as feiras livres apresentam relevância por serem importantes fontes de renda familiar, cujos membros não se inseriram no mercado de trabalho via empregos, sendo a feira livre, em sua complexidade de relações sociais e econômicas, uma das poucas alternativas de sobrevivência. 
As feiras livres urbanas, como experiências em curso, podem ser identificadas como núcleos ecossocioeconômicos, que têm seus fundamentos de existência e permanência, nas dinâmicas participativas e associativas, que formam um entorno territorial de cooperação, saberes e fazeres intrínsecos ao local. Portanto, nos ambientes urbanos são espaços que apresentam desafios a serem enfrentados e onde, de acordo com Ornés (2014), somente uma consciente gestão do uso dos recursos ambientais, sociais, econômicos e institucionais, baseados na sustentabilidade, podem garantir qualidade de vida no curto, médio e longo prazo. Isso decorre da complexidade dos componentes, processos e as inter-relações que envolvem uma urbe.

Assim, busca-se neste artigo analisar as práticas de transformação social e a gestão do espaço urbano na cidade de Curitiba, sob a perspectiva dos arranjos socioprodutivos denominados feiras livres e seus impactos ecossocioeconômicos.

\section{PLANEJAMENTO E A GESTÃO URBANA ENQUANTO PRÁTICA DE PARTICIPAÇÃO SOCIAL}

Os avanços em torno do planejamento urbano e a descentralização do poder nacional para os níveis locais atribuíram às cidades maior autonomia para a criação das suas estratégias de desenvolvimento, incorporando o conceito de gestão como instrumento fundamental, coletivo e participativo para viabilizar projetos com impactos na comunidade local. Isso tem levado os gestores urbanos a compreenderem que, para haver desenvolvimento sustentável é necessária a realização do planejamento integrado que associe cooperação técnica, território e participação popular. Neste contexto, quando se trata da mobilização de esforços coletivos, essa associação com o planejamento urbano autônomo implica, como propõe Bizzotto, Carvalho e Gonçalves (2014), “abandonar a compreensão do discurso dominante tecnocrático como dotado de poder em uma versão estruturalista, resgatando a experiência cotidiana e do culto ao saber local” (p.133).

Balizando os esforços para o avanço do tema da participação, as experiências dos movimentos populares nas décadas de 1970/80 trouxeram importantes contribuições para o processo de politização da sociedade civil organizada e conquistaram visibilidade no cenário político nacional. Tal processo abriu espaço para que movimentos sociais debatessem o papel do Estado, formas de organização da sociedade, cultura política do País, direitos sociais e a democracia. Contudo, nos anos de 1990, de acordo com Abranches (2013, p. 7), tais movimentos entraram em crise, tendo como causas as externalidades da política neoliberal, a convulsão econômica do país, a descrença na política e a crise 
das utopias. A autora destaca também fatores internos dessa crise que fizeram com que "movimentos populares não se fundamentassem em projetos políticos próprios, independentes e autônomos, que garantissem, na atualidade, estratégias que assegurassem seu campo de atuação na sociedade civil voltadas para a discussão da transformação social" (ABRANCHES, 2013, p. 7). Paralelamente à crise dos movimentos sociais, o planejamento regulado por leis e normas criadas pelo Estado demonstram sinais de enfraquecimento em decorrência de seu elevado custo e da necessidade de o Estado ter de, incessantemente, atrair investimentos externos.

Em relação ao planejamento urbano, Castells (1986) considera que seu surgimento, de certo modo, está atrelado às sociedades industriais avançadas e ao agravamento dos "problemas urbanos, isto é, processos sociais de consumo coletivo" (CASTELLS, 1986, p.209-210). Para muitos críticos, o que traz legitimidade a qualquer sistema de planejamento é que seja desenvolvido a partir de bases políticas. É dessas bases, pois, que ocorrem ajustes em função do que os cidadãos participando de processos democráticos fazem com que suas aspirações sejam contempladas nos planos. Sem política, temos, pois, o velho planejamento tecnocrático

De forma ampla, as condições para obtenção de uma cidade mais sustentável e humana demanda um novo modelo de urbanismo mais voltado para a qualidade de vida de seus moradores. E, neste contexto, Rebouças (2015) chama atenção para a necessidade de construção de um planejamento urbano menos vertical, mas, articulado horizontalmente, com base nas necessidades e desejos locais, incorporando os conflitos inerentes às realidades de cada lugar.

\section{O DESENVOLVIMENTO E OS ARRANJOS SOCIOPRODUTIVOS DE BASE TERRITORIAL}

Para Jean (2010), a noção de território surge do entendimento formado pela dinâmica de atores sociais que ocupam um espaço determinado, nomeado e identificado na forma de identidade individual e social, com referenciais familiares e profissionais. O desenvolvimento territorial faz "referência a um espaço geográfico que não é dado, mas construído" (JEAN, 2010, p. 51), pela história, por uma cultura e por redes sociais que desenham suas fronteiras.

O conceito de território inclui a noção de patrimônio sociocultural e a necessidade de mobilização dos recursos e competências por meio da atribuição de responsabilidades sociais, normalmente via processos participativos. A concepção de território passa pelo senso de identidade, ou seja, não se concebe 
um indivíduo sem antes ser identificado com seu território. Portanto, a identidade sociocultural individual está inarredavelmente ligada aos atributos do espaço concreto (SOUZA, 2002).

É a partir do território que surgem novas propostas de desenvolvimento, somadas a visões críticas não conformes com as posturas de um progresso linear, que dão ressonância a reivindicações no terreno social e ambiental (UNCETA, 2009). Isso requer maior capacidade e grau de organização e de articulação da sociedade civil e das instâncias institucionais mecanismos de descentralização que busquem a efetivação dos princípios de igualdade e de garantia dos direitos humanos.

A importância de reorganizar os territórios com base no fomento de ações descentralizadas tendeu a ampliar a dinamização das sociedades locais, ganhando natureza estratégica para promover a competitividade e a competência de sistemas produtivos locais, tendo como sustentação a capacidade de comunidades de criarem meios para oportunizar decisões coletivas, como contraponto às pressões exercidas pela economia global (BOISIER, 1996), e pelas forças estatais centralizadas desde a década de 1960, principalmente no caso brasileiro.

A trajetória histórica que levou à explicitação de tensões entre a necessidade de manter um mínimo de poder para constituir identidades locais e a necessidade de potencializar a capacidade de ação de estados nacionais, as estratégias de países em vias de desenvolvimento voltadas para a diminuição das desigualdades e redução da pobreza passam, com diferentes intensidades no tempo e no espaço, a se pautarem em políticas de desenvolvimento territorial, cuja finalidade tem sido "promover uma redução das disparidades regionais, de maneira autônoma e endógena, a partir da indução da constituição de arranjos socioprodutivos", atendendo aos propósitos "participativos do poder político local e da sociedade civil organizada” (ORTEGA, 2001, p. 3).

Em meio a essas tendências, a concepção de arranjos socioprodutivos (ASP), embora não necessariamente vinculada ao dinamismo técnico e científico, tem se mostrado promissora para a geração de bem-estar em contextos em que o capital humano não se ajusta, não tem espaço ou não se mostra propenso a suprir demandas das forças produtivas de massa. Nesses espaços, a organização das feiras urbanas parece ter mais identificação com uma conjunção de fatores vinculados à capacidade local de mobilizar capital social para buscar perspectivas de desenvolvimento pautado em uma lógica menos dependente daquelas formas de produção intensivas em recursos de capital e de forte presença regulatória estatal. Esse capital social se manifesta através da confiança, normas e cadeias de relações sociais e, ao contrário do capital físico convencional, que é privado, ele é 
um bem público e é pautado em " [...] características da organização social como confiança, normas e sistemas que contribuem para aumentar a eficiência da sociedade, facilitando as ações coordenadas" (PUTNAM, 2005). Para Coleman (1990), o capital social é um recurso alicerçado na estrutura de relações entre atores, constituindo um bem produtivo que torna possível realizar objetivos que, na sua ausência, são impossíveis de concretizar. Nessa linha, o "capital social é um fator intangível por natureza. É o acumulo de compromissos construídos pelas interações sociais em uma determinada localidade" (PELLIN; ALCANTARA; GONÇALVES, 2016, p. 3).

Neste contexto, os arranjos socioprodutivos (ASP), de acordo com Sampaio, Mantovaneli e Fernandes (2011), se articulam por uma lógica socioeconômica comum, dando ênfase à cooperação-competição, identidade sociocultural local, confiança mútua, fatores locais favoráveis (recursos naturais, recursos humanos, cultura, sistemas cognitivos, logística, infraestrutura etc.), capital social e capacidade de governança da comunidade. É, portanto, possível sugerir que os espaços ocupados por essas atividades preservam importantes traços dos modos de vida vinculados a outros tempos e a outros ciclos econômicos, combinando cultura e tradição para se tornarem elementos estratégicos de desenvolvimento sustentável a partir do fortalecimento das lógicas locais de convívio. Como elementos característicos desses espaços, as feiras livres urbanas, tão antigas quanto às próprias cidades, guardam consigo muito da cultura e do modo de vida do território em que estão implexas.

As feiras livres urbanas, como experiências em curso, podem ser identificadas como arranjos socioprodutivos que têm seus fundamentos, de acordo com Crocco et al. (2003), na forma de organização que auxilia a superar as barreiras de crescimento e assume os mais variados tamanhos, particularmente de pequenas e médias empresas. Para o autor, o arranjo socioprodutivo contribui para o surgimento de externalidades pecuniárias e tecnológicas ao mesmo tempo em que cria condições para uma interação cooperativa. Além dos efeitos positivos da troca e desenvolvimento de ideia, do compartilhamento de conhecimentos em tentativas coletivas de melhorar a qualidade de produtos e processos; de ocupar segmentos de mercado; de coordenar ações e de resolver problemas conjuntamente (CROCCO et al., 2003).

Portanto, considerando as articulações em microescala densamente associadas interna e externamente, as feiras livres urbanas podem ser consideradas como aglomerações de atividades familiares e de micro organizações que atuam sob a lógica de complementaridade em dado território. Como o ASP, essas feiras tendem a manifestar especializações produtivas vinculadas a identidades 
espaciais que facilitam a inserção da produção de microescala em mercados locais e, quando associada às atividades turísticas, com potencial de difusão mais global.

$\mathrm{Na}$ análise da constituição de um ASP é fundamental compreender a natureza das demandas das atividades familiares e empresariais comerciais e industriais de pequeno porte, inseridas densa e profundamente nos tecidos urbanos e voltadas para mercados locais ou regionais. Dentre essas atividades, as dos produtores ligados à pequena agricultura e ao artesanato podem se mostrar importantes para a dinamização da vida econômica e social local. Assim, por um lado, as iniciativas desses segmentos podem estabelecer perspectivas de sustentabilidade do desenvolvimento local/regional e, por outro, como importantes meios para combater a pobreza e a exclusão social a partir da melhoria das condições de vida. A identificação e sistematização das condições estruturais que condicionam a concretização de tais benefícios é passível de ser observada em numerosas experiências exitosas, o que fortalece e inova postulados da ecossocioeconomia no debate contemporâneo.

\section{FEIRAS LIVRES: TERRITÓRIOS DE ORGANIZAÇÃO E INCLUSÃO}

Os registros históricos sinalizam que os povos sumérios 3.000 a.C., já organizavam feiras para viabilizar transações comerciais mediante trocas e barganhas em local e dias específicos, o que futuramente daria origem ao uso da moeda para compra e venda de mercadorias, gerando as condições iniciais para expansão e institucionalização do intercâmbio entre os diferentes lugares da Europa e do mundo, com base em distintas moedas utilizadas nas negociações. Nessa trajetória, o surgimento de cambistas e comerciantes especializados na troca de moedas são exemplos de atividades originárias pelo comércio das feiras, o que, mais tarde, daria origem aos bancos e banqueiros e, com eles, os novos sistemas de pagamentos, como letras de feira e letras de câmbio.

Com a expansão internacional das atividades comerciais que as feiras propiciaram, passou a se desenvolver um novo sistema de administração comercial pautado em taxas de juros e métodos matemáticos, como o sistema decimal. Retomar à origem dessas atividades comerciais é fundamental para compreender o início do sistema capitalista racional, sustentado por taxas, juros, capital, bancos e lucros. Assim, o microssistema organizacional da feira continua a desempenhar um "importante papel econômico, social e cultural e [...] quando entendida como um negócio, [...] se torna um forte instrumento de políticas públicas e um grande gerador de emprego e renda para o município" (SALES; REZENDE; SETTE, 2011, p. 1). 
Baseadas nos postulados da economia solidária, as feiras caracterizam-se por promover a inclusão social e contribuir com o desenvolvimento sustentável, como um processo de melhoria da qualidade de vida que compatibiliza o crescimento econômico, a conservação dos recursos naturais e a igualdade social, no curto e no longo prazo (MINISTÉRIO DO TRABALHO E EMPREGO, 2007). Para Singer (2002), a economia solidária baseia-se no humanismo, na solidariedade e na cooperação materializadas na propriedade coletiva dos meios de produção e autogestão, preservando-se o direito à liberdade individual.

Não obstante a passagem do tempo, a feira é uma atividade econômica e social relevante para a vida de muitos brasileiros, mas, em grande parte, as dificuldades para incorporação de inovações as tem colocado em crescente desvantagem para acompanhar a evolução dos super e hipermercados (SATO, 2007), bem como dos serviços prestados por outros locais de comercialização. Do ponto de vista cultural, a feira livre se mantém como importante instituição que resguarda tradições, que resistem ao processo de modernização (COUTINHO; NEVES; SILVA, 2006). As feiras livres apresentam singularidades que as tornam um espaço de comercialização atrativo aos consumidores, por oferecerem produtos diferenciados (produzidos de maneira quase artesanal e em pequena escala) e por estreitarem relações de amizade e confiança entre vendedores e compradores (SALES; REZENDE; SETTE, 2011).

Mesmo com tantos diferenciais e atributos competitivos, o crescimento e desenvolvimento das feiras livres ainda é cerceado pela falta de conhecimento, informação e recursos dos feirantes, que, por não possuírem condições de promover suas vendas e atrair clientes, perdem espaço para grandes canais de comercialização. Como um negócio, a feira "precisa receber a aplicação de princípios administrativos, de forma a garantir a sobrevivência dos feirantes, como empreendedores, no mercado competitivo em que estão inseridos" (SALES; REZENDE; SETTE, 2011,p.3).

Não obstante as dificuldades que enfrentam na atualidade, as feiras livres urbanas mantêm grande parte da sua dinamicidade que historicamente tem acompanhado a vida humana, principalmente nos centros urbanos e respectivos entornos. Considerando as peculiaridades de cada época, elas sempre foram e continuam a ser objeto de interesse para políticas públicas, que procuram promover a geração de trabalho e renda, oferecendo alternativas econômicas, sociais e de preservação ambiental para comerciantes, pequenos proprietários rurais e para sociedades locais. 


\section{MATERIAIS E MÉTODO}

As etapas metodológicas foram estruturadas da seguinte forma: (a) pesquisa bibliográfica e documental; (b) coleta de dados para análise do encadeamento ecossocioeconômico; (c) entrevistas com gestores municipais e feirantes e (d) registro de campo.

O instrumento constituiu-se de um formulário padrão de pesquisa ecossocioeconomica para coleta de informações qualitativas a partir da interação de processos (ambientais, sociais e econômicos). Essas informações são obtidas a partir de: (a) aspectos gerais: histórico, organização; (b) problemática que deu origem à experiência e objetivos; (c) ações desenvolvidas e indicadores de sustentabilidade e; (d) da análise macro ambiental para apontar pontos fortes, fracos, ameaças e oportunidades. Os dados também foram coletados em entrevistas em profundidade realizadas com a Coordenação da Feira de Arte e Artesanato de Curitiba, responsável pela gestão da Feira do Largo da Ordem. Durante 4 meses (setembro a dezembro de 2016) foram realizados registros de campo, com visitas à Feira, entrevistas com feirantes e prestadores de serviços terceirizados.

Com base nesses métodos, a pesquisa apresenta enfoque exploratório, com análise sistemática do tema para produzir informações sólidas sobre uma espacialização em que incidem articulações dos setores governamentais e da sociedade civil para a elaboração de propostas conjuntas visando à intervenção no espaço urbano, empreendidas na cidade de Curitiba, e que resultaram na promoção da geração de trabalho e renda, na melhoria da qualidade de vida urbana, na constituição de um espaço de interações culturais e em estratégias de promoção da imagem turística da cidade.

\section{RESULTADOS E DISCUSSÕES}

A apresentação dos resultados e das discussões é realizada nas seções abaixo, primeiro, com base no mapeamento da feira do Largo da Ordem e, depois, a partir do encadeamento ecossocioeconômico do arranjo socioprodutivo a partir de categorias analíticas as dimensões socioculturais, econômica, ambiental e político espacial.

\subsection{MAPEAMENTO DA FEIRA DO LARGO DA ORDEM}

A Feira de Arte e Artesanato do Largo da Ordem é tradicionalmente conhecida como feirinha hippie ou simplesmente feirinha. Ela surgiu no início na 
década de 1950 no contexto do movimento hippie, caracterizado por Pereira (1990) como um anarquismo romântico. Nesse movimento grupos "marginalizados (Beatnik) ganham notoriedade. Com umaideologia anti-intelectualista, movimentos de contestação e agitação, por meio da poesia denominada beat, exprimem suas angústias, dramaticidade e ideologias" (BONZATTO; POLICHUK, 2014, p. 103). No espaço da feira esse grupo de artistas populares tinha como objetivo valorizar a cultura e divulgar sua arte, cuja exposição era feita em panos esticados na calçada. Nessa época não havia interferência governamental e os artesãos se organizavam de forma solidária e cooperativa, com suas atividades sujeitas às intempéries.

No final da década de 1960, a feira funcionava na Praça Osório e início da década de 1970 migrou para a Praça Zacarias, onde foram propostas diversas ações de restauro com a finalidade de revitalizar o lugar e transformá-lo em um centro cultural e turístico, retomando desta forma a finalidade e característica de espaço público (GALLARZA; BAPTISTA; CAVALCANTI, 2013). Em 1973 a feira se estabeleceu definitivamente no espaço do Largo Coronel Enéas, conhecido tradicionalmente como Largo da Ordem. Desde então seu crescimento vem sendo gradativo de acordo com os espaços disponíveis e, além da oportunidade de comercialização, tornou-se um atrativo turístico visitado de acordo com Lessnau (2017) por mais de 22.000 pessoas a cada edição.

Atualmente, a feira acontece aos domingos, das $9 \mathrm{~h}$ às $14 \mathrm{~h}$, no Centro Histórico de Curitiba. O deslocamento desde os bairros ou municípios metropolitanos pode ser considerado de fácil acesso, por meio de ônibus, automóvel ou mesmo de bicicleta. Seu layout compreende 5 trechos, em um total de $1,6 \mathrm{~km}$ de extensão.

Percorrendo ruas e praças, estão dispostas, de acordo com Lessnau (2017), 1.400 barracas com trabalhos artesanais de diversos expositores. Nesse espaço ocorrem também manifestações culturais e artísticas. Entre os produtos comercializados estão alimentos e bebidas, onde uma paradinha para comer um pastel e/ou tomar um caldo de cana é uma opção e uma tradição dos curitibanos que visitam a feira. Como espaço multicultural, a feira exibe diversidade de produtos, do mais simples aos mais elaborados. Há exposição nos segmentados de acessórios, artes plásticas, artesanato temático (natal, páscoa etc.), artesanato em madeira e MDF, artigos femininos, chocolate artesanal, lembrancinhas, produtos para bebê, produtos para a casa, vestuário, brinquedos pedagógicos, trabalhos em ferro e uma infinidade de outros produtos.

O Instituto de Turismo de Curitiba regulamenta o funcionamento e as atividades da Feira de Arte e Artesanato, por meio do Decreto no 112 , de 
01.02.2010. Esse regulamento define características, administração, comissão de feiras, comissão de avaliação e vistoria, organização, critérios de acesso à feira, categoria dos expositores, licença de funcionamento, critérios de cancelamento de licença, forma de participação, notificação da licença de funcionamento, penalidades, processo de aplicação das penalidades e termo de compromisso.

Para ter acesso ao espaço como feirante, o candidato deve estar atento ao período de cadastramento. De acordo com Lessnau (2017), o pedido é feito por meio de solicitação escrita. $\mathrm{Na}$ carta, o candidato deve relatar sobre as características de seus produtos e protocolar o pedido junto ao Instituto de Turismo de Curitiba, no setor de artesanato. Entretanto, esclarece a coordenadora, atualmente não há como expandir a feira, pois as vagas possíveis estão todas tomadas e, por essa razão, quem pretender um lugar deve aguarda em fila de espera.

Ao surgir uma vaga, por desistência ou outro motivo qualquer, buscamos nessa fila de espera e os melhores trabalhos são avaliados por uma Comissão específica e o que for melhor avaliado entra. Na avaliação pesa, execução, criatividade, funcionalidade, apresentação qualidade e o resultado final. Leva-se também em conta que o produto seja diferenciado, ou raro na feira (LESSNAU, 2017).

A organização do arranjo conta com a parceria público-privada. Os feirantes, eleitos como representantes, fazem parte de uma Comissão que se reúnem mensalmente com a Administração para apresentarem suas reivindicações e em conjunto analisar e solucionar eventuais problemas (LESSNAU, 2017). Vale destacar que as normas pré-estabelecidas no Decreto n⿳0 112, de 01.02.2010, determinam e adequam a forma de funcionamento e gestão da feira.

Em relação à gestão participativa, esta pode ser considerada um aspecto positivo da administração pública, que busca trabalhar em parceria com os feirantes. De acordo com Lessnau (2017), a responsabilidade sobre as barracas é do expositor (montagem, guarda e conservação), que paga à prefeitura uma pequena taxa anual referente ao uso do solo. Á prefeitura cabe a responsabilidade com o pagamento dos funcionários que trabalham na administração da feira, bem como garantir a limpeza, segurança, ações de marketing integrada ao turismo e o plano de mobilidade que facilite o deslocamento ao local do evento por meio do transporte público.

Lessnau (2017) aponta que "além de ter se tornado o grande atrativo dominical da cidade, proporcionando lazer para moradores e turistas, a feira gera renda para centenas de famílias de Curitiba e Região". Sua gestão privilegia a inserção ao mercado de trabalho de parte da população local e regional. 
Visitado por turistas, o local tem atrativos que vão além do conhecer e comprar os produtos da feira. Circulando pelo lugar é possível visitar a Igreja da Ordem terceira de São Francisco das Chagas, construída em 1737, considerado o edifício mais antigo de Curitiba, que, na atualidade, abriga o Museu de Arte Sacra de Curitiba; a Casa Romário Martins, antigo armazém de secos e molhados e a Casa Vermelha, que era uma loja de ferragens. Todos esses prédios foram restaurados e se transformaram em museus. Também há a fonte, conhecida como "cavalo babão", que foi edificada em homenagem aos tropeiros, que levavam suas mulas e cavalos ao bebedouro que ali existia.

Como coordenadora da Feira de Arte e Artesanato, vinculada ao Instituto de Turismo de Curitiba, Lessnau (2017) fala com entusiasmo sobre a gestão da feira destacando que:

[...] há nove anos muito me envaideço ao ouvir os mais variados e efusivos elogios à Feira do Largo da Ordem, que vem sendo considerada por turistas de vários locais do país e do mundo como sendo, senão a melhor, uma das melhores e mais organizadas já visitadas. Orgulho para nós administradores e para a cidade de Curitiba. Nossa feira vem sendo referência para pesquisas e trabalhos de conclusão de curso de nível superior assim como vem sendo rotina de motivação para reportagens diversas de jornais, revistas e demais veículos de comunicação no âmbito de destaque local, nacional e internacional.

Considerando a complexidade dos aspectos culturais, econômicos, ambientais, sociais, que tornam a Feira do Largo da Ordem um marco no turismo curitibano e, por se constituir em rico espaço de inserção social, planejamento e gestão do espaço público urbano, ela é emblemática como um arranjo socioprodutivo (GRIMM et al., 2016), e uma experiência exitosa, que fortalece e inova os postulados da ecossocioeconomia.

\subsection{O ENCADEAMENTO ECOSSOCIOECONÔMICO DO ARRANJO SOCIOPRODUTIVO}

No processo de planejamento para o desenvolvimento local, o espaço urbano se defronta com desafios ambientais, sociais e econômicos onde as soluções podem estar constituídas de saberes e fazeres cotidianos, bem compreendidos em dado território, mas, que podem ser de difícil entendimento fora dele. De acordo com Etzioni (2015), o dimensionamento ecossocioeconômico admite iniciativas individuais socioprodutivas. No entanto, considera que experiências mais duradouras e com resultados mais consistentes são aquelas que admitem e se estruturam em arranjos institucionais e socioprodutivos. 
Os estudos sobre ecossocioeconomia são emergentes. As primeiras pesquisas realizadas em âmbito internacional sobre o tema têm como base a publicação da obra seminal de Karl William Kapp (1950), The social costs of private enterprise (Os custos sociais da empresa privada). Esse trabalho tratou sobre custos socioambientais das empresas, o que atualmente se denomina como externalidade, trazendo uma crítica à lógica de privatizar lucros de curto prazo e socializar custos socioambientais de médio e longo prazo, além de relacionar esta visão com questões estruturais, como Estado, mercado e sociedade civil, bem como suas sobreposições, tal como sugere a economia institucional. O estágio inicial da pesquisa sobre Ecossocioeconomia no Brasil tem suas contribuições nas obras "Rumo à ecossocioeconomia: teoria e prática do desenvolvimento" (SACHS, 2007), e "Gestão que privilegia uma outra economia: Ecossocioeconomia das organizações” (SAMPAIO, 2010). Esses autores reconhecem esforços e defendem pesquisas em torno de uma nova concepção pautada em um novo paradigma de desenvolvimento cujo cerne não deve estar na racionalidade de processos de desenvolvimento essencialmente voltados para fins econômicos, mas na análise da cidadania centrado no respeito às diferenças socioculturais, incorporando o conceito de interculturalidade, interdisciplinaridade e intergeracionalidade.

Para aprofundar a compreensão dessa teoria foi necessário fundar uma nova concepção ontológica acerca do desenvolvimento sustentável e do ecodesenvolvimento, que passou a ser apreendida e interpretada como nexo de boas práticas realizadas em dado território, mas que, em muitas vezes, não podem ser bem compreendidas fora dele. Neste caso, a ecossocioeconomia pressupõe o estabelecimento de diálogos com a teoria e a realidade vivida no contexto do dia a dia das comunidades.

Constituída como campo de conhecimento recente e interdisciplinar, a ecossocioeconomia é utilizada para denominar e demonstrar experiências que evidenciam que é possível operacionalizar ou colocar em prática outra gestão que resulte no desenvolvimento sustentável, tal como sugerem Smith e Max-Neef (2011). A ecossocioeconomia se sobressai no sentido de incorporar no processo de tomada de decisão a dimensão socioambiental, o que, na maioria das vezes, tem sido relegado por outras perspectivas à predominância da lógica mercantil, como se a vida pudesse ser reduzida a mero cálculo econômico (SAMPAIO, 2005).

A teoria ecossocioeconomia privilegia práticas cotidianas que ocorrem no mundo da empiria das organizações, sejam em grupos produtivos (não necessariamente para resultar ganhos econômicos), empresas, associações (cooperativas inclusive), comunidades, povoados, onde os problemas. São contextos em que as soluções acontecem, mas nem sempre são devidamente 
qualificados (SAMPAIO, 2005). Trata-se, como exposto por Mancebo e Sachs (2015) e Kapp (1950), de uma teoria pensada que parte das experimentações e da complexidade do cotidiano, que, de acordo com Grimm et al. (2016), pode surgir de novos arranjos visando soluções para problemas socioambientais ocorridos em dado território.

Os arranjos socioprodutivos de base territorial podem ser compreendidos como experiências de aglomerados autônomos surgidos de outra visão que não a capitalista. Essas experiências, de acordo com Ortega (2008), reconhecem a força desse processo hegemônico, mas implementaram respostas específicas e intencionais valorizando as diversidades econômicas, sociais e políticas existentes em seus territórios. Nelas, segue o autor, a motivação principal tem sido contribuir com o combate à pobreza e as desigualdades sociais, representando, portanto, uma “alternativa real” geradora de cidadania e inserção competitiva (ORTEGA, 2008).

Elementos locais - tais como laços históricos e culturais, processo de construção institucional, malha social - podem condicionar o sucesso de um arranjo socioprodutivo, que pode ser medido pela capacidade de cooperação das organizações participantes e pela sua trajetória evolutiva em termos do crescimento da produção, da geração de trabalho, do desenvolvimento tecnológico e da inserção social. O protagonismo dos atores pode condicionar a especialização produtiva, no caso da feira do Largo da Ordem pode contribuir para a melhoria na qualidade do produto e consequentemente na agregação de valor, no surgimento de lideranças, na confiança entre os agentes e principalmente proporcionar geração de trabalho e renda.

A dinâmica da Feira de Arte e Artesanato da Feira do Largo da Ordem, que se mantém e evolui há mais de quatro décadas, se consolidou como resultado de iniciativas cooperadas que passa pela comunidade, pelo capital social e não exclusivamente pelo mercado, embora institucionalmente represente uma estratégia de desenvolvimento territorial sustentável visando a inclusão social. Diante disso, é válido expor que, na Feira do Largo da Ordem, podem ser observadas algumas dimensões ecossocioeconômicas (Tabela 1). Isso indica que esse arranjo socioprodutivo contribui para a promoção de uma "outra economia" baseada em soluções pautadas em tecnologias apropriadas ao local e ou aos arranjos institucionais e produtivos, que visem o protagonismo de comunidades e populações. 
Tabela 1 - Dimensões ecossocioeconômicas observadas na Feira do Largo da Ordem em Curitiba (PR)

\begin{tabular}{|c|c|}
\hline $\begin{array}{c}\text { DIMENSÃO } \\
\text { SOCIOCULTURAL }\end{array}$ & $\begin{array}{l}\text { - participação cidadã } \\
\text { - empoderamento local } \\
\text { - espaços sociais de deliberação } \\
\text { - atores do desenvolvimento } \\
\text { - raízes endógenas } \\
\text { - história, valores e cultura } \\
\text { - equipamentos culturais e patrimoniais } \\
\text { - sentimento de pertencimento } \\
\text { - palco da vida }\end{array}$ \\
\hline $\begin{array}{l}\text { DIMENSÃO } \\
\text { ECONÔMICA }\end{array}$ & $\begin{array}{l}\text { - trabalho e renda } \\
\text { - desenvolvimento produtivo } \\
\text { - alocação de recursos financeiros } \\
\text { - inovação/criatividade }\end{array}$ \\
\hline $\begin{array}{l}\text { DIMENSÃO } \\
\text { AMBIENTAL }\end{array}$ & $\begin{array}{l}\text { - gestão sustentável } \\
\text { - uso responsável e social do território e de matéria prima } \\
\text { - ativo de desenvolvimento territorial }\end{array}$ \\
\hline $\begin{array}{c}\text { DIMENSÃO POLÍTICO } \\
\text { ESPACIAL }\end{array}$ & $\begin{array}{l}\text { - novas institucionalidades } \\
\text { - gestão social } \\
\text { - território tempo } \\
\end{array}$ \\
\hline
\end{tabular}

Fonte: Os autores (2017)

A dimensão sociocultural presente no espaço da feira constitui importante marco cultural da cidade, revelando relações onde histórias de vida também são de resistência e perpetuadoras de uma tradição local. Nela observam-se cores, sabores, cheiros, sons, sentimentos e saudade reproduzidos nos saberes e fazeres que se tornaram arte.

O dimensionamento econômico observado na dinâmica da feira apresenta-se como geradora de trabalho e renda, sendo responsável, de acordo com Lessnau (2017), pelo sustento de muitas famílias e constitui-se como local de trabalho para aproximadamente 1400 expositores.

$\mathrm{Na}$ pesquisa de campo foram entrevistados 112 feirantes, entre os quais $58 \%$ declararam que a feira representa $100 \%$ da renda familiar e, para $42 \%$ a feira representa $50 \%$ da renda familiar. Entre eles, 66\% se declaram autônomos e 34\% como microempresários. Em relação ao tempo, 25\% operam naquele espaço em período de até 5 anos, 17\% entre 5 a 10 anos, 8\% entre 10 a 20 anos, e 50\% dos expositores operam há mais de 20 anos. Em relação à dimensão ambiental, entre os feirantes, 18\% trabalham com alimentos e não reciclam materiais, mas declaram que os resíduos são separados e destinados adequadamente (matéria orgânica e material reciclável). Entre os artesãos, 75\% utilizam materiais de 
reciclagem na confecção de seus produtos, 7\% não utilizam reciclagem e 18\% não responderam. A respeito da destinação, os resíduos gerados durante a feira são separados pelos feirantes em orgânicos e recicláveis para a posterior coleta seletiva.

A dimensão política espacial é representada pelos arranjos institucionais e políticas públicas que surgiram com a consolidação da feira e que são fundamentais para garantir a gestão integrada e participativa. Quanto ao uso do território e sua temporalidade bem definida, ou seja, a apropriação deste espaço público aos domingos por este grupo específico, há feirantes que o territorializam ${ }^{1} \mathrm{em}$ determinados momentos, o que pode ser gerador de conflito com outros usuários do espaço (moradores, lojistas, proprietários de bares e restaurantes etc.).

A respeito das estratégias empreendidas, destaca-se que o sistema estrutural da feira pode ser caracterizado como de um arranjo socioprodutivo (Figura 1), composto por microempresas e pequenos empreendedores, onde se supera a competitividade utilitarista econômica e se privilegia uma rede de cooperação. Nesse arranjo, pequenos negócios ganham visibilidade e diante de uma economia de mercado pautada no lucro como máxima, aumenta-se a possibilidade de sobrevivência e se estabelecendo como estratégia local de geração de renda e inclusão social.

Figura 1 - Direcionamento do arranjo socioprodutivo

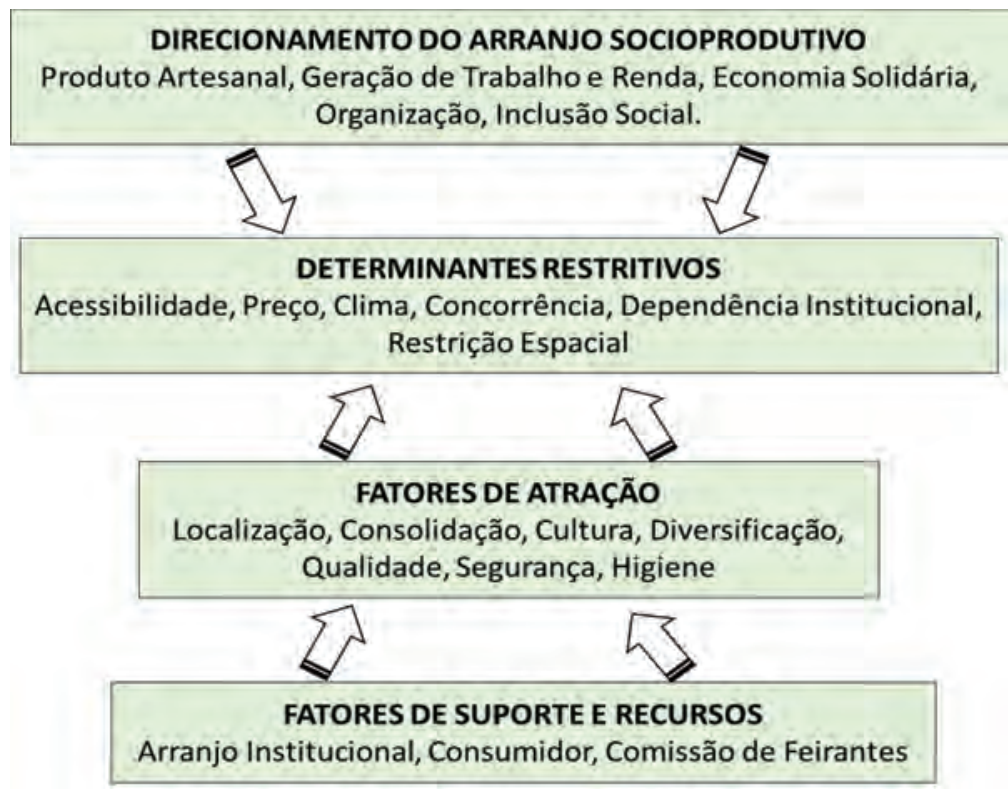

Fonte: Os autores, 2017.

Sobre território e territorialidades ver Souza (2002). 
O arranjo socioprodutivo constituído a partir da estrutura organizacional da Feira do Largo da Ordem representa um sistema simplificado, que não por fim maior no lucro, mas como alternativa de renda, que, em muitos casos, quando se trata de trabalhos manuais, muitas das técnicas são transmitidas entre gerações. A economia solidária, apontada pelos feirantes como princípio nesse arranjo, se manifesta na gestão do próprio trabalho, na luta pela sua emancipação e no fortalecimento das relações entre produtores e consumidores, bem como entre os próprios feirantes. A organização do local como espaço de inserção é apontada como importante fator para a promoção de parte da população local e regional ao mercado de trabalho.

A identificação de determinantes restritivos nesse arranjo se referem à acessibilidade, pois, localizada no setor histórico, a pavimentação irregular dificulta o acesso e a circulação para pessoas com mobilidade reduzida, por exemplo, pessoas idosas, com carrinho de bebê ou com cadeiras de rodas. Em relação aos preços praticados, observa-se intensa disputa, o que poderia ser solucionado com a cooperação dos feirantes para, coletivamente, atingirem economias de escala superiores, acima da capacidade individual; efetuar compras conjuntas de matéria prima e, com isso, praticarem preços justos para todos. Entre os fatores que dificultam o bom funcionamento da feira, o clima é apontado pelos visitantes e feirantes como fator restritivo, pois a cidade de Curitiba é caracteriza pelo clima frio e chuvoso em boa parte do ano e a feira acontece em espaço aberto, sem proteção às intempéries, trazendo em alguns momentos, desconforto aos frequentadores.

O espaço do Largo da Ordem é um território que comporta uma multiplicidade de grupos que se valem da movimentação local para interagir com o visitante, divulgando ou comercializando sua arte. São eles: músicos, estátuas vivas, palhaços, atores de teatro, artesãos não permissionários (hippie, indígenas) e vendedores ambulantes. A respeito dessa realidade, que envolve o uso e a gestão do espaço durante a feira, a coordenação e os feirantes destacam que os problemas encontrados se referem aos vendedores ambulantes que invadem a feira trazendo transtornos aos administradores, que estão em número insuficiente e trazem dificuldade à fiscalização.

Em relação ao seu tamanho, o espaço se encontra em sua capacidade máxima e, de acordo com Lessnau (2017), “ao longo do tempo a Feira cresceu de um modo que hoje não tem mais como se expandir, já extrapolou o número máximo de barracas". Muitos artesãos têm buscado garantir um espaço, mas a feira já se expandiu em seu limite máximo. Entretanto, de acordo com a coordenadora, esses problemas estão sendo avaliados e na medida do possível solucionados. 
A respeito da gestão, anteriormente descentralizada, em que os feirantes se organizavam e decidiam como e o que vender, atualmente é centralizada no poder público, priorizando o uso e ocupação do território, fiscalizando a forma, horário, qualidade e variedade do comércio, e decidindo sobre a cessão de espaço para novos feirantes. Esta administração institucionalizou o arranjo, trouxe controle e ordenamento, mas, ao mesmo tempo, parece não estimular a participação popular e o crescimento do protagonismo das comissões na busca de soluções aos problemas comuns.

Consolidada, a feira atrai turistas nacionais e estrangeiros, pois, ao longo dos anos (a Feira do Largo da Ordem completa 46 anos de existência em 2018) este espaço tem sido uma opção de lazer e importante atrativo turístico para Curitiba. Entretanto, observa-se entre as reinvindicações dos feirantes e gestores, a necessidade de maior divulgação do evento com vistas a promover os produtos "artesanais típicos da cidade", aumentar o fluxo de turistas e consequentemente a renda dos feirantes.

Para o conforto do visitante, a higiene e segurança pública seguem regras estabelecidas pelos órgãos competentes: Saúde Pública, Polícia Militar, Guarda Municipal, Posto de Atendimento da DIRETRAN e Resgate Social. No local existem quatro banheiros, que ficam à disposição dos artesãos e visitantes. $\mathrm{Na}$ região existem vários estacionamentos particulares, que oferecem serviços exclusivos durante o período da feira. Nas ruas próximas também é possível estacionar. A feira conta com infraestrutura disposta para ser um evento sociocultural e atrativo turístico tradicional da cidade, que lhe confere reconhecimento em âmbito regional e nacional.

De forma geral, o arranjo socioprodutivo representado pela organização da feira pode ser considerado uma rede interorganizacional que caracteriza uma experiência de associativismo e empreendimento socioeconômico compartilhado, coordenada por instituições governamentais, que resulta da combinação de diferentes lógicas, como a solidária (no sentido substantivo, valorativo), a utilitária (no sentido clássico da Ciência Política, na maximização de ganhos coletivos) e econômica individual (maximização de ganhos individuais).

\section{CONSIDERAÇÕES}

O arranjo socioprodutivo com enfoque territorial vem motivando atores sociais a buscarem soluções para questões locais de ordem econômica, social e ambiental, colocando em prática projetos de desenvolvimento que dependam da participação comunitária. Essa modalidade de ação e sociopolítica pode 
oferecer condições favoráveis para impulsionar o desenvolvimento em territórios fragilizados economicamente e que apresentem baixos índices de desenvolvimento humano, mas com potencial significativo de geração de capital social local. A esse modelo se apresentam como promissoras perspectivas pautadas em atividades agrícolas, pecuárias, de agricultura familiar, de turismo de base comunitária e de produção doméstica, que possuam menores níveis tecnológicos e de técnicas de produção em seus momentos iniciais de desenvolvimento.

As formas organizacionais em que se incluem as feiras livres urbanas se apresentam com importância significativa para a promoção de desenvolvimento economicamente efetivo e sustentável, que privilegiam o interesse coletivo sem desmerecer a inovação empreendedora individual e que, concomitantemente, operam de forma socialmente includente. A atuação desses arranjos em diferentes contextos territoriais da cidade pode contribuir para o fortalecimento da imagem turística e da economia solidária, o fortalecimento de formas alternativas de geração de renda a partir de produtos e serviços de natureza criativa - como os resultantes da aplicação de conhecimentos típicos locais e de ativos culturais em produtos artesanais - e de produtos ecossistêmicos, representados por aqueles originários de contextos e da aplicação de técnicas ambientalmente adequadas.

Assim, os dados analisados até o presente sinalizam que, a Feira do Largo da Ordem pode ser considerada um arranjo socioprodutivo de base territorial, pois ganhou ao longo do tempo novas conformações e usos, adaptando-se às necessidades da comunidade e transformando-se em espaço de lazer, de interação social e cultural integrante da imagem turística de Curitiba, dando oportunidade de inserção ao mercado de trabalho para aqueles que o saber fazer constitui-se em capital social.

\section{REFERÊNCIAS}

ABRANCHES, M. Controle social e planejamento urbano participativo: o mapeamento dos problemas da cidade pelos seus diversos atores. In: SIMPÓSIO MINEIRO DE ASSISTENTES SOCIAIS, 3. Belo Horizonte, 2013. Anais Eletrônicos... Belo Horizonte, 2013. Disponível em: <http://www.cress-mg. org.br/hotsite/1/paginas/home.php?pg=5>. Acesso em: 28 ago. 2016.

BIZZOTTO, L. M.; CARVALHO N. J.; GONÇALVES R. G. Espaço e o poder: por uma práxis no planejamento urbano autônomo. Revista Paranaense de Desenvolvimento, Curitiba, v. 35, n. 126, p. 131-145, 2014. 
BOISIER, S. Em busca do esquivo desenvolvimento regional: entre a caixa-preta e o projeto político. Planejamento e Políticas Públicas, Rio de Janeiro, n. 13, p. 111-145, jun. 1996.

BONZATTO, E. A.; POLICHUK N. K. Origem da feira do Largo da Ordem, Curitiba, em 1970: diálogos de arte e zanato. Revista Lumen et Virtus, v. 5, n. $10,2014$.

GALLARZA, G.; BAPTISTA, M.; CAVALCANTI, F. Caminhos Históricos: a estrada do Assungui. Curitiba: Fundação Cultural de Curitiba, 2013, 164 p.

CASTELLS, M. O planeamento urbano (Item 5). In: Problemas de Investigação em sociologia urbana. Lisboa: Presença, 1986, p. 209-250.

COLEMAN, J. Foundations of social theory. Cambridge: Harvard University Press, 1990.

COUTINHO, E. P.; NEVES H. C. N.; SILVA E. M. G. Feiras livres do brejo paraibano: Crise e Perspectivas. In: CONGRESSO DA SOCIEDADE BRASILEIRA DE ECONOMIA E SOCIOLOGIA RURAL, 44, Fortaleza, 2006. Anais... Fortaleza: SOBER, 2006.

GRIMM, I. J.; FREDER, S.; SAMPAIO, C. A. C.; PROCOPIUCK, M. Arranjos socioprodutivos de base territorial: uma análise das feiras livres comunitárias na cidade de Curitiba (PR). In: VI Encontro de Turismo de Base Comunitária e Economia Solidária (ETBCES). Salvador, 2016. Anais Eletrônicos... Salvador: UNEB, 2016. Disponível em: < http://www.etbces.net.br/edicoes/vietbces-2016/anais>. Acesso em: 25 jan. 2017.

CROCCO, M. A.; GALINARI, R.; SANTOS, F.; LEMOS, M. B.; SIMÕES R. Metodologia de Identificação de arranjos produtivos locais potenciais. Texto para Discussão 212 - Belo Horizonte: UFMG/CEDEPLAR, 2003.

CURITIBA. Prefeitura Municipal. Instituto Municipal de Turismo. Assuntos diversos feiras de arte e artesanato - regulamentação. 2006. Disponível em: <http:/ /www.informarejuridico.com.br/Prodinfo/boletim/2006/pr/dec79731-2006.htm>. Acesso em: 28 ago. 2016.

JEAN, B. Do desenvolvimento regional ao desenvolvimento territorial sustentável: rumo a um desenvolvimento territorial solidário para um bom desenvolvimento dos territórios rurais. In: VIEIRA, Paulo Freire et al. Desenvolvimento territorial sustentável no Brasil. Florianópolis: APED; SECCO, 2010. 
KAPP, W. Social cost of private enterprise. Cambridge, Massachusetts: Harvard University Press, 1950.

LESSNAU, M. Coordenadora das Feiras de Arte e Artesanato. Instituto de Turismo de Curitiba. Entrevista concedida em 2017.

MANCEBO, F.; SACHS, I. Transtions to sustainability. Dordrecht, Heidelberg, New York, London: Spring, 2015.

MINISTÉRIO DO TRABALHO E EMPREGO. Secretaria Nacional de Economia Solidária. Apresentação do atlas da economia solidária no Brasil. In: Senaes/MTE. Atlas da economia solidária no Brasil 2005-2007. Brasília: MTE, Senaes, 2017.

ONU - Organização das Nações Unidas. Perspectiva da população mundial. Relatório de 2014. Disponível em: <http://www.unric.org/pt/ actualidade/31537-relatorio-da-onu-mostra-populacao-mundial-cada-vez-maisurbanizada-mais-de-metade-vive-em-zonas-urbanizadas-ao-que-se-podem-juntar-25-mil-milhoes-em-2050>. Acesso em: nov. 2016. 2013

ORNÉS, S. V. La gestión sostenible: conceptos, rol del gobierno local e vinculación con el marketing urbano. Universidade Simón Bolivar Departamento de planificación urbana. Provincia, n.31. Venezuela, 2014.

ORTEGA, A C. Territórios deprimidos. Os desafios das políticas de desenvolvimento rural. Campinas-SP: Alínea; Uberlândia-MG: EDUF, 2008.

PELLIN, V.; ALCANTARA, L. C.; GONÇALVES, D. F. Contribuições do capital social para o desenvolvimento territorial. Revista Interdisciplinar Científica Aplicada, Blumenau-SC, v. 10, n. 4, p. 52-70, TRIII, 2016.

PEREIRA, C. A. M. O que é contracultura. São Paulo: Brasiliense, 1990.

PUTNAM, R. D. Comunidade e democracia: a experiência da Itália moderna. 4. ed. Rio de Janeiro: Editora FG, 2005.

REBOUÇAS, T. de M. Planejamento urbano enquanto campo de disputa: o caso do PDDU de Salvador. In: ENCONTRO NACIONAL DA ASSOCIAÇÃO DE POS-GRADUAÇÃO E PESQUISA EM PLANEJAMENTO URBANO E REGIONAL, 16. Belo Horizonte, 2015. Anais Eletronicos... Belo Horizonte: ANPUR, 2015. Disponível em: <http://anpur.org.br/xvienanpur/sobre-oevento.html>. Acesso em: 16 nov. 2016. 
SALES, A. P.; REZENDE, L. T.; SETTE, R. de S. Negócio Feira Livre: um estudo em município de Minas Gerais. In: ENCONTRO DE GESTÃO DE PESSOAS E RELAÇÃO DE TRABALHO, 3. João Pessoa, 2011. Anais Eletrônicos... Disponível em: <http://www.dae.ufla.br/pet/wp-content/ uploads/2017/03/2011_EnGPR395_Neg\%C3\%B3cio-Feira-Livre-um-estudoem-um-munic \%C3\%ADpio-de-Minas-Gerais.pdf>. Acesso em: 18 jun. 2016.

SAMPAIO, C. A. C. Gestão que privilegia uma outra economia: ecossocioeconomia das Organizações. Blumenau-SC: Edifurb, 2005, 128p.

SAMPAIO, C. A. C.; MANTOVANELI Jr O.; FERNANDES V. Racionalidade de tomada de decisão para o planejamento e a gestão territorial sustentável. REDES, Santa Cruz do Sul, v. 16, n. 2, p. 131-155, 2011.

SANTOS, M.S.; FERREIRA, D. de J.; SANTOS, R. L. A feira livre como alternativa de geração de renda para agricultura familiar no município de Santo Estevão (BA). In: CONGRESO IBEROAMERICANO DE ESTUDIOS TERRITORIALES Y AMBIENTALES, 6. São Paulo, 2014. Anais Eletrônicos... São Paulo: USP, 2014. Disponível em: <http://Gcieta.org/>. Acesso em: 18 jun. 2016.

SATO, L. Processos cotidianos de organização do trabalho na feira livre. Psicologia e Sociedade; 19, Edição Especial, p. 95-102, 2007.

SINGER, P. Introdução à economia solidária. São Paulo: Editora Fundação Perseu Abramo, 2002.

SMITH, P.; MAX-NEEF, M. Economics unmasked: from power and greed to compassion and the common good. Cambridge: Green Books, 2011.

SOUZA, M. O território: sobre espaço e poder, autonomia e desenvolvimento. In: CASTRO, I. E., et al. Geografia: Conceitos e Temas. 4. ed. Rio de Janeiro: Bertrand Brasil, 2002. p. 77 -116.

UNCETA, K. Desarrollo, subdesarrollo, maldesarrollo y postdesarrollo. Una mirada transdisciplinar sobre el debate y sus implicaciones. Carta Latinoamericana, CLAES, n. 7, 2009. 38p. 


\section{Um "skyline" em mutação: o velho centro e as transformações urbanas em Belém}

\section{A "skyline" in changing: the old center and the urban transformations in Belém}

Saint-Clair Cordeiro da Trindade Júnior - Doutor em Geografia Humana pela USP. Professor do Núcleo de Altos Estudos Amazônicos da Universidade Federal do Pará (NAEA/ UFPA), pesquisador do Conselho Nacional de Desenvolvimento Científico e Tecnológico (CNPq).E-mail: stclair@ufpa.br

\section{Resumo}

Os processos de requalificação de áreas centrais nas cidades brasileiras têm colocado questionamentos sobre a natureza da apropriação do espaço que se faz presente nessas cidades. Nesse sentido, busca-se indagar se as mudanças observadas na realidade urbana do Brasil seriam semelhantes às repercussões socioespaciais verificadas em outros países que vivenciaram processos de gentrificação. Ao discutir o caso de Belém, a análise situa a importância das intervenções urbanísticas no centro histórico da cidade e estabelece relação com o perfil das transformações que acontecem nos bairros de seu entorno imediato. Conclui-se mostrando que o centro histórico, pontualmente renovado, juntamente com alguns espaços que lhe são adjacentes, vivenciam processos de apropriação que sugerem pensar em uma forma embrionária de gentrificação urbana, mas com contornos particulares, e que merece ser adjetivada.

\section{Palavras-chave}

Reestruturação Urbana. Área Central. Requalificação Urbana. Apropriação do Espaço. Gentrificação. Belém.

\begin{abstract}
The requalification of central areas in the Brazilian cities have posed questions about the nature of the appropriation of the space that is present in some cities. In this sense, the article asks if the changes observed in the Brazil urban reality would be similar to the socio-spatial repercussions verified in other countries that experienced gentrification processes. In discussing the case of Belém, the analysis situates the importance of urban interventions in the center of this city and establishes a relation with the profile of the transformations that take place in its immediate neighborhoods. In conclusion, it shows that the historical center, punctually renewed, along with some adjacent spaces, experience processes of appropriation that suggest to think about an initial form of urban gentrification, but with particular contours, that needs to be qualified.
\end{abstract}

\section{Keywords}

Urban Restructuring. Downtown. Urban Renewal. Space Appropriation. Gentrification. Belém. 


\section{INTRODUÇÃO}

A partir do encontro do rio Guamá com a baía de Guajará, um skyline $e^{1}$ muito característico nos leva de imediato ao reconhecimento desta que é uma das cidades mais expressivas do cenário urbano brasileiro. Sempre a partir dos rios, consegue-se identificar, em primeiro plano, o mercado do Ver-o-Peso, com suas feiras, portos e embarcações, ladeados pelo casario antigo, pelo Forte que lhe deu origem e pelas igrejas barrocas com suas imponentes torres. Ao fundo, um movimento de arranha-céus se soma à composição daquela que se tornou conhecida, desde os primeiros momentos de sua história, como Santa Maria de Belém do Grão-Pará.

Num esforço similar ao empreendido pela arqueologia, poderíamos proceder à leitura da silhueta dessa cidade num reconhecimento de camadas ou estratos históricos capazes de revelar não apenas linhas arquitetônicas que lhes são características, como também estéticas e conteúdos socioeconômicos, simbólico-cultural e artístico-arquitetônicas que se mostram ao observador por meio de perfis espaço-temporais de diferentes períodos de sua trajetória.

A "Belém portuguesa" a nós se apresenta como o primeiro desses estratos, por meio, por exemplo, do Forte e do casario colonial, que identificam, com seus traços e desenhos, a cidade em sua gênese, tornada o ponto de partida para a conquista do vale amazônico pelos colonizadores a partir do século XVII. A "Belém italiana" se revela em seguida, como segundo estrato, em forma de igrejas barrocas, de palácios e de espaços públicos surgidos no século XVIII por meio, por exemplo, dos rabiscos caprichosos do urbanismo bolonhês de Antônio Landi $^{2}$. Referem-se esses dois estratos a uma Belém mais antiga, sem ainda os grandes traços de modernidade que lhe seriam acrescentados a partir da segunda metade do século XIX.

Sucedendo aquelas camadas, portanto, é que nos deparamos com a estética de uma pretensa "Paris N'América", em forma de mercados, de portos, de boulevares, de mobiliários urbanos e de elementos outros que são tradução

\footnotetext{
Essa palavra, de origem inglesa - sky (céu, horizonte) e line (linha, traço) - compõe o glossário da Arquitetura, do Urbanismo, do Planejamento e da Geografia Urbana, referindo-se à silhueta arquitetônica de uma cidade que se projeta no horizonte, tendo o céu como fundo. Ela demarca, em forma de desenho, os contornos e elementos que são mais característicos de uma cidade e que chamam a atenção quando vista a partir de uma certa distância, tornando-a facilmente reconhecida por meio de suas linhas, símbolos, edifícios e traços, a exemplo do que acontece com os skylines de Londres, Paris, Nova Iorque e Rio de Janeiro, que são inconfundíveis em relação a outras cidades.

2 Arquiteto italiano bolonhês que, com seus desenhos, traços e estética, muito influenciou a arquitetura e a concepção urbanística da cidade a partir do século XVIII.
} 
na cidade de um padrão urbanístico francês e inglês da Belle Époque europeia. E a essa cidade de estilo sofisticado, ajusta-se, por fim, e ao fundo de toda a composição eclética mencionada, uma "Belém miamizada", com edifícios de até quarenta andares, a desenhar uma espécie de paisagem pós-moderna, configuradora de bairros contíguos ao seu núcleo central, aqui também chamado de centro histórico.

Emoldurando esse ecletismo urbano, têm-se ainda a floresta e os rios, onde a presença de barcos e de canoas que, ao aportarem na cidade com pessoas e produtos procedentes do interior da região, denunciam a permanência de um tempo lento que, mesmo atual, parece anterior a tudo isso, pois é portador de valores e de culturas que têm sua origem antes mesmo que essa sucessão de camadas de tempos e de objetos espaciais tivessem ganhado configuração na forma de cidade.

É nesse cenário urbano, à maneira de um mosaico geográfico, que, há quase duas décadas, projetos e obras de intervenção começaram a sinalizar para uma tendência de requalificação urbana no centro histórico da cidade, buscando dar outra qualidade, de forma e de conteúdo, ao espaço pré-existente. A exemplo de outras cidades brasileiras, a riqueza patrimonial e outros apelos paisagísticos tornaramse os elementos centrais das propostas de requalificação em curso, redefinindo parcialmente usos e formas de apropriação do espaço de sua área central.

Das repercussões geradas pelas mudanças, surgem questionamentos se centros históricos em mutação no Brasil, como o de Belém, seguiriam os mesmos destinos daqueles outros de cidades europeias e norte-americanas, que vivenciaram ou estariam vivenciando o difundido processo de gentrificação urbana $^{3}$. A presente reflexão busca discutir essa questão. Além de situar a importância das intervenções urbanas nas áreas mais centrais de Belém, associa o perfil que apresentam às repercussões imediatas no contexto da reestruturação urbana que se anuncia, especialmente nos chamados bairros pericentrais, e, ao mesmo tempo, busca indagar se, nesse caso, poder-se-ia falar também de tendência de gentrificação do seu centro histórico.

Nessa mesma perspectiva, chama-se atenção, em particular, para especificidades do processo em curso, que visa a inserção de Belém na lógica

Com apoio nas contribuições de Smith (2006), entende-se a gentrificação como um processo originado nos anos 1960, que ganhou generalização no urbanismo contemporâneo mundial, pressupondo ações do mercado e do Estado no espaço acompanhadas de discursos de "reabilitação" ou de "regeneração" urbana. Associadas a uma geografia econômica em plena mudança, tais ações implicam no deslocamento dos moradores das classes populares das áreas centrais para outros espaços das cidades, em razão das alterações que aquelas áreas passam a vivenciar em sua paisagem cultural e em seu conteúdo social. 
competitiva das cidades contemporâneas, assim como, para novas formas de apropriação material e simbólica, por parte dos agentes locais, em relação aos espaços renovados, que configuram a nova paisagem urbana e que contribuem para definir práticas espaciais apoiadas em interesses e valores que acompanham os processos de transformação da cidade.

\section{REINVENTANDO O VELHO CENTRO}

Combinando rugosidades (SANTOS, 1986) ${ }^{4}$ integradas na paisagem ao longo de seus mais de quatrocentos anos de história, o skyline atual de Belém anteriormente descrito, apresenta-se para nós como um verdadeiro mosaico de tempos e espaços que narram seu passado e, igualmente, permitem compreender em muito o seu ritmo presente. Em grande parte, a imagem que se tem hoje da cidade, e mesmo da metrópole vista em seu conjunto, ganhou contornos muito fortes a partir da dinâmica imprimida pela economia da borracha na Amazônia.

É desse momento, inclusive, que o elemento mais característico de sua imagem, o mercado de ferro do Ver-o-Peso, passa a integrar a cena urbana, ainda que o entreposto comercial que lhe deu origem acompanhe praticamente toda a existência da cidade. Com a borracha, o centro histórico - com seus elementos característicos herdados de momentos anteriores, como o Forte do Presépio, e suas igrejas barrocas (das Mercês, da Sé e de Santo Alexandre), do século XVIII, no formato que possuem hoje - foi artisticamente retocado com elementos do Art Nonveau e do Art Déco e, especialmente, da arquitetura de ferro, que ajudaram a difundir a higienização da elitista Belém da borracha.

Assim, até a primeira metade do século XX, a principal imagem da cidade divulgada mundo afora era formada por esses contornos, permanecendo dessa maneira até o fim da primeira metade do século XX, quando começaram a subir os modernos edifícios comerciais e residenciais relativamente altos, encravados no interior do núcleo central e em suas imediações, alterando a paisagem que existia bem ao fundo do famoso Mercado.

Eles foram aí construídos quando a legislação urbana era permissiva com relação a esse tipo de edificação relativamente alta para os padrões construtivos

\footnotetext{
4 Termo inspirado nos estudos de Geomorfologia e que, na Geografia Humana, conforme proposição de Santos (1986), serve para referenciar formas espaciais herdadas do passado, apresentando-se, no presente, como testemunhos de dinâmicas e processos históricos mediatos que deixaram suas marcas no espaço por meio de objetos e formas que permaneceram na paisagem geográfica atual.
} 
do entorno. Essa nova paisagem permaneceu assim quase inalterada - salvo novos contornos proporcionados por um ou outro arranha-céu que a ela se somaram - até o século XXI, quando o núcleo central tem sua imagem mais uma vez alterada, com a subida das torres de altíssimo gabarito a que nos referimos anteriormente e que aparecem ao longe, bem ao fundo, a completar o skyline urbano que se desenha hoje para a cidade.

É nesse contexto que os projetos de intervenção com vistas à requalificação do núcleo central precisam ser compreendidos. Nas concepções que portam, à maneira aparente de uma "bricolagem" local/regional, reproduzem, em suas relativas sofisticações e propostas, tendências que fazem parte de ideias que circulam pelo mundo todo, difundindo e propagando modos urbanos de vida em sintonia com o processo de mundialização da cultura.

Os novos projetos urbanísticos sugerem a reinvenção da antiga cidade e de seu velho centro, sinônimo, ao olhar do poder público, de deterioração e de decadência. No lugar dele, propõe-se outro, junto com o (re)nascimento de uma cidade mais promissora e atrativa, conforme se percebe nos quatro principais projetos que se situam no interior do núcleo central ou no seu entorno imediato, e que compõem o centro histórico, a saber: o "São José Liberto", o "Feliz Lusitânia", o "Mangal das Garças" e o "Estação das Docas".

As retóricas que se associam a esses projetos trazem a preocupação de substituir uma imagem deteriorada e decadente da cidade, e especialmente de seu centro histórico, libertando-a de um passado que a torna estigmatizada e que a associava ao antigo, ao medo, ao perigo e à sua degradação física e social. Propõese, em seu lugar, espaços mais atrativos e convidativos, conforme se verifica no projeto "São José Liberto".

5 Termo originário de bricolage, da língua francesa, que se refere à prática de realizar por si próprio, em espécie de hobby, atividades manuais, normalmente domésticas, de maneira não especializada, artesanal e lúdica, com resultados ecléticos e soluções criativas, a combinar materiais, tendências e estilos diferenciados.

6 Edificação que já fora convento, olaria, hospital e, por último, cadeia pública, hoje desativada e transformada em polo joalheiro e em centro turístico e cultural.

7 Acervo formado pelo Forte do Castelo (símbolo da fundação da cidade) e por um conjunto arquitetônico adjacente, que foram requalificados e refuncionalizados para fins turísticos e culturais.

8 Grande vazio urbano na área central transformado em parque à beira-rio com elementos da flora e da fauna amazônica combinados com outros que remetem ao patrimônio arquitetônico e cultural da cidade.

9 Antigos galpões da área portuária, frutos da época áurea da borracha, transformados em um espaço waterfront, voltado para o turismo e o lazer. 
Outras vezes, a tônica da requalificação passa a ser a projeção do patrimônio histórico-cultural e o resgate de seu passado, no sentido de preservá-lo e de potenciá-lo no presente. A partir das rugosidades existentes, busca-se conferir novo sentido ao lugar e ao antigo centro, que, apresentado como esvaziado, tornase "repaginado", preenchido em suas formas e objetos, e, também, ressignificado, seja em relação às suas antigas funções, seja em relação aos novos papéis que lhes são atribuídos. Esse preenchimento do suposto vazio se faz a despeito da vida plena e das funções econômicas e socioculturais que animam o antigo centro, mas que pouco são inseridas e articuladas às novas composições espaciais propostas pelas intervenções, tal como aconteceu no projeto "Feliz Lusitânia".

Mas não é apenas o patrimônio histórico-arquitetônico que se busca projetar nessas intervenções. Nelas se faz presente, igualmente, o potencial da natureza amazônica, assimilado por meio do paisagismo que compõe a beleza cênica de alguns desses projetos, como o "Mangal das Garças". Neste caso, além do patrimônio histórico, recorre-se à beleza do rio, da fauna e da flora regional, como pretexto para pensar o centro histórico por meio de uma espécie de retórica ambiental a integrar a ideia da renovação urbana. Essa é a proposta do referido parque naturalístico, surgido em plena área central em espaço tido como ocioso e subaproveitado.

Por fim, como síntese de todas esses atributos mencionados anteriormente e presentes nas propostas de requalificação, têm-se projetos que parecem combinar todos eles - a imagem de superação do declínio e da decadência da área central; a valorização e a preservação do patrimônio histórico, cultural e arquitetônico; o potencial e a beleza cênica da natureza; e a condição de cartão postal waterfront -, a exemplo do que se observa no "Estação das Docas". Em verdade, ele é o primeiro a ser implantado entre todos os projetos, antecipando, assim, um pouco dos demais atributos que estariam presentes parcialmente naqueles outros.

Conforme já destacamos, os projetos de requalificação urbana em referência estão situados basicamente em dois bairros do centro histórico, a Cidade Velha e a Campina, ou em bairro do seu entorno imediato (o Jurunas), respectivamente os de número 7, 8 e 1 do Mapa 1. Contíguos ou às suas proximidades, têm-se os bairros tidos como de maior poder aquisitivo de Belém, nomeadamente, Batista Campos, Nazaré, Reduto e Umarizal, respectivamente reconhecidos por meio dos números 14, 13, 9 e 10 do mapa anteriormente mencionado. 
Mapa 1 - Belém: bairros oficiais

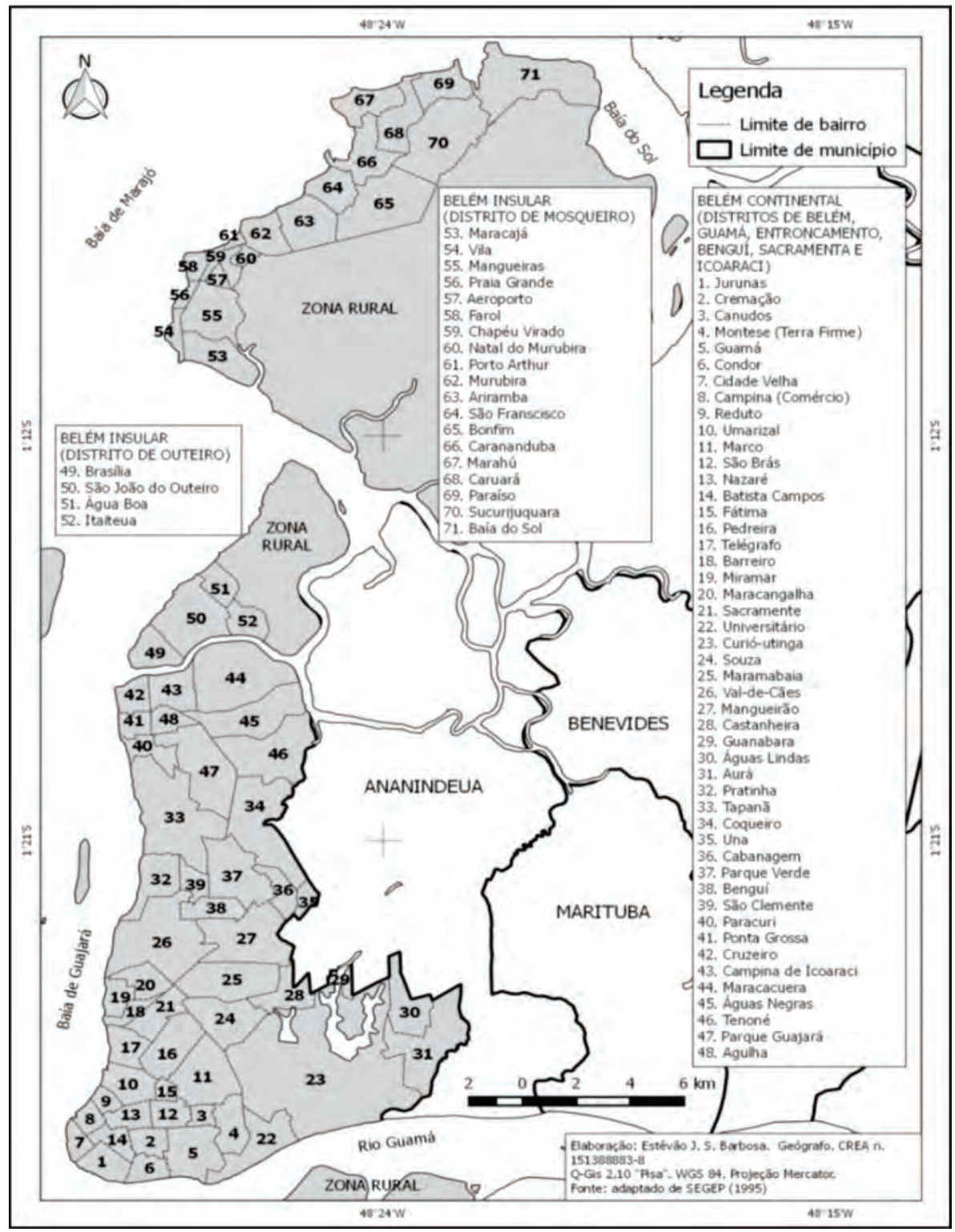

Nesses bairros, novos produtos imobiliários são ofertados, apelando ao massificado hábito de consumo de uma classe média em ascensão e que se faz refletida na paisagem por meio de arranha-céus. É principalmente a essas classes sociais, localizadas em bairros como os do entorno do centro histórico, que os projetos de requalificação urbana, colocados em prática a partir do início do século XXI em Belém, parecem, em boa parte, atender, justificando a reinvenção 
do centro para acolher novas funções associadas às velhas centralidades existentes. Compreender o sentido que é atribuído a esses espaços pressupõe entender também a estrutura urbana que lhes abriga.

\section{AMPLIANDO ESCALAS PARA ENTENDER O VELHO CENTRO}

O primeiro momento da metropolização de Belém foi responsável pela concentração de um grande contingente populacional de baixo poder aquisitivo, em parte, fruto de movimentos migratórios que reconfiguraram a forma urbana, densificando suas áreas mais centrais. Referimo-nos, particularmente, aos espaços sem infraestrutura e de péssima qualidade ambiental, abaixo da cota quatro de altimetria, chamados localmente de baixadas, e muito próximos do núcleo central da cidade (TRINDADE JR., 2016).

Diante desse processo, o velho centro, formado principalmente pelos bairros da Cidade Velha e Campina, e que antes, especialmente no auge da borracha era o espaço de circulação das elites locais, passou a se caracterizar, sobretudo a partir da segunda metade do século XX, pela forte presença do comércio popular e pelas demais práticas cotidianas associadas ao circuito inferior da economia urbana (SANTOS, 1979), do qual o complexo do Ver-oPeso é seu melhor exemplo.

Acompanhava essa mesma dinâmica, que se desenhou a partir da década de 1960 (TRINDADE JR., 2016), um processo de mudança no entorno imediato do núcleo central e que levou, nas décadas seguintes, ao processo de verticalização embrionário no seu interior e nas suas proximidades. Algumas das transformações nesse entorno imediato do núcleo central foram acompanhadas de processos de remoção de populações de baixo poder aquisitivo que habitavam moradias precárias localizadas em espaços com problemas de saneamento e infraestrutura urbana, conforme pudemos demonstrar em outro estudo sobre o processo de valorização de uma dessas áreas (TRINDADE JR., 1997).

Essa forma de reapropriação das áreas centrais foi responsável por configurar junto com outros bairros, mais bem dotados de infraestrutura, a presença de espaços pericentrais direcionados notadamente para uma demanda solvável da população local e constituindo uma espécie de cinturão de bairros verticalizados a contornar o centro histórico de Belém, que se tornou foco de intervenções pontuais, principalmente a partir do início do século XXI, sob a justificativa de requalificá-lo.

Tais intervenções vieram se somar àquelas estratégias do mercado imobiliário no entorno desse mesmo centro histórico, que se dirigiam à produção 
de apartamentos para a classe média e alta com o apoio no sistema financeiroimobiliário. Qualquer levantamento que se faça nos bairros onde acontecem essas intervenções e que definem os novos fluxos de consumidores rumo ao centro histórico, dificilmente seria capaz de constatar aumento significativo dos valores dos imóveis nele existentes, ou mudança de perfil dos moradores, a exemplo do que acontece em cidades de países centrais que vivenciaram processos de gentrificação urbana.

Seja no bairro da Cidade Velha, seja no bairro da Campina, os principais que definem o centro histórico da cidade, poucas evidências surgem de chegada de novos moradores de mais alto poder aquisitivo, bem diferente do que se percebe nos bairros do entorno, que aqui estamos chamando de bairros pericentrais, especialmente os bairros de Batista Campos, Nazaré, Reduto e Umarizal (Mapa 1).

Os dois primeiros se caracterizam historicamente por serem os bairros que, ao longo do tempo, definiram-se, pela infraestrutura instalada e pela proximidade do núcleo central, como os de maior interesse de moradia das classes altas e médias de Belém. Os dois últimos, banhados pela baía de Guajará, situam-se, em boa parte, em antigas áreas de baixada e, até a primeira metade do século XX, eram caracterizados como bairros onde vivia uma população pobre e, no caso do Reduto, uma população operária, que trabalhava nas indústrias lá existentes até esse período.

Nesses bairros se faziam presentes, inclusive, áreas de favela, como a existente ao lado do atual Canal da Doca de Souza Franco, hoje ladeado por ampla avenida marginal ao antigo igarapé e que define o limite entre os dois bairros. Com as obras de saneamento que deram lugar a ela, os moradores pobres foram em grande parte desalojados e removidos para a área de expansão na periferia distante de Belém, ainda na década de 1960. No espaço de onde foi tirada a população, bem como em seus arredores, promoveu-se a chegada de uma nova classe média, incentivada a morar em apartamentos às proximidades do núcleo central, dos principais serviços, em área saneada e infraestruturada, conforme pudemos demonstrar em trabalho anterior (TRINDADE JR., 1997).

No caso do Umarizal, trata-se, na verdade, de um bairro pericentral a abrigar principalmente camadas altas e médias da população belenense que apreciam a vista da baía e os serviços culturais e de entretenimento que a proximidade do centro proporciona, mas principalmente os valores de uma nova classe média que é atraída pela presença de espaços de lazer, de contemplação, de serviços, de consumo em geral, considerados seletos.

Em outro extremo do pequeno semicírculo dos bairros pericentrais, às margens do rio Guamá, e acompanhando uma dinâmica embrionária semelhante 
ao do Umarizal, mesmo que retardatária em relação a este, tem-se o popular bairro do Jurunas. Esse bairro, ainda hoje é habitado majoritariamente por uma população de baixo poder aquisitivo que desfruta da proximidade do núcleo central da cidade e do rio Guamá, por onde chega parte da cultura ribeirinha que nele se reproduz. Nos últimos anos, entretanto, um processo de substituição contínuo e gradativo tem-se feito notar em setores desse bairro situados nas proximidades do núcleo central ou em seu limite com o bairro de Batista Campos.

Tal tendência mostra que o mesmo processo que se verificou no Umarizal começa também a se manifestar no Jurunas, tal a presença de investimentos imobiliários direcionados para uma classe média que ainda valoriza a proximidade do núcleo central da cidade e a proximidade de bairros tidos tradicionalmente como sendo habitados pela classe alta e média de Belém. É nesse sentido que, se quisermos entender a repercussão do processo de requalificação urbana que aconteceu no núcleo central de Belém, é necessário ampliar o campo de observação para os bairros adjacentes, aqui chamados de pericentrais.

Esses bairros, dos quais o melhor exemplo é sem dúvida alguma o Umarizal, vivem uma espécie de "boom" imobiliário que dá sentido aos novos espaços de frequência requalificados para a classe média e alta e que estão situados no interior do centro histórico, sendo por essas mesmas classes visitados de forma pontual para fins culturais e de lazer.

\section{ADJETIVANDO A GENTRIFICAÇÃO URBANA EM BELÉM}

No sentido de melhor entender o processo que aqui queremos caracterizar, tomaremos como referência estudos realizados recentemente sobre a produção imobiliária em Belém, cujos resultados e dados apresentados ratificam o argumento aqui sustentado a respeito no novo sentido atribuído ao centro histórico de Belém e da dinâmica imobiliária dos bairros de seu entorno.

Cardoso (2017), em análise sobre o mercado imobiliário e a verticalização de empreendimentos residenciais no contexto belenense, demonstra a lógica e as estratégias do processo de apropriação do espaço nas proximidades do núcleo central, em cotejo com os demais espaços de expansão imobiliária. Seu estudo se voltou para onze bairros onde se pode detectar, por meio de dados quantitativos, a maior incidência da corrida imobiliária, responsável, em consequência, pelo incremento da produção vertical na cidade.

Com uma amostra de 1.720 anúncios levantados em empresa on line de compra e venda e de locação de produtos imobiliários ${ }^{10}$, analisa indicadores

${ }_{10} \quad$ Base de dados elaborada a partir do site da empresa OLX. 
desse mercado na cidade. Tais indicadores levam à constatação, como já era de se esperar, que a zona central de Belém - onde se encontram os bairros centrais e pericentrais, como Batista Campos, Nazaré, Umarizal e Reduto - é a que detém os mais altos valores de mercado.

Considerando os valores médio do preço de aluguel em 2016, tem-se, em ordem decrescente, as seguintes performances dos onze bairros considerados: 1) Batista Campos (R $\$ 2.484,75), 2)$ Umarizal ( $\$ 2.346,26), 3)$ Nazaré (R $\$ 2.310,34)$, 4) Reduto ( $\mathrm{R} \$ 2.025,43)$, 5) São Brás $(\mathrm{R} \$ 1.833,62)$, 6) Marco $(\mathrm{R} \$ 1.747,93), 7)$ Parque Verde (R\$1.694,77), 8) Pedreira (R\$1.545,86), 9) Souza (R\$1.224,04), 10) Coqueiro ( $\mathrm{R} \$ 1.035,45), 11)$ Marambaia ( $\$$ 892,81) (CARDOSO, 2017).

Tomando como parâmetro os valores médios do preço de venda por bairro, os resultados foram os seguintes: 1) Umarizal ( $\$$ \$63.064,14), 2), Nazaré (R\$750.000,00), 3) Souza (R\$659.642,86), 4) Reduto (R\$653.100,00), 5) Batista Campos ( $\mathrm{R} \$ 550.432,28)$, 6) Marco $(\mathrm{R} \$ 454.583,33), 7)$ Pedreira ( $\$ 337.626,60)$, 8) São Brás $\mathrm{R} \$ 345.785,71)$, 9) Parque Verde (R $\$ 299.811,04), 10)$ Marambaia (R\$198.026,81), 11) Coqueiro (R \$146.772,27) (CARDOSO, 2017).

Nesse estudo, o autor constata ser o Umarizal, dentre os bairros da área mais central de Belém, o principal alvo da verticalização e a atrair a atenção das principais empresas que atuam na produção imobiliária da cidade nos últimos anos, chegando essas mesmas empresas a somarem juntas aproximadamente $70 \%$ dos investimentos imobiliários existentes no bairro, percentual esse assim distribuído: Quadra Engenharia (13,3\%), Marko Engenharia (11,7\%), Síntese Engenharia (11,7\%), Cyrela Brazil (8,3\%), Reality (8,3\%), Freire Mello (8,3\%) e Leal Moreira (8,3\%) (CARDOSO, 2017).

A mesma importância do bairro do Umarizal aparece na análise de Ventura Neto (2015). Segundo esse autor, nos últimos anos, coalizões de interesses das empresas imobiliárias ajudaram a promover a reestruturação urbana em Belém, que tem reforçada a sua estrutura expandida de metrópole, ao mesmo tempo em que reafirma a reapropriação do espaço em bairros situados no entorno do centro histórico.

Esta última tendência pode ser percebida por meio da performance dos bairros que possuem o maior número de novos empreendimentos imobiliários por bairros no período de 1999 a 2011 (Tabela 1); dados esses informados pelo autor a partir de dados da Secretaria de Urbanismo (SEURB) sistematizados pelo Núcleo Belém do Observatório das Metrópoles para o período de 1999 a 2008, e pelo próprio autor, para o período de 2009 a 2011 (VENTURA NETO, 2015). 
Tabela 1 - Belém: bairros com maior número de novos empreendimentos (1999-2011)

\begin{tabular}{c|l|c|r}
\hline Posição & Bairro & Número de novos empreendimentos & \% do total \\
\hline 1 & Umarizal & 40 & $22,73 \%$ \\
\hline 2 & Marco & 29 & $16,48 \%$ \\
\hline 3 & Pedreira & 21 & $11,93 \%$ \\
\hline 4 & Batista Campos & 16 & $9,09 \%$ \\
\hline 5 & Nazaré & 16 & $9,09 \%$ \\
\hline 6 & Jurunas & 11 & $6,25 \%$ \\
\hline
\end{tabular}

Fonte: SEURB. Elaboração: Núcleo Belém/Observatório das Metrópoles para o período de 1999 a 2008 (2008); próprio autor para o período de 2009 a 2011 (2012) apud Ventura Neto (2015, p. 137).

Do estudo realizado por Ventura Neto (2015), buscamos listar apenas os bairros com melhores performances em relação ao número de novos empreendimentos. Nessa lista, além dos principais bairros pericentrais já mencionados, dois outros - Marco e Pedreira (respectivamente 11 e 16 no Mapa 1) - indicam os vetores de expansão dos investimentos imobiliários mais próximos do núcleo central. Entre os seis bairros que encabeçam a lista, o de maior destaque é novamente o Umarizal.

Essa tendência de verticalização do bairro é facilmente percebida na paisagem da cidade há alguns anos, conforme mencionado em estudo que fizemos ainda no início da década de 1990 (TRINDADE JR., 1997); momento em que citamos matéria do jornalista e sociólogo Lúcio Flávio Pinto, que já alertava para esse processo de valorização do Umarizal no final dos anos 1970:

na memória dos belenenses ainda estava muito viva a lembrança do que aconteceu com os moradores da baixada da Marechal Hermes e de todo o canal do igarapé das Almas. Ontem este mesmo jornal informava que a Prefeitura autorizou a construção de mais 18 prédios residenciais na doca de Souza Franco, que se juntarão aos sete em construção. Brevemente todo o cenário dessa área terá sido mudado: um visitante não imaginará que ali existia uma baixada idêntica à do Una (PINTO, 1979, p. 6 apud TRINDADE JR., 1997, p. 148).

Observações semelhantes do mesmo autor são citadas em recente estudo sobre a verticalização em Belém realizado por Vieira (2017), demonstrando o quanto o crescimento vertical do bairro é facilmente detectado no conjunto da cidade. 
uma única construtora está levantando, ao mesmo tempo, sete novos prédios no bairro do Umarizal, a maioria com mais de 30 andares. Se essa febre continuar, os moradores de Belém vão pagar a conta do calor: o paredão de concreto que está se formando no antes aprazível e ventilado Umarizal vai afetar toda a cidade. Não está mais exatamente na hora de regulamentar a onda de espigões nessa área, tão intensamente explorada pela construção civil e seu vício acompanhante, a especulação imobiliária. Já está tarde (PINTO, 2003, p. 6 apud VIEIRA, 2017, p. 125-126).

Não só se multiplicaram com grande rapidez os prédios como eles foram se tornando cada vez mais altos. Já são numerosos os "arranha-céus" com mais de 30 andares e agora a cidade já tem um novo topo: as duas torres de 40 andares levantadas na valorizada Doca de Souza Franco, que acabaram com o reinado de meio século do "Manuel Pinto da Silva" como o edifício mais alto do Norte e Nordeste do Brasil.

A desenfreada verticalização ocorre exatamente quando a frota de veículos também experimenta desempenho semelhante, batendo em quase 300 mil veículos, sem que o poder público tenha acompanhado as duas evoluções. Parece que Belém toma São Paulo como modelo (PINTO, 2012, p. 7 apud VIEIRA, 2017, p. 126).

O que se percebe por meio da simples observação da paisagem pode ser também ratificado por meio de dados que demonstram o avanço da produção imobiliária no bairro, conforme ainda a sistematização de Vieira (2017), ao mostrar que até o ano de 2005 o bairro possuía apenas 90 edifícios verticais. Essa situação mudou ao longo dos anos, passando a 130 edificações em 2009 e a 174 em 2015.

Conforme o mesmo autor, o percentual de crescimento do número de edifícios no primeiro período referenciado em sua série temporal (julho de 2005 a julho de 2009) é de 44,4\%, e de 33,8\% para o segundo período (julho de 2009 a julho de 2015), que permanece relativamente elevado se considerarmos que este último adentra nos anos de crise econômica mundial, repercutindo na desaceleração de crescimento do setor imobiliário em nível local. O fato é que em dez anos a quantidade de edifícios no bairro do Umarizal teve um crescimento de quase $100 \%$, uma vez que saltou de 90, em julho de 2005, para 174 edifícios, em julho de 2015 (VIEIRA, 2017).

O que justifica esse processo de valorização de bairros pericentrais como o Umarizal? Sem dúvida, a tendência das classes de mais alto poder aquisitivo de habitar as áreas centrais da cidade, considerando fatores tais como: o potencial e a relativa qualidade da infraestrutura instalada ao longo de sua história, a proximidade dos principais serviços voltados às classes mais solventes, os investimentos em obras de saneamento e macrodrenagem nas antigas áreas de 
baixadas por parte do Estado, as amenidades naturais e as socialmente produzidas ligadas à imagem da cidade.

Em relação a estas últimas, o fato de o Umarizal situar-se às margens da baía de Guajará tem sido um dos elementos que se fazem presentes no marketing das empresas imobiliárias responsáveis pela produção de apartamentos em prédios verticais nesse bairro. Soma-se a isso, entretanto, como hipótese, o fato de que a nova imagem que se tem veiculado a respeito da cidade, encontra-se diretamente associada aos novos espaços requalificados no interior de seu centro histórico ou mesmo em suas imediações. Não coincidentemente, o avanço imobiliário no bairro se deu concomitantemente à tentativa do poder público de definir uma nova imagem para o centro histórico da cidade e, igualmente, de voltar o olhar de seus habitantes em direção aos rios, por muito tempo negados pelo processo de crescimento urbano.

Nesse sentido, diferentemente do que acontece em grande parte das cidades de países centrais, que têm vivenciado processos clássicos de gentrificação urbana, no caso de Belém, as classes de mais alta renda não tendem a substituir as populações de inferior poder aquisitivo a elas que habitam o núcleo central; mesmo porque o processo de requalificação não tem sido extensivo àquelas edificações residenciais de valor histórico-patrimonial situados no interior do centro histórico.

A processos semelhantes como esses, autores diferentes não têm descartado o reconhecimento da gentrificação. Buscam, entretanto, adjetivá-la, de maneira a melhor caracterizar as particularidades das formas como se manifestam em distintas realidades, por se tratar, com efeito, de uma estratégia urbana de nível global, conforme pontua Smith (2006), que chama a atenção para o fato de que:

seria um erro considerar o "modelo nova-iorquino" como uma espécie de paradigma, e medir o progresso da gentrificação em outras cidades pelos estágios que foram lá identificados. Não é isso o que estou sugerindo. Por ser uma expressão de relações sociais, econômicas e políticas mais amplas, a gentrificação em uma cidade específica irá exprimir as particularidades da constituição de seu espaço urbano (SMITH, 2006, p. 74).

Buscando entender tais particularidades, autores como Van Criekingen (2006), chamam atenção para a necessidade de buscar elementos reveladores do mesmo processo em diversas realidades locais:

compreender as transformações contemporâneas dos espaços urbanos antigos, tanto para superar o entusiasmo imediato dos discursos sobre o "renascimento" do centro, como a desolação fatalista quanto a seus impactos sobre as populações pobres, exige antes de tudo quebrar o 
molde indiferenciado do "gentrificador" e da dinâmica da qual ele era o herói. A demanda por espaços urbanos revitalizados é assegurada por grupos econômicos e demográficos diversificados, com modos de inserção no mercado da habitação e itinerários residenciais variados (VAN CRIEKINGEN, 2006, p. 112).

Sustenta que as situações tendem a variar bastante, e a reapropriação residencial e comercial, mesmo a de atividades de escritório, com finalidades turísticas ou recreativas, na verdade, expressam-se em diversas combinações nos bairros antigos em transformação (VAN CRIEKINGEN, 2006, p. 97-98). Acompanhando o seu raciocínio, diríamos também que tais combinações das dinâmicas urbanas que se relacionam à gentrificação extrapolam mesmo os limites de bairros objetos de intervenção urbana.

De sua discussão sobre Bruxelas, a diferença que faz entre a "gentrificação residencial" e "gentrificação do consumo" parece interessar à interpretação de situações como a aqui apresentada a respeito de Belém. Chama a atenção, entretanto, o processo de substituição que tem ocorrido notadamente no entorno do chamado centro histórico, que parece possuir certa sintonia com o movimento pontual de requalificação no interior desse mesmo espaço.

Nesse caso, não se constata de maneira genérica a requalificação de antigas estruturas comerciais e residenciais que promovam uma mudança completa no interior do centro histórico, mas sobretudo a produção de um novo espaço e de imóveis mais modernos no entorno que, fundada no discurso da segurança e das opções de lazer que oferecem, tornam-se atrativos às classes médias e altas que não demonstram interesse em habitar o velho centro em imóveis antigos, mesmo que restaurados. Os indícios de requalificação desses antigos imóveis, se existem, são ainda muitos tímidos e se prestam principalmente a serviços e atividades comerciais muito pontuais.

No entorno da "Estação das Docas", por exemplo, chama a atenção a restauração de alguns exemplares de um conjunto de casario antigo situado a sua frente, onde foi instalado um espaço cultural, voltado a atividades do Serviço Social do Comércio (SESC), e um restaurante pouco convencional de venda de açaí, com uma proposta mais sofisticada de atendimento aos que visitam a cidade e a um público local mais seleto.

Nas imediações do complexo "Feliz Lusitânia" também somente duas novas atividades instaladas em prédios de valor histórico atraem a atenção. Tratase de restaurantes especializados em comida internacional, sendo que em um deles também funciona uma espécie de hotel de charme, que associa os serviços 
de hospedagem oferecidos à beleza e ao valor histórico do bairro da Cidade Velha e às amenidades dos espaços restaurados nas suas imediações.

Situação semelhante acontece com o Parque Naturalístico "Mangal das Garças", que pouco dinamizou atividades em seu entorno. As exceções referemse a um bar com proposta de música e cardápio diferenciado, frequentado por uma classe média que aprecia a boa música e a boa gastronomia local; assim como, a um hotel, de médio porte, que se instalou em um casarão restaurado no entorno do parque e que desfruta de suas amenidades apresentando-as como um dos atrativos para quem nele deseja se hospedar.

Por fim, o Polo Joalheiro e Cultural "São José Liberto" pouca repercussão trouxe no sentido de atrair novas atividades para o local onde se instalou. Se nos demais, as atividades instaladas a partir dos projetos de requalificação urbana reaproveitaram antigas estruturas arquitetônicas existentes, neste último caso, os poucos bares que no seu entorno foram dinamizados, não chegam propriamente a ocupar edificações consideradas de valor patrimonial de natureza histórica e arquitetônica.

Não se trata, portanto, no caso belenense, de gentrificação clássica, à maneira como foi descrita por Smith (2006) para as cidades de países centrais, em que as áreas renovadas pressupõem, além da restauração de antigas estruturas, a saída de classes de inferior status social e que tendem a ser substituídas por estratos sociais de mais alto poder aquisitivo. Isso não significa dizer, todavia, que o caráter classista do processo referenciado por aquele autor não se faça presente no caso belenense.

Leite, ao tratar das alterações na área central de Recife, mostra que a questão da gentrificação toca diretamente a "transformação dos significados de uma localidade histórica em um segmento do mercado, considerando a apropriação cultural do espaço a partir do fluxo de capitais" (LEITE, 2004, p. 20). E parece ser exatamente isso o que se verifica embrionariamente na realidade belenense.

Há um novo significado atribuído aos lugares requalificados que nega a presença de seus antigos frequentadores ou daqueles que circulam em seu entorno. Em contraponto, abrem-se nesses espaços possibilidades de apropriação cultural ou voltada ao lazer em forma de consumo induzidos a partir de interesses diretamente ligados, não apenas, mas principalmente, a comportamentos e valores de uma classe média local e aos turistas que visitam e frequentam, com certa regularidade, esses lugares.

Nesse sentido, em Belém, à semelhança de outras cidades brasileiras, a requalificação estimula novos usos dos espaços objetos de intervenção. Tal utilização dos espaços em referência é feita com certa recorrência dada a oferta 
de serviços ligados ao entretenimento, à vida cultural, ao turismo e ao lazer de determinadas classes sociais, que visitam a área central pontualmente, mas que não necessariamente estendem suas visitas às suas imediações; estas que são vistas normalmente como perigosas e mal frequentadas.

É esse mesmo caráter de frequência recorrente que faz Frúgoli Jr. (2006) adjetivar também o processo de gentrificação ao se referir a algumas experiências verificadas em cidades latino-americanas, mostrando que, diferentemente das constatações de Smith (2006) para Nova Iorque, em várias situações o papel do Estado é fundamental para a ocorrência desse processo, cuja expressão não é propriamente vinculada ao uso residencial.

Inspirado em Melé (2006) e Hiernaux (2006), sugere falar de "gentrificação de frequência e de consumo". Esse tipo de manifestação do processo se aproxima mais do que acontece na realidade belenense, onde, além dos turistas, que fazem dos espaços requalificados verdadeiras referências de conhecimento a respeito da cidade, algumas práticas rotineiras protagonizadas por classes médias e abastadas, por meio de seus hábitos e valores de consumo e pela proximidade e facilidade de acesso, definem a frequência, de forma mais seletiva, dos "espaços públicos" requalificados.

Exemplo disso são os concertos de música na capela do Espaço Cultural "São José Liberto" e na de Santo Alexandre; este integrante do "Feliz Lusitânia", onde são também realizados, com certa regularidade, casamentos da elite belenense ou de sua classe média, que podem pagar caro para a realização de eventos dessa natureza.

No Parque Naturalístico "Mangal das Garças", por seu turno, a frequência dessas mesmas classes acontece para usufruir do restaurante de alta qualidade que ali foi instalado e para reafirmar uma outra função que, cada vez mais, faz-se presente no interior desse espaço público. Trata-se da presença de famílias, casais, turmas de formaturas, aniversariantes e modelos que escolhem aquele espaço para servir de cenários para fotografias que irão compor books profissionais ou de datas e eventos importantes e/ou comemorativos.

Situação semelhante se constata em relação à "Estação das Docas", que apesar de possuir espaços culturais que servem de atrativos para esses mesmos estratos sociais, tem seu dinamismo atribuído especialmente pela frequência a bares e restaurantes de médio e alto padrão nela instalados, servindo também de espaço de contemplação e de uso cenográfico para fins semelhantes aos do "Mangal das Garças". Diante disso, são relativamente poucos os momentos em que uma apropriação mais diferenciada e diversa de classes e de grupos acontece, como o que se verifica nas festas de réveillon, quando então os espaços 
não privatizados por bares e restaurantes são mais plenamente ocupados pela população em geral que para lá se dirige para festejar a chegada de um novo ano.

A concepção preservacionista e a "maquinaria patrimonial" (JEUDY, 2005), sobre as quais se apoia a volta ao passado e à sua referência como condição de afirmação de uma imagem do presente, é também um mecanismo de reapropriação seletiva e de transformação de áreas tidas como "marginais" em complexos culturais e de lazer. Paradoxalmente, reforça também a segmentação dessas mesmas áreas centrais, tornadas cenários de disputas entre um espaço que se concebe para a visitação pública ocasional e seletiva e aquele que se presta a existência cotidiana dos que ali vivem e transitam a maior parte do tempo.

Esse modelo desigual de política urbana dá sentido ao que Vaz e Jacques (2006) identificam como "gentrificação cultural", que, no caso de Belém, por se fazer presente em espaços pontuais, em vez de tornar mais coeso o velho centro, culmina por fragmentá-lo ainda mais, dada a presença de espaços sofisticados culturalmente visitados e aqueles em que a cultura popular e espontânea passa a ser vista como marginal e indesejável.

Pode-se falar, assim, como Vaz e Jacques (2006), de uma "culturalização da cidade", que promove espaços desiguais em seu interior. Associada à espetacularização e ao incremento turístico, a funcionalização cultural que preenche espaços requalificados atende notadamente a objetivos econômicos e divide a cidade em "zonas culturais" - requalificadas com equipamentos culturais - e "zonas não culturais" - onde aqueles mesmos equipamentos se fazem ausentes.

Nos casos mencionados, as transformações que causaram pontualmente a determinadas frações do centro histórico de Belém e o sentido de enclave que possuem nos espaços onde se localizam, muitas vezes desarticulados e sem grandes interações com o entorno imediato, reafirmam a ideia de seletividade cultural mencionada. Trata-se de espaços que definiram novos fluxos pontuais para o núcleo central da cidade, dada a regularidade de frequência por parte de um público - turistas ou moradores locais -, que a eles se dirigem, mas que, de fato, não interagem com o centro histórico na sua totalidade.

Tornam-se, assim, reapropiados apenas pontualmente e temporariamente por classes locais de alto e médio status e por visitantes que, por meio de um consumo mais cultural e voltado ao entretenimento, contribuem para legitimar o forte apelo patrimonial, contemplativo e de lazer desses espaços. Isso a despeito dos fluxos cotidianos pré-existentes nessa área central, relacionados ao comércio popular, aos diversos portos onde ancoram os barcos regionais, às feiras e às outras atividades do circuito inferior da economia urbana (SANTOS, 1979), que aí se fazem fortemente presentes. 


\section{CONSIDERAÇÕES FINAIS}

A gentrificação tende a combinar requalificação dos usos de determinadas frações da cidade, intervenção no patrimônio histórico-cultural e arquitetônico, assim como melhorias na infraestrutura instalada, associada a uma releitura estética do espaço objeto de intervenção, que passa a atrair, por esse motivo, camadas sociais de mais alto status econômico em comparação àquelas que normalmente frequentam ou habitam esses mesmos espaços.

No caso belenense e de outras cidades brasileiras, a questão que se coloca é se as transformações que hoje essas cidades vivenciam em suas áreas centrais requalificadas traduziriam o mesmo processo de reapropriação de áreas centrais já identificado em outras cidades de outros países desde o século passado, ou se ganham novas configurações, conforme pontua Smith (2006), no século XXI. Fato comum nesses casos é a saída ou recuo de territorialidades de moradores das classes populares dos centros e a chegada e territorialização de classes economicamente mais solváveis que as substituem ou restringem seus espaços de uso e de vivência, sinalizando para a natureza classista do processo.

Reafirmando essa posição de Smith (2006), Bidou-Zachariasen (2006) sustenta que:

qualquer que seja a sua natureza, espontânea e marginal, ou programada e mundial, a gentrificação tem por corolário a saída das classes populares dos centros urbanos. E, embora a dimensão classista do processo haja sido sublinhada pelos primeiros trabalhos que a estudaram (cf. Glass), esta dimensão será eufemizada ou silenciada pelos discursos dos que a programam como política de "renascimento" ou "regeneração" urbana (BIDOU-ZACHARIASEN, 2006, p. 32).

Muito se tem falado a respeito da inexistência da gentrificação em realidades urbanas como as latino-americanas. No caso brasileiro, esse argumento tem aparecido principalmente porque os processos de mudanças por que passam os centros de cidades como Belém, não têm, de fato, trazido as classes médias e altas para habitarem seus centros históricos, não obstante o processo de requalificação por qual têm passado.

Em contrapartida, os novos espaços renovados não escapam a outras formas de apropriação por parte dessas mesmas classes, sinalizando para uma forma de gentrificação nada clássica que se manifesta, ainda que de modo tímido, e que pode revelar uma tendência de seletividade socioespacial, tal o grau de adesão que provoca nas classes médias, especialmente as que habitam bairros próximos do centro histórico. 
Resulta, em geral, da reinvenção de espaços cujas centralidades existentes são praticamente desconsideradas, recriando-se neles novos fluxos de visitantes e frequentadores motivados pela nova cidade projetada a partir de experiências de requalificação urbana. São intervenções fragmentárias e pontuais que, de forma metonímica, apresentam-se como o todo, sendo, entretanto, apenas uma parte do centro histórico.

Por essa razão, os espaços requalificados são frequentados apenas furtivamente e de forma pontual por classes de mais alto poder aquisitivo, pois não é do centro como um todo que se busca reapropriar, mas tão somente daqueles pedaços que foram renovados, requalificados e refuncionalizados para usos bem específicos. Ainda que estejam resguardados pelo discurso da socialização na condição de espaços públicos reinseridos na vida urbana, antes controlados por instituições ou esferas governamentais que lhe conferiam uso restrito ou mesmo privativo, a renovação da forma espacial e/ou arquitetônica faz assumirem uma identidade que os reduz a espaços apenas coletivos em detrimento do adjetivo "público" a que buscam estar associados.

Isso acontece porque se sujeitam a uma forma de apropriação ainda muito limitada a determinados estratos sociais, posto que as práticas de uso que lhes são induzidas pelo poder público ou pelas Organizações Sociais (OS) que os gerenciam tendem a inibir uma forma de apropriação de caráter mais universal, onde o sentido de copresença, de coabitação, possa ser marcado pela pluralidade, civilidade, diálogo e relação contratual de agentes diversos, como seria de se esperar de espaços públicos no sentido pleno do termo (GOMES, 2002). Há, portanto, uma natureza classista de apropriação do espaço a ser considerada.

$\mathrm{Na}$ verdade, referem-se verdadeiramente a espaços mediados pelo consumo, com apelos culturais, de turismo e de lazer, e que não favorecem esse sentido pleno de "público", já que são seletivos, algumas vezes camuflados, labirínticos, vigiados, material ou simbolicamente blindados e pouco favoráveis ao acesso e ao uso plural e diverso (AMENDOLA, 2000).

São esses novos conteúdos e valores da vida urbana em Belém que redesenham seu skyline. O centro histórico, agora pontualmente requalificado, continua a aparecer em primeiro plano, como acontecia nas antigas imagens que se tinha da cidade; mas, ao seu fundo, a compor uma nova imagem tornamse flagrantes os prédios em altura, como os existentes no adjacente bairro do Umarizal, um dos bairros da nova classe média de Belém, que recorrentemente passa a frequentar os espaços requalificados do centro histórico para fins de entretenimento cultural e de lazer de um modo geral, mas que não o constitui 
como seu espaço de moradia, preferindo habitar apartamentos modernos, com área de lazer completa, às suas adjacências; aí também substituindo populações de menor poder aquisitivo que habitavam esse mesmo bairro.

\section{REFERÊNCIAS}

AMENDOLA, G. La ciudad postmoderna: magia y miedo de la metrópolis contemporánea. Madrid: Celeste Ediciones, 2000. (Colección Intersecciones Arte y Arquitectura)

BIDOU-ZACHARIASEN, C. Introdução. In: (Org.). De volta à cidade: dos processos de gentrificação às políticas de "revitalização" dos centros urbanos. São Paulo: Annablume, 2006. p. 21-57.

CARDOSO, W. S. Mercado imobiliário e verticalização de empreendimentos residenciais na produção da segregação socioespacial em Belém. 2017. 436f. Tese (Doutorado em Desenvolvimento Sustentável do Trópico Úmido) de Núcleo de Altos Estudos Amazônicos, Universidade Federal do Pará, Belém, 2017.

FRÚGOLI JR., H. Intervention dans les espaces centraux des villes brésiliennes, le cas de São Paulo. In: RIVIERE D’ARC, H., MEMOLI, M. (Ed.). Le pari urbain en Amérique latine: vivre dans le centre des villes. Paris: Armand Colin, 2006. p. 133-147.

GOMES, P. C. C. A condição urbana. Rio de Janeiro: Bertrand Brasil, 2002.

HIERNAUX-NICOLAS, D. A reapropriação de bairros da Cidade do México pelas classes médias: em direção a uma gentrificação? In: BIDOUZACHARIASEN, C. (Org.). De volta à cidade: dos processos de gentrificação às políticas de "revitalização" dos centros urbanos. São Paulo: Annablume, 2006. p. 229-264.

JEUDY, H-P. Espelho das cidades. Rio de Janeiro: Casa das Palavras, 2005.

LEITE, R. P. Contra-usos da cidade: lugares e espaço público na experiência urbana contemporânea. Campinas-SP: Unicamp, 2004.

MELÉ, P. (Re)investir nos espaços centrais das cidades mexicanas. In: BIDOUZACHARIASEN, C. (Org.). De volta à cidade: dos processos de gentrificação às políticas de "revitalização" dos centros urbanos. São Paulo: Annablume, 2006. p. 167-195. 
SANTOS, M. Por uma geografia nova. 3. ed. São Paulo: HUCITEC, 1986.

O espaço dividido: os dois circuitos da economia urbana dos países subdesenvolvidos. Rio de Janeiro: Francisco Alves, 1979.

SMITH, N. A gentrificação generalizada: de uma anomalia local à "regeneração" urbana como estratégia urbana global. In; BIDOU-ZACHARIASEN, C. (Org.). De volta à cidade: dos processos de gentrificação às políticas de "revitalização" dos centros urbanos. São Paulo: Annablume, 2006. p. 89-120. p. 59-87.

TRINDADE JR., S-C. C. Formação metropolitana de Belém (1960-1997). Belém: Paka-Tatu, 2016. (Série Belém 400 Anos).

Produção do espaço e uso do solo urbano em Belém. Belém: NAEA, 1997.

VAN CRIEKINGEN, M. A cidade renasce! Formas, políticas e impactos da revitalização residencial em Bruxelas. In: BIDOU-ZACHARIASEN, C. (Org.). De volta à cidade: dos processos de gentrificação às políticas de "revitalização" dos centros urbanos. São Paulo: Annablume, 2006. p. 89-120.

VAZ. L. F; JACQUES, P. B. Territoires culturels de Rio. In : JEUDY, H-P ; JACQUES, P. B. Corps et décors urbains: les enjeux cultureles des villes. Paris: L'Harmattan, 2006. p. 61-78.

VENTURA NETO, R. S. Belém e o imobiliário: uma cidade entre contratos e contradições. Belém: Imprensa Oficial do Estado, 2015.

VIEIRA, B. S. Verticalização imobiliária e controle do uso e da apropriação do espaço urbano em Belém: discursos e conflitos em torno da outorga onerosa do direito de construir. 2017. 227f. Tese (Doutorado em Desenvolvimento Sustentável do Trópico Úmido) - Núcleo de Altos Estudos Amazônicos, Universidade Federal do Pará, Belém, 2017. 


\section{Comunidades quilombolas e o Programa Nacional de Habitação Rural}

\section{The quilombola communities and the National Rural Housing Program}

André Augusto Brandão - Doutor em Ciências Sociais. Professor do Programa de Estudos Pós-Graduados em Política Social da Universidade Federal Fluminense. Diretor adjunto do DATAUFF. E-mail: andre_brandao@id.uff.br

Salete Da Dalt - Doutora em Política Social pela Universidade Federal Fluminense. Coordenadora do DATAUFF. Diretora do IPPECET. E-mail: salete@datauff.uff.br

Sidimara Cristina de Souza - Mestre e doutoranda em Política Social pela Universidade Federal Fluminense. Pesquisadora do LAPPDAR / UFVJM. E-mail: sidi.mara@hotmail.com

\section{Resumo}

Este artigo tem como objeto a inserção da população quilombola nas políticas definidas pelo Programa Nacional de Habitação Rural. Lançando mão de dados coletados em pesquisas recentes, discutimos as características das comunidades quilombolas que têm acessado a moradia por esta via. Os elementos que caracterizam a construção destas unidades habitacionais, são apresentados e avaliados a partir da relação com o desenho do Programa e com os gargalos operacionais que se impõem ao processo de implementação.

\begin{abstract}
This article has as its object the insertion of the population quilombola in the policies set by the National Program of Rural Housing. Using data collected in recent research, we discuss the characteristics of the quilombola communities that have accessed the dwelling this route. The elements that characterize the management of the processes of construction of these housing units, are presented and evaluated from the relation with the design of the Program and with the operational bottlenecks imposed on the implementation process.
\end{abstract}

\section{Palavras-chave}

Política Habitacional. Comunidades Quilombolas. Avaliação. Desenho de Programas.

\section{Keywords}

Housing Policy. Rural Communities. Evaluation. Program Design. 


\section{INTRODUÇÃO}

A política habitacional no Brasil se adensa na agenda pública no início da década de 1960, com a criação do Banco Nacional da Habitação. No entanto, o déficit habitacional e a não generalização de condições dignas de moradia são importantes fatores de desigualdade social e vulnerabilidade que persistem em alta proporção no país ainda hoje.

Segundo Maricato (2006), os estudos sobre carência de moradia e falta de condições dignas mostram que os déficits habitacionais estão concentrados nos extratos populacionais de baixa renda ( $92 \%$ dos casos), ou seja, famílias que recebem renda de até 5 salários mínimos. No entanto, destes $92 \%$, nada menos que $84 \%$ estão concentrados na faixa correspondente a até 3 salários mínimos de renda.

Outro fator relevante é a localização das moradias que não apresentam condições adequadas de habitabilidade, no geral construídas em áreas periféricas, de risco e insalubres (com carência de esgoto sanitário, contaminação da água e solo etc.). Não é ocioso enfatizar que a política implementada na década de 1960 também não levou em conta estes problemas e nem seguiu um planejamento que resultasse a inclusão das famílias em programas habitacionais seguros e de qualidade; bem como também não foi desenvolvido um planejamento financeiro adequado para atender a esta demanda.

Na década de 1980 o Banco Nacional da Habitação foi extinto e apenas na Constituição de 1988 o debate sobre a questão retorna com mais força a arena pública. Nesta carta constitucional, ficou estabelecido que através do processo de descentralização, a gestão da política habitacional seria de competência dos estados e municípios. No entanto, esta política só ganha espaço com a mobilização da sociedade civil, que passou a pressionar o Governo Federal a retomar a discussão sobre políticas públicas no Brasil em sua relação com o tema da inclusão social.

Em 2004, o Ministério das Cidades passou a implementar a Política Nacional de Habitação (PNH), proporcionando assim, de forma gradual, o enfrentamento do déficit neste campo da política social no Brasil. Estas ações tiveram como base estudos voltados para o diagnóstico e mapeamento de cada município, para subsidiar e garantir a mobilização de recursos e planejamento adequados à demanda existente.

A Política Nacional de Habitação (PNH) foi regulamentada pela Lei $\mathrm{n}^{\circ}$ 11.124/2005, que instituiu o Sistema Nacional de Habitação de Interesse Social e o Fundo Nacional de Habitação de Interesse Social (FNHIS). A partir daí, foi 
possível buscar uma maior aproximação com a demanda existente e trabalhar no sentido da inclusão de populações tradicionais, como indígenas e quilombolas. Mas este direcionamento havia começado um pouco antes, com a criação em 2003, do Programa Nacional de Habitação Rural (PNHR) que tem por objetivo reduzir os déficits habitacionais existentes nos territórios rurais. O Programa procurava oferecer acesso, com crédito muito facilitado, à financiamentos na área da habitação rural, para agricultores familiares em condição socioeconômica vulnerável.

A capilarização deste Programa somente iria ocorrer mais à frente. Especificamente, em 2007, a Lei no 11.1977, de 07 de julho, cria o Programa Minha Casa, Minha Vida (PMCMV), destinado ao incentivo à produção e aquisição de imóveis tanto urbanos, quanto rurais, para famílias com renda de até $\mathrm{R} \$ 4.650,00$. Já em 2009, uma Portaria Interministerial (nº 326, de 31 de agosto) dos Ministérios da Cidade e da Fazenda, localizam o Programa Nacional de Habitação Rural no âmbito do Programa Minha Casa, Minha Vida (vale ressaltar que somente em 2011, a Lei no 12.424 vai alterar a Lei de criação do PMCMV, para incluir o PNHR como um subprograma deste).

Com tais alterações, o Programa Nacional de Habitação Rural passa a corresponder a uma modalidade do Programa Minha Casa, Minha Vida, regulamentado pelo Ministério das Cidades. Seus objetivos se voltam para a população rural brasileira, atendendo agricultores familiares, trabalhadores rurais, assentados do Programa Nacional de Reforma Agrária e membros de comunidades tradicionais (quilombolas, extrativistas, pescadores artesanais, ribeirinhos, indígenas etc.).

O desenho do Programa indica possibilidades de financiamento diferentes para as regiões Nordeste, Centro-Oeste, Sudeste e Sul (onde a edificação da unidade habitacional é financiada até o limite de $\mathrm{R} \$ 28.500,00$ e a reforma até $\mathrm{R} \$ 17.200,00$ ) e para a região Norte (onde o a edificação da unidade habitacional é financiada até o limite de $\mathrm{R} \$ 30.500,00$ e a reforma até $\mathrm{R} \$ 18.400,00)$. Esta diferença seria explicada pelo "custo logístico" superior nesta última região.

São elegíveis famílias com até $\mathrm{R} \$ 60.000,00$ de renda anual bruta, mas somente aquelas com até $\mathrm{R} \$ 15.000,00$ (vale ressaltar que este é o caso absolutamente majoritário nas comunidades quilombolas) recebem o subsídio mais significativo e contribuem com somente $4 \%$ do valor inicialmente repassado para a construção ou reforma. Neste caso, o pagamento é dividido em quatro parcelas anuais, de valor igual, com a primeira devendo ser paga 12 meses após a assinatura do contrato. Ao contrário do que ocorre com o financiamento da habitação urbana, que é individualizado por unidade habitacional; no caso deste Programa Nacional de Habitação Rural o financiamento é coletivo, quando se trata de famílias com até $\mathrm{R} \$ 30.000,00$ de renda anual bruta. 
Aqui estamos em contato com certa "mística" - que parece mais advinda do senso comum do que de estudos científicos - que insiste em alocar as populações rurais no polo da Gemeinschaft (comunidade), enquanto que a população urbana estaria no pólo da Gesellschaft (sociedade). Esta oposição, que remonta a obra de um dos fundadores da sociologia como ciência, o alemão Ferdinand Tonnies, publicada em 1887, ainda reverbera hoje, quando são desenhadas políticas para populações rurais.

Isto porque, há uma insistência em tomar o rural como algo que teria uma "afinidade eletiva" com elementos comunitários, no sentido ainda próximo da definição de Tonnies, ou seja: aglomerados humanos caracterizados por relações mais íntimas, interiores e gregárias. Tal configuração estaria marcada por relações de parentela e amizade próxima, que tenderiam ao consenso e à possibilidade de entendimento, convivência e por decorrência, vida em comum (TONNIES, 1947 p. 41). No polo oposto disto, teríamos a articulação societária onde as diferenças interpessoais tenderiam a gerar autonomia individual e, por conseguinte, uma permanente tensão com o coletivo.

Está ainda para ser feito um amplo estudo acerca da história da disseminação deste modelo teórico nas formas de pensar o mundo rural e o mundo urbano no Brasil. O fato é que, como um espectro, implícito ou explicito, esta oposição entre Gemeinschaft e Gesellschaft se faz notar ${ }^{1}$ em nossas políticas públicas.

Assim, os beneficiários deste Programa Nacional de Habitação Rural que possuem renda de até $\mathrm{R} \$ 30.000,00$ são atendidos em grupos de no mínimo 4 e no máximo 50 famílias. Estes precisam estar aglutinados em uma "entidade organizadora". Tal entidade pode ter caráter público (prefeituras, por exemplo) ou privado. Neste último caso o desenho do Programa aponta para as entidades representativas dos segmentos comunitários (obviamente sem fins lucrativos), tais como associações comunitárias, sindicatos de trabalhadores rurais, cooperativas de produtores etc.

\footnotetext{
No caso dos quilombolas o peso desta oposição é óbvio. Desde as primeiras titulações de territórios quilombolas, realizadas em 1995, os títulos de propriedade da terra foram de natureza coletiva e emitidos em nome de associações comunitárias. Em 2001, o Decreto 3.912 regulamenta este formato para as titulações, o que será mantido pelo Decreto 4.887/2003 que revoga o 3.912. No entanto, pesquisas que vêm sendo realizadas junto a comunidades quilombolas nos últimos anos, mostram que apesar destas imposições legais o quadro encontrado é distinto. Em 2011 uma pesquisa com lideranças comunitárias de 161 comunidades quilombolas que já estavam com o título de propriedade coletiva da terra emitido, encontrou em somente 14,9\% destas, iniciativas de produção agrícola coletiva (BRANDÃO; DA DALT; JORGE, 2015). Em estudo anterior, realizado com aproximadamente 150 comunidades quilombolas tituladas e não tituladas (BRANDÃO; DA DALT; GOUVEA, 2010), já apontavam que atividades de produção agrícola coletivas são desenvolvidas por uma parcela pequena das comunidades quilombolas brasileiras (o que de resto é uma característica do conjunto do campesinato brasileiro), pois o amplo predomínio entre estas é da produção familiar.
} 
A construção ou reforma destas unidades habitacionais deve utilizar um único regime de execução (acentuando, mais uma vez o caráter coletivo da produção do bem social que é alvo do Programa). O desenho proposto admite quatro possibilidades, das quais uma deve ser elegida.

A primeira seria o "mutirão assistido", onde os beneficiários produzem ou reformam em conjunto as unidades habitacionais, tendo apoio de assistência técnica especializada (engenheiro, mestre de obras, pedreiro, eletricista etc.). A segunda corresponde a "autoconstrução assistida", na qual o próprio beneficiário realiza a construção ou reforma, mais uma vez com auxílio de assistência técnica especializada. A terceira opção corresponde a "administração direta". Neste regime, a "Entidade Organizadora" fica responsável pela execução das obras e pode utilizar mão-de-obra do seu quadro de funcionários (quando houver) ou vinculada a ela (no caso de associações representativas de comunidades tradicionais, isso significa que os moradores podem ser captados para a tarefa). Por fim, há ainda a opção pela "empreitada global", onde uma construtora especializada é contratada para a execução da obra ou dos serviços de reforma, sendo previamente definido o valor e o tempo para finalização.

No caso das comunidades quilombolas, que pleiteiam acesso ao Programa, estas devem possuir o certificado de reconhecimento emitido pela Fundação Cultural Palmares (FCP). Também para estas, não impera o mesmo limite de até 4 módulos fiscais, por família, para acesso ao PNHR, uma vez que o título de terra das comunidades quilombolas, como já apontamos antes, é de natureza coletiva, por força da legislação vigente.

\section{MAS O QUE SÃO COMUNIDADES QUILOMBOLAS?}

Segundo informações da Secretaria Especial de Políticas de Promoção da Igualdade Racial (SEPPIR), a Fundação Cultural Palmares havia emitido até 2012, a certificação como "Quilombola” para 2.040 comunidades, 63\% destas situadas no Nordeste do país (SEPPIR, 2012). Apesar desta proporção de comunidades, a invisibilidade social constitui uma marca que historicamente vem atingindo estas populações em todo o país (REIS; GOMES, 1996). Por conta desta invisibilidade, os processos de vulnerabilização social são sobre determinados por ações de preconceito e discriminação de origem social e racial. Contra esse processo, o Governo Brasileiro vem tomando, desde 2003, tais comunidades como alvo de ações públicas.

De fato, a problemática relativa às comunidades quilombolas aparece na agenda das políticas públicas brasileiras a partir de 1988, mais especificamente 
quando estas são nomeadas (e, portanto, começam a ganhar alguma visibilidade) em dois momentos da Constituição Federal, a saber:

a) no artigo 216, $\int 5^{\circ}$ : "Ficam tombados todos os documentos e os sítios detentores de reminiscências históricas dos antigos quilombos" e;

b) no artigo 68 do Ato das Disposições Transitórias: “Aos remanescentes de quilombos que estejam ocupando suas terras é reconhecida a propriedade definitiva, devendo o estado emitir-lhes os títulos definitivos".

As comunidades remanescentes de quilombos se caracterizam pela organização em torno de uma identidade étnica diferenciada, além de dependerem de seus territórios para a viabilização de sua reprodução física, social, econômica e cultural. Sabemos que nas últimas décadas as discussões públicas e as ações políticas ancoradas em perspectivas tipicamente multiculturais têm invadido a cena pública brasileira. Neste campo, as questões relacionadas às relações raciais e aos problemas advindos das desigualdades entre os grupos de cor ou raça se destacam.

Ainda não foi feito um inventário preciso dos bastidores da formulação do tão conhecido artigo 68 dos Atos das Disposições Transitórias da Carta Constitucional de 1988. Seja como for, ali se nomeavam e se atribuíam direitos a um heterogêneo conjunto de comunidades de predominância negra que, salvo raras exceções, ainda não se pensavam como "remanescentes das comunidades dos quilombos" (JORGE, 2016).

$\mathrm{Na}$ Constituição de 1988, não se tratava de disponibilizar direitos para "quilombos", mas para populações negras (naquele momento pensadas como exclusivamente rurais) que tinham uma descendência em antigas comunidades quilombolas. Por outro lado, a definição e a própria imagem de quilombo subjacente, seja ao texto constitucional, seja ao próprio senso comum nacional do momento, ligava tais comunidades a ocorrências de fugas de escravos e constituição a partir daí de comunidades isoladas que resistiam a ações de recaptura. Para a grande maioria dos brasileiros, naquele ano de 1988 a representação do termo "quilombo" estava ainda ancorada em Palmares e seu grande herói Zumbi - tratava-se, portanto, muito mais de um estereótipo do que de uma leitura empírica da realidade destas populações.

No processo de operacionalização do Artigo 68, a dificuldade de produção de direitos à posse da terra para os "remanescentes das comunidades dos quilombos" ficou transparente por conta de dois aspectos: a) as comunidades negras rurais (e depois também urbanas) existentes no Brasil não são homogêneas entre si; e b) estas não constituem "fósseis arqueológicos" passíveis de serem submetidos a testes precisos de medição para atestar a veracidade de sua origem. 
Do difícil diálogo entre os agentes públicos e da intensa pressão do movimento negro e do nascente movimento quilombola, resultou uma progressiva modificação na forma de interpretar o que seriam os "quilombolas". Neste novo formato, a vinculação das comunidades com um passado de fuga da escravidão passa a ser somente um dos elementos a serem considerados neste processo de garantia de direitos. De fato, independente da forma como foi construída a comunidade (fuga, ocupação de territórios sem proprietários, ocupações de territórios abandonados pelos antigos proprietários, heranças, doações, migrações etc.), o importante passa a ser a existência de uma continuada reprodução material e cultural. É nesta direção, portanto, que a legislação começa a interpretar de forma diferenciada o termo "remanescentes das comunidades dos quilombos".

Assim, o decreto número 4.887, de 20 de novembro de 2003, em seu artigo $2^{\circ}$ considera:

Remanescentes das comunidades dos quilombos os grupos étnicoraciais, segundo critérios de auto atribuição, com trajetória histórica própria, dotados de relações territoriais específicas, com presunção de ancestralidade negra relacionada com a resistência à opressão histórica sofrida.

Parágrafo $1^{\circ}$. Para os fins deste Decreto, a caracterização dos remanescentes das comunidades dos quilombos será atestada mediante auto definição da própria comunidade.

Parágrafo $2^{\circ}$. São terras ocupadas por remanescentes das comunidades dos quilombos as utilizadas para a garantia de sua reprodução física, social e cultural.

Já no que tange às políticas sociais voltadas para esta população específica, em 2004 o Governo Federal lançou, por meio da SEPPIR, o Programa Brasil Quilombola. No desenho deste programa, fica claro que outros órgãos componentes do Estado também aderiram a interpretações mais ampliada do que seriam os "remanescentes dos quilombos".

Assim, o Programa Brasil Quilombola caracteriza-os como um "grupo étnico". Vemos referências implícitas a Weber (2011) no seu conhecido capítulo sobre relações étnicas e raciais, a Barth (2000) e a Castells (1999), quando o documento marca o caráter de autodefinição da etnia e da identidade, que teriam como matérias-primas possíveis tanto uma "ancestralidade comum", quanto "formas de organização política e social" e ainda "elementos linguísticos e religiosos". A partir deste pressuposto, o que singularizaria as comunidades quilombolas e atestaria uma proximidade entre os quilombos do passado e os quilombos atuais seria um conjunto de práticas sociais e econômicas, que envolvem o uso comum da terra (SEPPIR, Programa Brasil Quilombola: 10). 
A partir de pesquisas de amplo escopo realizadas em 2006, 2008 e 2011 junto a comunidades quilombolas de todas as regiões do país Brandão, Da Dalt e Gouvea (2010) e Brandão, Da Dalt e Jorge (2015), apontam que tais comunidades possuiriam, na atualidade, as seguintes características gerais (o que obviamente não anula a existência de características mais específicas):

a) Se localizam em áreas rurais, embora encontremos também algumas poucas comunidades urbanas no Brasil (seja em metrópoles - como a Família Silva em Porto Alegre-RS - seja como bairros situados na área urbana de municípios mais tipicamente rurais - como a comunidade de Bairro Novo em Penalva-MA).

b) Ampla maioria dos responsáveis pelos domicílios trabalha em atividades agrícolas, principalmente na qualidade de agricultores de subsistência - embora encontremos também trabalhadores rurais autônomos e assalariados rurais (em pequena quantidade). A presença de chefes de domicílios ocupados com atividades urbanas é ínfima entre os quilombolas do país.

c) As comunidades quilombolas compõem o pequeno campesinato, que sobrevive da produção descapitalizada e em pequena escala, de insumos agrícolas (e em poucos casos agropecuários), que são consumidos pelo núcleo familiar e comercializados de forma esporádica quando há excedente e quando existe mercado de consumo.

d) As situações de produção econômica coletiva são pouco frequentes entre os quilombolas. De forma semelhante ao conjunto do campesinato pobre típico do Brasil, vemos entre estas amplo predomínio da produção agrícola familiar, com raras iniciativas de produção coletiva ou comunitária.

f) Os quilombolas em geral possuem baixa escolaridade. Entre os responsáveis pelos domicílios encontramos uma majoritária parcela de indivíduos que chegam somente a quatro anos completos de estudos.

g) A renda das famílias é, em média, muito baixa.

h) No que tange às creches, a cobertura nas comunidades quilombolas é pequena, pois o percentual de crianças de até 04 anos inseridas nestes espaços é praticamente nulo. Já no campo da educação básica a cobertura se mostra efetiva: entre os 5 e 19 anos de idade há um percentual sempre muito baixo de indivíduos que não frequentam a escola.

i) Encontramos entre os quilombolas um percentual pequeno, mas não insignificante, de crianças (de ambos os sexos) envolvidas com o trabalho na agricultura. 
j) A infraestrutura das comunidades está muito aquém do ideal. É quase inexistente a presença de redes de coleta de esgoto nestas comunidades.

h) Encontramos nas comunidades quilombolas uma situação de grande insegurança alimentar.

\section{COMO AS COMUNIDADES QUILOMBOLAS TÊM ACESSADO O PNHR}

As ações no campo da habitação junto às comunidades quilombolas estão relacionadas ao Programa Brasil Quilombola (PBQ), instituído a nível federal em 2004 e vigente até os dias atuais. Tal Programa contém um "EIXO 2: Infraestrutura e Qualidade de Vida" que prevê o desenvolvimento de políticas públicas federais nas áreas de habitação, saneamento, eletrificação, comunicação e vias de acesso.

Vale ressaltar que o Programa Brasil Quilombola foi criado com o objetivo de sistematizar e consolidar uma política de Estado de abrangência transversal para os territórios quilombolas. Do Programa derivou a Agenda Social Quilombola (Decreto nº 6261/2007), que agrupa as ações voltadas às comunidades em várias áreas. A coordenação geral do Programa é de responsabilidade da Secretaria Especial de Políticas para a Igualdade Racial, que atua em conjunto com os ministérios que compõem o seu Comitê Gestor.

O Programa Brasil Quilombola gerou um projeto piloto de construção de casas para famílias quilombolas na comunidade Kalunga, situada no estado de Goiás. Mas a inclusão das comunidades quilombolas nos programas habitacionais se verificou de forma mais sólida com a criação do já citado Programa Nacional de Habitação Rural, que se materializa como linha de financiamento do Programa Minha Casa, Minha Vida.

Por conta de um acordo de cooperação firmado em novembro de 2009 entre a SEPPIR e a Caixa Econômica Federal (CEF) as comunidades quilombolas passaram a ser priorizadas no processo de seleção dos projetos habitacionais. Nesta direção, segundo o último relatório do Programa Brasil Quilombola, datado de 2012 (SEPPIR, 2012), até 2011, cerca de 2.800 unidades habitacionais voltadas para este grupo foram construídas ou estavam com construção em vias de finalização. Havia a previsão naquele momento de que a partir de 2012 mais 2.049 casas fossem construídas.

Em pesquisa realizada no ano de 2011, junto a 161 comunidades quilombolas que já haviam obtido o título de propriedade coletiva dos seus territórios, foram encontradas 100 comunidades em que os moradores apontavam terem acessado 
ou estarem acessando programas habitacionais. Estas 100 comunidades estavam dispersas em 52 municípios, 23 situados na região Nordeste, 2 na região Sudeste, 2 na região Sul, 19 na região Nordeste e 6 na região Centro-Oeste. Destas 100 comunidades somente duas estavam localizadas em área urbana, exatamente as da Região Sul do país. Trata-se de comunidades com baixo número de habitações, uma situada em Porto Alegre-RS e outra em Canoas-RS.

Vejamos as características destes domicílios que acessaram algum programa habitacional. A primeira constatação importante diz respeito à generalização do fornecimento de energia elétrica no país na última década. Como vemos no Quadro 1, 90\% destas residências têm acesso a rede pública para iluminação interna.

Quadro 1 - Forma de iluminação da residência.

\begin{tabular}{|c|c|}
\hline Forma de iluminação & $\mathbf{\%}$ \\
\hline Elétrica (de rede, gerador, solar) & 90,5 \\
Óleo, querosene ou gás de botijão & 8,0 \\
Outra & 0,8 \\
Não tem & 0,4 \\
Total & 99,7 \\
NS/NR & 0,3 \\
\hline Total & 100,00 \\
\hline
\end{tabular}

Fonte: Tabulação própria a partir do banco de dados da pesquisa: Avaliação da Situação de Segurança Alimentar e Nutricional em Comunidades Quilombolas Tituladas (DATAUFF, 2012).

Já a situação referente ao destino do lixo é deficitária. Como vemos no Quadro 2, a coleta (direta ou indireta) é realizada somente em cerca de 10\% destes domicílios.

Quadro 2 - Destino do lixo residencial

\begin{tabular}{|l|r|}
\hline \multicolumn{1}{|c|}{ Destino do lixo } & \multicolumn{1}{c|}{$\%$} \\
\hline Coletado diretamente & 8,7 \\
\hline Coletado indiretamente & 1,6 \\
\hline Queimado ou enterrado na propriedade & 80,9 \\
\hline Jogado em terreno baldio ou logradouro & 8,3 \\
\hline Jogado em rio, lago ou mar & 0,4 \\
\hline Total & 99,8 \\
\hline NS/NR Total & 0,2 \\
\hline \multicolumn{1}{|c|}{ Tra } & 100,0 \\
\hline
\end{tabular}

Fonte: Tabulação própria a partir do banco de dados da pesquisa: Avaliação da Situação de Segurança Alimentar e Nutricional em Comunidades Quilombolas Tituladas (DATAUFF, 2012). 
Também é complexa a situação da infraestrutura quando tomamos como indicador o destino do esgoto sanitário nos domicílios que acessaram programas habitacionais. A rede pública chega a somente 9 destes. Mas, mesmo as soluções que poderiam ser mais aceitáveis em áreas rurais, têm baixa frequência. É o caso da fossa séptica ligada à rede coletora (que atinge 1,4\% destas residências) e da fossa séptica não ligada à rede (11,5\%). O predomínio absoluto é da fossa rudimentar (50,9\%), seguida pelo despejo à céu aberto ou em vala $(33,7 \%)$.

O potencial de contaminação de rios, nascentes e solos que tais resultados expressam é bastante preocupante.

Quadro 3 - Destino do esgoto sanitário

\begin{tabular}{|l|r|}
\hline \multicolumn{1}{|c|}{ Destino do esgoto } & \multicolumn{1}{c|}{$\%$} \\
\hline Rede pública coletora de esgoto ou pluvial & 0,2 \\
\hline Fossa séptica ligada à rede coletora de esgoto ou pluvial & 1,4 \\
\hline Fossa séptica não ligada à rede coletora de esgoto ou pluvial & 11,5 \\
\hline Fossa rudimentar (poço, buraco) & 50,9 \\
\hline Vala / céu aberto & 33,7 \\
\hline Direto para o rio, lago ou mar & 1,8 \\
\hline Total & 99,5 \\
\hline NS/NR & 0,5 \\
\hline \multicolumn{2}{|c|}{ Total } \\
\hline
\end{tabular}

Fonte: Tabulação própria a partir do banco de dados da Pesquisa Avaliação da Situação de Segurança Alimentar e Nutricional em Comunidades Quilombolas Tituladas (DATAUFF, 2012)

O acesso à água encanada também não é generalizado. Como vemos no Quadro 4, somente cerca de 42\% destes domicílios recebem água desta forma. É claro que formas alternativas de coleta de água tendem a gerar impactos negativos sobre a saúde das famílias.

Quadro 4 - Acesso à água encanada

\begin{tabular}{|c|c|}
\hline Água encanada & $\%$ \\
\hline Sim & 42,4 \\
\hline Não & 57,4 \\
\hline Total & 99,9 \\
\hline NS/NR & 0,1 \\
\hline Total & 100,0 \\
\hline
\end{tabular}

Fonte: Tabulação própria a partir do banco de dados da Pesquisa Avaliação da Situação de Segurança Alimentar e Nutricional em Comunidades Quilombolas Tituladas (DATAUFF, 2012) 
Neste campo do acesso à saúde, uma opção que vem sendo utilizada pelo governo federal desde os anos 1990, consiste na disseminação de Agentes Comunitários de Saúde (ACS), em geral coordenados por enfermeiros. Tais agentes atuam com ponta de lança de uma estratégia de saúde preventiva (de fato, estes ACSs estão inseridos no programa federal chamado Estratégia de Saúde da Família).

A presença deste serviço público entre as famílias que haviam acessado os programas habitacionais é elevada, mas não generalizada. Considerando que, em geral, existem precárias condições de acesso à saúde na zona rural do país, seria salutar encontrar uma maior cobertura por parte deste programa.

Quadro 5 - Famílias que são atendidas por Agente Comunitário de Saúde

\begin{tabular}{|l|r|}
\hline \multicolumn{1}{|c|}{ Atendidas por agente comunitário de saúde } & \multicolumn{1}{|c|}{$\mathbf{\%}$} \\
\hline Sim & 77,0 \\
\hline Não & 22,8 \\
\hline Total & 99,8 \\
\hline NS/NR & 100,0 \\
\hline \multicolumn{2}{c}{ Total } \\
\hline
\end{tabular}

Fonte: Tabulação própria a partir do banco de dados da pesquisa: Avaliação da Situação de Segurança Alimentar e Nutricional em Comunidades Quilombolas Tituladas (DATAUFF, 2012)

Quase 80\% destes domicílios são cobertos pelo Programa Bolsa Família (PBF). Esta taxa de acesso é um pouco maior entre estes e os que acessaram programas habitacionais, quando comparados com o conjunto dos domicílios investigados na pesquisa. Nestes últimos, o acesso ao PBF atinge 61\%, o que parece indicar que os programas habitacionais têm conseguido chegar a famílias quilombolas mais vulneráveis.

Quadro 6 - Acesso da família ao Programa Bolsa Família

\begin{tabular}{|c|c|}
\hline Acesso ao Programa Bolsa Família & $\%$ \\
\hline Sim & 79,0 \\
\hline Não & 20,7 \\
\hline Total & 99,8 \\
\hline $\mathrm{NS} / \mathrm{NR}$ & 0,2 \\
\hline Total & 100,0 \\
\hline
\end{tabular}

Fonte: Tabulação própria a partir do banco de dados da Pesquisa Avaliação da Situação de Segurança Alimentar e Nutricional em Comunidades Quilombolas Tituladas (DATAUFF, 2012) 
Esta afirmação relativa à vulnerabilidade das famílias se verifica também no Quadro 7 abaixo. Quando buscamos mapear a forma principal de obtenção de recursos financeiros das famílias, verificamos que mais de $61 \%$ destas não recebem recursos de fontes vinculadas à venda de produtos agropecuários, trabalho remunerado ou aposentadoria. Isto mostra que, como havíamos apontado anteriormente, tais comunidades em geral possuem produção agrícola, mas a mesma raramente chega ao mercado, sendo utilizada para o autoconsumo das famílias. Também o acesso ao trabalho remunerado é baixo (e predominante sob a forma de diária). Daí o elevado percentual de cobertura do Programa Bolsa Família.

Quadro 7 - Forma principal de obtenção de recursos financeiros da família nos últimos 12 meses antes da pesquisa

\begin{tabular}{|l|r|}
\hline \multicolumn{1}{|c|}{ Forma principal de obtenção de recursos financeiros } & \multicolumn{2}{c|}{$\%$} \\
\hline Venda do cultivo ou criação de animais & 9,6 \\
\hline Trabalho remunerado - ano todo & 3,9 \\
\hline Trabalho remunerado - temporário & 2,0 \\
\hline Trabalho remunerado - diarista & 7,7 \\
\hline Venda de artesanato ou produção cultural &, 4 \\
\hline Aposentadoria & 6,9 \\
\hline Nenhum & 61,4 \\
\hline NS/NR Total & 8,1 \\
\hline \multicolumn{2}{|c|}{ Tra } \\
\hline
\end{tabular}

Fonte: Tabulação própria a partir do banco de dados da Pesquisa Avaliação da Situação de Segurança Alimentar e Nutricional em Comunidades Quilombolas Tituladas (DATAUFF, 2012)

Como decorrência, a renda familiar per capita é muito baixa (vale ressaltar que consideramos para o cálculo desta, também o que a família recebe através de transferência de renda de programas sociais). Nada menos que metade destes domicílios alcança somente $\mathrm{R} \$ 70,00$ de renda per capita e estariam na faixa tipicamente considerada como de população miserável. Outros 21,8\% chegam a R \$ 139,99 de renda. Estes dados, mais uma vez apontam para uma situação de maior precariedade, quando comparados com aqueles extraídos do conjunto das 161 famílias que foram alvo da investigação (nestas, 45\% estavam na primeira faixa e $17,9 \%$ na segunda). 
Quadro 8 - Renda mensal domiciliar per capita

\begin{tabular}{|c|c|}
\hline Classe de renda mensal domiciliar per capita & $\%$ \\
\hline Menos de 70,00 & 50,3 \\
\hline 70,00 a 139,99 & 21,8 \\
\hline 140,00 a 254,99 & 17,4 \\
\hline 255,00 a 509,99 & 8,1 \\
\hline 510,00 ou mais & 2,4 \\
\hline Total & 100,0 \\
\hline
\end{tabular}

Fonte: Tabulação própria a partir do banco de dados da Pesquisa Avaliação da Situação de Segurança Alimentar e Nutricional em Comunidades Quilombolas Tituladas (DATAUFF, 2012)

$\mathrm{Na}$ pesquisa que deu origem aos dados aqui apresentados, foram coletadas informações para a composição da "Escala Brasileira de Insegurança Alimentar" (EBIA). Trata-se de um dos principais instrumentos de mensuração da situação de insegurança alimentar em uso no Brasil. A EBIA corresponde a uma escala composta por 15 perguntas que são lidas pausadamente para o responsável pela família, e que somente podem ser respondidas com as opções "sim" ou "não". Do escore obtido pelas respostas, são derivadas as quatro categorias que aparecem no Quadro 9.

Como vemos, entre as famílias que acessaram programas habitacionais a situação de "segurança alimentar" é rara, atingindo somente 10,1\% destas. Já a maior frequência está na "insegurança alimentar grave” (49,8\%), situação na qual a família já experimentou e/ou experimenta situações de fome. Mais uma vez, estas famílias encontram-se em situação ainda pior do que a encontrada entre as 161 comunidades pesquisadas (nas quais a "segurança alimentar" chegava a 14,1\% das famílias e a "Insegurança alimentar grave" atingia 47,5\%).

Quadro 9 - Disposição das famílias na Escala Brasileira de Insegurança Alimentar

\begin{tabular}{|l|r|}
\hline \multicolumn{1}{|c|}{ Categoria na EBIA } & \% \\
\hline Segurança Alimentar & 10,1 \\
\hline Insegurança Alimentar Leve & 14,7 \\
\hline Insegurança Alimentar Moderada & 24,4 \\
\hline Insegurança Alimentar. Grave & 49,8 \\
\hline NS/NR & 1,0 \\
\hline \multicolumn{2}{|c|}{ Total } \\
\hline
\end{tabular}

Fonte: Tabulação própria a partir do banco de dados da Pesquisa Avaliação da Situação de Segurança Alimentar e Nutricional em Comunidades Quilombolas Tituladas (DATAUFF, 2012) 
Este conjunto de problemas identificados acima, apontam para tensões que atravessam a formulação e implementação de programas públicos que se voltam para os segmentos mais pobres e vulneráveis da população. Ainda que seja necessário frisar que somente agora, no século XXI, políticas habitacionais chegaram às comunidades tradicionais brasileiras, os resultados ainda estão muito aquém do que deveríamos esperar quando temos como horizonte a garantia de níveis mínimos de bem-estar.

Aqui cabe uma reflexão acerca da própria dinâmica que atravessa o binômio formulação-implementação de políticas sociais (ARRETCHE, 2001). Vamos nos deter em somente dois elementos, que podem nos ajudar a entender os déficits que cercam os domicílios quilombolas que acessaram programas habitacionais.

O primeiro elemento diz respeito à necessária existência de uma "entidade organizadora" para aglutinar as famílias (entre 4 e 50, como vimos), que estão pleiteando acesso ao Programa Nacional de Habitação Rural. Tal entidade deve ser sempre sem fins lucrativos, mas pode pertencer tanto à esfera pública (prefeituras, por exemplo), quanto a esfera privada (associações comunitárias, por exemplo). No caso das comunidades quilombolas, suas entidades de representação são as "associações quilombolas" ou "associação comunitárias", que, pelo menos formalmente devem ter existência, uma vez que o título coletivo de propriedade da terra é emitido em nome desta.

Nos dois casos é necessário nos perguntarmos acerca da capacidade de gestão da "entidade organizadora", frente às tarefas pelas quais deve ser responsável. Isto porque a lista de "atribuições" é enorme e inclui não somente o levantamento da documentação das famílias que serão beneficiadas, mas também a articulação de pessoal técnico para produzir projetos de engenharia e arquitetura; a organização das famílias em torno da construção da proposta mais geral de habitação rural; o acompanhamento através dos técnicos da execução das obras, etc.

Parece bastante evidente, que dificilmente uma associação quilombola possuirá a estrutura e mesmo a capacidade de gestão para desempenhar tais atribuições. Mesmo as prefeituras municipais de grande parte do mundo rural brasileiro não apresentam tal estrutura de recursos humanos ou se os possuem, isto se dá sempre na tangente da carência ou rotatividade de profissionais. Vemos aqui um exemplo, de um desenho de Programa caracterizado pelo conhecimento impreciso das características dos beneficiários e dos agentes que podem atuar em conjunto com estes.

Mais especificamente, no mundo perfeito do desenho do Programa, a prefeitura municipal poderia ceder um engenheiro de sua hipotética Secretária 
de Obras para - em conjunto com um hipotético sociólogo lotado na secretaria de agricultura - atuar na comunidade, produzir a proposta de habitação rural, construir plantas, gerenciar e fiscalizar as obras, etc. O problema é que este mundo ideal raramente vai ser encontrado na realidade brasileira.

Assim, o desenho do programa, tal como definido pelos seus formuladores, dificilmente poderá ser implementado da forma prevista. Isto porque, como nos lembra Arretche (2001), a forma que o programa adquire, quando colocado em funcionamento, depende das possibilidades dos implementadores, que em geral carregam limitações que são desconhecidas do formulador.

No caso em tela, é possível supor que o "pessoal técnico" previsto no desenho da Política Nacional de Habitação Rural, que deve ser articulado pela "entidade organizadora", será de fato, um funcionário da prefeitura, ou membro de uma ONG, que despenderá o tempo que lhe for possível, para atuar no processo. Mas deste técnico, dificilmente se poderá cobrar exclusividade, ou mesmo um nível maior de comprometimento.

O segundo elemento que queremos problematizar corresponde ao que o Programa Nacional de Habitação Rural define como o "regime construtivo das moradias rurais". As famílias agrupadas em torno da "entidade organizadora" devem optar por uma das quatro formas já descritas em item anterior. São estes:

- o "mutirão assistido", no qual os moradores vão produzir em conjunto as moradias ou reformas com o assessoramento técnico necessário;

- a "autoconstrução assistida", onde cada morador constrói sua própria unidade, mais uma vez com o apoio da assistência técnica;

- a "administração direta", em que será a "entidade organizadora" que executará a obra e;

- a "empreitada global”, regime em que é contratada uma construtora para a execução da obra, sendo fiscalizada por uma "comissão de representantes", eleitos em assembleia entre as famílias beneficiárias.

Nas quatro possibilidades listadas acima é possível intuir problemas de adequação entre o desenho do Programa e as limitações da implementação. Vejamos. Seja no "mutirão assistido" ou na "autoconstrução assistida", sobressai a demanda pela "assistência técnica”, em geral escassa nas áreas rurais e de baixa presença nas equipes das prefeituras municipais - questão já levantada por nós quando discutíamos as atribuições das "entidades organizadoras".

No que tange ao "mutirão assistido", ainda devemos ressaltar, que este formato de atuação produtiva coletiva, dificilmente é encontrado em comunidades "quilombolas", apesar do território destas receber titulação conjunta pro indiviso. Pesquisas realizadas indicam que os formatos de produção 
familiar e o sentimento de posse individual da moradia são quase generalizados entre as inúmeras comunidades que foram alvo de investigações sociológicas recentes (BRANDÃO; JORGE; DA DALT, 2016; BRANDÃO; DA DALT; GOUVEA 2010). O formulador do Programa parece ter operado aqui com a noção de Gemeinschaft (TONNIES, 1947), que parece informar certa leitura da população rural brasileira e mais do que isso, parece orientar a expectativa que várias políticas sociais atuais possuem em relação às respostas dos seus possíveis beneficiários. $^{2}$

No caso da "administração direta", fica evidente que a "entidade organizadora" - seja esta a própria "associação quilombola" ou mesmo a prefeitura municipal - precisará de um prévio acúmulo de experiência na área da construção ou reforma de moradias, para se desembaraçar a contento desta tarefa. Além do fato de que, uma ou outra, ainda dependerão da escassa possibilidade de obtenção de uma "assistência técnica" dedicada.

Por fim, a "empreitada global" implica em dois aspectos complexos. O primeiro se refere ao capital social e a confiança intersubjetiva (PUTNAM, 2007) que o desenho do Programa espera da comunidade, quando se refere a uma "comissão de representantes". Esta deveria ter a capacidade de sintetizar as aspirações, perspectivas e demandas do conjunto das famílias beneficiárias em torno da fiscalização da execução das obras, no sentido de atender a um projeto coletivo. O problema é que estes elementos que correspondem ao que a literatura da ciência política nomeia como "capital social" são bens de relativa raridade em sociedades com baixo grau de associativismo, como a brasileira.

Neste ponto, a baixa frequência de experiências de atuação econômica coletiva entre as comunidades quilombolas impõe uma dificuldade para a implementação. Mais uma vez, se pensarmos no "mundo perfeito" do desenho do Programa, estaremos esperando comunidades com alto nível de organização interna, com ampla confiança intersubjetiva e grande quantidade de capital social acumulado. Nestas, eleger uma "comissão de representantes", que se manterá completamente vinculada ao tecido social local e será a "expressão" da comunidade, é algo relativamente simples. Mas tal configuração não é encontrada com facilidade nas comunidades.

\footnotetext{
Um exemplo disto encontramos no Programa de Aquisição de Alimentos (PAA). Este possibilita a compra de insumos agropecuários produzidos pela agricultura familiar à preços de mercado. O Programa acaba gerando o que podemos chamar de um mercado institucional, bastante importante, seja para liberar os agricultores familiares da figura do atravessador, seja para evitar perda da produção em momentos de baixa demanda. No entanto, o acesso ao PAA não se faz pelo agricultor individual, mas sim por uma associação que aglutine este e os represente. Assim, a pressuposição de um caráter coletivo ou de uma predisposição associativa, marca o desenho do Programa.
} 
O segundo aspecto diz respeito à própria capacidade técnica que esta comissão terá para realizar a requerida "fiscalização". E aqui retornamos ao problema da escassez de pessoal técnico especializado nas prefeituras municipais.

Quando o desenho proposto pelo Programa não se adéqua às características dos seus futuros beneficiários, ou quando não existem as condições institucionais (de ordem material ou política) para que seja seguido o que fora inicialmente definido; os implementadores são levados a "improvisar" (ARRETCHE, 2001). Ou seja, o caminho possível é o da adaptação do desenho às possibilidades e características concretas das realidades onde a intervenção está sendo efetivada.

Como lembrar Arretche (2001), quem faz a política, de fato, não é o formulador desta, mas sim aqueles que a implementam. Estes, em geral agentes localizados em estruturas de gestão simplificadas, são pagos para que os programas sejam implementados, têm, portanto, problemas concretos para resolver. Não podem contar nem com os recursos que jamais poderão obter, nem com expectativas pressupostas de como os beneficiários vão responder às políticas.

\section{CONCLUSÃO}

Como já apontamos, constitui um indicador da baixa densidade de nosso aparato de políticas sociais, o fato de somente na primeira década do século XXI, o Estado brasileiro ter iniciado a produção de uma estrutura voltada para a questão habitacional relativa às nossas populações quilombolas.

Foram necessários quase 100 anos de regime republicano para que estes grupos entrassem na agenda do Estado. Mas tal entrada não gerou rapidez na incorporação ou na extensão da cobertura estatal. Um exemplo, encontra-se no fato de que, ainda que somente com a Constituição de 1988 estes grupos - até então pensados como "comunidades negras rurais" - sejam reconhecidos e recebam a garantia da propriedade definitiva de seus territórios ancestrais; somente em 1995 ocorre a primeira titulação de um destes (trata-se da comunidade de Boa vista, situada na área de floresta do município de Oriximiná-PA).

Nesta direção, o processo de regularização da situação fundiária dos quilombolas continua caminhando a passos lentos. Tínhamos até 2012, nada menos que 2.040 comunidades com certificação emitida pela Fundação Cultural Palmares, mas somente 207 comunidades tituladas. Fazendo um cálculo rápido, vemos que o ritmo médio é de 8,6 comunidades tituladas por ano. Caso este ritmo seja mantido, serão necessários 213 anos para que todas recebam a titulação territorial definitiva. 
Por outro lado, apesar de existirem esforços públicos na esfera federal para incrementar o acesso destas populações às políticas sociais e assistências, ainda encontramos entre estas, índices muito baixos de bem-estar material e de desenvolvimento socioeconômico, como mostramos antes.

$\mathrm{O}$ acesso à política habitacional por parte destes grupos constitui de fato uma novidade no panorama brasileiro. Mas este acesso carrega as marcas de certa improvisação ou da necessidade de realizar o que for possível, deixando de lado protocolos fundamentais para o bem-estar das famílias e mesmo para a saúde das comunidades (como aqueles ligados à qualidade mínima das unidades habitacionais, ao abastecimento de água, à coleta de esgoto e ao destino do lixo doméstico).

Nesta área onde o Estado brasileiro acaba de entrar e na qual possui baixo acúmulo de experiências de formulação e implementação, o avanço possível demanda iniciativas públicas - mas independentes - de avaliação destes programas habitacionais voltados para áreas rurais e para populações tradicionais como os quilombolas. Isto porque, avaliações cientificamente construídas - voltadas não somente para apontar se o Programa "acertou" ou "errou" podem mapear e identificar pontos de estrangulamento, que fazem com que os objetivos desenhados não sejam alcançados ou que os objetivos mesmo quando alcançados, não produzam impactos.

Este tipo de investigação, ao eleger como pano de fundo principal as características dos grupos beneficiários, pode subsidiar alterações e correções de rota. Isto é fundamental para que no futuro, encontremos maior grau de eficácia e efetividade nas ações públicas que envolvem o bem-estar social de grupos populacionais que foram historicamente discriminados e mesmo invisibilizados pela sociedade envolvente e pelo Estado.

\section{REFERÊNCIAS}

ARRETCHE, Marta. Uma contribuição para fazermos avaliações menos ingênuas. In: BARREIRA, Maria Cecília; CARVALHO, Maria do Carmo Brant de (Org.). Tendências e perspectivas na avaliação de políticas e programas sociais. São Paulo: PUC-SP, 2001.

BARTH, Fredrik. Os grupos étnicos e suas fronteiras. In: BARTH, Fredrik. O guru, o iniciador e outras variações antropológicas. Rio de Janeiro: Contracapa. 2000.

BRANDÃO, André; DA DALT, Salete; GOUVEIA, Vitor. Comunidades 
quilombolas no Brasil: características socioeconômicas, processos de etnogênese e políticas sociais. Niterói-RJ: EDUFF, 2010.

BRANDÃO, André; DA DALT, Salete; JORGE, Amanda L. Avaliação da situação socioeconômica das comunidades quilombolas já tituladas: crônica de um mau resultado anunciado. Trabalho apresentado no XVII Congresso Brasileiro de Sociologia, Porto Alegre, 2015.

BRANDÃO, André; JORGE, Amanda L.; DA DALT, Salete. Faz diferença estar na agenda: Lideranças comunitárias quilombolas e percepções sobre acesso às políticas sociais nos anos recentes. Trabalho apresentado na $40^{\mathrm{a}}$ Reunião Anual da ANPOCS, Caxambu, 2016.

CASTELLS, Manuel. O poder da identidade. São Paulo: Paz e Terra, 1999.

IBGE. Síntese de Indicadores Sociais. Rio de Janeiro, 2012.

JORGE, Amanda L. O processo de construção da questão quilombola: discursos em disputa. Rio de Janeiro, Gramma, 2016.

MARICATO, Ermínia. O Ministério das Cidades e a política nacional de desenvolvimento urbano. In: IPEA. Políticas sociais - acompanhamento e análise. Brasília, fev. 2006.

PUTNAN, Robert. Comunidade e democracia. Rio de Janeiro: FGV, 2007.

REIS, João José e GOMES, Flávio. Liberdade por um fio: história dos quilombos no Brasil. São Paulo: Companhia das Letras, 1996.

SEPPIR. Programa Brasil Quilombola: relatório de gestão. Brasília, 2012. Programa Brasil Quilombola. Brasília, 2004.

TÖNNIES, Ferdinand. Comunidad y sociedad. Buenos Aires: Losada, 1947.

WEBER, Max. Economia e sociedade. Brasília: UNB, 2011. (2 volumes) 


\title{
Saberes e práticas tradicionais em movimento: a comunidade do Maracanã na rota de um projeto global
}

\author{
Traditional knowledge and practices in movement: yhe community of \\ Maracanã on the route of a global project
}

Joaquim Shiraishi Neto - Doutor em Direito pela UFPR. Professor Visitante da UFMA, vinculado ao Programa de Pós-Graduação em Ciências Sociais (PPGCSoc-UFMA) e Bolsista de produtividade do CNPq. E-mail: shiraishineto@gmail.com

Rosirene Martins Lima - Doutora em Meio Ambiente e Desenvolvimento pela UFPR (MADE-UFPR). Docente do Curso de Ciências Sociais da Universidade Estadual do Maranhão (UEMA-CCSA). Coordenadora do Grupo de Pesquisa "Cidade, Território e Meio Ambiente". E-mail: rosirenelima@uol.com.br

Luzinele Everton de Alcobaça - Mestre em Ciências Sociais pela UFMA e Doutoranda em Antropologia pela Universidade Federal de São Carlos (UFSCar). E-mail: lu.zinele@ hotmail.com

\section{Resumo}

A comunidade do Maracanã, localizada na zona rural de São Luís, MA, desde a última década, vem sofrendo um processo de asfixia, decorrente da expansão urbana da cidade, com a construção, no seu entorno, de conjuntos do Programa Minha Casa Minha Vida. Os processos de devastação e o adensamento populacional da área do Maracanã produziu uma nova ordem de problemas, que reconfigurou o espaço, trazendo consigo novos desafios aos "antigos moradores". Assim, este artigo objetiva refletir sobre esses processos em curso, que implicam na reorganização das maneiras de viver da comunidade, coadunadas em saberes e práticas socialmente construídas. A metodologia utilizada se fundamentou em técnicas de observação direta e conversas com os moradores da comunidade, realizadas em distintos contextos. Os esforços em analisar as situações empiricamente observadas revelam o caráter preliminar da pesquisa.

\section{Palavras-chave}

Comunidade do Maracanã. Saberes e Práticas Tradicionais. Modelos de Natureza. Expansão Urbana.

\begin{abstract}
The Maracanã community, located in the rural area of São Luis, MA, since the last decade, has suffered a suffocation process, due to the urban expansion of the city, with the construction, in its surroundings, of the My Home My Life Program. The processes of devastation and the population density of the Maracanã area produced a new order of problems, which reconfigured the space, bringing with it new challenges to the "old community residents". Thus, this article aims to reflect on these ongoing processes, which involve the reorganization of community ways of living, consistent with socially constructed knowledge and practices. The methodology used was based on techniques of direct observation and conversations with the residents of the community, carried out in different contexts. Efforts to analyze empirically observed situations reveal the preliminary nature of the research.
\end{abstract}

\section{Keywords}

Community of Maracanã. Knowledge and Practices. Models of Nature. Urban Expansion. 


\section{INTRODUÇÃO}

$\mathrm{Na}$ última década, a comunidade do Maracanã, localizada no município de São Luís, MA, vem sofrendo transformações resultantes da construção, nos seus arredores, de 4 (quatro) conjuntos do Programa Minha Casa Minha Vida (PMCMV).

A edificação destes conjuntos do PMCMV demarca 2 (dois) períodos na vida da comunidade. Os problemas e os conflitos vividos atualmente além de evidenciar uma espécie de estranhamento com o "outro" (com os moradores dos conjuntos, recém-chegados), sinalizam rupturas com um passado recheado de boas histórias e lembranças de sossego e "calmaria". Tais períodos, que se interseccionam e se cruzam correspondem a de dinâmicas territoriais. Entretanto, como o objeto da pesquisa não era a comunidade em si, mas a compreensão dos "processos socioespaciais na Região Metropolitana de São Luís"1 , as experiências com essas "histórias locais" da comunidade que vieram à tona nesse período da pesquisa foram "deixadas de lado".

Aqui recuperadas, as conversas ${ }^{2}$ e os encontros com moradores da comunidade do Maracanã, que ocorreram em distintos períodos, condições e contextos $^{3}$, permitiram várias "descobertas", as quais, sistematizadas, compõem este texto. $\mathrm{O}$ artigo às vezes em tom de relatório expõe, portanto, o caráter preliminar e incipiente da pesquisa em andamento, que se revela a partir das experiências de "histórias locais", cruzadas e entrecruzadas por "projetos globais".

As noções de "historias locais" e "projetos globais", tomadas de Mignolo (2003), é aqui adaptada para se referir as dinâmicas dos processos que está submetida a comunidade do Maracanã, estabelecida desde o século XVII ${ }^{4}$.

1 Um dos resultados parciais da pesquisa foi a produção de um texto sobre as disputas pela cidade de São Luís, que deslocou as formas tradicionais de poder. A propósito, recomendamos Shiraishi Neto, Lima e Serra (2018).

2 Recorremos a Walter Mignolo sobre a conversa como um método da pesquisa: "Por conversações, não me refiro afirmações que podem ser gravadas, transcritas ou usadas como documentos. $\mathrm{Na}$ maior parte dos casos, as conversações mais significativas consistem em comentários sobre um acontecimento, um livro, uma ideia, uma pessoa que a gente viu de passagem. Se trata de conhecimentos que não podem ser transcritos, conhecimento que vai e vem, porém que permanece com um e introduz mudanças em determinadas analises." (MIGNOLO, 2003, p.10 - tradução livre dos autores).

3 Desde 2015, temos visitado a comunidade do Maracanã. Inicialmente, para acompanhar os trabalhos de pesquisa dos bolsistas do Programa de Iniciação à Pesquisa (PIBIC), do curso de Ciências Sociais da UEMA. Em outro período, levantando informações para o projeto de pesquisa "Processos socioespaciais na região metropolitana de São Luís: disputas territoriais e conflitos socioambientais" (UEMA- CCSA). Ao longo de todo esse período, retornamos em diversas ocasiões à comunidade para visitar as pessoas, com o intuito de participar de festas e reuniões.

4 À época, a comunidade do Maracanã fazia parte das várias aldeias indígenas do Tupinambás na ilha do Maranhão ("Upaon-Açu”) (D’ABBVILLE, 1975); embora tal fato seja desconhecido 
Por sua vez, os "projetos globais" explicitam distintas representações da comunidade do Maracanã, sendo que a percepção que serviu para orientar a construção dos 4 (quatro) conjuntos do PMCMV é de uma população "desprovida de bens e cultura", situado na zona rural de São Luís, sem interesse econômico para o capital.

Os estudos de Wacquant (2001), aqui utilizados, sobre os "espaços marginais" são valiosos, na medida em que nos permite compreender os interesses que dominam a configuração do espaço urbano. Em um contexto de financeirização da economia esses locais de isolamento e exclusão tem uma função socioespacial “[...] o armazenamento de uma população excedente sem utilidade política e econômica identificável [...]” (WACQUANT, 2001, p. 11).

Igualmente atuais são as reflexões de Achille Mbembe (2006). O estado de exceção econômica, sacralizado, no Brasil, por um golpe parlamentar midiático, que destituiu uma legitimamente presidenta, submete a população a um poder difuso, nem sempre estatal, inseridos em uma relação econômica da morte: "fazer viver ou deixar morrer". Essa "nova forma" de controle e gestão da vida é denominada por Achille Mbembe de "necropolítica".

Neste "espaço marginal", da periferia, da periferia do capitalismo, a comunidade do Maracanã é "envolvida" por um poder econômico difuso que determinou a construção dos conjuntos, em problemas e conflitos, que resultam em todo tipo de violência a essa comunidade. Como se não bastasse os impactos gerados pela construção dos conjuntos, problemas sociais graves revelam os resultados de uma política habitacional ditada pelos interesses do capital global. O PMCMV, sublinha Rolnik (2015) ${ }^{5}$, convergiu os interesses do setor imobiliário, já cevados do capital financeiro, e a política do governo federal.

Se em um primeiro momento, os conflitos poderiam ser percebidos como produto de diferentes "práticas socioespaciais" imbuídas de formas de representação da natureza e da própria cidade, tal como as pesquisas desenvolvidas por Acselrad (2004) ${ }^{6}$, neste período mais recente, os conflitos na comunidade

pelos "antigos moradores" que afirmam que a comunidade do Maracanã se originou de um "antigo quilombo".

5 Raquel Rolnik (2015) recorda que os empresários do setor imobiliário, liderados pela Gafisa, atingidos pela crise de 2008, fizeram um lobby junto ao Ministério da Fazenda para que o governo federal implementasse um "pacote habitacional" nos moldes do programa mexicano de habitação, inspirado no modelo chileno de Pinochet. A política econômica anticíclica adotada por meio do PMCMV, lembra Rolnik, fortaleceu os setores imobiliários, em especial, as incorporadoras, que se transformaram no principal agente da política habitacional no Brasil.

6 As pesquisas sobre esses conflitos são muitas no Brasil, dentre tantas, sugerimos a de Lima (2008a). A situação analisada em Curitiba em muito se aproxima da estudada, pois, assim como aqui, ela identificou a presença de uma organização criminosa disputando o controle sobre o território. Ver também Lima e Shiraishi Neto (2016). 
resultam de disputas, envolvendo o controle territorial, a partir da ação de uma organização criminosa, autodenominada "Bonde dos 40" , que expande o controle de seu território para além dos conjuntos do PMCMV nos espaços da comunidade do Maracanã. Sob a base do medo e da violência, o "Bonde dos 40" se impõe aos moradores dos conjuntos. As pichações do "Bonde dos 40" no conjunto Amendoeiras I, por exemplo, tais como: "Proibido Roubar. Lembra. Pena de Morte. B.40“, tem a clara intenção de, por meio de intimidação, impor unilateralmente regras de convivência aos moradores.

Como visto, essas dinâmicas territoriais vividas pela comunidade do Maracanã compreendem inúmeras questões que possibilitam infinitas abordagens. O recorte específico do artigo, porém, é singelo diante de tantos problemas, já que objetiva refletir sobre os saberes e as práticas tradicionais, que organizam a vida na comunidade, face aos desafios que lhes são colocados por esses "projetos globais".

Para cumprir este objetivo, o artigo se divide em 3 (três) tópicos. O primeiro intitulado "A 'economia da juçara': saberes e usos da natureza", procura analisar a organização das "práticas extrativistas" da economia da juçara e não do açaí, como é salientado pelos moradores da comunidade ${ }^{8}$. No caso, a sua relevância não se restringe aos aspectos meramente econômicos, mas na compreensão da importância que assume os vínculos afetivos criados.

Já no tópico segundo, "Festas, rezas e cânticos", busca-se articular a "economia da juçara" com as diversas práticas culturais e religiosas existentes na comunidade. Tais práticas, que organizam a vida, sinalizam para uma indissociação dos elementos da natureza com a dimensão religiosa.

"Nós e os Outros: 'histórias locais' e 'projetos globais"” se constitui do último tópico do trabalho. Nele, o objetivo é recuperar as discussões em torno

\footnotetext{
As informações obtidas a partir de uma conversa com o advogado criminalista, Nonato Masson, do escritório de advocacia Onidayô. Ele nos relatou que o "Bonde dos 40" nasceu por volta de 2007, organizado por presos do presídio de Pedrinhas, oriundos dos bairros da Liberdade e Vila Embratel, de São Luís, MA. Segundo Masson, esses presos se organizaram diante das "humilhações" que sofriam dos membros do Primeiro Comando do Maranhão (PCM), outra facção criminosa de Pedrinhas. Outras informações a respeito do "Bonde dos 40", PCM e sistema penitenciário do Maranhão podem ser lidas em Almeida e Masson (2014).

$8 \mathrm{Na}$ "verdade", cientificamente, a planta é designada de açaizeiro e o açaí (euterpe oleracea) é seu fruto. Há diferenças entre o açaí e a juçara (euterpe edulis), apesar de serem muito parecidos. Segundo o conhecimento científico, o açaí tem uma oferta de poupa maior. Da raiz do açaizeiro pode nascer até quatro palmeiras, enquanto que da raiz da juçara só nasce uma. A forma de uso e consumo dos frutos também definem as diferenças entre o açaí e a juçara. M. E. nos relatou que o açaí é tomado como suco e a juçara tem o acréscimo da farinha de mandioca, peixes, camarões e outros acompanhamentos (conversa realizada em 06.01.2018). Tais distinções, tanto ressaltadas nas conversas, é um elemento que suscita curiosidade no que diz respeito aos saberes e representações que envolvem essa palmeira e o manejo de seus frutos na comunidade.
} 
da comunidade do Maracanã no contexto de uma urbanização expandida, que desconhece outras formas de vida na cidade de São Luís. O "alisamento do território" é a expressão mais adequada para descrever os processos econômicos em curso no Maranhão contemporâneo. Os conflitos que resultam da escassez dos juçarais, dos buritizais e das águas desafiam os moradores a reinventar novas formas de usos e convivências.

\section{A "ECONOMIA DA JUÇARA": SABERES E USOS DA NATUREZA}

A "economia da juçara" é um dado relevante para se compreender a maneira de como se organiza a vida na comunidade do Maracanã. Quem visita o Maracanã fica encantado com os inúmeros juçarais, que se espalham por toda área, situados nos fundos das residências e na beirada das ruas, no meio de riachos, córregos e nascentes que atravessam os quintais das casas.

A "festa da juçara" realizada há mais de 50 anos (em 2017, foi realizada a 48 a edição da festa) no mês de outubro, pico da safra, que ocorre entre os meses de setembro e outubro, expressa a importância da "economia da juçara" para a comunidade que se envolve na sua realização. Nela, várias atividades acontecem, além da venda da juçara, comidas típicas e artesanatos, os grupos de cultura local aproveitam para fazer as suas apresentações (tais como: a dança portuguesa, o boi do maracanã, o tambor de crioula etc.).

Neste contexto, a análise da "economia da juçara" não pode ficar reduzida à compilação de dados estatísticos relacionados ao volume de produção da juçara, como foi observado em pesquisas na região envolvendo outros produtos extrativos como seringa, castanha e babaçu. As discussões em torno do "fim do extrativismo" na Amazônia e a emergência do movimento dos seringueiros e das quebradeiras de coco babaçu, por exemplo, corroboram com os argumentos assinalados, já que os esquemas interpretativos do que é designado por “economia extrativa", ao compartilhar de um mesmo quadro geral, tendem a esvaziar os conteúdos das relações históricas vividas (OLIVEIRA FILHO, 1979) ${ }^{9}$. Os estudos mais recentes sobre esses grupos sociais designados como povos e comunidades tradicionais, que emergiram nas últimas décadas, demarcam uma diversidade de existência de formas coletivas em suas relações com a natureza e a terra (ALMEIDA, 2008), que ensejam distintos saberes e práticas tradicionais ${ }^{10}$.

\footnotetext{
9 João Pacheco Oliveira Filho está se referindo a uma pesquisa realizada por Roberto Santos (1980) sobre a economia da seringa na Amazônia. A pesquisa de Jair Amaral Filho (1990), que envolveu a economia do babaçu, por sua vez, embora fundamentada em outro referencial teórico, apresentada resultados muito parecidos o "fim da economia extrativa".

10 As práticas extrativas do babaçu apresentam especificidades, que se distinguem dos seringueiros,
} 
No Maracanã, os problemas recentes em torno da "economia da juçara", que se desenvolve no âmbito das unidades familiares, vêm despertando uma grande preocupação por parte dos moradores, pois têm prejudicado a vida de toda a comunidade. A gradativa diminuição da produção que tem afetado o consumo das famílias, afeta também as relações socais e os cuidados com os juçarais, que têm se redobrado. Em muitos pontos observamos a exuberância da vegetação nativa, cerrada e fechada, porém, em outros, é visível o aterramento dos cursos d'água, o esgoto a céu aberto e a ampliação de áreas desmatadas.

\section{Mapa 1 - Comunidade do Maracanã e os 4 conjuntos do PMCMV}

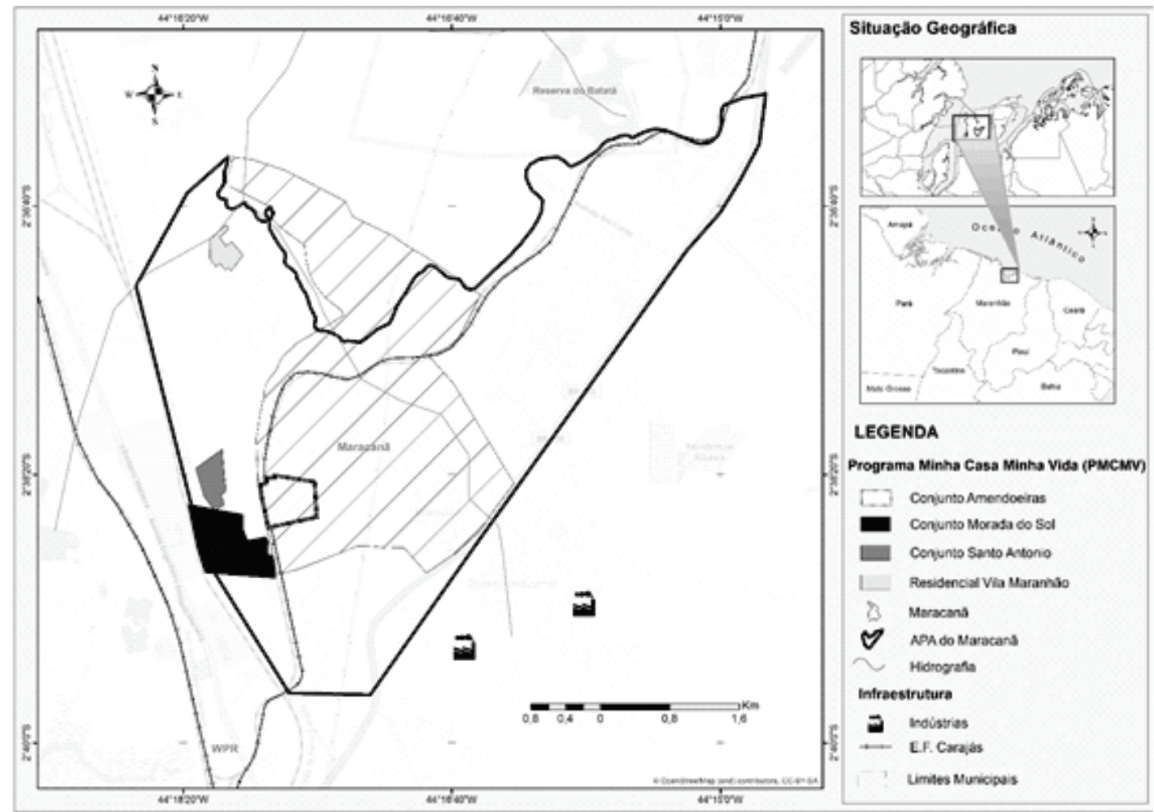

Fonte: Grupo de Pesquisa Cidade, Território e Meio Ambiente (CITEMA).

Nas conversas, os moradores relatam que os problemas ambientais, que devastam os juçarais, decorrem da construção dos 4 conjuntos do PMCMV. Entre os moradores, várias são as denúncias como esta: "A ETE (estação de tratamento de esgoto) do conjunto Amendoeiras I quebrou e passou mais de 15 dias jogando o esgoto direto nos riachos e alagados. Ela só foi consertada após muita insistência nossa e de uma denúncia ao Ministério Público” (conversa com

como foi observado por Shiraishi Neto (2017). A extensão das áreas das reservas extrativistas criadas na região evidencia a diversidade das práticas. Enquanto que para os seringueiros a apropriação e o uso das árvores de seringa ocorre de forma privada pelas famílias, para as quebradeiras de coco a apropriação e uso das palmeiras é comum, consoante capacidade e necessidade de cada família. A propósito da emergência dos vários grupos sociais designados por povos e comunidades tradicionais, recomendamos Shiraishi Neto (2010). 
C. R. M., realizada em 06.01.2018). Continua a moradora, agora, expressando toda a sua tristeza "As pessoas não querem mais comprar o buriti aqui do Maracanã, porque o buriti cai maduro no alagado e assim fica contaminado. É triste isso. Depois desses conjuntos a vida piorou muito aqui” (conversa com C. R. M., realizada em 06.01.2018).

Segundo os moradores, os problemas se iniciaram, ainda, quando da terraplanagem dos terrenos para a construção dos conjuntos, em antigas fazendas. A terraplanagem, que envolveu um conjunto de ações para planar o terreno, levou entulhos, galhos, terras... para os córregos, riachos e nascentes ${ }^{11}$ utilizados pela comunidade. A operação, além de tornar a água imprópria, levou a morte de vários cursos d'água, prejudicando os juçarais: "Infelizmente os juçarais estão se acabando por causa das construções” (conversa com S. R., realizada em 10.06.2017) ${ }^{12}$.

A escassez dos frutos vem causando outra ordem de conflitos que até então inexistia na comunidade, como o "furto da juçara". Isso, por exemplo, tem prejudicado a qualidade do produto que é comercializado na "festa da juçara". M. L. nos relatou a importância atribuída à "juçara local” que, segundo ela, tem maior qualidade pela colheita do fruto ainda maduro, o que seria um diferencial em relação à "juçara de fora", aquela que é importada de outros estados, "apanhada quase verde" (conversa realizada em 06.01.2018).

Os proprietários dos juçarais precisam ficar de olho, cercar ou contratar alguém para tomar conta, pois senão vão ficar sem a juçara. Como as pessoas que furtam desconhecem os ciclos da natureza, geralmente coletam a juçara verde, que é ruim para o consumo. Hoje, tem muito ladrão de juçara. Eles andam com um gancho, cortam os cachos com frutos verdes e maduros. Os donos das juçaras estão precisando comprar a juçara. GN (conversa com E., realizada em 20.05.2017).

No caso, observamos que a maioria dos juçarais pertencem a uma ou mais famílias. Os que se localizam nos quintais, geralmente, no fundo das casas, adentram nos terrenos vizinhos das outras famílias, isto é, não existem cercas delimitando as divisas entre os terrenos. Os cuidados com os juçarais e a distribuição da produção são, portanto, compartilhados entre as famílias que deles fazem uso. Ouvimos de uma senhora que a juçara coletada no quintal de sua casa serve para presentear os "filhos de santo" do terreiro de umbanda (conversa com S. J., realizada em 13.01.2018).

11 A extensa rede hidrográfica que compõe a bacia do Maracanã foi descrita por Cysne, Santos e Pereira (2010).

12 Esses problemas ambientais, assim como tantos outros relatados, serviram para a comunidade se organizar em torno de uma agenda, com denúncias e reivindicações, que foram encaminhadas à Secretaria de Estado do Meio Ambiente e Recursos Hídricos (SEMA). 
Nos espaços dos quintais, as juçaras e os buritis $^{13}$ se misturam à vegetação nativa, às árvores frutíferas e às plantas medicinais, que são cuidadosamente cultivadas pelas famílias de forma muito particular, especificamente, pelas mulheres, que se responsabilizam por essa obrigação. Os cuidados com a natureza são delegados pelas famílias às mulheres, que devem repassar esse conhecimento aos mais jovens, embora sejam poucos os que realmente se interessam, segundo informações.

Neste contexto, os quintais se constituem em espaços de convivência e de trocas entre as famílias, vizinhos e parentes. Os quintais são espaços também de diversão onde os adultos se juntam para comer, beber e ouvir música (reggae e "brega"); sendo que no período da pesquisa éramos recebidos nos quintais" As conversas, na maioria das vezes, interrompidas com a chegada de vizinhos, parentes ou crianças que brincavam no lugar. Em várias oportunidades, a conversa era interrompida para que a moradora pudesse nos indicar no quintal onde e como eram feitas as "coisas". As lembranças da infância eram recorrentes nestes momentos da conversa.

Com a escassez da juçara, o fruto passa a ser objeto de cobiça diante de seu valor econômico no mercado local. As situações de "furto de juçara" revelam um dado novo para a comunidade, em que os frutos eram compartilhados ou mesmo comercializados, na medida da necessidade das famílias para complementar a renda familiar.

Os "furtos"15, realizados por pessoas estranhas à comunidade, prejudicam os juçarais, já que o fruto é coletado verde, impróprio para o consumo e sem os cuidados necessários, desrespeitando os ciclos naturais para o desenvolvimento de novas palmeiras.

A coleta da juçara, aqui descrita, começa com a preparação da "pêa", um cordão feito de saco de nylon. Envolvendo os pés, o instrumento facilita a movimentação pelo caule da palmeira. $O$ uso da vara com um gancho na ponta ajuda alcançar os cachos mais altos, que são identificados pela coloração

13 Os buritizais que se encontram no meio dos juçarais também são consumidos, tanto os frutos, com os quais se produz o suco e o doce, como as palhas, que são utilizadas artesanalmente para confecção de bolsas e sacolas comercializadas em São Luís.

14 Para os moradores do Maracanã, os quintais têm a sua importância na vida da comunidade. Em contextos parecidos, Lima (2008a) descreve os usos dos quintais para as famílias de trabalhadores rurais residentes na cidade de Imperatriz, MA.

15 As situações de "furto do coco de babaçu" também foram observadas por Almeida, Shiraishi Neto e Carvalho (2005). A escassez do babaçu decorrente da valorização do coco para a produção do carvão de babaçu para atender as demandas das indústrias de ferro gusa na região gerou inúmeros conflitos envolvendo as quebradeiras de coco e os catadores. Os catadores, recrutados entre os trabalhadores desempregados das cidades da região, desconhecem os ciclos da natureza. Ao apanhar os cocos verdes, que se encontram nos cachos, interferem na reprodução das palmeiras nativas. 
dos frutos. Os conhecimentos implicados na colheita e manejo dos frutos são repassados de geração à geração pela observação, oralidade e prática cotidiana (conversa com F. E., realizada em 13.01.2017).

As crianças aprendem desde cedo com os adultos a identificação dos frutos maduros, a forma de coletá-los na palmeira, retirada dos frutos dos cachos, "debulhar", a seleção entre os verdes e os maduros e a extração da polpa ${ }^{16}$. O uso dos sentidos é imprescindível para o aprendizado e a realização de tais atividades que envolve a coleta da juçara. Ver, tocar e degustar, como foi observado em algumas ocasiões, são atos que passam por um longo período de aprendizado, que explica, como a coleta cuidadosamente realizada, é algo considerado aparentemente tão "simples" e "natural".

A "naturalidade" e "simplicidade", que envolvem o ato da coleta da juçara, fazem desse tipo de trabalho algo menor, se comparado às atividades que implicam o uso de tecnologias. Tais formas de conhecimento, lembra Escobar (2007), não eram apenas consideradas nulas, mas também eram tidas como obstáculos ao desenvolvimento das sociedades modernas ${ }^{17}$.

\section{FESTAS, REZAS E CÂNTICOS}

Respondendo ao convite de uma moradora do Maracanã, comparecemos à festa de Reis, no início do mês de janeiro. A festa em questão combina elementos do cristianismo católico com outras tradições. Logo que chegamos na casa de B. S. J. observamos o cuidado e os detalhes com a organização do presépio, enfeitado com as plantas cultivadas no local e palhas de coqueiro, que serão queimadas após a festa em um ritual denominado "queima de palhinha"18.

16 Atualmente, a polpa é produzida por meio de uma máquina específica. Ela tritura a casca do fruto, produzindo mais poupa em menos tempo. Esse método vem se popularizando e os produtores locais, principalmente os mais jovens, estão aos poucos deixando de lado a forma mais "rudimentar" de produção da poupa da juçara. Essa tarefa, engloba pôr os frutos na água sob o sol e esperar até que a casca esteja mais flexível. Depois, uma garrafa de vidro cheia de água (para ficar mais pesada) é usada para socar os frutos dentro de uma vasilha e, assim, extrair toda a poupa. Para os mais velhos, esse método dá uma maior qualidade final ao produto, diferentemente da máquina, onde o caroço não é triturado e misturado à poupa, o que melhora o sabor (conversa com S. E. M., realizada em 13.01.2018).

17 No âmbito do direito internacional, após a edição da Convenção sobre a Diversidade Biológica (CDB) e do Protocolo de Nagoya, foi construído, entre os países, um consenso sobre a necessidade de se proteger esse tipo de conhecimento tido como tradicional. Pena que no Brasil, os esforços em regulamentar tais direitos sejam pífios diante de um governo que mais se preocupou em proteger os direitos das indústrias e das empresas que sempre fizeram uso desse saber considerado "subalterno".

18 A "queima da palhinha" é realizada em momento posterior às festas de reis, de acordo com o calendário da família, que escolhe uma data significativa para fazê-lo. É quando a família e os convidados se reúnem para desmontar o presépio. Enquanto as peças permanentes são guardadas para o natal seguinte, as palhas de palmeiras que foram utilizadas para adornar o 
Segundo um dos organizadores, a cerimônia de Reis mistura cânticos, rezas e ladainhas, cantadas em latim. As ladainhas são cantadas em latim por uma rezadeira da comunidade, que atende os chamados, colaborando com a diversidade de festas religiosas na comunidade.

Contudo, não pudemos acompanhar toda a cerimônia da festa de Reis, perdemos a parte em que moradores se caracterizam de rei e rainha, mas identificamos a organização e os afazeres. Ali na casa de B. S. J., de 85 anos, um salão era cuidadosamente preparado para a cerimônia que aconteceria no período da noite, na cozinha da casa, os parentes e vizinhos preparavam a comida que seria servida aos participantes, independentemente de sua condição ou credo religioso. A fartura da comida oferecida na festa a todos os presentes tem, sobretudo, o sentido de agregar e de "manter a casa cheia, com muita participação e alegria".

A comida e a bebida (incluindo bebidas alcoólicas), bem como todo trabalho que envolve a sua preparação, resultam de doações recebidas durante o ano. Para B. S. J. e sua filha, S.E.M., é “...algo tão cansativo e dispendioso compensa porque é divertido e mantém uma tradição na comunidade.” (conversa realizada em 13.01.2018). A festa não tem finalidade econômica, lembra uma delas. A tarefa de "armação do presépio" foi confiada a B. S. J. por uma tia que faleceu ainda quando era criança.

A festa de Reis conjuga duas versões, a festa de "Reis Pobres" e de "Reis Ricos". A distinção das festas de Reis na comunidade entre "Reis Pobres" e "Reis Ricos" tem sua origem no processo de ocupação e organização territorial pelos diferentes grupos. Os escravos fugidos das fazendas ali se encontravam formando um quilombo, daí aquela afirmação de que o Maracanã se constituiu de um “antigo quilombo". Como nesse período, os ex-escravos não tinham condições materiais, saiam nas casas dos moradores pedindo auxílio para realização da festa de Reis, esta é origem da festa de "Reis Pobres". A festa de "Reis Ricos", por sua vez, se origina das famílias que vieram posteriormente a área, comprando pequenos lotes e terrenos para ali se estabelecer.

Entretanto, essa distinção, que marcava as diferenças entre os moradores "pobres" e "ricos", não persiste nos dias de hoje. Ela perdura, contudo, como uma forma de lembrança de um passado remoto, já que todos "brincam" igualmente nas festas.

"Aqui é muito místico" (conversa com E., realizada em 20.05.2017) é a forma encontrada por E. para expressar essas maneiras de viver, de criar e de fazer na comunidade do Maracanã. As festas de Reis, assim como tantas outras

presépio são juntadas e queimadas em meio a cânticos e ladainhas. Essa festa tem um sentido religioso e comemorativo. 
festas da comunidade ${ }^{19}$, emergem de uma experiência coletiva historicamente construída. Além de serem uma manifestação de caráter religioso, é uma prática de lazer, pois congrega parentes, vizinhos e amigos, que compartilham esses momentos de renovação dos vínculos e dos compromissos em torno da defesa do território.

Acontecimentos mais recentes na comunidade pós-construção dos conjuntos, envolvendo "furtos de juçara" e roubo nas casas ${ }^{20}$, vêm obrigando uma postura mais vigilante dos moradores, bem como estratégias de proteção. Em uma das festas de reis, por exemplo, os organizadores cercaram o espaço da festa para uma maior vigilância e controle de pessoas estranhas à comunidade do Maracanã, dos conjuntos do PMCMV, diante das ameaças sofridas. Isso não se constituiu em um fechamento da festa à participação de outras pessoas, já que “todas são bem vindas".

Os cercamentos dos espaços das casas, pelo visto, têm se constituído de uma prática de proteção dos moradores, dos juçarais, dos cultivos e dos objetos, imprescindíveis às garantias de reprodução das maneiras de viver da comunidade. Entretanto, vale ressaltar que esses cercamentos, não significa um processo de isolamento ou fechamento da comunidade, no sentido de evitar quaisquer tipos de relacionamento com o Outro. Trata-se de uma convivência que alterou o cotidiano da comunidade, por isso mesmo cheia de desconfianças e de cuidados.

As festas revelam outro detalhe, que as atividades culturais e religiosas estão articuladas a forma de como a comunidade representa e se relaciona com a natureza. Em meio às conversas, uma "mãe de santo" e outra moradora, aquela organizadora da festa de "Reis", relataram que recebem entidades defensoras da mata e que essas têm clamado por "cuidados com a natureza que sofre com os maus tratos".

Os juçarais na região ocultam cursos d'água denominados brejos que, para os moradores locais, são redutos da "mãe d'água". Esses seres encantados que habitam as matas estariam ameaçados porque as águas estão "sumindo" por conta dos processos de assoreamento e morte dos rios, riachos e córregos, decorrentes da construção dos conjuntos do PMCMV. A imbricada relação com a natureza é expressa por B. S. J. (conversa realizada em 13.01.2018) nos versos abaixo transcritos:

19 Araújo (2012) identifica e descreve as diversas atividades culturais realizadas no período 1930-1970, que seriam constitutivas da identidade da comunidade do Maracanã. A expressão "Maracanã de antigamente", que é utilizada pelos moradores, segundo o autor, é enfatizada como forma de lembrar essas experiências e trajetórias.

20 Em algumas oportunidades, as conversas se dirigiam aos relatos de crimes e violências sofridos pelos moradores da comunidade. O estado de insegurança se contrapõe às memórias de um tempo de sossego e tranquilidade quando era possível "descansar com as portas abertas." 
O nosso rio tá seco

Os peixes foram embora

O que será, meu Deus, de nós agora!

Os versos cantados por B. S. J. era para lembrar de um sonho. Nele, a "mãe d'água" revelava toda a sua dor com a morte da natureza e clamava por ajuda. $\mathrm{Na}$ condição de vidente, B. S. J., é o veículo por meio do qual os caboclos da mata ("Conceição da Piedade" e "Rei Leão da Mata") se servem para alertar sobre os problemas vividos que colocam em risco a natureza.

Em outros espaços da comunidade, como no quintal da casa de S. J., em meio aos juçarais e as plantas, rezas e oferendas são oferecidas a Oxóssi, como agradecimentos e pedidos de "proteção à natureza que se vê ameaçada", são dirigidos a ele no ritual (conversa com S. J., realizada em 13.01.2018).

Essas experiências locais de uma religiosidade que conecta o mundo dos encantados com a natureza a partir de um saber prático informado por entidades, orientam uma relação da comunidade com o lugar, mas também expressa um "modelo de natureza" (ESCOBAR, 2005) ${ }^{21}$. Neste artigo, Arturo Escobar lembra a importância do trabalho feminino no desenvolvimento de "práticas baseadas no lugar" que ele denominou de "modelos culturais da natureza". Na situação da comunidade do Maracanã, as mulheres desempenham um papel preponderante na produção e reprodução dos saberes e das práticas relacionadas à natureza. Ao manter a conexão entre a natureza e o sagrado, elas dão continuidade a um entendimento necessário para a sobrevivência da própria comunidade.

Nesse modelo, os encantados são os "donos" e os "cuidadores" da natureza, sendo que as pessoas devem agir em conformidade com essas lógicas. Esse agir, contudo, implica em compreender o funcionamento da natureza, que ocorre "ascultando" as entidades, por meio da intuição, da observação, dos sonhos e da incorporação de entidades nos rituais que ocorrem nos terreiros. As pesquisas desenvolvidas por Nicolas Floriani et. al. (2016), sobre os sistemas faxinais no Paraná, também identificam situações parecidas às analisadas, onde a natureza e o sagrado se constituem de uma mesma entidade.

Os saberes sobre a natureza apreendidos e difundidos em circunstancias especiais vinculadas a uma relação de proximidade, de parentesco espiritual, "filiação", se aproximam dos processos descritos por Almeida (2008) de uma "territorialidade específica". Em outras palavras, os "modelos de natureza" circunscritos às "práticas socioespaciais" determinam um domínio próprio sobre o território, que opõe aos "projetos globais" e a toda forma de "alisamento".

21 Esses modelos se distanciam do modelo hegemônico, hoje, globalizado. Apresentada como vantagem comparativa dos países, a natureza é exposta em um portfólio para ser apropriada e vendida (CORONIL, 2005). 


\section{NÓS E OS OUTROS: “HISTÓRIAS LOCAIS" E "PROJETOS GLOBAIS"}

A situação da comunidade do Maracanã, descrita acima, encontrase inserida nessa lógica global, dominada pelo capital financeiro, que tem a habitação como uma das últimas fronteiras de acumulação (SASKEN, 2015). Recorda Rolnik (2015) que esse programa de construções de moradia, PMVMV, foi entregue à iniciativa privada, que adotou como estratégia a compra de terrenos mais baratos ${ }^{22}$, sobretudo, aqueles situados em locais distantes das áreas mais urbanizadas para a edificação de casas a população de baixa renda. A escolha dos terrenos tornou-se um dos elementos imprescindíveis para a obtenção de maior rentabilidade, na medida em que foi deixado todo o poder de decisão às construtoras, que vai desde a arquitetura dos projetos à localização.

Tal modelo popular de habitação, que se impõe pela padronização, escala, rapidez e localização, produz uma nova forma de "periferização organizada", sob a orientação exclusiva do mercado imobiliário, financeirizado. Assim, a urbanização e o adensamento da área do Maracanã decorrente dessa política habitacional vêm gerando sofrimentos aos moradores da comunidade do Maracanã, como a devastação das matas, poluição, assoreamento, morte dos rios, riachos e córregos etc. Somados a esses problemas que comprometem a reprodução física e cultural da comunidade, outros tantos surgiram como resultado da densificação populacional na área do Maracanã. A rede de infraestrutura e de serviços, que já era precária, se manteve, agora, sobrecarregada, sem conseguir atender as demandas avolumadas.

Importa ressaltar que a expansão urbana da cidade São Luís ocorre em dois eixos perpendiculares, já descritos pelos autores em outro trabalho (SHIRAISHI NETO et al., 2018). Um, em direção ao porto de Itaqui, caracterizado principalmente pelas atividades industriais e, outro eixo, em direção aos municípios de São José de Ribamar e Raposa, com forte atividade imobiliária, ainda que não exclusiva. Acompanhando a beira mar, os condomínios Alphaville e Dahma "dão o tom" da expansão, isto é, "escolhem” os seus vizinhos, com a cumplicidade do Poder Público. Deste outro lado da cidade, longe das praias, as ocupações e os conjuntos do Programa Minha Casa Minha Vida (PMCMV) dominam a paisagem que até pouco tempo era caracterizada como zona rural.

Muito embora essa expansão venha absorvendo parte da área rural em direção aos outros municípios da região metropolitana, observa-se um intenso

\footnotetext{
22 Na Região Metropolitana de São Luís, o referido programa teve sua trajetória marcada pela fragmentação, disperso nos municípios situados na ilha do Maranhão, sobretudo em São José de Ribamar e Paço do Lumiar, mais especificamente na faixa periurbana dos municípios e na zona rural de São Luís.
} 
processo de densificação imobiliária no espaço intra-urbano da cidade de São Luís. Nos interstícios da malha urbana figuram diferentes empreendimentos imobiliários que compreendem condomínios fechados, horizontais e verticais, sendo estes últimos, os de maior expressão.

Tais situações, determinadas pelos empreendimentos econômicos privados, vêm sendo pensadas a partir de um entendimento de "modernização" da cidade e do urbano, que se efetiva através de projetos de intervenções do Poder Público municipal e estadual. As obras de infraestrutura realizadas por esses poderes se efetivam, no sentido de privilegiar frações da cidade, já valorizadas, pela iniciativa privada.

Vale recordar os estudos de Carlos Vainer (2011) sobre as intervenções urbanas no Rio de Janeiro quando da realização dos jogos olímpicos. Elas, segundo Vainer, revelam o deslocamento das políticas urbanas, que, orientada pelo e para o mercado ("market oriented"), tendem a ignorar as concepções de cidade e de planejamento urbano expressos na Constituição Federal de 1988 e na Lei no 10.257/2001 (o denominado Estatuto da Cidade). Os processos, que se assemelham, sinalizam para a enorme capacidade dos "novos agentes" na determinação e condução das políticas urbanas no Brasil.

\section{4 À GUISA DE CONCLUSÃO}

As tentativas de apreender os saberes e as práticas da comunidade do Maracanã tiveram como referência os processos nos quais a mesma se encontra inserida, principalmente, as estratégias práticas que os moradores vêm se utilizando para se repensar e buscar novos sentidos às suas vidas, em rápida e intensa transformação.

Submetida a uma lógica que se impôs, com uma força extremamente desigual, comparativamente às condições reunidas pela comunidade, essa se vê obrigada a uma convivência com "outros", aqui entendidos como toda sorte de "estranhos", desde os próprios empreendimentos imobiliários, na sua enorme extensão e devastação, à grande quantidade de novos moradores, com as suas distintas representações da natureza, que chegaram, mudando a rotina e o cotidiano dos moradores antigos.

Tomados de assalto por uma ordenação urbana do espaço de São Luís, em contraposição a um quase mundo rural, com as suas formas de vida e relação com a natureza, esse antigo tecido sócio-cultural-ambiental se viu esgarçado e atravessado por novas teias que desafiam a comunidade a uma nova política de convivências. 
Os saberes e as práticas já enraizados, assumem agora, um poder capaz de negociar o lugar, como abertura, e ao mesmo tempo, como elementos de territorialização, já que definem e asseguram o lugar das pessoas e das coisas. A ameaça de rompimento abrupto da relação da comunidade com os seus vínculos (terra, sagrado, juçarais, buritizais, águas etc.), produz enormes sofrimentos aos moradores e são estes sofrimentos que, paradoxalmente, impulsionam as lutas que ocorrem em várias frentes. As festas e as rezas autorizam, assim, uma forma de conivência que não excluí o "outro", de modo que lhes permitem continuar, ainda que não da mesma forma, as suas tradições.

\section{REFERÊNCIAS}

ACSELRAD, Henri. As práticas espaciais e o campo dos conflitos ambientais. In: Conflitos Ambientais no Brasil. Rio de Janeiro: Relume Dumará: Fundação Heinrich Boll, 2004. pp.13-35.

ALMEIDA, Alfredo Wagner Berno de. Terra de quilombo, terras indígenas, "babaçuais livre", "castanhais do povo", faxinais e fundos de pastos: terras tradicionalmente ocupadas. $2^{\circ}$ ed. Manaus: PGSCA-UFAM, 2008.

ALMEIDA, Alfredo Wagner Berno de.; SHIRAISHI NETO, Joaquim; MARTINS, Cynthia Carvalho. Guerra Ecológica nos Babaçuais: O processo de devastação dos palmeirais, a elevação do preço de commodities e o aquecimento do mercado de terras na Amazônia. São Luís: Lithograf, 2005.

AMARAl FILHO, Jair. A Economia Política do Babaçu: um estudo da organização daextrato - indústria do babaçu no Maranhão e suas tendências. São Luís: SIOGE, 1990.

CORONIL, Fernando. Natureza do pós colonialismo: do eurocentrismo ao globocentrismo. In: LANDER, Edgard (org.). A colonialidade do saber: eurocentrismo e ciências sociais perspectivas latino - americanas. Argentina: CLACSO, 2005. pp. 50-62.

ESCOBAR, Arturo. La Invención del Tercer Mundo. Construción e descontrución del desarrollo. Caracas: Fundación Editorial el perro y la rana, 2007.

O lugar da natureza e a natureza do lugar: globalização ou pósdesenvolvimento? In: LANDER, Edgard (org.). A colonialidade do saber: eurocentrismo e ciências sociais perspectivas latino - americanas. Argentina: CLACSO, 2005. pp.63-79. 
FLORIANI, Nicolas; CUNHA, Lúcia Helena de Oliveira; VEIGA, Andrea Mayer; GALDINO, José Roberto de Vasconcelos. A Floresta e a Territorialidade Faxinalense: espaço sagrado, espaço de lutas. In: BASSOLS, Narcisio Barrera; FLORIANI, Nicolas (orgs.). Saberes, paisagens e territórios rurais da América Latina. Curitiba: Ed. UFPR, 2016. pp.199-217.

LIMA, Rosirene Martins. Conflitos Socioambientais em Curitiba. São Luís: editora UEMA, 2008a.

O Rural no Urbano. Uma análise da produção do espaço urbano de Imperatriz- MA. Imperatriz: Ética editora, 2008b.

LIMA, Rosirene Martins; SHIRAISHI NETO, Joaquim. Conflitos Socioambientais. O direito ambiental como instrumento de legitimação das ações de intervenção do poder público. Intervenção no Jardim Icaraí, Curitiba, PR. In: FLORIANI, Dimas; HEVIA, Antonio Elizarde (orgs.). América Latina: sociedade e meio ambiente: teorias, retóricas e conflitos em desenvolvimento. Curitiba: Ed. UFPR, 2016.

MBEMBE, Achille. Necropolitica. In: Necropolitica seguido de Sobre o Gobierno Privado Indirecto. Espanha: Melusina, 2006. pp.19-75.

MIGNOLO, Walter. Historias locales/ diseños globales. Colonialidad, conocimentos subalternos y pensamiento fronterizo. Espanha: Ediciones Akal, 2003.

OLIVEIRA FILHO, João Pacheco de. O Caboclo e o Brabo. Notas sobre duas modalidades de força de trabalho na expansão da fronteira Amazônica no século XIX. Encontros com a Civilização Brasileira, n. 11, pp. 101-140, 1979.

ROLNIK, Raquel. Guerra dos Lugares: a colonização da terra e da moradia na era das finanças. São Paulo: Boitempo, 2015.

SANTOS, Roberto. História Econômica da Amazônia (1800-1920). São Paulo: T. A. Queiroz, 1980.

SHIRAISHI NETO, Joaquim. Direito dos Povos e das Comunidades Tradicionais no Brasil: Declarações, Convenções e Dispositivos Jurídicos definidores de uma Política Nacional. $2^{\circ}$ ed. Manaus: UEA Edições, 2010. Quebradeiras de coco: "babaçu livre" e reservas extrativistas. Revista Veredas. Belo Horizonte, vol.14, n.28, pp. 147-166, janeiro/abril de 2017. 
SHIRAISHI NETO, Joaquim; LIMA, Rosirene Martins; SERRA, Sergio Lopes. A Cidade em Disputa: São Luís sob a ordem do capital financeiro. [São Luís]: s. ed., 2018. 19p.

VAINER, Carlos. Cidade de Exceção: reflexões a partir do Rio de Janeiro. 2011. Disponível em: https://br.boell.org/sites/default/files/downloads/carlos_ vainer_ippur_cidade_de_excecao_reflexoes_a_partir_do_rio_de_janeiro.pdf. Acesso em: 08 de agosto de 2017.

WACQUANT, Loic. Os condenados da cidade. Rio de Janeiro: Revan, 2001.

\section{Sobre a Comunidade do Maracanã}

ARAUJO, Marcelo de Sousa. A Identidade em Movimento: um estudo sobre a comunidade do Maracanã (1930-1970). 2012. Dissertação (Mestrado em Cultura e Sociedade). PPGCULT- UFMA, São Luís, 2012.

CYSNE, Ana Lenira; SANTOS, Jorge Hamilton dos; PEREIRA, Edileia Dutra. A Bacia Hidrográfica como Unidade de Planejamento Socioambiental: caracterização geomorfológica e hidrográfica da sub-bacia do Maracanã. São Luís-MA. In: XVI Encontro Nacional de Geógrafos, 2010, Porto Alegre. Anais... Porto Alegre: UFPB, 2010.

D’ABBVILLE, Claude. História da Missão dos Padres Capuchinhos na Ilha do Maranhão e terras circunvizinhas. São Paulo: Ed. Da Universidade de São Paulo, 1975.

\section{Documentos, Reportagens, Entrevistas e Vídeos}

ALMEIDA, Rogério; MASSON, Nonato. Maranhão: sistema penitenciário entrou em colapso. São Luís, 2014. Disponível em https://www.cartamaior. com.br/?/Editoria/Politica/Maranhao-sistema-penitenciario-entrou-emcolapso-/4/29990. Acesso em: 06 de dez. de 2017. 


\section{Território e trabalho: análise geoeconômica com base em trajetórias camponesas}

\section{Territory and work: a geoeconomical analysys based on peasant trajectories}

Karen de Nazareth Santos Nogueira - Mestre em Planejamento do Desenvolvimento pelo Núcleo de Altos Estudos Amazônicos (NAEA/UFPA). Analista em Geoprocessamento no Instituto de Pesquisas Espaciais, Centro Regional da Amazônia (INPE/CRA). E-mail: kns.nogueira@hotmail.com

Francisco de Assis Costa- Doutor em Economia pela Freie Universität Berlin, professor titular da Universidade Federal do Pará, no Programa de Pós-Graduação em Desenvolvimento Sustentável do Trópico Úmido do NAEA e do Programa de Pós-Graduação em Economia da Faculdade de Economia. E-mail: francisco_de_assis_costa@yahoo.com.br

Marcos Adami - Doutor em Sensoriamento Remoto pelo Instituto Nacional de Pesquisas Espaciais. Pesquisador do Instituto Nacional de Pesquisas Espaciais no Centro Regional da Amazônia (INPE/CRA). E-mail: marcos.adami@inpe.br

\section{Resumo}

A pesquisa tem como foco a análise da configuração territorial rural do município de Mocajuba, que se localiza na região do Baixo-Tocantins. Com base na teoria de trajetórias tecnológicas rurais para a Amazônia, foi estudada a especificidade da economia camponesa, particularmente seu segmento baseado no agroextrativismo. Com isso objetiva-se indicar os tipos e percentuais de uso e cobertura da terra que os agentes da trajetória camponesa T2, empregam no território. Por meio do processamento de dados de satélite em associação a dados econométricos, concluise que os territórios onde se encontram as trajetórias agroextrativistas, apresentam níveis de conservação florestal consideráveis, se comparados a outras trajetórias. Pode-se afirmar ainda que o trabalho é parâmetro fundamental de alocação espacial, por expressar-se em extensão, mobilidade e padrões de alocação, bem como o território, que neste contexto torna-se o atributo essencial de fundamentação do trabalho.

\section{Palavras-chave}

Território. Trabalho. Trajetória Agroextrativista. Geoprocessamento.

\begin{abstract}
The research aims the analysis of the rural landed set of Mocajuba's county, which is located in Baixo-Tocantins region. Based in the theory of rural technological paths for the Amazon, it was studied the specificity of the peasant economy, particularly its segment based on the agro-extractivism. Therefore, objective is to indicate the types and percentages of land use and land cover that agents of peasant trajectory T2, employ the territory Through the processing of satellite data associated to econometric data. it is concluded that the territories where the agroextractivist trajectories, present considerable forest conservation levels, compared to other paths. One can also say that the work is fundamental parameter space allocation, to express in length, mobility and allocation patterns, and the territory, which in this context becomes the essential attribute of work reasons.
\end{abstract}

\section{Keywords}

Territory. Work. Agro-extractive Path. Geoprocessing. 


\section{INTRODUÇÃO}

A pesquisa tem como foco a análise da configuração territorial rural do município de Mocajuba, que se localiza na região do Baixo-Tocantins. Com base na teoria de trajetórias tecnológicas rurais para a Amazônia, foi estudada a especificidade da economia camponesa, particularmente seu segmento baseado no agroextrativismo.

O rural mocajubense é dominantemente camponês. Com base na noção de trajetórias, pretende-se estudar como a especificidade da economia camponesa, particularmente seu segmento baseado no agroextrativismo configura o território de Mocajuba. Esses agentes secularmente estabelecidos e com relações de produção e vivência muito bem delimitadas, são camponeses em uma acepção chayanoviana, cuja racionalidade é concretizada a partir dos padrões reprodutivos orientados pela satisfação das necessidades da família.

Por entendermos que a teoria de Chayanov (1974) tem aplicação aos múltiplos sistemas de produção amazônicos é que podemos dizer que a base produtiva destes camponeses se orienta em última instância por trajetórias tecnológicas, tal qual definidas por Costa (2009b) cuja base técnica está apoiada num conhecimento do bioma, de um manejo sobre o território. Esse campesinato ancestral fundou uma dinâmica ligada a processos estruturais que movimentam a economia da região a partir de uma lógica produtiva cujo domínio técnico da produção se dá por ativos específicos, cujas práticas de manejo pressupõem a manutenção do bioma. Com base em regras de convívio próprias, acordos tácitos e regras de manejo do recurso muito específicas marcam essa trajetória orientada para o agroextrativismo.

A dinâmica produtiva dessas territorialidades ancestrais na história da Amazônia vem sendo afetada nos últimos anos, de um lado, pelos movimentos de etnogênese de base camponesa; de outro, nas políticas de regularização fundiária nacional na escala compreendida por um mosaico de situações que tem como núcleo intervenções concretas: o estabelecimento de 4 projetos agroextrativistas (PAE da Ilha Grande de Conceição de Mocajuba ${ }^{1}$, PAE da Ilha Grande do Vizeu $^{2}$, PAE da Ilha de Angapijón ${ }^{3}$ PAE Ilha de Tauré ${ }^{4}$ ) e 1 território quilombola (TEQ 2ำ Distrito de Porto Grande ${ }^{5}$ ).

\footnotetext{
Portaria $\mathrm{n}^{\mathrm{0}} 187$, de 15 de dezembro de 2009.

Portaria $\mathrm{n}^{\mathrm{o}}$ 188, de 15 de dezembro de 2009.

Portaria no 186 , de 15 de dezembro de 2009.

Portaria n⿳⺈ 189, de 15 de dezembro de 2009.

Título outorgado pelo ITERPA, em 2 de dezembro de 2008.
} 
É especificamente desta economia em muito esquecido ou considerada como de segunda ordem que pretendermos dar conta na proposta em questão. Economia esta, secularmente, estabelecida e baseada na tradição indígena vem desenvolvendo sistemas econômicos baseados no manejo dos ecossistemas naturais e em cultivos capazes não apenas de coexistirem com ecossistemas naturais, como também de enriquecê-los.

A diversificação da produção nessa economia foi e só é possível graças ao desenvolvimento de tecnologias de manejo e cultivo, a exemplo da domesticação de vegetais como a macaxeira, base para produção da farinha, componente importante na dieta familiar. Também se criou tecnologia de utilização de outros produtos como o açaí, a bacaba, o buriti e a copaíba.

Tais formas produtivas, por se desenvolverem nas franjas do crescimento econômico capitalista, encontram no desinteresse político e na presença perversa do planejamento -voltado para atender a grandes demandas - a dificuldade na implementação de políticas que viabilizem o fortalecimento de tais economias com foco em suas potencialidades.

Esse modo de vida camponês está alicerçado sob relações identitárias e territoriais pré-estabelecidas e que ultrapassam os limites físicos propostos pelas áreas de regularização fundiária. Tais territorialidades fundamentam as relações produtivas e reprodutivas desses agentes que operam o bioma de forma específica.

Com isso, objetiva-se indicar os tipos e os percentuais de uso e cobertura da terra que os agentes da trajetória camponesa T2 empregam no território. Por meio do processamento de dados de satélite em associação com dados econométricos, conclui-se que resulta em níveis de conservação florestal consideráveis, se comparados a outras trajetórias. Dentro deste contexto, o trabalho é parâmetro fundamental de alocação espacial, por expressar-se em extensão, mobilidade e padrões de alocação, bem como o território, que neste contexto torna-se o atributo essencial de fundamentação do trabalho.

\section{TERRITÓRIO E TRABALHO}

Trabalho e território são categorias importantes do ponto de vista analítico, e carecem de integração do ponto de vista metodológico, haja vista que, por se inscreverem em temporalidades diferentes, apresentam dificuldade de articulação. O território tem inscrição em tempo longo e curto, já o trabalho inscreve-se em tempo curto, o que pode comprometer a análise dos processos sociais e institucionais. 
Trabalho e território são conceitos centrais em economia. Um movimento recente, sobretudo, na Economia vem buscando uma interpretação possível de articulação entre as duas categorias, haja vista que as duas noções são elementoschave para a compreensão da socialização dos indivíduos.

Para a Sociologia de Durkeim o trabalho se apresenta enquanto processo, como criador do vínculo social, enquanto que o território está ligado ao sentimento de pertencimento como constitutivo do reconhecimento identitário dos indivíduos.

De tais interpretações emerge a noção de territórios-atores no sentido de "pluralidade das temporalidades espacializadas" (BERTHELOT, 1996). Tal noção diverge da acepção geográfica de território, pois permite pensar o mesmo em dupla inscrição, pois expressa temporalidades sociais do trabalho e território.

A busca de soluções locais de desenvolvimento tem o território como vetor de diferenciação de economias internacionais e nacionais, o que tem efeito sobre a forma de organização do trabalho.

O território na geografia tradicional surge como alicerce do Estado "modo de existência do Estado no espaço" (ALLIĖS, 1980, p. 12), mas questões sobre a emergência do poder do Estado levam à transformação da noção móvel do espaço, a noção de território.

O Estado exerce poder sobre um território, e este expressa em última instância conflito de relações, o que lhe confere configuração e dinâmica especificas. Logo as instituições comprovam o ancoramento do território nas relações locais, o que confere a este inscrição em tempo longo, sob mediação do estado.

Por outro lado, os vínculos informais, as convenções e as regras reproduzidas em escala local oferecem suporte sobre a atividade de trabalho, por meio de códigos tácitos e explícitos, de formalidade e informalidade que dão o tom da dinâmica territorial do lugar. Tais arranjos referem-se a território em tempo curto, mais imediato.

\section{A MULTIDIMENSIONALIDADE DO TERRITÓRIO E A CENTRALIDADE DO TRABALHO NA SUA CONSTITUIÇÃO}

$\mathrm{Na}$ geografia a relação com o aspecto físico do território foi por longo tempo a base do exercício da vida em sociedade, sobretudo, a maneira como os indivíduos se relacionam e criam uma representação própria de espaço, está na origem e constituição dos territórios (AZAÏZ, 2004).

Economistas como Krugman (1998) vão além ao entender que o exercício de uma atividade econômica está profundamente ligado à funcionalidade de um 
dado lugar. Daí a importância no reconhecimento das redes na constituição de um sistema produtivo.

Na emergência desse debate, surge o interesse metodológico na dimensão meso, como aporte analítico ao entendimento de que a temporalidade permite distinguir as noções de território e espaço.

Prévot e Schapira (1997) foram precursores ao tratar do território como construção histórica que encontra seu princípio unificador nas práticas sociais do momento. Outros estudiosos da questão inserem nesse contexto a variável temporal dessas formas de desenvolvimento territorial. Ph Aydalot vai além e oferece complexa análise da implicação dessas formas de desenvolvimento em estruturas institucionais e socioeconômicas, em uma dada escala temporal.

De acordo com Bellet, Collettis e Yung (1993), o território é entendido como construção das práticas e das representações dos agentes econômicos, ou ainda como ator do desenvolvimento econômico. Portanto, o território ocupa lugar ativo por ser produtor de externalidades, ou seja, é uma estrutura ativa de desenvolvimento, estagnação e retrocesso. E as práticas sociais que se estabelecem em escala micro são a chave de sedimentação do território. "Portanto, o ponto de convergência entre o território e o trabalho reside na temporalidade, curta, que precisa da temporalidade longa do território para expressar-se plenamente" (AZAIS, 2004,p.38).

Diante do aqui exposto, pode-se dizer que a territorialidade permite ao trabalho e às formas variadas que adota tornar-se lugar privilegiado de construção do vínculo social, tendo no território a estruturação social do espaço, dinâmica, inscrita num tempo.

O esforço, sobretudo, dos economistas tem sido de compreender o desenvolvimento territorial sob a perspectiva da diferenciação dos territórios, no que se refere às esferas da produção e trabalho. Azaïs (2004) reforça a ideia de que desenvolvimento não se resume a desenvolvimento "top down" ou botton down". O processo é mais complexo, pois envolve influências estruturais aplicadas a escalas local e global.

Logo, do ponto de vista endógeno não se deve desconsiderar determinações de ordem macroeconômica ou microssocial, bem como, da perspectiva exógena não se pode negar a importância da estrutura socioeconômica e histórica, produto das instituições e dos homens que "fazem" o território e nele trabalham.

O território, dentro de uma lógica própria, tem capacidade de produzir e apoderar-se das externalidades e fazê-las render, sendo capaz portanto, de ser agente socialmente inovador. 
A territorialidade, entendida como processo de apropriação do espaço por um grupo, indivíduo ou organização, incorpora aspectos da relação entre os atores sociais e sua base natural de existência. Milton Santos (1996) via com clareza essa dimensão da vida social, entendendo a partir daí que as formas de operação do trabalho vivo (em fluxos) sobre esse fundamento, e os meios utilizados (diferentes estruturas e meios) obtidos por trabalho pretérito cristalizado (fixos), constituem a dimensão fundamental dos territórios.

Costa (2008) explicita como peculiaridade o bioma amazônico como objeto e meio dessas relações, as quais instrumentalizam um portfólio de tecnologias incorporadas no bojo do sistema de práticas sociais, em última instância, conformando estratégias refinadas de mobilização dos recursos naturais florestais e aquáticos que distinguem a região. Tais usos, nessa perspectiva, resultam de formas de conhecimento, associadas a valores e regras - instituições - que se revelam sob a forma de "trajetórias tecnológicas". Dentre essas, destacamse trajetórias camponesas, mobilizadas para resolver problemas produtivos e reprodutivos mediante, por um lado, uma racionalidade específica dominada por critérios da esfera reprodutiva, generalizável para economias camponesas em geral; por outro, formas particulares de ajustamento dessa racionalidade a condições materiais e institucionais próprias de lugares específicos - às formas territorializadas de existência camponesa.

Milton Santos (1996), em suas reflexões sobre o que chama de uma fenomenologia espacial, traz um entendimento da noção de território que, ao mesmo tempo que ressalta a dimensão espacial e seu substrato material, a natureza, portanto, como elemento-chave de compreensão da socialização dos indivíduos, sublinha que tal processo de construção social do espaço se faz pelo trabalho, como criador do vínculo social constitutivo que produz reconhecimento identitário, atrelando as pessoas à porção do espaço onde se reproduzem.

Nessas bases, se constitui a abordagem multidimensional que aqui será privilegiada, para a qual, em formulação ampla, o território é um híbrido da economia, da cultura e da política, com sua dimensão ambiental, ressaltam Saquet (2004, 2007) e Haesbaert (2004 p. 50).

Trata-se em última instância, retomando Santos (1996) para uma síntese, de dinâmica de poder em torno do uso de recursos tangíveis e intangíveis, gerando situações específicas onde eventos convergem na criação de realidade ímpar e dotada de possibilidades novas - na realidade, o espaço geográfico é sempre um campo de possibilidades (SANTOS, 1979), um produto das estratégias dos homens para produzir seus meios de existências, o que ocorre por meio do trabalho e o potencial criativo contido no seu exercício. 
Segundo Saquet (2007) a dimensão econômica é central do território, considerando este com enraizamento cultural, identidade, conexão societária, recursos naturais e as experiências do lugar de vida. Enfim, trata-se de síntese de processos - em sua articulação, processos de territorialização - que se dá por aspectos econômicos e culturais.

Autores como Raffestin (1993) ressaltam a dimensão material nas relações sociais constitutivas do território, destacando, entretanto, o caráter político dessas relações. A isso se refere Haesbaert (2007), quando enfatiza que o território nasce com a tomada de consciência dos homens sobre o significado do espaço como fundamento de poder. Nisso consistiria a dimensão subjetiva do território, relacionada a apropriação ou identidade territorial, que se verifica em unidade com uma dimensão objetiva em sentido concreto que se realiza por instrumentos de ação político-econômica (HAESBAERT; LIMONAD, 1999).

É como esforço de instrumentação de tais noções que compreendemos as indicações de economistas como Cristian Azaïs (2004), para quem trabalho e território são noções centrais em economia. Não obstante, adianta o autor, há dificuldades na articulação conceitual das duas esferas, o que se tem mostrado um desafio aos pesquisadores. Como contribuição à superação dessas dificuldades, o autor fornece um mapa possível de articulação, com a proposição de diferentes temporalidades operantes na noção de território-atores: as temporalidades sociais do trabalho, inscritas no curto prazo pelas premências reprodutivas imediatas, e as do território, expressando dinâmicas estruturais de tempo mais longo.

Este é, também, um ponto central na reflexão de Costa e Carvalho (2012), para quem a organização social do trabalho, não obstante, obedece em nível macro que é das regulações sistêmicas de um modo de produção dominante (o modo capitalista de produção como força hegemônica de última instância); em nível micro está condicionada por razões diversas, associadas a distintos atores e contextos. Assim sendo, em nível meso (onde se situam os territórios e sociedades locais), tal organização expressa essas diferentes razões em relação entre si na utilização das disponibilidades naturais, culturais e institucionais concretamente disponíveis (COSTA; CARVALHO, 2012).

Mobilizando tais supostos, Costa e Carvalho (2012) sugerem uma relação de dependência teórica estrita entre a categoria campesinato, de um lado com a categoria camponês e, de outro, com a categoria território. Nesse sentido, estes autores sugerem um modo de operar a proposição de Azaïs (2004), acima mencionada, de realçar as configurações relacionais território - atores como forma de superar as dificuldades de visão integrada entre economia e território. 
No Dicionário dos Movimentos Sociais no Campo, Costa e Carvalho (2012) definem de modo simples e direto o que seja campesinato como o conjunto de famílias camponesas existentes em um território. Parte da noção, todavia, é o conceito antes trabalhado por Costa e Carvalho (2012), de que:

Camponesas são aquelas famílias que tendo acesso à terra e aos recursos naturais que esta suporta, resolvem seus problemas reprodutivos - suas necessidades imediatas de consumo e o encaminhamento de projetos que permitam cumprir adequadamente um ciclo de vida da família - a partir da produção rural desenvolvida de tal maneira que não se diferencia o universo dos que decidem sobre a alocação do trabalho dos que se apropriam do resultado dessa alocação (COSTA; CARVALHO, 2012, p. 107).

E, ainda, que as famílias camponesas existem em territórios, isto é:

no contexto de relações sociais que se expressam nas regras de uso (instituições) das disponibilidades naturais (biomas e ecossistemas) e culturais (capacidades difusas internalizadas nas pessoas e aparatos infra-estruturais tangíveis e intangíveis) de um dado espaço geográfico politicamente delimitado (COSTA; CARVALHO, 2012, p. 28).

Em suma:

Unidades camponesas produzem orientadas pela finalidade comum da reprodução dos respectivos grupos familiares em perspectiva que incorpora consistência entre gerações - a geração operante se vê parte constitutiva das realizações de seus ascendentes e descendentes". Nisso se constitui sua especificidade, sua natureza essencial, a qual validam "[...] em combinações individualizadas de capacidades privadas, condicionadas por possibilidades e restrições das realidades locais, regionais e nacionais que findam por definir sua forma de existência. Nessa condição concreta constituem um campesinato (COSTA; CARVALHO, 2012, p.115).

\section{CAMPESINATOS AMAZÔNICOS E SEUS FUNDAMENTOS ESTRUTURAIS: AS TRAJETÓRIAS TECNOLÓGICAS}

Para entender a profunda diversidade estrutural da dinâmica rural na Amazônia, Costa (2010) utiliza a definição de Dosi (2006) de trajetória tecnológica e paradigma, e com base nela, diferencia, primeiro, as diferentes estruturas e razões camponesas e patronais; depois, apresenta as diferentes formas de evolução das estruturas camponesas expressas em diferentes trajetórias tecnológicas e faz o mesmo com as estruturas patronais.

Dosi define paradigma como "um modelo ou padrão de solução de problemas tecnológicos selecionados, baseado em princípios selecionados, 
derivados das ciências naturais e em tecnologias materiais selecionadas" (DOSI, 2006, p. 22-23). A solução para o problema tecnológico está no modo pelo qual os agentes econômicos operam sua produção e reprodução.

Dosi (2006, p. 22) define trajetórias tecnológicas como "um padrão usual de atividades, que resolvem com base em um paradigma tecnológico, os problemas produtivos e reprodutivos que confrontam processos decisórios de agentes concretos, em contextos específicos, nas dimensões econômica, institucional e social"

Assim é inserido o contexto ecológico (base natural) como determinante na estruturação de paradigmas e trajetórias tecnológicas para o agrário na Amazônia. Redimensiona o problema tecnológico ao tratá-lo como "problema na relação entre trabalho humano, objetivado por um modo de produção, e seu objeto último a natureza" (COSTA, 2010, p. 28). Ou seja, o padrão usual de como o agente opera seu objeto de trabalho, a natureza. Este modo de operação podese dar em dois paradigmas o agropecuário, cuja natureza é tratada como matériaprima, agregada aos processos produtivos e o paradigma agroextrativista, cuja natureza é considerada como capital natural, com capacidade produtiva tratada como valor de uso.

As soluções daí derivadas organizam as trajetórias tecnológicas entendidas por Costa (2009c, p. 229) como "a articulação processada por agentes orientados por racionalidades semelhantes, entre padrões produtivos e razões reprodutivas, expressas em heurísticas que se materializam em combinações particulares de meios e produtos."

Pautado na relação da diversidade de estruturas e agentes e em estatísticas disponíveis Costa (2009a) delimita para Amazônia trajetórias tecnológicas rurais, privilegiando as relações entre trajetórias e seus produtos.

De modo que observando, as características econômicas da produção, as interações que ocorrem entre os grupos de produtos e a distribuição espacial de sua ocorrência, a relação que apresentam com as instituições e a forma como se desenvolvem no tempo se espera configurar as trajetórias tecnológicas fundamentais na Amazônia (COSTA, 2009a, p.. 45).

O elemento que vai diferenciar uma trajetória da outra são as diversas formas técnicas utilizadas para combinar os meios produtivos, bem como a participação na divisão social do trabalho.

A diversidade de formas técnicas (combinação de meios) e de formas de participação na divisão social do trabalho (combinação de produtos) que diferencia as trajetórias depende das dotações naturais e institucionais que marcam as bases territoriais locais sobre as quais evoluem e dos nexos (que 
se conformam com a mediação destacada do mercado) que as vinculam a territorialidade mais amplas, nacional e mundial (cadeias de produção e troca) (COSTA, 2009a, p. 229).

Segundo Costa (2009b), uma trajetória tecnológica é um padrão usual de atividades que resolvem, com base em um paradigma tecnológico, os problemas (re) produtivo confrontando processos decisórios em contexto específico nas dimensões econômica, institucional e social.. Trata-se, assim, de noção capaz de operar a articulação entre as relações técnicas e sociais que configuram o território - como tal, este será visto como produto da reprodução de trajetórias em concorrência ou em cooperação.

Para a região Norte os atributos das diferentes trajetórias são comparados em acordo com sua relevância na economia regional, levando em consideração o Valor Bruto da Produção do setor Rural (VBPR), o que possibilitou ao autor a identificação de 6 trajetórias:

a) 'Trajetória Camponês.T1' reúne o conjunto de sistemas camponeses que convergem para sistemas com dominância de culturas permanentes e produção de leite. Marcada por uso intensivo do solo, com sistemas diversificados (baixo impacto na biodiversidade) e baixa formação de dejetos/impacto poluidor, explica 27\% do VBPR, 38\% do emprego, 10\% da área degradada e 11\% do balanço líquido de carbono. A economia em torno dessa trajetória cresce em termos absolutos a 5\% a.a., com rentabilidade crescente nos últimos tempos a 2,5\% a.a., por trabalhador a 4,3\% a.a. e por área a $0,3 \%$ a.a.

b) 'Trajetória Patronal.T4' reúne o conjunto de sistemas de produção em operação em estabelecimentos patronais que convergem para pecuária de corte. Marcada por uso extensivo do solo, homogeneização da paisagem (alto impacto na biodiversidade) e formação intensa de dejetos, explica 25\% do VBPR, 11\% do emprego, $70 \%$ da área degradada e $71 \%$ do balanço líquido de carbono. A economia em torno dessa trajetória cresce em termos absolutos a 5,1\% a.a., com rentabilidade crescente nos últimos tempos a 8,4\% a.a., por trabalhador a $9 \% \mathrm{e}$ por área a $6,2 \%$.

c) 'Trajetória Camponês. T2' reúne o conjunto de sistemas camponeses que convergem para sistemas agroflorestais com dominância ou forte presença de extração de produtos não-madeireiros. Explica 21\% do VBPR, 26\% do emprego, $3,5 \%$ da área degradada e 2,6\% do balanço líquido de carbono. A economia em torno dessa trajetória cresce em termos absolutos a 12\% a.a., com rentabilidade crescente nos últimos tempos, por trabalhador a $12,7 \%$ e por área a $11,4 \%$. Observe que seria uma trajetória expressão de um "paradigma agroflorestal" - 
no qual os processos produtivos, pressupõem, em algum nível, a preservação da natureza originária.

\section{O TERRITÓRIO DE PESQUISA}

O município de Mocajuba localiza-se à jusante da Usina Hidrelétrica de Tucuruí, na região do Baixo Tocantins, composta por mais de 10 municípios. A população que vive na área rural corresponde 52,79\% do total de 739.881 habitantes, destes 32.365 são agricultores familiares e 24.701 famílias assentadas (Plano Territorial de Desenvolvimento Rural Sustentável do Baixo Tocantins, de 2010), distribuídas em projetos agroextrativistas, terras indígenas e comunidades quilombola, e áreas das chamadas "colônias" ou "centros" - ocupações das áreas de terra firme.

Figura 1 - Mapa de localização do município de Mocajuba

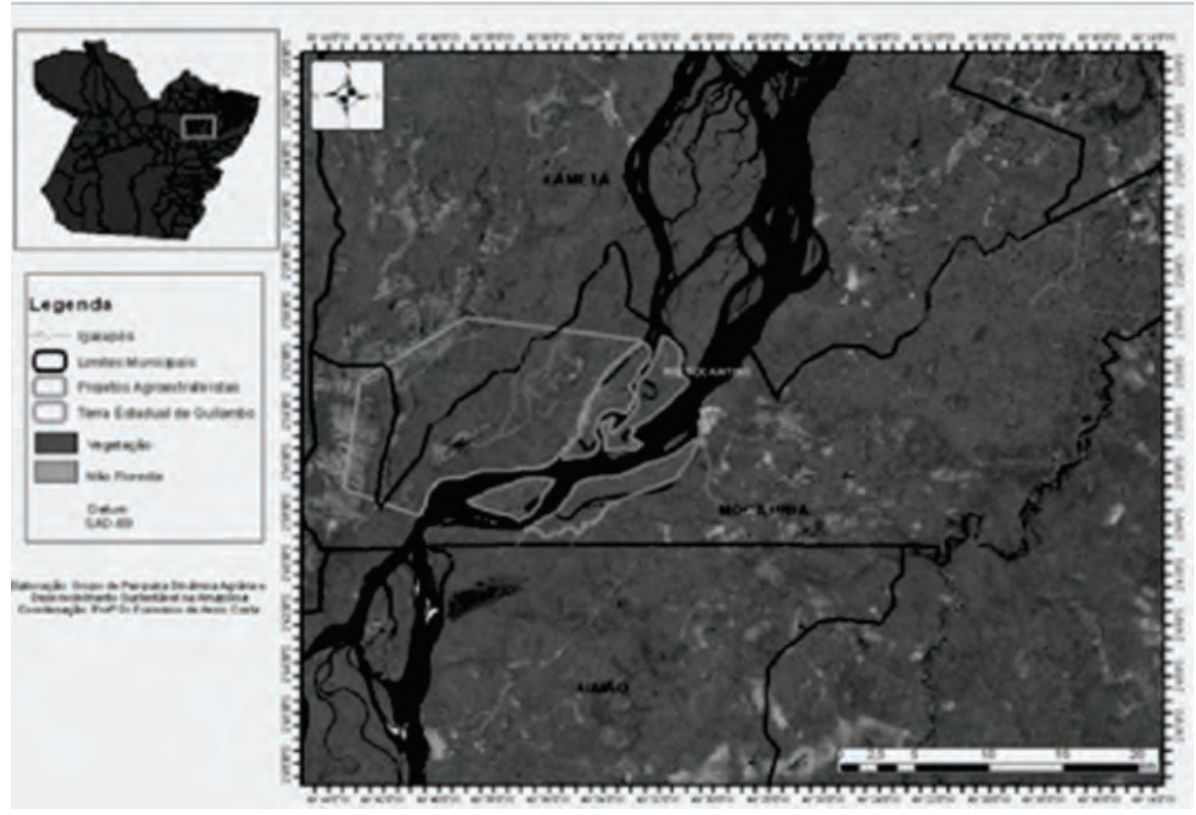

Fonte: GPDADESA/NAEA

A Terra Estadual de Quilombo do 2o Distrito de Porto Grande com 318 famílias (ITERPA, 2009) e os projetos de assentamento agroextrativista - Ilha Grande de Conceição de Mocajuba com 229 famílias; Ilha Grande do Vizeu com 204 famílias; Ilha de Angapijó com 36 e Tauaré com 187 famílias - englobam 17 comunidades legalmente reconhecidas. (Quadro 1). 
Quadro 1 - Comunidades presentes nos projetos de regularização fundiária em Mocajuba

\begin{tabular}{|l|l|}
\hline \multicolumn{1}{|c|}{ Projeto de regularização fundiária } & \multicolumn{1}{c|}{ Comunidades } \\
\hline TEQ- ${ }^{\circ}$ Distrito de Porto Grande & $\begin{array}{l}\text { Porto Grande, Mangabeira, São Benedito } \\
\text { do Vizeu, Santo Antônio do Vizeu, Uxizal, } \\
\text { Vizânia, Itabatinga }\end{array}$ \\
\hline PAE- Ilha Grande de Vizeu & Santo Antônio, Jacarecainha, Vizânia, \\
\hline PAE- Conceição de Mocajuba & Santana, São Joaquim, Costa de Santana \\
\hline PAE- Ilha Tauaré & Tauaré Grande, Tauarezinho \\
\hline PAE- Ilha Angapijó & Tatuoca, Angapijó \\
\hline
\end{tabular}

Fonte: Elaborado com base em informações do ITERPA e INCRA-SR 01 (2011)

As áreas que recentemente tornaram-se "assentamentos" em Mocajuba são dotadas de uma conotação geográfica/territorial, na qual a interação das comunidades com o meio revela uma dinâmica muito particular e reflete segundo Barbosa e Marin (2009) relações identitárias e os arranjos no uso do recurso disponível.

Pelos marcos legais temos uma situação peculiar para a compreensão das formas de uso do território na qual a dinâmica da paisagem revelada pelas análises de sensoriamento remoto apresenta baixa conversão da floresta a despeito da antiguidade dos processos de ocupação e formação histórico-territorial. Estas áreas correspondem a 44,3\% da área do município, e onde predominantemente encontram-se formas camponesas orientadas para o agroextrativismo.

Quadro 2 - Áreas de regularização fundiária em Mocajuba

\begin{tabular}{|l|c|c|c|c|}
\hline \multicolumn{1}{|c|}{ Local } & Área (ha) & Ato de criação & Capacidade & $\begin{array}{c}\text { Famílias } \\
\text { assentadas }\end{array}$ \\
\hline PAE Ilha de Angapijó & 996,451 & $186-15 / 12 / 09$ & 60 & 36 \\
\hline PAE Ilha C. de Mocajuba & $1.635,24$ & $187-15 / 12 / 09$ & 280 & 229 \\
\hline PAE Ilha Grande de Viseu & $1.497,77$ & $188-15 / 12 / 09$ & 260 & 204 \\
\hline PAE Ilha Tauaré & $2.174,87$ & $189-15 / 12 / 09$ & 250 & 187 \\
\hline TEQ - 2o Distrito & 17,220 & - & - & 318 \\
\hline
\end{tabular}

Fonte: Elaborado pelo autor com base em informações do INCRA-SR01 e ITERPA (2011)

Partimos do pressuposto que esse território de pequenos produtores familiares rurais é um território de mudanças, continuamente em movimento a partir dos seus processos de produção (trabalho). Os grupos constroem seus 
espaços de vivência com as técnicas que auxiliam no manejo dos elementos da natureza indispensáveis a sua sobrevivência, com isso organizam a produção e por conseguinte organizam a vida social e o espaço na medida de suas necessidades (SANTOS, 1996).

\section{A PESQUISA EM SEU NÍVEL MACRO: MOCAJUBA, OS CAMPONESES E SUAS TRAJETÓRIAS}

O município de Mocajuba apresenta características ainda mais estritas no que se refere à dominância de trajetórias camponesas: apenas duas delas se apresentam no município, a T1 e a T2. As duas trajetórias dividem bastante equilibradamente a economia rural do município, com predominância, porém da T2: 54\% do número de estabelecimentos, 59\% do emprego e do VBP. No quesito terra, porém, os estabelecimentos da T1 têm quase três vezes mais terra que os da T2: respectivamente, 53.113 e 18.879, 74\% e 26\% do total (ver Tabelas 1 e 2).

Tabela 1 - Setor rural de Mocajuba (MRH Cametá-PA), segundo o Censo de 2006

\begin{tabular}{|c|c|c|c|}
\hline & Camponês T1 & Camponês T2 & Total \\
\hline \multicolumn{4}{|c|}{ Valor da produção } \\
\hline VBP do extrativismo não-madeireiro & 240 & 334 & 574 \\
\hline VBP do extrativismo madeireiro & - & 1 & 1 \\
\hline VBP animal & 100 & 108 & 208 \\
\hline VBP culturas Permanentes & $4.993,00$ & $10.145,00$ & $15.138,00$ \\
\hline VBP culturas temporárias & $1.081,00$ & $3.363,00$ & $4.444,00$ \\
\hline VBP outros & $3.778,00$ & 572 & $4.350,00$ \\
\hline VBP total & $10.192,00$ & $14.523,00$ & $24.715,00$ \\
\hline Participação relativa & $41 \%$ & $59 \%$ & $100 \%$ \\
\hline
\end{tabular}

Uso da área dos estabelecimentos

\begin{tabular}{l|r|r|r}
\hline Área sistemas agroflorestais & 259 & 4.470 & 4.729 \\
\hline Área mata & 13.656 & 1.974 & 15.630 \\
\hline Área floresta plantada & - & - & - \\
\hline Área lavouras permanentes & 17.475 & 8.499 & 25.974 \\
\hline Área lavouras temporárias & 7.123 & 1.694 & 8.817 \\
\hline Áreas degradadas & - & 10 & 10 \\
\hline Outras & 14.600 & 2.232 & 16.832 \\
\hline Área total ha & 53.113 & 18.879 & 71.992 \\
\hline Participação relativa & $74 \%$ & $26 \%$ & $100 \%$ \\
\hline
\end{tabular}




\begin{tabular}{l|r|r|r}
\hline Tamanho médio da propriedade & 97,63 & 29,78 & 61,01 \\
\hline Número de estabelecimentos & 544 & 634 & 1.180 \\
\hline Participação relativa & $46 \%$ & $54 \%$ & $100 \%$ \\
\hline Pessoal ocupado & 1.179 & 1.668 & 2.846 \\
\hline Participação relativa & $41 \%$ & $59 \%$ & $100 \%$ \\
\hline \multicolumn{3}{c}{ Meta-função de produção dHaiamy-Hutan } \\
\hline VBP Total/pessoal ocupado = & $8.644,61$ & $8.706,83$ & $8.684,12$ \\
\hline VBP/Área total x & 191,89 & 769,27 & 343,3 \\
\hline Área/pessoal ocupado & 45 & 11,3 & 25,3 \\
\hline
\end{tabular}

Fonte: IBGE, Censo Agropecuário de (2006).

Os resultados econômicos principais são também equilibrados no que se refere à grandeza fundamental do trabalho aplicado, tal como a economia camponesa se regula (COSTA; CARVALHO, 2012): em valores correntes de 2006, o ano do Censo, a produtividade monetária do trabalho na T1 e na T2 foram, respectivamente, de $\mathrm{R} \$ 8.644,66$ e $\mathrm{R} \$ 8.706,83$.

Tabela 2 - Composição relativa do VBP e do uso da terra em Mocajuba no Censo de 2006

\begin{tabular}{l|r|r|r}
\hline & Camponês T1 & Camponês T2 & \multicolumn{1}{c}{ Total } \\
\hline \multicolumn{3}{|c|}{ Valor da produção } \\
\hline VBP do extrativismo não madeireiro & $2,40 \%$ & $2,30 \%$ & $2,30 \%$ \\
\hline VBP do extrativismo madeireiro & & $0,00 \%$ & $0,00 \%$ \\
\hline VBP animal & $1,00 \%$ & $0,70 \%$ & $0,80 \%$ \\
\hline VBP culturas permanentes & $49,00 \%$ & $69,90 \%$ & $61,30 \%$ \\
\hline VBP culturas temporárias & $10,60 \%$ & $23,20 \%$ & $18,00 \%$ \\
\hline VBP outros & $37,10 \%$ & $3,90 \%$ & $17,60 \%$ \\
\hline VBP total & $100,00 \%$ & $100,00 \%$ & $100,00 \%$ \\
\hline Participação relativa & $41 \%$ & $59 \%$ & $100 \%$ \\
\hline \multicolumn{1}{c|}{ Uso da área dos estabelecimentos } \\
\hline Área sistemas agroflorestais & $0,50 \%$ & $23,70 \%$ & $6,60 \%$ \\
\hline Área mata & $25,70 \%$ & $10,50 \%$ & $21,70 \%$ \\
\hline Área floresta plantada & & & \\
\hline Área lavouras permanentes & $32,90 \%$ & $45,00 \%$ & $36,10 \%$ \\
\hline Área lavouras temporárias & $13,40 \%$ & $9,00 \%$ & $12,20 \%$ \\
\hline Área degradadas & & $0,10 \%$ & $0,00 \%$ \\
\hline Outras & $27,50 \%$ & $11,80 \%$ & $23,40 \%$ \\
\hline
\end{tabular}

Fonte: IBGE, Censo Agropecuário de (2006). 
Esses valores equilibrados, todavia, resultam de fundamentos bastante desbalanceados. Sabemos que a produtividade por trabalhador (VBP/Pessoal ocupado) é igual a produtividade monetária da terra (VBP/Área) e do volume de terra por trabalhador (Área/Pessoal ocupado). A isso os economistas chamam de meta-função de produção de Hayami e Rutan (COSTA; CARVALHO, 2012). Pelos dados do Censo, portanto, as produtividades (monetárias) praticamente iguais da T1 e da T2 em Mocajuba se explicam por razões inversas: a produtividade monetária da terra é, para a primeira, $\mathrm{R} \$ 191,89$ e, para a segunda, $\mathrm{R} \$ 769,27$; a relação terra/trabalhador, por seu turno, na T1 é quatro vezes maior que na T2, respectivamente, 45,0 ha e 11,3 há (ver última parte da Tabela 3).

\section{6 ÁREAS DE TERRA FIRME E REGIÕES DE ILHAS: OS TERRITÓRIOS DA T1 E DA T2}

A pesquisa demonstrou claramente que as famílias camponesas das ilhas de Mocajuba são típicas da Trajetória T2. A Tabela 3 apresenta os resultados do valor da produção para as famílias pesquisadas, os quais não deixam lugar a dúvidas: suas unidades produtivas são baseadas em um perfil da produção completamente compatível com a expectativa em relação a essa trajetória.

A relevância das lavouras permanentes (35,2\% do VBP do conjunto de familias pesquisadas), da pesca (28,8\% do mesmo total) e da extração nãomadeireira (15,2\%), indica se tratar de produção baseada em SAF, típicas da T1 (ver Tabelas 1, 2 e 3). Isto nos permite afirmar ser a região das ilhas de Mocajuba um território da T2. Cabe dizer, em complemento, que, como se pode avaliar no Anexo 1, onde se esclarece o plano amostral da pesquisa, a amostra é suficiente para expressar o universo, considerando os dados do Censo para a trajetória e da base considerada para a população de várzea na amostra; respectivamente, 634 (ver Tabela 3). Não é o caso da amostra relativa às famílias do ambiente de terra firme, insuficiente para garantir inferência estatística, uma vez que se considerou, para o cálculo da amostra, 318 unidades familiares (baseados nas listas de assentamento que se dispunha), quando o universo apresentado no Censo seria de 544 unidades familiares. Não se recorrerá a ela, portanto. Não se precisaria dela, na verdade, para concluir o que importa: se está suficientemente demonstrado que as ilhas de Mocajuba constituem o território da T2, a T1 se assenta, seguramente, nas áreas de terra firme.

Isto posto, vale discernir as consequências do achado, detalhando as características dos dois padrões territoriais indicados e associando-os aos padrões produtivos das duas trajetórias. Nisso, torna-se fundamental trazer para 
a discussão as indicações territoriais resultantes das análises combiná-las com os dados já apresentados da Tabela 3.

Tabela 3 - Valor Bruto da Produção (VBP) das famílias pesquisadas nos ambientes das ilhas e de terra firme em Mocajuba

\begin{tabular}{l|r|r}
\hline \multicolumn{1}{c|}{ Atividades } & \multicolumn{1}{c|}{ VBP } & \multicolumn{1}{c}{$\%$} \\
\hline Alimentação pequenos animais & $1.267,05$ & $2,00 \%$ \\
\hline Artesanato de artefatos & 384,3 & $0,60 \%$ \\
\hline Artesanato de produtos & 264,84 & $0,40 \%$ \\
\hline Caça & 90 & $0,10 \%$ \\
\hline Comercialização & $7.312,19$ & $11,70 \%$ \\
\hline Extração madeireira & 629,9 & $1,00 \%$ \\
\hline Extração não madeireira & $9.499,54$ & $15,20 \%$ \\
\hline Fabrico & 613,9 & $0,10 \%$ \\
\hline Lavoura permanente & $22.033,61$ & $35,30 \%$ \\
\hline Lavoura temporária & 506,19 & $0,80 \%$ \\
\hline Pesca & $17.957,57$ & $28,80 \%$ \\
\hline Trabalho externo & $1.800,00$ & $2,90 \%$ \\
\hline Total & $62.358,47$ & $100,00 \%$ \\
\hline
\end{tabular}

Fonte: Pesquisa de Campo do GPDadesaNAEA.

São os seguintes os pontos importantes:

Na paisagem, a área detectável como ligada à produção rural é, no território da T1, 31\% da área passível de se tornar, por critério privados, em áreas com tal destinação; no território da T2 essa proporção é $1 / 3$ menor - 10,4\%.

A distribuição dos usos na produção rural difere, também: enquanto na T2 praticamente se explica por culturas permanentes e SAF, no território da T1 há presença com algum significado de diferentes formas de pasto, bem como de roça.

Em 2012 não se constatou desmatamento no território da T2 e, não obstante existir, o que se verifica para a T1 se aproxima da irrelevância.

O território da T2 apresenta $67,1 \%$ coberto por vegetação originária (floresta e campinarana), enquanto o da T1 36,4\%;

Se se consideram formas de intermediárias de bosque florestal, isto é, florestas originárias (provavelmente) sobre-exploradas (que o TerraClass classifica como Floresta degradada) e, na direção inversa, áreas antes agricultadas hoje em regeneração avançada (capoeiras), tem-se, nessa condição, 16,5\% no território da T2 e 25,8\% no território da T1. 
Se se compõe os dois itens anteriores, chegando a um agregado de formas florestais e outras vegetações originais não florestais, no território da T2 elas cobrem 89,5\%, enquanto que no da T1 elas chegam a 62,2\%.

Por fim, um resultado importante para este trabalho: o território da T1 teve $92,4 \%$ da área apropriável para a produção rural (a área total do território menos áreas urbanas e mananciais de água) declarada no Censo Agropecuário como propriedade ou domínio de alguém presente no território, uma vez que respondeu à entrevista do IBGE. Isso já era esperado para essa trajetória. Surpreendente é o fato de que a proporção para o território da T2 não é muito diferente: nada menos que $89,1 \%$ da área foi declarada como de domínio privado no Censo.

Os seis primeiros pontos listados apresentam as diferenças objetivas nos padrões territoriais indicados antes - e corroboram com a hipótese de que as trajetórias conformam, sim, às respectivas imagens, de modos bem distintos, seus territórios. O último, a sua vez, contraria nossa expectativa de que as grandes diferenças se explicariam pela presença de "recursos comuns" em territórios dominados pela T2, implicando em soluções de acesso e uso preservadores. Se assim fosse, a eficiência que se verificou na produtividade monetária da terra agregada para a trajetória, como se viu no censo, deveria ser resultado da não consideração (contabilização) das terras onde deveriam se encontrar os "recursos comuns", que nessa condição não encontram abrigo na lógica baseada em estabelecimentos do Censo.

As técnicas utilizadas combinam conhecimento do comportamento da fauna silvestre, do clima regional e técnicas de manejo do solo. As práticas sócio-culturais, bem como a gestão do território pela T2 enquanto, sistemas de manejo local, configuram as técnicas identificadas a partir de trabalho de campo, estas divididas em três grandes conjuntos: a) as agrícolas ligadas ao uso do solo, essencialmente; as técnicas agro-florestais; técnicas de uso de recursos aquáticos e/ou pesqueiros que subdividem-se em técnicas de pesca de camarão e pequenos mariscos; e as técnicas de pesca de peixes e aquicultura;

As técnicas agrícolas usadas na exploração das Florestas Ombrófilas densas de terras baixas para a produção de farinhas e processamento de derivados da mandioca, conhecidos como "roças", são pautados no uso do corte e queima relevam a forma mais expressiva quanto a conversão de áreas de florestas em áreas antropizadas. No entanto, o sistema de pousio, herança indígena, leva a processos de regeneração das florestas originando grandes áreas de florestas primárias.

Juntos os percentuais de Floresta Secundária, Floresta Ombrófila Densa de Terras Baixas, Floresta Ombrófila Densa Aluvial e Floresta Ombrófila Densa Aluvial com Dorsel Emergente somam 44,3\% de áreas ocupadas por cobertura 
vegetal para o município de Mocajuba. Os índices sugerem maior nível de conservação nas áreas de ocupação da T2, se comparados aos 22,9\% de culturas cíclicas e permanentes encontrados na margem direita do rio Tocantins onde se localiza a sede municipal com maior concentração populacional e predominância da trajetória T1

Nas tabelas abaixo têm-se demonstrado os percentuais correspondente aos tipos de uso por área territorial, primeiro para o município e em seguida para áreas com predomínio das trajetórias camponesas T1 e T2, respectivamente.

O mapeamento do projeto Terraclass, reforça mais ainda o nível de preservação natural das áreas de ilhas, onde se concentrou a pesquisa, mostrando que depois da vegetação secundária, considerada um estágio sucessional de desenvolvimento, a classe predominante é de Floresta com aproximadamente 15,67\% de área estimada para o município, seguida de mosaico de ocupações com 19,39\% representados por estes pequenos camponeses que diversificam sua produção e conseguem com métodos específicos de manejo a manutenção de altos níveis florestais, o que nos leva a crer mais condizentes com o ideal de sustentabilidade. Ao analisarmos a territorialidade expressa em trajetórias, temos os seguintes resultados de área $(\mathrm{km})$ encontrados para o território da T1 (Tabela 4):

Tabela 4 - Classes de uso e cobertura da terra na área da T1

\begin{tabular}{l|r|r}
\hline Classes de uso e cobertura da terra & Área $\left(\mathrm{km}^{2}\right)$ & Área $(\%)$ \\
\hline Área não observada & 0,77 & $0 \%$ \\
\hline Área urbana & 5,22 & $1 \%$ \\
\hline Desflorestamento 2012 & 0,23 & $0 \%$ \\
\hline Floresta & 34,30 & $6 \%$ \\
\hline Hidrografia & 2,50 & $0 \%$ \\
\hline Mosaico de ocupações & 87,46 & $17 \%$ \\
\hline Não floresta & 102,10 & $19 \%$ \\
\hline Outros & 2,92 & $1 \%$ \\
\hline Pasto limpo & 19,37 & $4 \%$ \\
\hline Pasto sujo & 4,31 & $1 \%$ \\
\hline Regeneração com pasto & 0,67 & $0 \%$ \\
\hline Vegetação secundária & 269,97 & $51 \%$ \\
\hline Total & 529,04 & $100 \%$ \\
\hline
\end{tabular}

Fonte: Terraclass (2012)

Ao correlacionar a territorialidade da T1 com a área total, temos mosaico de ocupação com 10,05\%, seguido de pasto limpo com 2,22\%, como as mais expressivas formas de uso da terra na porção oeste do município, onde se deu 
grande parte de sua ocupação e se estabeleceu a trajetória que convertia para o plantio de pimenta-do-reino, e atualmente com a introdução de novos vetores produtivos com destaca-se, fortemente, o plantio de dendê (Elaeis guineenses). Para as classes de cobertura vegetal a vegetação secundária corresponde a pouco mais de 31\% do total, enquanto que as áreas de floresta a 3,94\% de área. Já para a trajetória T2 que se concentra espacialmente à margem esquerda do rio Tocantins foram encontrados as seguintes áreas:

Tabela 5 - Classes de uso e cobertura da terra na área da T2

\begin{tabular}{l|r|r}
\hline Classes de uso e cobertura da terra & Área $\left(\mathrm{km}^{2}\right)$ & Área $(\%)$ \\
\hline Área não observada & & $0 \%$ \\
\hline Desflorestamento 2012 & 0,09 & $0 \%$ \\
\hline Floresta & 102,13 & $30 \%$ \\
\hline Hidrografia & 73,50 & $22 \%$ \\
\hline Mosaico de ocupações & 10,75 & $3 \%$ \\
\hline Não floresta & 66,93 & $20 \%$ \\
\hline Outros & 0,07 & $0 \%$ \\
\hline Pasto limpo & 0,17 & $0 \%$ \\
\hline Pasto sujo & & $0 \%$ \\
\hline Regeneração com pasto & & $0 \%$ \\
\hline Vegetação secundária & 86,46 & $25 \%$ \\
\hline Total & 340,09 & $100 \%$ \\
\hline
\end{tabular}

Fonte: Terraclass (2012)

Observa-se com isso que as classes de cobertura vegetal mais expressivas no território da T2 em Mocajuba são Floresta e Vegetação secundária, respectivamente com 11\% e 9\% correspondentes ao percentual total de área, em contrapartida as a única classe de uso da terra que identificada é a classe mosaico de ocupações com 1,23\% de ocupação de área. Ao analisar os proporcionais de área para as duas trajetórias espacializadas, observa-se para o território de T2 usos como regeneração com pasto, pasto sujo e pasto limpo são pouco sem nenhuma expressão, tais formas de manejos do bioma usos atribuídos a áreas que já foram anteriormente desmatadas para alguma finalidade, no caso da T1 o que nos leva a crer, áreas usadas para o plantio de pimenta, e atualmente do dendê, que requer grandes extensões de área para plantio, por outro lado, a forte presença de classe como regeneração com pasto, pasto limpo e pasto sujo no território da T1 responde por quase $25 \mathrm{~km}^{2}$ de área. Enquanto que no território da T2 juntas as áreas de floresta e vegetação secundária, respondem por 188,54 $\mathrm{km}^{2}$ de área. 


\section{CONSIDERAÇÕES FINAIS}

A trajetória T2 configura o território em que atua, com base no processo de trabalho, resultante de formas de operacionalização específicas do bioma amazônico. Orientandos por uma lógica, que tem como fundamento primordial a racionalidade camponesa, baseada na eficiência de seus padrões (re)produtivos, que agregam capacidades de uso sustentável do bioma, o que em última instância revela uma forma de gestão territorial mais correspondente aos pressupostos da sustentabilidade.

Pode-se afirmar ainda que o trabalho é parâmetro fundamental de alocação espacial, por expressar-se em extensão, mobilidade e padrões de alocação, bem como o território, que neste contexto torna-se o atributo essencial de fundamentação do trabalho. O que reforça a ideia de que trabalho e território são categorias analíticas centrais para a economia e que em conjunto, tornam-se chave de interpretação dos processos de socialização dos indivíduos, que dão, em última análise, sob bases espaciais.

\section{REFERÊNCIAS}

ALLIĖS, P. L'invention du territoire. Grenoble: PUG, 1980.

AZAÏS, C. Território e trabalho: uma inscrição em temporalidades diferentes. Novos Cadernos NAEA, Belém, v. 7, n. 1, p. 31-56, jun. 2004.

BELLET, M.; COLLETIS, G.; YUNG, Y. Introduction au numéro spécial Économie de Proximités. RERU, [S.1.], n. 3, 1993.

BERTHELOT, J-M. Sciences sociales, temps et espace. In: OSTROWETSKY, S. (Ed.). Sociologues en ville. Paris: L'Harmattan, 1996. p. 65-70.

COSTA, F. de A. Heterogeneidade estrutural e trajetórias tecnológicas na produção rural da Amazônia: delineamentos para orientar políticas de desenvolvimento. In: BATISTELLA, M.; MORAN, E.; ALVES, D. S. (Org.). Amazônia: natureza e sociedade em transformação. São Paulo: EDUSP, 2008. 304 p.

Desenvolvimento agrário sustentável na Amazônia: trajetórias tecnológicas, estrutura fundiária e institucionalidade. In: BECKER, B.; COSTA, F. A.; COSTA, W. M. Desafios ao Projeto Amazônia. Brasília, DF: CGEE, 2009a. p. 215-363.

Trajetórias tecnológicas como objeto de política de conhecimento para a Amazônia: uma metodologia de delineamento. Revista Brasileira de Inovação, v. 8 , n. 1, p. 35-86, jan./jun. 2009b. 
Dinâmica agrária e balanço de carbono na Amazônia. Economia, v. 10, n. 1, p. 117-151, jan./mar. 2009c.

Mercado e produção de terras na Amazônia: avaliação referida a trajetórias tecnológicas. Boletim do Museu Paraense Emilio Goeldi. Ciências Humanas, Belém, v. 5, p. 25-39, 2010.

COSTA, F. de A; CARVALHO, H. de. Campesinato. In: CALDART, R. S.; PEREIRA, I. B. et al. (Org.). Dicionário de Educação no campo. Rio de Janeiro, São Paulo: Escola Politécnica de Saúde Joaquim Venâncio, Expressão Popular, 2012. p. 45

DOSI, G. Technological paradigms and technological trajectories. Revista Brasileira de Inovação, v. 5, n. 1, p. 17-32, jan./jun. 2006.

HAESBAERT, R. O mito da desterritorialização: do "fim dos territórios" à multiterritorialidade. Rio de Janeiro: Bertrand Brasil, 2004.

HAESBAERT, R.; LIMONAD, E. O território em tempos de globalização. GeoUERJ. Revista do Departamento de Geografia, Rio de Janeiro, UERJ, n. 5, p. 7-19, 1999.

KRUGMAN, P. Space: the final frontier. Journal of Economic Perspectives, [S.1.], v. 12, n. 2, p. 161-174, 1998.

PRÉVÔT SCHAPIRA, M-F. Territoires, pouvoirs et sociétés em Amérique latine. Tours: Université de Tours François Rabelais, UFR de Droit, d'Economie et des Sciences Sociales, 1997. Rapport d'habilitation à diriger des recherches, document ronéo.

RAFFESTIN, C. Por uma geografia do poder. São Paulo: Ática, 1993.

SANTOS, M. A natureza do espaço. Técnica e tempo, razão e emoção. São Paulo: Hucitec, 1996.

O espaço dividido. São Paulo: Francisco Alves, 1979.

SAQUET, M. A. Abordagens e concepções de território. [S.1.]: Expressão Popular, 2007.

O território: diferentes interpretações na literatura italiana. In: RIBAS, A. D.; SPOSITO, E. S.; SAQUET, M. A. Território e desenvolvimento: diferentes abordagens. Francisco Beltrão-PR: Unioeste, 2004, p. 87. 


\section{Estratégias e formas de reprodução social na agricultura familiar da fronteira oeste do Rio Grande do Sul}

\section{Strategies and reproduction of social forms family in fronteira oeste do Rio Grande do Sul}

Alessandra Troian - Doutora em Desenvolvimento Rural, Universidade Federal do Rio Grande do Sul (UFRGS). Professora adjunta na Universidade Federal do Pampa (Unipampa), campus Santana do Livramento. E-mail: alessandratroian@unipampa.edu.br

Raquel Breitenbach - Doutora em Extensão Rural, Universidade Federal de Santa Maria (UFSM). Professora do Instituto Federal de Educação, Ciência e Tecnologia do Rio Grande do Sul (IFRS), campus Sertão. E-mail: raquel.breitenbach@sertao.ifrs.edu.br

\section{Resumo}

O papel e a importância da agricultura familiar ganhou destaque nas duas últimas décadas. A valorização se deu tanto em nível de governo, quanto pela academia, passando a agricultura familiar a fazer parte da agenda política do Brasil como uma estratégia de desenvolvimento rural. Neste sentido, reconhecendo a sua heterogeneidade, o presente estudo objetiva analisar a agricultura familiar da região da Fronteira Oeste do Rio Grande do Sul, destacando o surgimento, as principais características e a dinâmica de reprodução social. Metodologicamente utilizou-se a revisão bibliográfica. Identificou-se que a agricultura familiar, embora sempre se fizesse presente na região, ganha destaque a partir dos 1990, com a implantação dos assentamentos rurais, o reconhecimento acadêmico da categoria e com as políticas públicas. Entre as estratégias de reprodução social da agricultura familiar local destaca-se a diversificação de cultivos, a cooperação e o acesso a políticas públicas, tanto para crédito quanto de comercialização.

\section{Palavras-chave}

Assentamentos Rurais. Heterogeneidade Rural. Políticas Públicas.

\begin{abstract}
The role and importance of family farming gained prominence in the last two decades. The appreciation occurred both at the government level, as the academy, through family farming part of Brazil's political agenda as a rural development strategy. In this sense, recognizing their heterogeneity, this study aims to analyze the family farming of the Fronteira Oeste do Rio Grande do Sul, highlighting the emergence, the main characteristics and the dynamics of social reproduction. Methodologically we used the literature review. It was identified that family farming, though they typically do this in the region, stands out from 1990, with the implementation of rural settlements, the academic recognition of the category and with public policies. Among the strategies of social reproduction of the local family farming highlights the diversification of crops, cooperation and access to public policies for both credit as marketing.
\end{abstract}

\section{Keywords}

Rural Settlements. Rural Heterogeneity. Public Policy. 


\section{INTRODUÇÃO}

A agricultura familiar tem sido reconhecia em maior grau e importância nas duas últimas décadas, especialmente pelos governos e pela academia. Isso tem ocorrido especialmente como reflexo dos esforços no sentido de identificar e quantificar a participação da agricultura em aspectos econômicos e sociais em diferentes países e, inclusive, no Brasil. O último Censo Agropecuário passou a identificar e contabilizar a participação da agricultura familiar para a produção e economia do país e demonstrou em números a importância da mesma. A partir do Censo Agropecuário de 2006, foi identificado que no Brasil a agricultura familiar ocupa 84,4\% dos estabelecimentos agropecuários, 85,75\% no Rio Grande do Sul e na região da Fronteira Oeste do Rio Grande do Sul - foco da presente análise - 58,42\% (SILVA, 2012).

Destaca-se também, que embora os números se refiram à agricultura familiar de forma geral, é importante alertar que dentro desse percentual de agricultores familiares existe a heterogeneidade, o que nos leva a dizer que não exista uma agricultura familiar, mas várias. Ou seja, existem múltiplas realidades quando o assunto é agricultura familiar, seja comparativamente entre países, internamente num país, considerando as especificidades do Brasil e até mesmo num estado, como é o caso do Rio Grande do Sul.

Ao longo de suas contribuições acadêmicas e científicas, Sérgio Schneider (1999; 2001; 2004, entre outros) tem alertado para a heterogeneidade da agricultura familiar, bem como para sua flexibilidade em se adaptar às mudanças de mercado e às diferentes realidades regionais. Essas características têm feito com que esse setor permaneça e se reproduza, o que por consequência, diminui a probabilidade de extinção dos estabelecimentos familiares. Ou seja, embora o nível de inserção e permanência nos mercados agrícolas esteja aumentando ao longo dos anos, a agricultura familiar apresenta-se como persistente e competitiva, impedindo que ocorra seu desaparecimento frente a outras formas de agricultura.

Portanto, a agricultura familiar surgiu como uma nova categoria social e política, a qual passou a congregar o conjunto dos pequenos proprietários rurais, assentados, arrendatários, agricultores integrados, entre outros, dessa forma, esses agricultores passaram a construir uma nova identidade política. Nesse sentido, a agricultura familiar traz a noção de unificadora de interesses dos pequenos proprietários rurais, excluídos politicamente e prejudicados economicamente, principalmente pela abertura comercial, a qual ameaçava setores da agricultura brasileira. O fortalecimento das lutas dos agricultores familiares foi decisivo para 
que o Governo Federal reconhecesse a legitimidade dessa categoria, com exemplo do Programa Nacional de Fortalecimento da Agricultura Familiar (Pronaf), em 1996 (SCHNEIDER, 1999). Outra análise assinalada por Schneider (1999) é o fato de que as unidades familiares não desaparecem frente à integração aos mercados, pois esses agricultores atuam como produtores simples de mercadorias. Dessa forma, a propriedade dos meios de produção continua relacionada às relações de parentesco.

A fim de contribuir com a discussão, destacam-se as observações de Veiga (1991) que apresenta as vantagens da agricultura familiar: trabalho e gestão intimamente relacionados; direção do processo produtivo assegurada diretamente pelos proprietários; ênfase na diversificação; ênfase na durabilidade dos recursos naturais e na qualidade da vida; trabalho assalariado complementar; decisões imediatas, adequadas ao alto grau de imprevisibilidade do processo produtivo; tomada de decisões in loco, condicionada pelas especificidades do processo produtivo; e ênfase no uso de insumos internos.

Já em 1996, Veiga observava a promoção da agricultura familiar na agenda política do Brasil como uma estratégia de desenvolvimento rural. O autor alertou ainda, a importância de se quebrar o mito da superioridade econômica da agricultura patronal (VEIGA, 1991).

Conforme a FAO (2014, p. 2):

A agricultura familiar inclui todas as atividades agrícolas de base familiar e está ligada a diversas áreas do desenvolvimento rural [...] Tanto em países desenvolvidos quanto em países em desenvolvimento, a agricultura familiar é a forma predominante de agricultura no setor de produção de alimentos.

Além disso, salienta-se a diferença entre agricultura familiar e não familiar. Del Grossi e Silva (2006) citam que a agricultura familiar tem na sua composição famílias que trabalham por conta própria ou com até dois assalariados permanentes, agrícolas ou pluriativas, já a não familiar é composta por famílias com três ou mais assalariados permanentes, são agrícolas ou pluriativas. Marafon (2006), por sua vez, destaca que a agricultura patronal tem clara separação entre gestão e trabalho, predomínio de trabalho assalariado, bem como tecnologias para eliminar decisões emergenciais. Já a agricultura familiar tem trabalho e gestão relacionados, adota o trabalho assalariado apenas como complementar e trabalham com decisões imediatas, adequadas ao alto grau de imprevisibilidade do processo (MARAFON, 2006). 
Ainda comparando agricultura familiar e não familiar no Brasil, os dados do Censo Agropecuário de 2006 demonstram que a agricultura familiar representa 84,4\% dos estabelecimentos, enquanto a não familiar 25,6\%. Os produtores familiares representam mais de 50\% dos estabelecimentos, são eles os principais fornecedores de alimentos básicos para a população brasileira, bem como ocupam mais pessoas no campo, sendo 74,4\% (IBGE, 2006).

Nesse contexto, as particularidades da agricultura familiar baseiam-se em mão de obra, terra e renda, já que a família concentra o trabalho e a renda na propriedade. Além disso, os agricultores familiares produzem e vendem o excedente da produção que não é designado para a sua subsistência (TINOCO, 2008). Portanto, a agricultura familiar representa uma forma de produção e trabalho que detém autonomia nas decisões sobre onde alocar os fatores de produção, especialmente se confrontada com o contexto social e econômico em que está inserida (GAZOLLA, 2004).

Porém, embora a existência de discussões amadurecidas e representadas por esses dois autores (Schneider e Veiga), ainda existem, a nível nacional e mundial, discordâncias acerca do real significado da agricultura familiar. Conforme já indicava Schneider (1999), permanecem muitas dúvidas e divergências entre estudiosos na utilização do termo agricultura familiar. Esse debate é relativamente recente no Brasil, mas a agricultura familiar é uma forma social reconhecida e legitimada na maioria dos países desenvolvidos.

Tendo por base essas discussões envolvendo o termo e, especialmente, buscando demonstrar a importância e as características da agricultura familiar em diferentes localidades e países, elaborou-se um projeto de pesquisa intitulado "Agricultura familiar sobre diferentes óticas: características e diferenciações através de imagens". O projeto é uma parceria entre as instituições: Instituto Federal de Educação, Ciência e Tecnologia do Rio Grande do Sul, Universidade Pública de Cabo Verde (Uni-CV), Universidade Federal do Pampa, Universidade Federal de Santa Maria, Ministério da Ciência e Tecnologia de Angola, Cégep do Sherbrooke. O mesmo tem por objetivo, demonstrar e descrever a agricultura familiar em distintas realidades brasileiras e internacionais. O Quadro 1 apresenta as informações referentes às localidades estudadas e parceiros envolvidos na pesquisa. 
Quadro 1 - Locais de realização da pesquisa e parceiros

\begin{tabular}{|l|l|l|}
\hline \multicolumn{1}{|c|}{$\begin{array}{c}\text { Locais de realização da } \\
\text { pesquisa }\end{array}$} & \multicolumn{1}{|c|}{ Instituições parceiras } & \multicolumn{1}{|c|}{$\begin{array}{c}\text { Pesquisadores } \\
\text { colaboradores }\end{array}$} \\
\hline $\begin{array}{l}\text { Fronteira Oeste, Norte e } \\
\text { Noroeste do Rio Grande } \\
\text { do Sul, Brasil }\end{array}$ & $\begin{array}{l}\text { Instituto Federal do Rio } \\
\text { Grande do Sul na área de } \\
\text { Gestão Rural; Universidade } \\
\text { Federal do Pampa. }\end{array}$ & $\begin{array}{l}\text { Dra Raquel Breitenbach e } \\
\text { Dra Alessandra Troian }\end{array}$ \\
\hline Cabo Verde & $\begin{array}{l}\text { Universidade Pública de } \\
\text { Cabo Verde - Uni-CV }\end{array}$ & Dra Maria de Lourdes $^{\text {a }}$ \\
\hline Quebéq no Canadá & Cégep do Sherbrooke & Carl Thibeault \\
\hline $\begin{array}{l}\text { Comunidade Autônoma de } \\
\text { Aragon, Espanha }\end{array}$ & $\begin{array}{l}\text { Universidade Federal de } \\
\text { Santa Maria }\end{array}$ & $\begin{array}{l}\text { M.Sc.Carolina da Silveira } \\
\text { Nicoloso }\end{array}$ \\
\hline $\begin{array}{l}\text { Mayombe - Cabinda, } \\
\text { Angola }\end{array}$ & $\begin{array}{l}\text { Ministério da Ciência e } \\
\text { Tecnologia da República de } \\
\text { Angola }\end{array}$ & Dr. Alfredo Gabriel Buza \\
\hline
\end{tabular}

Fonte: Elaboração própria

Metodologicamente a pesquisa caracteriza-se como qualitativa, a partir da técnica da fotografia como principal meio de coleta de dados. O alicerce baseado no uso de imagens busca por meio de fotografias retratar as distintas realidades da agricultura familiar das regiões em questão. Além da fotografia, faz parte da pesquisa, também como método de coleta de dados, o relato detalhado acerta das imagens captadas. Como resultado, espera-se ampliar o conhecimento acerca das diferentes agriculturas familiares no mundo.

Neste sentido, o presente estudo objetiva apresentar o projeto de pesquisa com foco, nessa ocasião, para análise na Fronteira Oeste do Rio Grande do Sul. A análise da agricultura familiar da referida região teve como destaque o seu surgimento, suas principais características e a dinâmica e reprodução social da mesma. Para tanto, utilizou-se de revisão bibliográfica. Salienta-se que neste estudo não se incluiu as imagens e sua análise, já que o mesmo se deteve na parte histórica de formação e caracterização da agricultura local, mediante a análise de dados secundários.

\section{A FRONTEIRA OESTE DO RIO GRANDE DO SUL: DELIMITAÇÃO E CARACTERIZAÇÃO}

A região Oeste do Estado do Rio Grande do Sul localiza-se no bioma Pampa, em uma parte da América do Sul caracterizada por clima subtropical, vastas planícies suavemente onduladas, cobertas por vegetação de campos e 
pradarias. Caracteriza-se pela presença marcante do pampa gaúcho, bioma de vegetação rasteira. O relevo da região caracteriza-se por ser plano, condições estas que beneficiam a consolidação de atividades agrícolas, sobretudo da pecuária extensiva.

Os municípios que abrangem a Fronteira Oeste são: Itacurubi, Alegrete, Barra do Quaraí, Itaqui, Maçambará, Manoel Viana, Quaraí, São Borja, Uruguaiana, Rosário do Sul, Santa Margarida do Sul, Santana do Livramento e São Gabriel. Dos municípios que compõem a região cabe lembrar que sete deles fazem divisa com outros países. Sendo que Itaqui, São Borja, Uruguaiana, Quaraí e Barra do Quaraí fazem divisa com a Argentina e Quaraí, Barra do Quaraí, Uruguaiana e Santana do Livramento com o Uruguai. A localização da Fronteira Oeste pode ser visualizada na Figura 1.

Figura 1 - Localização da Fronteira Oeste do Rio Grande do Sul

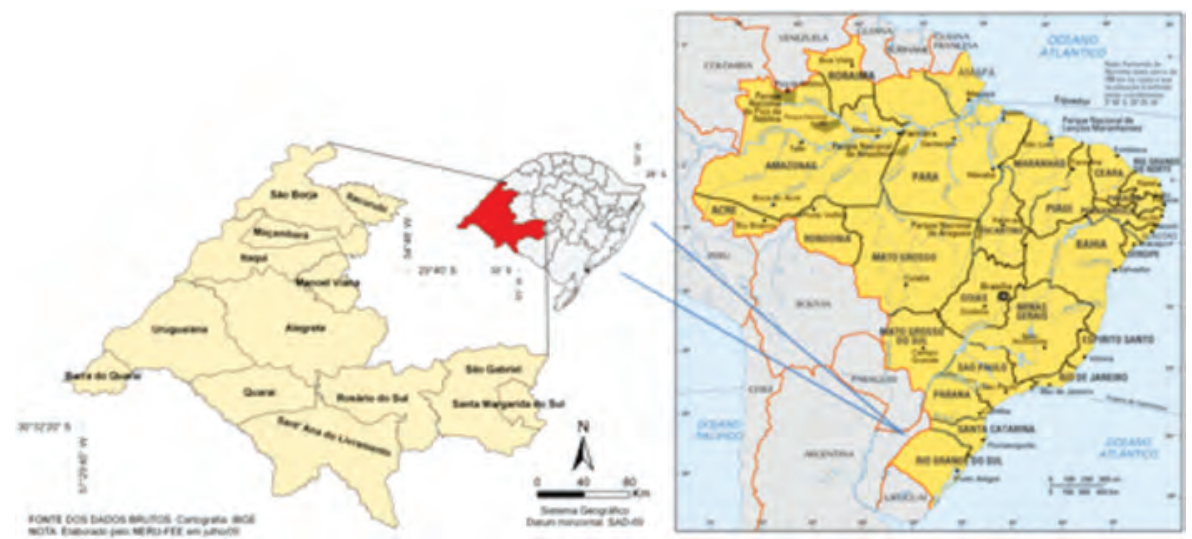

Segundo a Fundação de Economia e Estatística (FEE, 2012), a região compreendida por treze municípios abrigava em 2012 cerca de 5\% da população gaúcha, aproximadamente 530.000 habitantes caracterizando a mais baixa densidade populacional do Estado. Em 2009, o Produto Interno Bruto (PIB) da região foi de R $\$ 8,2$ bilhões, de 3,8\% do PIB do Rio Grande do Sul, e um PIB per capita de $\mathrm{R} \$ 15.439,00$ abaixo da média estadual de $\mathrm{R} \$ 1$ 19.778,00. Segundo Barcelos (1997), a metade sul do Rio Grande do Sul caracteriza-se pela estrutura fundiária marcada pelas grandes propriedades, concentração de renda, predomínio da produção agropecuária, assim como pela baixa densidade populacional.

A região caracteriza-se ainda pelo cultivo de arroz, cucurbitáceas e hortaliças, pela produção de sementes e de animais como ovinos e criação de gado para leite e corte. Segundo Pereira (2014), na região existem pequenos, 
médios e grandes estabelecimentos rurais. Ou seja, no meio rural local é possível perceber a existência de grandes propriedades, assim como a agricultura familiar. É possível observar desde a miséria, até estabelecimentos produtivos eficientes econômica e tecnicamente (SOUZA, 2000).

Boa parte da metade sul está composta por grandes propriedades rurais com pecuária extensiva, monocultura de arroz e áreas de florestamento de eucalipto ocasionado vazios demográficos e concentração de terra e renda (ALVEZ; SILVEIRA; FERREIRA, 2007). Conforme Souza (2000), a região da Fronteira Oeste abriga 4,34\% dos estabelecimentos dos agricultores familiares do estado do Rio Grande do Sul, num total de 16.426 estabelecimentos. No entanto, como a região é conhecida pelas grandes extensões de terras e pela pecuária extensiva, a agricultura familiar passa despercebida pelos órgãos de investigação e, principalmente, pelas políticas públicas.

Para Alende (2006), a presença da agricultura familiar no espaço agrário da Fronteira Oeste era até pouco tempo ignorada e, de maneira geral, continua sem muita importância para os programas de desenvolvimento da região. Segundo Alvez, Silveira e Ferreira (2007), a economia da região está relacionada ao comércio e agricultura, com destaque para a produção de arroz, soja e a pecuária de bovinos e ovinos. Na agricultura, a partir da década de 1970, ganha evidência a fruticultura, produção de peras, pêssegos, ameixa, morango, melancia, mas principalmente a vitivinicultura. $\mathrm{Na}$ economia da região também aparece uma bacia leiteira ainda insipiente, mas em expansão (CUPSINSKI, 2015).

\section{A ORIGEM DOS AGRICULTORES FAMILIARES NA FRONTEIRA OESTE DO ESTADO GAÚCHO}

O estado do Rio Grande do Sul, quando comparado com o restante do país, teve diferente colonização, o que caracteriza as distintas formas de organização social e produtiva. Os europeus estavam interessados em se localizar e estabelecer de forma que permitisse o fácil acesso ao Atlântico e, assim, escoar os produtos explorados no continente. Já os índios habitavam uma vasta área da campanha, entre o que temos hoje parte do território uruguaio e rio-grandense (FURTADO, 2007).

Durante mais de três séculos de presença humana com atividades econômicas complexas na Fronteira Oeste do Rio Grande do Sul, a posse das terras foi concentrada nas mãos de um grupo limitado de pessoas, geralmente herdeiros dos antigos detentores das sesmarias concedidas pelo governo entre os séculos XVII e XVIII (CUNHA, 2012). 
Visando a proteção e a manutenção das áreas de terras portuguesas, a campanha gaúcha foi ocupada por elites indicadas pela coroa portuguesa, em vistas de grandes extensões territoriais, nas quais se desenvolveu a pecuária de corte e exploração do couro.

Podemos verificar o duplo caráter da ocupação do Rio Grande do Sul: de um lado, os estancieiros que possuíam um poder que advinha de seus títulos e de seu dinheiro e que, originalmente, não se deslocaram para assentar família, mas para combater por seu rei e, assim, receber as Sesmarias como recompensa; de outro lado, os antigos caboclos e imigrantes que disputavam as menores e piores terras, onde buscavam, respectivamente, manter e assentar suas famílias (RAMOS, 2012, p.. 53).

A divisão de terras por heranças e as terras cuidadas por agregados das grandes estâncias originaram parte das pequenas propriedades encontradas na Campanha Gaúcha. Neste sentido, Farinatti (2010), identificou três grupos de trabalhadores, a saber:

[...] os filhos de lavradores de roça, que complementavam a renda familiar com trabalho assalariado, os migrantes recém-chegados à região, e velhos ex-cativos, em geral africanos. [...] tratava-se de uma forma de sobreviver e construir laços que permitiriam a inserção social, a formação de famílias e o futuro estabelecimentos como produtores independentes. [...] Essa situação somente existia em virtude da possibilidade de acesso ao uso de uma porção de terras, ainda que não à sua propriedade, e do estabelecimento de uma organização familiar que fornecia o capital social básico para a instalação como produtores autônomos no mundo rural (FARINATTI, 2010, p. 418).

Os agregados eram "acolhidos" pelos estancieiros que lhes permitiam viver ali, mas: "ao mesmo tempo em que criavam seus próprios animais, ajudavam o estancieiro no cuidado com os rebanhos, mantendo seu domínio territorial legitimado pela lei de terras. A nosso ver, aí residem as origens sociais do campesinato tradicional gaúcho" (CHELOTTI, 2009, p. 87-88). Além disso, os agregados produziam gêneros alimentícios para o abastecimento da estância, tornando-a um sistema de produção autossustentável no que diz respeito à autonomia alimentar.

Durante o "anos dourados" (1880-1929) a produção nas estâncias da região Fronteira Oeste do Rio Grande Sul era o centro do dinamismo econômico no estado. Porém, a situação começa a mudar entre os anos de 1950/70, quando as commodities, principalmente a carne e o arroz, perdem abruptamente seu valor de mercado. Tais condições, de acordo com Scherer e Moraes (2000), fazem o sistema de produção agrária entrar em crise. Com o fechamento dos frigoríficos 
e o maciço desenvolvimento que a região norte e nordeste do Rio Grande do Sul sofreu nesse período, pois haviam diversificado tanto a suas atividades econômicas como sua matriz agrícola, a região sul começou a enfrentar um prolongado período de retração econômica e decadência social. Como consequência, as ricas cidades que se encontravam entre as estâncias como Santana do Livramento, Bagé e Alegrete declinaram rapidamente para centros urbanos atrasados (SCHERER; MORAES, 2000).

A força exercida pela grande propriedade rural por meio de seus donatários, vigorou de forma imperativa sobre os acontecimentos políticoeconômicos desta região do Rio Grande do Sul. Porém, com a decadência do modelo agroexportador de commodities a partir da segunda metade do século XX, a elite agrária começa a observar o arrefecimento de seus poder econômico e consequentemente de sua influência política (CUNHA, 2012).

Com o fim do período ditatorial experimentado pelo Brasil entre 1964 e 1985, um novo período começa a vigorar sobre a realidade social brasileira. A constituinte realizada na década de 1980 e promulgada em 1988 trouxe novidades importantes na Carta Magna. Dentre o conjunto de novos textos jurídicos estava a citação de que "A propriedade atenderá a sua função social" tal frase permitiria a realização de uma reforma agrária no país (JANILEK, 2006).

Em 1988, o Congresso Nacional passava por intensas reformas, a ditadura militar havia acabado e em seu lugar emergia um novo sistema político, democrático. O marco deste sistema foi à constituição de 88 , e entre os direitos sociais que a Carta Magna trouxe para a população brasileira estava à reforma agrária, que permitia a desapropriação de terras improdutivas para a consolidação de assentamentos (ARAÚJO, 2001). No artigo 5 da Constituição inciso XXIII está escrito: "a propriedade atenderá à sua função social”. Assim, havia, além de mecanismos legais, oportunidades sociais para realizar a tentativa de se consolidar a agricultura familiar na Fronteira Oeste do Rio Grande do Sul (JELINEK, 2006).

A introdução dos assentamentos na região tem seu início na década de 1990, com a chegada das primeiras famílias, o inicio das atividades teve como marca a ausência do Estado na gestão e nas instalações de atividades para que os assentados pudessem começar a produzir. A ausência do Estado levou a formação de grupos de colonos para que em conjunto proviessem as condições necessárias para a sua consolidação (FERNANDES, 2008).

A falta de assistência estatal no princípio, inicialmente suprida pela formação de grupos entre as famílias assentadas, deixou em longo prazo os agricultores sem assistência e sem condições de consolidarem estratégias de produção mais sofisticadas. Assim, toda a produção se deu através dos cultivos 
que os assentados possuíam alguma familiaridade, neste estágio os núcleos que haviam sido criados para a consolidação dos assentamentos no início do processo foram desfeitos pelas diferenças existentes entre os cultivos familiares (FERNANDES, 2008; SPAROVEK, 2003).

Também cabe salientar que o fim do regime militar e o término do crédito farto para a agricultura, iniciado em 1965, via Sistema Nacional de Crédito Rural (SNCR), associado com a crise das commodities e a pressão dos movimentos sociais, sobretudo pelo Movimento dos Trabalhadores Rurais (MST), fez com que medidas governamentais em prol de colonização se concretizassem. Os assentamentos modificaram a base produtiva e deu nova dinâmica a estrutura agrária da região. A organização da estrutura sociocultural da metade sul é marcada pela figura do grande fazendeiro pecuarista, o qual tem peões que trabalham na propriedade. A agricultura familiar diversificada é praticamente ausente nessa estrutura socioeconômica, quadro que começou a mudar a partir da década de 1980, com a implementação de assentamentos rurais nessa região (ALVEZ; SILVEIRA; FERREIRA, 2007).

Com o estabelecimento de núcleos de produção de origem familiar na região, o modelo de produção baseado na concentração de terras e atividades econômicas acentua seu declínio, embora mantenha sua soberania sobre as demais produções. No momento em que são estabelecidos estes novos modelos de produção, têm-se inicio na região a diversidade produtiva agrícola (SPAROVEK, 2003).

O cultivo fracionado em várias atividades teve característica dual sobre o sistema produtivo da região. Se por de um lado dificultou a formação de estratégias coesas de produção, por outro trouxe a diversidade produtiva, ainda que em pequena escala (CUNHA, 2012). Atualmente, a Campanha Gaúcha é composta por um número maior de pequenas e médias propriedades, entretanto, a extensão territorial ainda é dominada pelos latifúndios. A respeito da estrutura fundiária da campanha rio-grandense, Chelotti (2009), afirma:

Ao contrário do que pensa o senso comum, a maioria, ou seja, mais de $60 \%$ das propriedades rurais da região são constituídas por pequenas unidades de produção, mas territorialmente ocupando menos de $15 \%$ de toda sua superfície. Esse desconhecimento, em parte é explicado pela hegemonia que o espaço latifundiário regional exerceu historicamente sobre a pequena propriedade camponesa (CHELOTTI 2009, p. 85).

Apesar da presença da agricultura familiar na Fronteira Oeste do Rio Grande do Sul, cabe registrar a escassez de estudos acadêmicos sobre a temática. Assim, busca-se, com a limitação mencionada, apresentar a dinâmica dos agricultores 
familiares na região. Em Manoel Viana, para Cunha (2012), a agricultura familiar representa as famílias vindas da região metropolitana do estado para desenvolver a pecuária. Estes foram os ocupantes das áreas de terra e em função das partilhas por herança, a grande estância se desintegrou, foi fragmentada e hoje se apresenta divida em diversas propriedades.

\begin{abstract}
No que tange às estâncias, algumas foram divididas com o passar do tempo em função da herança, ou tornaram-se ainda maiores. No entanto, outras foram adquiridas pelos agricultores (gringos) que, a partir da década de 1960, migraram para a região em busca de terras para o cultivo do arroz irrigado, verificando-se a aquisição de "antigas" estâncias principalmente daqueles em que o preço do arroz esteve elevado. Assim, passaram das mãos de seus tradicionais proprietários (luso-brasileiros) para as mãos dos agricultores (de origem teuto-italiana). A partir dessa mudança, algumas estâncias passaram a adotar nova racionalidade produtiva, consorciando lavoura-pecuária (CHELOT'TI, 2009, p. 93).
\end{abstract}

Ainda de acordo com Cunha (2012), em estudo realizado na campanha, especificamente em Moisés Viana, os agricultores familiares, na sua maioria nasceram e se criaram na região, sendo assim, homens que lidaram com a terra por toda vida, herdaram suas propriedades de seus avós e pais. Nesse processo, as antigas estâncias foram sendo divididas entre os herdeiros e, ainda, vendidas em parcelas, tornando-as progressivamente menores e, dessa forma, colocando seus proprietários na posição de pequenos produtores. As unidades familiares de Moises Viana têm em média de 30 a 50 hectares. Já em Santana do Livramento, a agricultura familiar ganhou destaque e representatividade a partir da década de 1990 com a criação dos assentamentos rurais (ALVEZ; SILVEIRA; FERREIRA, 2007).

Dessa forma, pode-se dizer que a agricultura familiar na região é fruto do processo de colonização do Rio Grande do Sul, da partilha de terra entre os herdeiros, bem como do processo de distribuição de terra - lotes dos programas governamentais - formação de assentamentos rurais, que ocorreu na década de 1990. Os assentamentos, pelo número de famílias assentadas, muitas delas oriundas de diversas e distintas regiões do estado, juntamente com o reconhecimento e as políticas públicas para a agricultura familiar dão uma nova cara e dinâmica para a região.

\title{
2.1 ESTRATÉGIAS DE REPRODUÇÃO DA AGRICULTURA FAMILIAR NA FRONTEIRA OESTE DO RIO GRANDE DO SUL
}

Os agricultores familiares da região possuem um diferencial nos seus sistemas de produção, tendo na pequena exploração da pecuária de corte, 
ovinocultura e pequenas plantações como o arroz, a sua principal fonte de subsistência e de renda. Alguns complementam sua renda agrícola com fontes externas, como a aposentadoria rural e/ou venda de mão-de-obra (ALVEZ; SILVEIRA; FERREIRA, 2007).

Segundo Alvez, Silveira e Ferreira (2007), a economia da região está relacionada ao comércio, à agricultura, com destaque para a produção de arroz, soja, e à pecuária de bovinos e ovinos. A partir da década de 1970, ganha evidência a fruticultura, produção de peras, pêssegos, ameixa, morango, melancia, mas principalmente a vitivinicultura. $\mathrm{Na}$ economia da região, também aparece uma bacia leiteira ainda insipiente, mas em expansão (CUPSINSKI, 2015).

Entre lavouras de soja e florestas de eucaliptos, a pecuária familiar é frequente nessa localidade. Pode-se observar o gado bovino em diversas áreas de pastagens, mas também é possível encontrar ovelhas, cultivo de batata, mandioca, milho e o gado leiteiro para autoconsumo (CUNHA, 2012).

No município de Manoel Viana, segundo Cunha (2012), os sistemas de produção são mistos nos quais diversas culturas são encontradas, além da criação animal extensiva. A produção é voltada tanto para o mercado, quanto para o autoconsumo. O excedente é comercializado no comércio local e regional. Entre a produção encontra-se milho, feijão, mandioca, galinha (carne e ovos), ovelha (carne e pelego), gado de corte, gado leiteiro, porco, batata, verduras, tomate, melancia, laranja, uva, pêssego, entre outros. Recentemente, a produção de mel também foi introduzida nas propriedades de alguns agricultores familiares. A maioria das famílias produzem também derivados da produção como queijos, doces, conservas, conseguindo agregar valor nesses produtos, diversificando ainda mais sua produção e alimentação (CUNHA, 2012).

Segundo Gazola e Schneider (2007) é por meio da produção para autoconsumo que o agricultor familiar não depende, totalmente, do ambiente social e econômico em que está inserido e, principalmente, não depende das constantes flutuações das condições de troca no mercado. Constituindo, dessa forma, a produção para o autoconsumo como uma estratégia de reprodução social.

Já no município de Alegrete os estabelecimentos familiares, com propriedades entre 20 e 40 hectares, desenvolvem o cultivo de milho, pastagens, mandioca, hortaliças, feijão, batata doce, árvores frutíferas, melancia, arroz, batata inglesa, abóbora, amendoim, pipoca e cana-de-açúcar, evidenciando, assim a diversificação como estratégia de reprodução social. Salienta-se ainda que nas propriedades também se criam animais, como: bovinos, ovinos e galináceos (SILVA, 2012). 
Para Ploeg (2008), a diversificação produtiva é vista como forma de reduzir a dependência a um único mercado e fonte de renda, elevando assim a autonomia dos agricultores. Estudos têm evidenciado que, quando os agricultores diversificam suas atividades, eles reduzem os riscos de perdas. $\mathrm{Na}$ agricultura familiar, a diversificação torna-se uma alternativa consistente para garantir maior autonomia e espaço de agenciar frente às contingências de contextos socioeconômicos adversos. Ou seja, a diversificação vai contra a centralidade da especialização tanto nos roteiros empresariais como nas teorias de modernização (PLOEG, 2008).

A diversificação agrícola tem sido considerada uma estratégia a fim de garantir renda para a reprodução social da agricultura familiar. Embora atualmente, frente à dificuldade em se manter no campo, a silvicultura, monocultivo de árvores exóticas como Pinnus e de Eucalyptos, e a soja também tem sido estratégias econômicas dos agricultores familiares (PEREIRA, 2014).

A economia de Rosário do Sul, por exemplo, sempre esteve ligada a exploração agropecuária, inicialmente com as charqueadas, a produção de bovinos para abastecer o frigorífico Swift ${ }^{1}$ e atualmente a pecuária, a soja e o arroz. Embora se mantenha a estrutura fundiária, alguns elementos têm se modificado, como a introdução dos grãos e a fruticultura. A presença do pecuarista familiar é intensa, criando bovinos, sobretudo a ovinocultura (lã, pelego e carne) e alguns gêneros alimentícios para o autoconsumo (ROZALINO et al., 2008).

De acordo com o Decreto $n^{\circ} 48.316$ do Executivo Estadual, são considerados pecuaristas familiares os produtores que atendam simultaneamente às seguintes condições: $\mathrm{i}$ - tenham como atividade predominante a cria ou a recria de bovinos e/ou caprinos e/ou bubalinos e/ou ovinos com a finalidade de corte; ii - utilizem na produção trabalho predominantemente familiar, podendo utilizar mão de obra contratada em até cento e vinte dias ao ano; iii - detenham a posse, a qualquer título, de estabelecimento rural com área total, contínua ou não, inferior a trezentos hectares; iv - tenham residência no próprio estabelecimento ou em local próximo a ele; e v - obtenham no mínimo setenta por cento da sua

O frigorífico se destinava ao abate de gado e produção de charque. Posteriormente iniciou-se a industrialização da carne, principalmente a carne enlatada, que passa a atender a demanda em decorrência da crise da I Guerra e Pós I Guerra Mundial que assolou os países da Europa e dos Estados Unidos. Em 1943 o frigorífico inicia também a industrialização de frutas e legumes enlatados, também destinados ao mercado internacional. Em decorrência deste processo, Rosário do Sul passa a ser conhecida como a capital nacional da ervilha. Em 1962 o frigorífico inicia mais uma nova atividade: a produção de carne cozida congelada. Em meados da década de 1970 começa a ocorrer à crise nos frigoríficos brasileiros, agravada posteriormente pela abertura dos mercados para a carne Argentina e Uruguaia (de maior qualidade e menor preço). $\mathrm{Na}$ década de 1980 o frigorífico Swift Amour S/A encerra suas atividades no município de Rosário do Sul. 
renda provinda da atividade pecuária e não agropecuária do estabelecimento, excluídos os benefícios sociais e os proventos previdenciários decorrentes de atividades rurais (RIO GRANDE DO SUL, 2011).

Percebe-se que a agricultura familiar da região tem como principal característica a diversificação de cultivos e criações, sejam eles para consumo ou para a venda. A produção de alimentos diversos é uma premissa básica para uma estratégia de manutenção e reprodução social da agricultura familiar (ALENDE, 2006). Este fator a diferencia da agricultura patronal, pois a mesma se caracteriza, na região, pelos monocultivos e/ou então pela criação extensiva de animais e grãos. Além disso, a estratégia de combinar conciliar a produção agrícola coma criação de animais, bovinos e ovinos, tem sido adotada como forma de reprodução social da agricultura familiar da Fronteira Oeste do estado. Também merece ser destacado o fato de na região em estudo estar presente a categoria pecuarista familiar, em que neste estudo é entendido como agricultor familiar.

Os agricultores familiares têm buscado mercados paralelos, às vezes alternativos, para escoar a produção e, dessa forma, agregar valor aos produtos e garantir a comercialização. Como forma de reprodução percebe-se a venda de produtos, sobretudo leite e frutas, via cooperativas e o acesso aos programas de compras institucionais do governo federal, como o Programa de Aquisição de Alimentos (PAA) 2 e o Programa Nacional de Alimentação Escolar (PNAE) ${ }^{3}$. Além da comercialização em cadeias curtas, como nas feiras no perímetro urbano dos municípios. Cabe salientar as dificuldades enfrentadas pelos agricultores na venda em feiras e comércio local, em função, muitas vezes da distância e das péssimas condições de trafegabilidade das estradas.

As distintas formas de cooperação, como formação de associações e cooperativas, também têm sido utilizadas como estratégia de reprodução social da agricultura familiar na Fronteira Oeste, a exemplo da cooperativa de leite COPERFORTE $^{4}$ de Santana do Livramento. Embora se perceba a ausência, ou o pequeno número de cooperativas e associações rurais, acredita-se que as

2 Criado em 2003 é uma das ações do programa Fome Zero. Compreende as compras governamentais de gêneros alimentícios para diversos fins e permite os agricultores familiares acessarem o mercado. O programa promove o acesso a alimentos às populações em situação de insegurança alimentar e a inclusão social e econômica no campo por meio do fortalecimento da agricultura familiar. O PAA contribui ainda para a formação de estoques estratégicos e para o abastecimento de mercado institucional de alimentos.

3 Criado em 2009, a partir das experiências positivas do PAA, também faz parte do programa Fome Zero. O programa estabelece que, no mínimo 30\% dos alimentos escolares, deverá ser utilizado na aquisição de gêneros alimentícios diretamente da agricultura familiar e do empreendedor familiar rural ou suas organizações, priorizando os assentamentos da reforma agrária, as comunidades tradicionais indígenas e comunidades quilombolas.

4 Cooperativa Regional dos Assentados da Fronteira Oeste Ltda, possui sua sede no município de Santana do Livramento. 
diferentes formas de cooperação, sejam através da formação de associações e ou cooperativas, por meio da participação e da cooperação dos agricultores, seja uma estratégia de reprodução e manutenção da agricultura familiar em meio ao cenário do latifúndio.

Ainda entre as estratégias de reprodução social utilizadas pelos agricultores familiares da Fronteira Oeste, pode-se citar o acesso às políticas públicas. Entre as políticas acessadas destacam-se o Programa Nacional de Fortalecimento da Agricultura Familiar (Pronaf), sobretudo nas modalidades crédito, custeio e investimento; o Programa Nacional de Habitação Rural; o Programa "Minha Casa, Minha vida", além de políticas municipais como a de perfuração de poços artesianos, de limpeza de açudes, tratores para serviços em geral, entre outras (CUPSINSKI, 2015).

O pecuarista familiar, por pertencer a grupos sociais marginalizados no processo da modernização e padronização técnica da agricultura, é visualizado como um grupo potencial no uso sustentável e conservação dos campos sulinos que estão ambientalmente ameaçados (NICOLA; MARQUES, 2016). Nicola e Marques (2016) destacam que as características da pecuária familiar da Fronteira Oeste do RS possuem singularidades culturais, cognitivas e técnicas que podem representar o diferencial para a emergência de inovações contextualizadas localmente e para processos endógenos de desenvolvimento. Essa afirmação se baseia no fato desses atores estarem envolvidos com a coprodução de ovinos, bovinos e derivados, em sistemas de criação adaptados aos contextos locais, em seus aspectos históricos, sociais, técnicos e ambientais, ou seja, processos diferenciados e originais de desenvolvimento rural que vem emergindo no estado.

Entre as barreiras encontradas para o desenvolvimento da agricultura familiar na região pode-se elencar a falta de liderança e ausência do cooperativismo, bem como certo abandono do poder público. Estes fatores podem estar associados às características locais, como a distância entre as unidades produtivas e a distância destas dos órgãos tomadores de decisões. Cabe salientar que esta distância muitas vezes não se limita apenas à distância geográfica. Também pode estar associada à cultura local das grandes propriedades e esta se sobrepor, sombrear a agricultura familiar. Com relação à influência da cultura local na falta de reconhecimento e investimentos na agricultura familiar, Fonseca (1994) destaca:

[...] as dificuldades para o desenvolvimento da pequena propriedade da Fronteira Oeste do Rio Grande do Sul devem-se, fundamentalmente, embora não só, à cultura do latifúndio arraigada na sociedade e transmitida de geração em geração pelo exercício da hegemonia da classe estancieira, ou latifundiária (FONSECA, 1994, p. 8). 
No entanto, para Silva Neto (1994) a agricultura familiar na região mostrou possibilidades de promover sistemas de produção eficientes que assegurariam, através da reforma agrária, a viabilidade da agricultura familiar.

\section{CONSIDERAÇÕES FINAIS}

No Brasil o descaso histórico com a agricultura familiar, fomentado pela modernização conservadora da agricultura, privilegiou as grandes propriedades e os grandes produtores, desde as políticas de acesso ao crédito até as de assistência técnica (ALENDE, 2006). O relativo recente reconhecimento da agricultura familiar no Brasil como categoria social, pela academia e por meio das políticas públicas, como o Programa Nacional de Fortalecimento da Agricultura Familiar, vêm modificando as características e os privilégios que antes eram dos médios e grandes produtores. Privilégios estes que escondiam, mascaravam a existência da agricultura familiar, principalmente na região de campanha, como na Fronteira Oeste do estado gaúcho.

$\mathrm{Na}$ metade sul do Rio Grande do Sul criou-se e perpetua a ideia de que não há pequenos produtores na região, muito menos agricultura familiar. A invisibilidade da agricultura e da pecuária familiar relaciona-se à dominância ideológica da cultura dos latifúndios (RIBEIRO, 2003; ROZALINO et al., 2008). A agricultura familiar, embora sempre estivesse presente na região, passou a ter destaque a partir dos anos 1990 com a criação de políticas públicas, como a de redistribuição de terra, através dos assentamentos rurais, de crédito, como o Pronaf, dando condições para que os agricultores familiares fossem competitivos, assim como as políticas de comercialização, como as compras institucionais. Antes disso, ela se reproduzia nas margens das estâncias, da agricultura patronal produtora de commodities.

No entanto, cabe destacar que, apesar do considerável número e do maior reconhecimento da agricultura familiar, os latifúndios continuam em evidência e pressionando, ocupando a maior (e as melhores) área de terra e acessando mais crédito (PEREIRA, 2014). Enquanto isso, a agricultura familiar local utiliza-se de artifícios para se reproduzir e ganhar competitividade, a exemplo da diversidade de cultivos e criações desenvolvidos, sejam eles para consumo ou para a venda e da busca pela autonomia, através da produção de um leque variado de alimentos para a subsistência. Também, embora em menor proporção, vem buscando formas cooperativas de produzir e comercializar seus produtos. 
Porém, alguns são os entraves para o desenvolvimento da agricultura familiar. Entre eles destaca-se o fato da baixa diversidade produtiva, a reduzida interação social e convívio em comunidades em função da distribuição espacial e também da localização em assentamentos rurais, na maioria das vezes distantes uns dos outros e distantes do perímetro urbano, dificultando a interação, o acesso a saúde, educação, lazer e a comercialização dos produtos. Além disso, o investimento nos monocultivos, como de eucaliptos, pínus, soja, arroz e carne, têm ameaçado a biodiversidade do Bioma Pampa.

Por fim, cabe mencionar a carência de estudos acerca da temática da agricultura familiar especificamente na região Fronteira Oeste do RS e fazer menção ao projeto "Agricultura familiar sobre diferentes óticas: características e diferenciações através de imagens", ao qual este estudo é fruto. Salienta-se que o projeto encontra-se em distintas fases, considerando as diversas localidades pesquisadas. Na região da Fronteira Oeste do Rio Grande do Sul o projeto encontra-se na etapa de revisão bibliográfica, com previsão de ida a campo no primeiro semestre de 2016, enquanto, por exemplo, a pesquisa na região Noroeste do estado já possui imagens das distintas categorias representativas da agricultura familiar local.

\section{REFERÊNCIAS}

ALENDE, C. R. M. Estudo dos sistemas de produção dos agricultores familiares da Fronteira Oeste do Rio Grande do Sul. 2006. Dissertação (Mestrado em Extensão Rural) - Universidade Federal de Santa Maria, Santa Maria-RS, 2006.

ALVEZ, F. D.; SILVEIRA, V. C. P.; FERREIRA, E. R. Territorialização camponesa, identidade e reproduções sociais: os assentamentos rurais na metade sul do Rio Grande do Sul. Campo-Território: Revista de Geografia Agrária, v. 2, n. 4 p. 82-97, ago. 2007.

ARAÚJO, L. E. B. A reforma agrária na constituição de 1988 - Artigo produzido para o curso de direito da Universidade Federal de Santa Maria, p. 4-6, dez. 2001.

BARCELOS, T. M. Novas Migrações no RS: Os casos de Uruguaiana e Bagé. In: ENCONTRO NACIONAL SOBRE MIGRAÇÃO, 1. Curitiba, 1997. Anais... Curitiba, 1997.

CHELOTTI, M. C. A estância metamorfoseou-se: (re)configurações territoriais e expressões da reterritorialização camponesa na Campanha Gaúcha (1990- 1997). 2009. Tese (Doutorado em Geografia) - Universidade Federal de Uberlândia, Uberlândia-MG, 2009. 
CUNHA, A. S. Agricultura familiar e suas estratégias de resistência na campanha gaúcha: o caso do rincão dos Saldanhas e do Cerro da Jaguatirica Manoel Viana/RS. 2012. Dissertação (Mestrado em Geografia) - Universidade Federal de Santa Maria, Santa Maria-RS, 2012.

CUPSINSKI, T. C. Agricultura familiar: uma perspectiva de crescimento e de desenvolvimento em Santana do Livramento/RS. 2015. Trabalho de Conclusão de Curso (Administração) - Universidade Federal do Pampa, Santana do Livramento, 2015.

DEL GROSSI, M. E.; SILVA, J. G. da. Movimento recente da agricultura familiar. In: FILHO, F. B. B. (Org). Avaliação de políticas públicas rurais. Brasília: Centro de Estudos Avançados Multidisciplinares, Núcleo de Estudos Agrários. Universidade de Brasília, 2006. v. 6, n. 24.

FAO - Organização das Nações Unidas para Agricultura e Alimentação. O que é agricultura familiar? Disponível em: < http://www.fao.org/family-farming-2014/ home/what-is-family-farming/pt/>. Acesso em: 20 dez. 2014.

FARINATTI, L. A. Confins meridionais: famílias de elite e sociedade agrária na fronteira sul do Brasil (1825-1865). Santa Maria-RS: Editora UFSM, 2010.

FERNANDES, B. M. O MST e as reformas agrárias no Brasil. Revista Debates, UNESP, v. 9, n. 24, out. 2008.

FEE - Fundação de Economia e Estatística. Fronteira Oeste: Perfil socioeconômico. Porto Alegre, 2012.

FONSECA, V. P. S. da. A hegemonia do latifúndio pastoril e a sua relação com a pequena propriedade da Fronteira Oeste do Rio Grande do Sul: a contradição do camponês fronteiriço e a sua concepção de mundo estancieira.1994. Dissertação (Mestrado em Educação) - Universidade Federal de Santa Maria, Santa Maria-RS, 1994.

FURTADO, C. Formação econômica do Brasil. 34. ed. São Paulo: Companhia das Letras, 2007.

GAZOLA, M.; SCHNEIDER. S. A produção da autonomia: os "papeis" do autoconsumo na reprodução social dos agricultores familiares. Revista Estudos Sociedade e Agricultura, Rio de Janeiro, v. 15, n.1, p. 89-122, 2007.

GAZZOLA, M. Agricultura familiar, segurança alimentar e políticas públicas: uma análise a partir da produção para autoconsumo no território do Alto Uruguai/ RS. 2004. Dissertação (Mestrado em Desenvolvimento Rural) - Universidade Federal do Rio Grande do Sul, Porto Alegre, 2004.

IBGE - Instituto Brasileiro de Geografia e Estatística. Censo agropecuário 2006: Brasil, grandes regiões e unidades da federação. Rio de Janeiro, 2009.

Censo Agropecuário 2006. Agricultura Familiar - Brasil, Grandes Regiões e Unidades da Federação. Primeiros Resultados. Disponível em: <www.ibge.gov. br/home/estatistica/economia/agropecuaria/censoagro/agri_familiar_2006_2/ default.shtm> Acesso em: 1 maio 2015. 
Censo Agropecuário 2006. Disponível em: <ttp://www.ibge.gov.br/ home/estatistica/economia/agropecuaria/censoagro/2006/default $>$. Acesso em: 19 dez. 2014.

Cidades. Disponível em: <http://www.ibge.gov.br/home/estatistica/ economia/agropecuaria/censoagro/2006/default>. Acesso em: 19 dez. 2014.

JANILEK, R. O princípio da função social da propriedade e sua repercussão sobre o sistema do código civil. Porto Alegre: PUCRS, 2006.

MARAFON, G. J. Agricultura familiar, pluriatividade e turismo rural: reflexões a partir do território fluminense. Revista de Geografia Agrária, Uberlândia-MG, v. 1, n. 1, p. 17-60, fev. 2006.

NICOLA, M. P.; MARQUES, F. C. Transições em direção ao uso sustentável e conservação dos campos sulinos gaúchos: o lugar da pecuária familiar. Extensão Rural, DEAR - CCR - UFSM, Santa Maria-RS, v. 23, n. 1, jan./mar. 2016.

PEREIRA, C. V. Elementos para pensar a contribuição do Desenvolvimento Rural para a conservação do Bioma Pampa. Mundo Agrário, v. 15, n. 28, p. 1-26, abr. 2014.

PLOEG, J. D. van der. Camponeses e impérios alimentares: lutas por autonomia e sustentabilidade na era da globalização. Porto Alegre: Editora da UFRGS, 2008.

RAMOS, V. G. As estratégias sociais e produtivas no assentamento Santa Maria do Ibicuí, Manoel Viana - RS. 2012. Dissertação (Mestrado em Geografia e Geociência), Universidade Federal de Santa Maria, Santa Maria-RS, 2012.

RIBEIRO, C. M. "Pecuária familiar” na região da Campanha do Rio Grande do Sul: definições e estratégias. Porto Alegre: Emater, 2003. (Série: Realidades Rurais, v. 34, p. 11)

RIO GRANDE DO SUL. Decreto n. 48.316. Regulamentação do Programa Estadual de Desenvolvimento da Pecuária de Corte Familiar. Diário Oficial do Estado do Rio Grande do Sul, Porto Alegre, 01 setembro 2011.

ROZALINO, L.; SÁ BRITO, A. N.; NEUMANN, P. S.; SILVEIRA, P. R. C.; GENRO, C. J. M. A histórica concepção de desenvolvimento frente às identidades regionais: o caso do Rincão dos Mendes no Município de Rosário do Sul/ RS. In: CONGRESSO DA SOCIEDADE BRASILEIRA DE ECONOMIA, SOCIOLOGIA E ADMINISTRAÇÃO RURAL (SOBER), 48. Rio Branco, 2008. Anais... Rio Branco, de 2008.

SCHERER, W. J. G.; MORAES, S. L. Análise locacional das atividades dinâmicas do Estado do Rio Grande do Sul. 2000. Dissertação (Dissertação de Mestrado) Pontifícia Universidade Católica do Rio Grande do Sul, 2000. p. 3-7

SCHNEIDER, S. Agricultura familiar e desenvolvimento rural endógeno: elementos teóricos e um estudo de caso. In: FROEHLICH, M.; DIESEL, V. Desenvolvimento rural: tendências e debates contemporâneos. Ijuí-RS: UNIJUI, 2006. 
Agricultura Familiar e industrialização: pluriatividade e descentralização industrial no Rio Grande do Sul. 2. ed. Porto Alegre: UFRGS, 2004.

A pluriatividade como estratégia de reprodução social da agricultura familiar no Sul do Brasil. Estudos Sociedade e Agricultura, Rio de Janeiro, v.16, p. 164-184. Abril de 2001.

Agricultura familiar e industrialização: pluriatividade e descentralização industrial no Rio Grande do Sul. Porto Alegre, Editora da UFRGS, 1999.

SILVA NETO, B. da. As potencialidades da agricultura familiar em região de grandes estabelecimentos de pecuária extensiva: uma contribuição à reflexão sobre a reforma agrária no Rio Grande do Sul. 1994. Tese (Tese de Doutorado). Institut National Agronomique de Paris, Grignon, Paris, 1994.

SILVA, P. T. O. A agricultura familiar e a função social da propriedade rural: o caso da região Fronteira Oeste do Rio Grande do Sul. 2012. Dissertação (Mestrado em Desenvolvimento Regional) - Universidade de Santa Cruz, Santa Cruz do Sul-RS, 2012.

SOUZA, C. F. Contrastes regionais e formações urbanas. Porto Alegre: UFRGS, 2000.

SPAROVEK, G. A qualidade dos assentamentos da reforma agrária brasileira. São Paulo: Páginas \& Letras Editora e Gráfica, 2003.

TINOCO, S. T. J. Conceituação de agricultura familiar uma revisão bibliográfica. Parte da Tese: Análise socioeconômica da piscicultura em unidades de produção agropecuária familiares da região de Tupã, SP. 2008. Disponível em: <http://www.cati.sp.gov.br/Cati/_tecnologias/teses/CONCEITUACAO_ AGRICULTURA_FAMILIAR_PARTE_DA_TESE_DOUTORADO.pdf $>$. Acesso em: 22 set. 2014.

VEIGA, J. E. O desenvolvimento agrícola. São Paulo: Hucitec/Edusp, 1991. 


\section{Usinas hidrelétricas sob os véus da "sustentabilidade": o pescador artesanal da Ponta do Abunã e a Usina Hidrelétrica de Jirau, em Rondônia}

\section{Hydroelectric plants in the Amazon under the veils "sustainability": the fishermen of Ponta do Abunã of the Jirau Dam in Rondonia}

Fabiano Moreira da Silva - Mestrando em Desenvolvimento Regional pela Universidade Federal do Acre (UFAC). Docente do Instituto Federal de Educação Ciência e Tecnologia do Acre (IFAC). Área: Geografia. E-mail: fabianogeo@yahoo.com.br

Elder Andrade de Paula - Doutor em Ciências Sociais pela Universidade Federal Rural do Rio de Janeiro, Pós Doutorado em Sociologia do Desenvolvimento pela Universidad Nacional Autónoma de México - UNAM. Professor do Centro de Filosofia e Ciências Humanas e do Programa de Mestrado em Desenvolvimento Regional da Universidade Federal do Acre. E-mail: elderpaula@uol.com.br

\section{Resumo}

A partir da primeira década do século XX novas hidrelétricas têm sido propostas para a Amazônia Legal. Os exemplos das hidrelétricas de Balbina, Tucuruí e Samuel deixaram muito a desejar no que diz respeito à participação e à inclusão da população atingida. A Hidrelétrica de Jirau é divulgada pelos seus proponentes como experiência díspar das anteriores no bioma amazônico sendo propagada e impulsionada pela ideologia do desenvolvimento sustentável. Neste trabalho, objetiva-se perceber a forma como os pescadores artesanais da região rondoniense da Ponta do Abunã estão inseridos no "mundo" de Jirau. Por meio de entrevistas e trabalhos de campo marcados por observação direta e participante, o presente trabalho possibilitou perceber que apesar das exigências da nova legislação ambiental brasileira, as novas hidrelétricas propostas para a Amazônia Legal ainda são marcadas pela insuficiência de estudos ambientais, exclusão de considerável parcela da população atingida e graves efeitos sociais, semelhantes àqueles do período ditatorial.

\section{Palavras-chave}

Amazônia. Hidrelétricas. Pescadores. Efeitos Sociais.

\begin{abstract}
From the first decade of the twentieth century new dams have been proposed for the Legal Amazon. Examples of hydroelectric Balbina, Tucuruí and Samuel left much to be desired with regard to participation and inclusion of the population. The Jirau hydroelectric plant is disclosed by its proponents as disparate experience of previous in the Amazon biome being propagated, based and driven by sustainable development ideology. This work aimed to understand how the fisherfolk of Rondonia region of Ponta do Abunã are included in the "world" of Jirau. Through interviews and field work marked by direct observation and participant, this work made it possible to realize that despite the demands of the new Brazilian environmental legislation, new dams proposed for the Amazon, are still marked by insufficient environmental studies, exclusion considerable portion of the population and serious social, similar effects those of the dictatorial period.
\end{abstract}

\section{Keywords}

TAmazon. Hydropower. Fishermen. Social Effects. 


\section{INTRODUÇÃO}

O trabalho tem como objetivo mostrar a maneira como os pescadores artesanais da Ponta do Abunã estão inseridos no mundo da Usina Hidrelétrica (UHE) de Jirau. Para tanto, inicia-se com a caracterização da área de estudo, ou seja, da região rondoniense da Ponta do Abunã e da pesca artesanal que se estabelece nesta porção do território de Rondônia. Em seguida, são feitos apontamentos em relação à pesca artesanal nesta região, após a UHE Jirau. A escassez de pescado se apresenta como uma insígnia importante após o empreendimento. Derradeiramente é feita uma análise do Programa de Compensação Social da UHE Jirau e sua influência no dia-a-dia do pescador artesanal da Ponta do Abunã.

\section{CARACTERIZAÇÃO DA ÁREA DE ESTUDO: A PONTA DO ABUNÃ}

A Ponta do Abunã é uma estreita faixa de terra localizada no município de Porto Velho, no estado de Rondônia, que se estende desde a confluência do rio Abunã com o rio Madeira, até o estado do Acre (Figura 1). A região limita-se ao norte com o município amazonense de Lábrea, ao sul tem como limite natural o rio Abunã, também conhecido na Bolívia como Abuná. Ao sul limita-se com o Departamento de Pando na Bolívia, e ao oeste, encontra sua divisa com o distrito de Abunã, já localizado na margem direita do rio Madeira.

De acordo com o IBGE, a Ponta do Abunã está inserida na mesorregião de Madeira-Mamoré e, mais especificamente, na microrregião de Porto Velho (IBGE, 1990). A região denominada Ponta do Abunã é formada por quatro distritos de Porto Velho, localizados à margem esquerda do referido rio. Os distritos são: Nova Califórnia, Extrema, Vista Alegre e Fortaleza do Abunã. A região compõe uma área total de $5.515,87 \mathrm{~km}^{2}$, correspondendo a $16,18 \%$ da área total do município de Porto Velho.

Dos quatro distritos, Fortaleza do Abunã se diferencia dos demais em termos de localização geográfica. Está localizado a margem do rio Abunã onde, inicialmente, durante o período da frente extrativista servia de entreposto comercial entre o rio Madeira e o rio Abunã. Os outros três distritos estão localizados ao longo da BR-364, a qual consolidou o processo de ocupação e formação dos mesmos. Vale ressaltar ainda que os pescadores artesanais em estudo neste trabalho têm o rio Abunã como seu principal local de pesca. Até mesmo os pescadores de Fortaleza do Abunã, que é aquele que se localiza mais próximo à confluência com rio Madeira, pescam mais naquele rio que no rio Madeira 
Figura 1 - Localização da área de estudo: A Ponta do Abunã- Porto Velho-RO

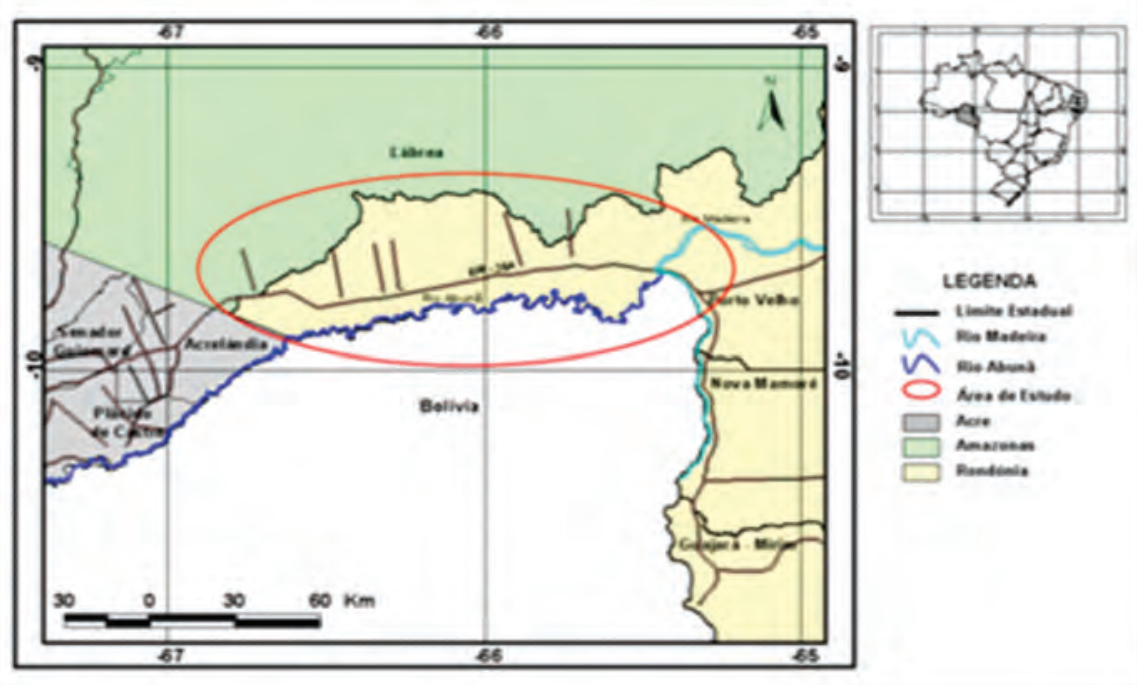

Fonte: Base cartográfica do ZEE/AC - IMAC/SEMA, 2000

O distrito mais populoso da Ponta do Abunã é o distrito de Extrema com uma população de 6176 habitantes, seguido pelo distrito de Vista Alegre com 4.125 habitantes, Nova Califórnia 3.631 e, Fortaleza do Abunã com 450 habitantes de acordo com dados do censo de 2010, realizado pelo IBGE. Curiosamente o distrito de Extrema localiza-se a aproximadamente $180 \mathrm{~km}$ de Rio Branco, capital do estado do Acre e a cerca de 327 km da capital de Rondônia, Porto Velho. É o distrito que concentra a maior parte das instituições públicas (administração, saúde e educação) e privadas (banco e pontos comerciais em geral), o que a coloca na posição de principal polo regional.

No que diz respeito à ocupação populacional, a existência natural da espécie Hevea brasiliensis atraiu a vinda de considerável número de pessoas para a Ponta do Abunã a partir da segunda metade do século XIX, por meio da exploração dos seringais nativos da região. Contudo, em meados do século XX, com a chegada dos soldados da borracha ${ }^{1}$ é que a colonização da região foi ainda mais impulsionada.

\footnotetext{
Soldados da Borracha foi o nome dados aos brasileiros que foram alistados e transportados para a Amazônia, com o objetivo de extrair borracha para os Estados Unidos da América durante a Segunda Guerra Mundial. Considerados os peões do Segundo Ciclo da Borracha e da expansão demográfica da Amazônia os soldados da borracha eram, em sua maioria, nordestinos.
} 
A partir da década de 1970, impulsionada pela expansão da fronteira agropecuária, a economia da região sofre uma forte guinada com a substituição do extrativismo vegetal pela pecuária extensiva. Neste período muitos migrantes oriundos das regiões Sul e Sudeste do Brasil se direcionaram para a Ponta do Abunã, onde foram vítimas dos precários projetos de assentamentos encabeçados pelo INCRA.

Não se pode negar ainda que a maior ocupação da Ponta do Abunã, nas últimas duas décadas do século XX e início do século XXI, teve como grande incentivo a pavimentação asfáltica da BR-364, ligando primeiramente as cidades de Cuiabá a Porto Velho e, em seguida, Porto Velho à cidade de Rio Branco, no estado do Acre.

Ao relacionar a posição da Ponta do Abunã na Figura 1 com a localização dessa região na Figura 2, nota-se que as comunidades de pescadores artesanais, de acordo com o EIA, estão inseridas na Área de Influência Indireta (AII) do meio socioeconômico das primeiras UHE do Complexo Hidrelétrico do rio Madeira (CHM). Neste sentido, devido à maior proximidade geográfica com o AHE Jirau, supõe-se que os mesmos devam estar inseridos, principalmente, no "mundo de Jirau".

Figura 2 - Localização da Área de Influência Indireta (AII) e dos empreendimentos Jirau e Santo Antônio

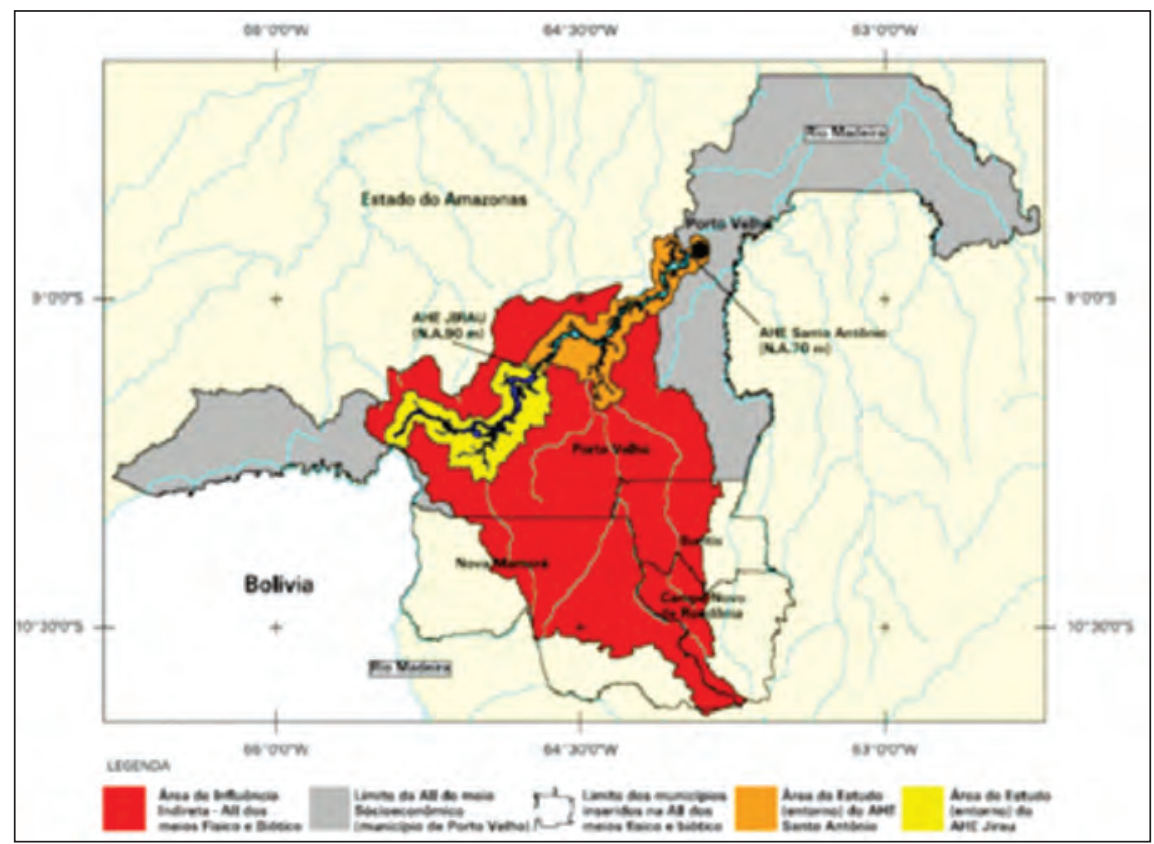

Fonte: EIA (2004, p III-5), Figura A. III-2 
Ademais, a partir dos levantamentos obtidos em campo, fica claro que na visão dos pescadores artesanais da Ponta do Abunã, os mesmos devem ser considerados atingidos pelo empreendimento. A experiência obtida pelos pescadores artesanais durante os vários anos de trabalho no rio Abunã, demonstra claramente a redução do pescado após o início das obras dessa UHE e, consequentemente, a necessidade dos mesmos terem que buscar alternativas de sobrevivência, uma vez que, segundo os pescadores, não dá mais para viver apenas do peixe.

\section{CARACTERIZAÇÃO DA PESCA ARTESANAL NA PONTA DO ABUNÃ}

Os pescadores em estudo neste trabalho são membros da Colônia de Pescadores e Aquicultores Z-1 - Tenente Santana - Porto Velho/RO. Segundo dados obtidos na Colônia, dos 2.800 pescadores registrados na organização, 851 são residentes na Ponta do Abunã. Esses pescadores estão dispersos pela região, sendo que na entidade não foi possível saber a distribuição dos mesmos pelos distritos de Porto Velho, uma vez que a Colônia de Pescadores e Aquicultores Z-1 não dispunha destes dados. Entretanto, estima-se que a quantidade de pescadores artesanais nessa importante região do estado de Rondônia tende a ser bem mais expressiva uma vez que nem todos são membros da Colônia de Pescadores e Aquicultores Z-1-Tenente Santana- de Porto Velho/RO.

Devido ao fato do distrito de Extrema ser aquele que concentra a maior parcela da estrutura urbana da região e, ainda, ser o mais populoso, estima-se que este seja também, o distrito que ajunta a maior parcela de pescadores artesanais na Ponta do Abunã. Além disso, é neste distrito que está localizada a principal Capatazia da Colônia de Pescadores Z-1- Tenente Santana, na Ponta do Abunã. É na sede desta Capatazia que os pescadores artesanais da Ponta do Abunã procuram resolver a questão de suas obrigações e direitos, como a mensalidade ( $\mathrm{R} \$ 60,00)$, a contribuição sindical anual $(\mathrm{R} \$ 30,00)$, INSS, Seguro Defeso, auxílio doença etc.

A pesca artesanal representa em alguns pontos, como no distrito de Fortaleza do Abunã a principal atividade econômica local ao longo do ano. Como uma das principais atividades humanas historicamente desenvolvidas na Amazônia, a pesca artesanal representa fonte de alimento, comércio, renda e até mesmo lazer para grande parte da população, com expressiva relevância econômica para a região. 
Além do rio Abunã e dos lagos naturais formados ao longo de suas margens, o rio Marmelo, considerado o principal afluente do Abunã em terras rondoniense, é também um importante ponto de pesca na Ponta do Abunã. $\mathrm{Na}$ Vila Marmelo (também conhecida como Vila Progresso, ou ainda Vila Preguiça), o rio Marmelo se destaca como importante ponto de pesca.

A pesca artesanal praticada na Ponta do Abunã é marcadamente uma atividade de cunho familiar e comunitário. Em geral os casais de pescadores são os principais parceiros de pesca e, juntos, se aventuram pelos rios e lagos interiores da região. As mulheres além de executar os serviços domésticos como lavar as roupas, e cuidar das crianças, também são importantíssimas durante a pesca. Elas muitas vezes pilotam as canoas, ajudam a armar as malhadeiras, despescar, "tratar" e armazenar os peixes. As pescarias em geral são realizadas em dupla, como forte tendência a ser uma atividade de cunho familiar, ou parceria de três ou mais pescadores.

As pescarias em geral são de curta duração. A duração aproximada de cada pescaria varia geralmente de três a quatro dias e perfazem os três turnos diários. Essas características também são comuns em outras comunidades ribeirinhas da Amazônia, onde os pescadores realizam viagens mais próximas das suas residências, assim minimizando gastos com combustível e alimentação.

No que diz respeito aos apetrechos de trabalho dos pescadores artesanais da Ponta do Abunã, alguns constroem suas próprias malhadeiras e canoas, entretanto, outros compram já prontas no comércio regular ou de pescadores reconhecidamente hábeis na arte de construir suas ferramentas de trabalho como canoas e malhadeiras. Vale destacar o fato de que os pescadores artesanais são possuidores de toda a tralha necessária para realizar o seu trabalho. Muitas vezes se unem em parceria com objetivo de potencializar a produção. Os pescadores artesanais utilizam desde artes tradicionais como o caniço e a linha de mão, até outros mais específicos como a fisga, a zagaia e o espinhel, usados principalmente, durante a captura dos grandes bagres.

É comum durante o período do defeso muitos pescadores se aventurarem principalmente na coleta e quebra da castanha do Brasil para complementar sua renda mensal. Ademais, conforme relatado por alguns pescadores durante as entrevistas de campo, tal atividade foi de extrema importância durante o final do ano de 2015 e no início de 2016, visto que o governo federal suspendeu o benefício neste período. Assim, a atividade foi a solução para que muitas famílias não passassem a necessidade de insumos básicos para a sobrevivência humana. 


\section{OS PESCADORES ARTESANAIS DA PONTA DO ABUNÃ E SUA "PARTICIPAÇÃO" NO PROCESSO DE LICENCIAMENTO DA UHE JIRAU}

Uma questão marcante em relação às primeiras grandes UHE construídas na Amazônia é a pouca ou quase inexistência da participação popular nos processos decisórios referentes a construção destes empreendimentos. A situação torna-se facilmente compreensível quando se atenta para o fato de que algumas foram impostas pelo Estado em virtude da característica marcante de se apresentar como um período tipicamente ditatorial.

Entretanto, a partir da consolidação da nova constituição brasileira esperase que um dos diferenciais das novas UHE construídas e, a serem construídas na Amazônia, seja a participação da população atingida no processo de liberação das obras. Espera-se que a democracia, por meio de um de seus pilares como a participação popular na tomada de importantes decisões, seja parte dos alicerces dessas grandes obras previstas para a Região Amazônica.

A questão aqui apresentada é que durante as entrevistas e encontros realizados com pescadores na Ponta do Abunã para a realização deste trabalho, não se percebeu que os mesmos foram ouvidos nos processos decisórios de construir, ou não, as primeiras UHE do rio Madeira. É preciso ressaltar que das poucas audiências públicas (apenas 4 audiências) que aconteceram no processo de licenciamento ambiental das UHE do rio Madeira, nenhuma delas aconteceram na Ponta do Abunã.

Bermann (2007) ressalta a desconsideração com que são tratadas as populações ribeirinhas atingidas pela implementação das UHE. Os interesses dessas populações são negligenciados no processo de construção das usinas, uma vez que seu envolvimento no processo decisório é limitado pela falta de transparência e assimetria de informações. A gestão democrática dos recursos hídricos pressupõe a participação das populações atingidas pelos empreendimentos hidrelétricos no processo de decisão subjacente, mediante a construção de consensos, reconhecendo interesses divergentes que devem ser incorporados no processo de negociação (BERMANN, 2007).

De acordo com a legislação atual, as audiências públicas se consolidaram como um instrumento de participação da população, sendo fundamental no processo de Avaliação de Impacto Ambiental, conforme referido nas Resoluções 01, de 1986, e 09, de 1987, do CONAMA, que disciplina sobre as audiências públicas para expor informações sobre Grandes Projetos de Investimentos e seus possíveis impactos ambientais para fins de licenciamento ambiental. As 
audiências públicas são ratificadas no texto da Constituição Federal de 1988, cuja realização se dá após a execução dos Estudos de Impactos Ambientais e do Relatório de Impacto ao Meio Ambiente.

No caso do CHM conforme divulgado por meio do Parecer Técnico 014/2007 do IBAMA, a área de influência das UHE podem extrapolar até mesmo as fronteiras nacionais, incluindo áreas da Bolívia. Assim, conforme pode ser facilmente notado, a comunidade de pescadores artesanais da Ponta do Abunã deveria ter sido consultada e ouvida, sobre os possíveis impactos naturais e sociais a atingir este grupo de representação social, uma vez que os mesmos residem inclusive, na mesma unidade administrativa (município de Porto Velho), onde se encontram os empreendimentos.

As UHE na Amazônia como Balbina, Samuel e Tucuruí geralmente implicaram impactos naturais e efeitos sociais de proporções significativas que geralmente beneficiavam os empreendedores, em detrimento das populações tradicionais e dos pequenos produtores. A inexpressiva participação dos pescadores artesanais da Ponta do Abunã nas audiências públicas e no processo de licenciamento das UHE do rio Madeira como um todo, implicitamente revelam no mínimo, o desconhecimento e o desrespeito à realidade local.

É interessante ainda ressaltar que, conforme mencionado por Baraúna (2009), até mesmo dentro da universidade o projeto de construção das UHE do rio Madeira não estava claro. A autora expressa a fala de um dos professores da UNIR durante a audiência pública realizada em Porto Velho, em 11 de novembro de 2006:

Porque pra mim não está claro, o discurso que vem atender o desenvolvimento de Rondônia não está claro! Eu tô colocando isso como professor da universidade, porque na minha universidade que taí o nome, nós não discutimos. Se na universidade não se discutiu, eu quero saber se na associação de moradores se discutiu? Se discutiu nas entidades de classes? Eu quero saber disso, mas estamos sabendo também que há um interesse de manipulação das pessoas, para vir pra cá concordar. Não vamos concordar, vamos debater e é a partir do debate que a gente pode chegar a um objetivo! Essa é a questão, essa é questão que eu coloco, obrigado! (BARAUNA, 2009, p. 149).

A partir do momento em que se legitimam as audiências públicas como suficientes no processo de licenciamento ambiental, considera-se como sanadas as dúvidas da população em relação aos impactos do empreendimento. Teoricamente, as audiências públicas deveriam possibilitar à sociedade a participação no processo de decisão referente aos bens de interesse público e coletivo, como no caso das águas fluviais amazônicas. 
Ao limitar as audiências públicas do processo de licenciamento das primeiras UHE do rio Madeira, à cidade de Porto Velho e aos distritos de Jacy Paraná, Mutum Paraná e Abunã, cerceou a participação dos pescadores artesanais da Ponta do Abunã nas audiências públicas, uma vez que o gasto com transporte até essas localidades se apresenta como bastante oneroso. Além do custo normal de deslocamento até os pontos de realização das audiências públicas, como passagem de ônibus, combustível etc., ainda tem o transtorno da travessia do rio Madeira por meio de uma balsa privada. Ademais, as audiências públicas deveriam ter ocorrido em lugares de fácil acesso a essa importante parcela da população e porque não, nos distritos de Porto Velho da Ponta do Abunã.

A maioria dos pescadores artesanais entrevistados durante o trabalho nem sequer sabiam expressar o significado do termo "audiência pública". O termo é estranho a eles. Contudo, segundo os entrevistados, definitivamente nunca participaram de um encontro com representante da UHE Jirau, no período de licenciamento do empreendimento. Tal fato corrobora com a questão levantada por Baraúna (2009), que nem mesmo em Porto Velho, desde o início da idealização do projeto CHM, houve diálogo com a sociedade. Surpreendidos e atingidos com os barramentos do rio Madeira, os pescadores artesanais da Ponta do Abunã também se tornaram vítimas da escassez de pescado, acentuando a questão do desemprego na região e a insegurança para com os dias vindouros.

\section{A PESCA ARTESANAL NA PONTA DO ABUNÃ APÓS A UHE JIRAU}

Inicialmente é preciso ressaltar o fato de que a região da Ponta do Abunã é uma área que do ponto de vista geográfico é relativamente grande. Dentro dessa região de Porto Velho, encontram-se quatro distritos e alguns pequenos povoados como a Vila Marmelo. Muitas vezes, a realidade do distrito de Fortaleza do Abunã que está muito próximo da confluência do rio Madeira com o rio Abunã e, portanto, mais perto do reservatório da UHE Jirau, não coincide com a mesma realidade dos distritos de Extrema ou Nova Califórnia mais distantes deste ponto.

Não obstante, estarem afastados e, portanto, se configurarem como diferentes espaços de aglomeração humana, a pesca artesanal e o rio Abunã conferem aos distritos e vilas muita semelhança socioeconômica e cultural. Daí o fato de que os pescadores da região, em sua maioria, fazem parte da mesma Colônia de Pescadores Z-1.

$\mathrm{Na}$ Amazônia a pesca extrativa contribui durante séculos para a manutenção das populações tradicionais (BATISTA; FABRÉ, 2003, p. 131). A atividade 
de pesca artesanal é exercida por meio de regime de economia familiar e/ou individual, atendendo à subsistência da família e, às vezes, gerando excedente para ser comercializado. A atividade pesqueira regional pode ser caracterizada como pesca artesanal de pequena escala, ou seja, obtida com aparelhos de pesca simples e em viagens de curta distância. Mesmo com as dificuldades enfrentadas pelos pescadores em relação à escassez de pescado no rio Abunã após a UHE Jirau, muitos ainda se dedicam de forma integral à atividade pesqueira, enquanto outros, de forma parcial.

Na Ponta do Abunã a situação tem se apresentado de forma bastante comprometedora. "Quando barragens são construídas em rios com populações de peixes migratórios, as comunidades acima do rio são as primeiras a perder o acesso aos peixes" (BARNES, 2008, p. 122). Durante as entrevistas e encontros com pescadores artesanais da Ponta do Abunã, era notório em cada depoimento uma saudade dos tempos em que a pesca no rio Abunã era suficiente para satisfazer as necessidades básicas e financeiras da família. Alguns(as) pescadores(as) chegavam a marejar os olhos ao se falar da falta de peixes e as mudanças provocadas pela escassez do mesmo na organização familiar. A fala a seguir é de um experiente pescador ${ }^{2}$ e relata um pouco da angústia vivenciada todos os dias:

Antes eu ia pra dentro do rio Abunã eu pegava meus 120, 150 quilos de peixe, $75 \%$ era peixe de primeira e $25 \%$ era peixe de segunda. Mas os $75 \%$ que eu pegava de primeira, cobria os $25 \%$ de segunda que é a traira, piranha que você sabe né? De primeira dava o braço de moça, dava o surubim, o tucunaré, o piau que é o peixe de primeira aqui na nossa região. Então, um cobria o outro. Aí dava pra gente pagar 70 conto de frete pra gente ir lá em baixo (no porto de Extrema), dava pra comprar um paninho de malhadeira, dava pra manter a luz, dava pra manter a água. Que tudo aqui a gente paga e depois da barragem, de 2009, 2010, 2011 aí nós tivemos que correr pra outros cantos, porque aí faltou o peixe. Eu não tenho dúvida da barragem da usina de luz (PIRARARA, 2016).

A estrutura familiar e social está comprometida, pois na Ponta do Abunã é notório que os filhos de pescadores, ao contrário do caráter histórico tradicional de que a profissão de pescador é transmitida entre gerações, devido às dificuldades enfrentadas pelos pescadores nos últimos anos, grande parte não está disposta a seguir a profissão do pai. Alegam que as dificuldades são muitas e não se pega peixe. A alternativa tem sido procurar emprego em centros urbanos como Porto Velho e distritos próximos. Geralmente, quando estão ocupados, isso se

2 Conforme combinado com os pescadores durante os levantamentos de campo, as identidades dos mesmos não serão reveladas durante o trabalho. Para diferenciação dos pescadores, os nomes dos mesmos serão substituídos por nomes de peixes da região. 
dá em trabalhos que requerem menos especialização como garis, ajudantes na construção civil etc. Até mesmo os pais se veem obrigados a procurar outras atividades que de forma geral são classificadas pelos mesmos como "bicos" para complementar a renda familiar.

Esses dias nós tava quebrando castanha, a castanha acabou. Agora na época do verão que é a época do peixe, não tem peixe pra pegar. E aí a dificulidade fica grande. Emprego aqui na rua, não tem. Se a gente for trabaiá de empregado, tem que ter o segundo grau, tem que fazer um curso, você sabe como é que é né? A dificulidade é grande. Então aqui não tem emprego. Nós aqui na Extrema, nós tão esquecido pelo governo, o governo só se lembra da renda, só dos impostos, mas nós aqui tamo esquecido. Então aqui é uma dificulidade muito difícil pra gente trabaiá nesse negócio de peixe (SURUBIM, 2016).

$\mathrm{Na}$ Ponta do Abunã os pescadores que há mais tempo se dedicam à atividade de pesca são enfáticos em dizer que não dáa mais para viver apenas da pesca artesanal. Apresentam argumentos como a escassez do peixe (principal), a baixa valorização do pescado, a elevação nos custos de uma pescaria como gelo, gasolina, malhadeiras, anzóis, caixas térmicas etc.

Não da mais pra sobreviver do peixe e a gente tem que procurar serviço em outro canto. A gente incentiva os filhos a pescar, mas aí eles fala que não tem futuro né. Não tem sobrevivência. Muito pouca produção do nosso peixe na Ponta do Abunã. E é tanto que por isso botei até as minhas canoas la na balsa (rio Madeira), pescar lá. Canoa, minha tráia ta toda lá, hoje se você procurar minha tráia pra poder filmar, não tem como. Ta tudo lá na balsa porque aqui não dava peixe. Agora, pescando lá e trazendo a produção toda aqui pra Extrema, levando pra Rio Branco quando aqui enchia muito. Agora esse ano (2015), nem pra mandar pra cá. Foi ruim. Nem na balsa esse ano deu pra pegar peixe (...) (PIRARARA, 2016).

No relato supracitado, percebe-se ainda o fato de que os pescadores artesanais da Ponta do Abunã que ainda se dispõem a enfrentar os desafios da atividade pesqueira têm buscado como refúgio aumentar sua área de pesca, chegando a pescar em locais onde antigamente não eram obrigados a se aventurar. Tal fato confirma a previsão de pesquisadores como Barnes (2008), em relação à pesca no rio Madeira, mas que devido à proximidade geográfica, podemos estendê-las até a Ponta do Abunã. Segundo Barnes (2008), as UHE no rio Madeira iriam atingir a estrutura econômica dos pescadores da região, uma vez que, com a diminuição de pescado, os custos de pesca aumentariam consideravelmente.

Os pescadores teriam (e agora estão tendo) que gastar e/ou investir mais em transporte, apetrechos de pesca, compra de gelo e material de armazenamento 
do pescado. Ao ser obrigado a procurar outros locais de pesca, toda a estrutura de pesca precisa ser revista. A aventura em novos pontos de pesca demanda custos e apetrechos que antes não eram necessários. Como exemplo, segundo relato de pescadores o custo do frete de uma viagem do distrito de Extrema até a região da balsa do rio Madeira para levar o material necessário pra realizar uma pescaria, gira em torno de 350 reais.

Alguns pescadores relataram ainda que no ano de 2015 foram obrigados a tentar a sorte na região do que eles denominam de alagado. O "alagado", ou "alagadão" é como eles se referem as partes do rio Madeira que coincidem com o reservatório da UHE Jirau. Ali, segundo eles, "costuma se pegar peixe". Entretanto, os custos com o transporte para se chegar até o reservatório e, para escoar a produção, inviabiliza muito a ida frequente neste ponto de pesca. Ao falar sobre o assunto, um pescador disse o seguinte:

No ano passado (2015) nós pesquemo lá no alagadão. A dificulidade que tem é o transporte né. Pra gente levar daqui (Extrema) a gente tem que fretar o carro, aí o carro cobra 400 reais pra levar e trazer. Aí leva aqui, cobra 200 reais, deixa a gente lá, aí você marca o dia dele ir buscar, aí ele vai lá e busca. Aí você vai comprar o gelo, você vai comprar a gasolina que é pra gente que tem motor rabetinha né? Tem vez que lá tem fiscalização direto. Aí vai, toma seu peixe, toma sua malhadeira, bota ele pra correr. E agora tem que ter o colete procê andar, você tem que ter habilitação pra pilotar o barco, tem que ter o documento do motor e habilitação. Nesse caso aí eu não sou contra. (...) A gente trás peixe de lá e vende em Rio Branco, aí fica caro. E aí quem não tem transporte fica mais caro né? Dali, lá no alagadão a Rio Branco, cobra 500 reais praí deixar lá (MANDUBÉ, 2016).

Outro fato constantemente relatado pelos pescadores no distrito de Extrema é a necessidade de se aventurar em rios (principalmente no rio Mamu) e lagos na margem direita do rio Abunã, ou seja, em território boliviano. Segundo os pescadores, não raro, acontecem conflitos entre pescadores brasileiros e representantes do exército da Bolívia. Na maioria das vezes pescam pouco peixe e, recorrentemente, os pescadores são obrigados a deixar parte do pescado como forma de pagamento por ter pescado em águas daquele país.

É típico da Região Amazônica o fato de a pesca se desenvolver como uma atividade basicamente extrativista, condicionada pelo nível das águas dos rios, com superprodução na época da "seca" e escassez durante a época de cheia (PARENTE; OLIVEIRA JÚNIOR; COSTA, 2003), o que determina o caráter sazonal da produção. O ciclo das águas (enchente/cheia - "inverno amazônico" período de dezembro a julho, vazante/ seca - "verão amazônico"- período agosto 
a novembro) é um fator crucial que afeta naturalmente a pesca na Amazônia. O pescador artesanal amazônico se adapta a essas características naturais e depende delas para exercer sua função, pois são elas que renovam a vida nos rios.

Entretanto, para os pescadores da Ponta do Abunã até a variação regular do nível das águas do rio Abunã foram alteradas após a construção da UHE Jirau. Em Fortaleza do Abunã, além das dificuldades com a escassez de pescado, os pescadores demonstraram intensa preocupação também, com a queda na atividade turística (principalmente de acreanos). A atividade se apresenta como renda complementar, gerando uma renda extra e fundamental. Se as águas do rio Abunã não abaixam, não tem como formar as praias que atraem os turistas. Mesmo em locais mais distantes da confluência do rio Madeira com o rio Abunã, os pescadores têm percebido que após a UHE Jirau o regime do rio Abunã foi alterado consideravelmente. Segundo os pescadores, se o rio não enche e inunda as várzeas, não tem como os peixes se reproduzirem.

Nos distritos com maior aglomeração humana como nos casos de Extrema e Vista Alegre, o pouco peixe que ainda se pesca é comercializado no próprio distrito. Normalmente, os clientes procuram comprar o peixe na própria residência do pescador. Em alguns momentos, os peixes são vendidos por meio do sistema que eles denominam de "porta em porta", pelo pescador e sua família. Em Fortaleza do Abunã e na Vila Marmelo, como o mercado consumidor é muito restrito, muitos pescadores artesanais são obrigados a entregar o pescado a atravessadores que pagam um valor bastante reduzido para os mesmos.

\section{OS PESCADORES ARTESANAIS DA PONTA DO ABUNÃ E A “COMPENSAÇÃO SOCIAL” DA UHE JIRAU}

O Programa de Compensação Social é uma das partes integrantes do Projeto Básico Ambiental (PBA) da UHE Jirau. De acordo com o referido documento, o Programa de Compensação Social está subdividido em cinco subprogramas: (1) Subprograma de Apoio ao Município, (2) Subprograma de Qualificação da População e Desenvolvimento de Oportunidades, (3) Subprograma de Apoio ao Plano Diretor, (4) Subprograma de Fomento à Tecnologia de Extração de Produtos Florestais e (5) Subprograma de Apoio às Atividades de Assistência a Grupos Populacionais Vulneráveis.

A questão aqui apresentada é perceber de que forma a população atingida de pescadores artesanais da Ponta do Abunã se encontra inserida dentro do Programa de Compensação Social da UHE Jirau. Segundo informações 
constantes no PBA, o objetivo central do programa é contribuir na compensação de potenciais impactos sociais e econômicos provocados com a implantação da UHE Jirau. Neste sentido, é de se esperar que os pescadores artesanais da Ponta do Abunã, como parcela da população atingida pelo empreendimento, estejam diretamente inseridos na compensação social da UHE Jirau.

Portanto, em relação ao subprograma de apoio ao município, percebese a nítida priorização de atendimento à Área de Influência Direta (AID) do empreendimento e, em especial, a localidade denominada preliminarmente de Nova Mutum. Nestes moldes, a maior parcela da população de pescadores artesanais da Ponta do Abunã não se encontra diretamente atendida pelo programa, uma vez que, apesar da inclusão do distrito de Fortaleza do Abunã, a maioria reside na AII.

É importante destacar o fato de que a Energia Sustentável do Brasil (ESBR) justifica a área de abrangência da atuação do empreendedor para a realização das ações de compensação social, a partir das informações levantadas em reuniões realizadas com as comunidades, onde essas, segundo a empresa, manifestaram suas demandas por serviços e infraestrutura. Como a participação dos pescadores artesanais da Ponta do Abunã foi bastante inexpressiva (se houve) no processo de licenciamento do empreendimento, pode-se logo deduzir que as necessidades específicas dos mesmos, não podem se fazer presentes nas políticas de compensação social da UHE Jirau, uma vez que os mesmos não foram diretamente ouvidos.

Em relação ao Subprograma de Qualificação da População e Desenvolvimento de Oportunidades, o público-alvo das ações propostas novamente são as comunidades localizadas na AID da UHE Jirau. A grande questão levantada neste subprograma é a qualificação da mão-de-obra local. Certamente, seria um quesito de extrema importante para as famílias de pescadores artesanais da Ponta do Abunã, uma vez que, a partir da redução e/ ou escassez de pescado percebida após o empreendimento, cursos na área da pesca e/ou em outras áreas minimizariam os efeitos sociais sobre as famílias de pescadores artesanais da região. Não foi observada durante os trabalhos de campo a vinculação direta dos pescadores artesanais da Ponta do Abunã nas obras da UHE Jirau, nem registro na capatazia do distrito de Extrema de cursos de qualificação ofertado pela empresa.

O Subprograma de Apoio a Revisão do Plano Diretor do Município de Porto Velho destaca como área prioritária de atuação os distritos de Nova Mutum, 
Jaci-Paraná, Abunã e a comunidade de Fortaleza do Abunã, além das localidades à beira da BR-364, Cical, Palmeiral, Dois Irmãos, Imbaúba e Jirau, e os ramais (assentamentos) localizados próximos a estes distritos e localidades. Contudo, os distritos de Vista Alegre, Extrema e Nova Califórnia que juntos abrigam a maior parcela da população de pescadores da Ponta do Abunã, se receberam atenção, foi de forma secundária, uma vez que os mesmos não se encontravam dentro da principal área de atuação do subprograma.

Outra ramificação do Programa de Compensação Social é o Subprograma de Fomento à Tecnologia de Extração de Produtos Florestais (4). Segundo informações presentes no PBA este subprograma:

tem a proposição de contribuir com as populações residentes na AID do AHE Jirau na busca de melhores condições de vida, obtendo rendas com a exploração sustentável de produtos florestais. Além dessa oportunidade, este Subprograma visa impulsionar junto as comunidades ribeirinhas as atividades de coletas de frutos e sementes destinadas ao consumo direto e à produção do mercado visando a obtenção de renda complementar (ESBR, 2008, p. 30. Grifo nosso).

É recorrente o fato de que principalmente durante o período do defeso, os pescadores artesanais da Ponta do Abunã pratiquem outras atividades extrativistas típicas da floresta amazônica, com grande destaque para a coleta da castanha do Brasil. Tais atividades complementam a renda familiar dos pescadores e, às vezes, como ocorreu durante o período de pesquisa deste trabalho, se apresentam como única fonte de renda.

Infelizmente, talvez devido às ações deste subprograma terem por objetivo principal a AID da UHE Jirau, não foi notada a participação dos pescadores artesanais da Ponta do Abunã em nenhuma ação deste subprograma. A capacitação dos pescadores para exercerem outras atividades extrativas além da pesca, seria fundamental para minimizar os efeitos da falta de pescado e, poderia abrir novos horizontes que assegurem a dignidade humana e ascensão social dos mesmos.

O derradeiro subprograma que consta no Programa de Compensação Social presente no PBA da UHE Jirau é o Subprograma de Apoio às Atividades de Assistência a Grupos Populacionais Vulneráveis. Novamente o âmbito de aplicação é atuar principalmente nos distritos de Mutum-Paraná, Nova MutumParaná, Jaci-Paraná, Abunã e Fortaleza do Abunã, e as localidades à beira da BR364, Cical, Palmeiral, Dois Irmãos, Imbaúba e Jirau, e os ramais (assentamentos) 
localizados na AID do AHE Jirau. De novo, a maior parte dos distritos da Ponta do Abunã, (excetuando apenas o pequeno distrito do Fortaleza do Abunã), não serão atendidos diretamente pelo subprograma.

Não obstante, o consórcio responsável pela hidrelétrica de Jirau trazer em seu nome a expressão "sustentável”, o que pôde ser percebido a partir da análise das ações de Programa de Compensação Social é que em relação à população atingida de pescadores artesanais da Ponta da Abunã, mantida a situação atual, esta será insustentável para os mesmos.

\section{CONSIDERAÇÕES FINAIS}

Desde o final do terceiro quarto do século XX a Amazônia vem sendo também apresentada mediante o seu grande potencial hidrelétrico. As primeiras grandes hidrelétricas construídas na Amazônia foram marcadas pelos graves impactos naturais e efeitos sociais provocados pelas mesmas. Com o fim da ditadura no Brasil e a estruturação da nova legislação brasileira, esperava-se muito, que, ao se decidir construir uma nova UHE na Amazônia, alguns erros do passado pudessem ser evitados e/ou corrigidos, uma vez que os exemplos anteriores poderiam balizar um novo olhar sobre as bondades de la naturaleza amazônica.

Ao relacionar o CHM e, em especial a UHE Jirau, com a comunidade de pescadores artesanais da Ponta do Abunã, foi possível perceber a influência de um novo GPI na Amazônia e suas relações com uma comunidade de população tradicional. Neste trabalho, foi possível perceber e confirmar que os pescadores artesanais da Ponta do Abunã foram atingidos pela UHE Jirau. A maneira que o pescador artesanal amazônico tem de expressar a importância do rio e dos peixes é diferente da forma como o empreendedor e o Estado colocam. Para estes últimos, os rios são verdadeiras "máquinas" de gerar energia e, os peixes se apresentam como algo secundário, como mais um problema a ser resolvido. Enquanto que para os primeiros, os rios são parte de si e, os peixes que neles existem, a razão de viver, de se levantar da cama, o alimento, a esperança de dias melhores para ele e sua família.

Este estudo possibilitou perceber ainda que apesar de alguns avanços em relação ao trato da natureza e dos homens na Amazônia, muito ainda precisa ser feito. Os ideais da chamada sustentabilidade, ou como muitos preferem, do desenvolvimento sustentável, têm sido eficazes em contribuir para o avanço e legitimação de grandes obras na Amazônia, inclusive aquelas ligadas ao setor de 
geração de energia e corroborando também para que erros do passado sejam revividos e legitimados no presente.

A nova legislação ambiental que deveria exigir o reconhecimento e garantir os direitos das populações atingidas, e que, agora, as coisas fossem diferentes, em muitos casos, tem sido eficaz também em contribuir para legitimar as grandes incursões do capital na Amazônia.

A questão é que a "fio d'água" ou não, a população de pescadores artesanais residentes na região rondoniense da Ponta do Abunã, não se sente inserida no "mundo de Jirau". Na sua maioria, não participaram da elaboração do EIA/ RIMA, e nem das obras durante a construção do empreendimento.

O grupo de pescadores artesanais da Ponta do Abunã, em sua maioria, não hesitam em afirmar que a disponibilidade de pescado no rio Abunã reduziu consideravelmente após o início da construção da UHE Jirau no rio Madeira. Entretanto, como muitos dos programas socioambientais do AHE Jirau não se estendem à maior parte dos distritos da região, muitas variáveis em relação a pesca e aos pescadores ficam à mercê da inexistência de conhecimento.

Apesar dos esforços do MAB, do IBAMA e de algumas ONG sérias ligadas à preservação da natureza, ao observar o processo de licenciamento e materialização da UHE Jirau, no rio Madeira, deixa nítido o fato que ainda persistem muitos comportamentos típicos de quatro décadas atrás.

Ademais, vale ressaltar que os pescadores aqui representados reconhecem a natural variação sazonal da disponibilidade de pescado e, com clareza, demonstram que a quantidade e a variedade de pescado podem alterar naturalmente de um ano para outro. Contudo, a experiência de muitos anos de vida e pesca no rio Abunã lhes permite condições de assegurar que a partir do momento da construção das UHE do CHM, em especial a UHE Jirau, a situação da pesca foi fortemente influenciada pelos mesmos. Afirmam que "não existe" peixe como no passado e, ainda, que as dificuldades de conseguir o "peixe de cada dia" se tornam cada vez maiores.

Em relação às políticas de compensação da UHE Jirau, mantida a situação atual, elas dificilmente chegarão a englobar a maior parte da população de pescadores artesanais atingidos da Ponta do Abunã. Tais políticas têm priorizado a Área de Influência Direta do empreendimento. Neste sentido, é mister o reconhecimento dos pescadores artesanais da Ponta do Abunã como integrantes da população atingida pela UHE Jirau e a integração direta dos mesmos no programa de compensação social. 
Na Ponta do Abunã, o pequeno distrito (talvez até por isso) de Fortaleza do Abunã é o que tem recebido algum auxílio de forma mais “considerável”. Nos distritos de Vista Alegre, Extrema e Nova Califórnia, durante o trabalho, não foi registrada a inserção direta de nenhum pescador artesanal nas políticas de apoio e monitoramento da pesca e muito menos, em quaisquer políticas compensatórias diretas específicas oriundas do empreendedor do AHE Jirau. O que foi percebido é uma nítida desconsideração com esta importante parcela da população atingida.

Levando em consideração todos os avanços trazidos pela nova legislação brasileira e, ainda, pelo desenvolvimento tecnológico, percebe-se que o ideal de sustentabilidade não tem conseguido eliminar e/ou diminuir muitos dos impactos e efeitos sociais semelhantes àqueles do período ditatorial. Imposição da obra e do modelo energético, ausência ou inexpressiva participação popular nas decisões, falta ou insuficiência de estudos ambientais, limitada definição da área de influência, não reconhecimento da população atingida, entre outros, ainda se mostram como características marcantes nos grandes empreendimentos hidrelétricos propostos para a Amazônia aos véus da sustentabilidade.

\section{REFERÊNCIAS}

BARAÚNA, G. M. Q. Análise das políticas governamentais definidas para a região do rio madeira e seus efeitos sobre a pesca artesanal. 2009. $172 \mathrm{f}$. Dissertação (Mestrado em Sociologia) - Instituto de Ciências Humanas e Letras, Universidade Federal do Amazonas, Manaus, 2009.

BARNES, E. A. Valores de mercado da pesca comercial. In: PATRICA, B. (Org.). Águas turvas: alertas sobre as conseqüências de barrar o maior afluente do Amazonas. São Paulo: International Rivers, 2008, p. 120-137.

BATISTA, V. da S.; FABRÉ, N. N. A pesca e o peixe na várzea: espaços, conflitos e conservação. In: ALBUQUERQUE, M. O. de; FABRÉ, N. N. (Org.). Sistemas Abertos Sustentáveis - SAS: uma alternativa de gestão ambiental na Amazônia. Manaus: EDUA, 2003. p. 131-152.

BERMANN, C. Impasses e controvérsias da hidreletricidade. Estudos Avançados, São Paulo, v. 21, n. 59, p. 139-153, jan./abr. 2007.

BRASIL. Ministério do Meio Ambiente. Parecer Técnico n. 014/2007 COHID/CGENE/DILIC/IBAMA. Brasília, 21 de março de 2007. 
Conselho Nacional de Meio Ambiente. Resolução n. 009, de 03 de dezembro de 1987. Dispõe sobre a realização de Audiências Públicas no processo de licenciamento ambiental. Disponível em: <http://www.mma.gov. br/conama $>$. Acesso em: 3 mar. 2015.

Resolução n. 001, de 23 de janeiro de 1986. Estabelece as definições, as responsabilidades, os critérios básicos e as diretrizes gerais para uso e implementação da Avaliação de Impacto Ambiental como um dos instrumentos da Política Nacional do Meio Ambiente. Disponível em: < http://www.mma.gov. br/conama $>$. Acesso em: 3 mar. 2015.

ESBR - Energia Sustentável do Brasil. Projeto Básico Ambiental do Aproveitamento Hidrelétrico Jirau. Programa de Compensação Social, Revisão 1. Dez. 2008.

IBGE - Instituto Brasileiro de Geografia e Estatística. Divisão Regional o Brasil em Mesorregiões e Microrregiões Geográficas. Rio de Janeiro, 1990. v. 1

PARENTE, V. M.; OLIVEIRA JÚNIOR, A. R. O.; COSTA, A. M. Piscicultura: Potencialidades regionais e estudo de viabilidade econômica. Manaus: SUFRAMA, 2003. 


\title{
Grandes projetos de mineração e direitos territoriais das comunidades locais em Moçambique
}

\section{Large mining projects and territorial rights of local communities in Mozambique}

\begin{abstract}
Albino José Eusébio - Doutorando em Sociologia no Programa de Pós-Graduação em Sociologia e Antropologia da Universidade Federal do Pará (PPGSA/UFPA). Mestre em Ciências Sociais pelo PPGSA/UFPA. Bolsista da Capes. E-mail: albinoeusebio@outlook.com
\end{abstract}

Sônia Barbosa Magalhães - Doutora em Antropologia pela Universidade Federal do Pará e em Sociologia pela Université Paris. Professora no Programa de Pós-Graduação em Sociologia e Antropologia da Universidade Federal do Pará (PPGSA/ UFPA).E-mail: smag@ufpa.br

\begin{abstract}
Resumo
No presente ensaio propusemo-nos - face ao avanço dos grandes projetos de mineração - a fazer uma reflexão sobre a questão fundiária e os direitos territoriais das comunidades locais em Moçambique. A nossa reflexão encontra-se dividida em três pontos. No primeiro, buscamos fazer uma análise crítica do discurso de desenvolvimento, que norteia os grandes projetos de mineração em Moçambique, evidenciando com base nos estudos da Amazônia brasileira o lado obscuro do mesmo. No segundo nos ocupamos por uma análise meramente jurídica sobre as formas de apropriação do território em Moçambique. No terceiro discutimos a questão dos direitos territoriais das comunidades locais face aos deslocamentos compulsórios provocados por grandes projetos. Neste advogamos a necessidade de uma discussão "profunda" sobre os direitos territoriais das comunidades locais, face ao avanço dos grandes projetos, tendo em conta que os deslocamentos compulsórios não são, exclusivamente, um deslocamento espacial, mas também, dos vestígios que reforçam a memória coletiva e da história sociocultural dessas comunidades.
\end{abstract}

\section{Palavras-chave}

Moçambique. Grandes Projetos de Mineração. Direitos Territoriais. Comunidades Locais.

\begin{abstract}
In this paper we proposed to analyze the land question and the territorial rights of local communities in Mozambique, before the advancement of large mining projects. Our reflection is divided into three points. In the first one we seek to make a critical analysis of the development discourse which guides the large mining projects in Mozambique showing based on studies of the Brazilian Amazon the dark side of it. In the second we make a juridical analysis of the appropriation forms of land in Mozambique. In the third we discuss the question of land rights of local communities before the forced displacement caused by large projects. In this point we advocate the necessity of a "thorough" discussion about the territorial rights of local communities, before de advancement of large projects in Mozambique, considering that the forced displacement are not simply a spatial displacement but also of the traces that strengthen memory collective and of the socio-cultural history of these communities.
\end{abstract}

\section{Keywords}

Mozambique. Large Mining Projects. Territorial Rights. Local Communities. 


\section{INTRODUÇÃO}

Nos últimos 10 anos vêm-se verificando em Moçambique grandes transformações socioeconômicas provocadas pelo avanço de grandes projetos de mineração, com destaque para o projeto de Moatize e o projeto de Benga na província de Tete, região centro de Moçambique, dois dos grandes projetos de exploração mineral. O projeto de Moatize é operado pela empresa Vale Moçambique $^{1}$, uma multinacional pertencente à empresa brasileira Vale, com uma licença de exploração, assinada com o Governo Moçambicano em 2007, numa área estimada em aproximadamente 23,780 hectares no distrito de Moatize (MOSCA; SELEMANE, 2011). O projeto Benga operado pelo Rio Tinto², uma empresa com capitais anglo-australianos e possui uma licença de concessão mineira para uma área de 4,560 hectares, com duração de 25 anos (SELEMANE, 2010). Ambas incluem áreas que eram historicamente habitadas.

Um dos efeitos sociais diretos dos dois grandes projetos foi a expropriação do território por meio do deslocamento compulsório das comunidades locais. O Projeto de Moatize, por exemplo, afetou e obrigou ao deslocamento compulsório de 1.365 famílias, transferidas involuntariamente na sua maioria em duas áreas determinadas pela empresa em convênio com o governo local (do distrito de Moatize e da província de Tete), nomeadamente Cateme, que se localiza a 40 $\mathrm{km}$ da Vila Sede de Moatize, para as populações que foram classificadas como rurais - foram classificadas como rurais a famílias que viviam da agricultura e outras atividade "informais" como olearia - e bairro 25 de Setembro na Vila de Moatize para as famílias classificadas como semiurbanas - funcionários e, por exemplo, trabalhadores das diversas empresas (SELEMANE, 2010; MOSCA; SELEMANE, 2011; HRW, 2013).

Estima-se que das 1.365 famílias do Projeto de Moatize, 717 famílias foram deslocadas para Cateme, 289 para o bairro 25 de Setembro, o restante foram deslocados compulsoriamente mediante indenização (MOSCA; SELEMANE, 2011; SELEMANE, 2010; HRW, 2013). Por sua vez, o projeto de Benga operacionalizado pela multinacional Rio Tinto obrigou ao deslocamento compulsório, aproximadamente 600 famílias de Benga, em sua maioria reassentadas em Mwaladzi, localidade kambulatsitsi, que se localiza a $4 \mathrm{~km}$ de

\footnotetext{
1 Importa frisar que a Vale constitui a segunda maior empresa mineradora do mundo com operações em quase todos Estados Brasileiros e em seis continentes (MARSHALL, 2012) incluindo a África, com destaque para as suas atividades em Moçambique.

2 A empresa Rio Tinto constitui uma das maiores empresas de mineração do mundo com presença em aproximadamente 40 países em todo o mundo (HRW, 2013, p. 46). Na África se destaca atualmente a sua presença em Moçambique.
} 
Cateme, o maior centro de reassentamento da Vale, e $40 \mathrm{~km}$ da cidade de Tete, a capital da província de mesmo nome (MOSCA; SELEMANE, 2011).

É diante desta realidade dos deslocamentos compulsórios em Moçambique - expropriação das comunidades locais do seu território, - provocados pelo avanço dos grandes projetos de mineração que no presente ensaio nos propusemos a analisar a questão fundiária e os direitos territoriais das comunidades locais em Moçambique.

O trabalho está dividido em três pontos essenciais, no primeiro, buscamos fazer uma análise crítica da ideia de desenvolvimento, enquanto um discurso que norteia os grandes projetos de mineração, evidenciado com base nos estudos da Amazônia brasileira o lado obscuro dos mesmos - degradação ambiental, usurpação e expropriação do território. No segundo nos ocupamos por uma análise meramente jurídica sobre as formas de apropriação do território em Moçambique. No terceiro e último ponto fazemos uma reflexão sobre a questão dos direitos territoriais das comunidades locais face aos deslocamentos compulsórios provocados por grandes projetos.

\section{GRANDES PROJETOS DE MINERAÇÃO: DO DISCURSO DE DESENVOLVIMENTO À USURPAÇÃO E DEGRADAÇÃO DO TERRITÓRIO}

Os Estados são inventados como modernos e Moçambique não foge a essa lógica. Enxerga-se dentro de uma "linha evolucionista" rumo ao desenvolvimento. "Cego seguidor" duma lógica de desenvolvimento, que tem, por exemplo, nos grandes projetos como um dos setores dinamizadores. Lógica de desenvolvimento essa, que, apesar de se apresentar como universal, é local inerente a uma cultura específica ocidental (SOUZA PINTO; MIGNOLO, 2015). Ou seja, é economicista, eurocêntrica e instrumental.

Economicista, pois, na forma em que é abordada pelos grandes projetos, incluindo os setores governamentais e órgãos locais de poder, se trata de uma perspectiva de desenvolvimento reduzida ao crescimento econômico, centrado em variáveis quantificáveis ignorando as questões "não quantificáveis” tais como a diversidade sociocultural e as lógicas específicas de produção, organização e reprodução social das comunidades locais. Eurocêntrica, na medida em que se baseia no parâmetro ocidental de sociedade como parâmetro universal de reprodução social ignorando a variabilidade dos contextos socioculturais. Instrumental, pois são práticas e discursos acoplados aos interesses de grande capital (VIOLA, 2000). 
Estas três características constituem o cerne do que se denomina de paradigma da modernização. Aliás, é neste contexto da redução do desenvolvimento à modernização que se fundamenta, se olharmos o contexto global, a distinção, por um lado, entre o primeiro mundo, segundo e terceiro, acoplado, segundo Lewis (2005), numa cadeia evolutiva, no sentido darwiniano, onde os primeiros seriam mais desenvolvidos e os últimos pobres. Por outro, entre Norte e Sul fundado num discurso que é fruto da distinção entre sociedades modernas e tradicionais, no sentido durkheminiano, onde os primeiros seriam modernos e os últimos periféricos e tradicionais. Estas distinções caracterizam atualmente o sistema global de poder (LEWIS, 2005).

Nesta lógica de pensamento as sociedades tradicionais, por exemplo, como as próprias sociedades africanas e algumas comunidades tradicionais da Amazônia brasileira, foram e continuam sendo percebidas como um obstáculo ao desenvolvimento (VIOLA, 2000). Pois "estas culturas eram identificadas com atitudes de fatalismo, imobilismo e obscurantismo e com estruturas sociais obsoletas" (LEWIS, 2005, p. 16).

Um das críticas ao paradigma da modernização provém do que se denomina da teoria da dependência. Esta rejeita as ideias evolucionistas da teoria da modernização e centram as suas análises na relação desigual entre Norte "dominador" e o Sul "dominado" em termos comerciais. Estas relações comerciais desiguais são vistas como um amplo processo que cria o subdesenvolvimento dos países periféricos, com destaque para os africanos no âmbito da sua integração no sistema capitalista global (LEWIS, 2005).

Contudo é na teoria do post-development (ESCOBAR, 2000, 2005; PIETERSE, 2000) - este último com uma vertente crítica à própria ideia de postdevelopment - que tem como uma das principais referências o antropólogo Arturo Escobar, em que se encontra uma das mais contundentes abordagens críticas ao "desenvolvimento". Este visto como um discurso e, acima de tudo, como um "discurso" ocidental hegemônico e de dominação global. É por essa razão que a teoria do post-development advoga uma necessidade radical de repensar as concepções e os objetivos de desenvolvimento entendidos como reflexo, de uma ideologia cultural ocidental hegemônica que impõe uma homogeneização de valores materiais, imposição de conhecimento, e cria um nível sem precedente de destruição do ambiente (LEWIS, 2005). Para Arturo Escobar, por exemplo, o discurso do desenvolvimento atua como um novo orientalismo permitindo a invenção do terceiro mundo (VIOLA, 2000).

Para os Estados classificados como de terceiro mundo, como é o caso de Moçambique, o desenvolvimento é um "sonho a ser alcançado desesperadamente" 
e os grandes projetos incentivados por uma política de "desenvolvimento" que vem cada vez mais se centrando, tal como acontece na Amazônia brasileira, na exploração e exportação de commodities representam atualmente uma "esperança", uma "falsa esperança", na melhor das hipóteses.

Um dos efeitos sociais diretos do avanço dos grandes projetos em Moçambique e consequentemente dessa lógica de desenvolvimento são, tal como destacamos na introdução, os deslocamentos compulsórios das comunidades locais. Estas são colocadas numa possibilidade de viver, mas na condição de deixarem de ser o que são (BOURDIEU; SAYAD, 2006). Entendemos por deslocamentos compulsórios como uma situação onde "determinados grupos sociais são obrigados a deixar ou a transferir-se de suas casas e/ou de suas terras" (MAGALHÃES, 2007, p. 14). Trata-se, no caso dos grandes projetos, de um processo de usurpação do território "atenuado" por um discurso "triunfalista de desenvolvimento" que é baseado, tal como vemos destacando, num olhar eurocêntrico homogeneizante e que ignora a diversidade sociocultural, esta vista como uma barreira ao próprio desenvolvimento e modernização (CREWE; HARRISON, 2005).

O discurso triunfalista de desenvolvimento que caracteriza os grandes projetos não pode ser visto de forma dissociada do discurso triunfalista da própria ideia de modernidade, - entendemos neste contexto por modernidade no sentido abordado pela perspectiva dos estudos pós-coloniais e da decolonialidade (SOUZA PINTO; MIGNOLO, 2015; MIGLIEVICH-RIBEIRO, 2014; MATA, 2014); como um projeto de dominação epistêmica, econômica e política do mundo - que esconde, segundo Souza Pinto e Mignolo (2015) horrores como a colonialidade, - uma relação já evidenciada por Aníbal Quijano (2005) - o genocídio dos outros povos, a destruição das diversidades socioculturais (MIGLIEVICH-RIBEIRO, 2014), degradação dos solos, bem como a expropriação ou os deslocamentos compulsórios das comunidades locais.

Trata-se de "contradições, desastrosas e camufladas" (MIGLIEVICHRIBEIRO, 2014, p. 68) por uma “cosmovisão moderna hegemônica”, que caracteriza os grandes projetos de desenvolvimento, por exemplo, em Moçambique e que norteia o discurso desenvolvimentista do Estado Moçambicano e das empresas multinacionais que se anunciam como "salvadores da pátria".

Ao reproduzir o discurso de desenvolvimento acoplado à ideia de modernidade, estes não se dão conta que o mesmo, apesar de se apresentar como universal ou uma realidade objetiva ele é local, é eurocêntrico, muito menos conseguem compreender que depois do pretexto salvacionista e civilizacionista, hoje o lógica desenvolvimentista assume-se de acordo com Souza Pinto e Mignolo (2015) como uma nova forma de dominação e de colonização dos povos. 
Primeiro foi, tal como evidenciam os autores, no continente Americano,

os povos originários desse continente foram os primeiros a sentir mais fortemente o impacto do esforço salvacionista, civilizatório e desenvolvimentista dos europeus ocidentais. Ao argumento de que resistiam às tentativas de salvá-los do paganismo e do primitivismo a que supostamente se encontravam aprisionados, os vários povos e etnias que milenarmente habitavam o continente americano, do sul ao norte, foram desapropriadas de suas terras, removidos e circunscritos a áreas "reservadas", pobres de recursos e impróprias a suas formas de organização econômica e política. Submetidos a um esmagador processo de dominação cultural, suas vozes foram silenciadas, suas memórias - inclusive de resistência - foram apagadas, suas crianças lhes foram arrancadas e internadas em escolas-fábricas de ocidentalizados. Sem passado nem futuro, os que não foram confinados, foram submetidos ao trabalho forçado, e os que sobreviveram ao extermínio - e muitos milhões foram exterminados já nos primeiros contatos com os europeus ocidentais - foram reduzidos à condição de "índios" (SOUZA PINTO; MIGNOLO, 2015, p. 389).

A Amazônia brasileira, por exemplo, seguindo essalógica desenvolvimentista dinamizada principalmente a partir da década 1980, transformou-se em uma zona de expansão do capitalismo industrial, que adentrou a floresta tropical úmida por meio, por exemplo, da exploração mineral, - hoje pelo agronegócio "realizada por diversos grupos empresariais, estatais e privados, secundada por um incipiente processo de industrialização que visou a verticalização da produção mineral e sídero-metalúrgica na região" (SILVA NETO, 2012, p. 18).

Esta expansão capitalista para a Região Amazônica foi realizada, segundo o mesmo autor, totalmente à revelia de um imenso número de grupos sociais que tradicionalmente ocupavam as terras que foram convertidas por essa lógica desenvolvimentista, em espaços de negócios; dentre os quais a grande heterogeneidade de povos indígenas, famílias camponesas emigrantes de várias áreas do Brasil, dentre outras populações tradicionais, secularmente "invisibilizadas", segundo Treccani (2014), desde o tempo colonial.

De acordo com Silva Neto (2012), os projetos de desenvolvimento pensados pelos órgãos de planejamento governamentais para esta região partiram, tal como acontece atualmente em Moçambique, sempre de uma perspectiva produtivista que tomou como forma ideal de organização social da produção a empresa capitalista, cuja instalação requereu naturalmente a apropriação privada de vastas extensões de terras outrora públicas, assim como de florestas primárias e secundárias, tradicionalmente usadas de modo livre ou comunal pelas populações locais, trazendo, junto com algum progresso econômico, inúmeros conflitos e 
tensões sociais (SILVA NETO, 2012). Ou seja, a Amazônia se transformou num território de capital contra o território dos povos (LEROY, 2010) e consequentemente num território de resistência e conflitos entre lógicas distintas de apropriação do território (MESQUITA, 2011; SANT’ANA JÚNIOR, 2014).

Em segundo plano o pretexto salvacionista, civilizacionista e hoje desenvolvimentista atingiu o continente Africano, onde,

à semelhança dos povos originários da América, os diferentes povos e etnias africanas, especialmente as subsaarianas, foram submetidas a um brutal controle e gerenciamento subjetivo e epistêmico, além de econômico e político. Diferentemente de seus consortes americanos, no entanto, por terem sido posicionados, por força de argumentos inicialmente cristãoteológicos e posteriormente científico-biológicos, no mais primitivo estágio da linha de evolução humana articulada no discurso eurocêntrico de modernidade, os subsaarianos, em sua grande parte, foram reduzidos a mera mercadoria, tendo sido comercializados, sobretudo na América, para onde foram massiva- mente exportados e utilizados como mão de obra escrava, até quando, por razões mais econômicas do que éticas, ou melhor, por força de uma ética econômica, foram trocados por trabalhadores assalariados, muitos dos quais imigrados de regiões periféricas da Europa (SOUZA PINTO; MIGNOLO, 2015, p. 390).

Portanto, longe da lógica civilizacionista e da colonização política, hoje o discurso "desenvolvimentista" caracteriza a nova forma de dominação e exploração dos povos, que tem nas empresas capitalistas e os grandes projetos como uns dos atores dinamizadores. É na América e concretamente na Amazônia brasileira que encontramos evidências claras do lado obscuro do projeto desenvolvimentista (COSTA, 2011; SILVA NETO, 2012, ALMEIDA, 2011; LEROY, 2010; FARIAS JÚNIOR, 2010; GAVIRIA, 2013; TRECCANI, 2014), hoje reproduzido no contexto moçambicano, diante da ingenuidade consciente dos setores governamentais, por meio de grandes projetos de desenvolvimento ligados à atividade de exploração mineral.

Farias Júnior (2010) evidencia, por exemplo, que o avanço das atividades de mineração no Município de Oriximiná com o apoio do Estado, por meio da criação de Unidades de Conservação Ambiental, - estes que segundo a realidade evidenciada pelo autor naquela realidade sociocultural, inviabilizam os direitos das comunidades tradicionais quilombolas de demarcação e titulação das suas terras tradicionalmente ocupadas, em detrimento dos interesses empresariais de mineração - põem em causa os próprios interesses ambientais das Unidades de Conservação devido às práticas devastadoras e altamente perigosas ao ambiente naquela região do estado do Pará (FARIAS JÚNIOR, 2010). 
O autor cita, por exemplo, o desastre ambiental ocorrido no Lago Batata, na Bacia do Rio Trombetas, "que entre as décadas de 79 e 89, era utilizado pela empresa MRN como bacia de rejeitos, despejando, aproximadamente 24 milhões de toneladas de rejeitos de lavagem de bauxita que causou danos ambientais incalculáveis e irreversíveis" (FARIAS JÚNIOR, 2010, p. 122), como um dos exemplos de desastre ambiental provocado pelas atividades de exploração mineral naquela região da Amazônia brasileira.

Este fato torna de certa forma, os conflitos entre as comunidades tradicionais e as empresas mineradoras inevitáveis. Aliás, é importante frisar que conflitos envolvendo as comunidades tradicionais e as empresas mineradoras constituem um fenômeno constante na Amazônia brasileira, devido à capacidade de resistências dos primeiros, denunciando, por exemplo, a incompatibilidade das atividades de mineração com as suas práticas históricas de ocupação e uso de território, que afetam as suas condições específicas de produção, organização e reprodução material, cultural e social, conforme constatado por Gaviria (2013), no município de Juriti Velho, no estado do Pará.

$\mathrm{O}$ privilégio dado pelo poder político às atividades mineradoras, e de um modo geral, aos interesses de exploração capitalista, como é o caso das empresas agropecuárias, madeireiras e os grandes projetos industriais e de infraestruturas, nas terras da Amazônia brasileira, é denunciada também por Treccani (2014). Tal como afirma o autor,

nas últimas cinco décadas, com apoio do Estado brasileiro, o capital avançou sempre mais sobre as últimas fronteiras naturais amazônicas disputando territórios com populações indígenas, quilombolas e demais populações tradicionais e locais, transformando as terras e floresta, água, solo e subsolo em 'mercadoria', a ser leiloada na perversa dinâmica das 'leis do mercado’ em que a exploração indiscriminada da natureza e da própria vida humana viraram 'oportunidade de negócio' destruição e conservação, que passam a ter preço (TRECCANI, 2014, p. 162).

A expansão das atividades de mineração está, ainda segundo o autor, entre os responsáveis pela ampliação dos conflitos socioambientais nessa região, sendo a usurpação e a expropriação do território das populações e outras comunidades locais elementos de grande destaque.

A relevância dessas abordagens, que podem parecer desconexas ao nosso horizonte espacial reflexivo, tendo em conta que são inerentes ao contexto da Amazônia brasileira e não moçambicano, reside no fato de evidenciarem que longe do "propagado" desenvolvimento, que norteia os discursos dos atores das empresas nacionais ou multinacionais, bem como dos órgãos governamentais, 
os grandes projetos de mineração apresentam efeitos "catastróficos" como a degradação ambiental, a ampliação de conflitos sociais e acima de tudo, a usurpação e expropriação do território, com efeitos sociais diretos nas comunidades locais.

Se por um lado essas discussões são um "alerta" para uma reflexão profunda sobre a lógica desenvolvimentista que vem sendo adotada em Moçambique, nos últimos anos, que tem nos grandes projetos ligados não só, à mineração, como também, à indústria energética e ao agronegócio, como uns dos setores dinamizadores. Por outro, tornam oportuno um profundo debate sobre os direitos territoriais das comunidades locais naquela realidade sociocultural.

\section{A QUESTÃO FUNDIÁRIA EM MOÇAMBIQUE: É POSSÍVEL FALAR DOS DIREITOS TERRITORIAIS DAS COMUNIDADES LOCAIS?}

O objetivo central nesse tópico é abordar as formas de apropriação do território em Moçambique, problematizando a questão da diversidade sociocultural e buscando refletir como ela se efetiva nos direitos territoriais. Discutir essa questão nos obriga a abordar em primeiro lugar a dicotomia entre a uniformidade ou a visão monista do direito e pluralismo jurídico, - os juristas Jose Heder Benatti (2011) e Deborah Duprat (2007) nos introduzem melhor nessas questões - tendo em conta que é neste último que se amparam, no caso brasileiro, as formas de apropriação coletiva do território.

\subsection{O DIREITO MOÇAMBICANO: VISÃO MONISTA OU PLURALISMO JURÍDICO?}

A visão monista do direito pressupõe a homogeneização do direito por meio de uma visão jurídica oficial, unitária e totalizante (BENAT'TI, 2011). Tratase de uma visão que se fundamenta na lógica imposta pelo direito oficial baseado na compreensão predominante de que só é "considerado jurídico o que o Estado elabora e o restante é pseudo direito ou um direito inferior" (BENATTI, 2011, p. 95). Esta perspectiva jurídica não pode ser vista de forma dissociada da lógica integradora de direito baseada, tal como evidencia Duprat (2007), na colonização da diferença.

No caso específico dos direitos territoriais, importa frisar que é nessa lógica monista e positiva de direito - que para Benatti (2011) reduz a dimensão ampla e complexa do jurídico, - que se ampara a configuração do regime jurídico de propriedade acoplado, exclusivamente, na propriedade individual como único modelo de apropriação do território, ignorando desse modo o direito a 
apropriação comunitária dos recursos, a propriedade comum ou apropriação coletiva do território (BENAT'TI, 2011).

O pluralismo jurídico pressupõe a descolonização da diferença pelo direito homogeneizante (DUPRAT, 2007) e, no que concerne aos direitos territoriais, representa uma nova configuração do regime jurídico de propriedade, alternativo à propriedade individual, como é o caso da propriedade comum (BENATTI, 2011).

O reconhecimento do pluralismo jurídico é o reconhecimento da diversidade sociocultural do Estado nacional e a superação da falsa homogeneidade nacional propagada pela ideia do Estado-Nação, baseado numa lógica da unidade como sinônimo da uniformidade e integração e não do reconhecimento da diferença (CASTELLS, 1999). No caso do Brasil, por exemplo, a promulgação da Constituição Federal de 1988 reafirma o caráter pluriétnico e multicultural do país, que o direito deve ter, segundo Duprat (2007), como marco referencial.

De acordo com a autora, com a Constituição de 1988 passa a se falar no Brasil, não só, dos direitos coletivos inerentes ao lócus étnico e cultural e a lógica específica de produção, organização e reprodução social, como também de espaços de pertencimento e de territórios, com uma configuração distinta da propriedade privava que é de natureza individual com viés da apropriação econômica (DUPRAT, 2007 p. 4). Ou seja, "a Constituição reconhece expressamente direitos específicos a índios e quilombolas, em especial seus territórios. Mas não só a eles. Também são destinatários de direitos específicos os demais grupos que tenham formas próprias de expressão e de viver, criar e fazer" (DUPRAT, 2007, p. 5).

Este fato representa, por um lado, uma vitória dos movimentos de reivindicação e de luta contra a invisibilização social ou cultural, por exemplo, das populações tradicionais com destaque para as comunidades quilombolas e dos povos indígenas, secularmente invisibilizadas e suprimidas pelo Estado Brasileiro, por outro, de todo o processo em que o Direito abandona, de um lado, "a visão atomista do indivíduo e o reconhece como portador de identidades complexas e multifacetadas. De outro, recupera o espaço comum onde são vividas as suas relações definitórias mais importantes" (DUPRAT, 2007, p. 4).

No caso de Moçambique, - um país caraterizado por uma diversidade sociocultural inerente a sua diversidade étnica, ou seja, Moçambique é tal como vários países africanos, pela sua formação violenta inerente aos interesses coloniais, um país multiétnico, multicultural e multilinguístico - a Constituição da República de Moçambique (CRM), se por um lado, reafirma o Estado de direito democrático baseado no pluralismo de expressão, na organização política 
democrática e acima de tudo no respeito e garantia dos direitos e liberdades fundamentais do homem (Art. 3 CRM). Por outro, destaca dentre outros aspectos, o caráter plural do ordenamento jurídico moçambicano, fundado nesse contexto no reconhecimento dos "vários sistemas normativos e de resolução de conflitos que coexistem na sociedade moçambicana" (Art. 4 da CRM).

A questão que permanece, - tendo como inspiração as discussões do contexto brasileiro onde o pluralismo jurídico garante o reconhecimento da diversidade sociocultural do Estado nacional, do caráter pluriétnico e multicultural, e dá amparo legal para a apropriação coletiva do território por parte dos povos indígenas, das comunidades tradicionais, - é relativa à relação que o pluralismo jurídico em Moçambique tem com os direitos do território. Abordar essa questão passa por analisar as formas de apropriação de território em Moçambique.

\subsection{FORMAS DE APROPRIAÇÃO DO TERRITÓRIO EM MOÇAMBIQUE}

A terra é segundo alínea 01 do Art. 109 (CRM), propriedade do Estado, isso significa que ela não pode ser vendida ou alienada, hipotecada ou mesmo penhorada, isso de acordo com o número 2 do mesmo artigo da CRM, conjugado com o Art. 03 da Lei n. 19/97 de 01 de Outubro, que estabelece os "os termos em que se opera a constituição, exercício, modificação, transmissão e extinção de direito de uso e aproveitamento da terra" (Art. 02); Lei de Terras de Moçambique. Ou seja, o direito exclusivo de propriedade que o Estado tem integra não só todos os direitos de propriedade, mas também, a faculdade de determinar, segundo o $\mathrm{n}^{\circ} 15$ do Art. 01 da Lei de Terras, as condições de uso e de aproveitamento da terra, por parte das pessoas singulares ou coletivas.

Neste contexto, a única forma de apropriação é a obtenção do Direito de Uso e Aproveitamento da Terra (DUAT), que pode ser conferido de acordo com a Constituição da República de Moçambique, a título singular conferido pelo Estado a pessoas singulares e a título coletivo, atribuído as pessoas coletivas (n. 02, Art. 110 CRM). Incluindo a apropriação coletiva da terra pelas comunidades locais, tal como evidencia a Lei de Terras nos seus artigos 10, 12, 13, 15, 24, respectivamente.

A Lei de Terras estabelece três formas de ocupação da terra: primeiro a ocupação por pessoas singulares e pelas "comunidades locais", segundo as normas e práticas costumeiras; segundo, a ocupação por pessoas singulares nacionais - quaisquer cidadãos de nacionalidade moçambicana - que, de boa fé, estejam a utilizar a terra há pelo menos dez anos; e terceiro mediante autorização pelo Estado, respectivo do pedido de uso e aproveitamento da terra apresentado por pessoas singulares ou coletivas. E nesta terceira forma, que se encontra 
segundo ACIS (2012) a única possibilidade de obtenção de DUAT por parte das pessoas singulares e coletivas estrangeiras. Incluindo as empresas multinacionais e em consonância com as normas específicas de cada atividade de exploração.

Definem-se no âmbito da Lei de Terras como "comunidades locais" o "agrupamento de famílias e indivíduos, vivendo numa circunscrição territorial de nível de localidade ou inferior, que visa à salvaguarda de interesses comuns através da proteção de áreas habitacionais, áreas agrícolas, sejam cultivadas ou em pousio, florestas, sítios de importância cultural, pastagens, fontes de água e áreas de expansão" (n. 01 do Art. 01).

O título de ocupação coletiva por parte das comunidades locais é emitido, tal como nas restantes possibilidades de obtenção de DUAT, pelos Serviços Públicos de Cadastro (n. 01 Art. 13), e é nominativo de acordo com a denominação adoptada pelas próprias comunidades (n. 04 Art. 13). Um fato que importa destacar é que a falta de titulação - documento emitido pelos serviços públicos de cadastro, gerais ou urbanos, que serve de comprovativo do direito de uso e aproveitamento da terra - ou de registro, não prejudica o direito de uso e aproveitamento da terra adquirido pelas comunidades locais por ocupação, desde que essa ocupação possa ser comprovada (n. 02 do Art. 13 e art. 14 da Lei de Terras). E essa comprovação pode ser feita, por exemplo, pela prova testemunhal dos membros, homens e mulheres, das comunidades locais, conforme alínea b do art. 15 da Lei Terras.

O reconhecimento dado às comunidades locais ao uso e aproveitamento coletivo da terra implica, por um lado, a consagração pela Lei de Terras dos direitos costumeiros (CAMBAZA, 2009) e consequentemente do pluralismo jurídico previsto no artigo 04 da CRM. E, por outro, o reconhecimento dos diretos territoriais inerentes à ocupação tradicional e histórica.

Torna-se imprescindível clarificar do que estamos falando quando nos referimos ao território e aos direitos territoriais. Esse é um dos aspetos que nos ocuparemos a seguir, ao mesmo tempo em que faremos uma reflexão crítica sobre os deslocamentos compulsórios das comunidades locais, apresentando desse modo as notas conclusivas.

\section{A QUESTÃO DOS DIREITOS DO TERRITÓRIO E OS DESLOCAMENTOS COMPULSÓRIOS POR GRANDES PROJETOS: NOTAS CONCLUSIVAS}

O conceito de território das comunidades locais abrange, - tal como podemos constatar na vasta literatura, seja ela jurídica ou socioantropológica, 
sobre as comunidades tradicionais e povos indígenas na Amazônia, (BRINGAS, 2006; VERDUM, 2011; MESQUITA, 2011; PRIOSTE; ALVES; CAMERINI, 2011; INGLEZ DE SOUSA, 2012; CRUZ, 2013; BECKER, 2014; ALMEIDA, 2011; 2014; TRECCANI, 2014, só para citar alguns.) - categorias como pertencimento, simbolismo, significado, história do grupo e acima de tudo identidade e autorreconhecimento. O reconhecimento de direitos territoriais das comunidades locais implica o reconhecimento dessa pluralidade de categorias.

Portanto falar do território das comunidades locais é falar de um espaço significado e transformado por meio das formas específicas de apropriação, uso, controle e atribuição de significados via formas de vivência e de identificação com o meio ambiente, por parte de um determinado grupo coletivo (BAINES, 2014; GODOI, 2014). O território é resultado de um investimento material e simbólico e se exprime por um sistema de representações e princípios de organização social, econômica, política e cultural, específicos de cada grupo social e geridos, por exemplo, por uma lógica de "pertencimento e de parentesco". Ou seja, "o território antes de se exprimir por uma ligação ao espaço é uma relação entre as pessoas e se refere a uma organização do espaço carregada de história" (GODOI, 2014, p. 13) e não pode ser entendido fora desse contexto. O território das comunidades locais é um produto histórico.

Isso implica que a nossa percepção de território se encontra longe das concepções que o compreendem, exclusivamente, como sinônimo de espaço, ou simplesmente como “fonte de recursos' disputados ou, ainda, de elementar 'apropriação da natureza” (GODOI, 2014, p. 10). Talvez o nosso entendimento se aproxime mais para o que a antropóloga Edna Alencar (2002; 2007; 2013) denomina de "lugar", visto por ela, como um espaço socialmente significativo, construído e transformado pelo trabalho das gerações passadas e é nele onde se inscreve a história do grupo.

Não existe, segundo a autora, um grupo social que não tenha alguma relação com o lugar. A relação que o lugar tem com a memória social, a história das gerações passadas garante o vínculo de pertencimento e serve de fator dissuasor - para alguns grupos sociais - à mobilidade para outros locais, tal como foi constatado pela autora na sua pesquisa onde buscou compreender o processo de afirmação da identidade dos moradores de São João, um povoado situado na área Reserva de Desenvolvimento Sustentável Mamirauá, região de várzea do médio Solimões, estado do Amazonas, que convive permanentemente com o fenômeno de "terra caída" (ALENCAR, 2002; 2007; 2013).

De acordo com Alencar (2007, p. 98), 
quando o grupo social abandona um lugar, o lugar deixa de existir e se perdem os fios da história do grupo que lhe deu origem. Portanto é o grupo social que constrói e dá significado ao lugar, e cada grupo constrói sua identidade a partir dos vínculos de parentesco que unem as famílias entre si e estas com o lugar aberto pelos ancestrais. O pertencimento ao lugar, e a um grupo de parentesco garante o acesso ao território e aos recursos naturais, e funciona como um mapa cognitivo que orienta as relações entre as pessoas e entre essas e o ambiente.

Neste contexto, podemos afirmar que os deslocamentos compulsórios das populações por grandes projetos ligados, principalmente as atividades extração mineral não são, simplesmente, um deslocamento espacial, mas sim um deslocamento dos vestígios que reforçam a memória coletiva e de toda uma história social de um grupo, em todos os seus aspetos culturais, sociais, simbólicos, econômicos, bem como dos aspetos ligados à lógica própria de produção, organização e reprodução social.

Isso introduz no debate sobre os direitos de território em Moçambique, principalmente, numa altura em que se vem verificando o avanço dos grandes projetos ditos de desenvolvimento ligados à mineração, à indústria energética e ao agronegócio. A reflexão na arena pública dessa pluralidade de categorias como pertencimento, memória coletiva, história do grupo, identidade, entre outros aspetos culturais e simbólicos, invisíveis para grandes empresas multinacionais e para o Estado, cego por uma falsa esperança de desenvolvimento que traduz o discurso dos grandes projetos.

No discurso de desenvolvimento dos grandes projetos está patente o privilégio do domínio econômico e ignorância "propositada" da diversidade sociocultural, e das lógicas específicas de organização, produção e reprodução social das comunidades locais afetadas. O desrespeito pela diversidade sociocultural conduz à reestruturação das formas de organização social das comunidades. Este fato que se verifica primeiro, pela disciplina do espaço como critério para disciplinar as lógicas de vida das pessoas, pondo em causa as estruturas originais das comunidades, como o caso das redes de parentesco e reciprocidade (COLSON, 1971). A disciplina de espaço é impositiva e evidencia o caráter autoritário dos deslocamentos compulsórios. Os constantes abandonos dos locais de reassentamento, tal como foi constatado nas pesquisas etnográficas de Colson (1971) entre os Gwembe Tongas, na Zâmbia, e de Magalhães (2007), em 'Tucuruí, são de certo modo uma forma de resistência a essa imposição.

Em segundo lugar o desrespeito pela diversidade sociocultural se evidencia pelo discurso de melhoria de vida, fundado somente na ideia de modernização. Neste contexto, as empresas e os governos locais se veem, usando as palavras 
de Bourdieu e Sayad (2006) como "atores emancipatórios" que buscam dar o privilégio das comunidades viverem, na condição, não só, de deixarem os seus territórios, mas também de deixarem de ser o que são; deixarem a sua “identidade", o que evidencia, mais uma vez, a lógica homogeneizadora e autoritária que caracteriza a expropriação do território das comunidades locais por parte dos grandes projetos.

Embora a Constituição da República de Moçambique destaque o pluralismo jurídico e a Lei de Terras reafirme o direito de uso e aproveitamento da terra para as comunidades locais por ocupação, a realidade evidencia que pouco se tem feito por parte do Estado para o incentivo a essa lógica de apropriação do território; o que contribui para a prevalência da apropriação singular ou da propriedade individual. Cria-se desse modo, usando as palavras de Costa (2011, p. 79), espaço para a configuração de uma teia de mecanismo para a transferência para o domínio privado de extensões de terras ocupadas pelas comunidades locais.

Isso pode transformar Moçambique num território de capital contra o território dos povos (LEROY, 2010) e consequentemente, tal como vem se verificando, num território de conflitos entre as comunidades locais e as empresas de exploração capitalista e alguns setores do governo que insistem em transformar o espaço e seus recursos em plena mercadoria, passível, usando as palavras de Zhouri e Oliveira (2007), de apropriação privada para geração de riqueza destinada à exportação.

Embora a falta de título ou registro não prejudique o direito de uso e aproveitamento da terra das comunidades locais inerentes à ocupação, a titulação do direito coletivo de uso e aproveitamento da terra pode reforçar o sentimento de pertencimento e de identidade das comunidades locais moçambicanas aos respectivos territórios historicamente ocupados, o que pode permitir uma melhor participação dessas comunidades na gestão dos recursos naturais, como também, no processo de negociação com as empresas multinacionais no âmbito do avanço dos grandes projetos em Moçambique.

Gostaríamos de terminar com um parágrafo que reflete o nosso apelo:

Em universo social marcado pelo dificilmente contestável poder dos fazendeiros, dos empresários do agronegócio, o direito dos "pequenos" [...], na maioria das vezes, não é reconhecido como um direito, nem mesmo como sujeitos com capacidade de tornar a terra produtiva. Mais grave ainda são vistos como "sujeitos biologizados", uma mera extensão dos recursos naturais (COSTA, 2011, p. 82).

Moçambique está a caminhar a passos largos para essa triste realidade. 


\section{REFERÊNCIAS}

ALENCAR, E. F. Nesse tempo não existia essas ilhas por ali: sobre modos de perceber o ambiente e narrar o passado. Iluminuras, Porto Alegre, v. 14, n. 34, p. 11-32, 2013.

Paisagens da memória: narrativa oral, paisagem e memória social no processo de construção da identidade. Teoria \& Pesquisa, São Carlos-SP, v. XVI, p. 43-56. 2007.

Terra caída: encante, lugares e identidades. 2002. 245f. Tese (Doutorado em Antropologia) - Departamento de Antropologia, Universidade de Brasília, Brasília, 2002.

ALMEIDA, A. W. B. Cartografia Social na Amazônia: os significados de território e o rito de passagem da "proteção" ao "protecionismo". In: SIFFERT, N.; CARDOSO, M.; MAGALHÃES, W. A.; LASTRES, H. M. M. (Org.). Um olhar territorial para o desenvolvimento: Amazônia. Rio de Janeiro: BNDES, 2014. p. 350-369.

Territórios Quilombolas e Conflitos: comentários sobre povos e comunidades tradicionais atingidos por conflitos de terra e atos de violência no decorrer de 2009. In:_ (Org.). Os Quilombos e as Novas Etnias. Manaus: UEA Edições, 2011. p. 170-187.

A reconfiguração das agroestratégias: novo capítulo da guerra ecológica. In: SAUER, S.; ALMEIDA, W. (Org.). Terras e territórios na Amazônia. Brasília: Editora Universidade de Brasília, 2011. p. 27-44.

ACIS - Associação de Comércio e Indústria. O quadro legal para o reconhecimento e obtenção de Direitos de Terras em áreas rurais em Moçambique. Um guia para a legalização da ocupação. Edição III, 2012. Disponível em: <http://www.acismoz.com/lib/services/publications/docs/ Acesso $\% 20$ Terra $\% 20$ Rural $\% 20$ Edicao $\% 20 I I I \% 20$ Portugues.pdf $>$. Acesso em: 27 jan. 2016.

BAINES, S. G. Territórios, territorialização, territorialidades indígenas e os direitos à terra. Raízes, Porto Alegre, v. 34, n. 02, p. 17-25, 2014.

BECKER, B. K. A Amazônia como um território estratégico e os desafios das políticas públicas. In: SIFFERT, N.; CARDOSO, M.; MAGALHÃES, W. A.; LASTRES, H. M. M. (Org.). Um olhar territorial para o desenvolvimento: Amazônia. Rio de Janeiro: BNDES, 2014. p. 396-401. 
BENATTI, J. H. Propriedade comum na Amazônia: acesso e uso dos recursos naturais pelas populações tradicionais". In: SAUER, S.; ALMEIDA, W. (Org.). Terras e territórios na Amazônia. Brasília: Editora Universidade de Brasília, 2011. p. 93-113.

BOURDIEU, P.; SAYAD, A. A dominação colonial e o sabir cultural. Rev. Sociol. Polít, Curitiba, n. 26, p. 41-60, 2006.

BRINGAS, A. M. Territorialidades indígenas. Hiléia: Revista de Direito Ambiental da Amazônia, Manaus, v. 4, n. 7, p. 123-148, 2006.

CAMBAZA, V. A Lei de Terras, de Minas e os Direitos Consuetudinários. Conference Paper $\mathrm{N}^{\circ}$ 12. In: CONFERENCIA DO IESE, 2. Dinâmicas da Pobreza e Padrões de Acumulação Económica em Moçambique. Maputo: IESE, 2009. Disponível em: < http://www.iese.ac.mz/lib/publication/II_conf/ CP12_2009_Cambaza.pdf>. Acesso em: jan. 2016.

CASTELLS, M. O poder da identidade. In: . (Org.) A era da informação economia sociedade e cultura. São Paulo: Paz e Terra, 1999. v. 2.

COLSON, E. The social consequences of resettlement. The impact of the Kariba resettlement upon the Gwembe Tonga. Manchester: Manchester University Press, 1971.

COSTA, S. M. G. Agronegócio e Terras na Amazônia: conflitos sociais e desterritorialização após a chegada da soja na região do Baixo Amazonas no Pará. In: SAUER, S.; ALMEIDA, W (Org.). Terras e Territórios na Amazônia. Brasília: Editora Universidade de Brasília, 2011. p. 69-89.

CREWE, E.; HARRISON, E. Seeing culture as a barrier. In: EDELMAN, M.; HAUGERUD, A. (Ed.). The anthropology of development and globalization: from classical political economy to contemporary neoliberalism. Malden: Blackwell Publishing, 2005. p. 232-234.

CRUZ, V. C. Das lutas por redistribuição de terra às lutas pelo reconhecimento de territórios: uma nova gramática das lutas sociais? In: ACSELRAD, H. (Org.). Cartografia social, terra e território. Rio de Janeiro: IPPUR/UFRJ, 2013. p. 119-176.

DUPRAT, D. O Direito sobre o marco da plurietnicidade/multiculturalidade. In: _- (Org.). Pareceres jurídicos: direito dos povos e comunidades tradicionais. Manaus: UEA, 2007. p. 9-19. 
ESCOBAR, A. Imagining a post-development era? In: EDELMAN, M.; HAUGERUD, A. (Ed.). The anthropology of development and globalization: from classical political economy to contemporary neoliberalism. Malden: Blackwell Publishing, 2005. p. 341-351.

El lugar de la naturaleza y la naturaleza del lugar: globalization o posdesarrollo. In: VIOLA, A. (Ed.). Antropología del desarrollo. Barcelona: Paidós, 2000. p. 169-216.

FARIAS JÚNIOR, E. A. Unidades de Conservação, mineração e concessão florestal: os interesses empresariais e a intrusão de territórios quilombolas no Rio Trombetas. In: ALMEIDA, A. W. B. (Org.). Cadernos de Debates Nova Cartografia Social. Territórios Quilombolas e Conflitos. Manaus: UEA Edições, 2010. p. 116-127.

GAVIRIA. E. M. Mineração e regulação social na Amazônia: o caso da mineradora Alcoa e as comunidades de Juruti Velho, Pará. In: ACSELRAD, H. (Org.). Cartografia social, terra e território. Rio de Janeiro: IPPUR/UFRJ, 2013. p. 201-273.

GODOI, E. P. Territorialidade: trajetória e usos do conceito. Raízes, Porto Alegre, v. 34, n. 02, p. 8-16, 2014.

HRW - Human Rights Watch. O que é uma casa sem comida: o boom da mineração em Moçambique e o reassentamento. EUA, 2013. Disponível em: <https://www.hrw.org/sites/default/files/reports/mozambique0513port_ ForUpload_0.pdf.> Acesso em: 04 jul. 2014.

INGLEZ DE SOUSA, C. N. Dimensão fundiária da gestão territorial de Terras Indígenas no Brasil. In: INGLEZ DE SOUSA, C. N. ALMEIDA, F. V. R. (Org.). Gestão territorial em terras indígenas no Brasil. Brasília: Ministério da Educação, Secretaria de Educação Continuada, Alfabetização, Diversidade e Inclusão; Unesco, 2012. p. 76-124.

LEROY, J. P. Amazônia: território de capital e território de povos. In: ZHOURI, A.; LASCHEFSKI. K. (Org.). Desenvolvimento e conflitos ambientais. Belo Horizonte: UFMG, 2010. p. 92-113.

LEWIS, D. Anthropology and development: an uneasy relationship. In: LSE research online. London: 2005. 15 p. Disponível em: <https://core.ac.uk/ download/files/67/92474.pdf>. Acesso em: 20 set. 2015. 
MARSHALL, J. Megaprojetos de mineração e trabalho: trabalhar para Vale a pior empresa do mundo: casos do Canadá, Brasil e Moçambique. In: CONFERÊNCIA DO INSTITUTO DE ESTUDOS SOCIAIS ECONÔMICOS-IESE, 3. Maputo: IESE, 2012. Disponível em <http:/ /www.iese.ac.mz/lib/publication/ III_Conf2012/IESE_IIIConf_Paper21.pdf>. Acesso em: 04 jul. 2014.

MATA, I. Estudos pós-coloniais: desconstruindo genealogias eurocêntricas. Civitas, Porto Alegre, v. 14, n. 01, p. 27-42, 2014.

MESQUITA B. A. Conflitos Territoriais na Amazônia na era do capital. In: SHIRAISHI NETO, Joaquim. (Org.). Meio ambiente, território \& práticas jurídicas: enredos em conflito. São Luís: EDUFMA, 2011. p. 53-84.

MIGLIEVICH-RIBEIRO, A. Por uma razão decolonial: desafios ético-políticoepistemológicos à cosmovisão moderna. Civitas, Porto Alegre, v. 14, n. 01, p. 66-80, 2014.

MOSCA, J.; SELEMANE, T. EL Dorado Tete: Os megaprojetos de mineração. Maputo: Centro de Integridade Pública-CIP, 2011.

PIETERSE, J. N. “After post-development”. Third World Quarterly, v. 21, n. 2, p. 175-191, 2000. Disponível em: <http://www.uvm.edu/ bgreene1/ Bibliography2014/Topic04/PieterseAfterPostDevl.pdf $>$. Acesso em: 20 set. 2015.

PRIOSTE, F. G. V., ALVES, C. C. N., CAMERINI, J. C. B. Quem tem medo da Constituição Federal? Quilombos e o direito ao território. In: SAUER, S.; ALMEIDA, W. (Org.) Terras e Territórios na Amazônia. Brasília: Editora Universidade de Brasília, 2011. p. 297-316.

QUIJANO, Aníbal. Colonialidade do poder, eurocentrismo e América Latina. In: LANDER, E. (Org.). A colonialidade do saber: eurocentrismo e ciências sociais. Perspectivas latino-americanas. Buenos Aires: CLACSO, 2005. p. $107-130$.

SANT'ANA JÚNIOR, H. Projetos de desenvolvimento e a criação de reservas extrativistas: estratégias de luta de grupos sociais locais no Acre e no Maranhão. In: ESTERCI, N; SANT'ANA JÚNIOR. H; TEISSERENC, M. (Org.) Territórios socioambientais na Amazônia Brasileira. Rio de Janeiro: 7 Letras, 2014. p. 105-136.

SELEMANE, T. Questões a volta da mineração em Moçambique: Relatório de monitoria das atividades mineiras em Moma, Moatize, Manica e Sussundenga. Maputo: Centro de Integridade Pública-CIP, 2010. 
SILVA NETO, N. M. Quebradeiras e carvoeiros: a transformação do extrativismo de coco babaçu nas terras do Araguaia-Tocantins. 2012. 271f. Tese (Doutorado em Antropologia) - Instituto de Filosofia e Ciências Humanas, Universidade Federal do Pará, Belém, 2012.

SOUZA PINTO, J. R.; MIGNOLO, W. D. A modernidade é um fato universal? Reemergência, desocidentalização e opção decolonial. Civitas, Porto Alegre, v. 15, n. 3, p. 381-402, 2015. DOI: http://dx.doi.org/10.15448/19847289.2015.3.20580.

TRECCANI, G. D. Populações tradicionais e mineração. In: DIAS, J. C.; GOMES, M. A. M. (Org.). Direito e desenvolvimento. Rio de Janeiro; Belém; São Paulo: Forense, CESUPA e Método, 2014. p. 161-190.

VERDUM, R. Terras, territórios e a livre determinação territorial indígena. In: SAUER, S.; ALMEIDA, W. (Org.) Terras e territórios na Amazônia. Brasília: Editora Universidade de Brasília. 2011. p. 205-219.

VIOLA, A. La crisis do desarrollismo y el surgimiento de la antropología del desarrollo. In: (Org.) Antropología del desarrollo. Barcelona: Paidós, 2000. p. 9-64.

ZHOURI, A.; OLIVEIRA, R. Desenvolvimento, conflitos sociais e violência no Brasil rural: O caso das usinas hidroelétricas. Ambiente \& Sociedade, São Paulo, v. 10, n. 02, p. 119-135, 2007.

MOÇAMBIQUE. Lei 19/97 de 01 de outubro: Lei de Terras. Boletim da República de Moçambique. I SERIE, n. 40, Maputo, 1997.

RODRIGUES, L. B.; ALVES, S.; NGUENHA, J. Constituição da República de Moçambique e Legislação Constitucional. Coimbra: Almedina, 2006. 


\section{Desenvolvimento sustentável do Marajó, Pará: uma visão a partir do Barômetro da Sustentabilidade}

\section{Sustainable development of Marajó, Pará: an overview based on the Barometer of Sustainability}

Patrick Diniz Alves Quintela - Mestrando em Ciências Ambientais pela Universidade Federal do Pará. Bacharel em Agronomia pela Universidade Federal Rural da Amazônia. E-mail: patrick.agronomia@gmail.com

Peter Mann de Toledo - PhD in Geology - University of Colorado. Mestrado em Geociências pela Universidade Federal do Rio Grande do Sul e pesquisador do INPE lotado na Coordenação de Ciência do Sistema Terrestre.E-mail: peter.toledo@hotmail.com

Ima Célia Guimarães Vieira - Doutora em Ecologia - University of Stirling. Mestrado em Genética e Melhoramento de Plantas pela Universidade de São Paulo e Pesquisadora do Museu Paraense Emílio Goeldi. E-mail: ima@museu-goeldi.br

\section{Resumo}

Este trabalho apresenta uma análise da sustentabilidade de 16 municípios que compõem a mesorregião do Marajó, Pará. A pesquisa utilizou o Barômetro da Sustentabilidade (BS) como ferramenta de análise e empregou 20 indicadores para o bem-estar humano (dimensão socioeconômica) e 06 para o bemestar ecológico (dimensão ambiental). A abordagem do Barômetro da Sustentabilidade indicou que os municípios do Marajó variam de "potencialmente insustentável” a “intermediário". O Marajó mostrou um quadro de desequilíbrio em relação ao nível de sustentabilidade dos municípios, e a isso associamos a ineficácia dos resultados de políticas públicas integradas aliada à discrepância dos diferentes modelos de gestão municipal.

\section{Palavras-chave}

Sustentabilidade. Marajó. Indicadores. Desenvolvimento Sustentável.

\begin{abstract}
This paper presents an analysis of the sustainability of 16 cities from the Marajó region, State of Pará. We used the Barometer of Sustainability as an analytical tool and applied 20 indicators for human well-being (human dimension) and 06 for ecological health (environmental dimension). The Barometer approach shows a range of sustainability of Marajó municipalities between "potentially unsustainable" and "intermediate". The Marajó displays a disequilibrium in relation to the level of sustainability of the municipalities, and to this we associate the inefficiency of the results of integrated public policies combined with the discrepancy of the different municipal management models.
\end{abstract}

\section{Keywords}

Sustainability. Marajó. Indicators. Sustainable Development 


\section{INTRODUÇÃO}

A mesorregião do Marajó, no estado do Pará, apresenta-se como um território com atributos que o singularizam no cenário nacional. É constituído por um mosaico de ecossistemas dinâmicos, com uma rica biodiversidade. A tradição e a modernidade coexistem espacialmente entre interesses diversos e conflitantes - a maior parte dele é Área de Preservação Ambiental, possui grandes áreas de produção pecuária e elevada população de comunidades tradicionais que vivem do extrativismo vegetal, pesca e agricultura - e, desde 2006, tem havido tentativas de implementação de novos modelos de gestão e ordenamento territorial (BRASIL, 2007; 2012), visando o planejamento e a gestão social de políticas públicas para o desenvolvimento sustentável.

É fato que o desenvolvimento sustentável está presente como questão fundamental nas políticas públicas e considerando-se a sustentabilidade como um conceito dinâmico que engloba diferentes dimensões (VAN BELLEN, 2004), espera-se que não exista um favorecimento de políticas em relação a alguma dimensão específica, o que comprometeria o desenvolvimento, dito sustentável, em qualquer escala de análise.

O tema sustentabilidade tem acelerado o desenvolvimento teórico e prático de um conjunto de indicadores que permitem avaliar o desenvolvimento sustentável de um território (VAN BELLEN, 2005). Neste sentido, vários sistemas de indicadores de desenvolvimento sustentável estão sendo criados, testados e aperfeiçoados na Amazônia (MARCHAND; LE TOURNEAU, 2014) e muitos desses estudos têm adotado o Barômetro da Sustentabilidade-BS (LAMEIRA; VIEIRA; TOLEDO, 2015, CARDOSO; TOLEDO; VIEIRA, 2016; IDESP, 2014), conforme concepção de Prescott-Allen (2001a), por atender os requisitos de precisão e simplicidade, ser didático no entendimento e de fácil motivação para tomadores de decisão (SIENA, 2008).

Em um contexto regional com um dos mais baixos níveis de qualidade de vida do país, espera-se que os planos de desenvolvimento aplicados ao Marajó atendam às necessidades de uma população esquecida pelo poder público há 
séculos. Espera-se ainda, que uma abordagem territorial do desenvolvimento venha fortalecer os grupos sociais locais e buscar a articulação e a sintonia entre as diferentes dimensões do desenvolvimento (CANIELLO; PIRAUX; RAMBO, 2012).

Isto posto, entende-se que as ações de políticas públicas estabelecidas recentemente nos municípios marajoaras tenham oferecido diretrizes e implementado ações voltadas à sustentabilidade socioeconômica e ambiental dos mesmos. Assim, medir o nível de sustentabilidade alcançado pelos municípios desta região é importante no sentido de vislumbrar tendências e comparações relacionadas ao bem-estar humano e ambiental.

Nesta pesquisa, avaliou-se 16 municípios da mesorregião do Marajó, Pará, utilizando o BS como ferramenta de análise, empregando-se 20 indicadores para o bem-estar humano (dimensão socioeconômica) e 06 para o bem-estar ecológico (dimensão ambiental).

\section{METODOLOGIA}

\subsection{CARACTERIZAÇÃO DA ÁREA DE ESTUDO}

O recorte da pesquisa tem como base a mesorregião do Marajó, que abrange uma área de $104.140 \mathrm{Km}^{2}$, ocupada por 16 municípios: Santa Cruz do Arari, Afuá, Anajás, Bagre, Breves, Cachoeira do Arari, Chaves, Curralinho, Gurupá, Melgaço, Muaná, Ponta de Pedras, Portel, Salvaterra, São Sebastião da Boa Vista e Soure, compreendidos nas microrregiões do Arari, Furos de Breves e Portel (Figura 1). A população total dessa região é de 487.010 habitantes, dos quais 56,59\% vivem na área rural (IBGE, 2010).

Apesar de apresentar grande biodiversidade e ser uma região internacionalmente notória, com potencial extraordinário de desenvolvimento, é uma das regiões mais pobres do estado do Pará e do Brasil (BRASIL, 2012; IDESP, 2014). Tem o menor índice de desenvolvimento humano - IDH do estado do Pará $(0,63 \%)$ e também o menor produto interno bruto - PIB per capita (IDESP, 2014). 
Figura 1 - Localização dos municípios da mesorregião do Marajó, estado do Pará

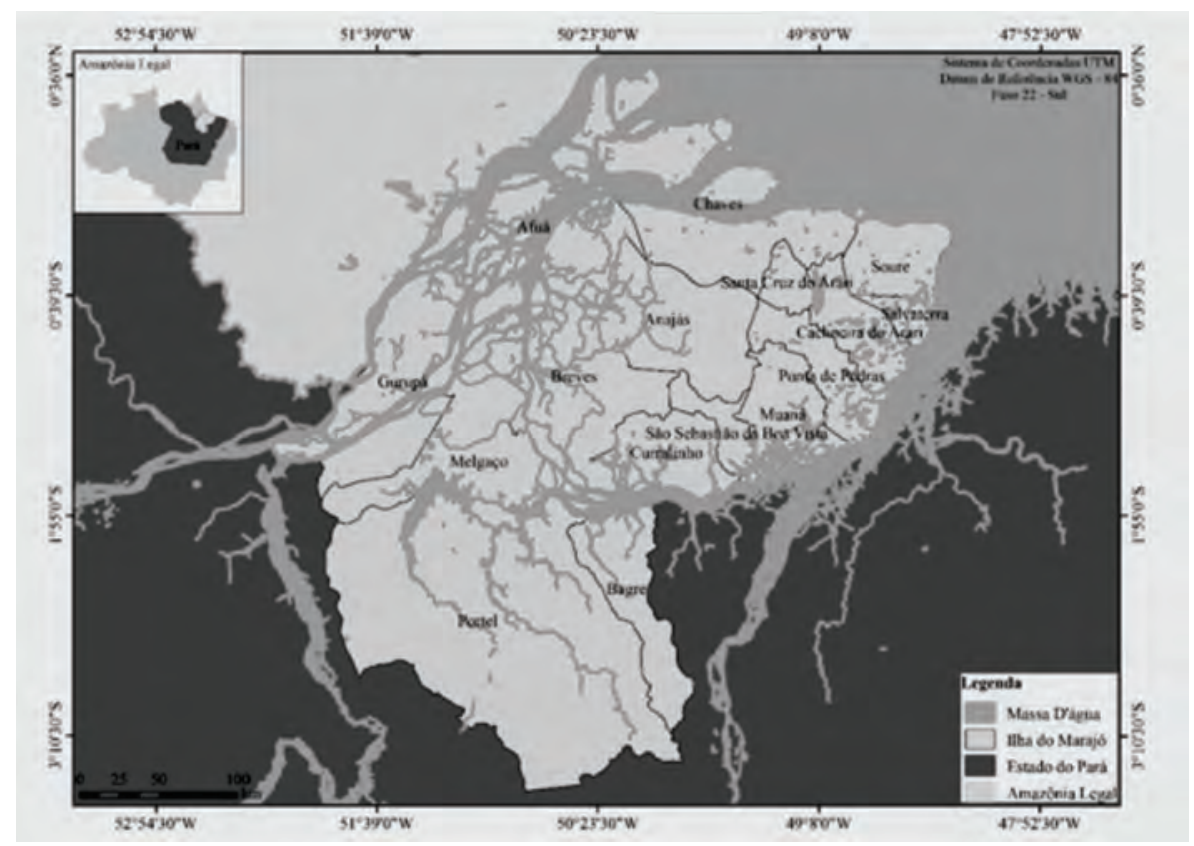

Fonte: Base de dados do IBGE, 2015. Elaboração própria.

\subsection{FERRAMENTA E INDICADORES DE SUSTENTABILIDADE DOS MUNICÍPIOS}

Este estudo aplicou a ferramenta do Barômetro da Sustentabilidade (BS), desenvolvido por diversos especialistas, ligados à IUCN (União Internacional para Conservação da Natureza) e ao IDRC (Centro Internacional de Estudos do Desenvolvimento) (PRESCOT'T-ALLEN, 2001b). O BS utiliza uma combinação de indicadores e seus resultados são demonstrados por meio de índices. Estes índices são apresentados através de uma representação gráfica, procurando facilitar a compreensão e dar um quadro geral do estado do meio ambiente e da sociedade (VAN BELLEN, 2004). Esta representação pode apresentar a dimensão principal de cada índice para realçar aspectos de performance que mereçam mais atenção, sendo adequada também para comparações entre diferentes avaliações (PRESCOTT-ALLEN, 1999, 1997).

Dois grandes eixos são formados: o Bem-Estar Humano (BEHum) e o Bem-Estar do Meio-Ambiente (BEAmb). Cada uma dessas duas grandes dimensões se subdivide em outras cinco dimensões. Para a sociedade considera- 
se: saúde e população, riqueza, conhecimento e cultura, comunidade e equidade. Para o meio ambiente tem-se: terra, ar, água, espécies e utilização de recursos (VAN BELLEN, 2004).

Utilizaram-se 20 indicadores na dimensão humana e 06 indicadores na dimensão ambiental, tendo como base os indicadores utilizados pelo governo do Estado do Pará (IDESP, 2014) como comparativo de desenvolvimento entre os municípios. Além destes, foram incluídos indicadores relacionados à agenda pós 2015 ou Objetivos de Desenvolvimento Sustentável (ODS), estabelecidos pela ONU.

Foram selecionados 26 indicadores, a maioria associados aos Objetivos de Desenvolvimento do Milênio (ODM) e considerados indicadores mais sensíveis às ações imediatas do estado, conforme aponta o Idesp (2014). Assim, foram distribuídos vinte indicadores no Bem-Estar Humano, subdivididos em dimensão social e econômica (Tabelas 1 e 2, respectivamente), e seis indicadores no BemEstar Ambiental, com apenas a dimensão ambiental (Tabela 3). A escolha dos indicadores foi condicionada à existência, consistência dos dados e facilidade de mensuração. Dada às dificuldades inerentes à busca de dados anuais, utilizou-se o período de 2010 a 2014 nesta análise.

Tabela 1 - Temas, indicadores, e parâmetros para construção das escalas de desempenho para a Dimensão Social do BS dos municípios do Marajó, estado do Pará

\begin{tabular}{|c|c|c|c|c|}
\hline \multirow{6}{*}{$\begin{array}{l}\text {.त్తు } \\
0 \\
\infty\end{array}$} & Temas & Indicadores & Fonte & Parâmetros \\
\hline & \multirow[t]{5}{*}{$\begin{array}{c}\text { Saúde e } \\
\text { População }\end{array}$} & $\begin{array}{l}\text { Mortalidade } \\
\text { na infância }\end{array}$ & $\begin{array}{c}\text { DATASUS } \\
2013\end{array}$ & $\begin{array}{l}\text { Considera-se Sustentável Mortalidade } \\
\text { na infância (abaixo de } 20 \text { mortes por } \\
\text { mil habitantes) (OMS). }\end{array}$ \\
\hline & & $\begin{array}{c}\text { Mortalidade } \\
\text { materna }\end{array}$ & $\begin{array}{c}\text { DATASUS } \\
2013\end{array}$ & $\begin{array}{l}\text { Considera-se Sustentável Mortalidade } \\
\text { Materna (abaixo de } 20 \text { mortes por } \\
100 \text { mil habitantes) (OMS). }\end{array}$ \\
\hline & & $\begin{array}{l}\text { Número de } \\
\text { médicos }\end{array}$ & $\begin{array}{c}\text { DATASUS } \\
2014\end{array}$ & $\begin{array}{l}\text { Considera-se Sustentável 2,7 médicos } \\
\text { para cada } 1.000 \text { habitantes (Ministério } \\
\text { da Saúde). }\end{array}$ \\
\hline & & $\begin{array}{c}\text { Leitos } \\
\text { hospitalares }\end{array}$ & $\begin{array}{c}\text { DATASUS } \\
2014\end{array}$ & $\begin{array}{l}\text { Considera-se Sustentável } 2,5 \text { a } 3 \\
\text { leitos hospitalares para cada } 1.000 \\
\text { habitantes (Ministério da saúde). }\end{array}$ \\
\hline & & $\begin{array}{l}\text { Gravidez na } \\
\text { infância e } \\
\text { adolescência }\end{array}$ & $\begin{array}{c}\text { DATASUS } \\
2013\end{array}$ & $\begin{array}{l}\text { Considera-se sustentável a não } \\
\text { ocorrência de gravidez nessa faixa } \\
\text { etária, conforme estabelecido nos } \\
\text { Objetivos de Desenvolvimento } \\
\text { Sustentável. }\end{array}$ \\
\hline
\end{tabular}




\begin{tabular}{|c|c|c|c|c|}
\hline \multirow{10}{*}{ 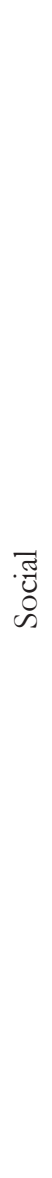 } & \multirow[t]{6}{*}{$\begin{array}{c}\text { Conhecimento } \\
\text { e Cultura }\end{array}$} & $\begin{array}{l}\text { Analfabetis- } \\
\text { mo }\end{array}$ & $\begin{array}{l}\text { IBGE } \\
2010 \\
\end{array}$ & $\begin{array}{l}\text { Considera-se sustentável que não } \\
\text { ocorra analfabetismo (ODM). }\end{array}$ \\
\hline & & $\begin{array}{l}\text { Ideb (séries } \\
\text { iniciais) }\end{array}$ & Inep 2013 & $\begin{array}{l}\text { As notas atribuídas pelo IDEB podem } \\
\text { variar de } 0 \text { a } 10 \text {. A meta brasileira, e } \\
\text { também considerado sustentável na } \\
\text { pesquisa, é a obtenção de nota } 6 \text {. }\end{array}$ \\
\hline & & $\begin{array}{l}\text { Ideb (séries } \\
\text { finais) }\end{array}$ & Inep 2013 & $\begin{array}{l}\text { As notas atribuídas pelo IDEB podem } \\
\text { variar de } 0 \text { a } 10 \text {. A meta brasileira, e } \\
\text { também considerado sustentável na } \\
\text { pesquisa, é a obtenção de nota } 6 \text {. }\end{array}$ \\
\hline & & $\begin{array}{l}\text { Evasão esco- } \\
\text { lar ens. Fun- } \\
\text { damental. }\end{array}$ & Inep 2013 & $\begin{array}{lrrr}\text { Considera-se sustentável } & 0 \% & \text { de } \\
\text { abandono escolar (ODM). } & & \end{array}$ \\
\hline & & $\begin{array}{c}\text { Evasão } \\
\text { escolar ens. } \\
\text { Médio } \\
\end{array}$ & Inep 2013 & $\begin{array}{lrll}\begin{array}{l}\text { Considera-se sustentável } \\
\text { abandono escolar (ODM). }\end{array} & 0 \% & \text { de } \\
\end{array}$ \\
\hline & & $\begin{array}{c}\text { Acesso à } \\
\text { internet }\end{array}$ & $\begin{array}{c}\text { IBGE } \\
2010\end{array}$ & $100 \%$ de cobertura (ODM). \\
\hline & \multirow[t]{3}{*}{ Comunidade } & Roubos & $\begin{array}{l}\text { SEGUP/ } \\
\text { SIAC } 2013\end{array}$ & $\begin{array}{l}\text { Considera-se sustentável } 8 \text { roubos } \\
\text { para cada } 10 \text { mil habitantes } \\
\text { (CIDADES SUSTENTÁVEIS). }\end{array}$ \\
\hline & & Homicídios & $\begin{array}{l}\text { SEGUP/ } \\
\text { SIAC } 2013\end{array}$ & $\begin{array}{l}\text { Considera-se sustentável } 0 \% \text { de } \\
\text { mortes por homicídio (Programa } \\
\text { Cidades Sustentáveis). }\end{array}$ \\
\hline & & $\begin{array}{l}\text { Acesso à } \\
\text { energia } \\
\text { elétrica }\end{array}$ & $\begin{array}{c}\text { IBGE } \\
2010\end{array}$ & 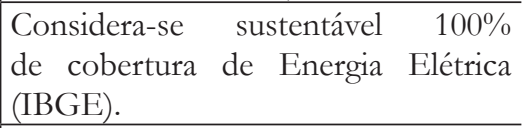 \\
\hline & Equidade & $\begin{array}{l}\text { Índice de } \\
\text { Gini }\end{array}$ & $\begin{array}{l}\text { IBGE } \\
2010\end{array}$ & $\begin{array}{l}\text { Considera-se sustentável a não } \\
\text { ocorrência de desigualdade (ODM). }\end{array}$ \\
\hline
\end{tabular}

Fonte: Elaboração própria.

Tabela 2 - Temas, indicadores, e parâmetros para construção das escalas de desempenho para a Dimensão Econômica do BS dos municípios do Marajó, estado do Pará

\begin{tabular}{|c|c|c|c|c|}
\hline \multirow{6}{*}{ 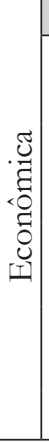 } & Temas & Indicadores & Fonte & Parâmetros \\
\hline & \multirow{5}{*}{ Riqueza } & Extrema pobreza & IBGE 2010 & $\begin{array}{l}\text { Considera-se sustentável a não } \\
\text { existência da extrema pobreza (ODM) }\end{array}$ \\
\hline & & Taxa & IBGE 2010 & $\begin{array}{c}\text { Considera-se sustentável que } 100 \% \text { da } \\
\text { população ativa esteja ocupada. }\end{array}$ \\
\hline & & Trabalho infantil & IBGE 2010 & $\begin{array}{c}\text { Considera-se sustentável a não } \\
\text { ocorrência do trabalho infantil (OIT) }\end{array}$ \\
\hline & & PIB (per capita) & \begin{tabular}{|c|} 
IBGE e \\
IDESP 2012 \\
\end{tabular} & $\begin{array}{l}\text { Consideraram-se os maiores e menores } \\
\text { PIB per capita do Estado do Pará }\end{array}$ \\
\hline & & Renda (per capita) & IBGE 2010 & Entre $\mathrm{R} \$ 624,00$ a $\mathrm{R} \$ 1.157,00$ (PNUD) \\
\hline
\end{tabular}

Fonte: Elaboração própria, 2016. 
Tabela 3 - Temas, indicadores, e parâmetros para construção das escalas de desempenho para a Dimensão Ecológica do BS dos municípios do Marajó, estado do Pará

\begin{tabular}{|c|c|c|c|c|}
\hline \multirow{7}{*}{ 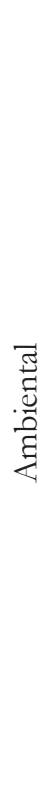 } & Temas & Indicadores & Fonte & Parâmetros \\
\hline & \multirow{2}{*}{ Terra } & $\begin{array}{c}\text { Cadastro } \\
\text { Ambiental Rural }\end{array}$ & Sema 2014 & $\begin{array}{l}\text { Considera-se sustentável acima } \\
\text { de } 80 \% \text { do território com imóveis } \\
\text { rurais inseridos no CAR (MMA) }\end{array}$ \\
\hline & & Desmatamento & $\begin{array}{l}\text { Prodes } \\
2013\end{array}$ & $\begin{array}{c}\text { Considera-se sustentável } \\
\text { Desmatamento inferior a 20\% da } \\
\text { área total do município (MMA) }\end{array}$ \\
\hline & Ar & Focos de calor & IBGE 2010 & $\begin{array}{c}\text { Considera-se sustentável Até } 10 \\
\text { focos por } 1000 \mathrm{~km}^{2} \text { (considerado } \\
\text { causas naturais) }\end{array}$ \\
\hline & \multirow[b]{2}{*}{ Água } & $\begin{array}{l}\text { Abastecimento } \\
\text { de água }\end{array}$ & IBGE 2010 & $\begin{array}{c}\text { Considera-se sustentável 100\% de } \\
\text { cobertura (IBGE) }\end{array}$ \\
\hline & & $\begin{array}{l}\text { Esgotamento } \\
\text { sanitário }\end{array}$ & \begin{tabular}{|c|} 
INPE \\
Queimadas \\
2014 \\
\end{tabular} & $\begin{array}{l}\text { Considera-se sustentável 100\% de } \\
\text { cobertura (IBGE) }\end{array}$ \\
\hline & $\begin{array}{l}\text { Utilização } \\
\text { dos } \\
\text { recursos }\end{array}$ & Coleta de lixo & IBGE 2010 & $\begin{array}{l}\text { Considera-se sustentável 100\% de } \\
\text { cobertura (IBGE) }\end{array}$ \\
\hline
\end{tabular}

Fonte: Elaboração própria.

\subsubsection{Construção das escalas de desempenho}

Após a escolha dos indicadores, foram construídas as Escalas de Desempenho Municipal (EDM), a qual é utilizada para avaliar a situação do indicador em relação à meta ou padrão estabelecido, e aplicado a diferentes períodos, possibilitando o monitoramento de avanços e retrocessos em direção ao desenvolvimento sustentável (KRONEMBERGER et al., 2004). A definição dos limites das EDM foi feita a partir de valores pesquisados na literatura especializada, tais como padrões definidos na legislação ou metas estabelecidas nacionais ou internacionalmente. A metodologia seguida nesse estudo para todos os indicadores foi baseada em estudo feito por Kronemberger, et al. (2004), compostas a partir da divisão do intervalo entre os extremos em cinco setores iguais, variando de insustentável a sustentável (Tabelas 4, 5 e 6). 
Tabela 4 - Escalas de desempenho dos indicadores municipais da dimensão social e sua transposição para a escala do Barômetro da Sustentabilidade dos 16 municípios da mesorregião do Marajó, Pará

\begin{tabular}{|c|c|c|c|c|c|}
\hline \multirow{4}{*}{ Indicadores municipais } & \multicolumn{5}{|c|}{$\begin{array}{c}\text { ESCALA DE DESEMPENHO DO BARÔMETRO } \\
\text { DA SUSTENTABILIDADE }\end{array}$} \\
\hline & $0-20$ & $21-40$ & $41-60$ & $61-80$ & $81-100$ \\
\hline & $\begin{array}{l}\text { Insusten- } \\
\text { tável }\end{array}$ & $\begin{array}{l}\text { Potenc } \\
\text { Insust. }\end{array}$ & $\begin{array}{l}\text { Interme- } \\
\text { diário }\end{array}$ & $\begin{array}{c}\text { Potenc. } \\
\text { Sust. }\end{array}$ & $\begin{array}{l}\text { Susten- } \\
\text { tável }\end{array}$ \\
\hline & \multicolumn{5}{|c|}{ ESCALA DE DESEMPENHO MUNICIPAL } \\
\hline Mortalidade na infância & $100-76$ & $75-50$ & $49-20$ & $19-20$ & $19-0$ \\
\hline Mortalidade materna & $800-150$ & $149-50$ & $49-20$ & $19-10$ & $9-0$ \\
\hline Número de médicos & $0-0,3$ & $0,4-0,6$ & $0,7-1,3$ & $1,4-2,6$ & $2,7-5$ \\
\hline Leitos hospitalares & $0-0,5$ & $0,6-1,9$ & $2-2,4$ & $2,5-2,9$ & $3-1$ \\
\hline $\begin{array}{l}\text { Gravidez na infância e } \\
\text { adolescência }\end{array}$ & $100-10,1$ & $10-5,1$ & $5-3,1$ & $3-1$ & $0,99-0$ \\
\hline Analfabetismo & $100-20,1$ & $20-10,1$ & $10-5,1$ & $5-1$ & $0,99-0$ \\
\hline Ideb (séries iniciais) & $0-1,9$ & $2-3,9$ & $4-5,9$ & $6-7,9$ & $8-10$ \\
\hline Ideb (séries finais) & $0-1,9$ & $2-3,9$ & $4-5,9$ & $6-7,9$ & $8-10$ \\
\hline $\begin{array}{l}\text { Evasão escolar ens. } \\
\text { Fundamental. }\end{array}$ & $100-20,1$ & $20-10,1$ & $10-5,1$ & $5-1$ & $0,99-0$ \\
\hline Evasão escolar ens. Médio. & $100-20,1$ & $20-10,1$ & $10-5,1$ & $5-1$ & $0,99-0$ \\
\hline Acesso à internet & $0-20$ & $21-40$ & $41-60$ & $61-80$ & $81-100$ \\
\hline Roubos & $400-33$ & $32-25$ & $24-17$ & $16-9$ & $8-0$ \\
\hline Homicídios & $300-50,1$ & $50-20,1$ & $20-10,1$ & $10-5$ & $4,99-0$ \\
\hline Acesso à energia elétrica & $0-69$ & $70-79$ & $80-89$ & $90-94$ & $95-100$ \\
\hline Índice de Gini & $1-0,81$ & $0,8-0,51$ & $0,5-0,41$ & $0,4-0,21$ & $0,2-0$ \\
\hline
\end{tabular}

Fonte: Elaboração própria. 
Tabela 5 - Escalas de desempenho dos indicadores municipais da dimensão econômica e sua transposição para a escala do Barômetro da Sustentabilidade dos 16 municípios da mesorregião do Marajó, Pará

\begin{tabular}{|c|c|c|c|c|c|}
\hline \multirow{5}{*}{$\begin{array}{l}\text { Indicadores } \\
\text { municipais }\end{array}$} & \multicolumn{5}{|c|}{$\begin{array}{l}\text { ESCALA DE DESEMPENHO DO BARÔMETRO DA } \\
\text { SUSTENTABILIDADE }\end{array}$} \\
\hline & $0-20$ & $21-40$ & $41-60$ & $61-80$ & $81-100$ \\
\hline & \multirow{2}{*}{ Insustentável } & Potenc. & \multirow{2}{*}{ Intermediário } & Potenc. & \multirow{2}{*}{ Sustentável } \\
\hline & & Insust & & Sust. & \\
\hline & \multicolumn{5}{|c|}{ ESCALA DE DESEMPENHO MUNICIPAL } \\
\hline Extrema pobreza & $100-50,1$ & $50-20,1$ & $20-10,01$ & $10-5$ & $4,99-0$ \\
\hline Taxa de atividade & $0-20$ & $21-40$ & $41-60$ & $61-80$ & $81-100$ \\
\hline Trabalho infantil & $100-10,1$ & $10-5,1$ & $5-3,1$ & $3-1$ & $0,99-0$ \\
\hline PIB (per capita) & $0-6793$ & $\begin{array}{l}6794- \\
12.006\end{array}$ & 12.007-18.159 & $\begin{array}{l}18160- \\
32.901\end{array}$ & $\begin{array}{c}35.641- \\
200.000,00\end{array}$ \\
\hline Renda (per capita) & $96-180$ & $181-333$ & $334-624$ & $625-1157$ & $1158-2000$ \\
\hline
\end{tabular}

Fonte: Elaboração própria, 2016.

Tabela 6 - Escalas de desempenho dos indicadores municipais da dimensão ecológica e sua transposição para a escala do Barômetro da Sustentabilidade dos 16 municípios da mesorregião do Marajó, Pará

\begin{tabular}{|c|c|c|c|c|c|}
\hline \multirow{5}{*}{ Indicadores municipais } & \multicolumn{5}{|c|}{$\begin{array}{l}\text { ESCALA DE DESEMPENHO DO BARÔMETRO } \\
\text { DA SUSTENTABILIDADE }\end{array}$} \\
\hline & $0-20$ & $21-40$ & $41-60$ & $61-80$ & $81-100$ \\
\hline & \multirow{2}{*}{$\begin{array}{l}\text { Insusten- } \\
\text { tável }\end{array}$} & Potenc & \multirow{2}{*}{$\begin{array}{l}\text { Interme- } \\
\text { diário }\end{array}$} & Potenc & \multirow{2}{*}{$\begin{array}{c}\text { Sustentá- } \\
\text { vel }\end{array}$} \\
\hline & & Insust. & & Sust. & \\
\hline & \multicolumn{5}{|c|}{ ESCALA DE DESEMPENHO MUNICIPAL } \\
\hline Cadastro Ambiental Rural & $0-20$ & $21-40$ & $41-60$ & $61-80$ & $81-100$ \\
\hline Desmatamento & $300-161$ & $160-121$ & $120-81$ & $80-41$ & $40-0$ \\
\hline Focos de calor & $200-41$ & $40-31$ & $30-21$ & $20-11$ & $10-0$ \\
\hline Abastecimento de água & $0-69$ & $70-79$ & $80-89$ & $90-94$ & $95-100$ \\
\hline Esgotamento sanitário & $0-69$ & $70-79$ & $80-89$ & $90-94$ & $95-100$ \\
\hline Coleta de lixo & $0-69$ & $70-79$ & $80-89$ & $90-94$ & 95-100 \\
\hline
\end{tabular}

Fonte: Elaboração própria. 


\subsubsection{Cálculo e ordenamento dos resultados}

Após a elaboração das Escalas de Desempenho (ED), foi feita a transposição do valor numérico do indicador municipal (EDR) para a Escala do BS (EBS), através de interpolação linear simples, de forma a atribuir grau ao indicador na Escala do Barômetro da Sustentabilidade, através da seguinte fórmula:

$$
E B S x=\left\{\left[\frac{\left(E D I_{a}-V R_{x}\right) x\left(E B S_{a}-E B S_{p}\right)}{\left(E D I_{a}-E D I_{p}\right)}\right] x(-1)\right\}+E B S_{a}
$$

Onde: $V \mathrm{R}_{x}=$ valor real do indicador $\mathrm{x}$;

$\mathrm{a}=$ limite anterior do intervalo que contém $V R_{x}$;

$\mathrm{p}=$ limite posterior do intervalo que contém $V R_{x}$.

Após os cálculos individuais de cada indicador na escala do BS, esses foram agregados hierarquicamente de forma que se obteve a média aritmética dos indicadores de cada tema, e então, calculou-se um índice para cada dimensão (ambiental, social, e econômica) através da média aritmética dos temas correspondentes. Por último, calculou-se dois índices para cada município da mesorregião do Marajó, correspondentes aos subsistemas sociedade e natureza: Índice de Bem-Estar Humano e Índice de Bem-Estar Ambiental.

\section{RESULTADOS E DISCUSSÃO}

Os índices de bem-estar humano (BEHum) e o de bem-estar ambiental (BEAmb), podem ser vistos na Figura 2. Pode-se afirmar que para a maioria dos municípios, o BEAmb está numa faixa aceitável de sustentabilidade (intermediário), e apenas Santa Cruz do Arari e Curralinho estão na faixa de potencialmente insustentável. Já o BEHum dos municípios apresenta-se na faixa classificada como de sustentabilidade pobre, mais próximo da insustentabilidade, com apenas quatro municípios na faixa intermediária (Gurupá, Salvaterra, Santa Cruz do Arari e Soure). Os municípios que atingiram o patamar mínimo de sustentabilidade (intermediário) foram Gurupá, Salvaterra e Soure. Observa-se, ainda, que as diferentes performances dos municípios do Marajó em relação ao BEHum e BEAmb confirmam que as ações municipais podem ser identificadas como a causa principal desta grande variabilidade nos indicadores e que o papel da gestão municipal em implementar políticas e programas é determinante no nível de sustentabilidade. 
Figura 2 - Visualização espacial dos índices de Bem-Estar Humano e Bem-Estar Ambiental nos16 municípios da mesorregião do Marajó, Pará

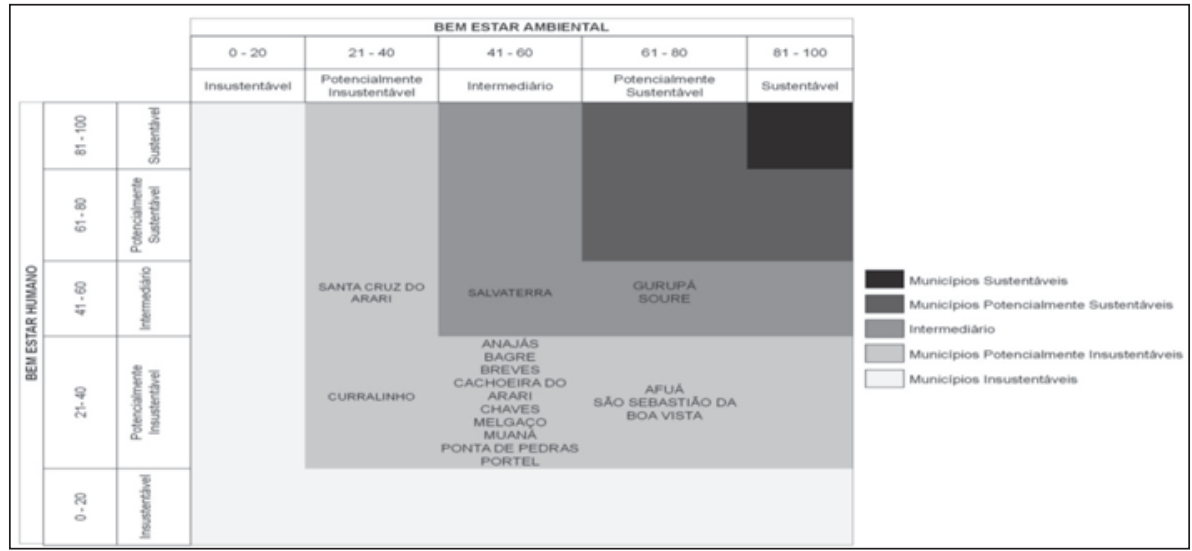

Fonte: Elaboração própria.

Dos municípios potencialmente insustentáveis, nota-se que Anajás, Melgaço, Breves e Afuá apresentam padrões similares de desenvolvimento, com melhor desempenho no eixo do BEAmb (Figura 3). Por outro lado, Santa Cruz do Arari, Muaná, Cachoeira do Arari e Curralinho, têm os piores desempenhos ambientais. $O$ município de Santa Cruz do Arari, apesar de estar situado na faixa Potencialmente Insustentável, obteve o melhor desempenho no eixo do BEHum, seguido por Salvaterra, Gurupá e Soure, situados na faixa do Intermediário. Os municípios de Afuá e Portel apresentaram os piores desempenhos do eixo do BEHum.

Figura 3 - Gráfico com representação das escalas de sustentabilidade do BS dos municípios da mesorregião do Marajó, Pará

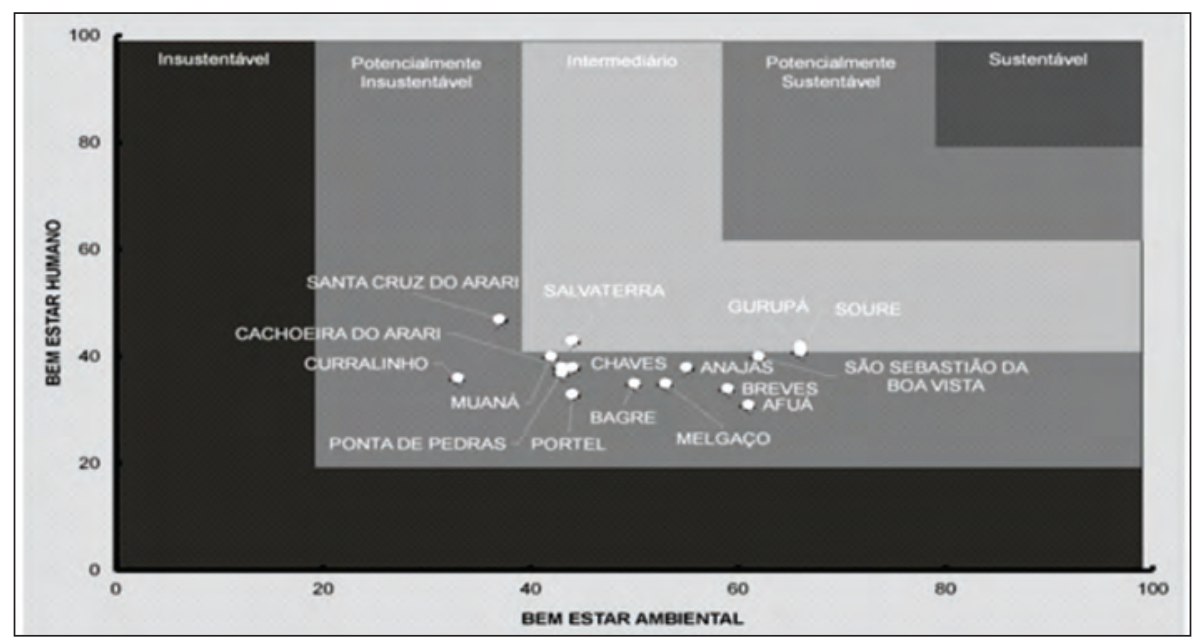

Fonte: Elaboração própria 
O panorama da sustentabilidade gerado por este estudo mostrou que o eixo do BEHum é bastante crítico nos municípios do Marajó, apresentando baixos índices de sustentabilidade e situações preocupantes de acesso aos direitos básicos. Os indicadores da dimensão social (Saúde e População, Conhecimento e Cultura, Comunidade, Equidade) evidenciam que essa região tem baixa eficácia e capilaridade das políticas públicas, de serviços de infraestrutura para promoção e proteção social voltadas ao desenvolvimento. Ribeiro (2002), ao calcular índices de sustentabilidade para cidades e regiões do estado do Pará, para o ano 2000, tendo como base uma proposta de modelo de indicadores para a Amazônia (IASAM), encontrou que a mesorregião do Marajó é uma das mais insustentáveis. Alta taxa de mortalidade infantil, poucas áreas municipais de proteção ambiental, PIB per capita com ondas de crescimento e queda num período de 20 anos e baixa participação política fornecem uma leitura de baixa sustentabilidade em todos os aspectos dentro da mesorregião.

$\mathrm{O}$ acesso à infraestrutura, mesmo descrita como prioritária em diversos planos estratégicos para o Marajó (BRASIL, 2004; ZEE - PARÁ, 2005, BRASIL, 2007), tem sido ausente na região e isso tem produzido problemas de saúde e de segurança alimentar. É alarmante o número de crianças nascidas por mães também "crianças" na região, com valores inaceitáveis nos municípios analisados. As altas taxas de gravidez na infância e adolescência são reflexos de uma fragilidade na estrutura social, e influenciaram o nível de potencial insustentabilidade alcançado pelos municípios marajoaras. Outros aspectos relevantes decorrentes deste padrão de insustentabilidade encontrado são as altas taxas de mortalidade na infância, de analfabetos, de evasão escolar e trabalho infantil, dentre outros indicadores que, quando acompanhados, podem explicar uma grande parcela dos problemas sociais recorrentes no Marajó.

Diante de um quadro persistente de estagnação econômica e com a finalidade de sanar as problemáticas existentes no território, o Plano Marajó Sustentável-PDTS (BRASIL, 2007) visava alterar esta realidade e estabelecer novas diretrizes a fim de atender demandas específicas de cada município. Neste plano estavam incluídas diversas metas para reverter o quadro socioeconômico da região, assim como fortalecer a organização do sistema público de saúde, apoiar os mecanismos de participação e organização da comunidade, objetivando o fim de práticas de exploração humana (trabalho infantil, exploração sexual de menores, tráfico de mulheres etc.) e o fortalecimento da cidadania (BARROS, 2013). A partir de uma metodologia inclusiva, o PDTS foi um marco no planejamento territorial e gerou enormes expectativas na população marajoara, porém, falhou em sua execução. Este estudo com o BS mostra um quadro de 
baixo desenvolvimento sustentável na região e isto, na prática, revela que não houve grandes modificações na estrutura socioeconômica do Marajó com os programas territoriais criados. O desenvolvimento sustentável do Marajó continua sendo um grande desafio para a sociedade brasileira.

\section{CONCLUSÕES}

O Barômetro da Sustentabilidade pode ser considerado uma ferramenta eficaz de avaliação da sustentabilidade, com potencial para incorporação nos processos de tomada de decisão que permitem a avaliação sistemática do bem estar humano e ambiental em nível local. Conforme apresentado, o Marajó mostrou um quadro de desequilíbrio em relação ao nível de sustentabilidade dos municípios, e a isso associamos a ineficácia dos resultados de políticas públicas integradas aliada à discrepância dos diferentes modelos de gestão municipal. Mesmo com a existência de várias propostas para restruturação do território sob a regência de planos de desenvolvimento sustentável, esta região não apresentou transformações sociais significativas na última década. Este quadro de fragilidade no processo de desenvolvimento sustentável expõe o Marajó a ações de projetos econômicos com alto potencial de risco de degradação ambiental num quadro de baixa resiliência social.

\section{AGRADECIMENTOS}

Os autores agradecem ao apoio do INCT/Biodiversidade e Uso da Terra na Amazônia (processo CNPq no 574008/2008-0), pelo financiamento para a realização dos trabalhos de campo, e concessão da bolsa de estudo pelo CNPq ao Patrick Quintela (Mestrado) e ao Programa de Pós-Graduação de Ciências Ambientais da Universidade Federal do Pará.

\section{REFERÊNCIAS}

BARROS, M. J. B. Uma análise crítica do Plano de Desenvolvimento Territorial Sustentável do Arquipélago do Marajó-Pará. GeoAmazônia, n. 01, v. 01, p. 40 - 54, 2013. DOI: 10.17551/2358-1778. Disponível em: <http://www.geoamazonia. net/index.php/revista/article/view/5/pdf_4>. Acesso em: abr. 2016

BRASIL. Ministério do Desenvolvimento Agrário. Relatório Analítico do Território do Marajó. Belém, 2012. Disponível em <http://sit.mda.gov.br/ download/ra/ra129.pdf>. Acesso em: abr. 2016. 
Governo Federal. Grupo Executivo Interministerial. Plano de Desenvolvimento Territorial Sustentável para o Arquipélago do Marajó: resumo executivo da versão preliminar para discussão nas consultas públicas. Brasília, Editora do Ministério da Saúde, 2007. 24 p. Disponível em: <http:// www.seplan.pa.gov.br/sites/default/files/PDF/ppa/ppa2016-2019/pdrs_ marajo.pdf $>$. Acesso em: abr. 2016.

Presidência da República. Casa Civil. Plano de Desenvolvimento Territorial Sustentável para o Arquipélago do Marajó. Brasília, 2007. Disponível em <http://www.mi.gov.br/c/document_library/get_ file?uuid $=9408 \mathrm{a} 880-6 e c 0-4 \mathrm{be} 0-9 \mathrm{cb} 7-$ feb01c4a6256\&groupId=24915>. Acesso em: abr. 2016.

Plano Amazônia Sustentável. 2004. Disponível em <http://www. ufmt.br/sinop/arquivos/c2b508dde9fbdc39679ee41525e12cae.pdf>. Acesso em: abr. 2016.

CANIELLO, M.; PIRAUX, M.; RAMBO, A. G. As políticas públicas territoriais e desenvolvimento rural sustentável no Brasil Contemporâneo. In: ENCONTRO DA REDE DE ESTUDOS RURAIS. Belém, 2012. Anais Eletrônicos... Belém: UFPA, 2012. Disponível em: <http://agritrop.cirad.fr/567066/1/ document_567066.pdf>. Acesso em: Acesso em: abr. 2016.

CARDOSO, A.S;TOLEDO, P.M; VIEIRA, I. C. G. Barômetro da sustentabilidade aplicado ao município de Moju, estado do Pará. Revista Brasileira de Gestão e Desenvolvimento Regional, Taubaté, v. 12, n. 1, p. 234-263, jan/abr. 2016

IBGE, Cidades. 2010. Disponível em: <http://www.cidades.ibge.gov.br/xtras/ uf.php?lang=\&coduf=15\&search=para $>$. Acesso em: 10 jul. 2015.

IDESP. Indicadores de qualidade ambiental dos municípios da região de integração do Marajó. Secretaria de Estado de Gestão. Belém, 2014.

INSTITUTO PEABIRU. Diagnóstico Socioeconômico, Ambiental e Cultural do Arquipélago do Marajó. 109 p. 2012. Disponível em: <https:// institutopeabiru.files.wordpress.com/2012/09/vivamarajo-escutamarajo.pdf $>$. Acesso em: Acesso em: ago. 2016.

KRONEMBERGER, D. M. P.et al. Indicadores de Sustentabilidade em Pequenas Bacias Hidrográficas: Uma Aplicação do Barômetro da Sustentabilidade à Bacia do Jurumirim (Angra dos Reis, RJ). Geochemical Brasiliensis, v.18, n.2. , 2004 Disponível em: <http://geobrasiliensis.org.br/ojs/index.php/geobrasiliensis/ article/viewFile/214/pdf>. Acesso: Acesso em: abr. 2016. 
LAMEIRA, W. J. M; VIEIRA, I. C. G; TOLEDO, P. M. Panorama da Sustentabilidade na Fronteira Agrícola de Bioenergia na Amazônia. Sustentabilidade em Debate, Brasília, v. 6, n. 2, p. 193-210, mai/ago. 2015.

MARCHAND, G; LE TOURNEAU, F. M. O desafio de medir a sustentabilidade na Amazônia: os principais indicadores e a sua aplicabilidade ao contexto amazônico. In: VIEIRA, I. C. G; TOLEDO, P. M; SANTOS JÚNIOR, R. A. O (orgs.). Ambiente e sociedade na Amazônia: uma abordagem interdisciplinar. Rio de Janeiro: Garamond, 2014. p. 155-220.

PARÁ, Macrozoneamento Ecológico-Econômico do Estado do Pará: Lei N ${ }^{\circ}$ 6.745, 6 de maio de 2005.

PRESCOTT-ALLEN, R. The Barometer of Sustainability. IUCN, 2001a. Disponível em: <http://www.iucn.org/themes/eval/english/barom.htm>. Acesso em: set. 2015.

Wellbeing of Nations (The)A country-by-country index of quality of life and the environment. Washington, IDRC/Island Press, 2001b. 350p.

Assessing Progress toward Sustainability: The System Assessment Method illustrated by the Wellbeing of Nations. Cambridge: IUCN, 1999.

Barometer of Sustainability: Measuring and communicating wellbeing and sustainable development. Cambridge: IUCN, 1997.

RIBEIRO, A. L. Modelo de indicadores para mensuração do desenvolvimento sustentável na Amazônia. 2002. Tese (Doutorado em Desenvolvimento Sustentável do Trópico UÚmido) - Núcleo de Altos Estudos Amazônicos, Universidade Federal do Pará, Belém, 2002.

SIENA, O. Método para avaliar desenvolvimento sustentável: técnicas para escolha e ponderação de aspectos e dimensões. Produção, São Paulo, v. 18, n. 2, p. 359-374, 2008. Disponível em: <http://www.scielo.br/scielo.php?script=sci_arttext\&pid=S010365132008000200012\&lng=en\&nrm=iso >. Acesso em: 14 ago. 2017.

VAN BELLEN, H. M. V. Indicadores de sustentabilidade: uma análise comparativa. Rio de Janeiro: FGV, 2005.

Desenvolvimento Sustentável: uma descrição das principais ferramentas de avaliação. Ambiente \& Sociedade, v. 7, n. 1, p. 67-88, 2004. Disponível em: <http://www.scielo.br/pdf/asoc/v7n1/23537.pdf>. Acesso em: 14 ago. 2017. 


\section{Para além do sucesso técnico: rede sociotécnica em pequenas comunidades rurais amazônicas, Amazonas- Brasil}

\section{Besides technical success: socio-technical network in small rural communities of the Brazilian Amazon}

Ana Claudeise Nascimento - Doutora em Sociologia pelo PPGSA/ UFPA. Pesquisadora do Instituto de Desenvolvimento Sustentável Mamirauá - OS/MCT. Email: claudeise@ mamiraua.org.br

Edila Arnaud Ferreira Moura - Doutora em desenvolvimento socioambiental pelo NAEA/ UFPA. Docente da UFPA atuando na graduação e no Programa de pós-graduação em Sociologia e Antropologia/PPGSA/IFCH. Email: eafmoura@gmail.com

Maria José da Silva Aquino Teisserenc - Doutora em Sociologia pelo PPGSA/UFRJ. Docente da UFPA atuando na graduação e no Programa de pós-graduação em Sociologia e Antropologia/PPGSA/IFCH. Email: mjaq@uol.com.br

\section{Resumo}

Este artigo tem como objetivo analisar a constituição de uma rede sociotécnica para desenvolver um melhor uso da água para o consumo humano e tarefas domésticas em pequenos agrupamentos populacionais da floresta alagada amazônica. O estudo toma por orientação a experiência empírica das pesquisadoras que atuam como agentes de programas de desenvolvimento sustentável em uma unidade de conservação de uso sustentável, há mais de 25 anos, e, os recursos analíticos da sociologia da tradução que contrapõe-se à ideia de uma separação entre social, tecnologia e ciência e, fundamentalmente, instiga a pensar o papel do ator na invenção. O estudo conclui que a produção científica e tecnológica precisa ser melhor compreendida nos seus processos e formas de alcance em relação às populações que se distanciam dos interesses dos mercados tecnológicos.

\section{Palavras-chave}

Rede Sociotécnica, Energias Alternativas, Tecnologia Social, Unidades de Conservação, Populações Ribeirinhas.

\begin{abstract}
This article aims to analyze the formation of a socio-technical network to develop a better use of water for human consumption and in household chores in small population groups in the Amazon flooded forest. The study takes as orientation the empirical experience of researchers who have worked as agents of sustainable development programs in a conservation unit of sustainable use for more than 25 years, and the analytical resources of sociology of translation that opposes the idea of a separation between the social, technology and science, basically inducing to think about the player's role in the invention. The study concludes that scientific production and technology need to be better understood in their processes and forms of achievement in relation to populations far from interests of the technological markets.
\end{abstract}

\section{Keywords}

Socio-technical Network, Alternative Energies, Social Technology, Conservation Units, Riverine Population. 


\section{INTRODUÇÃO}

As diversas expressões dos movimentos socioambientalistas que se destacaram no Brasil a partir do final do século passado, em especial aquelas que problematizaram os grandes riscos de perda da sociobiodiversidade amazônica, colocaram em evidência, no campo acadêmico e não acadêmico, as profundas assimetrias nas relações entre ciência, tecnologia e saberes locais relacionados às formas de organização da vida nos pequenos agrupamentos populacionais que ocupam as margens dos rios e outros corpos d’água, no amplo território da várzea (floresta alagada) amazônica. As consequentes ações políticas, em suas múltiplas manifestações, que vem se construindo sob o que se convencionou denominar de "desenvolvimento sustentável" tem evidenciado, mais intensamente, as questões relativas aos usos sociais da ciência e a constituição dos campos científicos (BOURDIEU, 1997) no conjunto das relações sociotécnicas (CALLON, LASCOUMES e BARTHE, 2011) onde se destacam as complexas redes de produção e de uso do conhecimento, na configuração de fóruns híbridos (CALLON, LASCOUMES e BARTHE, 2011), no alcance das soluções que requerem abordagens multidisciplinares.

Como largamente reconhecido, a qualidade de nossas respostas depende da qualidade de nossas perguntas. E aqui, trazemos ao debate, na condição de pesquisadoras e agentes sociambientais vinculadas ao Instituto de Desenvolvimento Sustentável Mamirauá - IDSM ${ }^{1}$, nossas experiências de atuação em uma ampla rede sociotécnica que se compõe há mais de vinte anos e que se estende entre vários territórios sociais no propósito de contribuir com inovações sociais para "melhor viver" em um ambiente onde os pulsos de inundação da água imprimem dinâmicas que se refletem na alteração da paisagem, nos ritmos da vida e na intensidade dos seus riscos e incertezas (JUNK, 2000; PORRO, 1995; MOURA, 2007).

Nossa questão central, neste artigo, se orienta para a compreensão dos diversos mecanismos em disputa na tentativa de produzir construções técnicas e sociais - inovações sociais - para proporcionar um melhor uso da água para o consumo humano e tarefas domésticas nas moradias de pequenos agrupamentos populacionais, que se autoreferenciam como comunidades, territorializados ao

O Instituto de Desenvolvimento Sustentável Mamirauá-IDSM, criado em 1999, é uma instituição de pesquisa qualificada como organização social em parceria com o Ministério da Ciência, Tecnologia, Inovações e Comunicações-MCTIC, do governo federal brasileiro, que se consolidou após uma trajetória como organização não governamental - Projeto Mamirauá e Sociedade Civil Mamirauá e que hoje agrega mais de 200 pesquisadores e extensionistas produzindo pesquisas e desenvolvendo projetos de inovação social em unidades de conservação de uso sustentável na Amazônia. www.mamiraua.org.br 
longo dos caudalosos e intrincados rios amazônicos e que, por isso, são também identificados como populações ribeirinhas. Formulamos essa questão a partir das análises orientadas pela sociologia da tradução (CALLON, LASCOUMES e BARTHE, 2011) que traz, como principal contribuição, a reflexão sobre os processos de descoberta e inovação científica e tecnológica atentando para o protagonismo dos não-humanos no processo de produção da ciência, aos processos de constituição do saber, assim como aos mecanismos de atribuição do coletivo relacionando os avanços da ciência às avaliações e demandas da sociedade no exercício da democracia técnica.

Segundo Machado e Teixeira (2005), os sociólogos da tradução (Callon, 1986; 1989; 1995; Law, 2002) questionam a sobre-determinação do social no processo de produção da ciência ressaltando que a ausência ou presença de materiais, equipamentos e instrumentos de manipulação de dados produzem, alteram e interditam estratégias de pesquisa. Ainda, segundo esses autores, duas exigências se impõem para os sociólogos da tradução. A primeira, é dar peso ao trabalho de representação dos não-humanos (coletivos). A segunda, é que o relativismo do sociólogo deve ser extensivo à sociedade. Os sociólogos devem também estar atentos às múltiplas interpretações da sociedade, dos atores e de seus interesses. A sociologia da tradução contrapõe-se à ideia de uma origem da inovação, à separação entre social, tecnologia e ciência e, fundamentalmente, instiga a pensar o papel do ator na invenção.

A pertinência dessa reflexão, que se expandiu da Inglaterra aos Institutos Cientificos Franceses e aos demais centros de pesquisa, se justifica neste estudo no sentido de que nos impulsiona a problematizar como esses processos ocorrem em sociedades com menor alcance na prioridade das pesquisas tecnológicas e sociais e em suas formas de intervenção. Nessa composição analítica, acrescentamos ainda os dados de estudos empíricos que realizamos no IDSM sobre os processos inovadores direcionados aos pequenos agrupamentos populacionais da floresta alagada amazônica, sob os parâmetros das políticas de conservação ambiental e das diretrizes de uma nova ciência mais comprometida com o desenvolvimento sustentável.

O IDSM é uma instituição de pesquisa vinculada ao Ministério da Ciência, Tecnologia, Inovações e Comunicações - MCTIC com sede na cidade de Tefé, principal centro econômico e político de uma área de floresta alagada, no estado do Amazonas, Brasil. Este instituto foi criado no ano de 1999, dez anos após o reconhecimento da primeira unidade de conservação de uso sustentável (SNUC, 2000) no Brasil e na sequência às movimentações socioambientais expressivas desse momento da história amazônica que envolveram várias organizações 
governamentais e não governamentais (MOURA, 2007). Ao longo desses anos, o IDSM agencia pesquisas sobre a sociodiversidade amazônica como também impulsiona inovações sociotécnicas com uma variada composição de atores sociais (www.mamiraua.org.br). Em sua trajetória institucional podemos identificar práticas que se relacionam com o que Callon, Lascoumes e Barthe denominam de interseções entre a Recherche confinée e recherche de plein air (CALLON, LASCOUMES e BARTHE, 2011) que expressam as diversas formas de lidar com as incertezas que, de forma paradoxal, se intensificam no mundo contemporâneo e se evidenciaram ainda mais no percurso dos recentes estudos ambientais. Ao tomar o IDSM como um objeto de reflexão exercitamos também o entendimento de Callon e sua equipe sobre os Foruns Híbridos, categoria de análise proposta por esses autores para analisar as controvérsias que ocorrem em espaços públicos envolvendo diversos atores e interesses da sociedade (CALLON, LASCOUMES e BARTHE, 2011). Para este estudo, recorremos a uma, dentre as várias inovações sociais desencadeadas por este Instituto.

No desenvolver do artigo apresentamos a análise distribuída da seguinte forma: caracterização da situação-problema e as bases para o processo da tradução, composição da relação sociotécnica em relação às características e demandas das populações e reflexões sobre os mecanismos de disputa e o alcance das expectativas geradas ao longo de mais de 25 anos do processo dessa inovação. Com esta análise compartilhamos e intendemos avançar, a partir dos sociólogos da tradução, a expectativa de que a produção científica e tecnológica precisa ser melhor compreendida nos seus processos e formas de alcance em relação às populações que se distanciam dos interesses dos mercados tecnológicos.

\section{A SITUAÇÃO-PROBLEMA E O PROCESSO DA TRADUÇÃO: O MODO DE VIDA NA VÁRZEA E OS USOS SOCIAIS DA ÁGUA}

\subsection{O MODO DE VIDA NA VÁRZEA E OS USOS SOCIAIS DA ÁGUA}

O IDSM concentra suas ações para as populações das reservas de desenvolvimento sustentável Mamirauá e Amanã, que correspondem a uma área de 3.474.000 hectares de florestas alagáveis (várzea e igapó) e terra firme, na região do Médio Solimões, estado do Amazonas. Esse território é reconhecido pelos estudos científicos como área de grande endemismo de espécies, variedade 
e abundância de pescado, recursos madeireiros e não madeireiros, um ambiente de floresta alagada (várzea) e áreas de terra firme, como característicos de outras paisagens ao longo dos rios Solimões/Amazonas ${ }^{2}$, mas com uma fascinante e expressiva sociobiodiversidade (AYRES, 1993; LIMA, 2005; ALENCAR, 2002 e 2010; MOURA, 2007). Nesse vasto território (Figura 1) estão distribuídos 212 pequenos povoados, variando de 4 a 35 moradias, localizados sempre a margem dos rios, paranás ou lagos, caracterizando, em toda essa extensão, uma população totalmente dependente dos cursos d'água para seu deslocamento a pequenas e a grandes distâncias, entre as áreas rurais assim como em direção às áreas urbanas. Em 2011, o total dessa população era de 9.532 pessoas, correspondendo a 0,27 habitantes por quilometro quadrado. Neste estudo, por razões que serão esclarecidas no decorrer deste tópico, a análise vai se direcionar aos habitantes da várzea da área da Reserva de Desenvolvimento Sustentável Mamirauá -RDSM.

Figura 1 - Mapa das Reservas de Desenvolvimento Sustentável Mamirauá e Amanã, Amazonas, Brasil

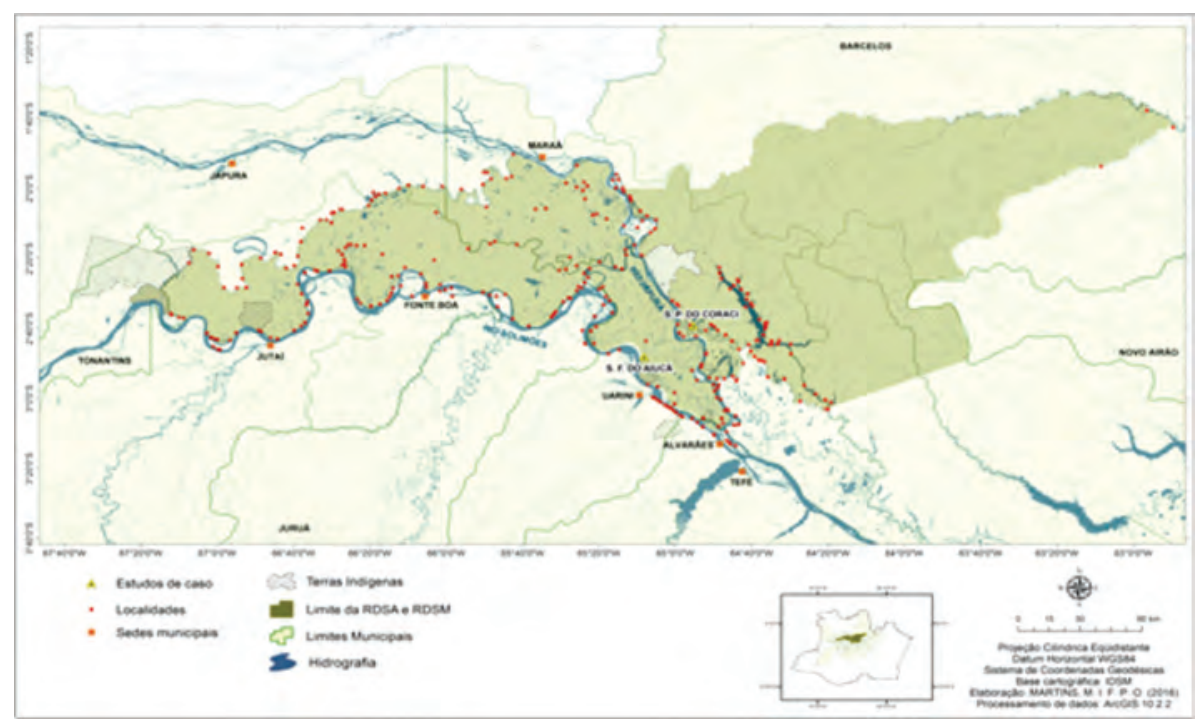

Fonte: Base Cartográfica IDSM. Martins, M. I. F. P. O, 2016

Segundo Lima (2005), estudar a população da várzea é conhecer os habitantes das margens baixas do rio com o maior volume de água do mundo. É também conhecer a região de colonização mais antiga da Amazônia (p.11). Forma

\footnotetext{
2 Segundo Lima (2005), ao longo dos $3.000 \mathrm{~km}$ de extensão dos rios Solimões/Amazonas, em terras brasileiras, ocorrem dois tipos de ambientes: a várzea, como é chamada a área de planície inundada anualmente, e a terra firme, terras altas que consistem em extensões do platô do periodo terciário que alcançam as bordas do rio. Esses dois tipos de ambiente se alternam ao longo das margens do rio, e neles moram populaçöes ribeirinhas que, embora vizinhas, apresentam modos de vida diferenciados (p. 11).
} 
de organização social que foi profundamente afetada pelos vários processos civilizatórios que, seja através da Igreja Católica ou através das políticas de Estado entre outras formas de dominação do território, ocorreram nessa região ao longo da história da formação da sociedade brasileira.

\subsubsection{A SAZONALIDADE DA VÁRZEA AMAZÔNICA³}

Na cheia "Está todo mundo de bubuia". Na seca "ficamos completamente isolados". Essas são referências dos moradores da várzea exemplificando aos momentos contrastantes em relação aos pulsos de inundação ao longo do ano, que compõem um calendário com os períodos de enchente (meados de novembro a início de maio), cheia (maio a meados de julho), vazante (final de julho a meados de setembro) e seca ( setembro a meados de novembro). A série de dados coletados, anualmente, pelo IDSM desde 1990 sobre a variação desses pulsos d'água na área da RDSM constata uma variação média de até 12 metros de elevação das águas entre os períodos de seca e cheia. Há ainda as imprevisíveis grandes cheias e grandes secas. Nas grandes cheias o nível das águas atinge mais de 15 metros acima do nível do mar, o que causa perdas na produção econômica, de equipamentos de trabalho, moradias e outros bens além da gravidade do registro de afogamentos de crianças. Nas grandes secas, ampliam-se as áreas isoladas, ocorrem perdas significativas na produção econômica como também na comercialização dos produtos. Por isso, como os moradores da várzea - os "varjeiros"- costumam dizer, morar na várzea é "estar sempre recomeçando" (MOURA, 2007).

Essa sazonalidade imprime variação nas fontes de renda, nos arranjos domiciliares, nas situações de risco, nas formas de sociabilidade. A enchente é o tempo da expectativa. Os ribeirinhos acompanham pelos programas de rádio as notícias sobre o nível da enchente na cidade de Tabatinga, rio Solimões acima, na fronteira com a Colômbia. E se preparam para o inevitável. Se a enchente prenunciar uma grande cheia é hora de acelerar a colheita da mandioca, preparar a farinha estendendo a jornada de trabalho doméstico por mais de 14 horas. É o tempo também de avaliar as condições para a extração da madeira nas áreas onde o manejo florestal comunitário está organizado (MOURA, 2007).

3 Neste item, e nos próximos dois, fazemos uma síntese da análise feita em MOURA, E. A F. Práticas socioambientais na Reserva de Desenvolvimento Sustentável Mamirauá. Tese (Doutorado em Desenvolvimento Sustentável do Trópico Úmido) - Núcleo de Altos Estudos Amazônico, Universidade Federal do Pará, Belém, 2007Capítulo 1, por a considerarmos bastante completa e ainda atual.

4 Expressão local que quer dizer estar flutuando na água. 
A cheia é o tempo de apreensão com a alagação. É o tempo de maior atenção com as crianças, que são muitas, de cuidado com os idosos, que dependendo da alagação tem que migrar para as casas de parentes na cidade. É o tempo também de proteger os animais, de grande e médio porte, nas marombas - gaiolas flutuantes para proteger o gado. Para os que não trabalham com gado nem com madeira, é também o tempo de descansar. "A gente sabe que o rio vai baixar... é só esperar". Se a cheia é grande, é tempo de reforçar as práticas de solidariedade, fornecendo o abrigo e trocando bens geralmente adquiridos com a renda das aposentadorias dos idosos, às vezes a única renda garantida nesse período. A pesca fica mais difícil com os peixes espalhados na profusão das águas. Os corpos d'água se fundem em um só corpo d'água, que, quando tranquilo, se assemelha a um grande espelho (MOURA, 2007).

A época da vazante é o tempo de avaliar as perdas com a cheia e novamente recomeçar. Reencontrar alguns dos objetos caídos n’água e que ficaram enterrados na lama que emerge com a descida das águas. Perdem-se equipamentos de trabalho, até motores rabeta. São grandes as perdas de pequenos animais e por isso muitos moradores preferem vendê-los quando se apresenta a expectativa de uma grande cheia. O consolo que todos sabem é que essa "benção das águas" fertiliza o solo com os nutrientes trazidos desde os Andes e traz a certeza do retorno do plantio em forma de alimento. É o tempo de organizar o replantio da roça, negociar a troca de sementes. Em algumas situações é preciso buscar sementes de terra firme porque a cheia levou tudo. É a época do surgimento das praias, da ameaça à predação dos quelônios, de se organizar para proteger a reprodução dos "bichos de casco". Na vazante, como na enchente, é também o tempo de apreensão com as terras caídas ${ }^{5}$, fenômeno natural que apavora os moradores por fazer submergir casas, canoas, barcos (MOURA, 2007). Esse fenônemo é também um dos responsáveis pela necessidade de deslocamento das famílias para outros lugares, uma forte característica da forma de ocupação na várzea. Estudos realizados com base em histórias orais, constataram que o tempo médio de permanência de um povoado em um mesmo lugar é de apenas 25 anos (LIMA e ALENCAR, 2000; ALENCAR, 2002; ALENCAR, 2010)

A seca é o tempo da fartura dos peixes nos lagos, dos moradores se organizarem para combater os "invasores" que colocam em risco a perda de um

\footnotetext{
5 "Terras caídas" ou desbarrancamento é um fenômeno natural da Amazônia. Causada pela erosão das margens de rios de águas barrentas. Esses rios, por terem fortes correntes, de pouca sedimentação, arrastam materiais nele contidos ou onde suas águas alcançam. Outro fator é a ação do vento e da chuva em margens desprotegidas de vegetação altas e rasteiras e/ou gramíneas. Também pode ser ocasionada pela dinâmica dos rios à procura de acomodação para seu leito, e pela degradação ambiental.
} 
ano ou mais de trabalho para preservar os lagos. É o tempo do maior esforço físico nas longas caminhadas em busca da água abaixo no barranco que surgiu em frente à comunidade, que pode atingir até mais de dez metros de altura, ou ir mata adentro na busca pelos igarapés e olhos d’água. É a época do espraiamento da paisagem, alongando a chegada aos rios, por onde passam os regatões ${ }^{6}$, com os comerciantes interessados nos produtos locais e na venda de mercadorias. É necessário caminhar na areia com o "rancho" nas costas, por mais de uma hora. É o tempo do isolamento em algumas comunidades pela total impossibilidade das pessoas se deslocarem a outros lugares (MOURA, 2007).

\subsubsection{O "CAMPESINATO DA VÁRZEA" E AS DEMANDAS DO "MERCADO ECOLÓGICO”}

Nesses ambientes de várzea da RDSM a vida social se reproduz com as características de uma organização social camponesa, em condições de acesso comum aos recursos naturais, fortemente definidos pela sazonalidade da variação do nível das águas. Esses aspectos socioambientais imprimem uma identidade a esse campesinato, no sentido de que se diferencia de outras situações na região Amazônica, que podemos lhe atribuir a denominação de "campesinato da várzeạ" (MOURA, 2007).

A organização produtiva é feita com base no trabalho da família como unidade doméstica de consumo e produção, avessa aos riscos das relações mercantis, limitada pela estrutura demográfica do grupo familiar - extenso e predominantemente jovem, fortemente afetada pelas imposições da sazonalidade dos recursos naturais, influenciada por relações com os mercados urbanos e pelas formas de atuação das políticas públicas nessa região. Essa organização produtiva é integrada a outros aspectos da vida social da localidade onde as relações pessoais são determinantes, definindo um modo de vida que diferencia um povoado do outro. As condições de acesso comum aos recursos naturais são estabelecidas pelas normas tradicionais de uso e apropriação dos recursos, onde as relações de parentesco são importantes atributos de pertencimento social. Mas, é pelo trabalho na natureza, como em outras organizações camponesas, que são demarcados os domínios entre os espaços usados em comum e os espaços usados privativamente pelas unidades familiares. Essas condições de trabalho são afetadas de formas diferenciadas pelas mudanças nas condições ambientais,

\footnotetext{
6 Barcos de pequeno porte que transitam frequentemente nos rios Solimões e Japurá e que praticam o comércio de produtos com as comunidades da reserva.

7 Rancho é como se referem aos itens adquiridos no mercado mais frequentemente.
} 
pelas ameaças de escassez dos recursos, pelas novas relações com o mercado que se compõem nas possibilidades trazidas com a modernização ecológica em curso desde a criação da reserva, que estimula a agregação de valores aos denominados produtos sustentáveis com inovações sociais de comprometimento com a convervação ambiental da várzea (MOURA, 2007).

Os produtores fazem o plantio logo que as águas começam a baixar e a colheita se inicia quando as águas começam a subir e se acelera com o ritmo de subida das águas. $\mathrm{Na}$ seca os moradores definem o plano de manejo comunitário dos recursos madeireiros, mas as árvores só serão cortadas quando o nível das águas atingir aquelas selecionadas para a comercialização nesse ano, pois as toras só podem ser transportadas pela via fluvial e só podem ser retiradas da floresta quando o nível da água permitir. Se fizerem a derrubada antes disso, os trabalhadores correm o risco de perder a madeira. $\mathrm{Na}$ seca a atividade mais intensa é a pesca, principalmente dos peixes de maior valor comercial como o pirarucu e o tambaqui. Para os moradores das localidades próximas aos lagos de maiores estoques, é esse período, cerca de dois meses, que garante $75 \%$ da sua renda monetária anual. Essa situação faz com que todos os esforços de trabalho possíveis sejam utilizados pelo grupo familiar para a atividade na pesca, assim como acontece na época da extração da madeira nas localidades onde essa extração é favorável. A época da cheia facilita o aumento da renda com a venda da madeira e em algumas áreas esta é a única fonte de renda para as famílias nesse período. A renda monetária familiar pode ser acrescida pelas aposentadorias rurais, pensões, a Bolsa Família, salários de professores e agentes de saúde e formas de assalariamento dos postos de trabalho de assistentes de pesquisa, fiscais, prestadores de serviços gerais na estrutura ocupacional criada pelo IDSM a partir de 1992. A atividade econômica predominante é a pesca, de lagos e de rios, conforme a época do ano e conforme os lugares. É da pesca que provem o alimento básico - o peixe, principalmente o bodó, complementado com a farinha de mandioca (MOURA, 2007).

Essa alternância dos fluxos da água, além de determinar as condições de acesso aos recursos altera também o ritmo de vida das pessoas que habitam esses lugares. $\mathrm{Na}$ cheia, o tempo de deslocamento entre as localidades e em direção aos centros urbanos fica menor. $\mathrm{Na}$ seca, o trajeto torna-se mais longo e perigoso. É preciso desenvolver habilidades para o trânsito fluvial, pois corre-se o risco de encalhar a embarcação nos bancos de areia que se formam com a descida das águas.

Até o início dos anos 1990 a produção econômica era feita predominantemente através do trabalho familiar, com relações mercantis com os "patrões" (regatões) e com o comércio dos centros urbanos, dependendo do tipo 
de produto e das oportunidades. Ainda é a forma predominante de produção econômica e de comercialização, porém, a partir de 1998 os produtores familiares, em algumas localidades, se relacionam também com outras formas de produção e comercialização no âmbito do mercado ecológico que ocorre com intermediações de vários atores numa ampla rede sociotécnica.

Para participar desse mercado os produtores locais recebem orientações para executar as atividades de produção e comercialização em acordo com as exigências dos compradores, com melhoria na qualidade e apresentação dos produtos, respeito à legislação ambiental e às normas estabelecidas no Plano de Manejo da RDSM, instrumento de ordenação dos princípios da conservação ambiental nessa unidade de conservação. Essas orientações são feitas, em grande parte, pela intermediação dos técnicos do desenvolvimento sustentável do Instituto de Desenvolvimento Sustentável Mamirauá - IDSM e outros agentes sociais. Essas intervenções possibilitam aumento na renda familiar, diversificar e, principalmente, intensificar as atividades no trabalho familiar e comunitário e também nas relações com agentes de comercialização de outras regiões, nacionais e internacionais. Essa intensificação decorre do fato de que, ao diversificar e ampliar os produtos, a produção se faz em continuidade ao uso intensivo de força de trabalho física e familiar, com reduzidas e limitadas inovações tecnológicas para redução de tempo de trabalho, do esforço físico e de riscos de acidentes. Essas limitações decorrem em grande parte pela desestruturação neste coletivo (humanos e não humanos, conforme Callon) em relação ao uso de energia elétrica e de sistemas de abastecimento de água para as atividades econômicas e para o consumo doméstico, além de outros elementos relacionados às ações políticas como a ausência de subsídios para a produção agrícola, calendário escolar apropriado à sazonalidade da várzea, entre outras mais. Estas são questões que identificamos como elementos contraditórios às propostas de um desenvolvimento sustentável (NOBRE e AMAZONAS, 2002).

\subsubsection{ACESSO À AGUA E ENERGIA ELÉTRICA COMO DEMANDAS ESTRUTURAIS DESSE COLETIVO}

Os moradores da várzea nessa região Amazônica convivem com o paradoxo da grande quantidade de água disponível pelo seu intrincado e farto sistema fluvial mas com a precariedade de água potável e com a ausência de sua distribuição para uso nos domicílios. Por outro lado, o forte imáginário amazônico de abundância de água pela caudalosidade dos seus rios esconde da sociedade 
civil os problemas vivenciados por esses amazônidas durante os períodos da seca, com privação de água e situações de isolamento social.

Nesses povoados a água para consumo e uso doméstico ainda é retirada diretamente dos rios, assim como o faziam desde o início da ocupação deste território. Em alguns domícilios, coletam a água dos rios ou igarapés, decantam de um dia para o outro e coam em um pano para depois depositar nos potes, seguindo as orientações que receberam dos agentes de saúde comunitária da Pastoral da Criança vinculada à Prelazia de Tefé, nos anos 1980. Essa instituição religiosa também teve importante influência no gerenciamento das questões de saúde comunitária ao orientar sobre o uso de potes com pequenas torneiras para que os usuários evitassem a maior contaminação da água pelo uso direto das mãos dentro dos potes, mas essa ainda não é uma prática usual nos domicílios apesar dos mais de 30 anos de sua atuação nessas localidades, algumas vezes em parceria com agentes comunitários de saúde das prefeituras locais.

Nos meses de seca os cursos d'água em frente às comunidades, principal fonte de água para o consumo doméstico e humano, secam bastante tomando uma cor esverdeada, repleta de musgo e detritos orgânicos, de odor fétido por causa dos peixes mortos pelo forte calor da água. A água fica inapropriada para a lavagem das roupas, para o consumo, para o banho. "O cabelo da gente fica duro $e$ é puro bodó" 8 . Os moradores têm que regrar o uso da água para o consumo doméstico e humano e se organizarem para as buscas de água no interior da mata, nos olhos d'água e igarapés, "naquelas monstras distâncias", geralmente uma atividade destinada às mulheres e crianças na distribuição do trabalho doméstico. Nos meses de seca as chuvas escasseiam por dez a quinze dias. Quando chove, todas as vasilhas domésticas são usadas para aparar a água.

É recente a alternativa de armazenamento da água da chuva para beber e para os usos domésticos. E, surpreendente a atualidade dos dados dos levantamentos epidemiológicos realizados pelo IDSM, em 2005, que identificaram que há uma baixa ingestão de água por essas pessoas principalmente durante as atividades na roça quando ficam por várias horas expostos ao sol (PERES e BRUCKI, 2005). As populações convivem em ambiente de abundância de água e com muitos obstáculos e ausência de tecnologias para acesso à água potável.

Outro grande desafio estrutural às inovações científicas e tecnológicas diz respeito ao fornecimento de energia elétrica de forma contínua e eficiente para esses pequenos agrupamentos populacionais. Assim como nos séculos anteriores e em outras espaços amazônicos, na maior parte desses povoados a

8 Bodó é um peixe pequeno muito usado na alimentação cotidiana. É facilmente capturado nos igapós, rios e lagos. 
oferta da energia elétrica é feita pelas concessionárias com o uso de miniusinas a termodiesel, restrita a até quatro horas por dia e fortemente dependente das condições de entrega do diesel que geralmente é feita como um ato político das prefeituras locais. Quando a seca é rigorosa, a comunidade toda fica às escuras porque não é possível transportar o diesel da cidade. A iluminação domiciliar é completada com uso de velas, lamparinas a querosene ou a diesel com consequências perigosas à saúde dos moradores em especial das crianças e idosos.

A tecnologia das miniusinas a termodiesel é ecologicamente incorreta, com máquinas de pouca eficiência energética, operadas de forma improvisada e precária com muitos acidentes de trabalho, além de fazerem muito barulho e do desperdício de óleo inclusive com contaminação do solo (GALVÃO, et al, 2003). A falta de energia elétrica na estrutura produtiva dessas populações dificulta o uso de inovações como a conservação do pescado e outros alimentos, processamento da madeira, atividades de artesanato, e outras mais. $\mathrm{Na}$ matriz energética do governo brasileiro essas localidades são consideradas sistemas isolados e as concessionárias têm que inovar nas adequações tecnológicas ${ }^{9}$ de geração de energia para essas áreas distantes do alcance dos sistemas de distribuição convencionais.

O Programa Luz para Todos, com 12 anos de existência, se propõe a estender a iluminação elétrica a todos os domicilios brasileiros e embora já tenha levado luz elétrica a mais de 3 milhões de domicílios rurais em todo o Brasil, na área da RDSM e RDSA só atendeu até o momento algumas localidades de terra firme, próximas ao sistema de distribuição, onde é possível aplicar e estender as formas usuais de produção de energia, sem que inovações para o uso de energias alternativas tenham sido incrementadas.

Estes fatos em relação ao acesso à água potável e ao uso de energia elétrica evidenciam a grande carência de inovações sociais que possibilitem um melhor viver nesses pequenos agrupamentos populacionais da floresta alagada amazônica. Os desafios à intersecção dos diversos atores da sociedade, da ciência e da tecnologia já são antigos e se tornaram mais reconhecidos no conjunto das reivindicações por políticas sociais de maior alcance que se associaram aos movimentos socioambientais.

9 Em uma das localidades, Aiucá, está em andamento, desde 2005, um projeto de pesquisa para a análise das condições de uso de energia solar fotovoltaica em sistemas domiciliares em 24 horas de uso ininterrupto, em acordo com as normas da ANEEL. O projeto, financiado pelo CTEnerg-Cnpq e executado pelo IEE/USP e IDSM, teria um efeito disseminador a outras localidades nas mesmas condições no interior da floresta amazônica. Apesar dos resultados positivos obtidos com essa tecnologia é ainda, em 2018, a única localidade com esse tipo de investimento. 
Ao longo dos anos negociando com agencias financiadoras e com agentes de políticas públicas testemunhamos incorretas e veementes afirmações de atores institucionais de que promover acesso a bens modernos a essas populações descaracterizaria uma forma tradicional e bucólica de viver, como que condenando essas pessoas à uma condição de exclusão tecnológica, seja por sua identidade estar fortemente associada a um modo de vida com tecnologia rudimentar, seja porque se distanciam de uma relação com o mercado tecnológico uma vez que, por suas condições de baixa renda não se tornariam efetivos consumidores dos produtos dessa tecnologia.

Por outro lado, em nossa convivência com essas populações sempre testemunhamos o grande anseio desses moradores por usufruir do conforto de água na torneira dentro de casa, chuveiro no banheiro interno para evitar riscos dos banhos noturnos nos rios principalmente para os idosos, para facilitar as tarefas domésticas de cozinhar e lavar roupa, para ter água em casa para todos beberem com segurança; assim como, ter energia elétrica por 24 horas, permitindo uso de equipamentos elétricos como o freezer e a geladeira para armazenar seus alimentos e produtos diminuindo a fadiga da produção diária de alimentos, usar máquina de lavar roupa, como também fazer uso de instrumentos de trabalho, como a serra elétrica entre outras facilidades. Objetos de desejo que são descobertos com as idas mais frequentes aos centros urbanos ${ }^{10}$ e na expansão imagética da sociedade de consumo a esses rincões amazonicos pelos canais televisivos nacionais. Nos últimos 15 anos, a renda média monetária familiar se elevou, seja pelo acesso ao mercado ecológico como, principalmente, pelos programas de transferência de renda e muitas famílias se equiparam com bens de uso durável dependentes de energia elétrica (MOURA et al., 2016).

Ao discorrer sobre esses fatos, na perspectiva de uma sociologia da tradução, identificamos uma situação-problema que instiga a composição de uma rede sociotécnica com as seguintes características fundamentais: como conciliar o incremento das inovações com manutenção de uma forma de organização familiar camponesa da várzea, respeitando os arranjos e práticas socioambientais locais, com baixos custos operacionais, com facilidades de deslocamento de um lugar a outro em menos de uma geração, face às dinâmicas geomorfológicas desse ecossistema.

10 Com o aumento da renda, nos últimos dez anos, houve um enorme aumento na compra de rabetas (pequenos motores de popa para pequenas embarcações) o que deu a esses moradores uma maior mobilidade, sendo muito mais frequente a ida à cidade do que foi nas gerações anteriores. Nas comunidades mais afluentes economica como as vinculadas às atividades do ecoturismo ou da pesca manejada do pirarucu, todos os domicílios tem um motor rabeta, em algumas situações, mais de uma por moradia (MOURA et al., 2016) 


\subsection{O PROCESSO DA TRADUÇÃO}

A tradução, segundo Callon (1986, 1991, 1999), envolve quatro momentos distintos: a problematização, a atração, o envolvimento ou recrutamento e a mobilização. No momento da problematização ocorrem dois movimentos: a interdefinição dos atores e a definição de pontos de passagem obrigatórios. Os diferentes atores, ou um determinado ator, desenvolvem uma interpretação, uma hipótese sobre determinada controvérsia e procuram demonstrar que os interesses dos demais atores convergem para a problematização proposta. Neste momento é necessária a definição da identidade do problema, com seu sistema de alianças ou associações entre entidades. Para que uma determinada problematização se viabilize, o ator cria dispositivos de atração que podem ser traduzidos em eventos científicos, discursos, artigos científicos, documentos técnicos, definição das fontes de financiamento entre muitos outros. Esses dispositivos orientam a formulação de uma ou mais hipóteses de ação e se constituem um sistema de alianças em torno do protagonista da problematização. Essa atração deve ter êxito para confirmar a problematização proposta edar sequência ao processo.

A atração, por sua vez, só será bem-sucedida se a definição e a coordenação dos papéis na rede tiver resultado positivo. Esse momento da operação de tradução pode ser denominado como envolvimento ou recrutamento de atores e suas formas podem ser variadas. E, a quarta etapa é a mobilização dos aliados, quando, pela escolha de porta-vozes e ao estabelecimento de intermediários, entidades humanas e não-humanas poderão ser deslocadas e reunidas em um ponto. O processo de mobilização permite simplificar o mundo heterogêneo e complexo transformando as entidades em representantes que falam em nome dos outros. Quando uma tradução tem êxito, ela assume a configuração de uma rede. O resultado desse processo é sempre fruto de um trabalho coletivo.

Ao problematizar sobre as inovações adequadas ao uso da água e acesso à energia elétrica em pequenas comunidades da várzea amazônica, o papel do IDSM foi de ator-rede no sentido de que foi somente a partir de sua configuração como ator institucional e agenciador de um conjunto de possibilidades que tornou possível refletir sobre a várzea como parte integrante de um coletivo de humanos e não humanos com expressão peculiar da sociobiodiversidade da região amazonica. Os dispositivos de atração foram desde então traduzidos nas evidências registradas sobre esse ecossistema em eventos acadêmicos nacionais e internacionais, na circulação entre agencias governamentais e não governamentais, em diálogos com várias controvérsias que tentam convergir para a conservação da sociobiodiversidade, entre vários outros. Em um desses eventos, 
um dos técnicos do IDSM tomou conhecimento, por trajetos não planejados, da existência de placas solares fotovoltáicas que possibilitam a captação da energia solar e que com uso dessa tecnologia seria possível usar para impulsionar bombas para deslocar água de superfície dos rios para armazenamento e distribuição domiciliar. Essa se apresentou como a grande possibilidade de investimento para as comunidades de várzea. A porta de entrada para várias outras inovações. Essa tradução ocorreu pela primeira vez em 1997 e desencadeou um extenso processo de mobilização para compor uma marcante rede sociotécnica nessa trajetória institucional, que descreveremos em maior detalhe nos itens seguintes. As associações que se dão a partir de operações de tradução fundamentam a formação de uma rede sociotécnica.

Um outro aspecto ressaltado pela análise de Callon nesses caminhos da tradução é que esse processo de construção mobiliza um conjunto de técnicas e procedimentos de pesquisa de campo que constituem parte da tradição das ciências sociais, particularmente da antropologia. Por fim, as ciências sociais e humanas ao romperem com as polarizações entre sociedade / natureza, contexto / conteúdo inseriram a produção de conhecimentos sobre a ciência e a tecnologia na discussão da produção da sociedade moderna. Nessa compreensão, os atores envolvidos nos diversos processos investigativos de registros sobre o modo de vida na várzea abrem possibilidades para compreender as demandas e significados das inovações.

Ao descrevermos com recursos etnográficos uma situação problema que ressalta um conjunto de demandas por melhor viver no ambiente da várzea, colocamos em maior evidência as incertezas sobre o conhecimento desse ecossistema, como também a definição das agendas de pesquisa pelos institutos de pesquisa nacionais e locais e como operam as políticas públicas quando os sujeitos são pequenos agrupamentos populacionais, com caracteristicas ambientais e demandas muito específicas e desafiadoras tecnologicamente.

\section{A CO]MPOSIÇÃO DA REDE SOCIOTÉCNICA EM RELAÇÃO ÀS CARACTERISTICAS E DEMANDAS DAS POPULAÇÕES DA VÁRZEA DA RDSM}

Conforme Callon (1989) e seus seguidores, a rede sociotécnica compreende um conjunto de atores heterogêneos, humanos e não-humanos, associados no processo de concepção, produção e difusão de conhecimentos, dando origem a definições tecnológicas obtidas no processo de solução de controvérsias. Nesses contextos os conflitos e acordos são portas de entrada para esta investigação. 
Com uso de recursos metodológicos apropriados à apreensão dos confrontos entre os diversos interesses em jogo é possível compreender que a construção da tecnologia se torna socialmente relevante quando dialoga com o modo de produzir conhecimento diante da importância atribuída a este processo pelas instituições de ciência e tecnologia.

O senso comum nos conduz a identificar uma tecnologia apenas como uma consequência linear de decisões racionais que conduziram até a sua concretude. No entanto, quando reconstituímos a rede da qual se origina uma inovação, percebemos que o processo de desenvolvimento de tecnologias também é socialmente construído. A tradução, nessa perspectiva, expressa um processo contínuo ao longo do qual os atores se contrapõem, modificam seus interesses, definem estratégias. É, portanto, importante e necessário observar e mapear o desdobramento da rede sociotécnica que se articula entre os processos e debates tecnocientífcos e políticos na definição de novas estratégias de ação.

A partir da problematização identificada, neste artigo, analisamos a seguir os percursos na constituição de uma rede sociotécnica que teve como propósito contribuir com uma inovação social que pudesse levar água encanada aos domícilios de uma região de várzea, com uso de energia solar fotovoltáica.

No passado recente foram feitas tentativas de perfuração de poços artesianos nessa área de várzea, com a constituição de uma outra rede sociotécnica que teve como principais porta-vozes os agentes missionários da Igreja Católica nas ações da Prelazia de Tefé que, em diligência com grupos religiosos de outros países, agenciaram e financiaram a instalação dessa tecnologia de bombeamento de água. A água era obtida com uso de bombas manuais instaladas nesses poços. No entanto, seja pelo baixo nível da perfuração do poço, seja pelas características da água com muita salobridade, o uso não teve aceitação dos moradores e logo os equipamentos foram abandonados pela população. A instalação foi feita apenas em algumas comunidades católicas.

Nos últimos 20 anos, o IDSM vem implementando e aprimorando uma tecnologia social de bombeamento e abastecimento de água com uso de energia solar fotovoltáica. Para alcançar o modelo atualmente usado, esse sistema vem sendo aprimorado ao longo dos anos, na tentativa (entre acertos e erros) de encontrar o modelo mais adequado para esse ambiente. A estratégia utilizada foi instalar, inicialmente, o sistema em quatro comunidades de forma experimental para que seus resultados fossem acompanhados tanto em relação aos usos da tecnologia quanto em relação aos processos de gestão e posterior aprimoramento para expansão para as demais áreas. Foram escolhidas comunidades com: a) bom nível de organização social para garantir um bom 
suporte para a gestão do sistema; b) com características geomorfológicas diferenciadas para que fossem avaliados os níveis de pulsão da água e consequentes ajustes da tecnologia; c) foi dada preferência às comunidades situadas em limites municipais de prefeituras com maior comprometimento com essas populações para que as ações pudessem ser feitas em parceria com o poder público que, na sequência, assumiria a expansão dessa tecnologia para outras comunidades sob sua administração. No período de 2009 a 2013 foram instalados sistemas em apenas 12 das 170 localidades situadas na várzea da RDSM, o que revela a grande dificuldade de replicabilidade e expansão da inovação. As principais limitações são de natureza financeira e de gestão.

A construção da tecnologia levou em consideração, além de outros fatores operacionais, as seguintes condições : a) a sazonalidade da várzea que alterna períodos de abundância e escassez de água; b) ausência de energia elétrica de qualidade e de forma contínua; c) que trata-se de pequenos agrupamentos populacionais dispersos entre si e distantes dos principais centros comerciais da região; e d) que essas populações precisam se deslocar para outros lugares em períodos que correspondem a menos de duas gerações, em média, em virtude das frequentes alterações geomorfológicas da região.

A rede sociotécnica foi constituída por atores locais, nacionais e internacionais, estes principalmente na condição de financiadores. Grande parte desses atores ainda continua atuando nesta rede. O principal ator foi o Instituto de Engenharia Elétrica da Universidade de São Paulo IEE/USP, onde engenheiros elétricos e seus estudantes de graduação e pós graduação, fazem análises de usos e adaptações do uso das placas solares fotovoltáicas em laboratórios especializados e com interconexões com a Espanha e Alemanha. Outros atores são os pesquisadores da Universidade Federal do Pará, sendo parte deles formados por esse grupo do IEE/USP. Ainda, organizações não governamentais atuando na região amazônica, implantando sistemas de uso de energia solar fotovoltáica em comunidades indígenas; moradores e lideranças comunitárias, técnicos e agentes do desenvolvimento sustentável vinculados ao IDSM, entre outros mais. A rede possibilita, em diversas dimensões, a discussão sobre as controvérsias em relação à necessidade de barateamento do custo do sistema para que ele possa ser mantido pelos moradores das comunidades; testes com bombas de propulsão que facilitem e resistam à variedade no nível das águas dos rios e trânsito de material orgânico nesse fluxo; que tenha a maior efetividade possível durante os períodos de seca quando a população deve ficar atenta às necessidades de extensão dos tubos plásticos pelo distanciamento do rio em relação às moradias, entre outras demandas de gestão. 
O sistema é composto por placas solares fotovoltáicas, balsas flutuantes para sustentar essas placas permitindo a sua adaptação à subida e descida do nível das águas, bomba de sucção, depósitos para armazenamento da água e tubos de plastico para distribuição para as casas. A opção por uso da sucção da água de superficie foi resultado de uma observação atenta de um agente de desenvolvimento sustentável do IDSM que apresentou essa proposta após ter testemunhado o insucesso da perfuração dos poços com essa finalidade.

\section{REFLEXÕES SOBRE OS MECANISMOS DE DISPUTA E O ALCANCE DAS EXPECTATIVAS GERADAS AO LONGO DE MAIS DE 20 ANOS DE USO DESSA INOVAÇÃO.}

A primeira iniciativa relacionada a essa tecnologia na região Amazônica foi implantada pelo Programa de Desenvolvimento Energético dos Estados e Municípios (Prodeem), um programa do Governo Federal instituído em 1994 para atender às localidades isoladas não supridas de energia elétrica pela rede convencional, obtendo essa energia de fontes renováveis locais. O IEE/USP participou deste programa inicial e em conjunto com a equipe técnica do IDSM propôs um projeto experimental que foi financiado com recursos desse programa.

O modelo experimental foi sendo readaptado, redimensionado e os moradores das comunidades, que nunca tinham ouvido falar sobre as potencialidades energéticas do sol, foram aos poucos se acostumando com essas placas, interpretando as suas formas de uso, aprendendo a administrar os cuidados com o equipamento que requer proteção dos animais que transitam nas comunidades, como jacarés e bois, fazendo a limpeza das placas para melhorar sua capacidade de armazenamento de energia, entre outros aprendizados.

Os principais problemas identificados no sistema estão relacionados ao processo de sucção da água do rio para o reservatório. O modelo de bomba utilizado atualmente é importado, de alto custo, em média $\mathrm{R} \$ 8$ mil reais, e tem se demonstado como um tipo de bomba de difícil manutenção. Portanto, o maior desafio, desde a primeira implementação até os dias atuais, é encontrar uma bomba adequada às características físicas do ambiente, ou seja, com alto recalque e alta vazão, além de suportar a grande concentração de sedimentos (barro) da água dos rios.

A bomba utilizada na primeira instalação, com recursos do PRODEEM, foi um modelo importado chamado McDonald que não apresentou o desempenho desejado em termos de vazão e recalque, mas que ainda teve uma vida útil de 5 anos. Entretanto, segundo o técnico do IDSM responsável pelo 
aocmpanhamento desses experimentos, este modelo de bomba, devido à sua rusticidade tecnológica suportou bem as caracteristicas dessa água de rio com grande presença de sedimentos.

O modelo utilizado na segunda instalação também foi importado, da marca Grunfos, considerada uma tecnologia mais avançada com alta vazão e recalque, ideal para atender a demanda de água nos domicílios. Entretanto, essa marca se mostrou mais sensível às características da água da região, registrando uma vida útil de menos de 3 anos. Outro problema verificado com os primeiros equipamentos instalados, que chamou atenção dos representantes comerciais da marca e de pesquisadores do Laboratório do IEE/USP foi a oxidação do material externo que reveste a bomba. Os técnicos atribuíram a corrosão ao alto $\mathrm{PH}$ da água barrenta do rio Solimões. Mesmo depois de procurados insistentemente pelos técnicos do IDSM, os representantes dessa marca no Brasil não deram retorno sobre as possíveis soluções para a falha.

Esse modelo de bomba é o que Akrich et al. (1988) chamam de modelos rígidos, para os quais os fabricantes não estão dispostos a questionar o design, onde não existe flexibilidade tecnológica que permita uma adaptação com bricolagem. As tecnologias estabelecidas no mercado possuem o princípio de "pegar ou largar" (AKRICH et al.,1988)

Segundo um dos técnicos do IDSM, esse modelo de bomba apresenta duas dificuldades que precisam ser superadas para viabilizar o sistema de bombeamento de água do rio com energia solar fotovoltaica: a primeira está relacionada à complexidade da tecnologia, que não permite o conserto fora das oficinas autorizadas da marca, inviabilizando a autonomia e a gestão dos problemas pelas famílias; e a segunda está relacionada ao preço da bomba no mercado nacional - em 2016, custava em torno de $\mathrm{R} \$ 8$ mil reais, e disponível apenas nas grandes capitais do país.

Essas condições dificultam o processo de construção social da tecnologia por parte das famílias usuárias dos sistemas, principalmente pela restrição do mercado e pelo baixo domínio cognitivo sobre a mesma. Portanto, o sistema almejado exige um tipo de equipamento que seja robusto no bombeamento, facilmente encontrável no mercado, que tenha valores praticados no contexto local e cuja tecnologia permita a sua manutenção (bricolagem) localmente e de forma menos corporativa.

Uma outra alternativa, iniciada em 2010, desenvolvida por essa rede sociotécnica foi um sistema híbrido de armazenamento de água, instalando junto ao sistema uma cisterna com capacidade de armazenar 25 mil litros de água da chuva. As famílias tinham o hábito de armazenar água da chuva em 
pequenos recipientes, como baldes, potes e garrafas PETs. A ideia de testar esse modelo híbrido surgiu depois de entrevistadas as famílias, que informaram que a quantidade estocada em casa não era suficiente para atender os períodos de maior estiagem, e que com um depósito maior poderiam resolver o problema do armazenamento de água.

Entretanto, esse modelo não se mostrou eficiente por duas razões: a primeira, pelo curto tempo que chegou a ser usado pelas famílias - cerca de dois anos -, pois um incêndio afetou o equipamento, não dando tempo para que tecnologia fosse apropriada pela comunidade; a segunda razão se deveu à dificuldade de implementar o projeto coletivo para o uso do sistema, que exige a organização da comunidade para esse uso. Em entrevistas, 55\% das famílias declararam preferir captar a água da chuva, pois conseguem fazer o manejo do recurso de forma mais autonoma.

A implementação dos sistemas de bombeamento de água de superfície é feito de forma participativa. As tarefas são divididas entre os técnicos do IDSM e as famílias da comunidade que estão recebendo a tecnologia. As etapas seguem um procedimento orientado pelos agentes externos, de acordo com a especialidade de cada grupo. Os técnicos ficam responsáveis pela instalação e capacitação, e às famílias cabem as tarefas de extração da madeira para construir as bases de sustentação das placas fotovoltaicas e do reservatório, e de instalação da rede de distribuição de água para os domicílios. Após a instalação, os técnicos do IDSM realizam capacitações para os usuários. Essas capacitações são importantes para o processo de apropriação e empoderamento das famílias na gestão dessa nova tecnologia introduzida no seu cotidiano. Exemplo disso ocorre no período da seca, quando o distanciamento do rio exige que os moradores se organizem para estender também a tubulação; ou quando novas casas são construídas e o grupo familiar que chega precisa negociar a ampliação do sistema até sua casa.

A orientação inicial dada pelos técnicos para a composição do grupo responsável pela gestão do sistema é que este seja composto por dois homens e uma mulher. No primeiro momento, as famílias costumam seguir a orientação, entretanto, os responsáveis pelo sistema logo começam a se defrontar com a sobrecarga de atividades e com a criação de uma situação de dependência da comunidade para com o grupo gestor. A partir dos enfrentamentos travados na gestão comunitária, os moradores vão encontrando formas alternativas para minimizar os efeitos negativos da introdução da tecnologia, adotando estratégias de revezamento semanal ou mensal entre os responsáveis pela manutenção da mesma.

O funcionamento do sistema exige dos gestores um esforço diário e na falta de um responsável a comunidade toda ficará sem água ou energia. O 
funcionamento do sistema de água é contínuo, somente interrompido quando ocorre uma grande cheia. Nesse período, que dura em torno de dois a três meses, a bomba é desligada, pois o terreno enxarcado amolece, correndo risco de não suportar o peso da caixa d'água, cuja capacidade média é de 10 mil de litros. Um dilema enfrentado pelas famílias é o de encontrar a melhor forma de gestão compartilhada, sem comprometer as múltiplas atividades já desempenhadas no dia a dia pelos grupos e nem o funcionamento dos serviços básicos e essenciais.

Quadro 1 - Características da organização política e nível de mobilização em comunidades com sistema de bombeamento de água.

\begin{tabular}{|c|c|}
\hline $\begin{array}{l}\text { Comunida- } \\
\text { des com me- } \\
\text { nor nível de } \\
\text { mobilização }\end{array}$ & $\begin{array}{l}\text { Os trabalhos são concentrados em um pequeno grupo eleito; } \\
\text { Os gestores não conseguem articular a comunidade para partilhar os } \\
\text { trabalhos; } \\
\text { Os gestores geralmente moram próximo ao sistema ou assumem uma } \\
\text { função de liderança e acumulam atividades; } \\
\text { Não há um revezamento ou nova eleição para seleção de novos } \\
\text { responsáveis pelo funcionamento do sistema; } \\
\text { Não há uma mobilização por parte dos eleitos para articular nova } \\
\text { eleição, o que pode estar relacionado à falta de interesse da comunidade, } \\
\text { ou a disposição dos eleitos em continuar assumindo a função, de forma } \\
\text { a concentrar um poder legítimo perante o grupo; } \\
\text { O sistema funciona com maior interrupção, por depender } \\
\text { exclusivamente de poucas pessoas; } \\
\text { Não há um conhecimento geral das famílias sobre quem são os } \\
\text { responsáveis pela gestão do sistema; } \\
\text { Pouca disposição para pagar pelo uso da água encanada e pela taxa de } \\
\text { manutenção; } \\
\text { Postura de sempre esperar por integrantes do IDSM para resolver os } \\
\text { problemas técnicos do sistema. }\end{array}$ \\
\hline $\begin{array}{l}\text { Comuni- } \\
\text { dades com } \\
\text { maior nível } \\
\text { de mobili- } \\
\text { zação }\end{array}$ & $\begin{array}{l}\text { Após a instalação seguem a orientação recebida pelos técnicos do } \\
\text { IDSM em eleger três representantes; } \\
\text { Identificam a dificuldade de depender de poucas pessoas e testam outras } \\
\text { formas de compartilhar o trabalho para garantir o funcionamento do } \\
\text { sistema; } \\
\text { Articulam a indicação de novos membros e formas alternativas de } \\
\text { gestão com a comunidade; } \\
\text { Aumentam o número de eleitos; } \\
\text { Fazem revezamento semanal ou mensal por família; } \\
\text { Controlam mais eficiente sobre o funcionamento do sistema por parte } \\
\text { da comunidade; } \\
\text { Reagem de forma positiva ao desafio de criar um fundo de reserva } \\
\text { para eventuais problemas técnicos com o sistema; } \\
\text { Procuram os técnicos do IDSM quando há alguma dificuldade com o } \\
\text { sistema de água. }\end{array}$ \\
\hline
\end{tabular}


Em seus depoimentos as famílias relatam os efeitos da introdução desse sistema no dia a dia da comunidade. Os principais relatos referem-se à diminuição do esforço físico no trabalho doméstico, geralmente desempenhado por mulheres e crianças. Mas também dizem respeito à menor exposição ao sol; à redução do risco de acidentes por afogamento com crianças que sempre acompanham as mães nas tarefas de lavar roupa à beira do rio; possibilidade da privacidade na higiene pessoal; facilidade nas atividades produtivas, como na limpeza do pescado; diminuição de doenças diarreicas e de suas consequências, como a anemia, desidratação, desnutrição e óbitos, principalmente das crianças.

Os depoimentos abaixo sobre os usos sociais do sistema de água, ressalta os benefícios à vida das famílias ao longo desses anos.

- Antes nós tínhamos que ir na beira carregar água, lavar roupa - bacia de louças pesada. E no período da seca a água fica muito longe. E tinha que carregar água três vezes por dia. Hoje com água dentro de casa, parece que tudo é fácil, tudo é feliz. Os homens já estão fazendo as casas com o banheiro dentro, com chuveiro, para seus filhos e esposa. Muita mulher diz que se o sistema esculhambar, vai embora para a cidade. (L.M.S, 28 anos).

- A gente sofre muito no período da seca. Tem seca que quando chega no barro de louça faz. um barraco de 16 degraus, quando ia pegar água na volta eu chegava quase morta dentro de casa. Uma vez, meu filho foi pegar água lá em baixo e quando chegou no último degrau o balde virou para trás e caiu, quebrou balde, perdeu a água e quase acontece um acidente e perco meu filho. Tinha momento que dava vontade de chorar, quando olhava para o barranco e via a escadaria. Agora não, tá todo mundo feliz. (R.C.S, 39 anos). Outubro/2015

Serpa (2001) identificou na experiência em Lagamar com famílias caiçaras, no interior do estado de São Paulo, que a construção coletiva do projeto de bombeamento exige um papel preponderante e participativo das mulheres desde as discussões iniciais, e que é fundamental a valorização do papel feminino no contexto do sistema energético local. Na divisão sexual do trabalho, como é registrado em outros grupos tradicionais, cabe às mulheres um papel importante na manutenção do sistema energético, com sua participação nas roças e no processamento dos produtos, no provimento de água para consumo, e nos cuidados da casa e dos filhos. (SERPA, 2001, p. 174).

Essa divisão apresentada por Serpa se assemelha à forma como as famílias ribeirinhas se organizam e dividem os trabalhos diários. Portanto, o envolvimento das mulheres em todo o processo garante a sustentabilidade da tecnologia social, 
tendo como sustentação a organização dos usuários e a efetiva participação das mulheres nas atividades e nas tomadas de decisões. Akrich et al. (1988) reforçam que para alcançar o sucesso de inovação é importante considerar a escolha de representantes ou porta-vozes que irão interagir, negociar, moldar o projeto e transformá-lo, seria um porte parole légitime no sentido de representar a comunidade em determinados espaços que possam atrair outros atores para compor a rede.

\section{CONSIDERAÇÕES FINAIS}

O estudo possibilita refletir sobre o processo de desenvolvimento de tecnologias como socialmente construído, e no caso específico, como as inovações são afetadas pelas políticas nacionais de ciência e tecnologia, na medida em que, no seio de uma sociedade capitalista, esse desenvolvimento sofre as pressões do direcionamento das pesquisas para o desenvolvimento de tecnologias economicamente competitivas que podem realimentar e manter o mercado tecnológico.

Os dados apresentados a partir da tradução de uma situação de demandas de sociedades de organização camponesa, com reduzida composição demográfica e habitantes de uma área de floresta alagada, instigam a reavaliar os princípios constitutivos da ciência e tecnologias modernas no sentido de estimular a criação de inovações tecnológicas que, distanciadas das prioridades da sociedade de consumo possam contribuir com o bem viver dessas populações.

\section{REFERÊNCIAS}

ALENCAR, E. F. Memórias de Mamirauá. Tefé. Am. Instituto de Desenvolvimento Sustentável Mamirauá. 2010.

ALENCAR, Edna Ferreira. Terra Caída: Encante, Lugares e Identidades. 262 f. Tese (Doutorado em Antropologia) - Departamento de Antropologia, Universidade de Brasília - UNB, Brasília, 2002.

AKRICH, M., CALLON, M. et LATOUR B., 1988, A quoi tient le succès des innovations? 1 : L'art de l'intéressement, Gérer et comprendre, Annales des Mines, 11, 1988: p. 4-17. 
AYRES, J. M. As matas de várzea do Mamirauá: Médio Rio Solimões. Brasília: CNPq, Sociedade Civil Mamirauá, 1993. (Estudos Mamirauá, 1).

BAUMGARTEN, M. Sociedade e Sustentabilidade: qual o lugar do conhecimento?. Sociologias, Porto Alegre, ano 16, n. 37, set/dez, p. 14-22. http://dx.doi.org/10.1590/15174522-016003701. 2014.

BIJKER, W. E. Of bicycles, bakelites, and bulbs: toward a theory of sociotechnical change. Massachusetts: The MIT Press, 1995.

BLOOR, D. Conocimiento e imaginario social. Barcelona: Gedisa, 1998.

BRANDÃO, F. C. Programa de Apoio às Tecnologias Apropriadas - PTA: avaliação de um programa de desenvolvimento tecnológico induzido pelo CNPq. Dissertação (mestrado em desenvolvimento sustentável) - UnB, Brasília, 2001.

CALLON, M Le réseau comme forme emergente et comme modalité de coordination: le cas des interactions stratégiques entre firmes industrielles et laboratoires académiques. In: CALLON, M. Et al. Réseau et coordination. Paris: Economica.1999. p.13-64.

CALLON, M Réseaux technico-économiques et irréversibilité. In: BOYER, R.; CHAVANCE, B.; GODARD, O (eds). Les figures de 1'irréversibilité en économie. Paris: Editions de L'École des Hautes Études en Sciences Sociales, 1991. p. 194-230.

CALLON, M. Society in the making: the study of technology as a tool for sociological analysis. In: BIJKER, W. E. et al. (Ed). Social construction of technological systems. Cambridge: Cambridge University Press, 1987.

CALLON, M. Some elements of a sociology of translation: domestication of the scallops and the fishermen of St Brieuc Bay. In: Law, J. (Ed). Power, Action and Belief: a new sociology of knowledge? Sociological Review Monograph 32. London: Routledge and Kegan Paul. 1986 p. 196-233.

CALLON, M. "Struggles and Negociations to Define What Is Problematic and What Is Not: the Socio-Logics of Translation", In: KNORR, K. D., KROHN, R. e WHITLEY, R. (Eds.), The Social Process of Scientific Investigation, Dordrecht: D. Reidel. 1980. p. 197-219, 1980.

CALLON, M. Por uma nova abordagem da ciência, da inovação e do mercado. IN: PARENTE, A. (Ed.) A trama da rede. Porto Alegre: Sulina, 2004. 
CALLON, M; LASCOUMES, P. e BARTHE, Y. Agir dans un monde incertain: essai sur la démocratie technique. Paris: Éditions du Seuil, 2001.

DAGNINO, R. Tecnologia apropriada: uma alternativa? Dissertação (mestrado) - UnB, Departamento de Economia, Brasília, 1976.

DAGNINO, R. Enfoques sobre a relação ciência, tecnologia e sociedade: neutralidade e determinismo. In: Organização dos Estados Iberoamericanos para a Educação, a Ciência e a Cultura. Sala de Lectura CTS+I de la OEI, 2002b. Disponível em: < http://www.campusoei.org/salactsi/index.html

DAGNINO, R. A relação universidade-empresa no Brasil e o "argumento da hélice tripla". Revista Brasileira de Inovação, Rio de Janeiro, Finep, v. 2, n. 2, p. 267-308, jul./dez. 2003.

DAGNINO, R.; BRANDÃO, F.C. e NOVAES, H.T. Sobre o marco analítico conceitual da tecnologia social. In: Tecnologia Social - uma estratégia para o desenvolvimento. Rio de Janeiro, Fundação Banco do Brasil, 2004.

DAGNINO, R., NOVAES, Henrique T., A Adequação Sócio-Técnica na agenda do Complexo de C\&T e dos Empreendimentos autogestionários. XI Seminário Latino-Iberoamericano de Gestion Tecnológica. 25 a 28 de outubro/2005. Salvador. Brasil.

DICKSON, D. Tecnología alternativa y políticas del cambio tecnológico. Madri: H. Blume, 1978.

GALVÃO, Luiz Cláudio Ribeiro, UDAETA, Miguel Edgard Morales, PAZZINI, Luis Henrique Alves, GIMENEZ, André Luis Veiga e NISHIMARU, Rodrigo Shinji. Relatório de Visita Técnica à Reserva de Desenvolvimento Sustentável Mamirauá. Grupo de Energia do Departamento de Engenharia de Energia e Automação Elétricas da Escola Politécnica da Universidade de São Paulo.São Paulo; GEPEA, 2003.

GIDDENS, Anthony. Modernização Reflexiva. São Paulo: UNESP. 2002.

JUNK, Wolfang J.,The Central Amazon river floodplain: concepts for the sustainable use of its resources. IN: JUNK, Wolfang J.; OHLY J.J.; PIEDADE, M.T. F; e SOARES, M.G.M. (ed.) The Central Amazon Floodplain: Actual Use and Options for a Sustainable Magagement. Leiden: Bachhuys Publishers, Netherlands, 2000: 75-94. 
LATOUR, B. Ciência em ação: como seguir cientistas e engenheiros sociedade afora. Tradução de Ivone C. Benedettí; revisão de tradução Jesus de Pauta Assis. São Paulo. Editora UNESP, 2000.

LATOUR, B. A Esperança de Pandora: ensaios sobre a realidade dos estudos científicos. São Paulo: EDUSC, 2001.

LATOUR, B. Where are the missing masses? The sociology of a few mundane artifacts. In: BIJKER, W.; LAW, J. (Ed.) Shaping technology/building society. Cambridge: The MIT Press, 1992.

LIMA, D. de M. (Org.) Diversidade socioambiental nas várzeas dos rios Amazonas e Solimões: perspectivas para o desenvolvimento da sustentabilidade. Manaus: Provárzea/MMA/IBAMA/PPG7, 2004.

LIMA, D. de M e ALENCAR, E. F. Histórico da ocupação humana e mobilidade geográfica de assentamentos na várzea do médio Solimões. In: TORRES, Haroldo; COSTA, Heloisa. (Orgs.). População e Meio Ambiente: debates e desafios. São Paulo: Senac, 2000: p.133-161.

MACHADO, C.J.S, e TEIXEIRA, M. O. A inovação para a sociologia da Tradução. Revista de Antropología Iberoamericana, Ed. Electrónica Núm. Especial. Noviembre-Diciembre 2005 Madrid: Antropólogos Iberoamericanos en Red. ISSN: 1578-9705.

MOURA, E. A. F. Práticas socioambientais na Reserva de Desenvolvimento Sustentável Mamirauá. Tese (Doutorado em Desenvolvimento Sustentável do Trópico Úmido) - Núcleo de Altos Estudos Amazônicos, Universidade Federal do Pará, Belém, 2007.

MOURA, E.; NASCIMENTO, A.C.S ; CORREA, D. S.; ALENCAR, E; SOUSA, I. S.; Sociodemografia da Reserva de Desenvolvimento Sustentável Mamirauá: 2001- 2011 / Tefé, AM: Instituto de Desenvolvimento Sustentável Mamirauá; Belém: IDSM; NAEA; 2016.

NASCIMENTO, A. C. S. do., Tecnologia social para qualidade de vida em territórios de conservação. (Tese de Doutorado em Ciências Sociais Sociologia) - Instituto de Filosofia e Ciências Humanas - IFCH. Programa de Pós-Graduação em Ciências Sociais- PPGCS, Belém. 2017. 
NOBRE, M. e AMAZONAS, M. C. (Ed.) Desenvolvimento Sustentável: a institucionalização de um conceito. Brasília: IBAMA, 2002.

PERES, L. V. C.; BRUCKI, S. M. D. Condições de saúde e de acesso aos serviços públicos de saúde das comunidades ribeirinhas do Mamirauá e Amanã - IDSM. Relatório de pesquisa. Tefé: IDSM, 2005.

PORRO, Antonio. O povo das águas. Ensaios de etno-história amazônica. Rio de Janeiro: Vozes, 1995.

SERPA, P. M. N. Eletrificação fotovoltaica em comunidades caiçaras e seus impactos socioculturais. 252p. Tese (Doutorado) - Programa Interunidades de Pós-graduação em Energia da Universidade de São Paulo. 2001.

SNUC, Sistema Nacional de Unidades de Conservação da Natureza - lei n ${ }^{\circ}$ 9.985, de 18 de julho de 2000; decreto no 4.340, de 22 de agosto de 2002. $5^{\text {a }}$ ed. aum. Brasília: MMA/SBF.

TEISSERENC, M. J. da S. A.; SANT'ANA JÚNIOR, H. A. de; ESTERCI, N. (Ed.) . Territórios, mobilizações e conservação socioambiental. São Luís: EDUFMA, 2016.

THOMAS, H. E. Tecnologias para Inclusão Social e Políticas Públicas na América Latina. In: OTTERLOO, Aldalice. Tecnologias Sociais: caminhos para a sustentabilidade. Brasília, DF. 2009.

VARANDA, A. P. de M. e BOCAYUVA, P. C. C. Tecnologia Social, Autogestão e Economia Solidária. Rio de Janeiro : FASE | Ippur | Lastro | UFRJ, 2009.

VERCELLI, A. Reconsiderando las tecnologías sociales como bienes comunes. ÍCONOS, Revista de Ciencias Sociales de FLACSO Ecuador. CONICET de Argentina. 2009. 


\section{Etnoconservação e história ambiental para um novo modelo conservacionista do século XXI}

\section{Etnoconservation and environmental history for a new conservation model of the XXI century}

José Aécio Alves Barbosa - Doutor atuando no Programa de Pós-Graduação em Recursos Naturais da Universidade Federal de Campina Grande. Mestre em Recursos Naturais, Bolsista da CAPES. Membro do Grupo de Trabalho de História Ambiental da Associação Nacional de História e dos Grupos de Pesquisa em Estudos Culturais e em História, Meio Ambiente e Questões Étnicas da UFCG. E-mail: barbosa.joseaecioalves@gmail.com

José Otávio Aguiar - Doutor em História e Ciências Políticas pela UFMG. Possui pósdoutorado em História pela UFPE. Professor associado II da Universidade Federal de Campina Grande. Membro do Grupo de Trabalho de História Ambiental da Associação Nacional de História e coordenador dos Grupos de Pesquisa em Estudos Culturais e em História, Meio Ambiente e Questões Étnicas da UFCG. E-mail: j.otavio.a@gmail.com

\section{Resumo}

Diante do cenário ambiental mundial na atualidade, falar de conservação implica, necessariamente, em abarcar todo o conteúdo que envolve essa temática, a exemplo das questões de cunho socioeconômico, histórico e cultural. Sendo assim, o presente artigo tem como objetivo discutir algumas estratégias que vêm sendo postas como recursos úteis aos novos modelos de conservação necessários ante os desafios do século XXI, expondo a importância da inclusão dessas ferramentas (com destaque à etnoconservação e à história ambiental) na identificação de áreas prioritárias para conservação, e no planejamento, implementação e manutenção de áreas protegidas sustentáveis, usando nessa discussão uma abordagem aberta e interdisciplinar acerca da questão.

\section{Palavras-chave}

Conservação. Meio Ambiente. Sociedade. Cultura.

\begin{abstract}
Against the global environmental scenario today, talk about conservation necessarily imply in encompassing all the content that engages this theme, such as socioeconomic, historical and cultural issues. Thus, this article aims to discuss some strategies that have been placed as useful resources to new conservation models necessary given the challenges of the twenty-first century, exposing the importance of including these tools (especially the etnoconservation and environmental history) to identify priority areas for conservation, and planning, implementing and maintaining sustainable protected areas with a wide and interdisciplinary discussion on the issue.
\end{abstract}

\section{Keywords}

Conservation. Environmental. Society. Culture. 


\section{INTRODUÇÃO}

No Brasil, o obsoleto modelo seguido para delimitação de áreas prioritárias para conservação baseou-se, sobretudo, em padrões adotados pelos parques norte-americanos, onde a natureza deveria permanecer "intocada" e distante da “destrutiva presença humana" (RISSO, 2014).

Em uma ferrenha crítica a esse falido arquétipo, Diegues (2004) chamou-o de "Mito Moderno da Natureza Intocada", o que, convenhamos, foi bastante adequado, uma vez que o modelo mostrava-se absurdamente mítico em se tratando de áreas prioritárias para conservação nos países subdesenvolvidos, na sua maioria, extremamente povoados (AMEND, S.; AMEND, T., 1992).

A adoção desse molde de Unidades de Conservação (UC) gerou como implicação o estabelecimento de diversos "parques" em áreas antes habitadas por comunidades indígenas e tradicionais, desencadeando uma série de conflitos socioambientais decorrentes da ocupação estatal, expropriação e desapropriação dos territórios e sua consequente transformação em áreas protegidas (ARRUDA, 1999; FERREIRA, 2004).

As populações que habitavam essas áreas e seu entorno, antes de sua conversão em "santuários da vida natural", em absolutamente nada participavam das tomadas de decisão, uma vez que se pressupunha uma conflituosa dicotomia humano x natureza (RISSO, 2014). Insatisfeitos, esses habitantes viam agravadas suas condições de vida e, muitas vezes, acabavam por promover maior degradação ambiental que a existente antes da criação da UC, como exemplifica Botkin (1990), ao expor o caso do Tsavo National Park, no leste da África, e Diegues (1996) ao tratar do caso da Ilha do Cardoso, no Brasil; ambos casos em que a retirada das populções nativas locais culminou em maior perdas socioculturais e declínio ecológico.

Nesse contexto, o número de áreas de conservação onde os objetivos conservacionistas não eram atingidos apenas crescia, ao passo que os habitantes locais tinham criminalizados muitos dos seus atos (alguns deles tradicionalmente perpetuados), sendo proibidos de utilizar os recursos naturais e garantir sua manutenção socioeconômica e preservação da identidade cultural (CALEGARE; HIGUSHI; SIQUEIRA, 2008).

O quadro no Brasil começou paulatinamente a ser amenizado com a implementação de UC de Uso Sustentável, a exemplo de Áreas de Proteção Ambiental e Reservas Extrativistas. A adoção, mesmo que imperfeita desse tipo de modelo, de acordo com Sachs (2004), passou a impetrar, além do mapeamento e conservação do ambiente natural, a compreensão dos modos de 
vida e das relações socio-históricas e culturais das populações que habitavam as áreas agora protegidas.

Esse vem sendo um importante passo para o avanço conservacionista no país, uma vez que é inconcebível traçar estratégias de conservação para os recursos naturais sem considerar o elemento humano e sua influência cultural, ambiental e histórica sobre o ambiente (DIEGUES, 2000), considerando que o próprio meio físico e seu ordenamento estão arraigados a significados e interpretações sociais erigidas e repassadas entre as gerações por meio da tradição oral, que acabam por culminar em hábitos e costumes sociais, conhecimento e uso dos recursos ambientais (CALEGARE; HIGUSHI; SIQUEIRA, 2008).

É nesse cenário que a etnoconservação e a história ambiental inseremse como ferramentas eficazes para o levantamento de informações relevantes à adoção de estratégias diligentes de estabelecimento de áreas prioritárias para conservação que considerem os aspectos de ocupação e uso da área, formas de interação com os recursos naturais, percepção ambiental, conflitos de interesses e diversas outras demandas relacionadas. Sendo assim, o presente trabalho visa expor a importância da inclusão dessas ferramentas no plano de estabelecimento de áreas protegidas sustentáveis, em uma abordagem ampla e interdisciplinar sobre o tema.

\section{ETNOCONSERVAÇÃO COMO FERRAMENTA ANTE O MODELO SOCIOAMBIENTAL DO SÉCULO XXI}

As sociedades atuais deparam-se com a ampla questão da complexidade ambiental em virtude de um arcaico modelo de uso insustentável de recursos naturais. Para Leff (2005a), a própria necessidade de recorrer ao termo "sustentabilidade" é o significado de uma falha fundamental na história da humanidade; uma "crise de civilização" que alcança seu momento culminante na modernidade, cujas origens, entretanto, remetem à concepção do mundo que serve de base à civilização ocidental. Além da vulnerabilidade das espécies, o que por si só ameaça o equilíbrio dos mais diversos ecossistemas, impactos de natureza social, econômica, cultural e ambiental têm sistematicamente ocorrido com efeitos desastrosos à vida das populações que dependem diretamente dos recursos naturais para a sua reprodução social (SANTILLI, 2005). Essa gama de questões insurgidas ao longo dos dois últimos séculos veio interrogar o papel dominante da ciência como sintetizadora e direcionadora dos conhecimentos da humanidade (BARBOSA, 2013). 
A crise ambiental, que tomou dimensões marcantes a partir da segunda metade do século XX, transcende a superexploração dos recursos naturais. O cartesianismo da ciência dita moderna subjugou conhecimentos e saberes diversos e suscitou, no cerne de nossa sociedade, a ideia de única verdade como sendo aquela metodologicamente testada ou testável, mediante parâmetros préestabelecidos que, apenas depois de repetidos testes e produção de resultados seriam concretizados (CHEN, 2004). A existência das chamadas "Etnociências" e o estabelecimento de relações possíveis entre elas e as "Ciências" permaneceu para além dos limites do pensável, durante muito tempo (DIAS; JANEIRA, 2005). Assim, era impensável existir a possibilidade de juntar o prefixo éthos a scientiae; também não se podia conceber que pudessem existir outras realidades, com o mesmo radical, fora das ciências modernas (DIAS; JANEIRA, 2005). Ciência e técnica tiveram sua importância relacionada, principalmente a expansão do capitalismo nos séculos XVIII e XIX e no pós-Segunda Guerra Mundial. Neste âmbito, Gonçalves (2004) destaca que:

[...] A ciência e técnica modernas, tal como concebidas pelo Ocidente Europeu e como se expandiram para o mundo, foram instituídas como critério de verdade, como se essa verdade tivesse uma bondade moral naturalmente nela inscrita. Com isso, a verdade científica deslocou outras formas de construção de conhecimento e se tornou uma verdade possuída por uma espécie de mais-valia simbólica: “o que é científico é bom” e, assim, o Estado e os gestores passaram a invocar a verdade científica como se fosse A Verdade. Com isso, outros saberes se tornaram saberes menores - folclore. $O$ saber popular tornou-se um não-saber; a religião perdeu seu reino; a arte passou a ser acessória, entretenimento; a filosofia, pouco a pouco, foi deslocada, e até mesmo a política, para os gregos a mais sublime das artes, passou a ser substituída por uma espécie de saber competente [...] (GONÇALVES. 2004, p. 174. Grifos nossos).

Quaisquer hipóteses ou interpretações de fatos que não se encaixassem com as ideias vigentes da ciência "moderna" seriam ignoradas; quaisquer ensaios de incluir esclarecimentos criados fora do rigor científico ocidental, que fugissem da objetividade, eram banidos dos centros acadêmicos. Contudo, no apogeu desta crise, os demais saberes "não científicos", outrora subjugados, agora passariam a ganhar destaque, como atesta Leff (2005b).

O capitalismo em sua liberalidade, mas, ainda imperialista no início do século XX se caracterizava pela busca por uma produção de bens cada vez maior, e a incompetência em perceber o ambiente como uma fonte de recursos limitados, conduziu a humanidade para a crise ambiental atual. Entretanto, o período Pós-Segunda Guerra Mundial, sobretudo no final da década de 1950 
e início da década de 1960, marca o despertar de uma consciência ambiental (LEFF, 2005a; 2005b).

A partir da percepção da crise ecológica e ambiental, um conceito de ambiente com uma nova visão do desenvolvimento humano foi sendo configurado. Esse conceito reintegraria os valores e potenciais da natureza, as nuances e peculiaridades sociais, os conhecimentos e saberes reprimidos e subjugados, e a complexidade do mundo, renegados pela racionalidade mecanicista, unidimensional, simplificadora e fragmentadora, que regeu o processo de modernização (LEFF, 2005b).

Neste contexto de meados do século XX, ocorre a popularização das etnociências, como uma manifesta oposição ao racionalismo científico dominante. Muitas pesquisas passaram a empregar explicitamente termos precedidos pelo prefixo "etno", do grego Ethnos (identidade de origem/ costume), com variante latina em Ethos (jeito de ser / habitus). Esse prefixo, aplicado à ciência e apresentado em 1964 por Sturtvant, passou a designar as áreas do saber interdisciplinar de documentação, valorização e estudo das práticas e conhecimentos gerados e transmitidos por um grupo cultural (STURTEVANT, 1964).

Para Marques (2002), o que hoje se nomeia como etnociência, já insurgiu no cenário científico, não como um conjugado de disciplinas, todavia, como um campo interdisciplinar, de cruzamento de saberes, que originavam novos campos. Estes saberes foram originários do diálogo entre as ciências naturais e as ciências humanas e sociais. É nesta linha de raciocínio que as etnociências passam a destacar-se, não mais como uma disputa entre cientistas humanos, sociais e naturais, porém, como um pensamento que transcende as fronteiras disciplinares, caminhando em direção a uma almejada interdisciplinaridade (MOURA, 2002).

Os aspectos inerentes à abordagem etnocientífica foram - e vêm sendo - construídos alicerçados ao pressuposto do construtivismo social e abordam especificamente as características culturais de formação e uso de formas de conhecimento. Essa abordagem permite um entendimento de como os humanos variam seus conhecimentos e crenças dentro de contextos histórico-sociais, econômicos, culturais e ecológicos diferentes, a fim de expressar as múltiplas possibilidades apresentadas pelas civilizações humanas (RIST; DAHDOUHGUEBAS, 2006).

Como muitos desses conhecimentos e práticas manifestavam relação direta com o usufruto dos recursos ambientais, inexoravelmente as ciências conservacionistas, apropriando-se e ampliando adequadamente o termo, cunharam a expressão "Etnoconservação", relacionando-a ao cruzamento entre saberes tradicionais e científicos sobre o meio ambiente, de modo a valorizar 
articulações, comparações, conexões, integrações e, quem sabe, aprendizagens multilaterais (MARQUES, 2002; ALVES, 2008).

Em meio às múltiplas subclasses etnocientíficas, a etnoconservação faz jus a uma atenção peculiar por abarcar a análise e classificação de sistemas sobre a natureza e por apresentar uma intensa ligação com os temas da botânica, zoologia e ecologia (MOURÃO; ARAÚJO; ALMEIDA, 2006).

Mesmo sem uma definição universal de etnoconservação, pode-se ter por exemplar a que a expõe como: "o estudo do papel da natureza no sistema de crenças e de adaptação do homem a determinados ambientes, enfatizando as categorias e conceitos cognitivos utilizados pelos povos em estudo, aproveitandose dos paradigmas e da epistemologia da ciência moderna e provendo um arcabouço teórico para interligar diferentes áreas das ciências sociais e naturais com outros sistemas de conhecimentos não acadêmicos, buscando entender os processos de interação das populações humanas com os recursos naturais, com especial atenção à percepção, conhecimento e usos, incluindo o manejo de recursos, contribuindo para esclarecer diferenças sociais e analisar a diversidade ou heterogeneidade cultural" (POSEY, 1986; BEGOSSI; HANAZAKI; SILVANO, 2002; SANTOS-FITA; COSTA-NETO, 2007).

Nesse sentido, as etnociências - com destaque aqui à etnoconservação surgem e firmam-se como novas modalidades científicas agregadoras, que unem áreas específicas do conhecimento a fim de compreender fenômenos que seriam incompreensíveis com os conhecimentos de apenas uma área (BARBOSA, 2011). Essa interação inerente às etnociências é, de fato, essencial para o desenvolvimento científico de caráter interdisciplinar, adequado às necessidades que se colocam frente aos desafios ambientais, sociais e econômicos do século XXI, bem como ao desenvolvimento e manutenção de estratégias que, de fato, mantenham funcionais os eventuais espaços conservacionistas estabelecidos em zonas já habitadas por populações humanas, que teriam sua participação considerada nesse empreendimento, deixando o patamar de meros expectadores de sua exclusão.

Ante o cenário, um dos maiores desafios atuais para a etnoconservação reside exatamente em gerar um embasamento de dados e metodologias seguras ao empreendimento e gestão de UC de Uso Sustentável, com aporte de novos modelos conservacionistas que sejam densos tanto em conhecimento científico, quanto em saberes tradicionais (DIEGUES, 2000), para que, de fato, possam ser aplicados ao gerenciamento e manejo ambiental (LOUREIRO; CUNHA, 2008). Pra isso, contudo, é necessária a gradual abertura tanto da comunidade científica, com a mudança dos velhos paradigmas cartesianos reducionistas que 
definem a ciência clássica como a única detentora do verdadeiro saber sobre o mundo; quanto das populações locais, com a inclusão paulatina dos aspectos histórico-culturais e socioeconômicos dessas populações em análises ambientais (BARBOSA, 2011).

Outro desafio, e esse ainda mais complexo, diz respeito a conseguir-se gerir, de forma realmente sustentável - ambientalmente equilibrada, socialmente justa, econômicamente viável, culturalmente respeitosa e politicamente empenhada - esse modelo de Unidade de Conservação, uma vez que ele exige, para sustentabilidade da gestão, a exposição desnuda e austera de nuances múltiplas das relações humano/natureza, a exemplo dos indicadores sociais e das condições econômicas da população, além de certas peculiaridades culturais e políticas como origem ou agravante das problemáticas ambientais (BARBOSA et al., 2013), considerando a máxima de que "problemas ambientais, em sua grande maioria, são decorrentes de desvios de ordem social e/ ou econômica". $O$ porquê de se considerar esse desafio ainda mais intricado que o primeiro se dá em virtide do cenário sociopolítico comum a países em desenvolvimento, onde essa necessária transparência é um entrave intransponível se considerado que o Estado por vezes tem o hábito mascarar ou transferir as responsabilidades pela origem e agravo dos problemas nacionais, sejam eles ambientais, sociais ou econômicos.

\section{HISTÓRIA AMBIENTAL: NATUREZA, SOCIEDADE, TRADIÇÃO ORAL E OS DESAFIOS DO PRESENTE}

O grande desafio ambiental vivenciado atualmente explicita o quão necessário é assumir uma nova postura investigativa em estudos conservacionistas (CIPRIANO; MACHADO, 2009). Nesse sentido, destaca-se a história ambiental, quando esta, como ciência de campo eminentemente interdisciplinar, historiograficamente dá conta da exploração dos homens e dos recursos naturais no passado e no presente, assim como dos efeitos produzidos, no mundo natural, pelas diversas formações sociais e econômicas (MARTINEZ, 2006).

Na concepção de Leff (2005a), a história - "como uma das mais atrasadas entre as ciências sociais" - esqueceu-se durante muito tempo que seus fatos são condicionados pelo ambiente natural, negligenciando a destruição da natureza por preocupar-se demasiadamente com a dita supremacia humana. Nesse sentido, foi extremamente necessário e relevante à incorporação de variáveis ambientais nos estudos históricos bem como a inserção da história nos estudos da natureza (DRUMMOND, 1991; LEFF, 2005a). Desse modo chega-se à história ambiental, 
que capacita o pesquisador a descobrir a natureza enquanto agente de construção da história, considerando que outras forças significativas atuam sobre o tempo (WORSTER, 1991).

Diante da crise ambiental vivenciada pela humanidade, já apresentada no tópico anterior, bem como frente à urgência em reformular concepções e práticas ambientais segundo o que se entende por sustentável, a história ambiental, aparentemente surgida de motivações morais e compromissos político-éticos, apresenta-se extremamente relevante como campo do conhecimento humano e, à medida que amadurece, transfigura-se em empreendimento acadêmico deveras complexo e indispensável (CIPRIANO; MACHADO, 2009).

A história ambiental constitui-se então, de modo semelhante à etnoconservação, de uma nova forma de análise entre as relações do homem com a natureza, considerando o meio ambiente como agente e presente na história da humanidade, permitindo uma análise mais geral, por vincular fenômenos ambientais a fatores condicionantes da história, sobrepujando fronteiras temporais (FREITAS, 2006; PÁDUA, 2010).

Segundo Worster (1991), o objetivo inicial da história ambiental consiste em aprofundar a compreensão relativa aos impactos que os humanos sofrem em seu ambiente natural e vice-versa. Essa modalidade de prática historiográfica, para Martinez (2006), destaca-se pelo uso das relações sociais e, a partir das mesmas, o uso das relações estabelecidas com a natureza como agentes de construção histórica.

A história ambiental refuta a ideia segundo a qual a vivência das sociedades humanas se deu sem barreiras de cunho natural, destacando que os homens não advêm de um grupo especialmente elegido para dominar a Terra (CIPRIANO; MACHADO, 2009). Desse modo, consequências de feitos ecológicos passados não podem se ignorados na atualidade. Eis a necessidade de fazer emergir visões que permitam repensar e superar as tradicionais formas dominantes de intervenção na natureza (LEFF, 2005a), o que leva mais uma vez ao imperativo de um novo modelo de gestão e manejo dos recursos naturais.

Essa nova vertente histórica, como já mencionado, consiste, sobretudo na tentativa de "colocar a sociedade na natureza" (MUNARI, 2009). Com isso, busca-se equilibrar a interação entre sociedade e meio ambiente (DRUMMOND, 1991), com o suporte de muitas outras disciplinas, uma vez que, em meio à interdependência global, a cooperação interdisciplinar faz-se necessária aos pesquisadores, às disciplinas, bem como ao nosso mundo (WORSTER, 1991).

Como ao longo da história a tradição oral foi a grande responsável pelo repasse de conhecimento tradicional acerca do ambiente, e esse conhecimento, 
por sua vez, modelou as percepções desenvolvidas acerca do meio natural, nada mais coerente que utilizar como metodologia eficaz a história ambiental e a etnoconservação e o próprio discurso - a oralidade (MONTENEGRO, 2007; 2010; MEIHY; RIBEIRO, 2011), uma vez que ela é capaz de detectar a pluralidade de paradigmas envolvidos na questão socioambiental, bem como a existência de contradições internas nas próprias formas pelas quais os atores consultados descrevem a si mesmos, seus projetos, suas concepções e suas atuações sobre o meio (BARBOSA, 2013).

Este tipo de abordagem metodológica, adquirida dos campos críticoteóricos de procedimento em história oral, precisa romper com certos discursos disciplinares somente calcados na ideia de coerência e harmonia entre os sujeitos e os sistemas estudados. Isso porque o processo histórico envolvido nas relações natureza/sociedade/cultura - que precisam ser detalhadamente expostos e considerados de acordo com o novo modelo sustentável de gestão ambiental e estabelecimento de áreas prioritárias para conservação que se pretende alcançar, e sobre o qual o presente trabalho trata desde seu título - é caracterizado por continuidades, mas também, por rupturas tanto em sentido temporal, quanto envolvendo percepções, anseios, necessidades e diversas outras formas de relação e interação entre os atores sociais e o ambiente, que são determinantes para identificação de conflitos e potencialidades, fundamentais para implementar, administrar e manter Unidades de Conservação realmente sustentáveis (MENARIN, 2009).

\section{CONCLUSÃO}

Fica claro que tratar de conservação em cenários onde a problemática ambiental se entrelaça a questões econômicas, sociais, culturais e políticas, a exemplo do que acontece em países em desenvolvimento como o Brasil, exige uma abordagem diferenciada e abrangente que considere ao máximo essa multiplicidade de fatores.

Nesse percurso, a abordagem etnoconservacionista tem se mostrado bastante eficaz, por conseguir se postar de forma interdisciplinar, considerando a amplitude dos conhecimentos, relações e interações estabelecidas entre os seres humanos e o ambiente que os cerca.

Como essa relação humano/natureza é instituída desde os primórdios da civilização, sua análise exige um recorte temporal mais amplo, uma vez que atuais circustâncias socioambientais podem ter origem em eventos do passado. Desse modo, a história ambiental amplifica as possibilidades de compreensão do 
ambiente e de como ele e seus atores foram se articulando ao longo do tempo na construção de um cenário atual.

Assim posto, uma política conservacionista eficiente e que responda às múltiplas necessidades envolvidas, precisa portar-se de forma a considerar, além da dinâmica ambiental, o contexto das pessoas inseridas em seu entorno, tanto no presente quanto no passado, para só assim, ter perspectiva de futuro.

\section{REFERÊNCIAS}

ALVES, Â. G. C. Pesquisando pesquisadores: aspectos epistemológicos na pesquisa etnoecológica. In: REUNIÃO ANUAL DA SOCIEDADE BRASILEIRA PARA O PROGRESSO DA CIÊNCIA, 60. Associação Brasileira de Antropologia. Campinas-SP, 2008. Anais... Campinas: Unicamp, 2008.

AMEND, S.; AMEND, T (Coord.). Espacios sin habitantes? Parques nacionales de America del Sur. Caracas: Editorial Nueva Sociedad/IUCN, 1992.

ARRUDA, R. "Populações tradicionais" e a proteção dos recursos naturais em unidades de conservação. Ambiente \& Sociedade, São Paulo, v. 2, n. 5, p. 79 92, 1999.

BARBOSA, J. A. A. A caça e o uso da fauna no Agreste: um estudo etnobiológico a partir da memória dos caçadores do município de Queimadas-PB (1940-2012). 2013. 136f. Dissertação (Mestrado em Recursos Naturais) - Universidade Federal de Campina Grande, Campina Grande-PB, 2013.

Interdisciplinaridade, educação e sociedades - Breves considerações críticas. Rev. Âmbito Jurídico, Rio Grande-RS, v. 14, n. 91, p. 1-8, 2011.

BARBOSA, J. A. A.; ALMEIDA, A. L. L.; SILVA, G. L. A.; MARQUES, L. S.; SANTOS, L. F. F.; RAMALHO, M. S.; DÔSO, M. F.; NOGUEIRA, R. L.; ALMEIDA, S. K. A. Breves considerações críticas sobre a sustentabilidade no cenário socioeconômico e comportamental na atualidade. Rev. Âmbito Jurídico, Rio Grande-RS, v. 16, n. 119, p. 1-8, 2013.

BEGOSSI, A; HANAZAKI, N.; SILVANO, R. A. M. Ecologia Humana, Etnoecologia e Conservação. In: AMOROZO, M. C. M.; MING, L. C.; SILVA, S. M. P. (Ed.). Métodos de coleta e análise de dados em Etnobiologia e disciplinas correlatas. Rio Claro, SP: UNESP/CNPq, 2002. p. 93-128

BOTKIN, D. B. Discordant harmonies: a new ecology for the twenty-first century. New York: Oxford University Press, 1990. 
CALEGARE, M. G. A.; HIGUCHI, M. I. G.; SIQUEIRA, M. S. Indicadores socioambientais do modo de vida de populações tradicionais em Unidade de Conservação. In: ENCONTRO DA REGIÃO NORTE DA SOCIEDADE BRASILEIRA DE SOCIOLOGIA, 3.: Amazônia e Sociologia: fronteiras do século XXI. GT 13- Sociedade e ambiente: redes de sociabilidade e relações com a natureza no Norte e Sudeste do Brasil. Manaus, 2008. Anais... Manaus, 2008

CHEN, X. Culture and understanding: the Cartesian suspicion, the Gadamerian response, and the Confucian outcome. Journal of Chinese Philosophy, v. 31, n. 3, p. 389-403, 2004.

CIPRIANO, D. M.; MACHADO, C. R. S. Algumas reflexões sobre o estudo da história Oral da/na cidade. Relatório de Pesquisa. Universidade Federal do Rio Grande e Conselho Nacional de Desenvolvimento Científico e Tecnológico. 2009.

DIAS, A. S.; JANEIRA, A. L. Entre ciência e etnociências. Episteme, Porto Alegre, n. 21, p. 107-127, 2005.

DIEGUES, A. C. O mito moderno da natureza intocada. São Paulo: Hucitec, 2004.

(Org.) Etnoconservação: novos rumos para a proteção da natureza nos trópicos. 2. ed. São Paulo, NUPAUB-USP, 2000.

Repensando e recriando as formas de apropriação comum dos espaços e recursos naturais. In: VIEIRA, P. F.; WEBER, J. (Org.) Gestão de recursos naturais renováveis e desenvolvimento. São Paulo, Cortez Editora, 1996.

DRUMMOND, J. A história ambiental: temas, fontes e linhas de pesquisa. Estudos Históricos, Rio de Janeiro, v. 4, n. 8, p. 177-197, 1991.

FERREIRA, L. C. Dimensões humanas da biodiversidade: mudanças sociais e conflitos em torno de áreas protegidas no Valo do Ribeira, SP, Brasil. Ambiente \& Sociedade, São Paulo, v. 7, n. 1, p. 47-68, 2004.

FREITAS, I. História Ambiental e Geografia. In: ENCONTRO REGIONAL DE HISTÓRIA DA ANPUH, 12. Anais... 2006.

GONÇALVES, C. W. P. O desafio ambiental. Rio de Janeiro: Record, 2004. p. 179.

LEFF, H. Saber ambiental. 4. ed. Petrópolis-RJ: Vozes, 2005a. 494 p. 
Construindo a história ambiental da América Latina. Esboços / UFSC. n. 13, p.11-26, 2005b.

LOUREIRO; C. F. B.; CUNHA, C. C. Educação ambiental e gestão participativa de Unidades de Conservação: elementos para se pensar a sustentabilidade democrática. Ambiente \& Sociedade, São Paulo, v. 11, n. 2, p. 237-253, 2008.

MARQUES, J. G. W. O olhar (des)multiplicado. O papel do interdisciplinar e do qualitativo na pesquisa etnobiológica e etnoecológica. In: AMOROZO, M. C. M.; MINGG, L. C.; SILVA, S. M. P. (Ed.). Métodos de coleta e análise de dados em etnobiologia, etnoecologia e disciplinas correlatas. Rio Claro-SP: UNESP/CNPq, 2002. p. 31-46.

MARTINEZ, P. H. História Ambiental no Brasil: pesquisa e ensino. São Paulo: Cortez, 2006.

MEIHY, J. C. S. B.; RIBEIRO, S. L. S. Guia prático de História Oral. São Paulo: Loyola, 2011.

MENARIN, C. A. Unidades de Conservação: abordagens e características geográficas. Patrimônio e Memória, São Paulo, v. 5, n. 1, p. 195-201, 2009.

MONTENEGRO, A. T. História, metodologia, memória. São Paulo: Contexto, 2010.

História Oral e memória: a cultura popular revisitada. 6. ed. São Paulo: Contexto, 2007.

MOURA, F. P. Entre o peixe e o dendê: etnoecologia do povo dos Marimbús (Chapada Diamantina-BA). 2002. 121f. Tese (Doutorado em Ecologia e Recursos Naturais) - Universidade Federal de São Carlos, São Carlos-SP, 2002.

MOURÃO, J. S.; ARAUJO, H. F. P.; ALMEIDA, F. S. Ethnotaxonomy of mastofauna as practised by hunters of the municipality of Paulista, state of Paraíba-Brazil. Journal of Ethnobiology and Ethnomedicine, v. 2, n. 19, p. 7, 2006.

MUNARI, L. C. Memória social e ecologia histórica: a agricultura de coivara das populações quilombolas do Vale do Ribeira e sua relação com a formação da Mata Atlântica local. 2009. 217f. Dissertação (Dissertação de Mestrado) Instituto de Biociências, Universidade de São Paulo, São Paulo, 2009.

PÁDUA, J. A. As bases teóricas da história ambiental. Estudos Avançados, São Paulo, v. 24, n. 68, p. 81-101, 2010. 
POSEY, D. Introdução a Etnobiologia: teoria e prática. Suma Etnológica Brasileira, Petrópolis-RJ, v. 1, n. 1, p. 15-25, 1986.

RISSO, L. C. Unidades de conservação e comunidades: espaços de participação e conflitos territoriais. In: CONGRESSO IBEROAMERICANO DE ESTUDIOS TERRITORIALES Y AMBIENTALES, 6. São Paulo, 2014. Anais... São Paulo: UNESP, 2014.

RIST, S.; DAHDOUH-GUEBAS, F. Ethnosciences - A step towards the integration of scientific and indigenous forms of knowledge in the management of natural resources for the future. Environ Dev Sustain, v. 8, p. 467-493, 2006.

SACHS, I. Desenvolvimento includente, sustentável, sustentado. Rio de Janeiro: Garamond, 2004.

SANTILLI, J. Socioambientalismo e novos direitos. São Paulo: Peirópolis, 2005.

SANTOS-FITA, D.; COSTA-NETO, E. M. As interações entre os seres humanos e os animais: a contribuição da etnozoologia. Biotemas, Florianópolis, v. 20, n. 4, p. 99-110, 2007.

STURTEVANT, W. C. Studies in Ethnoscience. American Anthropologist, v. 66, n. 3 Part 2: Transcultural Studies in Cognition, p. 99-131, 1964.

WORSTER, D. Para fazer história ambiental. Estudos Históricos, Rio de Janeiro, v. 4, n. 8, p. 198-215, 1991. 


\section{Redes sociopolíticas e territorialidade na Reserva de Desenvolvimento Sustentável Igapó-Açu (AM, Brasil)}

\section{Sociopolitical networks and territoriality in the Development Reserve Sustainable Igapó-Açu (Amazonas, Brazil)}

Marilia Gabriela Gondim Rezende - Doutora em Ciências do Ambiente e Sustentabilidade na Amazônia (PPGCASA). Pesquisadora do Núcleo de Socioeconomia (NUSEC) da Universidade Federal do Amazonas (UFAM), . E-mail: mariliageoufam@gmail.com

Therezinha de Jesus Pinto Fraxe - Doutora em Sociologia pela Universidade Federal do Ceará. Professora da Universidade Federal do Amazonas (UFAM), E-mail: tecafraxe@ uol.com.br

Mônica Suani Barbosa da Costa - Pesquisadora do Núcleo de Socioeconomia (NUSEC) da Universidade Federal do Amazonas (UFAM), Mestra em Ciências do Ambiente e Sustentabilidade na Amazônia. E-mail: suanimorena@gmail.com

\section{Resumo}

O Amazonas vem se destacando na criação de Unidades de Conservação (UC), sendo a principal estratégia utilizada por agentes sociais para a conservação da biossociodiversidade. O objetivo deste artigo é analisar as práticas das organizações sociais, e seus desdobramentos territoriais, na governança da Reserva de Desenvolvimento Sustentável/RDS Igapó-Açu, localizada no estado do Amazonas. A metodologia contemplou a realização de entrevistas abertas e a aplicação de formulários entre as famílias residentes na RDS. As organizações sociais têm apresentado função central na RDS Igapó-Açu, pois $67 \%$ das famílias participam de atividades das diferentes formas de ações coletivas. A igreja é a principal organização social atuante na UC, com 43\% de participação das famílias, seguida da Associação de Moradores (ASSAM) e do Conselho Gestor. Portanto, o ordenamento territorial desta unidade é resultado de ações coletivas compartilhas entre grupos sociais, de modo que a distribuição dos objetos espaciais está ligada às territorialidades existentes.

\section{Palavras-chave}

Territorialidade. Ordenamento Territorial. Governança.

\begin{abstract}
The Amazon has been highlighting the creation of Conservation Units (UC), being the main stratagem used for the conservation of biosociodiversity. In this sense, the objective of this article was to understand the social organizations and their territorial unfolding in the governance of RDS Igapó-Açu, located in Amazonas. To achieve this goal, open interviews and application of forms were carried out in $100 \%$ of the families residing in the RDS. It can be inferred that social organizations have played a central role in RDS Igapó-Açu, since 67\% of families participate in activities of different forms of social organization. The church is the main social organization active in the UC, with a $43 \%$ participation of families, followed by the Association of Residents (ASSAM) and the Management Council. Therefore, the territorial ordering of this unit is a result of the imbrication between the different social groups, so that the distribution of space objects is linked to the existing territorialities.
\end{abstract}

\section{Keywords}

Territoriality. Territorial Planning. Governance. 


\section{INTRODUÇÃO}

A Reserva de Desenvolvimento Sustentável (RDS) Igapó-Açu localiza-se no estado do Amazonas, mais precisamente nos municípios de Beruri, Borba e Manicoré (Figura 1), entre os rios Purus e Matupiri. Possui uma área de cerca de 397.557,323ha, cujos limites territoriais fazem fronteira com a Terra Indígena (TI) Cunhã-Sapucaia, com o Projeto de Assentamento Agroextrativista Tupana Igapó-Açu I e II, com o Parque Estadual (PAREST) do Matupiri, com a RDS Rio Amapá, e com o Parque Nacional de Nascentes do Lago Jari. A intersecção de áreas fronteiriças com UC e TI confere um caráter singular à RDS Igapó-Açu.

Figura 1 - Localização da RDS Igapó-Açu

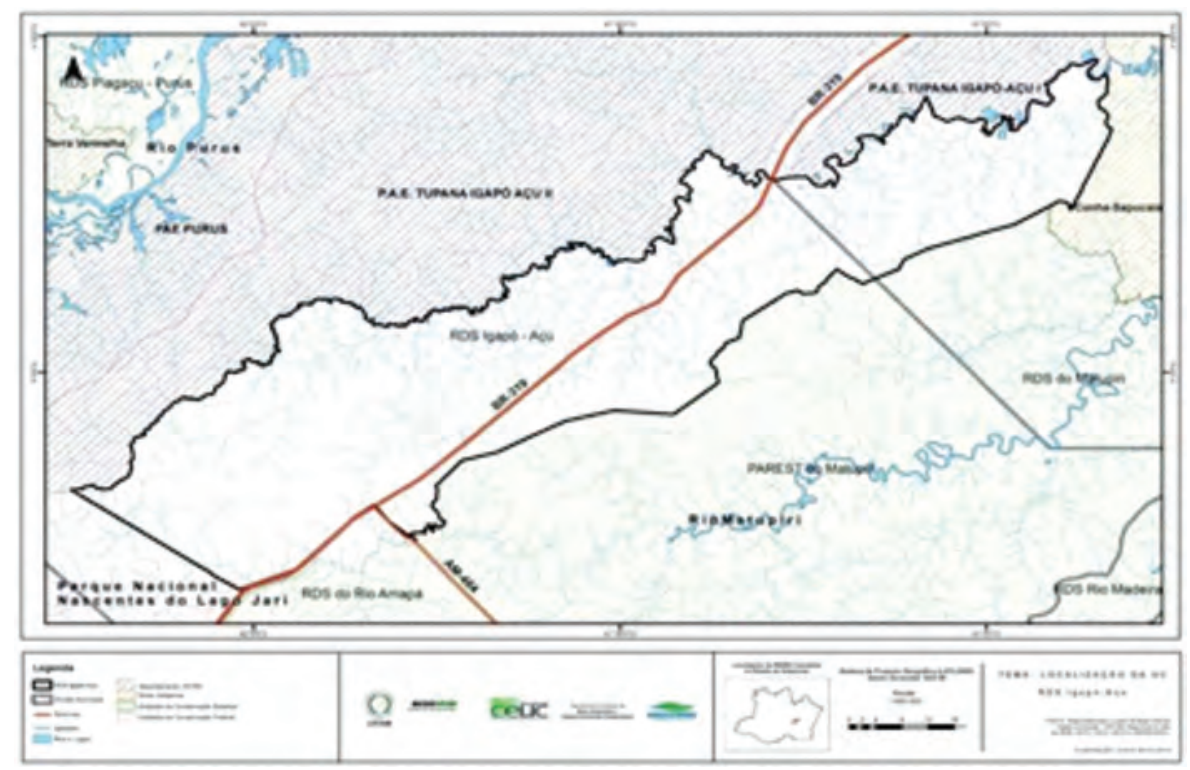

Fonte: Nusec (2015). Organizado por: Rezende e Costa (2015)

A rede de articulação política que configura a governança na RDS IgapóAçu evidencia uma constelação de elementos de suma importância para o entendimento dos desdobramentos e da materialização do poder na unidade política gerida. As formas de organização social emergem, nesse sentido, como importantes denominadores que influenciam consideravelmente na governabilidade e no governo da RDS Igapó-Açu, e promove, consequentemente, impactos significativos na materialização da governança ambiental. 
As organizações sociais são arquétipos de organização pública não estatal que surgem com o objetivo de atender atividades de interesse público e/ ou coletivo. Essas organizações têm um papel importante na configuração do controle social, visto que sua autonomia está para além da influência do Estado, e seus desdobramentos impactam consideravelmente o ordenamento do território e suas ramificações sociais.

A rede de articulação política forma-se a partir da interação entre os sistemas simbólicos e sociopolíticos que originam as organizações sociais e o ordenamento do território. Torna-se imprescindível analisar os desdobramentos dessa interação na governança da área de estudo, em razão dessa ingerência que é intrínseca a esse movimento interacionista.

\section{ORDENAMENTO TERRITORIAL E REDES SOCIOPOLÍTICAS}

A compreensão do ordenamento territorial permite o entendimento da materialização das relações sociais a partir da manifestação do poder no território. Diferentes relações sociais geram diferentes territórios, pois o mesmo configura-se e delimita-se a partir dessas relações e interações societárias. Silva (2000) afirma que o ordenamento territorial se refere ao modo como o território está organizado em razão de suas escalas, tendências, problemas, dentre outros fatores.

O entendimento da organização dos objetos geográficos propicia uma análise abrangente dos fenômenos e epifenômenos sociais organizados. As unidades de conservação apresentam um ordenamento territorial específico, pautado, em sua maioria, nas ações do Plano de Gestão, que é um documento técnico que estabelece normas de uso e ocupação do território delimitado. A RDS Igapó-Açu diferencia-se pela existência de uma rodovia federal em uma área protegida legalmente, isso lhe confere um ordenamento territorial específico, singular se comparado às outras unidades de conservação do Amazonas.

A população é bem diversificada, constituída por povos advindos de diversos municípios do estado do Amazonas (Figura 2). Esse deslocamento populacional justifica-se pelas condições iniciais da BR-319, caracterizada por uma infraestrutura que permitiu a mobilidade de pessoas e mercadorias. A partir dessas condições físicas que a RDS Igapó-Açu foi sendo configurada socialmente, uma congruência de atores sociais de diferentes territórios. A criação da UC ocorreu em 2009, e abarca uma área de aproximadamente 397.557,323ha. 
Figura 2 - Local de nascimento dos moradores da RDS Igapó-Açu

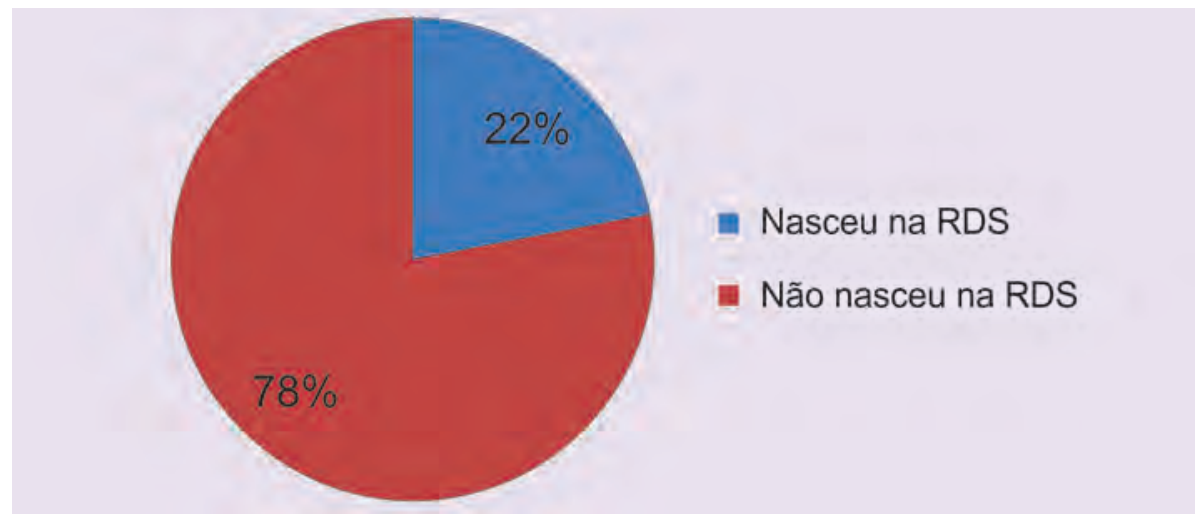

Fonte: Rezende (2016)

Conforme se observa na Figura 2,78\% das famílias que residem na UC não nasceram na RDS, evidenciando uma série de fatores, com destaque para as condições infraestruturais positivas da BR-319 no que concerne ao deslocamento populacional. Dos 78\% que não nasceram na RDS, 57,1\% nasceram em Borba, 28,6\% nasceram em Manaus, e 14,3\% nasceram em Boca do Acre. Inúmeros são os motivos do deslocamento de seu local de nascimento, conforme evidencia a Figura 3.

Figura 3 - Motivos que levaram os atuais residentes a morar na RDS Igapó-Açu

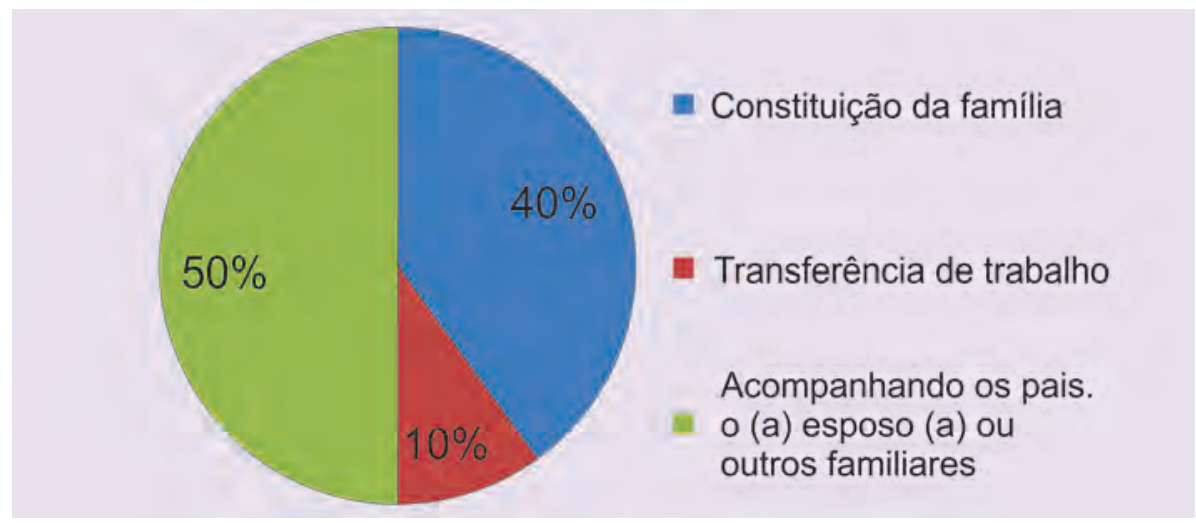

Fonte: Rezende (2016)

Dentre os motivos elencados, $50 \%$ das famílias afirmaram que se deslocaram à UC para acompanhar pais, esposo/esposa, e familiares; $40 \%$ para constituição da família, tendo em vista a abundância de recursos naturais para a reprodução social; e 10\% afirmaram que o deslocamento ocorreu devido à 
transferência de trabalho, com destaque para a necessidade de mão de obra para a expansão da BR e nos respectivos restaurantes que existiam no período de expansão da estrada.

Segundo Gaudemar (1977), a mobilidade espacial ocorre por inúmeros fatores, sendo os principais: a constituição da família, a escolaridade, e a mão-deobra (trabalho). As assertivas desse autor corroboram os dados apontados nessa pesquisa, no que concerne à mobilidade dos residentes da RDS Igapó-Açu.

A escolaridade na RDS Igapó-Açu, ou seja, o término de determinadas etapas de estudo é complexa, pois vários são os elementos que influem nas etapas posteriores ao ensino fundamental. A UC é constituída por apenas uma escola, com turmas de ensino primário e fundamental. A escola apresenta uma infraestrutura formada por duas salas de aula. Não há dificuldades de deslocamento até a escola da RDS, pela localização central que ela estabelece, tanto nos períodos de cheia como na vazante.

Os estudantes que anseiam terminar o ensino fundamental e cursar o ensino médio se deslocam até o município Careiro Castanho, local com escolas de ensino médio. Esse fator tem gerado um crescente deslocamento populacional e explica a prevalência dos dados referentes ao ensino fundamental incompleto, como se pode observar na Figura 4.

Figura 4 - Escolaridade na RDS Igapó-Açu

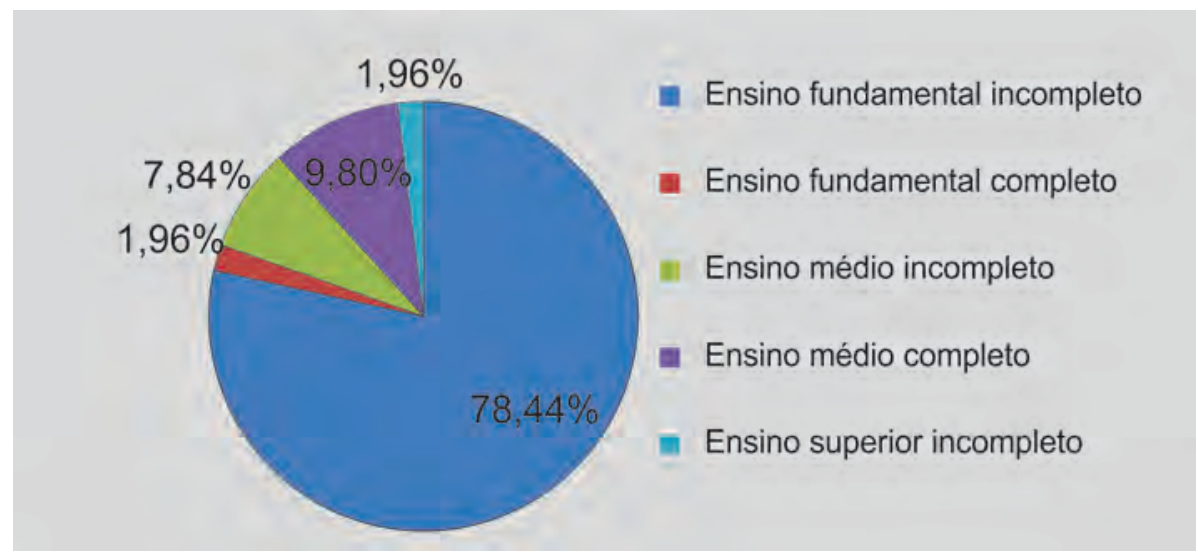

Fonte: Rezende (2016)

Quanto ao tipo de energia fornecida à RDS, 88,9\% advêm do Programa Luz para Todos (Figura 5), que é uma política pública desenvolvida pelo governo federal que objetiva a eletrificação de áreas distantes dos centros urbanos. Embora a garantia dos direitos básicos dos cidadãos seja parte do papel do 
Estado, a sociedade civil organizada da Comunidade São Sebastião do IgapóAçu (a ASSAM) teve forte influência para a instalação da rede elétrica, por meio de reivindicações junto aos órgãos competentes.

Figura 5 - Tipo de energia fornecida à RDS Igapó-Açu

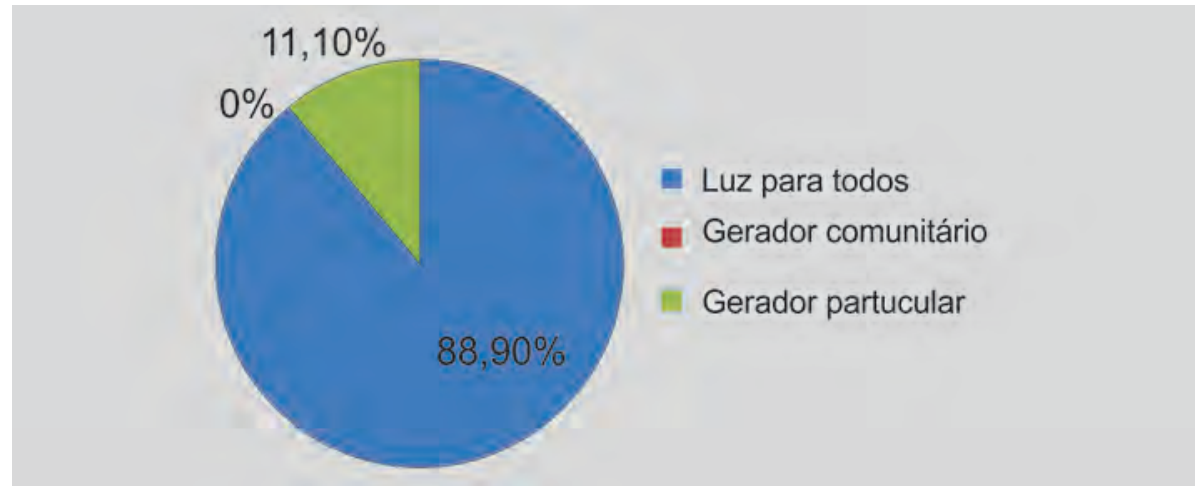

Fonte: Rezende (2016)

Os meios de transporte utilizados na RDS Igapó-Açu são variados, devido aos distintos usos que the são atribuídos. A Figura 6 evidencia que o meio de transporte mais utilizado é o carro (40\%), seguido do barco (26,60\%). O carro é usado para o deslocamento até os municípios de Careiro Castanho e Manaus; o barco e a voadeira para as atividades relacionadas à pesca; a bicicleta e a motocicleta para o deslocamento na comunidade; e o caminhão para o transporte de mercadorias.

Figura 6 - Meios de transporte

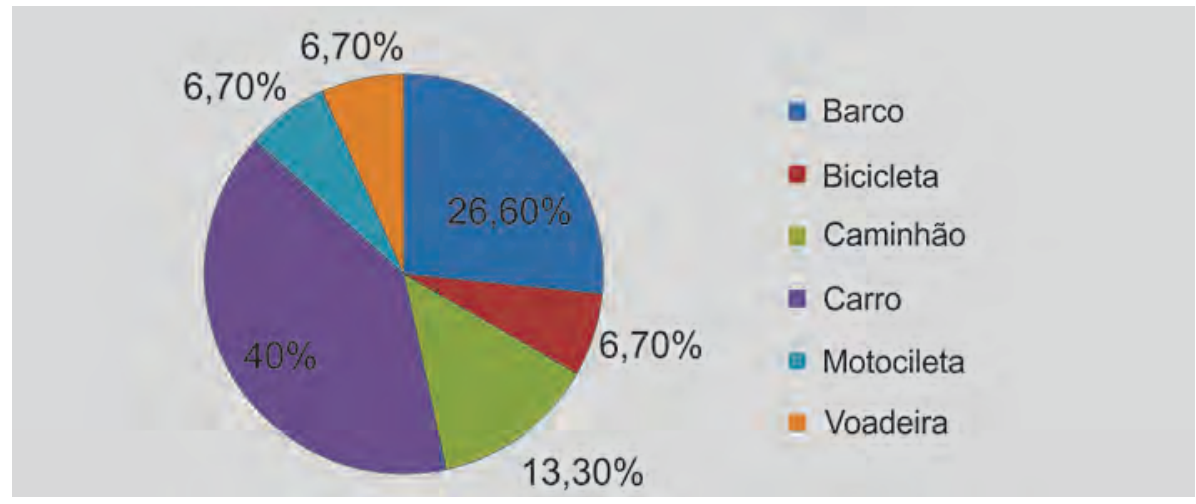

Fonte: Rezende (2016)

Os lugares mais distantes em que os residentes da RDS Igapó-Açu se deslocam são Manaus, Careiro Castanho e Borba (Figura 7). A ida ao Castanho é para visitar os filhos e familiares que estão concluindo os estudos, para consultas 
médicas e para buscar benefícios sociais. Diferentemente da ida à Manaus, que é para participar de cursos profissionalizantes e para fazer compras de produtos que não são encontrados nas adjacências da RDS. Os residentes que vão a Borba têm como objetivo visitar familiares.

Figura 7 - Lugares distantes frequentados pelos residentes

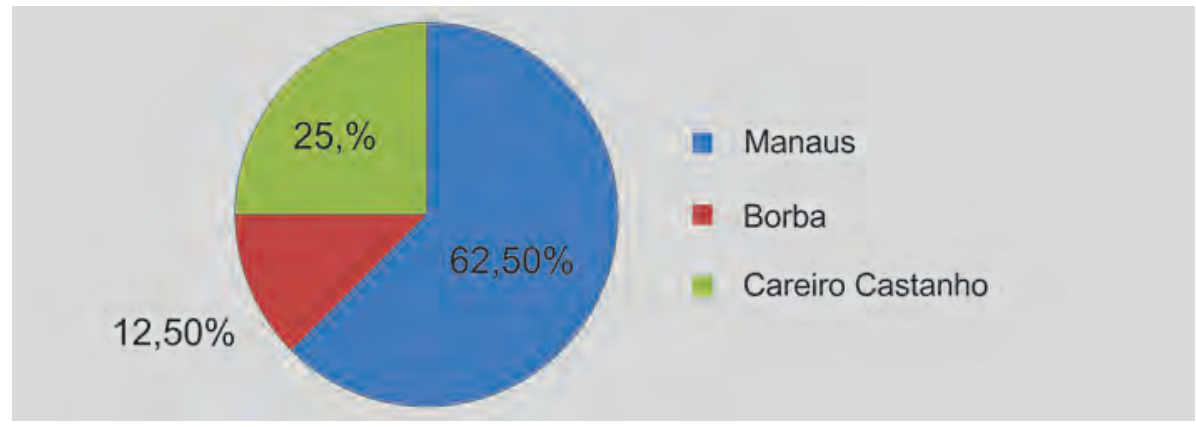

Fonte: Rezende (2016)

A principal fonte de renda das famílias da RDS Igapó-Açu advém da pesca (50\%), do Programa Bolsa Família (18,75\%), da agricultura (12,50\%), da aposentadoria (12,50\%), e de atividades autônomas (6,25\%). A expressividade do número de famílias que tem como principal fonte de renda a pesca, mostra a importância desta atividade econômica na reprodução social da RDS, conforme evidencia a Figura 10.

Essa dependência dos recursos pesqueiros por grande parte da população da RDS Igapó-Açu gerou e tem gerado conflitos territoriais. Segundo Sobreiro e Freitas (2008), desde a década de 1960 os conflitos por pesca vem se intensificando na Amazônia. As regiões que apresentavam e apresentam conflitos latentes são os lagos de várzea, locais de maior pressão por pesca comercial.

Figura 10 - Principal fonte de renda da família

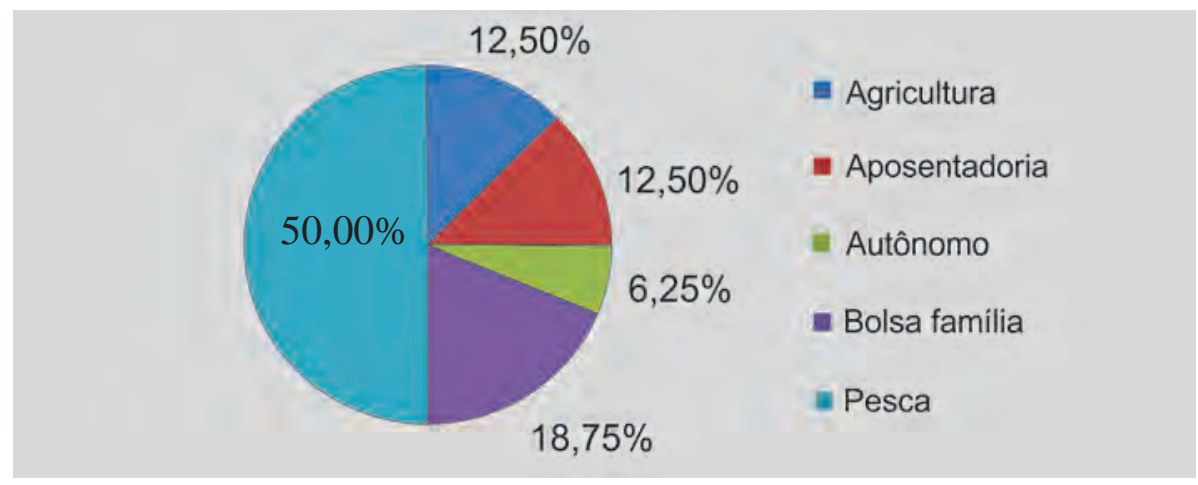

Fonte: Rezende (2016) 
Nos rios de águas pretas os conflitos por pesca estão relacionados com os diferentes modos de apropriação e uso das áreas de pesca (SOBREIRO; FREITAS, 2008). Na Amazônia, de uma maneira geral, e mais precisamente nos rios de água preta, intensificam-se as atividades pesqueiras, principalmente devido à perda de controle local sobre os recursos terrestres (SILVA, 2011). O rio Igapó-Açu apresenta farturas de espécies de peixes, principalmente de tucunaré, essa característica tem atraído os olhares externos à UC, e gerado conflitos territoriais, pelo uso das áreas de pesca e pela exploração de outros recursos naturais, conforme se observa na Figura 9.

Figura 9 - Tipos de conflitos existentes na RDS Igapó-Açu

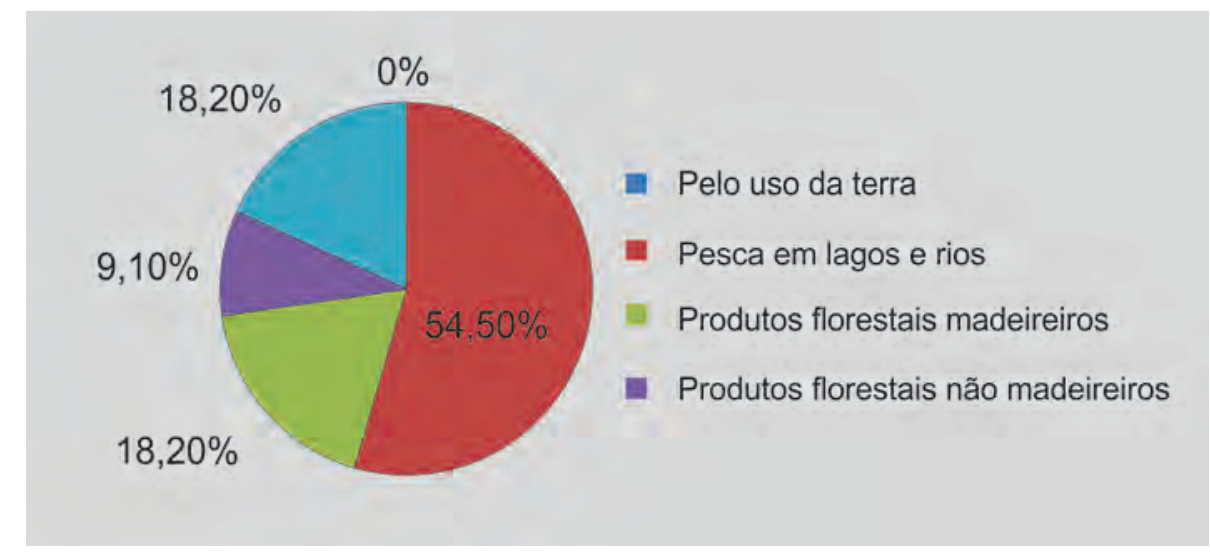

Fonte: Rezende (2016)

O principal conflito citado refere-se à pesca em lagos e rios $(54,50 \%)$, seguido dos conflitos por produtos florestais madeireiros $(18,20 \%)$, conflitos pessoais $(18,20 \%)$, e conflitos por produtos florestais não madeireiros $(9,10 \%)$. Os conflitos em UC são polissêmicos, ou seja, possuem vários significados e ângulos, e variam de acordo com as relações de interesses entre os sujeitos sociais envolvidos.

São resultantes das divergências de pontos de vista e de interesses e envolvem questões sociais, políticas e culturais, com destaque para a luta pela manutenção de territórios. Segundo Thiollent (1998) a divergência é resultante da ambivalência das diferentes ações sociais. Dessa forma, os conflitos territoriais são resultantes de interesses distintos e divergentes, portanto dissimétricos, que se materializam, refletem e são refletidos no território.

Assim sendo, pode-se compreender que os conflitos territoriais existentes na RDS Igapó-Açu são reflexos das relações antagônicas de interesse entre os atores sociais envolvidos. O cadastro e inserção no Seguro Defeso têm obstado 
os conflitos relacionados à pesca, por meio do fornecimento de auxílio financeiro nos períodos necessários à reprodução das espécies de peixes. Nos períodos de defeso, as famílias dedicam-se exclusivamente à agricultura e ao extrativismo.

Essa contextualização e caracterização territorial da RDS Igapó-Açu é imprescindível para a compreensão sistêmica das formas de organização social existentes e para o entendimento da materialização da governança. Assim sendo, as formas de organização social conformam-se a partir da congruência das relações sociais por interesses comuns e, contraditoriamente, divergentes. A coesão social estabelece-se por meio dessas relações e interações sistêmicas.

\section{A TERRITORIALIDADE NA RDS IGAPÓ-AÇU}

Compreender a territorialidade e a territorialização requer importantes inflexões teóricas, dada a complexidade em entender a transindividualidade a partir da noção de território. Essas conceituações devem transcender e remeter às características ônticas e ontológicas do ser no território, que configura a territorialidade a partir de um constante devir. Vários são os autores que trabalham a noção de territorialidade, com destaque para Souza (2001), Spósito (2009), Saquet (2009), Santos (2010), e Haesbaert e Limonad (2007).

Souza (2001), para construir seu conceito de territorialidade, concebe o território a partir da noção de campo de forças de Bourdieu, assim, estabelece algumas formas de territorialidade: a territorialidade cíclica, ou seja, relacionada à temporalidade; a territorialidade móvel, relacionada à fluidez das fronteiras; e a territorialidade em rede, relacionada às tessituras que formam uma malha complexa de territórios descontínuos. Para este autor essas três formas de estabelecimento da territorialidade podem se manifestar concomitantemente, ou seja, em um mesmo território pode haver territorialidades cíclicas, móveis e em redes.

Saquet (2009) conceitua territorialidade como sendo as relações diárias estabelecidas momentaneamente entre os homens e a natureza, é a expressão do cotidiano e do habitus no território. Saquet (2009) critica a noção territorial de Raffestin (1993), pelo tratamento do território como palco das relações destituído dos significados que lhe são intrínsecos, criadores da territorialidade. Desta forma, o autor concebe a territorialidade como a congruência da experiência do cotidiano no território.

Para Santos (2010), a territorialidade é a comunhão estabelecida com o território, são as atividades diárias que os homens executam e que dão vida e vivificam o território. A ausência de territorialidade seria um território sem vida, ou seja, um espaço físico isento de significados, por isso, o autor reitera a 
importância da compreensão da territorialidade para o próprio entendimento do território enquanto espaço produzido.

Os autores ícones, formuladores dos conceitos vigentes de territorialidade, citados anteriormente, foram importantes na medida em que inseriram elementos não trabalhados por outros teóricos. O conceito de territorialidade, aqui trabalhado, será centrado nos autores supracitados, entretanto, outros elementos serão incluídos na compreensão da questão, a partir das lacunas identificadas.

Assim sendo, a territorialidade é o reflexo material e imaterial da ação humana no território. É a congruência resultante da interação entre a dimensão simbólica e a dimensão objetiva. É a expressão do cotidiano, do modo de vida, do habitus dos diferentes grupos sociais intervenientes no território. Compreender a territorialidade destituída desses elementos interagentes significa retirar do território o que lhe é intrínseco.

Na RDS Igapó-Açu a territorialidade estabelece-se principalmente a partir do rio, ele é o elemento principal de condensação territorial, visto que as famílias passam a maior parte do seu tempo em atividades fluviais, seja relacionado à pesca ou ao lazer. Porém, a territorialidade é compreendida como a confluência simbólica e objetiva do fluvial e do terrestre (Figura 10), pois o território formase pela transcendência desses espaços. Os usos desses espaços produzidos, formadores da territorialidade, variam de acordo com o tempo estabelecido pela "natureza", pois os modos de apropriação dos recursos naturais estão diretamente ligados à resiliência ambiental.

Figura 10 - A territorialidade a partir da terra e da água

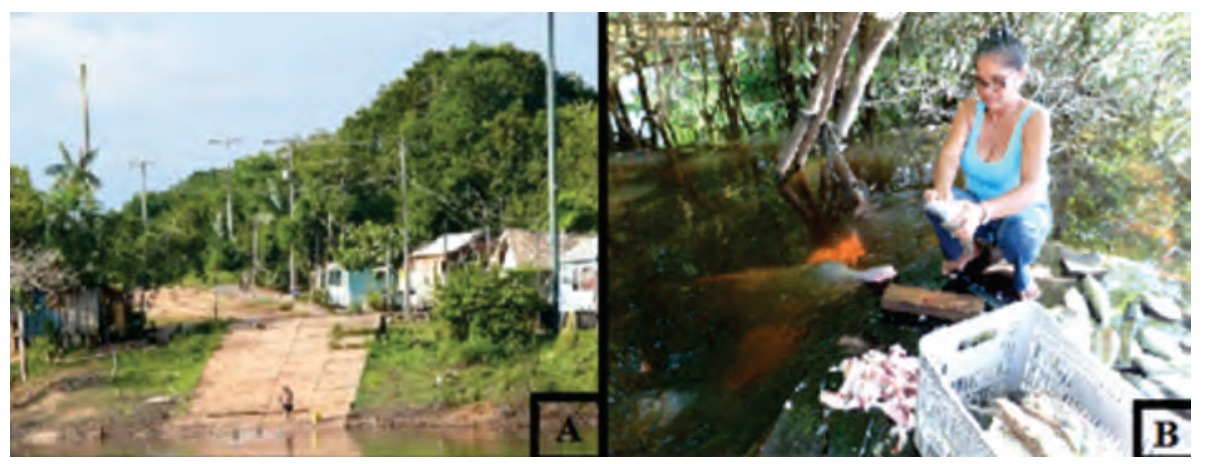

Fonte: Rezende (2016)

Na RDS Igapó-Açu a territorialidade é fundamentada na resiliência do sistema ambiental, pois as atividades desenvolvidas no território são conduzidas pelos modos de vida pautados na sustentabilidade, em suas múltiplas facetas. No período de defeso, as atividades centram-se na agricultura e no extrativismo. 
No período de abundância de recursos pesqueiros, as atividades são voltadas à pesca. O tempo prevalecente é o tempo reprodutor da autopoiese do sistema ambiental, e não o tempo dos interesses humanos. Há uma realocação de ações para a corroboração da sustentabilidade, e a territorialidade se estabelece a partir dessa noção de tempo.

Segundo Hawking e Mlodinow (2005), o tempo está diretamente relacionado ao espaço, de modo que o produto dessa relação é a noção espaçotemporal dos objetos geográficos. As diferentes noções de tempo são socialmente construídas e afirmadas, e estão indissociavelmente ligadas à concepção humana da relação transcendente estabelecida com o espaço.

A territorialidade na RDS Igapó-Açu é fundamentada na interação espaço/tempo, e a noção temporal reflete o trabalho simbólico de apropriação do território. Os significados atribuídos, ou seja, a valoração da "natureza", é que determina e consolida a territorialidade nesta UC, visto que os usos do território variam de acordo com a capacidade de resiliência dos diferentes ecossistemas.

O tempo ocupa papel central no entendimento das relações sociais na RDS Igapó-Açu, pois representa as possibilidades e não possibilidades da ação humana, sendo o fator central de interpretação do território. Atualmente, a modernidade conforma-se a partir de uma sociedade sincrônica, que vive sob a pressão do tempo do relógio econômico. Entretanto, há formações sociais que abdicam desse modo de vida, como é o caso dos grupos sociais da RDS Igapó-Açu.

Ao contrário de uma compressão espaço-tempo (HAESBAERT, 2005), o que se estabelece são formas específicas de uso e apropriação de diferentes espaços por diferentes lógicas temporais. O tempo passa a ser uma sucessão de contextos (ALTHUSSER, 1992), onde as diversas temporalidades coabitam o mesmo período histórico, inserindo uma ordem simbólica e subjetiva inerente à constituição da territorialidade.

A partir da compreensão dos aspectos formadores e conformadores da lógica da territorialidade da RDS Igapó-Açu, pode-se elucidar os aspectos que fundamentam as diferentes formas de organização social desta UC, afinal o modo como a sociedade se organiza está diretamente ligado à sua concepção simbólica de utilização do território. O tópico seguinte apresenta a constituição e o desdobramento das formas de organização social na governança. Esse desdobramento só se torna profícuo por meio dos elementos anteriormente abordados e compreendidos. 


\section{REDES SOCIOPOLÍTICAS, GOVERNANÇA E FORMAS DE ORGANIZAÇÃO SOCIAL}

A territorialidade está intimamente relacionada com a lógica temporal que conduz as ações dos diferentes atores sociais, como foi elencado anteriormente. A forma com que os grupos sociais se organizam relaciona-se inteiramente com a essência simbólica que comanda as decisões e ações objetivas. As formas de organização social emergem, nesse sentido, como um produto do conjunto das relações sociais projetadas.

Segundo Etzioni (1967) existem vários tipos de organizações: as organizações coercitivas, onde o poder é instituído por meio da força física e a principal forma de controle manifesta-se por meio de punições; as organizações utilitárias, onde o poder institui-se por meio do controle aos incentivos econômicos, e o controle manifesta-se por meio dos benefícios ansiados; e as organizações normativas, onde o controle moral ocupa papel central, e o poder é expresso por meio do envolvimento simbólico e motivacional.

Etzioni (1967) a partir de sua teoria estruturalista das organizações psicossociais deixou algumas lacunas em suas pesquisas, pelo fato de ter tratado as organizações a partir unicamente da lógica do controle. Porém, teve contribuições importantes no entendimento da organização das unidades sociais e de seus reflexos. Na RDS Igapó-Açu existem várias formas de organização social, cada uma objetivando seus interesses particulares. Os resultados da pesquisa mostram que $66,70 \%$ das famílias participam de organizações sociais. Do total de famílias partícipes, 42,90\% frequentam igreja, 35,70\% participam da Associação de Moradores, e 21,40\% participam do Conselho Gestor.

Figura 11 - Participação em organização Figura 12 - Organização social partícipe social

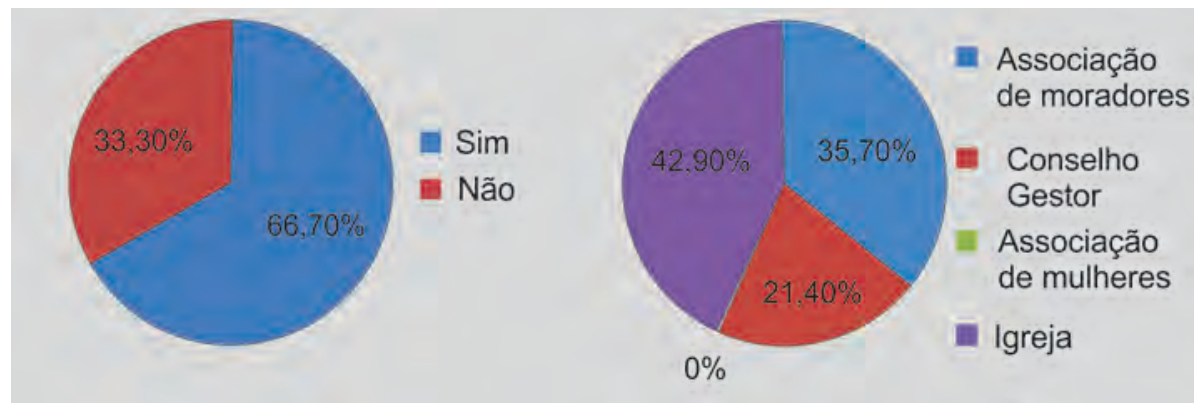

Fonte: Rezende (2016) 
A significativa participação das famílias na igreja justifica-se por inúmeros fatores: pela reterritorialização do sagrado instituído socialmente nos locais de nascimento e socialização; pela necessidade de encontro fraternal e vivificação espiritual proporcionado pelos encontros religiosos; e pela realização de festas religiosas.

Fraxe (2004) afirma que a Igreja Católica possuiu e possui um papel central nas comunidades rurais do Amazonas, por ser uma instituição política, cultural e social que se insere no cotidiano dos povos. A autora evidencia a importância da igreja na configuração socioespacial das comunidades e suas imbricações. A religião prevalecente na RDS Igapó-Açu é o catolicismo, representativo de 85,70\% das famílias (Figura 14).

Figura 13 - Detenção de crença Figura 14 - Crença religiosa das religiosa famílias
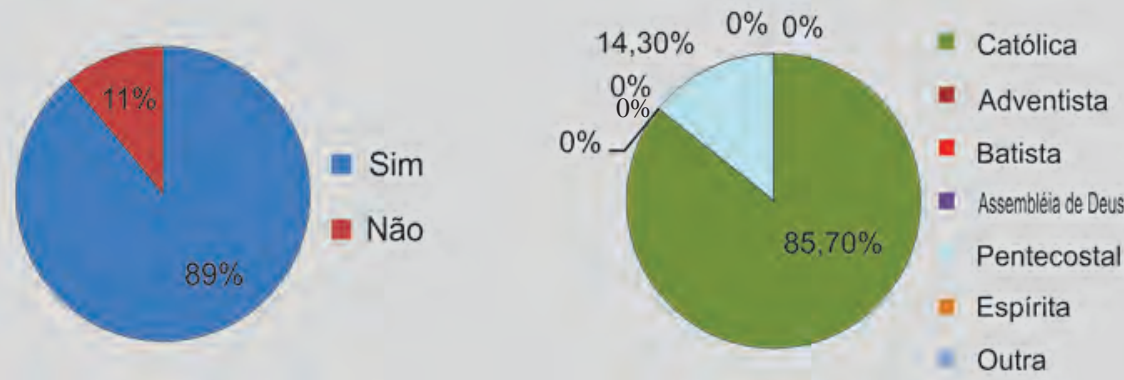

Fonte: Rezende (2016)

A comunidade São Sebastião do Igapó-Açu possui diversos festejos religiosos, com destaque para as festas de São Pedro, de São João, do Sagrado Coração de Jesus, e para a Festa dos Santos. As festas religiosas, além de serem vistas como momentos de diversão e de alimentação espiritual, são períodos de reafirmação cultural e reinvenção da tradição, pois corroboram por meio da socialização os elementos simbólicos produtores do cotidiano.

Dessa forma, na RDS Igapó-Açu, as festas apresentam-se como manifestações culturais de afirmação das relações de vizinhança e dos laços de religiosidade, que constituem as redes de sociabilidade formadoras de identidades e de topofilia. Além das festas religiosas, há festas temáticas, como a Festa do Tucunaré, conhecida em escala estadual, por congregar pessoas de diversos municípios do Amazonas. Observa-se que há festas na comunidade, como a Festa do Tucunaré destinada ao público externo e voltada ao turismo; e festas da comunidade, organizadas com vistas a atender os residentes, uma festa interna. 
Segundo Perez (2002), as festas são rituais que ocorrem em diferentes sociedades, são atos simbólicos que evidenciam a organização social e a sociabilidade dos grupos sociais territorializados. Nos momentos festivos os espaços são ressignificados, de acordo com o público (externo ou interno) e com o que se deseja explicitar.

Assim sendo, as festas na RDS Igapó-Açu representam o que Mauss (2003) denomina de fato social total, pois os rituais expressam todas as dimensões da vida (social, religiosa, cultural, econômica, estética, dentre outras) que constituem o sistema social em sua totalidade. As diferentes sociabilidades compõem o quadro festivo e lhe dão vida.

A compreensão das formas de organização social perpassa o âmago das sociabilidades, da socialização, das formas sociais, das ressignificações, dos significados, e dos sistemas simbólicos. Somente a partir da interação entre esses fatores, complementares e cônjuges, que as formas de organização social podem ser tratadas claramente. Nas comunidades rurais, como é o caso da RDS IgapóAçu, essa interação é cada vez mais fortalecida e revelada, pela topofilia criada e estabelecida pelos grupos sociais.

A socialização quanto ao trabalho e a inserção nas atividades produtivas começam na infância. A Figura 15 mostra a divisão social do trabalho por idade, pode-se observar que $75 \%$ das famílias não dividem o trabalho por faixa etária, as crianças são inseridas nas atividades de trabalho logo na infância, porém em atividades com menor esforço físico.

Figura 17 - Divisão social do trabalho por faixa etária

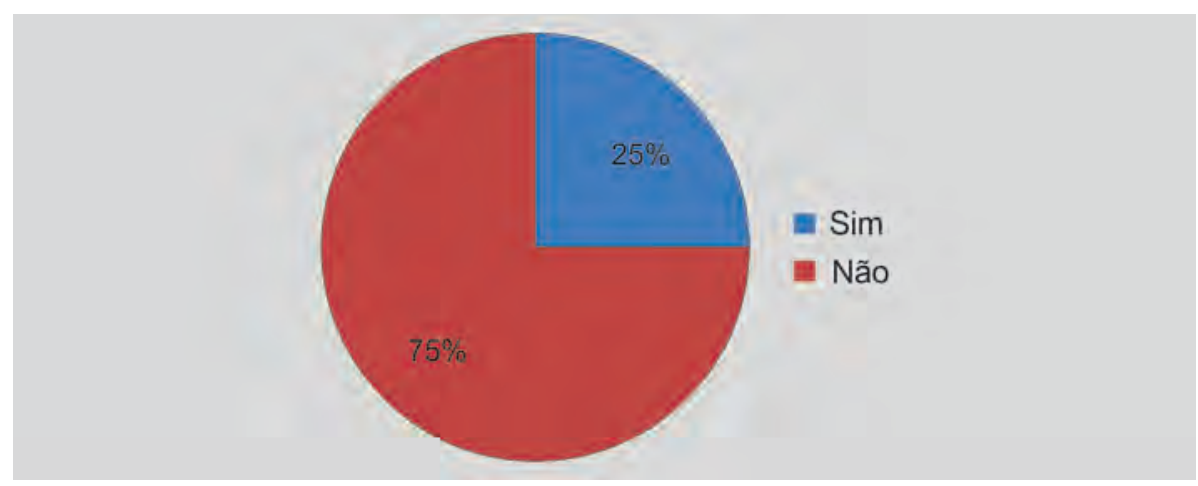

Fonte: Rezende (2016)

A inserção das crianças nas atividades de pesca e agricultura objetiva a transferência dos conhecimentos tradicionais adquiridos e perpassados por meio da socialização intergeracional; o fortalecimento dos laços familiares; e o 
aprendizado das técnicas perceptivas de sensibilização das características dos ecossistemas os quais estão inseridos. Leal (2010), em seus estudos sobre a socialização em comunidades rurais, afirma que:

É nesse momento de reconhecimento da infância que se percebe que é a criança que perpetua o modo de vida. Que é ela ao aprender e ao reproduzir o aprendido que torna re-existente em sua geração aquele saber, aquele fazer, aquele modo de vida (LEAL, 2010, p. 123).

Nesse contexto de perpetuação de valores e símbolos que se justifica a não distinção de faixa etária no trabalho na RDS Igapó-Açu. Não há indisposição das crianças no processo de aprendizagem de atividades como caça, pesca e agricultura. A participação nessas atividades está cristalizada no imaginário social da comunidade, criador dos sistemas simbólicos.

Na RDS Igapó-Açu há vários tipos de família: famílias díades nucleares, aquela em que os cônjuges não possuem filhos e nem parentesco em comum; famílias nucleares, com apenas um nível de descendência; e famílias extensas, com níveis de ascendência e descendência variados. Essa diversificação de tipos familiares justifica-se pela pluralidade de atores sociais que se deslocaram à UC no ápice do asfaltamento da BR-319.

Essas características são importantes para o entendimento da rede de articulação política que estabelece a governança ambiental, pois o modo como os atores sociais criam as relações de poder está intimamente relacionado com os sistemas simbólicos geradores dos sistemas sociopolíticos. Essa trama de relações e interações gera o governo da RDS Igapó-Açu, a partir da manifestação do poder e de seus desdobramentos sociais e, consequentemente, territoriais.

\section{CONSIDERAÇÕES FINAIS}

Os caminhos indicados pela pesquisa conduzem a análise da governança ambiental e das redes sociopolíticas para novos traçados, anteriormente não previsíveis. A ressignificação do conceito de governança ambiental foi o foco deste artigo. A governança estabelece-se a partir de inúmeros elementos: governabilidade, governo, relações de poder, territorialidades, temporalidades, sistemas simbólicos, sistemas sociopolíticos, formas de organização social, escalas, dentre outros.

A governabilidade apresenta-se como o conjunto de condições necessárias para o desenvolvimento do governo, elemento conformador da governança. As relações de poder apresentam-se como a característica básica que estabelece as 
formas de organização social. Os sistemas simbólicos, criados pelo imaginário social, formam os sistemas sociopolíticos, que são a expressão material da governança. As temporalidades distintas configuram as territorialidades, que são as práticas sociais objetivadas via subjetividade. Todos esses elementos, simétricos e dissimétricos, geram e corroboram, dialeticamente, a governança ambiental.

Essa governança ambiental transcende as fronteiras dos Estados Nacionais, e necessita de um tratamento transescalar dos fenômenos e epifenômenos sociais. Essa transcendência justifica-se pela significativa abrangência da governabilidade, que é conduzida por atores sociais de diversas partes do mundo. Além da escala internacional, explicada acima, destaca-se a importância e os impactos da escala nacional no contexto local, como a promulgação da Lei n⿳⺈ 6.938/91, que corroborou a Política Nacional do Meio Ambiente, e disseminou importantes políticas públicas para as UC do Brasil, e em especial para as da Amazônia brasileira.

Doravante, a governança ambiental constitui-se via transescalar. Em micro escala forma-se por meio da interação entre os sistemas simbólicos e os sistemas sociopolíticos. Em macro escala, condensa os diferentes elementos formadores da governabilidade e das políticas públicas. As formas de organização social fundamentam-se a partir de elementos transescalares, por isso a governança ambiental é transescalar.

Vários são os fatores que contribuíram para o estabelecimento atual da governança ambiental na RDS Igapó-Açu: a existência da BR-319, o deslocamento populacional por meio de incentivos estatais, o anseio pela constituição familiar em locais com abundância de recursos naturais, dentre outros fatores. Esses foram os principais elementos históricos que consolidaram o atual sistema sociopolítico da UC.

A significativa concentração populacional advinda de outros municípios $(78 \%)$ conferiu e confere um ordenamento territorial específico à RDS IgapóAçu, visto que os atores sociais tendem a reproduzir territorialmente os espaços vivenciados em seus locais anteriores de vivência. Os ecletismos das roças, das escolhas das áreas de pesca, do gosto pelas diferentes formas de lazer, conduzem a análise da governança cada vez mais para as formas de organização social.

A família exerce, nesse contexto, forte influência na continuidade do modo de vida pautado na sustentabilidade ambiental, pois a partir da reprodução cultural, insere as crianças na lógica simbólica das práticas sociais cotidianas, configurando assim a territorialidade, importante elemento analítico para a compreensão da governança. Aliado à família, a igreja emerge como a organização social mais ativa na RDS Igapó-Açu, com participação de 43\% das famílias. 
As festas da comunidade e na comunidade são momentos cruciais de observação da organização da governança. Elas evidenciam e fortalecem os sistemas simbólicos e demonstram substancialmente as relações de poder existentes e seus desdobramentos territoriais. Dessa forma, os festejos exercem função imprescindível na materialização da governança, em suas múltiplas escalas, e na reafirmação cultural e reinvenção da tradição.

A governança ambiental na RDS Igapó-Açu é uma governança democrática, que, a partir do Conselho Gestor, incrementa a participação de diferentes atores sociais, com diferentes pontos de vista e interesses. Ao invés de uma governança cosmopolita, o que se estabelece é uma forma democrática de governação dos processos de tomada de decisão.

\section{AGRADECIMENTOS}

À Coordenação de Aperfeiçoamento de Pessoal de Nível Superior (CAPES) pelo financiamento da pesquisa. A todos os residentes da Reserva de Desenvolvimento Sustentável Igapó-Açu, que contribuíram no processo de artesanato intelectual.

\section{REFERÊNCIAS}

ALTHUSSER, L. O futuro dura muito tempo. Paris: Editora Companhia das Letras, 1992.

BOURDIEU, P. O poder simbólico. Rio de Janeiro: Bertrand Brasil, 2005.

ETZIONI, A. Organizações modernas. São Paulo: Editora Pioneira, 1967.

FRAXE, T. J. P. Cultura cabocla-ribeirinha: mitos, lendas e transculturalidade. São Paulo: Annablume, 2004.

GAUDEMAR, Jean-Paul de. Mobilidade do trabalho e acumulação do capital. Lisboa: Editora Estampa, 1977.

HAESBAERT, R. A produção capitalista do espaço. São Paulo: Annablume, 2005.

HAESBAERT, R.; LIMONAD, E. O território em tempos de Globalização. Revista Eletrônica de Ciências Sociais Aplicadas, Rio de Janeiro, v. 1, n. 2, p. 39-52, 2007.

HAWKING, S; MLODINOW, L. Uma nova história do tempo. Rio de Janeiro: Ediouro, 2005. 
LEAL, A. Olhar o ser, ver o acontecer: socialização e comunidade. Revista Caminhos da Geografia, Uberlândia, v. 11, n. 34, p. 123-130, 2010.

MAUSS, M. Ensaio sobre a dádiva: forma e razão da troca das sociedades arcaicas. In: MAUSS, M. Sociologia e Antropologia. São Paulo: Cosac Naify, 2003.

PEREZ, L. F. Antropologia das efervescências coletivas. In: PASSOS, Mauro. A festa na vida. Petrópolis: Vozes, 2002.

RAFFESTIN, C. Por uma geografia do poder. São Paulo: Editora Ática, 1993. REZENDE, M. G. G. Governança ambiental na Reserva de Desenvolvimento Sustentável Igapó Açu (Amazonas, Brasil). Dissertação apresentada ao Programa de Pós-Graduação em Ciências do Ambiente e Sustentabilidade na Amazônia, 2016.

SANTOS, M. Abordagens e concepções de território. 2 ed. São Paulo: Expressão Popular, 2010.

SAQUET, M. A.; BRISKIEVICZ, M. Territorialidade e identidade: um patrimônio no desenvolvimento territorial. Caderno Prudentino de Geografia, Presidente Prudente, v. 1, n. 31, p. 03-16, 2009.

SILVA, A. L. da. Entre tradições e modernidade: conhecimento ecológico local, conflitos de pesca e manejo pesqueiro no rio Negro, Brasil. Boletim do Museu Paraense Emílio Goeldi. Ciências Humanas, Belém, v. 6, n. 1, p.141-163, 2011. SILVA, C. N. O sistema de gestão do território em Portugal. Revista de Ação Regional e Local, FAQ, Lisboa, XIV (74), p. 21-35, 2000.

SOBREIRO, T.; FREITAS, C. E. de C. Conflitos e territorialidade no uso de recursos pesqueiros do Médio rio Negro. In: IV Encontro Nacional da Anppas. Brasília, 2008. Anais eletrônicos... Brasília: ENANPPAS, 2008. Disponível em: <http:/ / www.anppas.org.br/encontro4/cd/gt2.html >. Acesso em 16 ago. 2018.

SOUZA, M. L. O território: sobre espaço e poder, autonomia e desenvolvimento. In: CASTRO, I. E. et al. Geografia: conceitos e temas. 3. ed. Rio de Janeiro: Bertrand Brasil, 2001.

SPOSITO, M. E. B. Introdução. In: SAQUET, M. A.; SPOSITO, E. S. (Org.). Território e Territorialidades: teorias, processos e conflitos. 1 ed. São Paulo: Expressão Popular, 2009. p. 7 -10.

THIOLLENT, M. J. M. Metodologia da pesquisa-ação. São Paulo: Cortez, 1998. 


\section{Prioridades locais e sua relação com o desenvolvimento regional no Codemi de Ijuí}

\section{Local priorities and its relationship with regional development in the Codemi from Ijuí}

Vinicios Gonchoroski de Oliveira - Doutorando em Desenvolvimento Regional pela Universidade de Santa Cruz do Sul/UNISC. Mestre em Desenvolvimento pela UNIJUÍ. E-mail: viniciosgdoliveira@gmail.com.

Rogério Leandro Lima da Silveira - Doutor e mestre em Geografia Humana pela Universidade Federal de Santa Catarina. Professor titular e pesquisador do Departamento de História e Geografia, e do Programa de Pós-Graduação em Desenvolvimento Regional da Universidade de Santa Cruz do Sul/UNISC. E-mail: rlls@unisc.br

\section{Resumo}

A democracia participativa/deliberativa introduz no debate sobre participação e democracia, distintos matizes de valorização da participação dos cidadãos nos processos circunscritos ao empoderamento e às tomadas de decisão, seus efeitos sobre o coletivo e para o regiões. Posto isto, procurou-se identificar, se os projetos prioritários eleitos por meio da participação da população na etapa municipal do processo de votação da Consulta Popular (CP) 2016-2017 dialoga com a perspectiva do desenvolvimento regional. O estudo é qualitativo, bibliográfico e documental, onde se analisou o Regimento Interno do Codemi, a ata com os resultados das demandas eleitas e o caderno de diretrizes da CP, comparandoos com o resultado da votação do CoredeNorc. Os principais resultados apontam para uma realidade desconexa com a compreensão de desenvolvimento adotada pelos estudos de desenvolvimento regional. Contudo, isto não torna o processo ilegítimo e desnecessário, pelo contrário, evidencia-se o desafio de se pensar uma agenda de desenvolvimento regional.

\section{Palavras-chave}

Democracia. Participação. Consulta Popular. Desenvolvimento Regional.

\begin{abstract}
Participatory / deliberative democracy introduces in the debate on participation and democracy, different nuances of valorization of citizen participation in processes limited to empowerment and decision-making, their effects on the collective and the development of the regions. Having said this, it was sought to identify whether the priority projects elected through the participation of the population in the municipal stage of the voting process of the Consulta Popular (CP) 2016-2017 dialogue with the regional development perspective. The study is qualitative, bibliographical and documentary, in which the Internal Regulation of Codemi was analyzed, the minutes with the results of the elect demands and the notebook of guidelines of the $\mathrm{CP}$, comparing them with the result of the Corede-Norc voting. The main results point to a disconnected reality with the understanding adopted in the regional development study. However, this does not make the process illegitimate and unnecessary, on the contrary, the challenge of thinking about a regional development agenda is evident.
\end{abstract}

\section{Keywords}

Democracy. Participation. Consulta Popular. Regional Development. 


\section{INTRODUÇÃO}

A configuração político-administrativa do Estado $^{1}$ brasileiro, após o processo de redemocratização de 1988, culminou na elaboração de um dos mais importantes documentos de garantia de direitos, deveres e liberdades de cidadãos em um Estado-nação, a Carta Magna ${ }^{2}$. Além disto, a carta assegurou a estados e municípios maior autonomia e descentralização político-administrativo em relação à União (VITALE, 2004). Situa-se, no espectro de mudanças, as iniciativas no campo da gestão orçamentária dos recursos públicos e o processo de constituição, disseminação e operação de instituições e mecanismos participativos.

Nesta linha, Leonardo Avritzer (2009) compreende enquanto possibilidade de cidadãos participarem e interferirem no processo de tomada de decisão política, via participação nas instituições participativas, à luz de três perspectivas: a primeira considera o desenho participativo de característica bottom-up dessas instituições, exemplo disso são as experiências do Orçamento Participativo $(\mathrm{OP})^{3}$ e da Consulta Popular $(\mathrm{CP})^{4}$; o segundo aspecto considera o desenho de partilha do poder, como ocorre nos conselhos deliberativos; a terceira e última perspectiva analisa o aspecto relativo ao desenho de ratificação pública, característica de cidadãos que participam de espaços públicos de discussão como audiências públicas ou na elaboração de planos diretores municipais.

A presença de instituições participativas nos três níveis de governo, isto é, no municipal, estadual e no federal, apresenta especificidades e particularidades,

1 O termo estado constitui a nomenclatura brasileira para nomear os entes que integram a federação: as regiões. Isto é, o Brasil constitui uma federação de 26 regiões acrescidas do Distrito Federal. Portanto, esta pesquisa, ao analisar o estado RS, está analisando uma região.

2 A Carta Magna é um termo que deriva do latim Magna Charta Libertatum, que faz menção à Constituição Federal do Brasil (CF). Em linhas gerais, a CF estipula um conjunto de instrumentos legais com vistas a garantir a legitimidade do sistema democrático, mas, sobretudo, assegura aos cidadãos um espectro de direitos e deveres, legitima o poder civil, definindo a democracia como representativa e participativa, e transferiu o poder do governo central para estados e municípios (MARQUETTI, 2003).

3 O OP consiste numa experiência de participação direta de cidadãos na esfera pública. Neste espaço, os cidadãos podem influenciar a administração pública sobre as decisões do orçamento, direcionando-o para setores da sociedade nos quais os participantes do processo julgam ser prioritários.

4 O Governo do RS realiza anualmente uma consulta direta à população para saber quais as áreas prioritárias devem receber investimento de ordem pública. O processo da $\mathrm{CP}$ vinha sendo realizado da combinação de votação através de cédulas e através do uso das TICS, em particular, por meio da internet. Em 2016, o processo passou a ser realizado somente por meio dos instrumentos tecnológicos, combinando um formato híbrido de votação, ou seja, a escolha das prioridades regionais pela população passou a se dar tanto através do uso da internet (online) como também por meio da escolha via dispositivos eletrônicos (off-line). Ver Lei no 11.179, de 25 de junho de 1998. 
principalmente ao introduzir no campo de pesquisa da ciência política e social, a discussão de alternativas frente ao atual modelo de desenvolvimento hegemônico das sociedades. Introduzir a temática do desenvolvimento regional, não somente é necessária para assegurar as particularidades da região como, também, se constituí num embate ao modelo democrático cunhado sob as bases do "mercado e sobre a desigualdade socioeconômica é uma farsa bem sucedida, visto que os mecanismos por ela acionados destinam-se apenas a conservar a impossibilidade de democracia" (SÁNCHEZ, 2002, p. 31). Ressalta-se a importância das decisões deliberadas pela população, por meio das instituições participativas, refletirem tal perspectiva.

É preciso acentuar que a participação dos cidadãos na $\mathrm{CP}$, via conselhos municipais e regionais, permite não só a descentralização do poder, como a sua (re)distribuição, privilegiando que as decisões tomadas reflitam os interesses coletivos frente aos interesses individuais. Parte-se da visão de Pires e López (2010, p. 565) para quem a organização política da participação e das tomadas de decisões possam contribuir para o desenvolvimento de "novas formas de mediação representativa entre Estado e sociedade".

Dada a relevância de vincular a perspectiva do desenvolvimento regional, o artigo consiste, a partir de uma linha participacionista/deliberacionista, em identificar comparativamente se os projetos prioritários eleitos por meio da participação da população na etapa municipal do processo de votação da Consulta Popular (CP) 2016-2017 dialoga com a perspectiva do desenvolvimento regional. A descrição comparativa se deu no âmbito local do Conselho Municipal de Desenvolvimento de Ijuí (Codemi) ${ }^{5}$ e, para o processo regional da CP, sob o recorte territorial do Conselho Regional de Desenvolvimento Noroeste Colonial $\left(\right.$ Corede-Norc ${ }^{6}$ ), enquanto instrumentos de governança territorial.

Em termos metodológicos, o estudo consiste numa abordagem qualitativa, de cunho bibliográfico e documental, no qual se analisou o Regimento Interno do Codemi, a ata com os resultados das demandas eleitas prioritárias por temática, o caderno de diretrizes da CP, comparando-os com o resultado da votação do Corede-Norc para a CP 2016-2017.

\footnotetext{
O Codemi/Comudes são um conselho consultivo-deliberativo de tomada de decisão. Os Comudes surgem em 2003/04 como funcionais ao processo de consulta popular, coordenado pelos Coredes e Governo do Estado.

6 O RS é formado por 28 microrregiões denominadas de Corede, e cada Corede é formado por um conjunto de municípios. Os Coredes são regulamentados Decreto 35.764 que regulamenta a Lei $\mathrm{n}^{\circ} 10.283$, de 17 de outubro de 1994, que criou os Coredes. Disponível em: <http://www.al.rs.gov.br/Legis/M010/M0100099.ASP?Hid_Tipo=TEXTO\&Hid_ TodasNormas=12439\&hTexto=\&Hid_IDNorma=12439> . Acesso em: 14 abr. 2017.
} 


\section{A VONTADE GERAL COMO PRESSUPOSTO NORTEADOR DA DEMOCRACIA PARTICIPATIVA E DELIBERATIVA}

As terminologias 'Democracia', 'Participação' e 'Deliberação' exprimem concepções teórico-conceituais indissociáveis de um ideário de sociedade contemporânea pautado na participação direta da sociedade civil na esfera governamental do Estado. Ao longo da história, foram utilizados como condição sine qua non na tentativa de se estabelecer uma relação entre sociedade e Estado que possibilitasse maior empoderamento da população.

A democracia enquanto um modelo de governo, a participação enquanto uma estratégia de consolidação democrática e a deliberação enquanto mecanismo de descentralização da tomada de decisão e empoderamento, expõem, em certa medida, uma visão teórica normativa que tenciona a democracia participativa/ deliberativa à luz de um ideal utópico, de como deve, ou deveria ser, o ideal democrático (ROUSSEAU, 1983; HARBERMAS, 1987).

É preciso acentuar que a noção de coletivo abordada neste estudo exprime a ideia de que as decisões tomadas no campo democrático - sejam elas de forma indireta pelos representantes eleitos pelo povo através do sufrágio universal, ou de forma direta pela população por meio da participação no campo político -, devam representar o interesse da maioria, isto é, a soma dos interesses coletivos da 'vontade geral' (CÓRDOBA, 2010).

A priori, a vontade geral prima por um sistema democrático no qual os cidadãos são os maiores beneficiados das políticas públicas, cabendo ao Estado resguardar os interesses coletivos frente aos interesses individuais, do setor privado, econômico, representado através da vontade de todos.

É necessário sublinhar a visão de Allebrandt (2002) ao expor o pensamento de que a ideia de democracia envolve, eminentemente, relações entre sujeitos e tomadores de decisões em relação aos modos de vida. Essas relações definem "políticas públicas que afetam tanto as instâncias governamentais quanto a sociedade civil em vários aspectos da vida em sociedade, considerando a complexidade de cada época e as ideias desenvolvidas" (p. 48).

Para Rawls (2001), uma sociedade democrática nem sempre é justa e isenta de interesses individuais. Não está a se dizer que não se possa ter interesses individuais, a crítica a se tecer é quando os interesses individuais sobressaem aos interesses coletivos. Uma democracia pensada à luz da coletividade requer a participação ativa de seus cidadãos, requer a presença de instrumentos de governança territorial que imprimem sentidos e significados ao mundo da vida no sentido de orientar as ações e a definição de políticas públicas em prol do bem comum. 
A Democracia Participativa/Deliberativa, pensada à luz da teoria da Ação Comunicativa ou comunicação linguística habermasiana, possibilita ao cidadão, ao menos no campo teórico, romper com dogmas que o inibem de manifestar o livre pensamento e o discurso aberto no mundo da vida. Trata-se de um processo cooperativo de interpretação, em que os participantes, por meio do processo dialógico, pautado no uso da razão, interagem entre si alinhando os argumentos até se chegar a um consenso comum. Ressalta-se, que ao intercambiar argumentos, ideias e informação, os participantes devem fazê-lo de modo a evitar a supressão da fala do outro, tornando assim o processo participativo mais democrático possível.

Habermas (1987) compartilha da ideia de que além do direito a fala, num processo participativo, deve-se ainda fazer uso da razão ao se tomar decisões. A racionalidade comunicativa que este autor menciona não visa substituir a racionalidade instrumental - uso da técnica - do processo participativo, pois esta última diz respeito a operacionalização daquilo que é discutido no campo dos processos dialógicos.

A exemplo do ideário normativo habermasiano de espaço público, enfatiza-se que o mesmo deve privilegiar a emancipação cidadã, contemplar procedimentos racionais, discursivos, participativos e pluralistas, e mesmo orientados por interesses técnico-instrumentais, devem propiciar condições de a sociedade civil estabelecer um consenso comunicativo e uma autorregulamentação (HABERMAS, 1987). Neste caso, a racionalidade instrumental deve estar subordinada a racionalidade comunicativa, e não o contrário. Todavia, por vezes, nos espaços participativos, as tomadas de decisão são pautadas no uso da racionalidade instrumental, suprimindo a racionalidade comunicativa.

$\mathrm{Na}$ atual dinâmica de ordenamento do território, a racionalidade comunicativa acaba por vezes sendo suprimida pela racionalidade instrumental. Haja vista que o território não é um espaço neutro, mas um ambiente marcado por conflitos, disputas, um espaço construído para atender, quase que sumariamente, os interesses dos grandes grupos hegemônicos que desconsideram as especificidades e particularidades da região (ETGES, 2001).

A descentralização decisória na esfera pública, principalmente por meio dos conselhos municipais de desenvolvimento, tem se consolidado cada vez mais em democracias participativas. Faz-se importante ressaltar que nem sempre a tomada de decisão ocorre de forma a propiciar o entendimento mútuo ou o bem comum, ou mesmo são atendidos os interesses coletivos. 


\section{COREDESECOMUDESCOMO EXPERIÊNCIADE PARTICIPAÇÃO NO RS}

A experiência do RS com os Coredes e Comudes, possibilitou significativos avanços no bojo da manutenção da democracia participativa e deliberativa no estado. A participação no RS, em que pese o campo normativo constitucional, é compreendido como um princípio da administração pública. De acordo com o Art. 19 da Constituição Estadual (CE) de 1989 do estado do RS, a participação na administração pública se dá

[...] direta e indireta de qualquer dos Poderes do Estado e dos municípios, visando à promoção do bem público e à prestação de serviços à comunidade e aos indivíduos que a compõe, observará os princípios da legalidade, da moralidade, da impessoalidade, da publicidade, da legitimidade, da participação, da razoabilidade, da economicidade, da motivação.

A CE foi inspirada na então recente promulgação da Constituição Federativa do Brasil (CF) de 1988, que já destacava um conjunto de elementos de democracia direta e semidireta para o exercício democrático em todas as dimensões do Estado.

Após a experiência brasileira com o regime militar, que perdurou duas décadas (1964-1985), a redemocratização do Brasil com a elaboração da CF alterou o modus operandi de se governar. Instituiu-se formas de regulação participativa e solidária, de reconstrução do espaço público e legitimação do mandato político, de emancipação dos indivíduos.

Neste contexto, não se pode esquecer de enfatizar que no atual modelo democrático brasileiro, de gestão descentralizada, com participação cidadã, a perspectiva municipal (local) é a primeira instância de contato dos cidadãos com os órgãos públicos. É, ainda, a instância onde ocorre a concretização das políticas públicas nos diferentes níveis político-administrativo do Estado.

A experiência de descentralização político-administrativa do RS resultou na institucionalização de diversos instrumentos de governança territorial (GT). Na perspectiva de Ferrão (2010), a partir do caso português, a GT valoriza a descentralização dos processos de decisão

face ao papel tradicionalmente desempenhado pelo Estado moderno, nuns casos desenvolvidos no âmbito de contextos mais desregulamentados, noutros [...] em mecanismos mais participativos, organizados em rede e colaborativos (FERRÃO, 2010, p. 133). 
Na concepção de Dallabrida (2012, p. 6) a governança territorial exprime a ideia de um "conjunto de iniciativas ou ações que expressam a capacidade de uma sociedade organizada territorialmente para gerir os assuntos públicos a partir do envolvimento conjunto e cooperativo dos atores sociais, econômicos e institucionais".

Por assim dizer, a governança territorial pode ser analisada tanto pelo prisma normativo de aplicação dos princípios da boa governança, até pelo viés das políticas territoriais e urbanas, como um processo de planejamento e gestão de dinâmicas territoriais. Sendo, neste segundo olhar, inovador, partilhado e colaborativo.

Num modelo de governança, pressupõem-se que haja maior cooperação entre sujeitos, governo, mercado, cujas políticas, tanto de base territorial como setorial, são mais articuladas com os interesses do coletivo.

Cabe mencionar, que os Coredes enquanto fóruns de discussão, decisão e integração de políticas, ações, lideranças e recursos orientados à promoção do desenvolvimento regional no Rio Grande do Sul, são exemplos de instrumentos de governança territorial. Os mesmos foram instituídos através da Lei n 10.283 , de 17 de outubro de 1994, e regulamentados através do Decreto n 35.764, de 28 de dezembro de 1994. De acordo com o que preconiza a Lei, eles têm por objetivo: a promoção do desenvolvimento regional harmônico e sustentável; a integração dos recursos e das ações do Governo e da região; a melhoria da qualidade de vida da população; a distribuição equitativa da riqueza produzida; o estimulo à permanência do homem em sua região; a preservação e recuperação do meio ambiente. Atualmente são 28 Coredes no estado do Rio Grande do Sul.

Os Comudes são outro exemplo de instrumentos de governança territorial. Assim como os Coredes, os Comudes representam o espaço físico onde a mobilização e deliberação do interesse coletivo se concretiza. No entanto, algumas peculiaridades os diferenciam um do outro. Enquanto os Coredes se organizam de forma descentralizada e representam um arranjo de municípios gaúchos, os Comudes também se organizam de forma descentralizada, mas sua atuação se dá na instância municipal. Todavia, é possível que as deliberações deste conselho visem o regional e não tão somente o local.

Pode-se dizer, que Coredes e Comudes são arranjos institucionais que possibilitam atingir níveis democráticos de participação mais consolidados. Numa democracia participativa a capacidade de mobilização e articulação política e social entre as múltiplas escalas do território é fundamental para a manutenção do processo participativo. 
Cabe lembrar, que estes arranjos institucionais formam a base do processo de regionalização do executivo do RS, que busca reconhecer diversas formas de mobilização, participação e articulação da sociedade, fomentando, assim, uma cultura participativa no estado. Os avanços na democracia participativa possibilitam que o cidadão seja soberano de suas ações e decisões atuando em prol do exercício da cidadania (BONAVIDES, 2008).

\section{CARACTERIZAÇÃO DO LÓCUS DO ESTUDO}

O município de Ijuí foi oficialmente fundado em 19 de outubro de 1890. De acordo com Allebrandt (2002), nesta época, Ijuí era uma colônia sob tutela de um governo central. Sob o ponto de vista étnico, prevalecia o modelo de centros hegemônicos, isto é, o povoamento das colônias se dava por integrantes de um mesmo grupo étnico, geralmente por italianos e alemães. Entretanto, sua emancipação para município só ocorreu na primeira metade do século XX, em 1912.

Com a emancipação política do município as colônias passaram a ser ocupadas por imigrantes vindos de outras regiões da Europa. Além dos grupos étnicos que predominavam nesta região (italianos e alemães), outros grupos como poloneses, portugueses, espanhóis, franceses, letos, suecos, húngaros, também começaram a ocupar esta região do estado do RS (ALLEBRANDT, 2002).

Com relação aos dados sociodemográficos, Ijuí possui uma população de 78.915 habitantes. Destes, 71.550 (90,67\%) habitantes residem na área urbana, o qual revela a existência de um alto grau de urbanização, pois apenas 7.365 (9,33\%) residem na área rural (IBGE, 2010). Ao comparar estes dados com o Censo Demográfico de 2000, percebe-se um acentuado êxodo rural. Em 2000, o total de habitantes era de 78.286. Destes, 67.181 (85,8\%) residiam no meio urbano e 11.105 (14,2\%) no meio rural. Em dez anos aumentou em 5\% o percentual da população que migrou da zona rural para a urbana.

Em relação aos indicadores socioeconômicos, o $\mathrm{PIB}^{7}$ municipal de Ijuí, no ano de 2012, foi de $\mathrm{R} \$ 2.760 .178,00$. Destes, $2.187 .717,08$ (79,26\%) são provenientes de prestação de serviços, $379.800,49$ (13,76\%) são da indústria e 192.660,42 (6,98\%) são da agropecuária. Isto desmistifica que a cultura de Ijuí essencialmente agrícola, pois se destaca nos segmentos pecuário, comércio, indústria e serviços. Porém, se salienta que a indústria e a prestação de serviços podem estar diretamente relacionadas ao primeiro setor.

Disponível em: <http://www.fee.rs.gov.br/wp-content/uploads/2015/12/20151217pibmunicipal-total-per-capita-2013.xlsx>. Acesso em: 29 abr. 2017. 
Já em relação ao Índice de Desenvolvimento Humano Municipal (IDHM), segundo a classificação do $\mathrm{PNUD}^{8}$, Ijuí ocupa a décima terceira $\left(13^{\circ}\right)$ posição no ranking dos 497 municípios gaúchos com melhor IDHM com 0,781. No mapa da Figura 1, é possível localizar o município de Ijuí a partir da subdivisão regional do Corede Noroeste Colonial Gaúcho.

Figura 1 - Localização do município de Ijuí a partir do recorte territorial do Corede-Norc

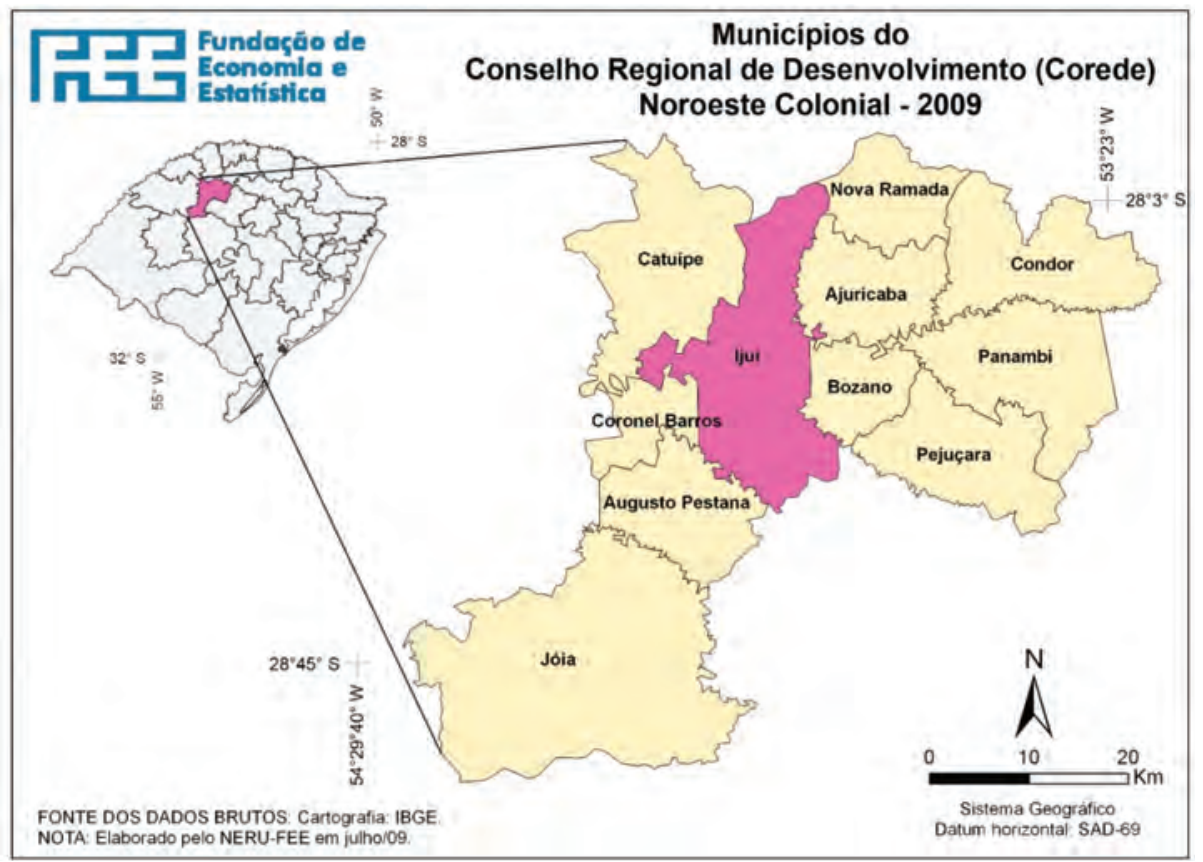

Fonte: Portal do Corede-Norc ${ }^{9}$ - Adaptado pelo autor.

Outro ponto importante a destacar sobre Ijuí, e que vai ao encontro do tema proposto neste artigo, é a sua experiência em relação ao desenvolvimento de práticas participativas deliberativas através dos conselhos municipais, meios estes que se caracterizam como espaços públicos de relacionamento e cooperação entre a sociedade civil e a esfera governamental.

No Plano Diretor ${ }^{10}$ de Ijuí, o artigo 10, inciso X, por exemplo, expõe a preocupação em se garantir a legitimidade de espaços de participação plurais, sendo objetivo da Política Municipal Participativa de Desenvolvimento de Ijuí

\footnotetext{
Disponível em: <http://www.atlasbrasil.org.br/2013/pt/ranking>. Acesso em: 29 abr. 2017.

Disponível em: < http://www.coredenorc.org.br/index.php/comudes>. Acesso em: 29 abr. 2017.

10 O Plano Diretor é um instrumento de política de desenvolvimento urbano e da expansão urbana do município, orientando as ações dos agentes públicos e privados na produção e gestão da cidade e das outras áreas urbanas de Ijuí.
} 
“instituir o Sistema Municipal de Planejamento e Gestão Participativa, garantindo canais de participação democrática nos processos de tomada de decisão" e no inciso XI "integrar o planejamento local ao desenvolvimento regional, através da articulação com os demais municípios da região".

Já o artigo 24, inciso III, também visa "garantir a participação popular, individual ou coletiva, através da criação de canais de participação da sociedade na gestão municipal da Política de Desenvolvimento [...]”. Desta forma, é importante frisar que o Plano Diretor atua no sentido de ser mais um instrumento que, se bem elaborado, reforça ainda mais a conquista e o empoderamento da sociedade civil na discussão dos problemas, na definição das prioridades, na implementação das ações e na avaliação e fiscalização das políticas públicas (controle social accountability) a nível local.

Allebrandt (2002) reforça a ideia de que a participação da comunidade ijuiense no Planejamento Estratégico Participativo de Ijuí, nos processos de planejamento setoriais (saúde, educação, turismo, etc.), no Plano Plurianual, na Lei de Diretrizes Orçamentárias (LDO) e na elaboração do Orçamento Anual, é resultado de um amplo esforço realizado há várias décadas entre os órgãos públicos, a sociedade civil e também em parecia com a universidade local.

Um exemplo desse esforço foi a construção do PPA realizado em Ijuí no ano de 2009 que serviu de exemplo para a construção do PPA do estado do Rio Grande do Sul, elaborado de forma participativa sob a coordenação da Secretaria de Planejamento do Estado e os Coredes, em 2011. Ijuí, adota como nomenclatura Plano Plurianual Comunitário Participativo, pois a construção do mesmo se dá com o apoio da comunidade. Outro instrumento que incorpora a palavra comunitário é o Orçamento Participativo, passando a ser chamado de Orçamento Comunitário Participativo de Ijuí. Estes instrumentos constituemse em processos de participação direta da comunidade, com o objetivo de debater, propor, deliberar e fiscalizar as políticas públicas indutoras para o desenvolvimento integrado de médio/longo prazo do município ou do estado.

\section{O CONSELHO DE DESENVOLVIMENTO DO MUNICÍPIO DE IJUÍ - CODEMI/COMUDE}

Com a Constituição Federal de 1988, marco que representa a redemocratização do país e a conquista de inúmeros direitos políticos, civis e sociais, assim como mecanismos instituídos para assegurar a participação cidadã nos assuntos relacionados ao Estado e à defesa de seus direitos (SILVEIRA; ALLEBRANDT; CAMPOS, 2015). 
O processo, em curso, de redemocratização do país, segue uma lógica de descentralização político-administrativa do Estado. Em outras palavras, isso quer dizer que há uma distribuição do poder do governo federal (central) a estados e municípios, valorizando os níveis subnacionais de governo.

Assim, a maior autonomia a estados e municípios - mas especialmente a municípios -, pode, segundo Allebrandt (2002, p. 73), "possibilitar novas formas de gestão pública modernas e democráticas como pode representar a persistência de práticas políticas patrimonialistas, que impedem a consolidação da cidadania e da democracia”.

Os Coredes, assim como os Comudes, são exemplos de como a gestão pública, por meio da participação cidadã, pode evitar práticas patrimonialistas, clientelistas, a ineficiência, a ingovernabilidade e a irresponsabilidade fiscal na condução da gestão pública.

A instituição dos conselhos municipais, em todos os municípios do território nacional, se deu após a promulgação da CF de 1988, mais especificadamente na década de 1990. Os conselhos municipais atuam de forma estratégica na condução do bem público, corroboram para que se mantenha o princípio da eficiência na administração pública e ainda atuam de forma articulada com o governo local, a esfera do mercado e da sociedade civil. Para este autor, os conselhos municipais são espaços públicos que legitimam a participação da sociedade civil na gestão pública local. Frutos do processo de descentralização (municipalização) das políticas sociais, os

Conselhos apresentam-se idealmente como elemento de ligação na relação da sociedade civil com o Estado. Têm a responsabilidade de orientar/definir as políticas, acompanhar sua implementação e fiscalizar a qualidade dos serviços, seja do ensino, da saúde, dos programas de emprego e renda, da assistência social etc. São, portanto, os conselhos municipais que deveriam consubstanciar a efetividade dos processos de participação na gestão pública, na busca de uma democracia cidadã real (ALLEBRANDT, 2002, p. 73- 74).

O Codemi foi fundado em 10 de março de 1992 por meio da Lei Municipal $\mathrm{n}^{\mathrm{o}}$ 2.743, mas somente dois anos mais tarde com o Decreto Executivo n ${ }^{\circ} 1.798$, de 04 de abril de 1994, foi aprovado o primeiro regimento interno deste conselho. É classificado como pessoa jurídica de direito privado, organizado sob a forma de associação civil, sem fins lucrativos, sua área de abrangência não ultrapassa os limites geográficos do município de Ijuí. Cada Comude atua de forma a respeitar os limites da jurisdição de seu município de origem, ou seja, somente atuam dentro do respectivo município ao qual foram criados. Além do mais, contam 
com a representação e participação da sociedade civil e das diferentes instâncias dos poderes públicos locais.

A Lei Municipal no 5.438 de 2014, em seu artigo 1, apresenta-o como “órgão deliberativo de assessoramento e cooperação [...], vinculado à Secretaria Municipal de Planejamento e Regulação Urbana”. No artigo 3, estão descritos os princípios que norteiam a sua ação:

I. Promoção do desenvolvimento local;

II. Autonomia, isenção e neutralidade em relação às diferentes instâncias governamentais, à correntes político-partidárias e à organizações;

III. Reconhecimento da individualidade do ser humano e de sua condição indeclinável de sujeito da história;

IV. Respeito à pluralidade de concepções, buscando sempre construir consensos em torno de temas de interesse para o desenvolvimento do município;

V. Democracia representativa e participativa;

VI. Visão do município como unidade integral e integrada, considerado como parte da região do estado e do país onde se localiza;

VII. Cooperação, parceria e respeito à autonomia de todas as instituições representadas no Conselho;

VII. Esforço permanente no sentido de aumentar a sua representatividade e a sua organização;

IX. Apoio à continuidade das políticas públicas de interesse para o desenvolvimento do município.

A partir dos princípios estabelecidos no Regimento Interno, sob tutela da Lei Municipal $n^{\circ}$ 5.438, o Codemi, no artigo 4, apresenta seis objetivos-chave:

I. Promover o desenvolvimento local harmônico e sustentável, visando à melhoria da qualidade de vida, à distribuição equitativa da riqueza produzida, à permanência das pessoas em seu município e à preservação e recuperação ambiental;

II. Viabilizar a participação plural dos cidadãos e das organizações da sociedade local na elaboração e gestão do plano municipal de desenvolvimento, constituindo-se em espaço de construção da cidadania interativa;

III. Promover a articulação entre as entidades e os demais Conselhos Municipais Setoriais e Temáticos e propor ações ao Poder Público Municipal, Estadual e Federal, visando o desenvolvimento econômico e social harmônico e integrado;

IV. Elaborar e priorizar projetos a serem propostos pela comunidade local junto ao Conselho Regional de Desenvolvimento e as demais instâncias de discussão e deliberação popular e participativa;

V. Fortalecer a cultura e a vivência da participação democrática na gestão da comunidade local;

VI. Promover a disseminação de informações relevantes para o desenvolvimento local e regional, qualificando a participação. 
Em relação a estrutura e composição do Codemi, o mesmo é formado por um Fórum Municipal de Desenvolvimento de Ijuí; Assembleia do Codemi; Conselho de Representantes do Codemi; Comissões Permanentes; Comissões Temáticas Especiais; e pelo Núcleo de Coordenação do Codemi.

Neste artigo explanar-se-á apenas brevemente as duas primeiras instâncias da estrutura e composição do Codemi, o Fórum Municipal de Desenvolvimento e a Assembleia do Codemi, pois entende-se que essas duas composições são as mais importantes deste conselho.

O Fórum Municipal de Desenvolvimento, “constitui-se no espaço público mais amplo para a discussão comunitária da problemática e potencialidades do desenvolvimento local e regional, com vistas à definição das diretrizes estratégicas para orientar o Plano Estratégico Participativo de Ijuí”. Cabe destacar ainda que ele é composto por "todas as entidades que integram a Assembleia do Codemi, outras entidades não credenciadas para a Assembleia e os cidadãos interessados na discussão do desenvolvimento" (REGIMENTO INTERNO, Capítulo III, Seção I, Art. $7^{\circ}$ e $8^{\circ}$ ).

A Assembleia Geral Municipal, de acordo com o Art. no 9 do Regimento Interno, é o órgão máximo de deliberação do Codemi. Ela é constituída por todos os cidadãos que comprovem através de título eleitoral e/ou cédula de identidade domicílio no município. Compete a ela: eleger os membros não natos do Conselho de Representantes do Codemi, apreciar e deliberar sobre o Plano Estratégico Participativo de Desenvolvimento de Ijuí, apreciar e aprovar o Regimento Interno do Codemi e discutir e deliberar sobre assuntos demandados pelo Codemi (REGIMENTO INTERNO, Capítulo III, Seção II, Art. 9º).

\section{DESCRIÇÃO DAS PROPOSTAS ELEITAS PELO CODEMI E COREDE-NORC NA CP 2016-2017}

Realizou-se em 02 de junho de 2016, no município de Ijuí, a Assembleia Pública Municipal para votação das prioridades municipais relativas à CP 2016/2017, a partir dos objetivos estabelecidos no Regimento Interno do Codemi, que tratam sobretudo de promover a articulação entre as entidades e os demais Conselhos Municipais Setoriais e Temáticos e propor ações ao Poder Público Municipal, Estadual e Federal, visando o desenvolvimento econômico e social harmônico e integrado, bem como de elaborar e priorizar projetos a serem propostos pela comunidade local junto ao Corede e as demais instâncias de discussão e deliberação popular e participativa. 
De acordo com a distribuição dos recursos da CP 2016 para o orçamento 2017, o governo do RS deliberou o montante de $\mathrm{R} \$ 50.000 .000,00$ a serem distribuídos entre os 28 Coredes. Inicialmente, foi pré-fixado igualitariamente o valor de $\mathrm{R} \$ 1.000 .000,00$ para cada um dos 28 conselhos regionais. De modo que este valor contemplasse as 8 áreas temáticas definidas no caderno de diretrizes da CP 2016-2017, que foi elaborado pela Secretária do Planejamento, Mobilidade e Desenvolvimento Regional do Estado do RS (Seplan/RS). Após esse rateio, foi acrescido ao montante pré-fixado um percentual por região considerando o Índice de Desenvolvimento Humano (IDESE) e a população total de cada região.

Desta forma, cada região deliberou sobre um valor distinto. Destaca-se que o menor valor deliberado foi para o Corede Rio da Várzea (R\$1.207.049,99). Enquanto que o maior valor foi para o Corede Metropolitano do Delta do Jacuí ( $\mathrm{R} \$ 4.838 .551,56)$. Já para o Corede-Norc, região na qual o Codemi está inserido, foram destinados $\mathrm{R} \$ 1.264 .227,12$. Como integram a região do Corede-Norc 11 municípios, este valor total será aplicado de modo a contemplar todos os municípios integrantes da região.

É oportuno citar as áreas temáticas definidas para o processo da CP 20162017. As 8 áreas são: 1) Agricultura, Pecuária e Irrigação; 2) Desenvolvimento Rural; 3) Turismo, Esporte e Lazer; 4) Cultura; 5) Desenvolvimento Econômico, Ciência e Tecnologia; 6) Minas e Energia; 7) Educação; e 8) Saúde.

A partir das oito áreas temáticas, no caso do Codemi, a população definiu 4 projetos prioritários que foram encaminhados a etapa regional da CP. Os projetos apresentados pela comunidade em Assembleia Pública Municipal, foram apresentados pelos solicitantes justificando os motivos pelos quais deveriam ser definidos como prioritários, para, assim, compor a cédula final de votação regional. Caso nesta etapa o projeto fosse um dos mais votados, estaria apto a receber o recurso público. Os projetos demandados pela população na fase de defesa na Assembleia Pública Municipal que tivessem proximidades um com o outro, foram agrupados de modo a torná-los uma só demanda. Ressalta-se que as propostas deveriam estar em consonância com os itens do caderno de diretrizes, do contrário, haveria a supressão das mesmas.

De acordo com a Ata de Assembleia Pública Municipal, as propostas eleitas como prioridade municipal para compor a cédula de votação da Consulta Popular 2016/2017 foram:

I. Agricultura, Pecuária e Irrigação (SEAPI) - Apoio à cadeia produtiva do leite. Distribuição de insumos.

II. Desenvolvimento Rural (SDR) - Apoio a Agroindústria Familiar. Aquisição de equipamentos. 
III. Desenvolvimento Econômico, Ciência e Tecnologia (SDECT) Redes de Cooperação. Apoio a micro, pequenas e médias empresas em toda a região noroeste colonial;

IV. Saúde (SES) - Qualificação e financiamento da rede de atenção. Aquisição de equipamentos para hospitais de referência regional - acima de 70 leitos.

Um ponto a se destacar quanto as áreas temáticas, diz respeito ao fato da área da segurança pública, historicamente contemplada na CP, não estar presente enquanto temática na CP. Percebe-se que as prioridades eleitas pelos cidadãos ijuienses no âmbito do Codemi não dialogam com a perspectiva do desenvolvimento regional, subentendido como sendo a união de esforços conjuntos, mormente articulados entre regiões com identidades em comum, que tem por finalidade

potencializar sua capacidade de auto-organização, transformando uma sociedade inanimada, segmentada por interesses setoriais, pouco perceptiva de sua identidade territorial e definitivamente passiva, em outra, organizada, coesa, consciente de sua identidade, capaz de mobilizar-se em torno de projetos políticos comuns, ou seja, capaz de transformar-se em sujeito de seu próprio desenvolvimento (ETGES, 2001, p. 10).

Isto é, ações de desenvolvimento regional visam as particularidades, as diversificações de cada região. Neste sentido, as demandas eleitas como prioridade pelo Codemi, não proporcionam a integração dos municípios sob o ponto de vista da unificação da região em prol da potencialização de suas identidades regionais, a fim de fortalecê-los frente a homogeneização do capital. Todavia, os itens III e IV, que tratam de fornecer incentivos/apoio a micro, pequenas e médias empresas em toda a região noroeste colonial, bem como a aquisição de equipamentos para hospitais de referência regional - acima de 70 leitos são tratados no processo da consulta e, consequentemente, são votados pelos munícipes de Ijuí, como sendo áreas de abrangência regional. Como aborda Santos (1997), o fortalecimento das regiões perpassa a adoção de um conjunto de estratégias de valoração das particularidades, das especificidades, do endógeno a partir de uma perspectiva horizontal bottom-up, que engloba as questões sociais, culturais, ambientais, históricas.

Para Santos (1997), a particularidade se dá no lugar/local, é no local que o homem descobre que não está isolado e o lugar torna-se o mundo do veraz e da esperança. Embora na literatura acadêmica haja um espectro de teorias que abordam as diferenças entre desenvolvimento local e regional e sua importância, compreende-se que a terminologia do regional dos itens III e IV, são utilizadas 
meramente para afirmar que uma ação não se restringe a apenas um município, mas a um conjunto deles. Diferentemente da visão de Etges sobre o significado de pensar o regional. Portanto, não foi possível identificar nenhuma prioridade com esse viés.

$\mathrm{Na}$ instância regional, todas as 4 prioridades eleitas pelo Codemi, foram contempladas na Consulta Popular 201611. Respectivamente, o item I - o apoio à cadeia produtiva do leite (distribuição de insumos) - recebeu um valor total de $\mathrm{R} \$ 41.245,00$. O item II - apoio a agroindústria familiar (aquisição de equipamentos) - recebeu o montante de $\mathrm{R} \$ 36.660,00$. Já o item III - apoio à micro, pequenas e médias empresas em toda a região noroeste colonial (atuação com foco nos microempreendedores individuais) - recebeu o valor de R $\$$ 54.361,77. Com relação ao item IV - apoio a qualificação e financiamento da rede de atenção (aquisição de equipamentos para hospitais de referência regional - acima de 70 leitos), foi contemplado com $\mathrm{R} \$ 450.000,00$.

A partir da descrição do resultado final das votações da CP a nível regional ${ }^{12}$, pode-se dizer que as propostas eleitas não estão alinhas com a construção de uma agenda de propostas que contemple a perspectiva do desenvolvimento regional, embora sejam propostas tidas como importantes para a região.

No Quadro 1, constam as demandas aprovadas no Corede-Norc por município e o respectivo valor empenhado.

Quadro 1 - Demandas eleitas por município

\begin{tabular}{|c|c|c|c|c|}
\hline \multicolumn{5}{|c|}{ COREDE NOROESTE COLONIAL } \\
\hline Valor total & \multicolumn{4}{|c|}{$\mathrm{R} \$ 1.264 .227,12$} \\
\hline Classificação & 1 & 2 & 3 & 4 \\
\hline $\begin{array}{l}\text { Programas } \\
\text { eleitos }\end{array}$ & $\begin{array}{l}\text { SAÚDE - Qua- } \\
\text { lificação e fi- } \\
\text { nanciamento da } \\
\text { rede de atenção } \\
\text { - Consolidando } \\
\text { a regionalização } \\
\text { da saúde. }\end{array}$ & $\begin{array}{l}\text { DESENVOL- } \\
\text { VIMENTO } \\
\text { RURAL - Apoio } \\
\text { à agroindústria } \\
\text { familiar. }\end{array}$ & $\begin{array}{l}\text { AGRI- } \\
\text { CULTURA } \\
\text { - Apoio à ca- } \\
\text { deia produtiva } \\
\text { do leite e da } \\
\text { pecuária de } \\
\text { corte. }\end{array}$ & $\begin{array}{l}\text { CIÊNCIA E } \\
\text { TECNOLO- } \\
\text { GIA - Redes } \\
\text { de Coopera- } \\
\text { ção. }\end{array}$ \\
\hline$\%$ de divisão & $43,50 \%$ & $26,10 \%$ & $26,10 \%$ & $4,30 \%$ \\
\hline $\begin{array}{l}\text { Valor desti- } \\
\text { nado }\end{array}$ & $\mathrm{R} \$ 549.938,80$ & $\mathrm{R} \$ 329.963,28$ & $\mathrm{R} \$ 329.963,28$ & $\mathrm{R} \$ 54.361,77$ \\
\hline $\mathrm{N}^{\mathrm{o}}$ de Votos & 5422 & 3184 & 2727 & 507 \\
\hline
\end{tabular}

11 Resultado final das demandas da Consulta Popular 2016 para Ijuí. Disponível em: < http:/ /www. consultapopular.rs.gov.br/wp-content/uploads/2015/07/NOROESTE-COLONIAL-2. pdf $>$. Acesso em: 02 maio 2017.

12 Resultado final das demandas da Consulta Popular 2016 no âmbito do Corede-Norc. Disponível em: <http://www.consultapopular.rs.gov.br/wp-content/uploads/2015/07/NOROESTECOLONIAL-2.pdf>. Acesso em: 28 abr. 2017. 


\begin{tabular}{|l|r|r|r|r|}
\hline MUNICÍPIOS & & & & \\
\hline Ajuricaba* & 68 & $* 484$ & 31 & 5 \\
\hline $\begin{array}{l}\text { Augusto Pes- } \\
\text { tana* }\end{array}$ & $* 193$ & $* 367$ & $* 476$ & 7 \\
\hline Bozano* & 61 & $* 131$ & $* 199$ & $* 8$ \\
\hline Catuípe* & 106 & $* 331$ & $* 442$ & 6 \\
\hline Condor* & 50 & $* 590$ & $* 574$ & 6 \\
\hline Coronel Barros* & 211 & 26 & $* 112$ & $* 45$ \\
\hline Ijui* & 2918 & $* 551$ & $* 289$ & $* 379$ \\
\hline Joia* & 47 & $* 248$ & 15 & $* 12$ \\
\hline Nova Ramada* & $* 1657$ & $* 75$ & $* 146$ & 1 \\
\hline Panambi* & 17 & $* 380$ & 38 & $* 38$ \\
\hline Pejuçara* & & 1 & $* 405$ & 0 \\
\hline
\end{tabular}

Fonte: Consulta Popular 2016, adaptado pelo autor.

Destaca-se, que o valor empenhado para a área temática da Saúde - qualificação e financiamento da rede de atenção - representa 43,50\% ( $\mathrm{R} \$ 549.938,80)$ do total de $\mathrm{R} \$ 1.264 .227,12$ destinado ao processo da CP. Dos 11 municípios, apenas 6 foram classificados.

Em relação à área do desenvolvimento rural, cujo foco foi para o apoio à agroindústria familiar, em especifico à construção e reforma de agroindústrias, aquisição de equipamentos, totalizou R \$329.963,28 (26,10\%). Dos 11 municípios, 9 foram classificados. $\mathrm{Na}$ área temática da agricultura, com ênfase ao apoio à cadeia produtiva do leite e da pecuária de corte, o valor empenhado e o percentual em relação ao total destinado para o Corede-Norc foram o mesmo da área do desenvolvimento rural, isto é, $\mathrm{R} \$ 329.963,28$ (26,10\%). As prioridades foram para a compra de equipamentos e distribuição de insumos, sendo que dos 11 municípios, apenas 8 foram contemplados.

No que tange à área da ciência e tecnologia, com ênfase nas redes de cooperação, o total empenhado foi de $\mathrm{R} \$ 54.361,77$ (4,30\%). Este valor será destinado a 5 municípios.

Desta forma, pode-se dizer que os projetos deliberados no Codemi estão em conformidade com os objetivos estabelecidos no seu Regimento Interno, especialmente o primeiro que aborda a promoção do desenvolvimento local. Ou seja, entende-se que as demandas eleitas como prioridades, bem como aquelas que se efetivaram por meio da votação regional da CP, estão alinhados com o diagnóstico e com a análise situacional da região, em termos de problemas e alternativas a serem priorizadas.

Ressalta-se, no entanto, que existem desafios a serem superados para que, de fato, as demandas eleitas pelos munícipes correspondam a perspectiva do 
desenvolvimento regional. Entre elas, destacam-se o baixo valor destinado para os projetos, uma vez que o recurso é pulverizado entre todos os municípios que compõe a região. Outro fator a considerar é a demora para o repasse das verbas do governo para o processo, bem como quando as verbas não são repassadas. Fato este que pode gerar desestímulo à participação.

\section{CONSIDERAÇÕES FINAIS}

Constata-se que o Codemi possui uma importante relevância para o desenvolvimento do município de Ijuí. Integrado e articulado com os demais conselhos municipais, amplia o poder dos mesmos no processo de interação com o Poder Público Local. É por meio dele que a população pode participar da definição das prioridades e dos investimentos do recurso público junto ao governo estadual do RS.

Embora o Codemi se caracterize como um instrumento de governança territorial, com potencialidades democráticas participacionista deliberativas, ainda é preciso que os projetos eleitos como prioridade contemplem a perspectiva do desenvolvimento regional, de modo a se pensar as particularidades da região.

Constata-se, que o valor disponível deliberado no conselho municipal de Ijuí não possibilita que todas as demandas da sociedade sejam atendidas. Acredita-se que o baixo valor disponível aplicado à deliberação seja um dos maiores empecilhos deste conselho, o que acaba, por conseguinte, aumentando a descrença e a desmotivação dos participantes junto a este processo de participação. Essa desmotivação e descrença no processo ocorrem, possivelmente, por duas razões: os atrasos no repasse, ou o não pagamento; e também o fato de suas prioridades não serem eleitas.

Ressalta-se, ainda, que as demandas eleitas pelo Codemi não promovem o desenvolvimento regional, o que evidencia o desafio de se pensar em uma agenda nessa perspectiva. Espera-se que a participação da sociedade civil nestas instâncias de participação e deliberação, possa contribuir para a promoção do desenvolvimento regional. Assim, o Estado deve priorizar as instâncias deliberativas de participação, ser uma gestão pública descentralizada, aonde os sujeitos não sejam meros agentes receptores das decisões políticas, mas sujeitos protagonistas das mudanças sociais, que participam ativamente de todas as etapas do processo de participação, como na elaboração, no planejamento e na avaliação das políticas públicas. 


\section{REFERÊNCIAS}

ALLEBRANDT, Sérgio Luís. A participação da sociedade na gestão pública local e na produção das políticas: a atuação dos conselhos municipais de IjuíRS, de 1989 a 2000. Ijuí: Ed. Unijuí, 2002. 264p. (Coleção Trabalhos AcadêmicoCientíficos. Série Dissertações de Mestrado, 32)

AVRITZER, Leonardo. Participatory institutions in democratic Brazil. Baltimore: John Hopkins University Press, 2009.

BRASIL. Constituição da República Federativa do Brasil. Brasília, 1988. Disponível em: <http://www.planalto.gov.br/ccivil_03/constituicao/constituicao. htm>. Acesso em: 29 abr. 2017.

Constituição do Estado do Rio Grande do Sul. Porto Alegre, 1989.

BONAVIDES, Paulo. Teoria da Democracia Participativa: Por um Direito Constitucional de luta e resistência. Por uma Nova Hermenêutica. Por uma repolitização da legitimidade. 3 ed. São Paulo: Malheiros Editores, 2008.

CADERNO DE DIRETRIZES - CONSULTA POPULAR 2016-2017. Disponível em: <http://www.sdr.rs.gov.br/upload/20170126101042caderno_de_diretrizes_ versao_completa2.pdf>. Acesso em: 01 fev. 2017.

COMPOSIÇÃO DO CODEMI. Disponível em: < https://leismunicipais.com.br/ a1/rs/i/ijui/decreto/2014/543/5438/decreto-n-5438-2014-aprova-o-regimentointerno-do-conselho-de-desenvolvimento-do-municipio-de-ijui-codemi-revogadecreto-que-menciona-e-da-outras-providencias>. Acesso em: 26 abr. 2017.

CÓRDOBA, Manuel B. F. de. El interés general en la filosofía política. Un concepto ético y normativo necesario para la planificación territorial. Boletín de la Asociación de Geógrafos Españoles, n. 53, 2010. Disponível em: < http://www.boletinage. com/articulos/53/06-Benavent\%20121-146.pdf>. Acesso em: 12 abr. 2017.

DALLABRIDA, Valdir R. Descentralização político-administrativa no Brasil: possibilidades de avanços rumo a uma prática de democracia deliberativa. In: SEMINÁRIO DE DESENVOLVIMENTO REGIONAL, ESTADO E SOCIEDADE, 1. Rio de Janeiro, 2012. Anais... Rio de Janeiro: ANPUR, 2012. Disponível em: <http://www.anpur.org.br/revista/rbeur/index.php/sedres/ article/view/3917/3828>. Acesso em: 22 mar. 2017.

DECRETO 35.764 que regulamenta a Lei no 10.283, de 17 de outubro de 1994, que criou os Coredes. Disponível em: <http:/ /www.al.rs.gov.br/Legis/M010/M0100099. 
ASP?Hid_Tipo=TEXTO\&Hid_TodasNormas $=12439 \&$ hTexto $=\& H i d$ IDNorma=12439>. Acesso em: 14 abr. 2017.

DECRETO 1.798, de 04 de Abril de 1994. Aprovação do regimento interno. Disponível em: <http://camara-municipal-de-ijui.jusbrasil.com.br/ legislacao/920464/decreto-1798-94>. Acesso em: 30 abr. 2017.

ETGES, Virginia Elisabeta. A região no contexto da globalização: o caso do Vale do Rio Pardo. In: VOGT, Olgário; SILVEIRA, Rogério. Vale do Rio Pardo: (re) conhecendo a região. Santa Cruz do Sul: Edunisc. 2001.

FERRÃO, João. Governança e Ordenamento do Território. Reflexões para uma Governança Territorial Eficiente, Justa e Democrática. Prospectiva e Planeamento, v. 17, p. 129-139, 2010. Disponível em: <https://economiadoterritorio.files. wordpress.com/2014/11/governanca-e-ordenamento-do-territc3b3rio.pdf $>$. Acesso em: 31 jun. 2017.

HABERMAS, Jürgen. Teoria de la acción comunicativa. Madrid: Taurus, 1987. v. 1

IBGE. Censo Demográfico. Brasília: Gov. Federal, 2010. Disponível em: Disponível em: $\quad<$ http://www.censo2010.ibge.gov.br/sinopse/index.php?uf=43\&dados $=1>$. Acesso em: 06 maio 2017.

LEI n 10.283 , de 17 de outubro de 1994. Dispõe sobre a criação, estruturação e funcionamento dos Conselhos Regionais de Desenvolvimento. Disponível em: <http://www.al.rs.gov.br/Legis/M010/M0100099.ASP?Hid_ Tipo $=$ TEXTO\&Hid_TodasNormas $=12666 \&$ hTexto $=\& H i d \_I D N o r m a=12666>$. Acesso em: 01 fev. 2017.

LEI no 11.179, de 25 de junho de 1998. Dispõe sobre a consulta direta à população. Disponível em: <http://www.al.rs.gov.br/FileRepository/repLegisComp/Lei\%20 n\%C2\%BA\%2011.179.pdf>. Acesso em: 10 abr. 2017.

LEI $\mathrm{n}^{\circ}$ 2.743, de março de 1992. Da criação do CODEMI. Disponível em: <https://leismunicipais.com.br/a1/rs/i/ijui/lei-ordinaria/1992/275/2743/leiordinaria-n-2743-1992-cria-o-conselho-de-desenvolvimento-do-municipio-de-ijui-eda-outras-providencias?q=2743>. Acesso em: 30 abr. 2017.

LEI no 5.438, de 12 de dezembro de 2013. Prevê a atualização do regimento interno do Codemi. Disponível em: < https://leismunicipais.com.br/a1/rs/i/ijui/ decreto/2014/543/5438/decreto-n-5438-2014-aprova-o-regimento-interno-doconselho-de-desenvolvimento-do-municipio-de-ijui-codemi-revoga-decreto-que- 
menciona-e-da-outras-providencias >. Acesso em: 30 abr. 2017.

MARQUETTTI, Adalmir. Participação e redistribuição: o Orçamento Participativo em Porto Alegre. In: AVRITZER, Leonardo; NAVARRO, Zander (Org.). A inovação democrática no Brasil. São Paulo: Cortez, 2003. p. 129-156.

PIRES, Roberto; LOPEZ, Félix. Instituições participativas e políticas públicas no Brasil: características e evolução nas últimas duas décadas. In: Brasil em desenvolvimento 2010: Estado, planejamento e políticas públicas. Brasília: IPEA, 2010. p. 565-585. Disponível em: < http://www.ipea.gov.br/participacao/images/ instituies $\% 20$ participativas $\% 20$ nas $\% 20$ ultimas $\% 20$ dcadas.pdf $>$. Acesso em: 23 abr. 2017.

PLANO DIRETOR DE IJUÍ. Disponível em: <http://www.ijui.rs.gov.br/ paginapref/plano_diretor>. Acesso em: 10 maio 2017.

RAWLS, John. The law of people: with, the idea of public reason revisited. Harvard University Press. Cambridge, 2001.

ROUSSEAU, Jean J. Do contrato social; Ensaio sobre a origem das línguas; Discurso sobre a origem e os fundamentos da desigualdade entre os homens; Discurso sobre as ciências e as artes. 3. ed. São Paulo: Abril Cultural, 1983.

SÁNCHEZ, Félix. Orçamento participativo: teoria e prática. São Paulo: Cortez, 2002.

SANTOS, Milton. Técnica, espaço, tempo: globalização e meio técnico-científico informacional. 3. ed. São Paulo: Hucitec, 1997.

SILVEIRA, Rogério L. da Silva; ALLEBRADNT, Sérgio L.; CAMPOS, Heleniza À. O Planejamento e o Desenvolvimento Regional no Rio Grande do Sul: Políticas Estaduais, Processos e Experiências Regionais. In: FELIPPI, Ângela C. T.; SILVEIRA, Rogério L. da Silva; ALLEBRANDT, Sérgio L. (Org.). Observando o planejamento regional no Rio Grande do Sul: uma análise da experiência recente dos Conselhos Regionais de Desenvolvimento (COREDEs). Santa Cruz do Sul: EDUNISC, 2015. p. 49-75. Disponível em: < http://www.unisc.br/portal/upload/ com_editora_livro/ebook_coredes_final.pdf>. Acesso em: 24 abr. 2017.

VITALE, Denise. Democracia direta e poder local: a experiência brasileira do Orçamento Participativo. In: COELHO, Vera S. P.; NOBRE, Marcos (Org.). Participação e deliberação. São Paulo: Ed 34, 2004. p. 239-254. 


\section{RESENHA}

SANTOS, José Vicente Tavares dos. Violências e conflitualidades. Porto Alegre: Tomo Editorial, 2009.

Maria Goreti Góes da Rocha - Doutoranda do Programa de Pós-Graduação em Sociologia e Antropologia (PPGSA), do Instituto de Filosofia e Ciências Humanas (IFCH), da Universidade Federal do Pará (UFPA).

O livro "Violências e conflitualidades" foi prefaciado pelo professor Cesar Barreira da Universidade Federal do Ceará (UFC), que o considera fruto de uma trajetória e ao mesmo tempo reconstitui um debate político/acadêmico sobre a temática da violência e dos conflitos nas sociedades contemporâneas. A obra baseia-se na constituição de uma Sociologia da Conflitualidade que explica os processos sociais conflitivos e contraditórios, tendo como cenário analítico as práticas sociais, classificadas como violentas, e o processo de controle social.

O livro está dividido em Introdução, seguida de 09 capítulos, com a Conclusão e as Referências. Na Introdução o autor fala sobre a construção da Sociologia da Conflitualidade afirmando que o início do século XXI pode ser denominado de processo de mundialização da sociedade, que significa um processo de constituição de formas sociais marcadas pelos efeitos excludentes das políticas neoliberais, desencadeando novos conflitos sociais e, por vezes, estabelecendo novos limites à atuação do Estado. A globalização promove para parte da população mundial desigualdade de oportunidades de vida, com acesso desigual a recursos e que se resume a oito dimensões dos aspectos da vida humana: saúde, habitação, trabalho, educação, relações de sociabilidade, segurança, informação e conhecimento, e participação política. Reconhece-se em cada uma dessas dimensões a configuração de novas questões sociais mundiais.

Que a construção de uma abordagem sociológica sobre conflitualidade parte de dois problemas sociais, o crime e a violência. A questão das conflitualidades - das formas de violência, das metamorfoses do crime, da crise das instituições de controle social e dos conflitos sociais - configura-se pela emergência de novas modalidades de ação coletiva, com lutas sociais protagonizadas por outros agentes sociais e diferentes pautas de reivindicações. 
No Capítulo 01 sob o título "As novas questões sociais mundiais e a violência" observa-se que houve profunda mutação na sociedade contemporânea, nos últimos trinta anos, a qual pode ser definida como processo de formação da sociedade mundializada, a era do globalismo. Novos dilemas e problemas sociais emergem no horizonte planetário, configurando novas questões sociais mundiais. Dentre as novas questões sociais, os fenômenos da violência adquirem contornos, passando a disseminar-se por toda a sociedade. Ao que chama de processo de dilaceramento da cidadania que se configura pela disseminação das várias formas de violência por toda a sociedade contemporânea: violência política, costumeira, de gênero, sexual, racista, ecológica, simbólica e violência na escola. Por conta disso, a violência como nova questão social mundial está provocando mudanças no Estado, que segundo o autor estamos diante de formas contemporâneas de controle social, com as características de um estado repressivo acompanhando a crise do Estado-providência. Por outro lado, defende que seria possível pensar a construção de uma cidadania transnacional ou mundial, marcada pela criação institucional e pela difusão e comunicação de práticas sociais, jurídicas e simbólicas inovadoras, invocando a reinvenção das formas de solidariedade e a redefinição do trabalho; enfim, a prevenção e erradicação das formas de violência social. A construção da cidadania transnacional supõe um conjunto complexo de preocupações com: necessidades da vida (por exemplo, geração de oportunidades de trabalho e renda); necessidades da sociedade do conhecimento (por exemplo, universalização da educação fundamental e média); necessidades sociais (por exemplo, superar a fragmentação social e o individualismo exacerbado) e necessidades simbólicas (por exemplo, desenvolver a construção de valores solidários orientadores da ação social).

No Capítulo 02 intitulado "Microfísica da violência", o autor trabalha com o conceito de microfísica do poder de Michel Foucault, para a compreensão da fenomenologia da violência, ou seja, criando o conceito de microfísica da violência. A prática da violência vai inserir-se em uma rede de dominações, de vários tipos - classe, gênero, etnia, por categoria social e violência simbólica que resultam na fabricação de uma teia de discriminações, estigmas e exclusões, possivelmente sobrepostas.

Faz uma distinção entre conflito, poder e violência. O conflito social consiste em um processo entre classes, categorias, frações de classe e grupos sociais que implica a possibilidade de negociação entre as partes, mesmo em intensa interação. $\mathrm{O}$ poder também supõe alguma possibilidade de negociação de um consenso, para se estabelecer com legitimidade e de modo hegemônico. Mas a violência - esta relação de alteridade que tem como característica o uso da 
força, o recurso à coerção, e que atinge, com dano, o outro - é uma relação social inegociável, posto que atinge, no limite, as condições de sobrevivência, materiais e simbólicas, daquele percebido como outro, anormal ou desigual, pelo agente da violência. A violência é antecedida, ou justificada, prévia ou posteriormente, por uma violência simbólica, que se exerce mediante modos de subjetivação dos agentes sociais envolvidos na relação.

No Capítulo 03 "A violência na escola e a juventude", o autor fala que a violência que ocorre no espaço escolar é reconhecida como uma nova questão social mundial. Fenômeno social caracterizado como um enclausuramento do gesto e da palavra. São manifestações de violência contra a pessoa, roubos, furtos e depredações, até mesmo assassinatos, que se repetem em um conjunto expressivo de sociedades. Assim, evidencia-se que estamos em face de uma conflitualidade que coloca em risco a função da escola na socialização das novas gerações. No que diz respeito às lutas sociais contra a violência escolar, cita o exemplo da cidade de Porto Alegre, onde as mobilizações sociais contra a violência vêm crescendo mediante grupos de reflexão-ação, campanhas internas em sala de aula, passeatas pelos bairros, petições às autoridades municipais e estaduais, declarações à imprensa e tentativas de construir redes de relações sociais com as coletividades locais. Essa ação coletiva contra a violência realiza uma pedagogia capaz de pensar a escola como espaço de construção de uma cidadania que contemple as aspirações dos jovens e dos adolescentes, bem como das coletividades envolvidas na instituição escolar.

No Capítulo 04 "A juventude fraturada: a agonia da vida no país do futuro" considera que no processo de mundialização de conflitualidade, muitas são as faces da juventude brasileira, sendo desiguais e diversas as situações de risco - naturais, tradicionais ou fabricadas - que vivencia cotidianamente. Os jovens são particularmente afetados pelo individualismo exacerbado, pelo narcisismo do culto da liberdade individual, cujo estímulo a um comportamento de vencedores e perdedores ameaça romper os laços de sociabilidade. Fala de diversos tipos ideais de juventude no Brasil atual, especificando a quais classes pertencem, com qual etnia ou cor se identificam, em quais grupos culturais se reconhecem: a juventude dourada, a juventude em instabilidade, a juventude trabalhadora, a juventude dos carentes, a juventude em vulnerabilidade e a juventude dos infratores.

O Capítulo 05 "A arma e a flor: formação da organização policial, consenso e violência" tem por objetivo a elaboração preliminar de uma abordagem sociológica acerca da organização policial, de sua formação na condição de aparelho de Estado de controle social formal e das estratégias de construção de um consenso acerca da função social da instituição policial nas sociedades modernas 
e contemporâneas, enfatizando o efeito da violência, legítima e ilegítima, sobre tal processo de institucionalização de uma legitimidade política. Para a consecução deste objetivo o autor primeiramente retraça as origens da organização policial desde o momento da formação do Estado-nação e de sua inserção no exercício da governamentalidade. Em seguida esclarece a constituição da organização policial como formadora de um ofício específico, marcado pela duplicidade: agente do exercício do monopólio da violência física legítima e, simultaneamente, agente de produção de consenso. Por fim, questiona a inserção da violência no cerne da organização policial, discutindo-se em que medida a violência produz um ofício no qual a norma social contém em si mesma a possibilidade, virtual ou real, do excesso de poder.

No Capítulo 06 "A polícia, uma nova questão social mundial”, o autor analisa que a questão policial tornou-se mundial, seja pela ineficácia e ineficiência frente ao crescimento dos fenômenos de violência difusa - violência política, violência social, violência de gênero, violência racial, violência simbólica, violência ecológica - seja pelos novos traços da criminalidade violenta. E o capítulo tem por objetivo a análise sociológica da crise mundial das policias, ao discutir as várias dimensões do problema: crise institucional, cultura organizacional, violência policial, legitimidade e alternativas para os dilemas do ofício de polícia. Destaca quatro tipos de polícia em disputa: o tipo-ideal autoritário, o tipo-ideal técnicoprofissional, o tipo-ideal de polícia comunitária e o tipo-ideal de polícia cidadã.

Ao tratar da questão policial no Brasil fala que uma das dificuldades se dá em como garantir o respeito aos direitos humanos em todos os momentos da atividade policial, tendo em vista denúncias de graves violações de direitos humanos por parte de membros das polícias civis e militares. A violência por eles exercida tem como origem uma cultura profissional marcada pela dominação masculina, pelo machismo. Que os problemas em jogo na questão policial brasileira são: relativos à organização das instituições policiais, relativos à educação e às carreiras policiais e a responsabilidade social das organizações. Na discussão sobre passagens a outra concepção de segurança, salienta a emergência de ações coletivas e de trabalhos institucionais como expressões de um movimento de passagem a outra concepção de policiamento na sociedade brasileira. No plano educacional, a colaboração entre universidades e escolas de polícia, indicando um movimento de transformação de currículos, de conteúdos e de concepção de ofício de policial.

No Capítulo 07 "Marchas, regressos e contrapassos na educação policial” observa que no início do século XXI, em relação à questão da segurança pública, a crise do Estado-nação, em virtude do processo de formação da sociedade global, 
e as vicissitudes do Estado de bem-estar social, face às políticas neoliberais, ambas as dimensões trouxeram dificuldades crescentes para o exercício do ofício de policial.

Que apesar de um novo período de transformações ter sido aberto na sociedade brasileira desde a Constituição de 1988, foi pouco discutida a questão da reforma das policiais e das mudanças na educação policial, havendo um déficit na agenda política e educacional no Brasil, de todas as instituições que não levaram em conta a necessidade de refletirmos sobre a formação das polícias. Diante deste quadro, o autor destaca as experiências de integração institucional das academias de polícia militar e das escolas da polícia civil, de alguns estados brasileiros.

No Capítulo 08 "As lutas sociais contra violências" analisa as lutas sociais contra a violência na sociedade brasileira contemporânea, na perspectiva de compreender os conflitos sociais como criadores de outras sociabilidades. $\mathrm{Na}$ sociedade brasileira, a emergência de lutas sociais contra a violência representa linhas de fratura no dispositivo da violência. Para compreender tais lutas, cumpre reconstituir a fenomenologia da violência no Brasil, classificando-a em quatro grandes grupos: a violência do Estado; a violência contra o poder do Estado; a violência difusa; a violência simbólica.

No Capítulo 09 "Violências e dilemas do controle social" o objetivo é analisar os fenômenos da violência difusa na sociedade contemporânea e discutir os dilemas do controle social, informal e formal. Estuda as modificações na construção de objetos sociais, expressos como problemas sociais, construídos por atores, instituições e discursos. Questiona as possibilidades de um controle social que incorpore a participação social, que representaria a instituição da concepção de uma segurança cidadã em um cenário de crescente violência difusa e de grandes dificuldades encontradas pelas sociedades e Estados contemporâneos para enfrentá-la.

$\mathrm{Na}$ Conclusão o autor finaliza seu texto afirmando que desenvolveu uma interpretação sociológica dos fenômenos de violência, construindo a noção de microfísica da violência na era da mundialização das conflitualidades. A intenção foi a de analisar os fenômenos da violência difusa na sociedade contemporânea e discutir os dilemas do controle social, informal e formal, mediante alguns conceitos: conflitualidade, violência, conflitos sociais, lutas sociais contra a violência, tecnologias sociais de poder e controle social. Dentre as questões sociais analisadas pelo autor - a juventude e a violência; a violência na escola; a relação entre a polícia e a violência; a crise mundial das polícias; as ambivalências dos ensinos policiais; a planificação emancipatória; e os dilemas do controle 
social - na condição de objetos sociológicos da sociologia da conflitualidade. Os jovens são particularmente afetados pelo narcisismo do culto da liberdade individual, estímulo proveniente de uma cultura de vencedores e perdedores que rompe os laços de sociabilidade. O reconhecimento da violência no espaço escolar partiu de sua compreensão como enclausuramento do gesto e da palavra, configurada por manifestações de violência contra a pessoa, por roubos etc. que se repetem em vários países. É preciso entender as mensagens escondidas nos atos de violência, reconhecendo o conflito como parte da dinâmica social.

A polícia, como uma nova questão social mundial, retraça as origens da organização policial, desde a formação do Estado-nação, e o exercício da governamentalidade. A organização policial vai se caracterizar por um campo de forças sociais que se estrutura em três dimensões: o exercício da violência legítima, a construção do consenso e as práticas de excesso de poder, a violência ilegítima.

A obra é atual, pois promove uma leitura que possibilita o senso crítico, quanto à questão policial, por exemplo, que requer a superação desde a fragmentação das atividades operacionais entre os diversos órgãos que exercem o controle social formal, até a efetiva implantação de um currículo de formação policial pautado na cidadania e na dignidade do ser humano. Cito minha experiência como profissional da segurança pública, quanto à participação no curso de Atualização em Segurança Pública e Direitos Humanos, a Especialização em Políticas e Gestão em Segurança Pública ofertada pela RENAESP, e ainda o Mestrado em Defesa Social e Mediação de Conflitos-UFPA onde tive a oportunidade de interagir em sala de aula com profissionais de diversos segmentos da área, possibilitando a quebra de paradigmas e preconceitos, aproximando diversos profissionais com reflexos positivos no dia-a-dia de suas atividades policiais. E na esteira deste novo pensar em busca de uma polícia cidadã, em breve a UFPA irá ofertar o Doutorado em Segurança Pública.

O autor José Vicente Tavares dos Santos é sociólogo, graduado em Ciências Sociais pela Universidade Federal do Rio Grande do Sul (1971); Mestre em Sociologia pela Universidade de São Paulo (1977); Doutor em Sociologia pela Université de Paris X, Nanterre (1987); Professor titular do Departamento e do Programa de Pós-Graduação em Sociologia e em Políticas Públicas da Universidade Federal do Rio Grande do Sul. Autor de vários livros entre os quais: "Violências no tempo da globalização" (1999); "Democracia, violências e lutas sociais na América Latina" (2009) e "Violência e cidadania: práticas sociológicas e compromissos sociais" (2011). 


\section{RESENHA}

PRADO JÚNIOR, Caio. História e Desenvolvimento: a contribuição da historiografia para a teoria e prática do desenvolvimento brasileiro1. 2. ed. São Paulo: Ed. Brasiliense, 1978

Brenda T. Cardoso de Castro - Doutoranda no Programa de Pós-Graduação em Sociologia e Antropologia - PPGSA/UFPA. Mestre em Ciência Política (PPGCP/ UFPA).E-mail: brendatcc@gmail.com

O desenvolvimento é um tema que muito determinou os caminhos das discussões e temáticas da Sociologia Brasileira, entretanto, o debate não se esgotou nas profícuas décadas de 1960, 1970 e 1980. A releitura contemporânea das dinâmicas históricas, econômicas e políticas dos processos de colonização também convidam a retornar a pensamentos de clássicos brasileiros a partir de novos contextos. Neste âmbito, propõe-se aqui uma revisitação à obra de Caio Prado Júnior sobre desenvolvimento e história do Brasil, colocando em destaque, além das contribuições do historiador, o pensamento e a representação da Região Amazônica inserida na ideia de desenvolvimento. Conclui-se que apesar do pensamento de ruptura proposto por Caio Prado Júnior nos anos 1960, sua visão no que concerne à Amazônia de certo modo ainda reproduzia e reforçava a lógica desenvolvimentista e de modernização, não de modo a invalidar seus pensamentos, mas demonstrando a necessidade de reconhecer os marcadores regionais históricos e a própria produção do conhecimento como necessário para a construção de uma sociologia brasileira mais próxima às idiossincrasias do país.

A questão do desenvolvimento é um tema que perpassa as Ciências Sociais desde a sua origem no contexto da modernidade e as ideias de progresso, marcando profundamente as diretrizes da disciplina que se expandiria da Europa para o restante do mundo a partir do século XIX.

Entretanto, ainda que seja recorrente a discussão sobre desenvolvimento nas Ciências Sociais, a sua origem é profunda na Economia, o que influenciou

Est artigo é resultado das discussões da disciplina Sociologia Brasileira, ministrada no mês de novembro de 2017 pela Profa. Dra. Edila Moura e o Prof. Dr. Renan Pinto no Programa de Pós-Graduação em Sociologia e Antropologia da UFPA (PPGSA/UFPA). 
o fato de muitas vezes as abordagens resumirem-se a parâmetros e índices econômicos na sua análise. Assim, quando a partir dos anos 1950 começam a ganhar reverberação estudos e publicações sobre o desenvolvimento e o caso dos países latino-americanos, como na criação da Cepal pela ONU e a difusão de várias teorias como a Teoria do Desenvolvimento, a Teoria da Dependência e a Teoria da Autonomia, são feitas contribuições de ruptura do pensamento sobre desenvolvimento como fenômeno apenas econômico.

Neste âmbito, pode-se inserir a publicação de Caio Prado Júnior de 1968 intitulada "História e desenvolvimento", em que o pensador critica as abordagens estritamente economicistas e propõe uma reconsideração do aspecto histórico para a compreensão do desenvolvimento no Brasil.

O presente texto pretende discorrer sobre a premissa principal trazida por Caio Prado Júnior e o seu impacto na discussão sobre desenvolvimento e, em seguida, realiza-se uma ponderação mais profunda sobre a análise regionalizada com enfoque no caso da Amazônia a partir da leitura.

Por fim, apontam-se possíveis continuidades com base no trabalho de Prado Júnior, seguindo provocações de contestações do caso amazônico e pensamentos de autores complementares, como dos estudos pós-coloniais.

\section{HISTÓRIA, DESENVOLVIMENTO E AMAZÔNIA}

Caio Prado Júnior (1907-1990) ocupa lugar de referência no pensamento brasileiro e influencia para além da História, também as Ciências Sociais. Nascido no início do século XX na capital de São Paulo, parte do centro político e econômico do país em uma família aristocrata, Prado Júnior teve uma trajetória diferente de outros pensadores brasileiros, não seguindo um caminho tão tradicional enquanto professor acadêmico, mas tendo muito impacto e contribuição nos seus estudos e publicações, facilitadas pelo fato de ser um dos fundadores da Editora Brasiliense em 1943.

Em 1928, obteve o bacharelado em Direito e atuou principalmente como livre-docente na área de Economia Política, referência importante para o contexto das suas contribuições críticas na obra sobre o viés econômico dado ao desenvolvimento.

Reler a obra de Caio Prado Júnior cinquenta anos depois da sua publicação é um convite a reconhecer tanto as contribuições no momento em que o livro foi escrito e o lugar que o autor e a discussão sobre desenvolvimento viria a ocupar na Sociologia brasileira, como também reconsiderar pontos que na época pouco ressoaram diante do ponto principal de ruptura que era proposto. 
Assim, nesta seção será apresentado o primeiro ponto acima: as contribuições e o significado de ruptura da obra "História e desenvolvimento" no contexto em que se dá a sua publicação. Em seguida, discutir-se-á um dos pontos que se convida a reanalisar na obra do autor: a sua visão e representação da Amazônia.

\subsection{CONTRIBUIÇÕES E RUPTURAS EM "HISTÓRIA E DESENVOLVIMENTO"}

Analisar um pensamento após cinquenta anos tem seus riscos, sendo o principal o anacronismo. Para realizar uma releitura crítica é preciso cautela no esforço de reconhecer as contribuições e o significado do texto em sua época e as condições em questão, o que muitas vezes após décadas, com o pensamento nele contido já difundido pode parecer para quem o lê posteriormente algo óbvio ou até mesmo pequeno. Entretanto, o outro risco é de não exercer a reflexão crítica da obra justamente por suas limitações históricas, a ponto de relativizar totalmente qualquer produção dada em outro tempo.

Isto posto, "História e desenvolvimento" traz como grande argumento a crítica a abordagens mais tradicionais de desenvolvimento, quase que restritamente ligadas à economia, o que, para ele, são insuficientes se não consideram também a história do contexto analisado, no caso, do Brasil:

O meu objetivo central, no presente trabalho, foi reivindicar para ela [a história], particularmente no caso brasileiro, o que de direito lhe cabe como fonte informativa e explicativa do processo de desenvolvimento do nosso país, chamando a atenção para a especificação de nossa formação (PRADO JÚNIOR, 1978, p. 7).

E é partindo desta premissa que Prado Júnior traça a história da formação do Brasil - a partir da colonização, ou seja, da chegada dos portugueses/europeus -, destacando a "função" primária atribuída ao território em questão, diferente de outras formas de colonização como dos EUA, o Brasil já tem na sua origem uma inserção como fonte de matéria-prima para atender a uma demanda externa. O que significa dizer que já se inicia na dinâmica do comércio internacional, ao contrário de outros Estados, que passam pela formação de uma identidade nacional, ou seja, a consolidação de um contexto cultural e político.

No Brasil, o processo é difuso: todas as estruturas (políticas, econômicas etc.) são criadas e pensadas de e para a necessidade da metrópole:

Não é a colonização que empreendeu e desenvolveu o aproveitamento da exploração canavieira, e sim o contrário: é essa exploração que deu origem à colonização e ao Brasil. [...] Não é a economia do açúcar que 
se conforma e adapta às necessidades de uma sociedade preexistente que nela procura a base econômica de sua subsistência. E sim, é esta sociedade que se origina, dispõe e organiza em função da finalidade precípua de produzir açúcar, e assim realizar um negócio. Negócio que tem, não como objetivo (pois o objetivo próprio de todo negócio é tão-somente o lucro mercantil), mas como o objeto o atendimento de necessidades e de um consumo estranhos ao país e à coletividade nele instalada (ibid., p. 37).

O exemplo dado sobre a cana-de-açúcar já havia sido também precedido pelo caso da exploração do pau-brasil e no âmbito da cana-de-açúcar a questão é crítica no sentindo também de uma transformação na cultura alimentar imposta pelas dinâmicas do mercado externo, enquanto a mandioca, base da alimentação em toda a extensão territorial, começa a perder espaço, no momento em que todos os recursos de terra e produção são voltados para a cana (além dos impactos ambientais da prática da monocultura).

Pode-se remontar a este contexto a desigualdade no sentido da fome e da insegurança alimentar para a população nativa deste contexto, assim como a prática da exploração forçada de mão-de-obra, primeiramente indígena e posteriormente africana, o que reforça o argumento de padrão de uma estrutura e formação da sociedade brasileira voltada tão somente para o mercado externo e a partir das necessidades e prioridades dos colonizadores, indiferente às demandas locais.

Em suma, apesar das transformações históricas que seguem os séculos no Brasil, Prado Júnior continua identificando a permanência da lógica da ideia de desenvolvimento no país servindo ao interesse do capital externo: nos outros ciclos econômicos que seguem após a cana-de-açúcar e o processo da Revolução Industrial na Europa, assim como os processos de modernização e construção de ferrovias e portos para a exportação da produção brasileira.

Apesar da independência formal de Portugal, percebe-se a continuação da concentração de poder e capital nas elites, dando seguimento na condição de desigualdade e dissonância de interesses elitistas da população em geral, desde o início marginalizada e desconsiderada como detentora do poder e do interesse do Estado.

Nesta ótica, pode-se compreender que até mesmo os avanços nos direitos civis, políticos e sociais acabam por girar em torno desta demanda externa de inserção no mercado internacional, marcada já no início da colonização e que com algumas roupagens novas durante os séculos acaba por se remodelar, mas reproduz a mesma relação de subordinação.

A crítica central a partir da construção do argumento de Prado Júnior é a ideia de uma limitação rumo a este dito desenvolvimento, já que a condição 
periférica do Brasil no sistema internacional é histórica e a condução da formação brasileira em relação às demandas externas fragiliza a possibilidade de uma economia e uma sociedade autônoma de fato.

E é neste sentido que a obra de Prado Júnior dá força a um processo de revisão dos parâmetros de desenvolvimento e do contexto tanto latinoamericano quanto brasileiro, que viriam a ficar conhecidas como as teorias do Desenvolvimento (PREBISCH, 1954), da Dependência (SANTOS, 2000) e da Autonomia (JAGUARIBE, 1979); sendo também uma grande influência para o pensamento de Celso Furtado em sua contundente crítica ao desenvolvimento.

Diante desta premissa, propõe-se um aprofundamento do pensamento de Prado Júnior em alguns pontos que se consideram aqui como pouco explorados por ele e que de certo modo reproduzem a própria lógica de desenvolvimento como fator universal e ocidental e a partir de autores complementares serão propostas a seguir revisões de abordagens especificamente sobre a questão amazônica no texto de Prado Júnior.

\subsection{A IDEIA DE AMAZÔNIA EM “HISTÓRIA E DESENVOLVIMENTO”}

No que se propõe a discussão de Prado Júnior - o argumento central da relevância de uma abordagem histórica para a análise do desenvolvimento no Brasil - e a construção das relações históricas e econômicas é bem sucedida, porém, talvez dado o contexto da produção acadêmica que levou à publicação como um caráter complementar de sua trajetória, aqui, aponta-se que a mesma apresenta limitações.

Ao analisar o processo de colonização do Brasil é preciso considerar as idiossincrasias regionais, os diferentes processos de ocupação e as consequências atuais. Falar de história e desenvolvimento no país é, também, falar dos processos que levarão às assimetrias e desigualdades regionais marcantes até hoje em dia.

A abordagem feita por Prado Júnior mantém um caráter de visão do Sudeste do país e ao tratar o desenvolvimento relega à Região Amazônica à periferia deste processo, reproduzindo, inclusive mitos e preconceitos sobre a mesma:

Além da resistência que ofereceu ao trabalho escravo, o índio se mostrou muito mau trabalhador, de pouca resistência física e de eficiência mínima. Nunca teria sido capaz de dar conta de uma tarefa colonizadora levada em grande escala. Está aí o exemplo da Amazônia, onde não chegou a ser substituído em escala apreciável por outro trabalhador; e onde, em grande parte por isso, a colonização estagnou até quase nossos dias (PRADO JÚNIOR, 1978, p. 42). 
Os elementos atribuídos no trecho acima pouco diferem da visão da época que atribuía certo "atraso" da Região Amazônica em relação às outras (especialmente do Sudeste) às populações indígenas (que existiam, na verdade, em todo território nacional).

Logo, atribuir à cultura dos povos nativos o "fracasso" da colonização na região reproduz uma visão ocidentecêntrica que hierarquiza as culturas ainda na base das dinâmicas econômicas (menos ou mais capitalistas). Ademais, uma visão também falaciosa, haja vista que a distribuição de populações indígenas por todo o território não foi impedimento para o genocídio e extermínio em regiões que a Metrópole atribuiu maior interesse como a costa brasileira e a região Sudeste.

Prado Júnior continua a sua consideração sobre os indígenas afirmando que:

O índio brasileiro, saindo de uma civilização muito primitiva, não se podia adaptar com a necessária rapidez ao sistema e aos padrões de uma cultura tão superior à sua como era aquela que lhe traziam os europeus. O Brasil, neste assunto, estava em situação bem diversa da do México e dos países andinos, onde a colonização encontrou populações de nível cultural elevado (id.).

O argumento é frágil, já que as assimetrias e desigualdades socioeconômicas presentes na Região Amazônica brasileira também se encontram em países andinos e no México atualmente, reforçando que não é a causa do dito atraso a cultura dos povos locais, mas sim o próprio processo de colonização levado a cabo pelos colonizadores europeus.

No caso da Amazônia, por exemplo, a região passou por muito tempo fora do enfoque da Metrópole, recebendo atenção principalmente em casos como da ocupação espanhola e de outros povos europeus como franceses e holandeses que aproveitando o vazio da presença portuguesa se instalaram na região.

A partir deste trecho, Prado Júnior segue analisando a história e o desenvolvimento do Brasil basicamente a partir da perspectiva do Centro-Sul e dos ciclos econômicos da região, principalmente da cultura cafeeira, descrevendo as mudanças econômicas e políticas no Sudeste, mas desconsiderando as consequências e a própria situação em regiões marginalizadas politicamente como a Amazônia. Brevemente cita-se o ciclo da borracha, mas tão pouco se destaca a real importância do mesmo e muito menos se localiza a sua ocorrência, ao contrário da atenção dada às dinâmicas que se dão em São Paulo que são comentadas em seus pormenores.

A seguir, propõem-se revisitações críticas a partir da abordagem sobre a Amazônia feita por Prado Júnior ao aproximarmos suas discussões de vertentes teóricas contemporâneas como os estudos pós-coloniais. 


\section{CONTINUAÇÕES PARA "HISTÓRIA E DESENVOLVIMENTO” A PARTIR DA AMAZÔNIA}

Como fora abordado anteriormente, a discussão sobre desenvolvimento na Sociologia Brasileira não apenas não é um assunto recente, como é uma das principais marcas da formação da disciplina no país no século passado. No caso da Amazônia, o tema desenvolvimento também é recorrente e raramente se produz sobre a região sem que o tema esteja em voga.

Entretanto, não significa dizer que a discussão já tenha sido exaurida ou até mesmo, que não necessite ser reconstruída a partir de novas visões e novos pilares, considerando a origem das Ciências Sociais enquanto área moldada por pensadores europeus e que traduzidos e importados levaram à reprodução interna de parâmetros e epistemologias díspares das múltiplas realidades da América Latina.

A partir dos dois apontamentos realizados na seção anterior, sendo o primeiro a contribuição da argumentação de Prado Júnior no âmbito de compreender o desenvolvimento considerando a história e, o segundo, o lugar (ou a própria falta de ênfase) que a Amazônia ocupou na apresentação do seu argumento; considera-se que para atender de fato a proposta feita por Prado Júnior, ou seja, uma análise histórica do desenvolvimento no Brasil, é peça basilar a análise regionalizada.

Ao tomar como base contribuições de pensadores como Dussel (1977; 2005), Quijano (2000) e Escobar (2005) sobre o desenvolvimento é possível notar convergências ao pensamento de Prado Júnior, como quando este critica uma visão do desenvolvimento "como modelo universal e invariável” (ibid., p. 56), assim como a sua abordagem histórica que relaciona a situação de dependência e do "subdesenvolvimento" como parte do processo intrínseco à colonização, sendo a condição de dependência dificilmente superável considerando que toda a estruturação e a criação do país girou em torno de uma demanda do mercado externo e não das necessidades da própria população.

Considerando que a popularização acadêmica da crítica pós-colonial e de sua consolidação enquanto referência no pensamento social se dá apenas no século XXI, é importante reconhecer a contribuição de Prado Júnior em 1968 neste sentido.

Entretanto, estas leituras também convidam a provocar questionamentos sobre a produção dos conhecimentos e suas legitimidades. Assim, vemos a Região Amazônica como muitas vezes objeto do qual se fala de longe. 
Logo, revisitar a análise histórica de desenvolvimento numa perspectiva amazônica pode revelar muito mais que apenas uma região "atrasada" ou que foi relegada à margem do poder por conta da resistência de culturas "primitivas". Ao contrário, analisar este viés nos possibilita contestar o projeto universalista e homogêneo pautado no modelo ocidental de modernização e progresso.

Analisar as desigualdades do Brasil, mais do que as regiões que atualmente mais se aproximam do modelo de desenvolvimento europeu, serve mais como fonte de contestação da validade e viabilidade de uma ideia de desenvolvimento que de reafirmação de uma hierarquia cultural.

Isto posto, as tentativas forçadas e mal planejadas de imposição deste desenvolvimento de fora para dentro, de modo irregular, de costas para a própria população enquanto se mirava o sistema internacional e os lucros que dele viriam a uma pequena parcela elitista, contribuíram para a desestruturação das formas de vida - e de desenvolvimento - que existiam desde antes da colonização.

Séculos de colonização espacial, política e mental desembocam atualmente na Amazônia enquanto região de conflitos socioambientais intensos entre diversos povos pela utilização do território, por diferentes formas de compreender a relação com a natureza e que, muitas vezes, são dissonantes de um modelo de desenvolvimento enquanto modernização, no sentido que uma vida melhor muitas vezes tem se mostrado como cada vez mais como algo distante de tudo aquilo atrelado ao progresso.

As políticas desenvolvimentistas são exemplos que se intensificaram no final do século passado e que nos últimos anos recaíram sobre a polêmica construção da Usina Hidrelétrica de Belo Monte no município de Altamira, assim como outras já em planejamento.

Nestes contextos, o discurso de um projeto nacional visando o desenvolvimento e a geração de energia para a melhoria da vida da população, pela geração de emprego e renda, modernização e infraestrutura é enfrentado por grande parte da população das áreas dos empreendimentos com descontentamento e discordância de uma visão nacional e as suas visões próprias do que consideram uma vida melhor.

Enquanto numa lógica nacional homogênea e reprodutora de colonialidade se vê a região como atrasada por fatores ocidentais de avaliação como densidade demográfica e urbanização, muitas visões locais defendem seus modos de vida como ideais para si e vêem as políticas nacionais como violadoras de seus direitos.

Por fim, tem-se que mais do que uma relação de dependência historicamente construída e dificilmente superável para o Brasil pelo processo de colonização onde toda sua formação buscava (e ainda busca) atender a 
demandas externas, olhando-se para dentro existem reproduções desta relação a âmbitos regionais, como proposto por Pablo González Casanova (2015) na ideia de colonialismo interno.

\section{CONSIDERAÇÕES FINAIS}

Neste breve trabalho visou-se a apresentação da relevante contribuição de Caio Prado Júnior e seu livro "História e desenvolvimento" de 1968 para a Sociologia Brasileira e, especialmente, a Sociologia do Desenvolvimento, marca da disciplina no país.

A partir da exposição dos argumentos centrais formados por Prado Júnior traçou-se a importância da sua ideia central - uma análise do desenvolvimento não apenas no viés econômico, mas também histórico - o que em sua proposta leva à afirmação de uma condição brasileira de dependência enquanto periferia do sistema internacional que remete ao próprio processo de colonização.

Entretanto, a partir de algumas passagens em que o autor descreve a Amazônia brevemente nesta dinâmica, nota-se a reprodução de mitos e preconceitos sobre a região, o que se buscou contestar a partir da própria máxima de Prado Júnior e fazendo uso também de visões complementares dos estudos pós-coloniais.

Em suma, o exercício aqui proposto visou apontar a possibilidade de revisitar referências clássicas da Sociologia Brasileira e atualizar discussões muitas vezes de difícil visualização à época de suas publicações pelas próprias dinâmicas da produção de conhecimento normalmente eurocêntrica e que marcaram muitos dos precursores da Sociologia no Brasil, sendo a Amazônia apenas um exemplo para contestação de visões universais e homogêneas sobre os processos históricos e econômicos no país.

\section{REFERÊNCIAS}

DUSSEL, Enrique. Europa, modernidade e eurocentrismo. In: LANDER, Edgardo (Org.). A colonialidade do saber: eurocentrismo e ciências sociais perspectivas latino-americanas. Buenos Aires: CLACSO, 2005. p. 25-34.

Filosofia da Libertação na América Latina. Trad. Luiz João Gaio. 2. ed. São Paulo: Loyola/UNIMEP, 1977.

ESCOBAR, Arturo. Lugar da natureza e a natureza do lugar: globalização ou pós-desenvolvimento? In: LANDER, Edgardo (Org). A colonialidade do saber: eurocentrismo e ciências sociais - perspectivas latino-americanas. Buenos Aires: CLACSO, 2005. p. 69- 86 
FURTADO, Celso. O mito do desenvolvimento econômico. Rio de Janeiro: Paz e Terra, 1974.

GONÇALVES, Carlos Walter Porto. Amazônia, Amazônias. 3. ed. São Paulo: Contexto, 2015.

GONZÁLEZ CASANOVA, Pablo. De la Sociología del poder a la sociología de la explotación: pensar América Latina en el siglo XXI. Antología y presentación de Marcos Roitman Rosenmann. Bogotá: CLACSO, 2015.

JAGUARIBE, Helio. Autonomia periférica y hegemonia céntrica. Revista Estudios Internacionales, Santiago (Chile), v. 12, n. 46, p. 91-130, 1979.

PRADO JÚNIOR, Caio. História e desenvolvimento: a contribuição da historiografia para a teoria e prática do desenvolvimento brasileiro. 2. ed. São Paulo: Brasiliense, 1978.

PREBISCH, Raúl. La cooperacion internacional en la política de desarrollo latinoamericana. New York: Naciones Unidas, 1954.

QUIJANO, Aníbal. El fantasma del desarrollo en América Latina. Revista Venezolana de Economía Y Ciencias Sociales, Caracas, n. 2, p. 38-55, 2000. Disponível em: <http://www.cesla.uw.edu.pl/cesla/images/stories/ wydawnictwo/czasopisma/Revista/Revista_1_quijano.pdf $>$. Acesso em: 17 nov. 2017

SANTOS, Theotônio dos. A teoria da dependência: balanço e perspectivas. Rio de Janeiro: Civilização Brasileira, 2000. 
Crescimento econômico, padrões de especialização e industrialização: um estudo comparativo das exportações do BRIC (1980-2013)

Economic growth, patterns of specialization and industrialization: a comparative study of BRIC exports (1980-2013)

André Luís Cabral de Lourenço e Franciane Alves Cardoso

Encadeamento ecossocioeconômico e gestão urbana: um estudo das feiras livres na cidade de Curitiba (PR)

Socio-economic and urban management: a study of the free trade fairs in the city of Curitiba (PR)

Isabel Jurema Grimm, Carlos Cioce Sampaio e Mario Procopick

Um "skyline" em mutação: o velho centro e as transformações urbanas em Belém

A "skyline" in changing: the old center and the urban transformations in Belém

Saint-Clair Cordeiro da Trindade Júnior

Comunidades quilombolas e o Programa Nacional de Habitação Rural

The quilombola communities and the National Rural Housing Program

André Augusto Brandão, Salete Da Dalt e Sidimara Cristina de Souza

Saberes e práticas tradicionais em movimento: a comunidade do Maracanã na rota de um projeto global

Traditional knowledge and practices in movement: yhe community of Maracanã on the route of a global project

Joaquim Shiraishi Neto, Rosirene Martins Lima e Luzinele Everton de Alcobaça

Território e trabalho: análise geoeconômica com base em trajetórias camponesas

Territory and work: a geoeconomical analysys based on peasant trajectories

Karen de Nazareth Santos Nogueira, Francisco de Assis Costa e Marcos Adami

Estratégias e formas de reprodução social na agricultura familiar da fronteira oeste do Rio Grande do Sul

Strategies and reproduction of social forms family in fronteira oeste do Rio Grande do Sul

Alessandra Troian e Raquel Breitenbach

Usinas hidrelétricas sob os véus da "sustentabilidade": o pescador artesanal da Ponta do Abunã e a Usina Hidrelétrica de Jirau, em Rondônia

Hydroelectric plants in the Amazon under the veils "sustainability": the fishermen of Ponta do Abunã of the Jirau Dam in Rondonia

Fabiano Moreira da Silva e Elder Andrade de Paula

Grandes projetos de mineração e direitos territoriais das comunidades locais em Moçambique

Large mining projects and territorial rights of local communities in Mozambique

Albino José Eusébio e Sônia Barbosa Magalhães

Desenvolvimento sustentável do Marajó, Pará: uma visão a partir do Barômetro da Sustentabilidade

Sustainable development of Marajó, Pará: an overview based on the Barometer of Sustainability

Patrick Diniz Alves Quintela, Peter Mann de Toledo e Ima Célia Guimarães Vieira

Para além do sucesso técnico: rede sociotécnica em pequenas comunidades rurais amazônicas, Amazonas-Brasil

Besides technical success: socio-technical network in small rural communities of the Brazilian Amazon

Ana Claudeise Nascimento, Edila Arnaud Ferreira Moura e Maria José da Silva Aquino Teisserenc

Etnoconservação e história ambiental para um novo modelo conservacionista do século XXI

Etnoconservation and environmental history for a new conservation model of the XXI century

José Aécio Alves Barbosa e José Otávio Aguiar

Redes sociopolíticas e territorialidade na Reserva de Desenvolvimento Sustentável Igapó-Açu (AM, Brasil)

Sociopolitical networks and territoriality in the Development Reserve Sustainable Igapó-Açu (Amazonas, Brazil)

Marilia Gabriela Gondim Rezende, Therezinha de Jesus Pinto Fraxe e Mônica Suani Barbosa da Costa

Prioridades locais e sua relação com o desenvolvimento regional no Codemi de ljuí

Local priorities and its relationship with regional development in the Codemi from Ijuí

Vinicios Gonchoroski de Oliveira e Rogério Leandro Lima da Silveira

Resenhas

Livro: SANTOS, José Vicente Tavares dos. Violências e conflitualidades. Porto Alegre: Tomo Editorial, 2009.

Maria Goreti Góes da Rocha

PRADO JÚNIOR, Caio. História e Desenvolvimento: a contribuiçao da historiografia para a teoria e prática do desenvolvimento brasileiro. 2. ed. São Paulo: Ed. Brasiliense, 1978.

Brenda T. Cardoso de Castro 